Федеральное

государственное

бюджетное

учреждение

науки

Институт

Российской

том 3 \# 1

мировой

академии наук

2018

литературы

имени

А.М. Горького

Москва

Studia Litterarum

Литературные исследования

Научный журнал

Издается с 2016 года 
Studia Litterarum:

Науч. журн. - 2018.

-T. 3, № I. - M.:

ИМЛИ РАН, 2018.

$-368 \mathrm{c}$.

Academic journal. - 2018 .

- Vol. 3, no I. - Moscow,

IWL RAS Publ., 2018.

$-368 \mathrm{p}$.
Журнал

зарегистрирован

в Федеральной службе

по надзору

в сфере связи и массовых

коммуникаций

Свидетельство

о регистрации

ПИ № ФС $77-66625$

от 27 июля 2016 г.

Подписной индекс

по каталогу «Роспечать»

80538

ISSN 2500-4247 (Print)

ISSN 254I-8564 (Online)

Адрес редакиии:

І2І069 г. Москва,

ул. Поварская, д. 25 а

Телефон:

+7 (495) 690-50-30

E-mail: stud-lit@mail.ru

www.studlit.ru
The journal

is registered

at the Federal Service

for Supervision

of Media and

Mass Communications

Registration Certificate

PE № FS $77-66625$,

July 27, 2016

Subscription index in the catalogue "Rospechat" 80538

ISSN 2500-4247 (Print)

ISSN 254I-8564 (Online)

Address of the Editorial

Department:

Povarskaya 25 a,

I2I069 Moscow

Phone:

+7 (495) 690-50-30

E-mail: stud-lit@mail.ru

www.studlit.ru 
Federal State

Budget

Institution

of Science

A.M. Gorky

of the Russian

vol 3 \#1

Institute

Academy

2018

of World

of Scienes

Literature

Moscow

Studia Litterarum

Literary Studies

Academic journal

Published since 2016 
Главный редактор

А.Б. Куделин (ИМЛИ РАН, Москва, Россия)

Заместитель главного редактора

О.А. Туфанова (ИМЛИ РАН, Москва, Россия)

Ответственный секретарь

Редакторы

М.В. Каплун (ИМЛИ РАН, Москва, Россия)

А.В. Голубков, А.П. Уракова (ИМЛИ РАН, Москва, Россия)

\section{МЕЖДУНАРОДНЫЙ РЕДАКЦИОННЫЙ СОВЕТ}

Д.П. Бак (Государственный литературный музей, Москва, Россия), Т.М. Горяева (Российский государственный архив литературы и искусства, Москва, Россия), Р. Джулиани (Университет Ла Сапиенца, Рим, Италия), Л.И. Ливак (Торонтский Университет, Торонто, Канада), Э. Лэрд (Университет Браун, Провиденс, США), Д. Ота (Кумамото Гакуэн Университет, Куматото, Япония), Ф.Б. Поляков (Институт славистики Венского университета, Вена, Австрия), Р.М. Распопович (Исторический институт Университета Черногории, Подгорица, Черногория), Д. Рицци (Университет Ка Фоскари, Венеция, Италия), И.В. Силантьев (Институт филологии СО РАН, Новосибирск, Россия), Г. Тиханов (Лондонский университет королевы Марии, Лондон, Великобритания), Л.С. Флейшман (Стэнфордский университет, Стэнфорд, США), М. Цимборска-Лебода (Университет Марии Кюри-Склодовской в Люблине, Люблин, Польша)

\section{РЕДАКЦИОННАЯ КОЛЛЕГИЯ}

М.Л. Андреев (ИМЛИ РАН, Москва, Россия), С. Гардзонио (Пизанский университет, Пиза, Италия), Б.Ф. Егоров (Санкт-Петербургский институт истории РАН, Санкт-Петербург, Россия), Ж.-Ф. Жаккар (Женевский университет, Женева, Швейцария), Н.В. Корниенко (ИМЛИ РАН, Москва, Россия), О.А. Коростелев (ИМЛИ РАН, Москва, Россия), А.Ф. Кофман (ИМЛИ РАН, Москва, Россия), А.В. Лавров (Институт русской литературы (Пушкинский Дом), РАН, Санкт-Петербург, Россия), Д.С. Московская (ИМЛИ РАН, Москва, Россия), В.В. Полонский (ИМЛИ РАН, Москва, Россия), А.Ф. Строев (Университет Новая Сорбонна - Париж 3, Париж, Франция), А.Л. Топорков (ИМЛИ РАН, Москва, Россия), М. Шруба (Рурский университет, Бохум, Германия)

Адрес редакции: г2го69 г. Москва, ул. Поварская, д. 25 а

Телефон: +7 (495) 690-50-30

E-mail: stud-lit@mail.ru

Сайт: www.studlit.ru 
Editor-in-Chief

Alexander B. Kudelin (A.M. Gorky Institute of World Literature of the Russian

Academy of Sciences, Moscow, Russia)

Deputy Editor-in-Chief

Olga A.Tufanova (A.M. Gorky Institute of World Literature of the Russian Academy

of Sciences, Moscow, Russia)

Managing Editor

Marianna V. Kaplun (A.M. Gorky Institute of World Literature of the Russian Academy of Sciences, Moscow, Russia)

Editors Andrei V. Golubkov (A.M. Gorky Institute of World Literature of the Russian Academy of Sciences, Moscow, Russia), Alexandra P. Urakova (A.M. Gorky Institute of World Literature of the Russian Academy of Sciences, Moscow, Russia)

\section{INTERNATIONAL EDITORIAL COUNCIL}

Dmitry P. Bak (State Literary Museum, Moscow, Russia), Tatiana M. Goryaeva (Russian State Archive of Literature and Art, Moscow, Russia), Rita Giuliani (Sapienza University, Rome, Italy), Leonid I. Livak (University of Toronto, Toronto, Canada), Andrew Laird (Brown University, Providence, USA), Jotaro Ohta (Kumamoto Gakuen University, Kumamoto, Japan), Fedor B. Poljakov (Institute for Slavistics, University of Vienna, Vienna, Austria), Radoslav M. Raspopovic (University of Montenegro, Historical Institute of the University of Montenegro, Podgorica, Montenegro), Daniela Rizzi (Ca' Foscari University, Venice, Italy), Igor V. Silantiev (Institute of Philology of Siberian Branch of the Russian Academy of Sciences, Novosibirsk, Russia), Galin Tihanov (Queen Mary University of London, London, Great Britain), Lazar S. Fleishman (Stanford University, Stanford, USA), Maria Cymborska-Leboda (Maria Curie-Skłodowska Universtity in Lublin, Lublin, Poland)

\section{EDITORIAL BOARD}

Mikhail L. Andreev (A.M. Gorky Institute of World Literature of the Russian Academy of Sciences, Moscow, Russia), Stefano Garzonio (University of Pisa, Pisa, Italy), Boris F. Egorov (Saint Petersburg Institute of History of the Russian Academy of Sciences, Saint Petersburg, Russia), Jean-Philippe Jaccard (University of Geneva, Geneva, Switzerland), Natalya V. Kornienko (A.M. Gorky Institute of World Literature of the Russian Academy of Sciences, Moscow, Russia), Oleg A. Korostelev (A.M. Gorky Institute of World Literature of the Russian Academy of Sciences, Moscow, Russia), Andrey F. Kofman (A.M. Gorky Institute of World Literature of the Russian Academy of Sciences, Moscow, Russia), Alexander V. Lavrov (Institute of Russian Literature (Pushkinsky Dom) of the Russian Academy of Sciences, Saint Petersburg, Russia), Darya S. Moskovskaya (A.M. Gorky Institute of World Literature of the Russian Academy of Sciences, Moscow, Russia), Vadim V. Polonsky (A.M. Gorky Institute of World Literature of the Russian Academy of Sciences, Moscow, Russia), Alexander F. Stroev (New Sorbonne University - Paris 3, Paris, France), Andrey L. Toporkov (A.M. Gorky Institute of World Literature of the Russian Academy of Sciences, Moscow, Russia), Manfred Schruba (Ruhr University, Bochum, Germany) 
Теория литературы

Iо Зенкин C.H. Натурщица и шедевр (Бальзак и его продолжатели)

Мировая литература

58 Горяева Л.В. К анализу образа халифа Али в малайской нарративной традиции

68 Евдокимова Л.В. Две мифологических баллады из «ста баллад» Кристины Пизанской: опыт анализа

88 Говенько Т.В. Приемы постмодернизма в романе Б.Т. Ханике «Rotkäppchen muss weinen» (2009) как способ детабуизации «недетских» тем в подростковой литературе

IO2 Астащенко E.B. Религиозное измерение немецкой «Бесконечной книги» в детском фэнтези К. Функе

Русская литература

II8 Кириллин В.М. Святая Земля - Римская Империя - Византия - Русь: идея наследничества по памятникам древнерусской литературы

I40 Римонди Дж. Музыкальное мироощущение в романе А.Ф. Лосева «Женщина-мыслитель»

К г5о-летию М. Горького

I54 Rolet S. Comment les Français ont découvert $\mathrm{Na}$ dne I78 Autant-Mathieu M.-Ch. Gorki et le Théâtre d'Art de Moscou: des affinités sélectives

I96 Heller L. Universelle russité: Les Bas-fonds, ou Gorki revu par Zamiatine revu par Renoir

2I2 Спиридонова Л.А. Творчество Горького и возникновение социалистического реализма 
234 Овчаренко О.А. М. Горький как теоретик литературы

252 Демкина С.M. Пьеса М. Горького «На дне» на немецкой сцене (по материалам Музея А.М. Горького ИМЛИ РАН)

266 Ариас-Вихиль М.А. Пьеса М. Горького «На дне» в Италии: постановка труппы Татьяны Павловой 1926 г. (по материалам Архива А.М. Горького)

Литература народов России и Ближнего зарубежья 282 Росовецкий С.К. Эпическое своеобразие украинских народных дум

Фольклористика

302 Агапкина T.A. Бегство святого семейства в Египет в славянских этиологических легендах о деревьях

3I8 Налепин А.Л. О фольклорной коллекции в архиве Евгения Платоновича Иванова, хранящейся в отделе рукописей ИМЛИ РАН

Текстология. Источниковедение. Публикации

332 Дормидонтова А.И. Новые поступления в фонды Московского литературного музеяцентра К.Г. Паустовского

Мемуары

344 Якимова Л.П. Из «Мемуаров ученой дамы». О Всесоюзной научной конференции в Ташкенте I975 г. (предисловие - Папкова Е.А.) 
Literary theory

IO Sergey N. Zenkin. The Model and the Masterpiece (Balzac and his followers)

World literature

58 Liubov V. Goriaeva. On the Image of Calif Ali in Malay Narrative Tradition

68 Liudmila V. Evdokimova. Reexamining Two Mythological Ballads from Christine de Pizan's Cent Balades

88 Tatiana V. Govenko. Postmodernist Techniques and Grown-Up Themes in the Juvenile Novel Learning to Scream (2009) by Beate T. Hanike

IO2 Elena V. Astashchenko. Religious Dimension of German "Unending Book" in the Children's Fantasy by Cornelia Funke

Russian literature

II8 Vladimir M. Kirillin. Sacred Land -Roman Empire - Byzantium - Rus': The Concept of Heredity in Old Russian Literature

I4O Giorgia Rimondi. Musical Outlook in Alexey Losev's Novel The Woman-Thinker

To the $150^{\text {th }}$ anniversary of Maxim Gorky

I54 Serge Rolet. Comment les Français ont découvert Na dne

I78 Marie-Christine Autant-Mathieu. Gorki et le Théâtre d'Art de Moscou: des affinités sélectives

I96 Leonid Heller. Universelle russité: Les Bas-fonds, ou Gorki revu par Zamiatine revu par Renoir 
2 I2 Lydia A. Spiridonova. Gorky's Work and the Rise of Social Realism

234 Olga A. Ovcharenko. M. Gorky as a Theoretician of Literature.

252 Svetlana M. Demkina. The Lower Depths on the German Stage

266 Marina A. Arias-Vikhil. The Lower Depths in Italy: the 1926 Performance Directed by Tatyana Pavlova

Literature of the Peoples of Russia and Neighboring Countries 282 Stanislav K. Rosovetsky. Epic Specificity of Ukrainian Folk Dumas

\section{Folklore Studies}

302 Tatyana A. Agapkina. The Flight to Egypt in Slavic Etiological Legends about the Trees

3I8 Alexey L. Nalepin. Folklore Collection in the Archive of Evgeny Platonovitch Ivanov Held by the IWL RAS Manuscript Department

Textology. Materials

332 Angelica I. Dormidontova. New Admissions to the K.G. Paustovsky Moscow Literary MuseumCenter

Memoir

344 Liudmila P. Yakimova. From The Memoir of An Academic Lady. About the All-Union Academic Conference in Tashkent, 1975 (introduction by Elena A. Papkova) 
УДК 82I.I3I.I.O

ББК $83.3(4 Ф$ ра $) 52$
НАТУРЩИЦА И ШЕДЕВР

(БАЛЬЗАК И ЕГО ПРОДОЛЖАТЕЛИ)

(C) 2018 г. С.Н. Зенкин

Российский государственный гуманитарный

университет,

Москва, Россия

Дата поступления статьи: о5 октября 2017 г.

Дата публикации: 25 марта 2018 г.

DOI: I0.22455/2500-4247-2018-3-I-IO-57

Аннотация: Новелла «Неведомый шедевр» - одно из самых комментируемых произведений Бальзака. В статье предлагается ее новое прочтение, соотносящее нарративные структуры текста с их деформирующим воздействием на искусственный визуальный образ (картину живописца), фигурирующий в рассказе. Этот процесс рассматривается на общем фоне подвижности «колышущегося» бальзаковского текста, существенно меняющегося при каждой авторской доработке, затемняющего важные обстоятельства сюжета и делающего двусмысленным заглавный визуальный образ: образ расслаивается, обретает толщину вместо глубины, а изображенная на нем фигура выступает из его гладкой поверхности. За анализом бальзаковского текста следует обзор других произведений французской литературы и кино, разрабатывавших вслед за ним сюжет о «шедевре и натурщице» (Теофиль Готье, братья Гонкуры, Эмиль Золя, Жак Риветт).

Ключевые слова: Бальзак, «Неведомый шедевр», Готье, Гонкуры, Золя, Риветт, визуальный образ в повествовании.

Информация об авторе: Сергей Николаевич Зенкин - доктор филологических наук, главный научный сотрудник, Российский государственный гуманитарный университет, Институт высших гуманитарных исследований, ул. Чаянова, д. I5, І25047 г. Москва, Россия.

E-mail: sergezenkine@hotmail.com 


\section{THE MODEL AND THE MASTERPIECE (BALZAC AND HIS FOLLOWERS)}

This is an open access article distributed under the Creative Commons Attribution 4.0 International (CC BY 4.0)
(C) 2018. Sergey N. Zenkin

Russian State University for the Humanities

Received: October 05, 2017

Date of publication: March 25, 2018

Abstract: Balzac’s short story “The Unknown Masterpiece” ("Le Chef-d'œuvre inconnu”) is one of his most commented works. This essay offers a new reading of the story by correlating the narrative structures of the text with the deforming effect these structures produce on the visual artifact (the painting) featured in "The Unknown Masterpiece." The analysis takes into consideration the dynamic history of Balzac's "waving” text undergoing changes with every new authorial revision that obscured the important circumstances of the plot and made the central visual image ambiguous. The latter is stratified as it acquires width instead of depth while the figure it represents protrudes from the smooth surface of the canvas. The close reading of Balzac's text is followed by the survey of French literary works and films that elaborate, after Balzac, on "the masterpiece and the model” plot. The latter include the works by Théophile Gautier, Goncourt brothers, Émile Zola, and Jacques Rivette.

Keywords: Balzac, “The Unknown Masterpiece,” Gautier, Goncourt brothers, Zola, Rivette, visual image in the narrative text.

Information about the author: Sergey N. Zenkin, DSc in Philology, Director of Research at the Russian State University for the Humanities, Chayanova I5, I25047 Moscow, Russia.

E-mail: sergezenkine@hotmail.com 
Новелла «Неведомый шедевр» (Le Chef-d'œuvre inconnu) - едва ли не самое комментируемое произведение Оноре де Бальзака. Она занимает всего два-три десятка страниц, но ее анализу посвящено несколько специальных монографий и множество статей, большинство из которых вышло в г98о-е гг., в пору подъема литературно-теоретических исследований во Франции. Такое внимание критики к одному небольшому тексту само по себе говорит о его повышенной сложности и его исключительном месте в огромном наследии своего автора. Дело в том, что в нем особую форму приняло взаимодействие текстуального и визуального начал: не просто визуальные мотивы используются как средство словесного «изображения» (как это систематически делает Бальзак в «Человеческой комедии») ${ }^{\text {I }}$, но искусственные визуальные образы сами служат предметом повествования. В текст новеллы введены пространные рассуждения о живописи, большинство персонажей - профессиональные художники, в сюжете фигурируют их произведения (в том числе одно совершенно необычное по структуре) ${ }^{2}$, а почти все излагаемые события представляют собой

I См. посвященную Бальзаку главу в монографии: [36]. Например, в «Неведомом шедевре» описание героя заканчивается уподоблением живописному полотну - не виртуальному художественному образу, а его материальному носителю, холсту: «Вы сказали бы, что это полотно Рембрандта, покинувшее свою раму и молча движущееся в полутьме, излюбленной этим великим художником» [II, р. 4I5; г, с. 372].

Здесь и далее ссылки на текст «Неведомого шедевра» даются сначала на французское, а потом на русское издание: [II; г]. Перевод И.М. Брюсовой в ряде случаев уточнен, обычно без специальных оговорок на этот счет. Курсив в цитатах из этого и других текстов, если не указано иначе, наш.

2 Отсюда двойственный состав критической литературы о «Неведомом шедевре»: одни авторы исследуют текст новеллы в контексте творчества Бальзака и литературы его времени, а другие (в их числе крупные теоретики визуального искусства Юбер Дамиш, Луи Марен, 
различные действия по отношению к этим произведениям: их создают, оценивают, поправляют, обсуждают, рассматривают, показывают, прячут, уничтожают. Эти события, образующие динамическую структуру текста, и будут рассматриваться ниже, у самого Бальзака и у некоторых его последователей.

\section{Колышущийся текст}

Динамика любого словесного выражения имеет два измерения - парадигматическое и синтагматическое. В первом аспекте текст меняется в ходе переработок и переизданий, во втором - развивается по мере развертывания от начала к концу.

Новелла «Неведомый шедевр» впервые была опубликована в І83і г. в журнале «Артист» и в дальнейшем при жизни автора несколько раз перепечатывалась в книгах, существенно при этом изменяясь (в I83I, I837, I846 и I847 гг.); разные ее редакции печатаются по сей день ${ }^{3}$ Если сравнивать их между собой (или читать комментарии, где проделано такое сравнение), то бальзаковский текст предстает не столько как жесткая конструкция, сколько как зыбкая масса, которая колышется, раздувается в одних местах и съеживается в других. Такая парадигматическая подвижность вообще типична для текстов Бальзака (см., например: [4]); ей соответствует и синтагматическая неоднородность рассказа, движущегося неравномерно: он то вздувается богатством подробностей, то скукоживается до краткого конспекта или даже проваливается в повествовательную лакуну, не сообщая толком ничего о важнейшем, ключевом эпизоде 4 . Повествовательная техника Бальзака - приемы

Жорж Диди-Юберман) ведут углубленный анализ фигурирующей в новелле воображаемой картины. Первые склонны недооценивать визуальную тематику новеллы, сводить ее к более общим литературным схемам - например, прочитывать ее как притчу о художнике и его творчестве; вторые, наоборот, фокусируют внимание на специфике придуманной Бальзаком картины и молчаливо признают более или менее прозрачной, «само собой разумеющейся» повествовательную структуру, в которую она включена.

3 В издании «Библиотеки Плеяды» («Человеческая комедия», т. Х, І979) «Неведомый шедевр» печатается в последней, пятой редакции - по сборнику «Провинциал в Париже» (Le Provincial à Paris, I847); из комментариев к этому научному изданию мы черпаем все сведения об истории текста. В более старом издании той же авторитетной серии (т. IX, I950) воспроизводилась четвертая редакция - текст прижизненного собрания сочинений Бальзака (издательство Фюрна, т. XIV, I846), с которого выполнен и русский перевод И. Брюсовой; а Жорж Диди-Юберман в приложении к своей монографии о «Неведомом шедевре» перепечатал третью редакцию, помещенную в «Философских этюдах» Бальзака (I837).

4 Первую демонстративную текстуальную лакуну, еще до начала собственно рассказа, образуют четыре строки точек, следующие за посвящением новеллы «Лорду...» [II, p. 4I3]. Это 
фокализации, замена «объективного» повествования прямой и косвенной речью персонажей, ряд более или менее умышленных умолчаний и противоречий - позволяет поддерживать двусмысленность в трактовке ряда мотивов новеллы, и прежде всего самого «неведомого» и невидимого нам шедевра5.

Пьер Лобрие, первым посвятивший целую докторскую диссертацию «Неведомому шедевру», так резюмировал смысл поправок, внесенных Бальзаком в первоначальную версию своего текста: «К философской новелле I83I года прибавилась новелла о живописи...» [26, р. І28]. Действительно, в ходе правки, особенно в редакции I837 г., Бальзак значительно расширил «живописную» тематику, добавив пространные тирады художника Френхофера об искусстве живописи; все это привлекает повышенное внимание к центральному визуальному образу - картине Френхофера. Однако поправки имели результатом не только тематический, но и перспективный сдвиг. Так, последовательно устранялись металитературные комментарии автора к собственному тексту, например: «...но искусства настолько больны, что было бы преступно еще создавать в литературе картины; оттого мы из учтивости обычно соблюдаем сугубую сдержанность в образах» [II, p. I4I2, комментарии $]^{6}$. Иного рода купюра сделана при описании картины одного из персонажей - работавшего во Франции фламандского художника Франса (Франсуа) Порбуса (историческое лицо, I569-1622). В первоначальном тексте рассказчик подробно излагал дальнейшую историю этой картины, доводя ее до своего времени, а после правки от этой истории осталась лишь одна первая фраза:

Эта прекрасная страница искусства изображала Марию Египетскую, намеревающуюся расплатиться за переправу в лодке. Шедевр, предназначенный для Марии Медичи, был ею впоследствии продан в дни нужды; $u$ во

посвящение, которое не воспроизведено в русском переводе и адресат которого не поддается опознанию, появилось лишь в редакции I846 г.

5 Такая «колышущаяся», подвижно-неустойчивая структура, последовательно создаваемая автором, сильнее всего отличает «Неведомый шедевр» от двух произведений Э.-Т.-А. Гофмана, которые считаются его сюжетными источниками, - от истории художника Франческо из романа «Эликсиры Сатаны» (I8I5-I8I6) и безымянной новеллы из цикла «Серапионовы братья» (г820), которую условно называют, по имени героя, «Барон Б.» или «Урок музыки барона Б.». Сводку тематических - не структурных! - соответствий между этими текстами и бальзаковской новеллой см. в предисловии Рене Гиза к изданию последней в «Библиотеке Плеяды» [II, p. 40I-407].

6 См. подробнее об изъятии подобных эффектов из текста «Неведомого шедевра»: [36, p. I63-I66]. 
время нашего вторжения в Германию (І8о6) один капитан артиллерии спас его от неминуемого уничтожения, спрятав в своем чемодане. Он был покровителем искусств и предпочитал подбирать, а не красть. Его солдаты уже пририсовали усы святой покровительнице кающихся грешниц, и, в пьяном кощунстве, собирались использовать ее как мишень для стрельбы - бедной святой даже на картине пришлось покоряться своей судьбе. Сегодня это великолепное полотно находится в замке Гренадьер, недалеко от Сен-Сира в Турени, и принадлежит г-ну де Лансе [II, р. І4І2, комментарии; г, с. 373] $]^{7}$.

Резкое сокращение истории картины с ее анекдотическими подробностями, так же как и исключение металитературных комментариев, обрубает связи между рассказываемыми событиями и моментом рассказывания о них ${ }^{8}$. В новой редакции текста границу между ними больше не пересекает ни рассказчик, фамильярно перебивающий сюжетное действие своими комментариями, ни искусство живописи, способное пережить много поколений и приключений и дойти до наших дней в неизменности 9 . Это одно из средств драматизации текста: найдя в І830-х гг. свой собственный стиль повествования, Бальзак начал писать романы с драматическим сюжетом, составившие

7 Начало цитаты приводится по русскому изданию, а ее изъятое автором продолжение (выделенное курсивом) - по комментариям к французскому изданию. И сама картина Порбуса, и ее владелец «г-н де Лансе» считаются вымышленными; напротив того, имение Гренадьер действительно существовало близ Тура, и его название стало заголовком другого произведения Бальзака (La Grenadière, I832-I834). Это имение - единственный «переходящий персонаж», связывавший новеллу (в первой редакции, до его исключения из текста) с остальным корпусом «Человеческой комедии».

8 Сказанному не противоречит то, что непосредственным мотивом последней купюры могло быть желание писателя устранить самоповтор: эпизод со спасением религиозной картины от буйных солдат, пририсовавших ей усы и готовившихся ее «расстрелять», фигурировал также в другой повести Бальзака - «Мараны» (Les Marana, I832, [9, p. Io4I]).

Включая оба произведения в издание «Философских этюдов» I837 г., Бальзак удалил повторяющийся мотив из текста «Неведомого шедевра».

9 В другой, написанной незадолго до «Неведомого шедевра» новелле «Сарразин» (Sarrasine, I830) также фигурировал неизменный художественный памятник прошлого картина, написанная в XVIII в., в пору основного сюжетного действия, и созерцаемая более полувека спустя, когда разворачивается обрамляющая история. Интересно, что при переработке этой новеллы Бальзак тоже постарался ослабить «связь времен» (не столь далеких друг от друга, как в «Неведомом шедевре»), заменив автора картины - вместо знаменитого и недавно скончавшегося художника Анна-Луи Жироде назвал таковым более старого и менее известного Жозефа-Мари Вьена, который в культурной памяти читателей должен был располагаться где-то на грани достоверной реальности и условного романного вымысла. См.: [36, p. I53]. 
впоследствии «Человеческую комедию»; в том же направлении он и корректирует «Неведомый шедевр», вплоть до введения (в I837 г.) мелодраматической концовки - безумия и смерти героя.

Драматизм предполагает замкнутость сюжетного мира, отделенного непроходимой границей, словно театральной рампой, от мира, где находимся мы. Между «тогдашним» и «нынешним» временем, между «сценой» и «залом» не должно быть ни словесного, ни визуального двустороннего контакта, они не могут ни переговариваться, ни переглядываться друг с другом. Оттого Бальзак не дает никаких намеков на будущую художественную карьеру одного из исторических персонажей новеллы - Никола Пуссена; оттого и рассуждения о живописи излагаются не от лица современного рассказчика, а устами одного из действующих лиц - художника Френхофера, в І6І2 г..

Особенно важно, что этот эффект дистанции распространяется не только на теорию живописи - ее практика, ее произведения тоже описываются по большей части персонажами новеллы, пропускаются через их восприятие. Рассказчик самое большее сообщает кратко-«инвентарную» характеристику картины, с самой общей оценкой: «Эта прекрасная страница искусства изображала Марию Египетскую, намеревающуюся расплатиться за переправу в лодке» [ІІ, р. 4І6; г, с. 373]; «это был “Адам” - картина, написанная Мабузе затем, чтобы освободиться из тюрьмы, где его так долго держали заимодавцы. Вся фигура Адама полна была действительно такой мощной реальности...» [II, p. 423; I, с. 380]; «великолепный портрет женщины» [II, p. 423; I, с. 38г]; «оба они остановились сначала перед изображением полунагой женщины в человеческий рост...» [II, p. 435; І, с. 393]. Любые более подробные описания этих произведений даются либо в репликах героев, либо от лица рассказчика, но со ссылками на их зрительный опыт: «Подойдя ближе, они заметили в углу картины...» [II, p. 436; І, с. 394]. Превосходно владея искусством экфрасиса - примером тому хотя бы описание внешности Френхофера, уподобленное описанию картины Рембрандта (см. выше, прим. I), - Бальзак систематически избегает пользоваться им в собственной

Iо Тот же прием - автор вкладывает рассуждения об искусстве (музыкальном) в уста одного из персонажей, не смущаясь непомерной длиной и подробностью этих устных тирад, использован Бальзаком в двух других «философских этюдах», написанных одновременно с третьей редакцией «Неведомого шедевра» и также затрагивающих проблемы эстетики и художественной теории: «Гамбара» (Gambara, I837) и «Массимилла Дони» (Massimilla Doni, I837-1839). 
речи, передоверяет его другим, вымышленным зрителям, как только дело заходит об описании собственно художественных визуальных объектов. Если продолжить сравнение с драмой, то каждая из картин в новелле словно вывешена на сцене обратной стороной к зрителю, так, чтобы он сам не мог ее видеть и, словно пленник платоновской пещеры, судил о ней лишь по косвенной информации - в данном случае со слов действующих лиц ${ }^{\mathrm{II}}$. Этот прием работает особенно впечатляюще применительно к главной из картин «неведомому шедевру» Френхофера, который показан нам исключительно глазами самого художника и двух его коллег, причем их впечатления резко расходятся: где один видит изображение прекрасной женщины, другие обнаруживают лишь бесформенный «хаос красок» [II, p. 436; г, с. 394].

Эти два видения, противоречие между которыми остается неразрешимым из-за недомолвок рассказчика (как на самом деле выглядела картина?), соответствуют двум формам познания, сталкивающимся в новелле и более или менее привязанным к двум ее героям. Иногда их пытаются различить как обучение и инициацию ${ }^{\mathrm{I2}}$, а фактически речь идет об оппозиции профанного и сакрального (мистического) знания.

Профанная версия познания, включающая профессиональное упражнение и стремление постичь тайны мастерства, реализована в истории начинающего живописца-провинциала Никола Пуссена. Бальзак подчеркивает его безвестность, долго не называя его имя, пока он не сделает это сам в необычной форме, соединяющей письмо и художественную графику, - подписью под своим «экзаменационным» эскизом. Он униженно признает собственную неумелость и желание учиться: «Я неизвестен, малюю по влечению и прибыл только недавно в этот город, источник всех знаний» [II, p. 420; I, c. 377]. В первой сцене он, «подобно нерешительному влюбленному» [II, p. 4I3; I, с. 370], робеет войти в дом к именитому художнику Порбусу, с помощью которого надеется приобщиться к высокому искусству Парижа:

\footnotetext{
II Новелла Бальзака неоднократно издавалась с иллюстрациями разных художников (включая Пабло Пикассо), но почти никто из них не решался изобразить иначе как сзади сам «неведомый шедевр» Френхфера, не поддающийся визуальному представлению. См.: [27]. I2 По словам Натали Эйниш, цеховому или академическому ученичеству противостоит в новелле Бальзака «другая форма передачи умения - инициация», включающая магию и мистическую одержимость [24, p. 78]. Ср. также: «Порбус принадлежит к системе, где живописи обучают <...>. Для Френхофера же <...> искусство является предметом инициации» [3I, p. 44].
} 
Юноша испытывал то сильное чувство, которое, должно быть, заставляло биться сердце великих художников, когда, полные юного пыла и любви к искусству, они приближались к гениальному человеку или к шедевру [II, p. 4I4; I, c. 370].

Здесь заранее резюмирован сюжет об освоении художественного мастерства через личность гения и созданный им визуальный образ. Эта история учения-инициации будет рассказана в дальнейшем: Пуссен действительно приблизится к гениальному художнику - правда, не Порбусу, а Френхоферу - и к необыкновенной картине, которую тот объявляет своим шедевром. Это приближение, как положено в процессе инициации, проходит через промежуточные стадии - знакомство с персонажем-посредником (Порбусом), испытание (написание того самого эскиза, по которому суровый Френхофер опознает в юноше художественный талант) и, наконец, дорогую плату за право взглянуть на «неведомый шедевр»: ради любви к искусству Пуссену придется пожертвовать любящей его девушкой. Повествование по большей части фокализовано на его восприятиях и переживаниях, он служит главным свидетелем происходящего, чему соответствует и его «средний», неисключительный характер, как у героев-свидетелей в исторических романах Вальтера Скотта - Уэверли, Квентина Дорварда и других. Однако у Скотта эти вымышленные персонажи служили посредниками между читателем и собственно историческими героями и событиями, а в «Неведомом шедевре» онтологическая перспектива обратная: глазами (по большей части) Пуссена - исторического лица, в дальнейшем одного из самых знаменитых французских живописцев XVII в. - показан вымышленный, сверхисторический персонаж Френхофер, на чьей точке зрения повествование не фокализуется ни разу.

Натали Эйниш убедительно доказала анахроничность фигуры Френхофера: этот мифологизированный, «инвестированный» романтический художник («совершенный образ прирожденного художника» [II, p. 426; с. 383]) якобы живет в XVII в., но тогда к нему не могло применяться даже слово artiste, он должен был бы именоваться peintre, «живописец». В ту эпоху он не мог быть богачом-дилетантом, его мастерская не могла помещаться прямо в квартире, он не мог не иметь учеников, не принадлежать к профессиональной корпорации. Анахроничны и его воззрения на искусство: 
Маргинальность богемы, таинственность инициации, энтузиазм творческой деятельности, рассматриваемой как творчество, а не воспроизведение природы, магия вместо техники, врожденный дар, для которого учитель служит медиумом, а не преподавателем, боговдохновенность всего тела художника <...> так под пером Бальзака создается современная, типично романтическая мифология искусства [24, p. 80].

Предложив было юноше Пуссену стать своим учеником и передать ему свои тайные приемы ${ }^{\mathrm{I}}$, Френхофер скоро забывает о своем обещании, озабоченный своей собственной творческой проблемой; в этот переломный момент новеллы, когда сюжет об ученичестве Пуссена отступает на второй план перед сюжетом о мистических исканиях Френхофера, старый художник вообще перестает слышать своих собеседников, и знающий его Порбус определяет его состояние как мистическое, духовидческое: «Это он ведет беседу со своим духом» (выделено Бальзаком) [II, p. 425; г, с. 383]. В редакции г83І г. «Неведомый шедевр» носил подзаголовок «Фантастическая повесть»; в I837 г. подзаголовок исчез, возможно, в связи с окончанием моды на «фантастический» жанр, но фигура Френхофера вполне сохранила мрачно-колдовской облик. В его лице «было что-то дьявольское» [II, р. 4І4; г, с. 37І], и «слабое освещение лестницы придавало» ему «фантастический оттенок» [II, p. 4I5; I, с. 372]. Френхофер - человек не от мира сего, неизвестно откуда. Он иностранец в Париже - судя по фамилии, немец ${ }^{\mathrm{I}}$, - и его биография темна: с одной стороны, Порбус дважды называет его «старым рейтаром» [II, p. 426; I, с. 384] и «старым ландскнехтом» [II, p. 436; I, с. 394], т. е. наемным солдатом; с другой стороны, тот же Порбус подчеркивает его наследственное богатство («у него мошна набита туже, чем у короля» [II, p. 422; I, с. 380]; «он имел несчастье

I3 «- Юноша, юноша, никакой учитель тебя не научит тому, что я показываю тебе сейчас! Один лишь Мабузе знал секрет, как придавать жизнь фигурам. У Мабузе был только один ученик - я. У меня же их не было совсем, а я стар. Ты достаточно умен, чтобы понять остальное, на что намекаю» [II, р. 42I; I, с. 378].

I4 Как полагают, Бальзак заимствовал эту фамилию, фонетически упростив ее, у немецкого ученого Йозефа фон Фраунхофера (Фраунгофера, I787-1826), знаменитого своими работами по оптике, в частности исследованиями солнечного спектра (см.: [29, p. 235-236]). Эта специфическая научная тема перекликается с рассуждениями бальзаковского Френхофера о преобладающей роли цвета в живописи (правда, они были введены в текст лишь в I837 г.); вообще же оптика для Бальзака и его современников ассоциировалась с Гофманом, представившим ее в «Песочнике» как магическую науку, оживляющую искусственные образы (о чем мечтает и Френхофер). 
родиться богачом» [II, p. 427; г, с. 385]), которое должно было бы избавить его от необходимости наниматься в армию. Таинственность его биографии способствует эффекту романтической фантастики, который определяется не сверхъестественным характером событий (они могут и отсутствовать или естественно разъясняться), а тем, что загадочные лица или события описываются только извне, чужими глазами, при дефиците информации.

Френхофер - жрец или даже шаман искусства, в тайне создающий сверхсовершенную картину, над которой он работает с исключительной тщательностью. Пытаясь написать на холсте абсолютно живую, «воплощенную» фигуру (см.: [17]), он соперничает с природой и богом и косвенно сближает себя с легендарными творцами людей - Прометеем и Пигмалионом ${ }^{15}$. Во время работы он приходит в «фантастический» экстаз, демоническую одержимость:

...Молодому Пуссену казалось, будто этим страннылм человеком овладел демон и фантастически, против его воли водит его рукой. Сверхъестественный блеск глаз, судорожные взмахи руки, как бы преодолевающие сопротивление, придавали некоторое правдоподобие этой мысли... [Іі, р. 422; I, с. 379] (в данном случае речь идет об исправлении Френхофером картины Порбуса).

У него когда-то был наставник, голландский художник Мабузе ${ }^{\mathrm{I} 6}$, которого он поминает часто и по-разному - то как гениального пьяницу, не всегда достигавшего совершенства («Мабузе сам сознавался в этом с грустью, когда не бывал пьян» [II, p. 423; I, с. 380]), то как высшее существо, к которому он взывает как к божеству («О Мабузе!...» [II, p. 420; I, с. 377]). Нельзя, конечно, утверждать, что именно дух голландского живописца вселяется в него в моменты творческого экстаза, но несомненно, что он переживает влияние учителя амбивалентно, наделяя его двусмысленной колдовской силой ${ }^{17}$ : Мабузе вроде

\footnotetext{
I5 «Факел Прометея угасал не раз в твоих руках...» [II, p. 4I7; I, с. 374] - говорит он, критикуя и собираясь поправить картину Порбуса; а затем уже в связи со своей многолетней работой над шедевром: «Нам неведомо, сколько времени потратил властитель Пигмалион, создавая ту единственную статую, которая ожила» [II, p. 425; І, с. 382].

I6 Его настоящее имя - Ян Госсарт (даты жизни варьируются по разным источникам: I478/I480 - I532/I54I). Лишнее напоминание о преклонном возрасте героя новеллы: в I6I2 г. ученику Мабузе Френхоферу должно быть более 8 о лет.

I7 Возможно, именно двусмысленную фигуру Мабузе из «Неведомого шедевра» вспоминал немецкий (люксембургский по происхождению) писатель Норберт Жак, нарекая доктором Мабузе респектабельно-демонического гения зла, который был выведен в его романах и рас-
} 
бы «передал ему секрет рельефа, свое умение придавать фигурам <...> необычайную жизненность» [II, p. 426; I, с. 384], но, по его же словам, передал не до конца, забрал с собой в могилу: «О учитель мой, ты вор, ты унес с собою жизнь!.» [ІІ, р. 420; І, с. 377]. Одержимый этим своим творческим «сверх-я», Френхофер одновременно и ревнует его, и стремится с ним сравняться.

Если Никола Пуссен по характеру напоминает других бальзаковских «провинциалов в Париже» - Растиньяка из «Отца Горио», Люсьена де Рюбампре из «Утраченных иллюзий», - то Френхофер принадлежит к «сверхчеловеческой породе людей всепожирающей страсти, таких как Вотрен, Гобсек, Горио и Валтасар Клаас» [I2, p. I47-I48]. Последний из перечисленных героев - алхимик Валтасар Клаас из повести «Поиски абсолюта» (La Recherche de l'Absolu, I834), а также мыслитель-мистик Луи Ламбер из одноименного романа (Louis Lambert, I832), особенно близки к Френхоферу как по времени своего появления в творчестве Бальзака, так и по специфически познавательной направленности своей страсти. Иx libido sciendi - настоящий трагический hybris; охваченный им герой пытается постичь нечто нечеловеческое, но в итоге гибнет, так и не сумев свершить задуманное ${ }^{\mathrm{r}}$.

\section{Расслоение образа}

Двум типам знания соответствуют в новелле два способа творчества, два вида художественного мимесиса.

Никола Пуссен занимается живописью в профанном режиме пробы. В его жилище «стены были оклеены гладкими обоями, испещренными карандашными эскизами» [II, p. 428; I, с. 385], у Порбуса он доказывает свой талант, скопировав «быстрыми штрихами фигуру Марии» с картины мэтра [II, p. 420; I, c. 377]. Он производит в большом количестве малоценные, учебные произведения, иные из которых прямо копируют чужие: это школьное подражание образцам.

Иначе работает мистик Френхофер. В его доме и мастерской развешаны «чудесные композиции», которые он презрительно объявляет своими

сказах 1920-х гг., а затем стал знаменитым киногероем благодаря фильмам Фрица Ланга. I8 Многие интерпретаторы ничтоже сумняшеся пишут о «самоубийстве» Френхофера, хотя у Бальзака сказано просто «умер в ночь, сжегши все свои картины» [II, p. 438; І, с. 397]. Писатель скорее имел в виду мотивировку не психологическую (самоубийство от отчаяния), а магическую - смерть от утраты своей «внешней души», прежде сосредоточенной в картинах, особенно в одной из них. 
«заблуждениями», промежуточными эскизами [ІІ, p. 435; I, с. 393], основные же свои усилия он употребляет не на создание новых произведений, а на совершенствование старых. В первой сцене он с необыкновенным мастерством поправляет картину Порбуса, а затем выясняется, что он сам уже много лет улучшает собственный шедевр. Его главное искусство - искусство класть новые мазки поверх старых:

Видишь ли, милый, только последние мазки имеют значение. Порбус наложил их сотни, я же кладу только один. Никто не станет благодарить за то, что лежит снизу [II, p. 422; I, с. 379].

Следует критически понимать его эстетический лозунг: «задача искусства не в том, чтобы копировать природу, но чтобы ее выражать» [II, p. 4I8; I, c. 375]. Вдохновенный, одержимый демоном художник стремится «выражать» внешнюю природу, но на самом деле воспроизводит вовне какой-то процесс, происходящий у него в душе и, возможно, не связанный прямо с изображаемой природой. Он «подражает» не чужим образцам и не внешним предметам, а своим собственным внутренним импульсам, позволяющим ему магически заклинать кисть с краской. По ходу работы он «приговаривает», и в его словах преобладают средства заговора - императивы и междометия:

- Паф! Паф! Паф! Вот как оно мажется, юноша! Сюда, мои мазочки, оживите вот эти ледяные тона. Ну же! Так, так, так! [II, p. 422; г, с. 379].

Профанная история Пуссена и сакральная судьба Френхофера сходятся в главном объекте повествования - «неведомом шедевре»: с одной стороны, его мечтает увидеть юный ученик (а также его собственный, «промежуточный» наставник - Порбус), с другой стороны, его пытается довести до совершенства вдохновенный мистик. В итоге оба сюжета заканчиваются катастрофой: явленный было зрителям образ оказывается несостоятельным, не приносит окончательного удовлетворения автору и ничему не может научить неофита.

В соответствии с типичной схемой, согласно которой функционирует интрадиегетический образ в романтической фантастике (см.: [5]), эта картина помещена в динамическую рамку из других визуальных образов, причем у Бальзака они не только размещены вокруг главного образа в пространстве, как 
«чудесные композиции», развешанные по стенам мастерской Френхофера, но и расставлены во временной последовательности по ходу рассказа. Сначала речь идет о прекрасной, но сурово критикуемой Френхофером «Марии Египетской» Порбуса, потом об ученическом эскизе Пуссена, потом в доме Френхофера его гости видят «Адама» Мабузе и еще одну безымянную картину, которую восхищенный Пуссен принимает за творение Джорджоне, а хозяин дома пренебрежительно называет «одним из первых опытов моей мазни» [II, p. 423; I, с. 38I] (эта картина еще сыграет свою роль в сюжете). И даже когда Порбус и Пуссен наконец проникают в мастерскую Френхофера, они, прежде чем добраться до главной, заветной картины, первым делом останавливаются в восторге перед каким-то «изображением полунагой женщины в человеческий рост», а автор опять-таки подчеркивает его промежуточно-эскизный характер - «это я намалевал, чтобы изучить позу, картина ничего не стоит» [II, p. 435; I, с. 393]. Временная, синтагматическая развертка визуальных образов соответствует рассказу об инициации - восхождении по ступеням художественного мастерства, - а теоретические речи Френхофера о живописи, подробные и вдохновенные (хотя, по мнению комментаторов, сбивчивые и малооригинальные) ${ }^{19}$, вводят все эти образы в одну парадигму, это варианты Образа как такового, судьба которого и развертывается в новелле, проходя через разные его воплощения. Визуальный образ одновременно и обобщается, и нарративизируется.

Подобно визуальным образам в романтической фантастике, шедевр Френхофера эфемерен - долгое время «неведомый», скрытый от чужих глаз, он является зрителям лишь однажды на короткое время, и они, как ни силятся, не могут разглядеть его предполагаемое совершенство. Сразу вслед за тем картина гибнет, сожженная собственным творцом, да она и была-то, возможно, лишь его мечтой, иллюзией, для других людей «на его полотне ничего нет» [II, p. 437; г, с. 396], а только их глазами картина нам и показана ${ }^{20}$. Это чисто негативное полотно, несуществующее (вымышленное писа-

I9 Как показал Пьер Лобрие, главным источником эстетических идей, приписанных Бальзаком Френхоферу, была художественная критика Дени Дидро, а сам этот персонаж - гений, не способный создать шедевра, - не лишен сходства с племянником Рамо из одноименного диалога Дидро (см.: [26, p. II6]). Вообще же новелла Бальзака, несомненно, предсказывает ситуацию в искусстве конца ХХ в., когда новое произведение при своем появлении на выставке должно сопровождаться теоретическим манифестом или философским комментарием - широковещательным и глубокомысленным, но часто неконкретным и малодоказательным. 20 Выше уже сказано о невидимости картин для читателя новеллы. Единственный абзац, где шедевр Френхофера описан формально от лица рассказчика, начинается словами 
телем), уничтоженное своим автором, невидимое (для нас, читателей) и, по свидетельству очевидцев, пустое (на нем «ничего нет»: Бальзак шесть раз повторяет устами разных персонажей слово rien, «ничто»). Оно наглядно демонстрирует - насколько «наглядным» может быть вообще словесный текст, - как ничтожится и опустошается субстанциальная полнота зрительного образа, попадающего в сеть виртуальных языковых отношений, например в структуру рассказа.

Несмотря на это, картину Френхофера много раз обсуждали критики, словно реальное произведение искусства, независимое от какой-либо повествовательной рамки. Ее называли предшественницей новейших направлений в живописи - «постклассического искусства» [2I, p. I9I], импрессионизма [26, p. 97], сюрреализма [26, р. I89], абстракционизма [І9, р. 58-78]; следы ее эстетики находили в абстрактном экспрессионизме Джексона Поллока [ı6, p. 44] и Виллема де Кунинга [28, p. І63]; а еще раньше в бальзаковском живописце узнавал себя Поль Сезанн [15, p. 65]. Действительно, созданный Френхофером визуальный объект являет взору странное явление - нулевую степень образа, уничтожение фигурации; так получилось не само собой, по природной случайности, а в итоге усилий художника создать адекватное, «живое» изображение. Его без-образность - высшая форма образа.

Жорж Диди-Юберман обозначил этот визуальный объект французским словом pan, которое в зависимости от контекста может означать «полу одежды» или «часть стены» (тот же латинский корень в словах «панель», «панно») [I7, p. 43-45]. Это плоская поверхность, ограниченная рамкой, но притом еще и гибкая (как ткань одежды) и обладающая некоторой толщиной (как деревянный щит или каменная кладка). В своих рассуждениях о живописи Френхофер подчеркивал, что главная задача - передать глубину пространства на полотне, так чтобы нарисованные фигуры можно было «обойти кругом» [II, p. 4I6; I, с. 373], чтобы ощущался «воздух между этими руками [персонажа] и фоном картины» [II, p. 4I6; I, с. 373]; он даже признавал превосходство скульптуры над живописью, так как она непосредственно воспроизводит объемы: «скульпторы могут ближе подходить к истине, чем мы, живописцы» [II, p. 424; I, с. 382]. В итоге он добился такого эффекта в своем «шедевре», но этот итог парадоксален: объемной оказалась не изображенная фигура (ее вообе

«Подойдя ближе, они заметили в углу картины...», означающими, что и здесь фактически излагаются впечатления персонажей. 
никто не видит, кроме самого автора), а материальный носитель образа, окрашенный холст - у картины появилась не глубина, а толщина. Многократно наложенные мазки образуют «стену из краски» [II, p. 436; I, с. 394], как определяет это озадаченный Пуссен. Стоящий рядом Порбус тут же уточняет: «Под этим скрыта женщина [Il y a une femme là-dessous]!» [II, p. 436; I, c. 394], - догадываясь, что живописец сделал невидимым собственно образ, бесконечно дописывая и докрашивая его ${ }^{21}$ Френхофер, как мы помним, утверждал, что «только последние мазки имеют значение» и «никто не станет благодарить за то, что лежит снизу [ce qui est dessous]»; здесь же «снизу», невидимой под «слоями красок, которые старый художник наложил один на другой, думая улучшить картину» [II, p. 436; г, с. 394], оказалась та самая фигура, которую он желал написать. Возможно, искусный реставратор сумел бы, сняв эти лишние напластования, добраться до скрытой под ними «женщины»...

Итак, «ничто» образуется путем умножения, а не вычитания; это не привативное, а мультипликативное ничто, причем умножаются не просто красочные слои, а образы. При каждой поправке картины Френхофер создавал (по крайней мере так ему казалось) какой-то новый, усовершенствованный образ, и эти образы накладывались друг на друга, словно фотоснимки при многократной экспозиции... или словно разные редакции самого бальзаковского текста ${ }^{22}$. Для зрителей они слились в «беспорядочное сочетание

$2 \mathrm{I}$ В словах Порбуса есть и переносный смысл: «В этом замешана женщина» - намек на эротическое отношение Френхофера к своей нарисованной «возлюбленной».

22 Этот эффект можно объяснить и иначе. В одной из своих речей Френхофер, в духе новейших художественных тенденций, утверждает приоритет света и колорита перед рисунком и готов вообще отказаться от последнего: «Строго говоря, рисунка не существует! <...> Может быть, не следовало проводить ни одной черты, может быть, лучше начинать фигуру с середины, принимаясь сперва за самые освещенные выпуклости, а затем уже переходить к частям более темным. Не так ли действует солнце, божественный живописец мира?» [II, p. 424-425; г, с. 382]. Допустимо предположить, что его работа над шедевром приняла именно такой оборот: решившись писать человеческую фигуру «с середины», одними цветовыми массами без контуров, художник в итоге добился того, что это цветовое пятно расползлось на весь холст, вытеснив любые контуры, кроме «множества странных линий», не обрисовывающих никакой фигуры. У нас нет оснований сделать выбор между этими двумя гипотетическими объяснениями - вертикальным наложением слоев краски и горизонтальным распространением цветовой массы; следует лишь заметить, что первый мотив присутствовал в тексте новеллы начиная с журнальной публикации г83 г г., а второй был введен, вместе с прочими рассуждениями о живописи, лишь в редакцию I837 г., причем в исходной версии текста Френхофер, в той же самой своей реплике, мечтал добиться не идеальной светотени и колорита, а... идеально точного рисунка: «О, верная линия! верная линия! <...> Я до сих пор не уловил верную линию, точный изгиб женских форм...» [II, p. I42I, комментарии]. 
мазков, очерченное множеством странных линий» [II, p. 436; I, с. 394], но этот не-образ - не изначальный хаос и не результат мгновенного творческого/разрушительного акта, а продукт длительной, развернутой во времени деятельности, наподобие повествовательной; он возник по нарративной логике, сравнимой с логикой собственно рассказа о нем.

Однако в представлении самого художника у этой серии отменяющих друг друга образов есть предел, они все отсылают к одному объекту. Задача, которую он стремился решить, - задача фигуративная, пусть даже реальный результат работы катастрофически разошелся с нею. Френхофер - не «беспредметник» XX в., он хотел написать не абстрактную цветовую композицию, но абсолютно похожее изображение, которое создавало бы полную иллюзию натуры, упразднив свою материальную основу: «это не полотно, это женщина» [II, p. 43I; I, с. 389]. Демонстрируя свой шедевр, он убежден, что достиг цели и что зрители вообще не могут отличить написанную им фигуру от реальности; он даже простодушно пытается вернуть их к реальности, указывая на свои инструменты живописца:

Перед вами женщина, а вы ищете картину. <..> Где искусство? Оно пропало, исчезло <...>. Да, да, это ведь картина <...> Глядите, вот здесь рама, мольберт, а вот, наконец, мои краски и кисти... [II, p. 435-436; I, с. 393-394].

По словам Луи Марена, Френхофер добивался эффекта «абсолютной обманки, т. е. предельной изобразительности, где фигуры, находясь в пространстве картины, перестают что-либо изображать и вместо этого буквально предстают как то, чем они являются в пространстве реальности» [29, р. 238]. Иными словами, исходным пунктом его деятельности остается натура, модель - та «женщина», которую он своим творческим взором видит вживе, вместо «исчезнувшего» «искусства», а его коллеги, наоборот, лишь угадывают «внизу» под нагромождением красок.

Об этой женщине он высказывается уклончиво и путано. Ее зовут Катрин Леско, в разных редакциях новеллы у нее то появляется, то исчезает прозвище La Belle-Noiseuse; это вымышленное лицо, ни разу

Очередной пример вариативности «колышущегося» бальзаковского текста: в данном случае варьируются эстетические установки главного героя - то он сторонник «линии» (как современник Бальзака Энгр), то «цвета» (как Делакруа). 
больше не упоминаемое в произведениях Бальзака, и комментаторы могут лишь строить догадки о происхождении ее фамилии [25]. Наиболее правдоподобны две из них: Lescault созвучно с фамилией Манон Леско (Lescaut) из романа аббата Прево и с французским названием Шельды (l'Escaut), главной реки Фландрии, родины Порбуса и Мабузе ${ }^{23}$. Однако ни та, ни другая ассоциация не дает надежных данных для понимания сюжета картины.

В классической живописи выбор объекта определялся жанром произведения, и категория жанра оставалась значимой для изобразительного искусства первой половины XIX в., когда писалась и переписывалась бальзаковская новелла, не говоря уже о XVII в., когда происходит ее действие. Каков же жанр картины Френхофера - а стало быть, кто его героиня?

$\mathrm{B}$ «Неведомом шедевре» упоминаются одна за другой две картины «Мария Египетская» Порбуса и «Адам» Мабузе (первая - вымышленная, вторая - лишь отчасти) $)^{24}$, - которые относятся к жанру религиозной живоnиси. Можно было бы ожидать, что и Френхофер, задумав создать сверхсовершенный шедевр, тоже обратится к этому высшему жанру; тщательное сокрытие картины само по себе является средством ее сакрализации и заставляет подозревать в ней некое сверхприродное содержание; наконец, на ее священную тематику косвенно намекает одно ее беглое определение - хотя формально оно лишь гипотетически излагает переживания ее автора. Френхофер мысленно сравнивает красоту своей Катрин Леско с красотой приведенной к нему натурщицы:

В возгласе Френхофера все еще чувствовалась любовь. Он словно кокетничал с созданным им подобием женщины и заранее предвкушал, как его дева победит своей красотой настоящую, живую девушку [ІІ, р. 434; г, с. 392].

Наш перевод этого пассажа расходится с переводом И. Брюсовой, которая пыталась сгладить противоречия бальзаковского текста. Действи-

23 Во Фландрии происходит действие двух других «философских этюдов» Бальзака, писавшихся в одну пору с «Неведомым шедевром»: «Иисус Христос во Фландрии» (Jésus-Christ en Flandre, 1831/1846) и «Поиски абсолюта» (1834).

24 Яну Госсарту (Мабузе) принадлежит целая серия картин на сюжет «Адам и Ева»; два персонажа всякий раз изображены вместе, в динамичных позах, не позволяющих отделить одну фигуру от группы. 
тельно, высокий термин «дева» (vierge) при характеристике живописного сюжета читается как отсылка если не к деве Марии ${ }^{25}$, то к какой-то другой легендарной целомудренной особе, и тогда понятно, чем эта идеальная фигура превосходит «настоящую, живую девушку»; однако с этим плохо вяжутся чувства, испытываемые художником к «созданному им подобию женщины», - не только «любовь», но и «кокетство». Не вяжется с этим и то, как он немного выше описывает свою композицию:

Тот, кто посмотрел бы на нее, увидел бы женщину, лежащую под пологом на бархатном ложе. Близ женщины - золотой треножник, разливающий благовония. У тебя явилось бы желание взяться за кисть шнура, подхватывающего занавес, тебе казалось бы, что ты видишь, как дышит грудь... [II, p. 432; I, с. 390].

Поза, обстановка, атрибут - золотая кадильница, обозначающая негу и сладострастие, - никак не согласуются со священным сюжетом и скорее напоминают знаменитые картины Тициана и Веронезе, изображающие Венеру ${ }^{26}$. Подобная трактовка сюжета картины могла лишь угадываться в журнальной публикации и была эксплицирована в первом книжном издании «Неведомого шедевра» (I83I): в нем Френхофер дважды - словно боясь, что мы не запомним, - повторяет, что на картине изображена куртизанка². Однако в последней редакции текста (I847) эти разъяснения опять исчезли, и героиня картины снова именуется просто «Катрин Леско». Бальзаковский текст опять колышется, загадка женщины на картине то разрешается, то вновь затемняется. Загадывалась она в первой части новеллы, а свое разрешение (эфемерное и неполное)

25 Слово vierge написано у Бальзака со строчной буквы, а не с прописной, как обычно принято при обозначении богоматери. Однако строчная буква тоже может употребляться, именно в тех случаях, когда речь идет не о евангельском персонаже как таковом, а метонимически о стандартном сюжете изобразительного искусства (les vierges sculptées, etc.). 26 См.: [26, p. 43]. Венеру упоминает сам Френхофер в своих мечтаниях об идеальной натуре («но где же найти ее живой < ...> эту необретаемую Венеру древних?» [II, p. 426; I, c. 383-384], а затем ее имя вновь возникает как метафора при описании его произведения: «Нога на картине производила такое же впечатление, как торс какой-нибудь Венеры из паросского мрамора среди руин сожженного города» [II, р. 436; г, с. 394]. В «Эликсирах сатаны» Гофмана - романе, который считают одним из сюжетных источников «Неведомого шедевра», - одержимый бесом художник Франческо пытается кощунственно пародировать икону святой Розалии, написав в ее облике Венеру.

27 «..Прекрасная куртизанка Катрин Леско, по прозванию La Belle-Noiseuse» [II, p. I424, комментарий; г, с. 39I]; «...для моей Катрин Леско, прекрасной куртизанки» [II, p. I425, комментарий; г, с. 393]. 
получает во второй - как и в других случаях, синтагматическая развертка повествования соответствует парадигматической смене версий текста.

Итак, Катрин Леско - скорее блудница, чем святая, хотя примененное к ней определение «дева» так никуда и не делось из текста. Это, однако, не разрешает вопрос о жанре френхоферовского шедевра. Действительно, у религиозной или же мифологической картины (будь то с изображением христианской «девы» или языческой «Венеры») часто бывает живая модель, натурщица; их может быть даже несколько, и их образы, слитые вместе, служат означающим для идеального, виртуального образа легендарного персонажа. Такова стандартная референциальная ситуация классической живописи: картину называют именем воображаемого героя, а не реальной модели. Напротив того, у Бальзака куртизанка Катрин Леско, даже если она и написана (такое могло быть) в облике богини Венеры, сама дала свое имя и прозвище картине Френхофера - она не означающее, а означаемое этой картины. Стало быть, картина относится к другому жанру - жанру портрета. Такое определение однажды действительно применяется к ней, хотя опять-таки вскользь и уклончиво, так, что его можно приписывать либо рассказчику, либо (в режиме несобственно прямой речи) кому-то из персонажей: «..стали искать портрет, о котором шла речь, но не могли его найти» [II, p. 435; I, c. 393$]^{28}$. По существу оно столь же сомнительно, сколь и первое определение: Френхофер, по его словам, работает над картиной целых десять лет - какой портрет пишется так долго, и какая женщина станет ждать столько времени своего портрета? И даже если допустить, что художник когда-то давно сделал с нее первый набросок, а дальше совершенствовал его по памяти (жива ли еще Катрин Леско? и жила ли она когда-нибудь вообще, или это плод фантазии старого живописца?), остаются необъяснимыми его жалобы на нехватку идеальной натуры, «небесной красоты», в поисках которой он готов отправиться в Азию и даже спуститься «в загробный мир» [II, p. 426; I, с. 384]. Действительно, портрет - это такой жанр, где не требуется изображать идеально прекрасного человека: художник должен, используя ресурсы своей техники, передать индивидуальность реального, конкретного лица; Френхоферу же,

28 Слова «портрет, о котором шла речь» (в оригинале le portrait annoncé) [II, p. 435; I, c. 393] отсылают к предыдущим репликам Френхофера; однако он ни разу не употреблял слова «портрет», пользуясь более общим термином «произведение» [II, р. 434; I, с. 393]. Можно предполагать недоразумение: зрители картины поняли из объяснений ее автора больше, чем он сам имел в виду сказать. 
судя по его словам, для завершения картины недостает одновременно и техники («я, вероятно, ошибся в каких-нибудь частностях» [II, p. 430; г, с. 388]), и натуры. Впечатление такое, что он пытается написать на полотне, условно говоря, Венеру, но почему-то называет ее не Венерой, а Катрин Леско: стремится к идеалу красоты, но фатально сбивается на его эмпирические индивидуальные воплощения.

Симптомом этого противоречия является «бурно-эротическое отношение, связывающее Френхофера» с Катрин Леско [г3, р. 83], т. е. перверсивное отношение к образу. Эротическое желание может направляться лишь на конкретный объект, а не на абстрактный идеал, и художник-иконофил видит на своей картине не обобщенно-воображаемую фигуру, а реальную (?) модель, которую называет своей «супругой», «женой» ${ }^{29}$ и с которой «живет уже десять лет».

Моя живопись - не живопись, это чувство, страсть! <... Разве обладаем мы фигурами Рафаэля, ариостовской Анджеликой, дантовской Беатриче? Нет! мы видим лишь их формы! Так вот, творение, которое я храню наверху под замком, - исключение в нашем искусстве; это не полотно, это женщина [II, p. 43I; I, c. 389].

Превратив искусственный образ в сакрально-эротический «идол» [II, p. 432; I, с. 390], художник ревниво прячет его от чужих глаз, вписываясь в ряд типичных романтических мужей-ревнивцев - вместе с восточными деспотами, держащими своих жен взаперти в гареме, или же с героем греческой легенды царем Кандавлом (выведенным позднее, в I844 г., в одноименной новелле Теофиля Готье), который тоже долго не решался никому показать свою красавицу-супругу.

\section{Прекрасная прекословница}

Итак, на «неведомом шедевре» Френхофера - по крайней мере по авторскому замыслу - не миф и не портрет, а лукавая подмена одного другим; образ фантазматически слипается с собственным объектом. В этом контексте следует истолковывать и главное сюжетное событие новеллы

29 В большинстве редакций текста (кроме собрания сочинений I846 г.), Порбус просит Френхофера показать свою «возлюбленную», maîtresse [ıг, p. 424; г, с. 38г]. 
Бальзака - появление второй модели, которая понадобилась Френхоферу, чтобы завершить свой шедевр. Зачем нужна вторая модель - об этом он говорит очень кратко, в связи со своей затеей поехать на Восток: «чтобы там найти себе модель и сравнить свою картину с различными натурами» [II, p. 430-43I; I, c. 388]. И потом повторяет, уже увидев приведенную к нему красавицу: «О, предоставьте мне ее на одно мгновение <...> и вы сравните ее с моей Катрин» [II, p. 434; I, с. 392]. Вторая модель нужна не для изображения, а для сравнения с первой, уже написанной красавицей; сравнивать будет сначала автор, а потом зрители-художники. Чтобы окончательно убедиться в совершенстве картины, ее нужно увидеть со стороны, сопоставить с натурой - но не с той, которая на ней собственно написана; с той же целью в первой части новеллы, закончив поправлять картину Порбуса, Френхофер разглядывает ее в зеркало, т. е. в искусственно искаженной, «остраненной» перспективе ${ }^{30}$. Семиотически это можно соотнести с трехчленной схемой знака: в нем взаимосвязаны материальное означающее (расписанный холст) и виртуальное означаемое (фигура Катрин Леско), но образуемая ими структура должна быть привязана, словно якорем, к реальному референту - каковым в данном случае и служит новая натурщица. Она вступает в действие во второй части новеллы и действует как разлагающий, аналитический элемент образа, делающий явным его имплицитное расслоение.

Двойственность была имплицитно присуща уже самой гипотетической героине картины. Как сказано выше, в ряде редакций новеллы она носит прозвище La Belle-Noiseuse. По форме оно соответствует именам других старинных куртизанок из произведений Бальзака - La Belle Imperia (одна из героинь «Озорных рассказов», Contes drolatiques, I832) или La Belle Romaine (эпизодический персонаж повести «Нелюбимый сын», L’Enfant maudit, I837). По смыслу же оно амбивалентно, подобно «фантастическому» облику художника, создавшего портрет Катрин Леско: она «прекрасная» (belle), но и «сварливая», «спорщица», «прекословница» (примерно таково значение редкого слова noiseuse) ${ }^{31}$. Референциальная двойственность живописного

30 Такой прием сходен с другим, нередко применяемым живописцами, - перевернуть картину вверх ногами, чтобы убедиться в уравновешенности ее композиции (благодарю за это указание О.Е. Этингоф).

3I Философ Мишель Серр улавливал в эпитете noiseuse старинное значение слова noise «шум, гам» (ср. современное английское noise). Героиня картины, по его мысли, воплощает стихийно-бесформенное начало, отчего она и непредставима в виде устойчивого образа; «la belle 
образа отражается в морально амбивалентном прозвище героини ${ }^{32}$, которая двусмысленна и по своему социальному статусу - куртизанка, воплощение греховной любви. Последний мотив подчеркнут, так как фигура куртизанки, вообще весьма значимая для Бальзака (ср. роман «Блеск и нищета куртизанок», Splendeurs et misères des courtisanes, I838-I847), представлена в «Неведомом шедевре» еще двумя женскими персонажами. Один из них - святая Мария Египетская на картине Порбуса. Согласно ее житию из Золотой легенды», уже после своего религиозного обращения, во время паломничества из Египта в Иерусалим, ей пришлось расплатиться собственным телом за перевоз по морю, в последний раз прибегнув к своему низменному ремеслу. Именно этот двусмысленный эпизод изображен Порбусом, и юный Пуссен, восхищаясь его работой, особо отмечает «выражение нерешительности у лодочника» [ІІ, р. 420; І с с. 377] - подразумевается, что эта «нерешительность» вызвана двойственностью самой Марии, которая вот в этот самый момент превращается из блудницы в святую отшельницу.

В роли продажной женщины - продаваемой за право взглянуть на запретный образ - чувствует себя и единственная реальная, т. е. не нарисованная героиня «Неведомого шедевра», подруга Никола Пуссена Жиллетта. Противясь его уговорам, она не хочет позировать Френхоферу, для нее это значит «погубить себя» [II, p. 429; г, с. 387], отдаться - пусть лишь «визуально», в виде образа - чужому человеку. Показ эквивалентен проституции; в том же смысле и Френхофер не желает выставлять напоказ свою Катрин, объясняя, что это было бы «бесчестием» и «отвратительной проституцией» [II, p. 43I; I, с. 389]; так же и Жиллетта, приведенная в его мастерскую, напоминает своим видом «юную грузинку, пугливую и невинную, похищенную разбойниками и отведенную ими к работорговцу», и слезы у нее на глазах являют «немой укор насилию над ее стыдливостью» [II, p. 433; I, c. 39I].

noiseuse - это море, ропот волн» [35, p. 50]. Такая идея соответствует подвижно-«колышащейся» природе всего бальзаковского текста, хотя вычитывать ее в конкретном прозвище персонажа, пожалуй, выглядит натяжкой, а морские метафоры автора - и вовсе проекцией на текст его личного биографического опыта (Мишель Серр в молодости служил офицером военного флота).

32 Cр. амбивалентный облик Венеры Илльской в одноименной новелле Мериме (La Vénus d'Ille, I835): «На этом лице - при всем том невероятно красивом - читались презрительность, насмешливость, жестокость. Поистине, чем больше я смотрел на эту великолепную статую, тем тягостнее ощущал, что такая чудная красота может сочетаться с полной бесчувственностью» [32, p. 97]. 
По замечанию одного критика, «“Неведомый шедевр” состоит из истории трех пар - Порбуса и Марии Египетской, Пуссена и Жиллетты, Френхофера и Катрин Леско..» [20, р. 47]. Можно добавить, что все эти пары изоморфны: в каждой из них есть художник + женщина, соотнесенная с живописным образом (изображенная, позирующая) и так или иначе реально или символически проституирующая себя. Дело обстоит даже еще сложнее: слово «проституция», сказанное в сердцах Френхофером, относится не к профессии Катрин Леско, а к предполагаемой демонстрации ее сакрализуемого, свято оберегаемого образа; блудница Мария Египетская уже стала подвижницей, и «лодочник», которому она отдается, в замешательстве ощущает себя участником священного обряда; наконец, символическая измена Жиллетты мало того что носит образно-визуальный характер, но и совершается не ради денег или иных выгод, а ради чести, чтобы доказать возлюбленному свою готовность всем пожертвовать ради него. Проституция в «Неведомом шедевре» - не корыстная, а жертвенная, а то и просто сакральная, как у пушкинской Клеопатры из написанных в те же годы «Египетских ночей» («Клянусь, о матерь наслаждений, / Тебе неслыханно служу..»).

Известно, как внимателен обычно Бальзак к денежным расчетам и сделкам своих персонажей. В «Неведомом шедевре» мотив денег возникает всего однажды, когда Френхофер щедро платит два золотых за ученический эскиз Пуссена: сумма очевидно завышенная, но это вообще не плата за работу, а благотворительное пожертвование старого и богатого художника талантливому и бедному собрату. Убеждая самолюбивого юношу не отвергать эту помощь, его старший коллега Порбус сравнивает Френхофера с «королем» - действительно, принять милость от короля не может быть стыдно; т. е. в мире новеллы нет буржуазной расчетливости, заботы о верной цене, деньги служат не рыночным средством платежа, а роскошным царским даром. Так же функционируют в этом мире и женщины: ими символически обмениваются мужчины, но это возвышенно-дарственный обмен. Он соревновательный, ставки в нем должны возрастать 33 , и в конце концов на карту ставится то, что дороже всего: живая Жиллетта обменивается - в конечном счете добровольно обменивает себя,

33 «ренхофер втягивается в игру потлача, дара и ответного дара...» [16, p. 23]. Как известно, по теории Клода Леви-Стросса обмен женщинами (в ходе межклановых брачных союзов) является одним из трех главных видов обмена в традиционных обществах, наряду с обменом словами и дарами. 
свой зримый образ - на нарисованную Катрин Леско, на право созерцать ее образ, предоставляемое ревнивым Френхофером. «Но ведь тут женщина - за женщину!» [II, p. 432; I, с. 390], - уговаривает старика Порбус, который служит посредником и в этой сделке. Он мог бы сказать «образ за образ», потому что в мире профессиональных образотворцев это и есть высшая ценность.

Как показал Юбер Дамиш, обмен в бальзаковском рассказе принимает разнообразные формы, но все время происходит по поводу искусства, по поводу визуального образа: вначале между художниками циркулируют имена (Пуссен подписывает свой рисунок, Френхофер готов подписать исправленную им картину Порбуса), а «после этого обмена именами, после обмена стыдливостью, если не девственностью, двух женщин [добавим: не просто женщин, а моделей. - С.3.], следует обмен взглядами, которым завершается цикл» [І6, p. 24]. Профессиональные взгляды двух художников - Френхофера на Жиллетту и Пуссена и Порбуса на его картину - получают символическую весомость как результат других, предшествующих обменов; эти обмены проецируются на главный визуальный образ новеллы, наполняя его энергией повествовательного сюжета. Сама по себе картина, где «ничего нет», оставалась бы лишь курьезом, не будь в нее впечатаны, вложены уже после ее написания судьбы трех участников обмена - Пуссена, жертвующего любимой девушкой, Жиллетты, теряющей любовь, и самого Френхофера, чья работа утрачивает цель: «У меня нет ни таланта, ни способностей, я теперь просто богатый человек, который ходит, никуда не идя» [II, p. 438; г, с. 396]. Заветная картина для них словно игорный стол, на который все они выложили свои ставки - и все проиграли.

Как же деформируется визуальный образ, будучи включен в этот сюжет? Обмен между людьми - процесс, развернутый во времени, образующий «историю» и, что еще важно, дискретный. В нем четко разделены и противопоставлены позиции «контрагентов», и Бальзак подчеркивает это, например, в драматическом диалоге Пуссена и Жиллетты, которые непрестанно обмениваются не просто словами, но вызовами, уступками и жертвами, разыгрывая не столько любовную близость, сколько соперничество в чести. Этой своей дискретностью обмен противоречит творческим установкам Френхофера; через него диегезис разъедает мимесис, дисконтинуальное начало рассказа вторгается в континуальность образа.

Френхофер - убежденный художник-континуалист; он отрицает рисунок, проводящий дискретные членения на картине, и мечтает воссозда- 
вать натуру, состоящую «из ряда округлостей, переходящих одна в другую» [II, p. 424; I, c. 382]. Его учитель Мабузе в качестве фокуса умел представить гнущуюся жесткими складками бумагу как мягко, непрерывно струящийся шелк, наподобие полы одежды (по-французски рап, согласно трактовке Ж. Диди-Юбермана):

...когда ему случилось пропить шелковую узорчатую ткань, в которую ему предстояло облечься для присутствия при торжественном выходе Карла Пятого, Мабузе сопровождал туда своего покровителя в одеждах из бумаги, разрисованной под шелк. Необычайное великолепие костюма Мабузе привлекло внимание самого императора, который, выразив благодетелю старого пьяницы восхищение по этому поводу, тем самым способствовал раскрытию обмана [II, p. 427; I, c. 384].

В этом анекдоте ${ }^{34}$ идея иллюзорной имитации непрерывной, хотя гибкой поверхности представлена комически; но того же эффекта всерьез добивается и Френхофер на своей картине. Михаил Ямпольский сближает его с эффектом «близкого», не-дистантного зрения, когда объект видения как бы вплотную, без перспективного разрыва «прилипает» к сетчатке глаза и соответственно не дает дискретно-расчлененного образа: «Френхофер создает свою живопись в соответствии с принципами изображения на сетчатке <...>. Чистое, нефигуративное видение - это видение чистого цвета, заменяющего фигурацию “оградой из красок” $[9$, с. I94, г96]35.

Действительно, для зрителей созданный Френхофером визуальный объект сплющен, лишен перспективы: вместо видимой глубины пространства - толща наложенных друг на друга цветовых пятен. И вот на этом-то сплошном фоне выступает одна опознаваемо фигуративная, т. е. резко ино-

34 Он позаимствован Бальзаком из книги Ж.-Б. Дешана «Жизнь фламандских, немецких и голландских живописцев» (I753-I763; см.: [26, p. 46]) и рассказан в новелле Порбусом, а «покровителем» и «благодетелем» Мабузе был, как можно понять, сам молодой Френхофер. 35 «Ограда из красок» - вариант перевода выражения muraille de peinture, «стена из красок». Трактовки Диди-Юбермана и Ямпольского не вполне совпадают: один подчеркивает гибкость и толщину рап, другой - абсолютную плоскость, отсутствие всякой глубины при «видении на сетчатке». Окончательно разрешить это разногласие нельзя: картина Френхофера - вымышленная и не может быть предъявлена для объективного анализа, а ее описание в тексте не дает достаточных оснований для выбора одного из двух объяснений. 
родная деталь - виднеющийся «в углу картины кончик голой ноги» [II, p. 456; I, с. 394]. Эта отделенная от тела, неизвестно кому принадлежащая ножка - элемент дискретности, внедренный в визуальный образ.

В ней, безусловно, отражается фетишистское отношение Френхофера к образу/телу Катрин Леско. Как комментирует психоаналитик Поль-Лоран Ассун, «“обожать” женщину удается лишь при ее “разделении на кусочки”», и таким способом мужчина-художник пытается избыть свой страх кастрации [Іо, p. I05, I07]. В плане собственно визуальных ассоциаций ножка «в углу картины» (вероятно, нижнем) кажется выступающей из-под полы, из-под подола - бесформенного нагромождения цветовых пятен, закрывающего от зрителей всю остальную фигуру словно платьем; возможно, Бальзак более или менее бессознательно имел в виду такую расхожую эротическую образность, изобретая главную деталь своей новеллы ${ }^{36}$. Тогда «хаос красок» на картине объясняется ревнивым стремлением живописца одеть вожделенную фигуру, оставив на виду только ножку-синекдоху, часть, по которой предлагается представлять себе целое ${ }^{37}$.

Можно, однако, пойти еще дальше. Если от гипотетической психологии Френхофера вновь обратиться к повествовательному развитию

36 Женская ножка как эротический фетиш - общее место в культуре XVIII - первой половины XIX вв.: см., например, во Франции роман Ретифа де ла Бретона «Ножка Фаншетты» (Le Pied de Fanchette, I769), а в русской литературе - знаменитое отступление о ножках в первой главе пушкинского «Евгения Онегина». В интертекстуальном плане особенно любопытна фантастическая новелла Теофиля Готье «Ножка мумии» (Le Pied de momie, I840): открывающая ее сцена в лавке древностей очевидным образом отсылает к «Шагреневой коже» Бальзака (La Peau de chagrin, I83I), а потому возможно, что и ее заглавный мотив ножка, отделенная от тела, - является визуальной реминисценцией из другого произведения того же автора, «Неведомого шедевра».

37 Так объясняет это Мишель Бютор: «..ББальзак - ученик Кювье, и по ноге надо уметь восстановить всю женщину» [І4, p. ІІг]. Иначе представляет дело Жорж Диди-Юберман. Согласно его интерпретации, «хаос красок», лишивший картину фигуративности, возник при попытке художника вывернуть вожделенное женское тело наизнанку, показать его в оптически невозможном внутреннем ракурсе: «Этот “хаос красок”, конечно, наводит на мысль об аутоскопии. Красочное полотнище [pan] на картине Френхофера <...>, возможно, представляет собой кровавую изнанку портрета Катрин: Катрин, как она видится изнутри» [I7, p. I26]. Если принять эту эффектную, хотя трудно доказуемую гипотезу, то фигуративная ножка окажется последним остатком «внешнего», не вывернутого тела, чем-то вроде Ахиллесовой пяты, не преображенной творческим радикализмом художника. Она не «торс какой-нибудь Венеры из паросского мрамора среди руин сожженного города» [II, p. 436; I, c. 394], она сама является руиной, остатком инвертированной, до неузнаваемости переработанной натуры. 
новеллы, то загадочная деталь на картине заставляет задаться вопросом о сеансе позирования, непосредственно предваряющем ее предъявление зрителям. Этот сеанс представлен в рассказе как «черный ящик»: на «входе» в мастерскую художника вступает натурщица, а на «выходе» появляется картина, которую художник объявляет своим «совершенным» творением [II, p. 434; г, с. 393]. Что же произошло в промежутке, за дверями мастерской?

Разумеется, подобные вопросы - «а как там было на самом деле?» следует ставить осторожно, они не всегда применимы к художественному повествованию. В его вымышленном мире существуют только факты, прямо или хотя бы намеком упомянутые в рассказе, и не существуют никакие другие, даже логически вытекающие из них ${ }^{38}$. Оттого бессмысленно гадать, например, о том, зачем в первой части новеллы Френхофер пришел в мастерскую Порбуса (мотив его визита никак не объяснен в тексте); или как случилось, что начинающий, нищий, никому не известный живописец Пуссен, едва приехав в Париж из провинции, завоевал там любовь красивейшей девушки Жиллетты (об этом сказано одной фразой, в самых общих словах). Подобные обстоятельства находятся за рамками рассказа, и их необъясненность входит в норму художественной условности. Иначе, однако, обстоит дело с позированием Жиллетты: это кульминационная сцена новеллы, к ней драматически подводит все предыдущее действие, и ее оккультация специально подчеркивается как повествовательная аномалия. Эта сцена не только выведена за рамки читательского кругозора (как и все произведения искусства, фигурирующие в новелле), но и скрыта от остальных персонажей - от Порбуса и Пуссена, которые в течение всего сеанса ожидают у двери мастерской и могут лишь строить предположения о том, что творится внутри: «Ах, она раздевается... Он велит ей повернуться к свету!.. Он сравнивает ее...» [II, p. 434; І, с. 393].

Фокализуя рассказ на этих не-видящих свидетелях, Бальзак искусно оставляет без ответа деликатный вопрос: действительно ли Жиллетте пришлось обнажаться перед Френхофером? Положительный ответ как будто очевиден и подтверждается рядом косвенных указаний: так предполагают

38 См.: [33, p. I34]. Томас Павел приводит пример как раз из Бальзака: в вымышленном мире «Человеческой комедии» есть персонаж Вотрен, но нет его предков, и мы не вправе строить никаких догадок о том, кем были эти люди. 
Порбус и Пуссен, мыслью об этом заранее терзается сама стыдливая девушка, на это намекает, по крайней мере внешне, и реакция Френхофера на ее появление («он, по привычке художников, так сказать, раздевал девушку взглядом, угадывая в ее телосложении все, вплоть до самого сокровенного» [II, p. 433; I, c. 39I-392] 39. Однако оговорки рассказчика обозначают гипотетичность изложения мыслей персонажа; в описаниях же своей картины тот ни разу не говорит определенно, что ее героиня изображена обнаженной; упоминаются лишь некоторые части ее тела - «как дышит грудь» [II, p. 432; г, с. 390] и т. д., - которые могли бы быть и прикрыты одеждой. Жорж Диди-Юберман отметил, что Френхофера-художника вообще интересует не столько нагота, сколько телесность изображаемой фигуры [I7, p. 2о] - «живая, пористая, влажная, теплая» поверхность кожи, где чувствовались бы «лоск и кровь» [I7, p. 34]. Такого эффекта можно добиться и не раздевая модель донага - достаточно лишь тщательно написать ее лицо, руки... или босую ногу.

Сеанс позирования Жиллетты не должен был продолжаться долго - «предоставьте мне ее на одно мгновение», просил Френхофер. Строго говоря, задуманное им сравнение живой натуры с готовой картиной вообще вряд ли могло называться позированием, однако Пуссен, убеждая свою подругу согласиться на неприятное для нее испытание, произносил именно такое слово: «...тебе пришлось бы позировать перед другим» [II, p. 429; I, c. 387]. А что если он угадал верно? Что если Френхофер, художник-перфекционист, мастер усовершенствований и «последних мазков», при виде новой прекрасной модели не удержался и взялся-таки снова за кисть? В первой части новеллы рассказано, как стремительно он умеет переделать картину; но, конечно, за короткое время он все же не успел бы радикально переписать «портрет» Катрин Леско, изобразив на нем Жиллетту. Что он мог бы сделать - это закрасить его, одеть «хаосом красок», подобно тому как в дальнейшем, после демонстрации коллегам, он «задергивал свою Катрин зеленой саржей» [II, p. 438; г, с. 396-397]. Но если все-таки допускать, что в картину каким-то способом была вписана сама Жиллетта, то напрашива-

39 Это казалось само собой разумеющимся и одному из первых рецензентов «Неведомого шедевра» Эмилю Дешану: «Никола Пуссен <...> заставляет свою восхитительную и стыдливую возлюбленную показываться обнаженной постороннему человеку... (Deschamps E.M. de Balzac // Revue des deux mondes. 1831. Vol. 4. Р. 313-322; цит. по предисловию Р. Гиза к «Неведомому шедевру» в издании «Плеяды»: [ІІ, р. 407]). 
ется иная гипотеза: Френхофер написал с нее ножку, единственную опознаваемо-фигуративную деталь на своей картине, единственный «реалистический» элемент, добавленный к «абстрактной» композиции; единственный внятный образ, который еще связывает видение безумного живописца с видением его здравомыслящих собратьев. Если так, то на картине совмещены не просто два разных образа, но образы двух разных женщин - один вообще незримый (фигура полулегендарной Катрин Леско), другой фетишистски частичный (нога реальной Жиллетты).

Следует подчеркнуть: эти гипотезы недоказуемы, и Бальзак, надо полагать, намеренно сочинял финал своей новеллы так, чтобы заставить читателя теряться в «фантастических» догадках ${ }^{40}$. Для рецептивной структуры текста существенно именно то, что своими недомолвками и двусмысленностями он побуждает читателя к подобным гипотезам. Схема «черного ящика» получает специфическое наполнение: на входе - новая натурщица, отличная от первоначальной модели картины, на выходе - деталь самой картины, отличная от основного визуального объекта, который на ней представлен. Девушка Жиллетта и ножка на холсте уравниваются своей инаковостью, инородностью по отношению к картине или к ее референту. В любом случае паралогическая логика повествования - «после этого, значит вследствие этого» [2, с. 207] - заставляет предполагать, что лицезрение Жиллетты повлияло на решение Френхофера показать зрителям свой шедевр, а стало быть именно оно и повлекло за собой катастрофическую развязку. Энергия читательских ожиданий, драматическая энергия вызовов и уступок между персонажами, которые привели Жиллетту в мастерскую художника, была слишком велика, чтобы разрядиться простым сравнением двух женских фигур, при котором художник всего лишь убедился бы в превосходстве своего произведения над живой натурой. Эта энергия должна была как-то деформировать сам сокровенный образ на холсте.

Иконическая инородность Жиллетты - мотив, развернутый на всем протяжении рассказа о ней. В отличие от прочих персонажей новеллы (считая

40 Подобный прием - подчеркнутая недосказанность кульминационной сцены, когда читатель не может даже угадать, какие события (вероятно, как-то связанные с эротикой) в ней происходят, - практиковался в «неистовой» и «фантастической» литературе начала I830-х гг. В другой работе мы разбирали, например, повесть «Летиция» из сборника Эдуарда Пуйя и Шарля Менетрие «Калибан» (Caliban, I834), где в таком уклончивом модусе сообщалось о страшной мести героини неверному любовнику. См.: [6, с. Іоо]. 
даже «закадровых» вроде Мабузе), эта девушка не только не является художницей, но и вообще враждебна образу. Она ревнует Пуссена к своим собственным изображениям, которые он с нее пишет, - «потому что в эти мгновения твои глаза мне больше ничего не говорят. Ты совсем обо мне не думаешь, хоть и смотришь на меня...» [II, p. 428-429; I, с. 385]; во время работы художник видum не модель, а образ, встающий в его воображении. Та же неприязнь к образу (а не просто стыд выставляться напоказ) была глубинной причиной ее нежелания позировать Френхоферу; если же в последний момент она все-таки дала согласие, то потому, что увидела, как Пуссен опять изменяет ей с образом, на сей раз с чужим, уже упоминавшимся в новелле раньше:

Она с гордостью подняла голову и бросила сверкающий взгляд на Френхофера, но вдруг заметила, что ее возлюбленный любуется картиной, которую при первом посещении он принял за произведение Джорджоне, и тогда Жиллетта решила:

- Ах, идемте наверх. На меня он никогда так не смотрел [II, p. 434; I, c. 392].

В первой редакции текста, удалившись позировать Френхоферу, она вообще бесследно исчезала из рассказа; в дальнейших редакциях она появляется вновь на последней странице, «забытая в углу» [II, p. 438; г, с. 396] спорящими между собой живописцами, потерявшая свою любовь и готовая умереть от отчаяния. Она остается единственным, кто совершенно не интересуется произведением Френхофера, не желает даже взглянуть на него. Подобно куртизанке Катрин, стыдливая Жиллетта на свой лад играет роль «прекрасной прекословницы», с нею связаны дискретно-негативные коммуникативные жесты новеллы - драматический диалог, обмен, несогласие, жертвенность. Она воплощает нарративное, а потому иконоборческое начало, и живописный шедевр Френхофера, да и он сам, не выдерживают встречи с нею4.

4I Если вновь обратиться к парадигматическому развитию текста, то она занимает все более значимое место в его заголовках. В журнальной публикации І8зг г. первая часть новеллы называлась «Мэтр Френхофер», в дальнейших версиях - «Жиллетта»; а в последней редакции I847 г. «Жиллетта» даже сделалась общим заголовком всего произведения, заменив «Неведомый шедевр» (эту поправку не решаются воспроизвести современные издатели, сохраняющие старое название). Вопреки намерениям своих партнеров-художников, Жиллетта утверждает себя скорее в писательском слове, чем в живописном образе. 
В последней сцене новеллы, в строках, добавленных в первой книжной редакции, безумный художник панически колеблется между двумя образами, двумя несовместимыми планами своего произведения, аккомодируя зрение то на одном, то на другом; сначала он яростно бранит зрителей, отказывающихся распознать шедевр под «хаосом красок», потом в ужасе признает «ничтожность» этого шедевра, а в конце концов, впав в подозрительность, спроваживает гостей и уединяется со своими картинами - чтобы уничтожить их и умереть самому. Этими маниакально-депрессивными метаниями героя завершается процесс раскачки и раздвоения, образующий динамическую структуру «Неведомого шедевра». Двойственность профанного и сакрального знания, двойственность жанра картины и ее таинственной героини, общая двойственность нарративного и визуального начал получают свое продолжение в двойственности, неопределенности главного визуального объекта, соответствующей раздвоению двух женских персонажей-моделей. Их образы, идеальный и реальный, воображаемый и зримый - в терминах самого Френхофера, «фигура» и «форма», - сталкиваются на полотне, не создавая стабильной структуры «означаемое + означающее», как при классическом режиме репрезентации. Пытаясь охарактеризовать их взаимодействие на собственно визуальном уровне, Юбер Дамиш использует метафору «плетения, где нити попеременно поднимаются и опускаются, так что одна и та же нить проходит то сверху, то снизу, и ей невозможно приписать однозначного положения» [ı, р. І6]. Однако на уровне нарративном, в развитии рассказа это взаимодействие носит более конфликтный характер: два образа не просто мерцают один из-под другого, они борются между собой, оспаривают друг у друга главенство, и их противоборство заканчивается взаимным уничтожением. В итоге на картине от «фигуры» если что и осталось, то лишь «кончик прелестной, живой ноги», тогда как «форма» превратилась в свою противоположность - «хаос красок, тонов, неопределенных оттенков, образующих некую бесформенную [sans forme] туманность» [II, p. 436; г, с. 394].

\section{Эмансипация модели}

Сюжет, где модель-натурщица перестает быть пассивным объектом художественного изображения и начинает энергично взаимодействовать с собственным образом, формируя и деформируя его, получил дальнейшее 
развитие. У Бальзака характер героини, чуть не пропавшей без вести еще до конца рассказа и «спасенной» лишь при последующей переработке текста, довольно схематичен и в основном описывается мелодраматическими стереотипами: красивая, гордая, любящая, жертвенная... У его последователей эта фигура усложняется, приобретает все большую значимость и всякий раз расценивается двойственно - как необходимый и вместе с тем инородный, конфликтный элемент искусственного образа.

Новелла Теофиля Готье «Золотое руно» (La Toison d'or, I839) написана «по мотивам» Бальзака, с которым Готье в те годы близко сотрудничал и дружил ${ }^{42}$. Герой новеллы, парижский эстет Тибурций, находит во Фландрии - стране, служившей неявным фоном в «Неведомом шедевре», два воплощения чаемого им идеала белокурой красавицы: фигуру Марии Магдалины с картины Рубенса из Антверпенского собора («прекрасной куртизанки», как и бальзаковская Катрин Леско) и похожую на нее живую девушку Гретхен. Вернувшись домой, он хандрит из-за несовпадения образа с реальностью: искренняя любовь Гретхен, последовавшей за ним в Париж, не заменяет ему воспоминания о рубенсовской Магдалине, ибо он «не понимал природу в подлиннике, поэтому читал ее только в переводах» [3, c. 250]43, а женскую красоту ценил лишь в искусстве или в сравнении с ним. За это эстетство его укоряет рассказчик:

...всецело отдавшись поэзии, вы отлучили себя от природы, мира и жизни. Любовницы были для вас картинами, более или менее удачными; ваша любовь к ним дозировалась по шкале - Тициан, Буше или Ванлоо, но вас никогда не волновала мысль: а может, под этой внешней оболочкой трепещет и бьется что-то живое? Горе и радость, хоть у вас и доброе сердце, вам кажутся гримасами, нарушающими гармоническое спокойствие линии: женщина для вас только теплая статуя [3, с. 272] ${ }^{44}$.

42 Выше уже упоминалась новелла Готье «Ножка мумии», первая сцена которой написана в подражание «Шагреневой коже»; и наоборот, в текст «Утраченных иллюзий» Бальзака (Illusions perdues, I837-І843) включено стихотворение, сочиненное Готье и приписанное герою романа. Высказывалось даже предположение (правда, признанное малообоснованным), что Готье, профессиональный художественный критик, был подлинным автором рассуждений о живописи, которые Бальзак ввел в редакцию 1837 г. «Неведомого шедевра», вложив их в уста Френхофера.

43 Перевод Н.М. Гнединой (М. Надеждина), с поправкой. Оригинал: [22, p. 784].

44 Последняя процитированная фраза - вероятный источник знаменитых стихов Бодлера: 
Лекарство от меланхолии находится в художественной игре - создании новых образов: сначала Тибурций одевает Гретхен в платье XVI в., похожее на одежду Магдалины, и превращает ее в «живую картину» - «вы бы сказали, что это фрагмент картины Рубенса» [3, с. 279]; а затем сама Гретхен, недовольная тем, что ее подменяют образом другой женщины, предлагает более эффективный способ избавиться от наваждения - написать с нее настоящую новую картину: «Если я не могу быть вашей любовницей, я буду хотя бы вашей натурщицей» [3, с. 28I]. Тут, в самом конце новеллы, Тибурций вдруг вспоминает, что «когда-то занимался живописью», и изображает свою подругу на холсте - не в виде Магдалины, копируя Рубенса, а в виде обнаженной Венеры, выходящей из волн; может быть, даже в виде статуи Венеры, с которой кокетливо сравнивает себя позирующая модель и на которую затем намекает рассказчик, говоря, что картина Тибурция, хоть и «не стала совершенным произведением», но все же «будила воспоминание о цветущей поре греческой скульптуры» [3, с. 28I]. Образный экзорцизм, искусно осуществленный героиней Готье по отношению к своему возлюбленному, предвещает исцеление другого эстета, одержимого старинным художественным образом, - героя «Градивы» Вильгельма Йенсена, чья история стала знаменита благодаря анализу этой повести Зигмундом Фрейдом; венский психиатр определил у ее героя латентный фетишизм женской ноги, который мы уже видели в «Неведомом шедевре» [8]. У Готье живая модель своим появлением (согласно фабуле, она впервые мелькнула перед взором Тибурция до лицезрения Магдалины Рубенса) вносит перемену в пространство визуальных образов: они начинают множиться, накладываться друг на друга, и в конце концов на смену пустым «романтическим» грезам Тибурция приходит положительно-«классическое», пусть и любительское произведение искусства, украшающее его супружеский быт (новелла заканчивается его помолвкой с Гретхен).

Натурщицы - в данном случае профессиональные, а не окказиональные, - фигурируют в двух романах братьев Гонкуров: «В I8.. году» (En I8.., I85I) и «Манетт Саломон» (Manette Salomon, I867), - причем обе они являются резко отрицательными персонажами, разочаровывающими или даже

Je hais le mouvement qui déplace les lignes,

Et jamais je ne pleure, et jamais je ne ris.

Я ненавижу движение, смещающее линии,

И я никогда не плачу и никогда не смеюсь

(Сонет «Красота»). 
губящими главного героя. В обоих романах они еврейки, что отражает как бытовой антисемитизм авторов, так и реальное положение этнорелигиозного меньшинства, объективированного в глазах большинства: на них смотрят со стороны. У этой объективации имелось конкретно-живописное проявление: художники-ориенталисты часто изображали на своих картинах еврейских женщин Магриба, которые, в отличие от мусульманок, не скрывали своих лиц и соглашались позировать. Нифа из романа «В І8.. году» представляется именно алжирской еврейкой по происхождению. Обольщенный этой девицей, герой романа в финале ошеломленно открывает сразу две ее позорных тайны: она не только зарабатывает позированием как обнаженная модель, но и является (мотив нечастый в тогдашней литературе) иностранной шпионкой! Впрочем, сам он не художник, и его отношения с Нифой не опосредуются никакими действиями с визуальными образами; в отсутствие такого сюжета в книге и нет катастрофической развязки, она вообще почти лишена повествовательности и в основном сводится к лирической декламации.

В отличие от этого раннего и малоудачного романа, действие «Манетт Саломон», одного из главных произведений Гонкуров, развертывается, как и в «Неведомом шедевре» Бальзака, в художественной среде. Заглавная героиня последовательно становится натурщицей, любовницей, а затем и женой одаренного живописца Кориолиса. Она красива, «от ее наготы в мастерской внезапно распространялось сияние шедевра» [23, р. 263], и первая картина, для которой она позирует Кориолису, написана на восточный сюжет - «Турецкая баня» (хотя сама она родом из Эльзаса). В дальнейшем, однако, она быстро перестает служить покорной моделью, зато с помощью своих родственников забирает полную власть над мужем. В финале слабовольный Кориолис показан разбитым и беспомощным, утратившим творческий дар под разрушительным влиянием женщины. Модель оказывается враждебной искусству, она не столько участвует в создании визуальных образов, сколько мешает их создавать и вытесняет их из романного повествования. «Манетт Саломон» - роман о художнике, но не о художественном произведении: картины Кориолиса не играют в нем самостоятельной сюжетной роли.

Иначе обстоит дело в «Творчестве» (L'Euvre, I886) Эмиля Золя, теснее связанном с бальзаковской новеллой: с историей перфекциониста Френхофера здесь перекликается история многолетней работы живописца Клода Лантье над огромным полотном-шедевром - работы, которая так и не за- 
вершается и обрывается самоубийством художника и последующим уничтожением картины. Золя подробно рассказывает о написании и внутренней структуре этого и нескольких других произведений Клода, два из которых написаны при участии случайно встреченной им девушки Кристины; она, как и Манетт Саломон у Гонкуров, становится ему моделью, затем возлюбленной, а затем и супругой.

Обе картины Клода поражают и скандализируют зрителей явной несообразностью, зрительной неконгруэнтностью своих сюжетов. Первая из них, законченная автором, изображает трех нагих купальщиц и рядом с ними «мужчину в черной бархатной куртке», полулежащего «спиной к зрителю» [7, с. 84], т. е. в позе внутреннего зрителя, наблюдающего за сценой купания изнутри картины. Идея соединить на одном полотне, в одном воображаемом пространстве обнаженные женские фигуры и одетую мужскую, по всей вероятности, взята писателем из «Завтрака на траве» Эдуарда Мане (Le Déjeuner sur l'herbe, I863); но зрительская поза мужчины производит здесь дополнительный эффект - пространство картины неявно разделяется на два пространства с разной степенью условности, на два визуально совмещенных, но эстетически несовместимых, сюжетно и перспективно разнородных образа: с одной стороны, традиционная живописная сцена с купальщицами, с другой стороны - изображенный со спины наблюдатель (как, например, на пейзажах К.-Д. Фридриха). А чтобы придать завершенность главной женской фигуре, аффективно связать ее с наблюдателем, понадобилась особенная, самостоятельная натура - не профессиональная модель, а скромная, стесняющаяся позировать и вместе с тем все более привязывающаяся к художнику Кристина.

Вторая картина Клода, более амбициозная по замыслу и оставшаяся незаконченной, воспроизводит сходный эффект раздвоения. В ней тоже совмещаются два разнородных образа: «реалистический» городской пейзаж (стрелка острова Сите в Париже, портовые грузчики с мешками на спине) и странные в этой обстановке, словно пришедшие из другого жанра живописи фигуры полуобнаженных и обнаженных купальщиц. Это вызывает оторопь даже у опытного и благожелательного ценителя - писателя Сандоза, глядящего на работу своего друга:

...лодка с женщинами в самом центре прорывала картину неуместно пламенеющей плотью. Особенно яркой, галлюцинаторно преувеличенной, 
была крупная нагая фигура, написанная в лихорадке, тревожно-странная и ложная среди окружающих ее реальных предметов ${ }^{45}$.

Глазами Сандоза, через его несобственно прямую речь (как это делал и Бальзак) Золя дает понять, что картина внутренне противоречива не только своим сюжетом (голые купальщицы в центре города), но и «ложной» визуальной структурой: главная фигура неестественно выделена, увеличена и высвечена, своей «пламенеющей плотью» она «прорывает» образ, вторгается в него каким-то другим, чужеродным образом. Эта фигура не сразу возникла на картине Клода: поначалу он долгое время писал обычный пейзаж, все более болезненно психически фиксируясь на нем. В конце концов фиксация «прорвалась» фантазматической женской фигурой, созданной в ненормальном состоянии («в лихорадке») и своим обликом имитирующей расстройство восприятия, галлюцинацию. Как и у Бальзака, она отмечена желанием, которое отклоняется от реального объекта к воображаемому. Френхофер в «Неведомом шедевре» эротически безразличен к реальной красавице Жиллетте, вожделея к «подобию женщины» - фигуре Катрин Леско; так же и Клод Лантье в «Творчестве» пишет главную фигуру своей картины с собственной жены, мучает ее многочасовыми сеансами позирования, но при этом равнодушен к ней самой, находит ее постаревшей и непривлекательной. Повторяя прегрешение бальзаковского Никола Пуссена, он изменяет ей с образом, и Кристина чувствует себя покинутой, страстную работу мужа над шедевром переживает как «какое-то грубое совокупление» [37, р. 377]. Отчаянная попытка отнять его у нарисованной соперницы заканчивается катастрофой: окончательно сойдя с ума, Клод ночью ускользает из супружеской постели, чтобы повеситься в мастерской, лицом к своей заветной картине.

Сюжет «Творчества» восходит к романтической литературе: превращение в искусственный образ ведет к телесной дезинтеграции изображаемого человека. Картина отбирает, похищает образ у собственной модели, переносит на холст молодость и красоту, которой та лишается; отделившись от человека, образ становится его злотворным двойником, отнимающим у него идентичность и жизнь (ср. новеллу Эдгара По «Овальный портрет», I842). Новая сюжетная идея Золя, развивающая и эксплицирующая интуицию Бальзака в «Неведомом шедевре», заключается в том, что похищенный образ

45 Ср.: [7, с. 286]. Перевод значительно изменен; оригинал: [37, р. 346]. 
уничтожает не только свою «хозяйку»-модель (которая в финале сама теряет рассудок от пережитого - она самая пассивная, страдательная из постбальзаковских натурщиц), но и своего «похитителя»; разрушает не только жизнь, но и творчество художника, выставленное в заголовок романа.

Фантазматический образ выглядит инородным на картине, не включается в ее визуальный контекст, а резко выступает из него - то ли «прорывает» поверхность полотна изнутри, то ли, наоборот, накладывается на него наподобие аппликации, не сливаясь с ним ни формально (зрительно), ни тематически. Такая внутренне конфликтная картина, будь она действительно написана, могла бы нормально и даже интересно выглядеть в современном музее или галерее; но для искусства конца XIX в., каким его изображает Золя - сам, помимо прочего, активный художественный критик, - ее динамическая структура неприемлема и может расцениваться только как продукт клинического психоза. У художников, критиков, посетителей выставок картины Клода Лантье вызывают в лучшем случае равнодушие, а нередко и подвергаются насмешкам; случись иначе, сумей он снискать успех, возможно, и его личная судьба сложилась бы благополучнее...

Новейшую версию сюжета предлагает фильм Жака Риветта «La Belle Noiseuse» (I99I) - вольная экранизация бальзаковского «Неведомого шедевра». Действие перенесено в наши дни и сосредоточено на взаимоотношениях художника Френхофера (Мишель Пикколи) с непрофессиональной, случайно встреченной им моделью Марианной (Эмманюэль Беар). Как и Жиллетта у Бальзака, Марианна по настоянию своего бойфренда-художника соглашается позировать знаменитому, но переживающему творческий кризис живописцу, и значительная часть длинного, четырехчасового фильма практически «в реальном времени» воссоздает ее последовательные сеансы: эти «полудокументальные» [18, p. 229] эпизоды снимались пять дней, столько же, сколько длится действие фильма ${ }^{46}$. Если Бальзак избегал прямо утверждать, что героине пришлось позировать обнаженной, то у Риветта именно так и происходит на протяжении почти всех сеансов; вместе с тем из общения Марианны с Френхофером принципиально исключены любые намеки на сексуальную близость, ухаживание или кокетство (да и у Бальзака, как мы

46 См.: [18, p. 231]. Эти сеансы живописной работы получают в фильме «статус не только фикциональный, но и документальный, как именно и хотел Бальзак, когда писал вторую версию “Неведомого шедевра”» [30, р. 165]. 
помним, живописец «кокетничал» не с натурщицей, а с собственной картиной!). Любовные мотивы проходят лишь пунктиром на периферии сюжета, в отрицательной форме ревности: Марианну ревнует ее партнер, а Френхофеpa - его жена; в отличие от своего бальзаковского прототипа, главный герой фильма женат. Что же касается отношений между художником и моделью, то эротика в них полностью сублимирована, они затрагивают не тело, а лишь визуальный образ, и это отношения не любви, а власти.

Поначалу Френхофер всецело господствует над Марианной и безжалостно третирует ее: обращается с нею как с неживой куклой ${ }^{47}$, требует принимать сложные и мучительные позы, иногда даже физически принуждает неестественно изгибаться и подолгу оставаться в таком положении. «В былые времена натурщиц привязывали», - говорит он и вспоминает не без садистской гордости: «Как-то раз я даже вывихнул модели руку». Небольшой старинный замок, где он живет, начинает напоминать зловещее пространство насилия; для этого служит ряд визуальных «готических мотивов» - зеркало, в которое тревожно смотрится Марианна, игра света и тени в ряде ночных эпизодов и т. п. (см.: [18, p. 333]). Дальше, однако, в сюжете происходит перелом: работа над картиной идет плохо, художник готов ее бросить, но теперь уже модель берет власть в свои руки и заставляет его продолжать. Для нее это участие в художественном творчестве стало экзистенциальным опытом, из которого она выходит другим человеком; в последних закадровых словах фильма она говорит: «Это я - Марианна. Вернее, это я была Марианной», - можно понять так, что она была в фильме «рассказчицей», едва ли не «режиссером» своей истории. Памятником психодрамы, talking cure [34, p. 46] ${ }^{48}$, разыгравшейся между нею и Френхофером, стала его картина, которая называется «La Belle Noiseuse», как и у Бальзака; это полотно тоже скрыто от зрителей и в конце концов вообще исчезает художник не сжигает его, но тайно замуровывает в стене замка.

На протяжении всего фильма картина не попадает в кадр; время от времени мы видим лишь наброски к ней, которые делает рука рисовальщика (в этих кадрах актера Мишеля Пикколи дублирует профессиональный художник Бернар Дюфур). Лишенные рам эскизы накапливаются и загромождают

47 Франческа Дози уместно вспоминает в качестве параллели эротических кукол Ханса Бельмера (см.: [г8, р. 3І9]).

48 Во время одного из первых сеансов работы над картиной, еще владея инициативой, Френхофер заявлял Марианне о своих намерениях, сравнимых с задачей психоаналитика: «Выну из тебя все, что в тебе есть». 
мастерскую, образуя уже знакомую нам динамическую рамку образов вокруг настоящей картины - смутное пограничное пространство, где творческие интенции художника хаотично смешиваются с контурами тела модели (см.: [I8, p. 304]). Единственный раз картину чуть-чуть видно в момент ее замуровывания: на ней слегка задирается подол-чехол (из зеленой саржи, как у Бальзака), и приоткрывается небольшой фрагмент внизу - но не изображение ноги, а лишь сплошной красный фон. Из персонажей фильма готовое произведение успевают увидеть три женщины, по-разному связанные с ним: натурщица Марианна, которая, в отличие от бальзаковской Жиллетты, весьма интересуется визуальным образом; жена художника Лиз (Джейн Биркин), зашедшая в пустую мастерскую и нарисовавшая крестик на задней стороне холста, рядом с инициалом мужа, - свою личную метку, знак любви и сопричастности к произведению49; и девочка-подросток Магали (Мари Беллюк), дочь экономки, эта юная помощница, свидетельница и хранительница образа помогает Френхоферу перенести громоздкую картину и разделяет с ним тайну ее погребения. Никак не участвовавшая в создании образа, она видит его последней и своим взглядом со стороны как бы ставит на нем печать после подписей Френхофера и Лиз, удостоверяя и «архивируя» его завершение и сокрытие:

- У нас с тобой будет один общий секрет...

- А долго его надо хранить?

- Всегда. И даже после меня.

Чтобы обмануть свое окружение, ожидающее от него шедевра, Френхофер быстро пишет другую, подменную, свою «первую посмертную картину» - изображение обнаженной женской фигуры. В одной из предыдущих сцен его жена Лиз советовала натурщице Марианне: «Не давайте ему писать свое лицо». На предъявленной нам картине, словно в насмешку над этим предостережением против магической «кражи образа», художник совсем скрыл лицо модели, зато изобразил крупным планом ее ягодицы. Но режиссер не искал грубого комического эффекта. Очередная искусственная поза, на сей раз не навязанная живописцем, а спонтанно принятая самой моделью в ходе

49 Как и положено в постбальзаковских сюжетах, Лиз ревнует мужа не столько к более молодой натурщице, сколько к визуальному образу, страдает от того, что перестала порождать образы, участвовать в их создании: «Я долго была любимой, единственной натурщицей Френхофера. Он писал меня, потому что любил. А теперь не пишет меня, потому что любит». 
одного из сеансов, не раз возникала потом в эскизах Френхофера - в том числе написанных поверх других, старых эскизов, на которых, словно старый текст на палимпсесте, угадываются наброски лица его жены: образы двух женщин накладываются один на другой, один поперек другого, так что лицо одной выступает из-под тела другой, словно неприкаянная ножка на картине бальзаковского художника. Возможно, они как-то и были запечатлены вместе на «настоящем», замурованном полотне - нам не дано этого знать.

Для внимательного кинозрителя, следящего за сменой планов, суррогатный характер подменного псевдо-портрета обозначен тем, что его рисует на экране не художник-дублер, а сам актер, исполнитель роли Френхофера. В финальной сцене фильма непосвященные зрители-мужчины с бальзаковскими именами - молодой художник Никола (Давид Бюрстейн) и арт-дилер Порбус (Жиль Арбона) - не совсем искренне восхваляют новое творение мэтра5 ${ }^{50}$ тогда как знающие правду женщины дружно отмалчиваются, завершая тем самым оккультацию и сакрализацию «неведомого шедевра». Визуальный образ еще раз расслоился на два - в данном случае на оригинал и (авторскую) подделку, причем подлинный портрет героини, запечатлевший историю ее драматичных отношений с художником, заключен в никому не видимой крипте, в могиле. При желании можно толковать это как притчу в неоплатоническом духе: настоящий образ (или эйдос) скрыт от нашего взора, искусство являет нам лишь его неподлинные подобия.

$* * *$

По сравнению с литературой XIX в. фильм Жака Риветта дает «феминистскую» трактовку сюжета «натурщица и шедевр». Женские персонажи в нем не только относительно многочисленны, но и служат ведущей силой событий, а история работы над картиной прямо демонстрирует переворот в гендерных ролях. В традиционном художественном быту наемная модель служила пассивным сырьем для эстетической переработки, являя собой пример социального отчуждения женщины. В ней отрицался, исключался всякий собственный душевный и даже телесный опыт (например, усталость и боль от неудобной позы), ее имя не сохранялось в памяти, ее индивидуальность редуцировалась до анонимной внешней видимости - ср. ножку на картине

50 Никола, догадываясь об обмане, с досадой говорит Френхоферу: «Я не хотел бы кончить как вы, в притворстве». 
Френхофера, о принадлежности которой можно только гадать. Ее обнажение, мотивируемое классицистическим культом прекрасного тела, фактически лишало ее человеческого достоинства, ставило в один ряд с проституткой (отсюда ассоциация «натурщица - куртизанка»). Именно с таким стандартным представлением имеют дело литература и кино: характерно, что в их сюжетах фигурируют обычно женщины-модели, тогда как в реальности живописцам и скульпторам часто позируют и мужчины. Напротив того, у Риветта модель сама берет на себя ответственность за создаваемое при ее участии произведение и сама меняется в ходе его создания. Ее самостоятельность уравновешивает сюжетную ситуацию и обусловливает сдержанный тон фильма: в нем нет бальзаковского мелодраматизма (напряженные отношения Марианны и Френхофера - скорее условный конфликт, как между психоаналитиком и его пациентом), никто не жертвует собой - единственной жертвой стал визуальный образ, которого никто больше не увидит.

Для сюжетов такого типа, как мы могли убедиться, характерно раздвоение визуального образа. Оно может быть внешним, когда противостоят друг другу две картины (картина Рубенса и картина Тибурция у Готье; настоящая и подменная картины Френхофера у Риветта), или внутренним, когда расслаивается, становится гетерогенным сам образ на полотне (у Бальзака и Золя, а также и на некоторых эскизах картины в фильме Риветта). Раздвоения образа нет у Гонкуров, потому что в их романах фигура натурщицы вообще не соотносится с изображающими ее произведениями, а только со своей социальной ролью.

Расслоение образа означает его деконструкцию: образ перестает быть прозрачно-репрезентативным, в нем возникают неразрешимые напряжения, включая дестабилизацию его референта - изображаемого человека. У Бальзака и его последователей модель отказывается исчезать в образе, требует себе собственного места и имени, ее реальное тело и реальные поступки выпирают из гладкого образа, куда художник пытался ее заключить. В фильме Риветта этот процесс особенно сложен: в живописном образе запечатлелась не только внутренняя жизнь модели (это нормальное качество живописного портрета) и даже не только ее отношения с художником (это тоже обычная ситуация, не раз воссозданная в литературе и искусстве) $)^{51}$, но и их отношения

5I Один из недавних примеров - роман Трейси Шевалье «Девушка с жемчужной серьгой» (1999), экранизированный в 2003 г. режиссером Питером Уэббером. 
с третьим лицом, которое оставляет свой след - буквально набросок своего лица - на картине. Визуальная двойственность живописного образа непосредственно продолжает собой нарративную двойственность женских персонажей фильма.

Следует еще раз напомнить, что первый из рассмотренных рассказов, «Неведомый шедевр» Бальзака, изначально именовался «фантастическим». Действительно, в таких сюжетах происходит - в «реальной» обстановке, без всяких сверхъестественных событий - оживление образа, образ сходит с живописного полотна и начинает вести себя самостоятельно. Непокорная, взрывающая образ модель - это новая, современная ипостась романтического призрака или двойника. Тем самым сюжет о натурщице и шедевре наглядно показывает параллелизм динамических процессов, происходящих на уровне формы и тематики произведения: судьба человека и судьба визуального образа развиваются в одних и тех же координатах. 


\section{Список литературы}

I Бальзак О. Собр. соч.: в г5 т. М.: Гослитиздат, г955. Т. г3. 664 с.

2 Барт Р. Введение в структурный анализ повествовательных текстов [І966] / перевод Г.К. Косикова // Французская семиотика: От структурализма к постструктурализму. М.: Прогресс, 2000. С. 196-238.

3 Готье Т. Избранные произведения. М.: Худож. лит., І972. Т. І. 574 с.

4 Грифцов Б.А. Как работал Бальзак [1937], глава I // Грифцов Б.А. Психология писателя. М.: Худож. лит., І988. С. 278-345.

5 Зенкин С.Н. Интрадиегетический образ в фантастическом рассказе // А.М.П.: Памяти А.М. Пескова. М.: РГГУ, 2013. С. 384-395.

6 Зенкин С.Н. Французский романтизм и идея культуры. М.: РГГУ, 2002. 288 с.

7 Золя Э. Творчество / пер. Т. Ивановой и Е. Яхниной. М.: Худож. лит., І98І. 400 с.

8 Фрейд 3. Бред и сны в «Градиве» Иенсена // Иенсен В. Градива. Одесса: Жизнь и душа, I9I2. URL: http://knigosite.org/library/read/906 (дата обращения 05.08.20I7). Ямпольский М.Б. О близком: Очерки немиметического зрения. М.: Новое литературное обозрение, 200I. 240 с. Assoun Paul-Laurent. La femme et l'œuvre: Le fétichisme dans Le Chef-d'œuvre inconnu // Analyses et réflexions sur Balzac: Le Chef d'œuvre inconnu, Gambara, Massimilla Doni. (Ouvrage collectif). Paris: Ellipses, I993.

II Balzac Honoré de. La Comédie humaine. X. Études philosophiques. Paris: Gallimard, I979. I834 p. (Bibliothèque de la Pléiade) Béguin Albert. Préface [du Chef-d'œuvre inconnu] // L’EEuvre de Balzac. Paris: Le Club français du livre, I955. T. I2.

I3 Bonard Olivier. La Peinture dans la création balzacienne (Thèse). Genève: Droz, I969. I90 p.

I4 Butor Michel. Le Marchand et le génie (Improvisations sur Balzac, I). Paris: La Différence, I998. $467 \mathrm{p}$.

I5 Conversations avec Cézanne. Paris: Macula, I978. 237 p.

I6 Damisch Hubert. Fenêtre jaune cadmium, ou les Dessous de la peinture. Paris: Le Seuil, I984.3I9 p.

I7 Didi-Huberman Georges. La Peinture incarnée. Paris: Minuit, I985. I69 p.

I8 Dosi Francesca. Trajectoires balzaciennes dans le cinéma de Jacques Rivette (Thèse Paris 3). La Madeleine: Lett Motif, 20I4. 630 p.

I9 Eigeldinger Marc. La Philosophie de l'art chez Balzac. Genève: Slatkine Reprints, I998 (I955). I82 p.

Filoche Jean-Luc. Le Chef-d'œuvre inconnu: Peinture et connaissance // Acta Baltica. I980. № I. P. 47-59. classique // Gans E.L. Essais d'esthétique paradoxale. Paris: Gallimard, I977. P. I79-I93. 
22 Gautier Théophile. Romans, contes et nouvelles. Paris: Gallimard, 2002. T. I. (Bibliothèque de la Pléiade). LXXIX-I582 p.

23 Goncourt Edmond et Jules de. Manette Salomon. Paris: A. Lacroix, Verboeckhoven \& $\mathrm{C}^{\circ}$, I868. 2 vol.

24 Heinich Nathalie. Le Chef-d'œuvre inconnu, ou l'artiste investi // Autour du Chef-d'œuvre inconnu de Balzac. Paris: ENSAD, I985. P. 75-83.

25 Kashiwagi Takao. Catherine Lescault, qui est-ce?: Le Chef d'œuvre inconnu, roman d'amour ou roman de peinture? // Osaka University Knowledge Archive. I993. URL: http://hdl.handle.net/ıI094/47855 (дата обращения: 05.05.20I7)

26 Laubriet Pierre. Un catéchisme esthétique: Le Chef-d'œuvre inconnu de Balzac. Paris: Didier, I96I. 258 p.

27 Le Men Ségolène. L'indicible et l'irreprésentable: Les éditions illustrées du Chef-d'œuvre inconnu // Autour du Chef-d'œuvre inconnu de Balzac. Paris: École nationale supérieure des arts décoratifs, I985. P. I5-33.

28 Lebensztejn Jean-Claude. Cinq lignes de points // Autour du Chef-d'œuvre inconnu de Balzac. Paris: École nationale supérieure des arts décoratifs, I985. P. I49-I7I.

29 Marin Louis. Les secrets des noms et des corps [1985] // Marin Louis. Lectures traversières. Paris: Albin Michel, 1992.

30 Massol Chantal, Couré Catherine. Postérité du Chef-d'œuvre inconnu // Balzac et la peinture. Tours: Farrago, I999. P. I53-I69.

3I Massol Chantal. L'artiste ou l'imposture: le secret du Chef-d'œuvre inconnu // Romantisme. I986. № 54. P. 44-57.

32 Mérimée Prosper. Romans et nouvelles. Paris: Classiques Garnier, I967. T. II. 704 p.

33 Pavel Thomas. L’Univers de la fiction. Paris: Seuil, I988. 210 p.

34 Seknadje-Askenazi Enrique. La Belle Noiseuse: peinture et vérité // Analyses et réflexions sur Balzac: Le Chef d'œuvre inconnu, Gambara, Massimilla Doni. (Ouvrage collectif). Paris: Ellipses, I993.

35 Serres Michel. Genèse. Paris: Grasset, I982. 222 p.

36 Vouilloux Bernard. Le Tournant «artiste» de la littérature française. Paris: Hermann, 20II. 535 p.

37 Zola Émile. L’Euvre. Paris: Charpentier, i886. 49I p. 


\section{References}

I Bal'zak O. Sobranie sochinenii: $v$ I5 t. [Complete works: in I5 vols.] Moscow, Goslitizdat Publ., I955. Vol. I3. 664 p. (In Russ.)

2 Bart R. Vvedenie v strukturnyi analiz povestvovatel'nykh tekstov [I966] [Introduction to the structural analysis of narratives], trans. G.K. Kosikov. Frantsuzskaia semiotika: Ot strukturalizma k poststrukturalizmu [French semiotics: from structuralism to poststructuralism]. Moscow, Progress Publ., 2000, pp. 196-238. (In Russ.)

3 Got'e T. Izbrannye proizvedeniia [Selected works]. Moscow, Khudozh. lit. Publ., I972. Vol. 2. 574 p. (In Russ.)

4 Griftsov B.A. Kak rabotal Bal'zak [I937], glava I [How Balzac worked]. Griftsov B.A. Psikhologiia pisatelia [Psychology of the Writer]. Moscow, Khudozh. lit. Publ., I988, pp. 278-345. (In Russ.)

5 Zenkin S.N. Intradiegeticheskii obraz v fantasticheskom rasskaze [Intradiegetic image in the fanstastic story]. A.M.P.: Pamiati A.M. Peskova [A.M.P.: In the memory of A.M. Peskov]. Moscow, RGGU Publ., 20I3, pp. 384-395. (In Russ.) Zenkin S.N. Frantsuzskii romantizm i ideia kul'tury [French Romanticism and the idea of culture]. Moscow, RGGU Publ., 2002. 288 p. (In Russ.)

Zolia E. Tvorchestvo [Zola E. The Work], trans. T. Ivanova and E. Iakhnina. Moscow, Khudozh. lit. Publ., I98I. 400 p. (In Russ.)

Freid Z. Bred i sny v “Gradive” Iensena [Freud Z. Delusion and Dream in Jensen's Gradiva]. Iensen V. Gradiva [Jensen V. Gradiva]. Odessa, Zhizn’ i dusha Publ., I9I2. Available at: http://knigosite.org/library/read/906 (Accessed o5 August 20I7). (In Russ.) Iampol'skii M.B. O blizkom: Ocherki nemimeticheskogo zreniia [About the closeness: Essays on non-mimetic vision]. Moscow, Novoe literaturnoe obozrenie Publ., 200I. 240 p. (In Russ.) Assoun Paul Laurent. La femme et l'œuvre: Le fétichisme dans Le Chef d'œuvre inconnu. Analyses et réflexions sur Balzac: Le Chef d'œuvre inconnu, Gambara, Massimilla Doni. (Ouvrage collectif). Paris, Ellipses, I993. (In French) Balzac Honoré de. La Comédie humaine. X. Études philosophiques. Paris, Gallimard, I979. I834 p. (Bibliothèque de la Pléiade). (In French) Béguin Albert. Préface [du Chefd'œuvre inconnu]. L'Euvre de Balzac. Paris, Le Club français du livre, I955. Vol. I2. (In French)

I3 Bonard Olivier. La Peinture dans la création balzacienne (Thèse). Genève, Droz, I969. I90 p. (In French)

I4 Butor Michel. Le Marchand et le génie (Improvisations sur Balzac, I). Paris, La Différence, I998. 467 p. (In French)

I5 Conversations avec Cézanne. Paris, Macula, I978. 237 p. (In French)

I6 Damisch Hubert. Fenêtre jaune cadmium, ou les Dessous de la peinture. Paris, Le Seuil, I984. 319 p. (In French) 
I7 Didi-Huberman Georges. La Peinture incarnée. Paris, Minuit, I985. I69 p. (In French)

I8 Dosi Francesca. Trajectoires balzaciennes dans le cinéma de Jacques Rivette (Thèse Paris 3). La Madeleine, Lett Motif, 20I4. 630 p. (In French)

I9 Eigeldinger Marc. La Philosophie de l'art chez Balzac. Genève, Slatkine Reprints, I998 (I955). I82 p. (In French)

Filoche Jean Luc. Le Chef d'œuvre inconnu: Peinture et connaissance. Acta Baltica, I980, no I, pp. 47-59. (In French)

Gans Eric Lawrence. Le chef d'œuvre inconnaissable de Balzac: Les limites de l'esthétique classique. Gans E.L. Essais d'esthétique paradoxale. Paris, Gallimard, I977, pp. I79-193. (In French)

22 Gautier Théophile. Romans, contes et nouvelles. Paris, Gallimard, 2002. Vol. I. LXXIX-I582 p. (Bibliothèque de la Pléiade). (In French)

23 Goncourt Edmond et Jules de. Manette Salomon. Paris, A. Lacroix, Verboeckhoven \& $\mathrm{C}^{\circ}$, I868. 2 vol. (In French)

24 Heinich Nathalie. Le Chef d'œuvre inconnu, ou l'artiste investi. Autour du Chef d'œuvre inconnu de Balzac. Paris, ENSAD, I985, pp. 75-83. (In French)

25 Kashiwagi Takao. Catherine Lescault, qui est ce?: Le Chef d'œuvre inconnu, roman d'amour ou roman de peinture? Osaka University Knowledge Archive, I993. Available at: http://hdl.handle.net/ıI094/47855 (Accessed o5 August 20I7) (In French)

26 Laubriet Pierre. Un catéchisme esthétique: Le Chefd'œuvre inconnu de Balzac. Paris, Didier, I96I. 258 p. (In French)

27 Le Men Ségolène. Lindicible et l'irreprésentable: Les éditions illustrées du Chef d'œuvre inconnu. Autour du Chef d'œuvre inconnu de Balzac. Paris, École nationale supérieure des arts décoratifs, I985, pp. 15-33. (In French)

28 Lebensztejn Jean Claude. Cinq lignes de points. Autour du Chef d'œuvre inconnu de Balzac. Paris, École nationale supérieure des arts décoratifs, I985, pp. I49-I7I. (In French)

29 Marin Louis. Les secrets des noms et des corps [1985]. Marin Louis. Lectures traversières. Paris, Albin Michel, I992. (In French)

30 Massol Chantal, Cœuré Catherine. Postérité du Chef d'œuvre inconnu. Balzac et la peinture. Tours, Farrago, I999, pp. I53-I69. (In French)

3I Massol Chantal. L'artiste ou l'imposture: le secret du Chef d'œuvre inconnu. Romantisme, I986, no 54, pp. 44-57. (In French)

32 Mérimée Prosper. Romans et nouvelles. Paris, Classiques Garnier, I967. Vol. II. 704 p. (In French)

33 Pavel Thomas. L'Univers de la fiction. Paris, Seuil, I988. 210 p. (In French)

34 Seknadje Askenazi Enrique. La Belle Noiseuse: peinture et vérité. Analyses et réflexions sur Balzac: Le Chef d'œuvre inconnu, Gambara, Massimilla Doni. (Ouvrage collectif). Paris, Ellipses, I993. (In French) 
35 Serres Michel. Genèse. Paris, Grasset, 1982. 222 p. (In French)

36 Vouilloux Bernard. Le Tournant "artiste" de la littérature française. Paris, Hermann, 20II. 535 p. (In French)

37 Zola Émile. L’EEvvre. Paris, Charpentier, I886. 49I p. (In French) 
УдК $82($ о9г)

ББК $83.3(0) 4$
К АНАЛИЗУ ОБРАЗА ХАЛИФА АЛИ

В МАЛАЙСКОЙ НАРРАТИВНОЙ

ТРАДИЦИИ

(C) 2018 г. Л.В. Горяева

Институт востоковедения

Российской академии наук, Москва, Россия

Дата поступления статьи: го ноября 2017 г.

Дата публикации: 25 марта 2018 г.

DOI: I0.22455/2500-4247-20I8-3-I-58-67

Аннотация: С приходом ислама в регионе островной Юго-Восточной Азии начинают распространяться сюжеты, посвященные Пророку Мухаммаду и его ближайшим сподвижникам. Важнейшее место в их ряду занимают малайские повести о ранних войнах ислама, героем которых выступает четвертый из «праведных» халифов - Али ибн Абу Талиб («Повесть о радже Хандаке», «Повесть о радже Лахаде», «Повесть об Абу Бакре»). В этих повестях Али представлен великим воином и одновременно святым, самым просвещенным из числа сподвижников Мухаммада. Подобно пророку Сулейману, Али обладает властью над джиннами и животными, наделен сверхъестественными способностями. При ближайшем рассмотрении становится ясно, что в малайских повестях и образ Али, и истории о ранних войнах ислама в целом тесно переплетены с местными преданиями и архаическими верованиями, согласно которым благополучие человека зависит от его отношений с обитающими в мире духами, а также горами, холмами и лесами. Несмотря на свои ближневосточные корни, малайские повести этого цикла обнаруживают множество черт сходства с домусульманской словесностью и театральной традицией островной Юго-Восточной Азии. Трансформация и адаптация образа Али малайской традицией связана по преимуществу с переходом этого персонажа в сферу устного предания благодаря распространенной практике чтения вслух. Очевидно, что по мере своего продвижения на восток сюжеты об Али и других персонажах священной мусульманской истории прошли сложный и долгий путь не только в географическом, но и в жанровом плане. Этот процесс сопровождался непрерывным взаимодействием устной и письменной традиций, постепенно стиравшим границу между легендой и историей.

Ключевые слова: Али, Мухаммад, ранние войны ислама, малайская литература, устная традиция.

Информация об авторе: Любовь Витальевна Горяева - кандидат филологических наук, ведущий научный сотрудник, Институт востоковедения Российской академии наук, ул. Рождественка, д.І2, Іо703г г. Москва, Россия.

E-mail: goriaeva@mail.ru 


\section{ON THE IMAGE OF CALIF ALI IN MALAY NARRATIVE TRADITION}

This is an open access article distributed under the Creative Commons Attribution 4.0 International (CC BY 4.0)
(C) 20I8. L.V. Goriaeva Institute of Oriental Studies, Russian Academy of Sciences, Moscow, Russia Received: November 10, 2017

Date of publication: March 25, 2018

Abstract: With the advent of Islam in the region of maritime Southeast Asia, stories about Prophet Muhammad and his closest companions began to spread there. The most important ones among them are Malay stories about early Islam wars, featuring the fourth of the "righteous" caliphs - Ali ibn Abu Talib - as their character ("The Tale of Rajah Handak”, “The Tale of Raja Lahad”, "The Tale of Abu Bakr"). In these stories, Ali is represented as both a great warrior and a saint, the most enlightened of Muhammad's companions. Like the prophet Sulaiman, Ali has power over jinnies and animals and is endowed with supernatural capacities. At close examination, it becomes clear that in the Malay stories, the image of Ali and the stories about the early Islam wars are intertwined with local legends and archaic beliefs according to which the well-being of a person depends on his or her relations with the spirits inhabiting the world, and with mountains, hills and forests. Their Middle Eastern roots notwithstanding, Malay stories of this series reveal many similarities to the pre-Islamic literature and to the theatrical tradition of maritime Southeast Asia. Transformation and adaptation of the image of Ali by Malay tradition are associated primarily with the transition of this character into the realm of oral tradition due to the widespread practice of reading books aloud. Obviously, as we move eastwards, stories about Ali and other characters of the sacred Muslim history undergo serious generic changes. This process is accompanied by continuous interaction of oral and written traditions, gradually merging the boundary between legend and history.

Keywords: Ali, Muhammad, early Islam wars, Malay literature, oral tradition.

Information about the author: Liubov V. Goriaeva, $\mathrm{PhD}$ in Philology, Leading Research Fellow, Institute of Oriental Studies, Russian Academy of Sciences, Rozhdestvenka I2, I0703I Moscow, Russia.

E-mail: goriaeva@mail.ru 
Возникновение малайской письменной традиции в ее дошедших до нас образцах принято связывать с эпохой, когда ислам становится господствующей религией островной Юго-Восточной Азии - сначала в княжестве Самудра-Пасей на северо-востоке Суматры (XIII в.), затем в Малакке, Аче (XV в.) и Джохоре-Риау (XVI в.). Сочинения вероучительного характера, предания и легенды исламского происхождения начали распространяться на северо-западе региона благодаря присутствию купцов из Ближнего и Среднего Востока, которые подолгу задерживались в тех краях в ожидании попутного муссона. Вместе с ними там появлялись и проповедники ислама, которые рассказывали жителям прибрежных портовых городов о жизни Пророка и его деяниях.

Рукописи, содержащие изложение мусульманской доктрины и написанные по-арабски с подстрочным переводом на малайский на основе адаптированной для этого языка арабской графики - джави, получают хождение в регионе, по меньшей мере, с конца XVI в. [4, 4 sqq]. Вместе с исламом в малайский мир приходят не только сочинения богословского характера, но и множество ближневосточных преданий, связанных с историей возникновения мусульманской религии, повестей о пророках древности, о Мухаммаде, его сотоварищах, исламских героях и подвижниках благочестия.

Отдельную группу текстов представляют собой малайские повести о войнах Пророка. Генетически они восходят к арабским повествованиям о военных походах Мухаммада, тесно связанным с устной традицией доисламских эпических сказаний о межплеменных войнах (айам ал-араб) и 
впоследствии оформлявшимся в биографические своды (сира). Наиболее раннее произведение этого жанра, где завоевательным походам Мухаммада посвящен специальный раздел, принадлежало перу арабского историка Ибн Исхака (704-767/8). Одновременно в арабской традиции продолжали существовать и передаваться от сказителя к сказителю устные предания о военных подвигах Пророка и его сторонников [5, p. 547-548].

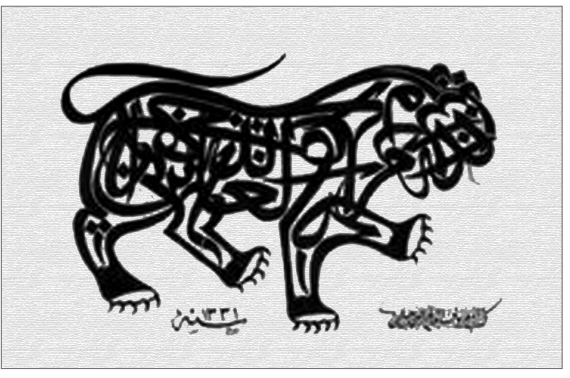

Каллиграфическая композиция на ткани, сложенная из слов: «Именем льва Аллаха, лика Аллаха, Али-победителя». Турция, I33I г.X. (I9I2-I9I3)

Calligraphic composition on the fabric composed of the words: «In the name of Allah's lion, the face of Allah, Ali the Victorer». Turkey I33I (I9I2-I9I3)

Переход преданий жанра сира в другие языки и культуры сопровождался неизбежной утратой их исторической достоверности, все большей и большей отдаленностью от первоисточника. По мере продвижения этих сюжетов на юго-восток Азии сказители-неарабы, передававшие их из уст в уста, перекраивали сюжеты на свой лад, давали свое собственное толкование событиям. Известно, в частности, что многие малайские истории о Мухаммаде восходят к персидским (шиитским) прототипам.

Если в пришедших с Ближнего Востока трактатах религиозного и юридического содержания следовало соблюдать верность букве, то популярный среди малайцев жанр повести (хикайат) допускал более свободное обращение с материалом. В соответствии с существующей практикой, добавки к тексту и правку вносили по своему усмотрению и копиисты. Так с течением времени в малайской литературе сформировался своеобразный жанр «исламского хикайата». В отличие от жанра сира, требовавшего точности, хикайат давал свободу вымыслу, когда исторические факты бессознательно искажались в угоду занимательности повествования. Элементы народных верований и мировосприятия все глубже проникали в малайский исламский хикайат, а исторические персонажи рисовались живыми людьми и наделялись чертами, близкими для малайцев. 
В числе историй о Пророке, созданных безымянными малайскими авторами, особое место занимают повествования о битвах Мухаммада против его врагов. Это, например, «Повесть о Радже Хандаке», «Повесть о радже Лахаде» и другие. Их действие разворачивается в Мекке, Медине и других областях Аравии, какими их представлял себе местный автор.

Названия повестей служат отголоском сражений с участием пророка Мухаммада, имевшим место в 627-630 гг. Заглавие «Повести о Радже Хандаке» отсылает читателя к знаменитой «Битве у рва» 627 г. (от арабского «хандак» - ров), призванной защитить Пророка и его соратников от нападения врагов - мекканцев. Согласно Корану, битвы как таковой не было - Аллах наслал на врага ветер, уничтоживший его палатки и вселивший в него такой ужас, что мекканцы стали отступать без боя (Коран 33: 9-І2). Другое название «Повести о Радже Хандаке» - «Повесть о радже Бадре» - напоминает о битве при Бадре (624), а заглавие «Повести о радже Лахаде» - о битве при Ухуде (627). Здесь топонимы трансформировались в имена собственные, которые носят враги Пророка. Наконец, битва при Хунейне (630) дала имя полю сражения, упоминаемому в той же «Повести о радже Хандаке».

Одним из главных персонажей во всех этих сочинениях выступает Али ибн Абу Талиб, родич и сподвижник Мухаммада. Возможно, причину популярности Али у малайцев следует приписать влиянию персидской, шиитской по духу, традиции (как письменной, так и устной). Образ Али издавна был окружен легендами, о которых еще в Х в. сообщал ал-Масуди: по его словам, в Сиффинской битве Али собственноручно убил 523 ратника, вражеских всадников он рассекал своим мечом надвое так, что их торсы падали на землю, а нижняя часть туловища оставалась в седле [5, p. 3I-32]. Образ Али как воина ислама стал ключевым и в малайских хикайатах.

Выступая как правая рука Пророка в борьбе против врагов истинной веры, он неизменно одерживает над ними верх. Порой Али приписываются победы в битвах, в которых он и не участвовал: например, в «Повести об Абу Бакре» это битва при Кадисии против Сасанидов во время арабского завоевания Ирана (636) - сюжет, окончательно утративший историческую достоверность под пером малайского автора.

Главная ипостась Али - одинокий воин и одновременно святой, обладающий рядом общих черт с пророком Сулейманом: как и тот, Али имеет власть над джиннами, животными и даже неодушевленными предметами. 
Подобно другим классическим героям эпоса, Али наделен сверхъестественными возможностями, является обладателем коня, способного летать по воздуху, и волшебного меча. Вот как описывается Али в «Повести о радже Хандаке»:

Сев на своего скакуна по имени Дулдул Джабарут, Али заставил его взмыть в воздух и испустил троекратный воинский клич. Его действия сотрясали небосвод, который, казалось, вот-вот обрушится на землю и разобьет ее в мелкие куски. Когда Али вновь испустил троекратный клич, три тысячи неверных тотчас же пали мертвыми. Затем он ринулся на врага. Едва он выхватил свой меч Зу-л Факар ${ }^{\text {, }}$ как тот сам собой вытянулся в длину, насколько хватало взора. Тогда Али принялся рубить неприятеля и справа, и слева, и спереди, и сзади от себя, и многие были убиты [8, p. 86].

Прежде чем вступить в сражение, Али обычно призывал противников принять ислам, но, когда они отвечали отказом и вызывали его на битву, Али не оставлял в живых ни одного. В шиитской традиции ему было присвоено прозвище «Лев Аллаха», тогда как в малайских хикайатах непривычное для Юго-Восточной Азии понятие «лев» было заменено на «тигр» - «Тигр Аллаха» [7, p. І05]. Когда в бою Али чувствовал, что теряет силы, он обращался к Всевышнему с просьбой: «О, Аллах, даруй мне нубуат (пророчество)», и получал искомое пророчество, т. е. заверение, что все для него завершится благополучно [8, p. 69-70]. Во время боя Аллах не однажды посылает на подмогу Али свое небесное воинство.

В этих сочинениях Али обычно предстает как наиболее просвещенный из сподвижников Пророка, причем его знания переданы ему самим Мухаммадом. В «Повести о Фатиме» Всевышний освящает союз Али с дочерью Пророка и от имени жениха шлет ей из рая свадебный подарок, сама же церемония происходит «на седьмом небе». Этому же событию посвящен еще один хикайат - «Повесть о бракосочетании Али». Особое положение Али в ряду соратников Пророка подчеркивается и в «Повести о халифе Умаре», где Али находит ответы на все заданные евреями вопросы, чего сам Умар сделать не мог. В «Повести о том, как Пророк наставлял Али» ясно

I $\quad$ Вариант транскрипции - Зульфикар. Меч Мухаммада, перешедший после его смерти к Али и обладающий, по легенде, магической силой и волшебными свойствами [3, с. 79]. 
указывается, что Мухаммад считал своим преемником именно Али и самолично наставлял его в исламской науке [6, p. пі6].

При ближайшем рассмотрении обнаруживается, что и образ Али, и истории о ранних войнах ислама в целом тесно переплетены с местными преданиями и архаическими верованиями, согласно которым благополучие человека зависит от его отношений с обитающими в мире духами, а также горами, холмами и лесами, которые в данном случае выступают союзниками Али. Действие повестей о военных походах Пророка разворачивается в вымышленном антураже Мекки, Медины и соседних с ними областей Аравии. Исходя из собственных представлений об этих незнакомых ему краях, малайский автор упоминает, например, джунгли, через которые якобы пролегает путь героев, или же животных, обитающих в Юго-Восточной Азии, а в Аравии неизвестных: носорогов, а также гиббонов и других крупных обезьян.

Несмотря на свои ближневосточные корни, малайские хикайаты этого цикла обнаруживают множество черт сходства с домусульманской словесностью и театральной традицией островной Юго-Восточной Азии. Это стилистика повествования - его язык, эпитеты и клишированные обороты, эпические повторы при описании типовых сюжетных ситуаций и диалогов.

Во время сражения Всевышний руководит действиями Али через посредство Джабраила, подобно тому, как в малайской версии «Махабхараты» небесные боги сообщают воюющим Пандавам, как им следует поступать, через своего посланца - бегавана Нараду. В «Повести о радже Хандаке» Аллах посылает Джабраила к Пророку с приказом остановить бой под предводительством Али, «пока тот по своему безрассудству не перебил всех неверных до единого, не то в аду никого не останется» [8, p. I36].

Если сравнить Али с братьями-Пандавами, то наибольшее сходство он обнаруживает с могучим и безудержным Бимой (Бхимой) и его сыном Гатоткачей, чье «упоение в бою» небесным богам то и дело приходится сдерживать. В одной из подобных сцен исламские и доисламские, архаические, элементы переплетены особенно причудливо: охваченный амоком Али сражается так яростно, что вызывает тревогу у самого Аллаха - а вдруг невзначай тот ранит своим мечом корову, на которой стоит мир? И Всевышний шлет Джабраила к Али с просьбой, чтобы тот умерил свой пыл, подобно тому, как в «Повести о победоносных Пандавах» боги сыплют с небес цветы, пытаясь 
угомонить разъяренных Гатоткачу и Баладеву, готовых в пылу сражения предать всю землю огню [2, с. I59].

Трансформация и адаптация образа Али малайской традицией связана по преимуществу с переходом этого персонажа в сферу устного предания. «Фольклоризация» исходно письменного материала путем распространенной практики чтения вслух в конце концов привела к тому, что Али, наряду с Джабраилом, Микаилом, Исрафилом, Азраилом и, конечно, Аллахом, стал объектом инвокации в таком архаическом жанре, как шаманское заклинание, дарующее победу над врагом [6, p. 132].

Очевидно, что по мере своего продвижения на восток сюжеты об Али и других персонажах священной мусульманской истории прошли сложный и долгий путь, причем не только в географическом, но и в жанровом плане. Этот процесс сопровождался непрерывным взаимодействием устной и письменной традиций, постепенно стиравшим границу между легендой и историей. И если при переводе богословских или законоведческих трудов малайские книжники строго следовали букве оригинала, то в полуфольклорном хикайате об исламском герое и воине они чувствовали себя более свободно. Об этом свидетельствуют, в частности, строки, которыми завершается «Повесть о радже Хандаке»: «Если что-то в ней [повести. - Л.Г.] написано нескладно или пропущено - добавьте сами, а если сказано что-то лишнее сокращайте, ибо писавший сие неумел и бестолков, способностями своими он ниже всех, сотворенных Аллахом в мире сем» [1, с. 37-46].

Популярность образа Али никоим образом не шла вразрез с общесуннитской доминантой малайско-индонезийского ислама. С одной стороны, этот герой олицетворял преданность Пророку и нетерпимость к врагам его веры, а с другой - напоминал привычные для малайцев фигуры театра плоских кожаных кукол, устных сказаний и издавна знакомых персонажей древнеиндийских эпопей: отважных воителей и любимцев богов. В этом в полной мере проявился «инклюзивный» характер культуры малайского мира, сохранившийся вплоть до наших дней. 


\section{Список литературы}

I Горяева Л.В. Две рукописи «Повести о раджах Пасея» (к истории текста) // Письменные памятники Востока. 2015. № I (22). С. 37-46.

2 Памятники малайской книжности XV-XVIII вв. Повесть о победоносных Пандавах. Бухари ал-Джаухари «Корона царей» / перевод с малайского, исследования, комментарии, приложения и указатели Л.В. Горяевой. М: Вост. лит., 20II. 646 с.

3 Пиотровский М.Б. Зу-л-Факар // Ислам. Энциклопедический словарь. М.: Наука, I99I. C. 79.

$4 \quad$ Syed Muhammad Naquib al-Attas. The Oldest known Malay manuscript: A I $6^{\text {th }}$ century Malay translation on the 'Aqaid of al-Nasafi. Kuala Lumpur, I988. I56 p.

5 Gibb H.A.R, Kramers, J.H. Shorter Encyclopaedia of Islam. Leiden; NY; Köln: E.J. Brill, I995. 67I p.

6 Ismail Hamid. The Malay Islāmic Hikāyat. Kuala Lumpur: Universiti Kebangsaan Malaysia, 1983. 228 p.

$7 \quad$ Wieringa E. Does Traditional Islamic Malav Literature Contain Shi'itic Elements? 'Ali and Fatimah in Malay Hikayat Literature // Studia Islamika. I996. Vol. 3. № 4. P. 93-III.

8 Wijaya E. (ed.) Hikayat Raja Handak Koleksi van de Wall. Perbandingan Alur Naskah W 88 dan W 9I. Fakultas Ilmu Pengetahuan Budaya Universitas, Indonesia. 2008. URL: http://lib.ui.ac.id/file?file=digital/20I60278-RBorWı9oh-Hikayat\%2oRaja.pdf (дата обращения: Іо.09.20I7). 


\section{References}

I Goriaeva L.V. Dve rukopisi "Povesti o radzhakh Paseia” (k istorii teksta) [Two manuscripts of Hikayat Raja Pasai (on the history of the text)]. Pismennye pamiatniki Vostoka, 20I5, no I (22), pp. 37-46. (In Russ.)

2 Pamiatniki malasko knizhnosti XV-XVIII vv. Povest o pobedonosnykh Pandavakh. Bukhari al-Dzhaukhari "Korona tsare" [Texts of Malay written heritage of the $15^{\text {th }}-18^{\text {th }}$ centuries. The tale of victorious Pandawas. Bukhari al-Jawhari “The Crown of Kings”], translation from Malay, research articles, comments, annexes and indexes by L.V. Goriaeva. Moscow, Vost. lit. Publ., 20II. 646 p. (In Russ.)

3 Piotrovski M.B. Zu-l-Fakar [Zu-l-Fakar]. Islam. Ėtsiklopedicheski slovar [Islam. Encyclopedia]. Moscow, Nauka Publ., I99I, p. 79. (In Russ.)

4 Syed Muhammad Naquib al-Attas. The Oldest known Malay manuscript: A I $6^{\text {th }}$ century Malay translation on the 'Aqaid of al-Nasafi. Kuala Lumpur, I988. I56 p. (In English)

5 Gibb H.A.R, Kramers, J.H. Shorter Encyclopaedia of Islam. Leiden; NY; Köln, E.J. Brill, I995. 67I p. (In English)

6 Ismail Hamid. The Malay Islāmic Hikāyat. Kuala Lumpur, Universiti Kebangsaan Malaysia, I983. 228 p. (In Malay)

7 Wieringa E. Does Traditional Islamic Malav Literature Contain Shi'itic Elements? 'Ali and Fatimah in Malay Hikayat Literature. Studia Islamika, I996, vol. 3, no 4, pp. 93-III. (In English)

8 Wijaya E. (ed.) Hikayat Raja Handak Koleksi van de Wall. Perbandingan Alur Naskah W 88 dan W 9I. Fakultas Ilmu Pengetahuan Budaya Universitas, Indonesia. 2008. Available at: http://lib.ui.ac.id/file?file=digital/20I60278-RBorWigoh-Hikayat\%2O Raja.pdf (Accessed September Io, 20I7). (In Indonesian) 
УДК 82I.І33.I.0

ББК $83.3(4 \Phi$ ра $) 4$
ДВЕ МИФОЛОГИЧЕСКИХ БАЛЛАДЫ

ИЗ «СТА БАЛЛАД» КРИСТИНЫ

ПИЗАНСКОЙ: ОПЫТ АНАЛИЗА

(C) 2018 г. Л.В. Евдокимова

Институт мировой литературы

им. А.М. Горького Российской академии наук,

Православный Свято-Тихоновский

гуманитарный университет,

Москва, Россия

Дата поступления статьи: І9 сентября 2017 г. Дата публикации: 25 марта 2018 г.

DOI: I0.22455/2500-4247-20I8-3-I-68-87

Подготовка статьи осуществлена при поддержке фонда развития ПСТГУ в рамках работы над проектом «Генезис литературного текста в период позднего Средневековья и раннего Нового времени: взаимодействие стилей и жанров».

Аннотация: Статья посвящена анализу двух мифологических баллад из раннего сборника стихотворений Кристины Пизанской «Сто баллад» (I399-I4II), которые мы предлагаем прочесть сквозь призму аллегорических комментариев к поэме Овидия «Метаморфозы»: поэму «Морализованный Овидий» и два латинских трактата «Морализованный Овидий» Пьера Берсюира и «О происхождении языческих богов» Боккаччо. Эти сочинения позволяют понять содержание баллады XС, которая исследователям казалась загадочной: речь в ней идет о скорой смерти Адониса, которому угрожают многие боги Олимпа. Кристина читала аллегорические комментарии к «Метаморфозам»; из них следует, что в балладе говорится о борьбе за человеческую душу, которую ведут аллегории: Адонис воплощает Юность, Вулкан - чувственную страсть, Паллада - мудрость; Юпитер - верховный Разум; Меркурий - красноречие; Юнона - волю. Адонис должен преодолеть чувственную страсть с помощью своей воли, - таков моральный урок, который Кристина в аллегорической форме сообщает своему читателю. Ее понимание воли как способности человека, связанной с разумом, близко к тому, которое развивал Фома Аквинский. Поэма «Морализованный Овидий» и трактат Берсюира открывают аллегорический смысл баллады LXI, где речь идет о счастливой любви Ио и Юпитера: Ио воплощает человеческую душу, на время погрязшую в грехах и утратившую человеческий облик, позднее же вернувшуюся к своему возлюбленному - Юпитеру, т. е. Богу.

ключевые слова: Кристина Пизанская, «Сто баллад», мифологические баллады, аллегорические комментарии к «Метаморфозам», Пьер Берсюир, «О происхождении языческих богов» Боккаччо.

Информация об авторе: Людмила Всеволодовна Евдокимова - доктор филологических наук, ведущий научный сотрудник, Институт мировой литературы им. А.М. Горького Российской академии наук, ул. Поварская, д. 25 а, І2Іо69 г. Москва, Россия; профессор, Православный Свято-Тихоновский гуманитарный университет, ул. Новокузнецкая, д. 23 б, II5I84 г. Москва, Россия.

E-mail: ludmila.evdokimova@gmail.com 


\title{
REEXAMINING TWO MYTHOLOGICAL BALLADS FROM CHRISTINE DE PIZAN'S CENT BALADES
}

This is an open access article distributed under the Creative Commons Attribution 4.0 International (CC BY 4.0)

\author{
(C) 20I8. L.V. Evdokimova \\ A.M. Gorky Institute of World Literature \\ of the Russian Academy of Sciences, \\ St. Tikhon Orthodox University, \\ Moscow, Russia \\ Received: September I7, 2017 \\ Date of publication: March 25, 2018
}

Acknowledgements: This article is supported by St. Tikhon Orthodox University Foundation. It is part of the project entitled "Genesis of a Literary Text in Late Middle Ages - Early Modern Times Period: Interaction of Styles and Genres.”

Abstract: The article analyzes two mythological ballads from Christine de Pizan's early collection Cent Balades (I399-I4II). I propose to interpret them against allegorical commentary on Ovid's Metamorphoses, a poem Ovide moralise and two treatises - Pierre Bersuire's Ovididius moralizatus and Boccaccio's De genealogia deorum gentilium. These works help us understand the ballad XC that critics have traditionally considered mysterious. The ballad tells the story of Adonis and his early death. Christine was familiar with the commentary on Metamorphoses that rendered the poem allegorically. The ballad can be therefore read as a story of the struggle for the human soul where Adonis emblematizes youth, Vulcan - desire, Pallas - wisdom, Juno - will, Jupiter - Supreme Reason, and Mercury - eloquence. Adonis must overcome corporeal passion voluntarily - this is the moral lesson that Christine gives in the allegorical form to her reader. Her relation of human will to reason is similar to that of Thomas Aquinas. The poem Ovide moralisé and Bersuire's Ovididius moralizatus shed light on the allegorical subtext of the ballad LXI that narrates the love story of Io and Jupiter. Io epitomizes a sinful human soul temporarily deprived of humanity that, however, returns to the beloved - Jupiter, or God. The analysed poems demonstrate Christine's taste for allegorical and obscure poetry that Boccaccio defended in his De genealogia deorum gentilium.

Keywords: Christine de Pizan, Cent Balades, mythological ballades, allegorical comments on Metamorphoses, Ovide moralis, Pierre Bersuire, Boccaccio's De genealogia deorum gentilium.

Information about the author: Liudmila V. Evdokimova, DSc in Philology, Leading Research Fellow, A.M. Gorky Institute of World Literature of the Russian Academy of Sciences, Povarskaya 25 a, I21069 Moscow, Russia; Professor, Saint Tikhon's Orthodox University, Moscow, Russia, Novokuznetskaya, 23 b, II5I84 Moscow, Russia.

E-mail: ludmila.evdokimova@gmail.com 
Баллада ХС из «Ста баллад», посвященная скорой гибели Адониса, к которому враждебны почти все боги Олимпа, за исключением Юноны и Меркурия, - наиболее загадочная в раннем сборнике стихов Кристины Пизанскойг Немногие исследователи пытались прокомментировать ее содержание. Наиболее развернутый комментарий содержится в статье Лейдло. Согласно ему, Кристина следует в своих балладах, включающих имена языческих богов, непосредственно Овидию и в известной степени Фруассару. Это утверждение Лейдло не подтверждает аргументами, отсылая к статье Грехэм [I4, p. 24-33]. Она не представляет интереса для анализа нашей баллады: здесь содержится лишь перечень мифологических реминисценций из произведений Фруассара без какого-либо анализа их источников. При этом имя Адониса приводится

I Приводим текст баллады по изданию, сопровождая его нашим подстрочным переводом: «I: Se de Juno, la deesse poissant, / N'est Adonis bien briefment secouru, / Le fiers dieu Mars l'ira trop angoissant. / Es fors lians Vulcans est encouru; / Venus l'ama jadis, bien y paru, / Mais ne lui peut ades en riens aidier; / Il y morra briefment, au mien cuidier. II: Et durement lui est Pallas nuisant, / Mais Mercures est pour lui acouru, / Qui fait son fait trouble apparoir luisant, / Devant le Dieu Jupiter comparu / Est Adonis, contre lui apparu / C'est Cerberus qui trop scet de plaidier; / Il y morra briefment, au mien cuidier. III: Trestous les dieux lui sont mal advisant, / Fors Mercures par qui Argus moru, / Mais s'a Juno aloit abelissant / Il ne seroit de nul a mort feru; / Mes s'Appolo le fiert a trop grand ru, / Sauldra le sang, tout lui fera vuidier; / Il y morra briefment, au mien cuidier» [8, p. 90]. - «I: Если Адонису / В скором времени не поможет могущественная Юнона, / Ему будет грозить жестокий бог Марс. / Вот подоспел Вулкан со своими крепкими цепями; / Некогда Венера благоволила Адонису, - всякий видел, / Но теперь не может ничем помочь; / Думаю, Адонис вскоре умрет. II: Паллада наносит ему урон, / Но на подмогу спешит Меркурий, / Придавая блеск его смущению. / Адонис предстал перед / Богом Юпитером, против него / Выступает Цербер, прекрасный сутяга, / Думаю, Адонис вскоре умрет. III: Все боги сулят ему зло, / Кроме Меркурия, принесшего гибель Аргусу, / Но если Юноне будет угодно, / Ни один не погубит его. / И все же если Аполлон нанесет ему страшный удар, / Его кровь хлынет ручьем, - вся изольется, / Думаю, Адонис вскоре умрет». 
один раз в неясном контексте; Юпитер и Юнона фигурируют как помощники в любовных делах; Меркурий назван «посланцем богов» - и только; что касается Вулкана и Цербера, то о них речи нет. Обращаясь к «Посланию Отеи» (чуть более позднему произведению Кристины), где Юнона определяется как символ богатства и власти, Лейдло предполагает, что таким же значением эта богиня наделена и в интересующей нас балладе. Далее привлекая это определение Юноны для истолкования баллады и в остальном надо думать, довольствуясь самими «Метаморфозами», он усматривает общий ее смысл в демонстрации того, что подлинная любовь невозможна в мире, где царствует алчность и другие пороки [I7, p. I05-I06] ${ }^{2}$.

На наш взгляд, смысл этой аллегории иной - менее расплывчатый и не сводимый к социальным инвективам. Он выстраивается, если принять во внимание аллегорические значения отдельных богов, извлекая их, разумеется, из овидианской экзегезы того времени, но не самого Овидия. В таком случае окажется, что речь в этой балладе идет, скорее, о своего рода «психомахии» - борьбе разных душевных сил в душе человека.

«Морализованный Овидий» был, как известно, одним из главных источников Кристины; к нему она обращалась, в частности, в «Послании Отеи», которое по времени близко к «Ста балладам» [2I, p. 32-35]. В предисловии к «Посланию Отеи» Г. Парусса показала, что Кристина уже в это время была в определенной степени знакома с трактатом Боккаччо «О происхождении языческих богов», по крайней мере с некоторыми его главам [2I, p. 65-66] (см. также: [го, р. 8]). В связи в «Посланием Отеи» некоторые исследователи упоминали также и «Ovidius moralizatus» Берсюира [ı6, p. Iоo-I24; 24, p. 72]. Эти три источника, на наш взгляд, позволяют прочесть и интересующую нас балладу. Сопоставление с ними баллады ХС показывает, как кажется, что, рисуя взаимодействие Адониса с различными богами Олимпа,

2 Ср. также: [г8, p. 75]. В этой более поздней статье автор повторяет те же выводы, по-прежнему полагая, среди прочего, что все свои сведения о богах Олимпа Кристина почерпнула непосредственно из «Метаморфоз» Овидия [г8, p. 8о, прим. 28]. В книге Д. Рош «Ста балладам» посвящена отдельная глава [25, p. 87-Іо5], однако здесь нет никакой попытки прочесть балладу ХC: о последней сказано лишь, что Кристина вначале позволяет читателю надеяться на спасение Адониса, однако затем возвещает о его гибели [25, p. 93]. Ср. также статью Альтман [3], которая вовсе не касается мифологических баллад сборника. Лори полагает, что в «Ста балладах» Кристина ориентируется на модели, предложенные Петраркой: отсылает к «Африке», а также к «Rime sparse», XXIII [I9, p. 43-66]; его аргументы нам не кажутся убедительными. 
Кристина имела в виду аллегорические значения богов, которые содержат эти комментарии «Метаморфоз».

Каждый из них предлагает, однако, множество разнообразных, зачастую противоположных - как положительных, так и отрицательных - значений для каждого бога. Как понять, к какому из них Кристина отсылала в каждом конкретном случае? Одним из критериев, позволяющих это сделать, должна быть, нам кажется, внутренняя непротиворечивость аллегорического сюжета, который сложится, если заменить имя бога названием добродетели или порока. Другим критерием являются некоторые эпитеты, которые сопровождают имя собственное того или иного бога; иногда, как мы убедимся, эти эпитеты отсылают к определенному источнику.

Главный герой поэмы - Адонис, - по-видимому, есть воплощение скоропреходящей юности и красоты. Это значение наиболее отчетливо проявлено у Боккаччо, который, объясняя превращение Адониса в цветок, пишет:

Quod autem Adon sit transformatus in florem, ob id fictum puto, ut nostri decoris brevitas ostendatur: mane quidem purpureus est, sero languens pallensque marcidus efficitur; sic et nostra humanitas mane, id est iuventutis tempore, florens et splendida est, sero autem, id est senectutis evo, pallemus et in tenebris mortis ruimus [5, p. 254].
Думаю, Адонис был превращен в цветок, чтобы тем указать на скоротечность нашей красоты; утром цветок окрашен пурпурным цветом; к вечеру же никнет, блекнет и гниет. Таков же и человек: утром, в пору юности, цветет и сияет, к вечеру же, в старости, бледнеет и влечется ко мраку смерти.

Сходное определение дается и в поэме «Морализованный Овидий»: Адонис стал цветком в ознаменование того, что красота скоро гибнет под действием возраста и болезни:

Pour petit de vent chiet et tramble

Telz flours, car biauté, ce me samble,

Pour mesaise ou par maladie

Ou pour viellece est tost fletrie

[20, t. 4, p. IOO].
Такой цветок трепещет и падает

На землю от слабого ветра;

Так и красота блекнет от лишений,

Болезни или старости.

Однако автор поэмы «Морализованный Овидий» склонен к осуждению Адониса: тот означает наслаждение, в котором живет похоть, а также праздность, с ней связанная; его погубила свинья - грязь его пороков. Объ- 
ясняя, что Адонис погибнет столь же скоро, сколь цветок, автор «Морализованного Овидия» утверждает, в отличие от Боккаччо, что это подлый человек, который заражает всех своими пороками [20, p. 99-Іоо]. Как и у Боккаччо, в балладе Кристины нет прямого осуждения Адониса; ее Адонис, быть может, амбивалентный, но едва ли однозначно отрицательный. По этой причине нам кажется, что Кристина ориентировалась в данном случае, скорее всего, на Боккаччо. Что касается Берсюира, то его толкование гибели Адониса кажется в данном случае не походящим к сюжету Кристины: тот-де погиб, поскольку напал на сильных мира сего, - львов и кабанов; кто так поступает, вскоре погибнет, подобно цветку [22, p. I54].

Значения многих богов, противостоящих или - реже - помогающих Адонису, приводятся в комментариях к истории Марса и Венеры, причем версия, содержащаяся у Берсюира, особенно богата в этом отношении: здесь с пороками или моральными качествами отождествляются не только Венера, Вулкан или Марс (эти параллели есть и в одноименной поэме), но также Юпитер, Юнона, Паллада. В самом деле, Берсюир толкует в комментарии к этому же мифу связанные друг с другом истории рождения Паллады и Вулкана:

Cum Iuno de Iove nihil pareret, Iuppiter timens ne in se peccatum esset, causa experimenti caput suum concussit per quam concussionem Pallas de cerebro eius nata est et in terram armata prosiliit. Iuno autem indignata volens ostendere quod ipsa non esset causa sterilitatis, levavit se et concutiens vuluam suam Vulcanum sine usu masculi peperit, qui Vulcanus quasi de vulva cadens propter hoc dictus est. Iste tamen quia turpis erat, facie de coelo fuit proiectus in terram et claudus est factus, qui in Lemno insula fuit absconditus et nutritus et tandem Veneri in matrimonio fuit datus.

Ista possunt exponi moraliter. Et sic dico quod Iuppiter significat intellectum; Iuno vero voluntatem et affectum. Iste enim sunt due potentiae in anima constitutae verum et etiam
Поскольку у Юноны не было от Юпитера детей, тот, опасаясь, что он сам в этом виноват, дабы испытать себя, сотряс свою главу; от этого сотрясения из его ума родилась Паллада и в полном вооружении ступила на землю. Возмущенная Юнона, желая доказать, что и она не причина бесплодия, поднялась со своего места, и, сотрясая вульву, безо всякой мужеской помощи тоже родила; из вульвы ее выпал Вулкан, который потому так и назван. Поскольку тот был весьма уродлив, его сбросили с неба головой вниз, отчего он охромел. Он скрывался и был вскормлен на Лемносе, а затем дан в мужья Венере.

У всего сказанного есть моральный смысл. Итак, скажу, что Юпитер означает разум; Юнона же - 
invicem coniugatae; verum quia волю или чувство. Оба они воплощают ipsae differunt inter se, non pariunt две душевные силы, соединенные между et nunquam actum unum et eundum собой. Верно и то, что они меж собой producere possunt; <..> Iuppiter ergo различны и никогда не способны соde cerebro imaginationis sue Palladem, вершить вместе одно и то же действие. id est sapientiam, produxit. Iuno vero, id < ..> Итак, Юпитер произвел на свет воest affectus, Vulcanum deum ignis, id est ображением своего ума Палладу, иначе ardorem concupiscentiae, generavit. Qui мудрость. Юнона же, то есть чувство, scilicet in terram cecidit per avariciam, родила Вулкана, бога огня, жар вождеVeneri fuit conjunctus per luxuriam [22, ления. А он из-за скупости был сброшен p. 75]. на землю, а из-за сладострастия соединен с Венерой.

Ниже, в той же главе, боги, решившие низвергнуть Вулкана на землю, названы рациональными движениями души, изгоняющими страстное вожделение из человеческого ума:

Et ideo dii, id est motus rationales ipsum [Vulcanum] debent a coelo, id est a mente, expellere et tanquam turpissimum de mentis tabernaculo effugare [22, p. 76].
А потому боги, то есть рациональные движения души, должны Вулкана сбросить с неба, то есть вытолкнуть его из ума и за его безобразие изгнать из шатра разума.

Отождествление Юпитера с Разумом, Паллады - с Мудростью, Юноны - с Волей проясняют, как кажется, общую картину действия, которая разворачивается в балладе ХС между противниками и споспешниками Юности-Адониса: Адонис, оставленный чувственной любовью, т. е. Венерой, может надеяться на помощь воли-Юноны; ему противостоят Вулкан-жар Вожделения, Юпитер-разум, Паллада-мудрость и Марс, названный здесь «богом войны» $[22$, p. 76]4.

3 Другие значения Юноны, которые Берсюир приводит в той же главе (богатство и могущество; Святая Дева; память, не дающая забыть о добрых делах) не позволяют описать борьбу противников и соратников Адониса, представленную Кристиной, как непротиворечивый сюжет. То же относится к сведениям о Юноне, которые сообщаются у Боккаччо (символ богатства и власти; покровительница брачных уз и др.) [5, p. 876, 873]. $4 \ll$ Martem deum belli». 
Между комментариями Берсюира и «Морализованного Овидия» есть сходство: Венера здесь также отождествляется с чувственной любовью, сладострастием, Вулкан несколько раз назван жаром вожделения:

Or vous dirai l'alegorie

Que ceste fable signifie.

$<\ldots>$

Venus, c'est a dire luxure,

Femme de Vulcan, c'est ardure

Qui les cuers fet ardoire et frire,

Fist celeement avoultire...
Итак, раскрою вам смысл аллегории, Которая представлена в этой басне. $<\ldots>$

Венера, то есть сладострастие, жена Вулкана, иначе страсти, Каковая жжет и печет сердца, Понуждая к тайным прелюбодеяниям...

$$
\text { (v. I630-I635) [20, t. 2, p. 47]. }
$$

Что касается Марса, то он в «Морализованном Овидии» именуется «destruisierres», «губителем» (v. I639 [20, t. 2, p. 47]), - по-видимому, олицетворяя угрозу гибели и смерти, в соответствии с одним из значений старофранцузского «destruire» [9; I3, p. 365]. У Кристины упоминание жестокого Марса среди недругов Адониса подхвачено далее рефреном, который возвещает о скорой гибели главного героя.

Надо думать, что поэма «Морализованный Овидий», наряду с комментарием Берсюира, оказала влияние на формирование аллегорического сюжета, разворачивающегося в балладе ХС. Помимо значения, которое сообщается здесь Марсу, поэма могла повлиять на Кристину и в том отношении, что в ней немалое место уделено описанию характерного атрибута Вулкана его крепких цепей; Кристина, напомним, также упоминает этот атрибут («Вот подоспел Вулкан со своими крепкими цепями», ст. 4):

Vulcans li maris, c'est l'ardure,

Forga d'arain et d'aïmant

Les subtis las dont li amant

Sont souvent pris et retenu.

$\mathrm{Li}$ las sont si grelle et menu

C'on ne les puet apercevoir.

Moult est li homs de grant savoir

Qui de ces las se set deffendre,

Et cilz folz qui s'i lesse prendre,

Quar, puis qu'il s'il lesse atraper,

A paine en puet mais eschaper.
Муж Вулкан, иначе страсть,

Выковал из бронзы и магнита

Тончайшие сети, в каковые часто

Попадаются влюбленные, не способные затем из них вырваться.

Сети эти тонки, как паутина,

Так что их не замечают.

Тот умен, кто сумеет от них ускользнуть, И тот безумен, кто в них попадется:

Раз уж пойман,

Ему не уйти. 
Li arains serre, et l'aïmans

Aleche et atrait les amans,

Tant que par la mauvese ardure

Sont mis a honte et a laidure,

A mort et a perdicion,

A dampnable derision

(v. I739-I755) [20, t. 2, p. 49].
Бронзовые нити держат крепко,

а магнит

Манит и притягивает влюбленных,

И в конце концов злая страсть

Доводит их до стыда и позора,

До смерти и погибели,

Всем на смех их выставляет.

Кроме того, в поэме история Марса, Венеры и Вулкана включает пространный перечень злоключений, которые несет чувственная любовь. Важно, что этот пассаж отмечен особой стилистической выразительностью и завершается к тому же прямым осуждением чувственной любви, которая ведет человека к смерти:

Nulz ne puet les peris esmer

Ne les maulz qui viennent d'amer.

Nulz homs n'i fet se perdre non

Son temps, son sens, son bon renom.

Terre et avoir et plus encors

I pert l'en: c'est l'ame et le cors.

Tuit cil que si fole amour lie

Sont en tenebreuse folie.

Trop y a mauvese acointence

(v. I724-I733) [20, t. 2, p. 49] $]^{5}$.
Никто не может исчислить опасности

И несчастья, которые таит любовь.

Всякому человеку она грозит

Утратой времени, разума, доброго имени.

С ней теряют земли и имущество, и что страшнее -

Теряют душу и тело.

Все, кого связует сильная любовь,

Ввергаются в бездну безумия.

Встреча с любовью влечет только зло.

Таким образом, если значения нескольких богов - Юноны, Юпитера и Паллады - заимствованы Кристиной, скорее, из комментария Берсюира к истории Марса, Венеры и Вулкана, версия того же сюжета, представленная в поэме «Морализованный Овидий», также, по-видимому, оказала влияние на ее балладу - и некоторыми деталями изложения, и, быть может, в особенности, патетическим осуждением чувственной любви.

Среди противников Адониса у Кристины фигурирует «Цербер, прекрасный сутяга» (ст. I5). Определение Кристины в данном случае прямо основано на комментарии Берсюира. В толкованиях к VII книге «Метаморфоз» Берсюир называет Цербера хулителем и зачинщиком ссор: 
Vel dic quod Cerberus est detractor, quia tria capita et tres latratus caninos habere dicitur inquantum tria genera detractionum noscitur emittere, ipse autem clamoribus verborum suorum solet totam terram litibus et contentionibus concutere. Et quia in tenebris id est in aliorum adversitatibus delectatur, quando lucem alienae prosperitatis conspicit, solet dolere et tunc magis solito sputum venenosum malorum verborum emittere et agros fertiles, id est bonas personas aconito venerare

$$
[22, \text { p. II } 8]^{6}
$$

Или скажи, что Цербер есть хулитель, у какового, как говорят, имеются три главы и троякий собачий лай, поскольку ему знакомы три вида хулы; сам же он оглашает всю землю в округе своей руганью и сотрясает ее ссорами и распрями. А поскольку находит наслаждение в несчастьях других людей, когда же взирает на их процветание, горюет, то тогда он обыкновенно и выплевывает свои ядовитые слова и отравляет аконитом плодородные поля, иначе добрых людей.

Также и Аполлон, мы полагаем, у Кристины, скорее, наделяется тем значением, которое придает ему Берсюир во вводном разделе к своему комментарию. Здесь он среди прочего, ссылаясь на других авторов, отождествляет Аполлона с добродетелью истины [23, p. І6-22]. В поэме «Морализованный Овидий» Аполлон - бог мудрости (так, в истории Марсы и Венеры [20, t. 2, p. 49]). Однако Паллада, упомянутая в ст. 8 («Паллада наносит ему урон»), как мы предположили, также символизирует мудрость; эта аллегория, таким образом, уже включена в действие. По этой причине, мы склонны

6 Отметим, что в «Морализованном Овидии» нам не удалось найти никакого аллегорического толкования этого мифологического персонажа, - так в пространном комментарии к мифу об Орфее и Эвридике о нем вовсе не заходит речь. Во вступительном разделе к комментарию (De forma figurisque deorum - «О внешнем виде и облике богов»), Берсюир упоминает среди спутников Плутона «злого советника Цербера»:

Et primo quidem ibi est Cerberus cum tribus caninis capitibus, et iste significat malos consiliarios caninos, insaciabiles et avaros, qui scilicet tria capita id est triplicem malam intencionem habent, unam scilicet ad gravandum subditos, aliam ad decipiendum et in amore suo manutenendum suos dominos, aliam ad lucrum proprium et ad ditandum se ipsos [23, p. 46].
Первым там был Цербер с тремя собачьими головами; он означает злых советников-псов, ненасытных и алчных, каковые имеют три главы, то есть троякое злое намерение, - одно в том, чтобы угнетать своих подданных, другое - обманывать начальников, в то же время удерживая их любовь, третье - стяжать выгоду и добиваться собственного обогащения.

Та же аллегория Цербера и в парижской, более поздней, редакции «Ovidius moralizatus», частично опубликованной Ф. Гизальберти [ı2, p. Іоо]. 
счесть Аполлона, упомянутого ниже, в ст. г9 («И все же если Аполлон нанесет ему страшный удар»), воплощением истины.

Помимо Юноны, Адонису у Кристины сочувствует Меркурий, придающий «блеск его смущению» (ст. Іо). Значения этого бога лучше известны, чем других, - он отождествлялся с красноречием, в том числе теми авторами, которых мы привлекаем к нашему разбору [5, p. 769-779]7. Эпитет, который у Кристины сопровождает упоминание Меркурия, не позволяет усомниться в том, что она ассоциировала Меркурия с красноречием.

Меркурий упоминается в балладе вместе с Аргусом: «Все боги сулят ему зло, / Кроме Меркурия, принесшего гибель Аргусу» (ст. I5-I6). Последний персонаж появляется в балладе не для того, чтобы напомнить читателю историю Ио и Юпитера, - но отсылает, как и другие имена богов, к ее аллегорическим интерпретациям. Аллегорическое значение Аргуса, которое наилучшим встраивается в сюжет Кристины, предлагает Боккаччо, - он отождествляет Аргуса с человеческим разумом, которого погружают в сон и губят дурные речи Меркурия:

... Argo <...>, id est rationi, cui profecto multa sunt lumina semper, et in salutem nostram vigilantia. Sane Mercurius, id est blande carnis astutia, caduceo, id est suasonibus pessimis, in somnum rationem deducit atque interemit ...

[5, p. 76o].
...Аргусу <...> то есть разуму, наделенному ста очами, дабы он мог заботиться о нашем спасении. Меркурий же, то есть сладкий телесный соблазн, своим кадуцеем, иначе злыми уговорами, наводит на разум сон и тем его губит.

Ни «Морализованный Овидий», ни комментарий Берсюира не дают в данном случае возможность подобрать для Аргуса то значение, которое бы смогло объяснить его участие в битве богов: в первом Аргус воплощает мир сей; во втором - дьявола [20, t. I, р. І45; 22, р. го].

Итак, значения богов, предложенные в трех комментариях к «Метаморфозам», позволяют прочесть балладу Кристины как борьбу за душу человека, которую ведут аллегории, по большей части воплощающие разные

7 Автор поэмы «Морализованный Овидий» отождествляет Меркурия с проповедником (комментарий к мифу об Ио); v. 3994-3996 [20, t. I, p. I47]. В одной из аллегорий Берсюира Меркурий предстает льстецом, который губит душу «сладкими и обманчивыми речами» [22, p. 9-10]. 
моральные свойства. Юность-Адонис, не желает расстаться с чувственной любовью; если он не сделает этого, страсть-Вулкан свяжет его цепями, ему грозит гибель-Марс (строфа I). Мудрость-Паллада и верховный Разум-Юпитер вызывают Адониса на суд. Против героя выступает злой сутяга Цербер; Адонис доверяет доводам красноречия-Меркурия и пытается защититься с их помощью (строфа 2). Однако эти доводы способны лишить рассудка; Истина-Аполлон неизбежно разоблачит их, и тогда Адонису грозит скорая гибель, если только его не спасет собственная воля, Юнона (строфа 3).

Таким образом, за душу героя сражаются две главные противоборствующие силы - желание и воля. Первую из них, как следует из баллады, надо отождествить с любовной страстью; вторая, мы полагаем, близка к тому пониманию воли, которое формулирует Фома Аквинский, - силы, неразрывно соединенной с разумом и устремленной к вечному блаженству; согласно Фоме Аквинскому, воля и свободный выбор, «относятся к одной и той же способности», хоть и не полностью совпадают [2, с. 239] ${ }^{8}$. В самом деле, в «Видении Кристины» (I405), написанным немногим позже «Ста баллад», Кристина формулирует сходное определение воли:

Or regarde a quel prejudice tournent les delices quant ilz rameinent la voulenté, qui doit suivre raison, a tel bestialité que elle ne vise, ne que une beste mue, ne mes aux pastures basses, et ne ne s'eslieve ne regarde a son naturel propre lieu, qui est le ciel dont l'ame formee a l'image de Dieu est venue et doit tendre a aler [7, p. I24].
Посмотри, до какого несчастья способны довести чувственные наслаждения: волю человека, которая должна следовать за разумом, они превращают в волю животного, так что она жаждет только низменной пищи, не устремляется ввысь и не взирает на свою родину, то есть на небо, откуда душа, созданная по образу Бога, явилась в этот мир и куда она должна желать вернуться.

В балладе ХC - одном из моралистических заключений сборника Кристина помещает своего героя на перепутье между чувственной и созерцательной жизнью, показывая, что предпочтение первого пути сулит гибель.

Из нашего анализа баллады ХС следует, что комментарий Берсюира был важным ее источником. Влияние этого автора на произведения Кристи-

8 Часть I, вопрос 82 (О воле) [2, с. 2І9-230]; вопрос 83 (О свободном решении; Раздел 4: Является ли свободное решение способностью, отличной от воли) [2, с. 238-239]. 
ны остается, как кажется, недооцененным. Так, баллада LXI из того же сборника, посвященная счастливой любви Ио и Юпитера, на наш взгляд, ближе всего к толкованию, которое этому мифу дает Берсюирэ.

Лэйдло и Рош не усматривали в этом стихотворении никакого аллегоризма, полагая, что его смысл сводится к рефрену, - прославлению силы любви, объединяющей влюбленных, которая превзойдет всевозможные препятствия: «Нет такого несчастья, / Какое нельзя было б одолеть» («Mais il n'est nul si grant meschief / Qu'on ne traye bien a bon chief») [ı8, p. 7I; 25, p. 93]. Д. Чейнс, вслед за Р. Блюменфельд-Козински, склонна видеть в балладе моральный смысл, сходный с тем, который истории об Ио придает Жан де Мен в «Романе о Розе»: «Женщину под стражу не возьмешь, / Если она сама себя не блюдет» («Nus ne puet metre en fame garde / S'ele meïsmes ne se garde»; v. I4385-86 [I5, p. 760]). В то же время она признает, что в романе эта сентенция носит более дидактический характер, тогда как Кристина радуется соединению влюбленных [6, р. І33-I57; 4, р. 268-269, прим. І4].

9 Приводим текст баллады: «I: Io fut une damoiselle / Que Jupiter ama moult fort. / Juno en ouÿ la nouvelle; / Se ne luy fu jeu ne deport: / Du ciel descent en une nue / Pour son mary surprendre ou fait; / Sur eulx est tout a coup venue / Si les eust surprist de fait; / Mais il n'est nul si grant meschief / Qu'on ne traye bien a bon chief. II: Car Jupiter d'une cautelle / Se couvri; car il fist un sort / Par quoy il tresmüa la belle / En une vache, mais au fort / S'en est Juno si pres tenue, / Qui souspeçon a du meffait, / Qu'elle a la vache retenue / Malgré que Jupiter en ait. / Mais il n'est nul si grant meschief / Qu'on ne traye bien a bon chief. III: La vache en garde bailla celle / A Argus, qui jamais ne dort; / Cent yeux avoit et la pucelle / Toudis gaitoit, mais il fu mort / Par Mercures qui l'en desnue, / Car au vachier tant tint de plait / Qu'il l'endort, puis l'a detenue; / Et ce fut a Juno moult lait. / Mais il n'est nul si grant meschief / Qu'on ne traye bien a bon chief. IV: Pour ce je di qu'une cenelle / Ne vaut la garde tant soit fort, / Ne a vallet ne a basselle; / Puis qu'ilz sont tous deux d'un acort, / Lamour d'eulz sera maintenue / Et verront, qui que dueil en ait, / L'un l'autre, et en est avenue / Mainte chose par tel agait; / Mais il n'est nul si grant meschief / Qu'on ne traye bien a bon chief» [8, p. 62-63]. - «I: Ио была девицей, / Которую сильно любил Юпитер. / О том прознала Юнона, / Что было ей вовсе не в радость. / Вот спускается на облаке, / Чтобы застигнуть мужа на месте преступления. / Внезапно является им двоим / И застает врасплох. / Нет такого несчастья, / Какое нельзя было б одолеть. II: Юпитер спрятался / За хитростью: так поступил, / Что обратил красотку в телку, но Юнона / В самый нужный миг / Была так близко, / Что догадалась о преступлении, / И телку забрала себе, / Хоть Юпитер в конце концов и одержал победу. / Нет такого несчастья, / Какое нельзя было б одолеть. III: Она поставила стоглазого Аргуса охранять телку, / Тот никогда не спал, / Все время ее стерег, но его убил / Меркурий, который ее и украл. / Столько дурачил пастуха своими речами, / Что усыпил его, а телку увел с собой; / Юноне это совсем не по душе. / Нет такого несчастья, / Какое нельзя было б одолеть. IV: А потому скажу: такая ничтожная девчонка / Не стоит сильной охраны, / Ни слуги ей не надо, ни служанки. / Раз двое меж собой согласны, / Все равно бы любили друг друга, / И встречались бы, пусть то кому не по нраву; / При всякой страже такое бывало всегда. / Нет такого несчастья, / Какое нельзя было б одолеть [8, р. 62]. 
Изложение этого мифа у Кристины отличается от других его версий. У самого Овидия или Боккаччо нет речи о том, что Ио соединяется с Юпитером после того, как к ней возвращается человеческий облик [I, с. 50; 5 , p. 758-765]: здесь сказано лишь, что Ио, превратившись в деву после многих странствий, становится египетской богиней Изидой, причем Боккаччо подробно останавливается на изложении и толковании этой части мифа. Кристина же не упоминает о превращении Ио в Изиду и об ее отъезде в Египет, но настаивает на том, что влюбленные останутся вместе навсегда, - как следует из баллады, также и после всех злоключений Ио: рефрен, который возвещает о неизбежном соединении влюбленных, повторен после второй и третьей строфы, где речь идет о превращении Ио в телку и о ее жизни под властью Аргуса.

О возвращении Ио к Юпитеру говорится и в поэме «Морализованный Овидий», и в комментарии Берсюира, которые в этом отношении восходят к более ранним аллегорическим толкованиям «Метаморфоз» - «Аллегориям» Арнульфа Орлеанского, составленным в XII в. Ио в этих толкованиях понимается как человеческая душа, впавшая во грех, обретшая форму зверя и оказавшаяся во власти дьявола Аргуса, позднее же принесшая покаяние и вновь вернувшаяся к Богу. Из всех толкователей Берсюир наиболее прямолинейно выстраивает аллегорию, называя Ио «супругой и подругой Юпитера» - иначе Бога, позднее вновь вернувшейся к своей «прежней любви»:

\section{Arnulfus, Allegorie}

Io virgo filia Inachi dei cuiusdam fluvii fuit. Quod ideo fingitur quia frigida fuit ante annos nubiles. Amata fuit a Iove, id est a deo creatore quia virgo. Tales siquidem amat deus que virginitatem conservando ad creatorem se erigunt. Que postea divirginata de numero virginum eiecta, in bovem mutata id est bestialis facta, traditur a Junone, id est inferiori aere id est viciis inferioribus et gravioribus, Argo, id est se-

\section{Ovidius moralizatus}

Vel dic quod Io amica Iovis id est anima Christi sponsa et amica quandoque efficitur vacca per peccatum, id est vilis et bestialis, et Argo, id est diabolo subiugatur: sed tandem Iuppiter, id est Christus ipsam de Argi, id est diaboli dominio liberat per contritionem et ad fluvium id est ad sacramentum baptismi vel fluvium lacrymarum fugit per confessionem et sic de peccatrice in iustam convertitur et mutatur et ad

\section{Ovide moralisé}

Tant pria son premier ami, / C'est Dieu, qui primes l'ot amee, / Ançois qu'ele eust entamee / Ne mal mise sa chasteé / En la flour de son joenne aé; / Tant se rendi vers Dieu forfaite / De la mauvestié qu'ele ot faite, / Que Dieus, par sa misericorde, / La reçut a bone concorde, / Et ses meffais li pardonna, / Et grace et vertu li donna / De relenquir sa foloience./ <...> /Si devint sage, sainte et bone, / Si li 
culo id est viciis gravissimis, quia per Argum multiplices oculos habentem possumus mundum habere, vel seculum multiplicibus illecebris irretitum. Qui mundus ita eam incarceravit quod deum creatorem noscere potuit.

Sed Mercurius Argum occidit. Per Mercurium deum facundie habemus et quemlibet facundum qui sua persuasione mundanas concupiscentias in ea mortificavit, et eam, melius quod nunquam fuit, creatori suo ad serviendum erexit. Unde fingitur de bove mutata in deam [II, p. 203].

Дева Ио была дочерью Инаха, бога некой реки. Этот вымысел возник оттого, что она была холодна прежде, чем достигла брачного возраста. Ее любил Юпитер, то есть Бог Создатель, поскольку она была девой. Ведь Бог любит тех, кто, сохраняя девственность, посвящают себя Ему. Позднее же, утратив девственность и перестав быть девой, была обращена в телку, то есть обрела звериную природу. Ее отдали во власть Юноны - нижнего неба, то есть низких и тяжких пороков; во власть Аргуса, то есть века сего, иначе пороков тягчайших, поскольку под Аргусом, наделенным многими глазами, следует понимать amorem pristinum quem per peccatum perdiderat recipitur et restaurat ei Iuppiter figuram humanam id est conversationem honestam. Et tandem in morte ipsam in coelo collocat: et inter coeli numina, id est inter sanctos angelos computatur [22, p. 45-46].

Или скажи, что Ио, подруга Юпитера, то есть душа, супруга и подруга Христа, стала некогда телкой из за своих грехов, то есть обрела вид подлого животного, и была отдана во власть Аргуса, то есть дьявола. Но затем Юпитер, иначе Христос, освободил ее от власти Аргуса, дьявола, и, раскаявшись, она устремилась к реке, то есть таинству крещения или же через исповедь пришла к реке слез; и так из грешницы стала праведницей и обрела прежнюю любовь, какую утратила из за грехов. И вернул ей Юпитер человеческий лик, то есть честную речь. А затем после смерти призвал ее на небо, где она заняла свое место меж небесных светил, то есть святых ангелов. dona Dieus la corone / Qu'il donne aus sains en paradis. / Ensi en avint il jadis /A Marie, cele d'Egipte, / Qui, selonc la legende escripte / $\mathrm{Fu}$ pecheresse et foloia... (v. 3982-40I5) [20, t. I, p. I46-I47].
Она столь молила своего первого друга, / То есть Бога, который любил ее в пору цветущей юности, / До того, как она утратила девственность / И осквернила ее, / Так каялась в грехах, которые совершила, / Что Бог в милосердии своем / Примирился с ней / И простил ей злодеяния, / И подал ей силу и благодать, / Дабы она смогла оставить распутную жизнь. <...> / И она вновь стала целомудренной, святой и праведной, / И увенчал ее Бог короной, / Какую святым дают в раю. / Так некогда случилось / С Марией Египетской, / Которая, как написано в ее житии, / Была грешницей и блудницей ... 
мир сей или же век, погруженный во многое беззаконие. Мир же ее стерег так, что она не могла узнать Бога Творца.

Но Меркурий убил Аргуса. Под Меркурием надо понимать бога красноречия или некого красноречивого человека, который своими речами умертвил в ней мирское вожделение и вернул ее во служение Творцу лучшей, чем она была прежде. Потому и рассказывают, что из телки она стала богиней.

Рисуя неизбежное единение влюбленных Ио и Юпитера, Кристина должна была иметь в виду одно из этих аллегорических толкований, поскольку в самом мифе такая перспектива отсутствует, - возможно, она ориентировалась при этом непосредственно на Берсюира, у которого мысль о взаимной любви между Ио-душой и Юпитером-Богом и их непременном единении выражена более прямолинейно.

Отметим, что Кристина излагает историю Ио и Юпитера с известной иронией, - ощутимой в выборе слегка сниженной лексики, простом синтаксисе, предпочтении короткого 8-сложника, который контрастирует с более торжественным го-сложником обрамляющих баллад, наконец, в использовании двустишного рефрена, бывшего в это время несколько старомодным. Диссонанс между буквальным смыслом баллады - прославлением чувственной любви, выраженным с намеренной, несколько архаической простотой, и аллегорическим смыслом, к которому она отсылает, усиливает эту иронию. В аллегорической перспективе рефрен, возвещающий о единении влюбленных, обретает иной смысл: отрицания чувственной любви и утверждения подлинной духовной любви в Боге.

Как показывают рассмотренные мифологические баллады, уже в этом раннем сборнике заметен вкус Кристины к темной аллегорической поэзии, достоинства которой отстаивает Боккаччо в своем знаменитом трак- 
тате: она обращается к «изысканным покровам и прекрасным материям, окутанным сладостным нравоучительным вымыслом»; несколько позже, в «Видении Кристины», она назовет такое обращение одной из черт «своего стиля» [7, p. ІІо].

\section{Список литературы}

I Овидий. Метаморфозы / пер. С. Шервинского. М.: Худож. лит., І977. 430 с.

2 Фома Аквинский. Сумма теологии / пер. А.В. Апполонова. М.: Савин С.А., 2007. T. 2. Ч. I. 648 c.

3 Altman B.K. L'art de l'autoportrait littéraire dans les Cent ballades de Christine de Pizan // Une femme de lettres au Moyen Âge. Études autour de Christine de Pizan / ed. L. Dulac, B. Ribémont. Orléans: Paradigme, 1995. P. 327-336.

4 Blumenfeld-Kosinski R. Reading Myth: Classical Mythology and Its Interpretations in Medieval French Literature. Standford: Standford University Press, I997. 328 p.

5 Boccaccio. Tutte le opere. Genealogia deorum gentilium / ed. V. Branca. Milano: Arnoldo Mondadori, I998. T. VII-VIII. 2I49 p.

6 Chance J. R. Re-membering Herself: Christine de Pizan's Refiguration of Isis as Io // Modern Philology. 2013. T. III. P. I33-I57.

7 Christine de Pizan. Le livre de l'advision Cristine / éd. C. Reno, L. Dulac. Paris: Champion, 200I. 26I p.

8 Christine de Pizan. Euvres poétiques / éd. M. Roy. Paris: Librairie Firmin Didot; Johnson Reprint Corporation, I886. T. I. 320 p.

9 Dictionnaire du Moyen français. URL: http://www.atilf.fr/dmf/ (дата обращения: 20.08.20I7).

Io Dulac L. Le chevalier Hercule de l'Ovide moralisé au Livre de la mutacion de fortune de Christine de Pizan // Cahiers de Recherches Médiévales et Humanistes. 2002. T. 9. P. I-I5. Ghisalberti F. Arnolfo d'Orléans. Un cultore di Ovidio nel secolo XII // Memorie del Reale istituto lombardo di scienze e lettere. Classe di lettere, scienze morali e storiche. I932. V. 24. P. I57-232. Ghisalberti F. L'Ovidius moralisatus di Pierre Bersuire. Estratto dal vol. XXIII degli Studi romanze. Roma: Ditta Tipografia Ciggiani, I933. I34 p.

I3 Godefroy F. Dictionnaire de l'ancienne langue française. Paris: Librairie Emile Bouillon, I898. T. 9. 792 p.

I4 Graham A. Froissart's Use of Classical Allusion // Medium Aevum. I963. T. 32. P. 24-33.

I5 Guillaume de Lorris, Jean de Meun. Le Roman de la Rose / éd. A. Strubel. Paris: Librairie générale française, 1992 (Lettres gothiques). II50 p. 
The Mytographic Art / ed. D. Chance. Gainesville: University of Florida Press, I990.

P. IOO-I24.

I7 Laidlaw J.C. L'unité des Cent balades // The City of Scholars. New Approaches to Christine de Pizan / ed. M. Zimmermann, D. De Rentiis. Berlin, New York: De Gruyter, I994. P. 97-106.

I8 Laidlaw J.C. The Cent balades: the marriage of content and form // Christine de Pizan and Medieval French Lyric / ed. J. Richards. Gainesville: University Press of Florida, I998. P. 53-82.

I9 Lori $W$. Chivalry and the (en)gendered poetic self: Petrarchan models in the Cent balades // The City of Scholars: New Approaches to Christine de Pizan / ed. M. Zimmermann, D. de Rentiis. Berlin, New York: De Gruyter, I994. P. 43-66.

20 "Ovide moralise". Poème du commencement du quatorzième siècle / ed. C. De Boer. Amsterdam: Johannes Müller, I9I5-I938. T. I-5.373 p. + 395 p. +303 p. +478 p. + $429 \mathrm{p}$.

Parussa G. Introduction. Christine De Pizan. Epistre Othea / éd. G. Parussa. Genève: Droz, 2008. P. 3I-I94.

Petrus Berchorius. Reductorium morale, Liber XV, cap. ii-xv. “Ovidius moralizatus” naar de Parijse druk van I509 / ed. J. Engels. Utrecht: Instituut voor Laat Latijn der Rijksuniversiteit (Werkmateriaal, 2), I962. I89 p.

23 Petrus Berchorius. Reductorium morale, Liber XV: Ovidius moralizatus, cap. i. De formis figurisque deorum. Textus e codice Brux., Bibl. Reg. 863-9 critice editus / ed. J. Engels. Utrecht: Instituut voor Laat Latijn der Rijksuniversiteit (Werkmteriaal, 3), I966. 83 p.

24 Rigby S.H. Wisdom and Chivalry: Chaucer's Knight's Tale and Medieval Political Theory. Leiden: Brill, 2009. 329 p.

25 Roch D. Poétique des ballades de Christine de Pizan (I363-I430). Paris: Champion, 2013. $232 \mathrm{p}$.

\section{References}

I Ovidii. Metamorfozy [The Metamorphoses]. Moscow, Khud. lit. Publ., I977. 430 p. (In Russ.)

2 Foma Akvinskii. Summa teologii [Summa Theologiae], trans. A.V. Apollonov, Moscow, Savin S.A. Publ., 2007. Vol. 2. 648 p. (In Russian and in Latin)

3 Altman B.K. L'art de l'autoportrait littéraire dans les Cent ballades de Christine de Pizan. Une femme de lettres au Moyen Âge. Études autour de Christine de Pizan, éd. L. Dulac, B. Ribémont. Orléans, Paradigme, I995, pp. 327-336 (In French) Blumenfeld-Kosinski R. Reading Myth: Classical Mythology and Its Interpretations in Medieval French Literature. Stanford, Stanford University Press, I997. 328 p. (In English) 
Boccaccio. Tutte le opere. Genealogia deorum gentilium, ed. V. Branca. Milano, Arnoldo Mondadori, I998. T. VII-VIII. 2I49 p. (In Latin and in Italian) Chance J.R. Remembering Herself: Christine de Pizan’s Refiguration of Isis as Io. Modern Philology, 20I3, t. III, pp. I33-I57 (In English)

Christine de Pizan. Le livre de l'advision Cristine, éd. C. Reno, L. Dulac. Paris, Champion, 200I. 26I p. (In French)

Christine de Pizan. Euvres poétiques, éd. M. Roy. Paris, Librairie Firmin Didot; Johnson Reprint Corporation, I886. T. I. 320 p. (In French)

Dictionnaire du Moyen français. Available at: http://www.atilf.fr/dmf/ (Accessed 20 August 20I7). (In French)

Dulac L. Le chevalier Hercule de l'Ovide moralisé au Livre de la mutacion de fortune de Christine de Pizan. Cahiers de Recherches Médiévales et Humanistes, 2002, t. 9, pp. I-I5. (In French)

Ghisalberti F. Arnolfo d'Orléans. Un cultore di Ovidio nel secolo XII. Memorie del Reale istituto lombardo di scienze e lettere. Classe di lettere, scienze morali e storiche, I932, vol. 24, pp. 157-232. (In Italian and in Latin) Ghisalberti F. L'Ovidius moralisatus di Pierre Bersuire. Estratto dal vol. XXIII degli Studi romanze, Roma, Ditta Tipografia Ciggiani, I933. I34 p. (In Italian and in Latin)

Godefroy F. Dictionnaire de l'ancienne langue française. Paris, Librairie Emile Bouillon, I898. T. 9. 792 p. (In French)

4 Graham A. Froissart's Use of Classical Allusion. Medium Aevum, I963, t. 32, pp. 24-33. (In English)

5 Guillaume de Lorris, Jean de Meun. Le Roman de la Rose, éd. A. Strubel. Paris, Librairie générale française, I992 (Lettres gothiques). II50 p. (In French)

6 Kellogg J.L. Christine de Pizan as Chivalric Mythographer: L'Epistre Othea. The Mytographic Art, ed. D. Chance. Gainesville, University of Florida Press, I990, pp. I00-I24. (In English)

7 Laidlaw J.C. L'unité des Cent balades. The City of Scholars. New Approaches to Christine de Pizan, ed. M. Zimmermann, D. De Rentiis. Berlin, New York, De Gruyter, I994, pp. 97-IO6. (In French)

8 Laidlaw J.C. The Cent balades: the marriage of content and form. Christine de Pizan and Medieval French Lyric, ed. J. Richards. Gainesville, University Press of Florida, I998, pp. 53-82. (In English)

9 Lori W. Chivalry and the (en)gendered poetic self: Petrarchan models in the Cent balades. The City of Scholars: New Approaches to Christine de Pizan, ed. M. Zimmermann, D. de Rentiis. Berlin, New York, De Gruyter, I994, pp. 43-66. (In English) “Ovide moralise". Poème du commencement du quatorzième siècle, éd. C. De Boer. Amsterdam, Johannes Müller, I9I5-I938. T. I-5. 373 p. + 395 p. + 303 p. + 478 p. + 429 p. (In French) 
2I Parussa G. Introduction. Christine De Pizan. Epistre Othea, éd. G. Parussa. Genève, Droz, 2008, pp. 3I-I94. (In French)

22 Petrus Berchorius. Reductorium morale, Liber XV, cap. ii-xv. «Ovidius moralizatus» naar de Parijse druk van I509. Ed. J. Engels. Utrecht, Instituut voor Laat Latijn der Rijksuniversiteit (Werkmateriaal, 2), I962. I89 p. (In Latin)

23 Petrus Berchorius. Reductorium morale, Liber XV: Ovidius moralizatus, cap. i. De formis figurisque deorum. Textus e codice Brux., Bibl. Reg. 863-9 critice editus, ed. J. Engels. Utrecht, Instituut voor Laat Latijn der Rijksuniversiteit (Werkmteriaal, 3), I966. 83 p. (In Latin)

24 Rigby S.H. Wisdom and Chivalry: Chaucer's Knight's Tale and Medieval Political Theory. Leiden, Brill, 2009. 329 p. (In English)

25 Roch D. Poétique des ballades de Christine de Pizan (1363-I430). Paris, Champion, 2013. 232 p. (In French) 
УДК 82I.ІІ2.2

ББК $83.3(4$ Гем $) 75$
ПРИЁМЫ ПОСТОМОДЕРНИЗМА В РОМАНЕ

Б.T. ХАНИКИ «ROTКӒРPCHEN MUSS

WEINEN» (2009) KAК СПОСОБ

ДЕТАБУИЗАЦИИ «НЕДЕТСКИХ» ТЕМ

В ПОДРОСТКОВОЙ ЛИТЕРАТУРЕ

(C) 2018 г. Т.В. Говенько

Институт мировой литературы

им. А.М. Горького Российской академии наук,

Москва, Россия

Дата поступления статьи: ог августа 2017 г.

Дата публикации: 25 марта 2018 г.

DOI: IO.22455/2500-4247-20I8-3-I-88-IOI

Аннотация: Роман Б.Т. Ханики «Rotkäppchen muss weinen» адресован читателю-подростку. Это роман о взрослении, роман-инициация, где главная героиня подвергает сомнению жизненные обстоятельства и находит в себе силы оказать сопротивление своим родным: с раннего детства с молчаливого согласия бабушки она подвергалась сексуальному насилию со стороны своего родного дедушки - участника Второй мировой войны, бывшего нациста. Тема сексуального насилия в семье в отношении несовершеннолетних, за которую берется Б.Т. Ханика, считалась табуированной и в обществе, и в литературе, адресованной юношеству, пока подростковая литература XXI в. не заявила о себе как о литературе без границ. Обращаясь к социальной прозе, современные авторы вынуждают героев пережить «свой» собственный, индивидуальный апокалипсис, но при этом сохраняют за произведением право на «happy end». Сказочные приемы и реминисценции всегда создавали особый эстетический и психологический климат произведений для детей и юношества. Средствами литературы постмодернизма Б.Т. Ханика снимает табу с «недетских» тем и рассказывает подросткам о травмированном детстве без травматизма.

Ключевые слова: современная немецкая литература для подростков, фольклор, постмодерн, интертекстуальность.

Информация об авторе: Татьяна Владимировна Говенько - кандидат филологических наук, старший научный сотрудник, Институт мировой литературы им. А.М. Горького Российской академии наук, ул. Поварская, д. 25 а, І2I069 г. Москва, Россия.

E-mail: govenko@mail.ru 


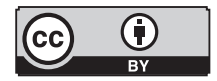

This is an open access article distributed under the Creative Commons Attribution 4.0 International (CC BY 4.0)
POSTMODERNIST TECHNIQUES AND GROWN-UP THEMES IN THE JUVENILE NOVEL LEARNING TO SCREAM(2009) BY BEATE T. HANIKE

(C) 2018. T.V. Govenko

A.M. Gorky Institute of World Literature

of the Russian Academy of Sciences, Moscow, Russia Received: August OI, 2017

Date of publication: March 25, 2018

Abstract: The novel Learning to Scream (Rotkäppchen muss weinen, 2009) by Beate Teresa Hanika is addressed to the adolescent reader. This is a novel about growing up, a novelinitiation which main character challenges life circumstances and finds the strength to put an end to the family abuse; from her early childhood, she was sexually abused by her own grandfather, a former Nazi who took part in the World War II, with the tacit consent of her grandmother. Sexual violence of minors in the family, a theme raised by B.T. Hanika was considered tabooed both in society and in juvenile literature up until the 2Ist century, when juvenile literature declared itself as literature without borders. Modern authors working with social-oriented fiction genres, make their characters experience their own, individual apocalypse, while at the same time, retain the right to the happy ending. Fairy tale techniques and allusions traditionally have created a special aesthetic and psychological climate for children and adolescents. By means of postmodernist literature, B.T. Hanika removes taboos from the grown-up audience topics and tells stories about traumatized childhood to adolescents without traumatizing them.

Keywords: modern German juvenile literature, folklore, postmodernism, intertextuality.

Information about the author: Tatiana V. Govenko, PhD in Philology, Senior Researcher, A.M. Gorky Institute of World Literature of the Russian Academy of Sciences, Povarskaya 25 a, I2IO69 Moscow, Russia.

E-mail: govenko@mail.ru 
Беата Тереза Ханика (Beate Teresa Hanika) родилась в 1976 г. в Регенсбурге. По профессии она фотограф. Роман «Rotkäppchen muss weinen» («Красная Шапочка, плачь») [го - дебютный, однако он сразу был замечен и критиками, и читателями. Так, например, на сайте книжного интернет-магазина «Amazon.de» положительные отзывы составили 98\%. Не менее щедрыми оказались и специалисты. Когда роман был еще рукописью и носил название «Malvina in der Seifenblase» («Мальвина в мыльном пузыре»), он был удостоен в 2007 г. награды «Oldenburger Kinder- und Jugendbuchpreis» («Ольденбургская литературная премия в области книг для детей и юношества») (действует с I977 г.). В 2009 г. книга получила «Bayerischer Kunstforderpreis» («Баварская премия в области искусств») (действует с г965 г.); в 20Іо г. «Deutsche Jugendliteraturpreis» («Немецкая молодежная литературная премия») (действует с I956 г.); в 2012 г. - премию IBBY (Международный совет по детской и юношеской литературе) (действует с 1953 г.). На русский язык роман был переведен Верой Комаровой при финансовой поддержке Немецкого культурного центра им. Гёте и опубликован в 2оІІ г. в издательстве «КомпасГид» в серии «Поколение www» с названием «Скажи, Красная Шапочка» [7]. Годом раньше, в 2ого г., увидел свет английский перевод романа под названием «Learning to scream» («Научиться кричать»). На сегодняшний день книга переведена почти на все европейские языки и продолжает оставаться предметом горячих споров и обсуждений.

Интерес к роману во многом объясним. Тема сексуального насилия в отношении несовершеннолетних, за которую берется Б.Т. Ханика, считалась табуированной и в обществе, и в литературе, адресованной подросткам. Од- 
нако с некоторых пор авторы, пишущие для «young adult» (І2-I8 лет), кажутся одержимыми в своем желании писать экспрессивно, аутентично и, если можно так выразиться, апокалиптично. Подростковая литература XXI в. уже заявила о себе как о литературе без границ, и чем моложе автор, тем больше рисков он готов брать на себя. Хотя, конечно, без предпосылок здесь не обошлось. В круг подросткового чтения давно вошли такие произведения, где писатели откровенно описывали пороки человеческого общества: «Приключения Оливера Твиста» (I837-I839) Чарльза Диккенса, «Подросток» (1874-I875) Федора Достоевского, «Над пропастью во ржи» (I95I) Джерома Селинджера, «Повелитель мух» (1954) Уильяма Голдинга, «Убить пересмешника» (1960) Харпер Ли и многие другие «жесткие, но правдивые» книги, - в том числе близкий по теме «Скажи, Красная шапочка» роман Владимира Набокова «Лолита» (1955) и роман современной американской писательницы Алисии Эриан «Towelhead» (2005) (Как на ладони. М.: Иностранка, 2009), в которой тринадцатилетняя девочка из-за безразличия к ней родителей также оказывается в объятиях взрослого мужчины.

Понятно, что в произведениях подобного формата, как роман Б.Т. Ханики, литературоведа привлекают отнюдь не откровенные сцены, а герменевтика текста, интертекстуальность, смысловая конвергенция. В этом отношении немецкая современная подростковая литература неожиданно оказалась продолжательницей традиций экзистенциальной философии и литературы постмодернизма. В текстах В. Херрндорфа «Tschick», 2оIо (в русском переводе «Гуд бай, Берлин!»), «Bilder deiner großen Liebe» («Картинки твоей большой любви»), 20I4, Т. Бах «Was vom Sommer übrig ist» («Что осталось от лета»), 20I2, «Marienbilder» («Фантазии Марии»), 20I4, Л. Шютцзак «Und auch so bitterkalt» («И еще очень холодно»), 20I4, А. Фореста «Der Teufel vor meiner Tür» («Черт перед моей дверью»), 20І6, кстати, и во втором романе Т.Б. Ханики «Erzähl mir von der Liebe» («Расскажи мне о любви»), 2ого, и многих других герои-подростки переживают кризис, коммуникационный голод, попадают в сложные психологические ситуации и испытывают яркие эмоциональные и духовные переживания. Бессильные что-либо изменить, они испытывают страх и отчаяние от своей безысходности, и только «экзистенциальное озарение», иначе говоря, самопознание, позволяет им обрести внутреннюю свободу и моральное очищение, сделать выбор в пользу ответственности за себя и других, выбрать свою миссию. А взрослым - «проник- 
нуть любовью к ребенку и дать дорогу взаимопониманию, пока не поздно» [4, с. 3I]. Другими словами, современная литература для подростков в Германии в основном ориентирована на повседневные психологические проблемы и поиски выхода из них. Деструктивные и в идейном, и в эмоциональном отношении эти произведения выходят за рамки традиционных для детской и подростковой литературы художественных средств и приемов и широко используют арсенал литературы постмодернизма.

При этом надо сказать, что в Германии постмодернизм долго не приживался по двум основным причинам: «инерция национальной логоцентрической традиции и необходимость осмыслить травматический опыт развязанной Германией второй мировой войны» [3, с. 32]. Поэтому первые опыты постмодернисткой литературы пришлись здесь уже на вторую половину XX в. Метаморфозы, аллюзии, множественность форм, «иронически-комические элементы метаигры стали интенсивно «расколдовывать» столь почитаемые в Германии, в немецкой духовной жизни табу и стереотипы» [7, с. 330]. Однако, по справедливому замечанию Ю.М. Лотмана, «взаимоотношение памяти культуры и ее саморефлексии строится как постоянный диалог: некоторые тексты из хронологически более ранних пластов вносятся в культуру, взаимодействуя с ее современными механизмами, генерируют образ исторического прошлого, который переносится культурой в прошлое и уже как равноправный участник диалога воздействует на настоящее. Но в свете трансформированного настоящего и прошлое меняет свой облик» [4, с. 385]. На этом основании в Германии случилась перманентная эвокация традиций романтической литературы. В возрождении ее идей, тем, мотивов, сказочной традиции сначала в литературе, адресованной взрослым (П. Зюскинд, К. Рансмайр, К. Модик, К. Крахт, Р. Шнайдер, Б. Штраус, А. Эшбах, Х. Крауссер и другие), а потом и в литературе для детей и подростков.

Роман Беаты Терезы Ханики «Скажи, Красная Шапочка» тоже из этого ряда. Концептуально он, конечно, о взрослении, об инициации. Но это далеко не реалистический роман. Почему Ханика выбирает для своего дебютного романа такую непростую тему? Дело в том, что в Германии, согласно официальным данным на сайте «Polizeiliche Kriminalstatistik» (PRS), ежегодно жертвами сексуального насилия становятся 30\% девочек и I5\% мальчиков. С этим явлением немецкие власти борются самыми разными методами: от психологического контроля до тюремного заключения. По словам самой 
писательницы, она «хотела написать книгу, которая помогла бы детям, подросткам и взрослым, вовлеченным в такую ситуацию, освободиться от этого всего. Но, оговорюсь, я писала не на личном опыте» [2, с. Іо]. Таким образом, абсурдная, катастрофическая и, по сути, постмодернисткая ситуация мотивирует Б.Т. Ханику создать гипертекст, сотканный из аллюзий, реминисценций, цитат, романтических героев, топосов и смыслов.

В романе «Скажи, Красная Шапочка» на протяжении всего произведения повествование ведется от первого лица. Но это не внутренний монолог, а именно «поток сознания» девочки-подростка тринадцати лет: в тексте даже диалоги выделяются крайне редко. Сенсорное впечатление, как некое блуждание по коридорам памяти, напластывания мыслей и ассоциаций, экзистенциальная фрустрация, отсутствие теплоты в межличностных отношениях - акценты, которые позволяют Ханике максимально идентифицировать себя с личностью героини, а читателю-подростку - сопереживать и достигать эмпатии.

Несмотря на обозначения в начале глав дней недели - линейное время как таковое в романе отсутствует. Однако зафиксировать эволюцию девочки совсем не сложно. И это еще один знак постмодернизма - время и пространство в романе Ханики не имеют значения. Фактологическим материалом становятся воспоминания. Пусть и скудные, но они отсылают нас к 5-6-летнему возрасту главной героини, в период неосознанных эмоций: «Когда я думаю о дедушке, я ощущаю стыд, очень неприятное чувство, как будто я сделала что-то неправильное. Как будто мне должно быть совестно за этот поцелуй. Каждый раз, когда я об этом думаю, у меня в животе начинается непонятное шевеление, как на карусели, только хуже» [7, с. 64]; «И правда, у меня внутри всё перепуталось: там безнадежный хаос, как в комнате, в которой всё перевернуто вверх дном, где повсюду валяется одежда, книги, бумажки и старые тетрадки, а я сама стою рядом, надо бы убраться, но хаос всё время только увеличивается» [7, с. 98-99]. Взрослея, она учится наблюдать за людьми, которые ее окружают, задавать вопросы, в первую очередь себе, сравнивать свои взаимоотношения с родными со взаимоотношениями с родными своих друзей, - и постепенно к ней приходит осознание. Метаморфозы героиня достигла через осмысление характеров всех членов своей семьи и разоблачение буквально каждого из них. В своем стремлении к правде она поняла, что с раннего детства с молчаливого согласия бабушки подвергалась сексуальному насилию со стороны своего родного дедушки - участника Второй мировой войны, бывшего нациста. 
Тема педофилии в романе «Скажи, Красная Шапочка», бесспорно, формообразующая: как и девочка, в начале произведения читатель еще ничего не понимает; потом появляется тонкий намек на странное поведение деда; с каждой главой маятник этой жесткой, болезненной и неприятной семейной истории набирает амплитуду; и в конце мы уже слышим набат.

Итак, Ханика ставит перед собой задачу смоделировать ситуацию, которая отразит болезненное явление современного германского общества, и вывести на разговор как взрослых, так и детей. Но как это сделать технически, чтобы не вызвать шквал негатива, чтобы соблюсти границы детской литературы, чтобы быть предельно корректной?

Стилистическая фигура, содержащая намек на сказку, притаилась уже в названии романа. И хотя многим кажется, что прозвище Красная Шапочка происходит из образа девочки с корзинкой продуктов, - это не совсем так. Первыми это заметили обозреватели «Frankfurter Allgemaine» (І2.03.2009), подчеркнув, что в книге, несмотря на жестокость, много сказочного. Надо сказать, что сказочные приемы, аллюзии и реминисценции характерны для детской и подростковой литературы в принципе. Но в этом романе они выполняют новую для себя функцию - датабуизации «недетских» тем (в отечественной литературе примером этого утверждения стал цикл книг Ю. Яковлевой под общим названием «Ленинградские сказки»). Опираясь на культурологический контекст, на хорошо узнаваемые сказочные блоки-стереотипы, цитаты из известных произведений Б.Т. Ханика создала в своем романе такую иерархию смыслов, благодаря которой ей удалось поговорить о травмированном детстве без травматизма.

Начнем с того, что в романе буквально все персонажи выполняют определенную образно-смысловую задачу. Как и в сказке о Красной Шапочке, мать главной героини на протяжении всего повествования производит одно единственное действие - готовит еду. Вместе с бутылкой вина она укладывается в корзину и передается младшей дочери, которая должна отнести ее деду. В остальное время мать прячется в спальне, за шторами, потому что у нее якобы мигрень, а на самом деле она таким образом прячется от жизни, от мужа, с котором явно несчастна: «Она опять совсем бледная, но ничего не говорит, она ничего и не скажет, даже если ее схватить и встряхнуть» [7, с. 233]. Другими словами, от бессилия и бесправности мать предпочитает уйти в себя, выразить свой протест молчанием. 
Аналогичным образом ведет себя и бабушка. В сказке о Красной Шапочке бабушка умирает, потому что ее проглотил волк, дабы выдать себя за бабушку и заполучить Красную Шапочку. В романе Б.Т. Ханики бабушка сначала умирает нравственно, поскольку не препятствует деду вести себя непристойно с внучкой, а потом она умирает физически, взяв с внучки клятву никому не рассказывать о том, что происходило в ее доме по пятницам. Бабушки нет в живых, но девочка постоянно вспоминает о ней, и читателю нетрудно заметить, что та была несчастной женщиной, которая не имела права голоса и очень боялась своего мужа. Когда девочка спросила бабушку, почему она заболела раком, то получила такой ответ: «Сначала это всего лишь мысль, чувство, ощущение несчастья, маленькая ранка, которую кто-то тебе нанес, но если не проследить за тем, чтобы эта ранка заросла, то из нее вырастет нечто, оно будет становиться все больше и больше, а потом примется поедать тебя изнутри, потому что долгие годы ты не обращала внимания на себя, на эту маленькую ранку. Потому что ты была несчастной все эти годы» [7, с. I57].

Волк - хищник. Дед - тот же хищник, но в человеческом обличье. «Что бы ты ни рассказывала, - говорит он внучке, - тебе не поверят!» [7, с. 98]; «Просто нужно быть осторожными, чтобы никто не узнал, не то они заберут тебя отсюда, понимаешь, они нас разлучат, они будут говорить, что ты ненормальная. Они тебя осудят» [7, с. г95-196], - внушает он ей.

Задавшись целью сделать всё, чтобы Красную Шапочку миновала судьба бабушки (и мамы), чтобы волк не смог ее проглотить, Беате Тереза Ханика встраивает в роман персонажей-помощников, в которых также легко узнать сказочных героев. Таким образом, текст романа, с одной стороны, отсылает нас к известным каноническим сказочным произведениям, а, с другой стороны, эта двуплановость создает эффект игры, благодаря которой шаг за шагом выстраивается оптимистичная линия сюжета.

Литературная игра наравне с «потоком сознания» становятся важными смысловыми и структурообразующими художественными приемами этого романа. Как писал Й. Хёйзинга: «В каждой игре - свои правила. Ими определяется, что именно должно иметь силу в выделенном игрою временном мире. Правила игры бесспорны и обязательны, они не подлежат никакому сомнению... Стоит лишь отойти от правил, и мир игры тотчас рушится. Никакой игры больше нет» [8, с. 30]. 
Это суждение, надо сказать, применимо не только к тексту, но и к ситуации, в которую невольно попал ребенок - героиня романа «Скажи, Красная Шапочка»: пока она была маленькой, взрослые установили для нее некие правила игры, которые ей явно были не по душе. И тогда она случайно (или интуитивно) пригласила в гости к бабушке и дедушке свою подругу. Это действие позволило ей избежать неприятного ритуала - водных процедур: каждую пятницу дедушка принимал с маленькой внучкой ванную в пене, навязывая ей свою игру - она должна была трогать его за разные места. Конечно, приводить подругу каждый раз девочке не удавалось, но Лиззи стала для нее не только лучшей подругой. В ней воплотился образ волшебного помощника, который часто приходит на выручку герою во всех сказках мира.

Как и положено детям, подруги любили играть между собой. Как-то раз они нашли заброшенную виллу, и она стала для них «землей обетованной»: девочки купались в бочке, фантазировали, устраивали быт, придумывали волшебный мир. Однако, как бы ни было хорошо главной героине здесь, рядом с Лиззи, она всегда помнила, что эта вилла когда-то принадлежала человеку с фотографии. Девочка зовет его «der böse Friederich», и это еще одна аллюзия - «История о злом Фридрихе» («Die Geschichte vom bösen Friederich») из сборника «Der Struwwelpeter» Г. Хофмана. Напомним, что жестокий Фридрих всех обижал, пока его не покусала собака. Эта отсылка к культурной памяти немецкого читателя (в переводе на русский язык злой Фридрих заменен на персонажа другой истории - Синюю Бороду) рождает загадку и вместе с тем создает художественный намек - излюбленный прием постмодернистов.

Разрушенная вилла, люди с фотографии и их вещи усиливают интонацию недосказанности, обреченности взрослого мира. Детский мир, мир игры, свободы и непосредственности противопоставляется миру взрослых, в шкафах которых хранится множество скелетов. И именно на этой во всех отношениях знаковой, пограничной территории, на переправе, на стыке, на оси двух миров, девочки совершают древнейший обряд - обряд сестричества. Со знанием дела Б.Т. Ханика рассказывает о том, как подруги делают надрезы на пальцах, как каждая выдавливает кровь на тарелочку с золотым ободком, и потом они смешивают ее со словами клятвы: «Мы теперь навсегда названые сестры». Чуть позже здесь, на вилле, главная героиня встречает свою первую любовь. В ходе дальнейшего повествования функциональное назначение виллы продолжает символизироваться. 
Понятно, что детской дружбы, даже самой крепкой, было бы недостаточно для того, чтобы победить Зло. Поэтому Ханике вводит в роман еще один персонаж, без которого никак не обойтись в сказке, где главный герой - тем более, девочка - попадает в беду. Фрау Бичек - иноземка, родом из Польши. Она многодетная мать, семья которой живет в квартире под дедушкой. О том, что фрау Бичек задумана как добрая волшебница, читателю сигнализирует ее фееобразный облик: у женщины светлые завитые волосы, круглое дружелюбное лицо, мягкие пухлые руки. Всюду фрау Бичек сопровождает кот. По сути, она единственная из лагеря взрослых, кто пристально следит за ситуацией и выражает желание поговорить с девочкой. Часто она выручает ее: забирает корзину с продуктами и сама относит ее соседу; когда главная героиня наносит визит деду, она неожиданно стучит в дверь и просит ее помочь снести коляску.

Волшебные способности фрау Бичек раскрываются постепенно по мере развития сюжетной линии. Однажды она пригласила девочку к себе в гости и стала учить гадать на кофейной гуще: выпивать кофе, опрокидывать чашку на блюдце, левой рукой крутить три раза. Потом женщина прочитала заклинание на польском языке, что уже звучит как абракадабра, сняла чашку и предрекла: «Очень темные облаки, тут молодой человек - солнце, а тут... кто-то еще, темные облаки, будь осторожна, это кто-то злой!» [7, с. г2о]. В другой раз девочка нашла фрау Бичек подле двери в квартиру деда. Женщина сыпала соль на порог: «Чтобы прогонять злой дух... Это надо делать на убывающая Луна, тогда хорошо получится» [7, с. I38]. «В твой дедушка злой дух... Он может решить, будет это добро или зло, и он решает - зло» [7, с. I73-I74].

Фрау Бичек не говорит напрямую с главной героиней об ее отношениях с дедом, но приходит момент, когда она сказала: «Хорошо, что пришла, я уже ждала, каждый день смотреть хрустальный шар... Слава Богу, наконец-то! Я думала, ты больше не придешь, думала - слишком поздно» [7, с. 259]. Переживания фрау Бичек небезосновательны. Девочка несколько раз пыталась рассказать родителям, старшему брату, почему она не хочет ходить к деду, но в ответ всегда получала презрение: «Они больше не обращают на меня внимание и ведут себя так, будто ничего не произошло, только мама нервно тычет вилкой по тарелке» [7, с. 237]. От безразличия членов семьи она чувствует себя опустошенной: плохо ест, часто падает в обмороки, начинает думать о смерти. Фрау Бичек кормит девочку и рассказывает историю своей подруги Кати. 
Мама Кати убежала из семьи с любовником, оставив с отцом двух дочерей. Отец потребовал от Кати, старшей дочери-подростка, чтобы она исполняла супружеский долг вместо матери. После этого Катя сильно изменилась, стала пропускать школу. Но, когда отец позарился и на младшую дочь, Катя взяла маленькую сестренку за руку, поднялась с ней на самую высокую скалу, и вместе они спрыгнули. «Ты знаешь, почему они спрыгнули! - говорит фрау Бичек. - Всё можно изменить, только если ты говоришь!» [7, с. 266-267].

Девочка молчит, ее душат слезы. Она выбегает из квартиры фрау Бичек и сразу попадает в объятия деда, который тащит ее к себе домой и требует никогда не ходить к соседке. Он обвиняет внучку в смерти бабушки: «То, что случилось с бабушкой, произошло из-за тебя... Пока мы были счастливы, мы втроем, всё шло хорошо... Но потом - потом ты привела эту свою подружку один раз, два, потом еще и еще... Она умерла из-за тебя, из-за тебя. Ты больше не хотела приносить себя в жертву. Но в жизни это нужно. Нужно жертвовать собой для других» [7, с. 269-270], - и дед идет наполнять ванну.

Главной героине романа I3 лет, но она не помнит своего детства, сколько бы ни силилась его вспоминать: «Я вообще ничего не помню, это как если открыть фотоальбом, а в нем сотни пустых мест» [7, с. I72]. Воспоминания ребенка похитил дед, и это еще одна сказочная аллюзия: чтобы сделать героя безвольным, его достаточно лишить памяти, как Кая из «Снежной королевы» $\mathrm{X}$.-К. Андерсена. Блокируя память, дед лишает внучку не только голоса, он пресекает в ней коммуникацию с внешним миром и с миром духовным. При ней он любит слушать пластинку «Так говорил Заратустра». И хотя в тексте прямых цитат на это произведение нет, читателю вполне хватает комментария девочки: «Ницше - это такой философ. Он сказал, что Бог умер. Может быть, он прав, думаю я, сворачиваясь клубочком возле дедушки, потому что Бог не позволил бы таких вещей. Бог сделал бы так, чтобы все стало в порядке» [7, с. 192].

Для окончательного разрешения конфликта Б.Т. Ханика продолжает опираться на сказочную архитектонику. Снять чары злого волшебника с плененной им девицы не способны ни добрая волшебница, ни чудесная помощница, а только добрый молодец, жених. Как уже было сказано выше, встреча главной героини с молодым человеком произошла в пограничной зоне, на вилле. «Принц» приехал на горном велосипеде и стал настойчиво и нежно ухаживать за девочкой. Ему г6 лет, и он красив собой: длинные ресницы, волосы на голове собраны в косичку, у него сильные мускулистые ноги и руки, а главное - он 
смел, независим и является лидером среди своих друзей. Влюбленные не знают имен друг друга: он называет ее Красной Шапочкой, а она его Klatsche (Трепло; в романе на русском языке переведено как Муха). Юноша хочет узнать подлинное имя своей избранницы и начинает гадать, как в сказке про Румпельштильцхен. И тогда происходит чудо: «Хочешь знать, как меня зовут?.. Мальвина хранительница закона!» [7, с. 28I-282], - стоило ей произнести эти слова, как она неожиданно приобрела заветный ключ к себе: «...мне в первый раз стало понятно, что же это на самом деле означает. Что на самом деле значит - быть хранительницей закона. Это значит, что я должна охранять свои права, свое право на жизнь, право защищать себя, право говорить» [7, с. 282]. Неожиданно Мальвина чувствует колоссальный прилив сил, «как будто он проткнул иголкой мыльный пузырь» [7, с. 320]. На прощание Трепло (Муха) целует ее в губы, и этот поцелуй совсем не похож на затхлые поцелуи деда. «Мы ведь, в конце-то концов, на стороне добра, - говорит он, - а добро всегда побеждает» [7, с. 299]. «Не сдавайся, Мальвина, только не сдавайся» [7, с. 3І3].

Имя мальчика так и остается неизвестным, но для читателя это не имеет значения. Благодаря его поддержке девочка начинает вспомнить всё, шаг за шагом, и приходит к выводу, что многого могло бы и не быть, если бы бабушка повела себя иначе: «Но она не заботилась обо мне, ни при жизни, ни потом, после смерти, она меня продала, потому что была слишком трусливой, чтобы сопротивляться дедушке, а потом она взяла с меня обещание, которое я таскала с собой все эти годы. Это несправедливо, бабушка» [7, с. 32I-323]. Вырвавшись из темницы своего сознания, из семейного плена, Мальвина наконец-то разобралась в себе, в своих мыслях и чувствах: «В голове вдруг образовалось неожиданно много места, как будто я открыла окно и впустила свежий воздух. Стало совершенно ясно, что мне надо делать» [7, с. 322]. Уверенная в себе, она едет к деду, чтобы сказать ему о своем решении, но находит его в неестественной позе за столом. На помощь девочка зовет фрау Бичек: «Ой-ой-ой, - говорит та, - ой-ой-ой! Вот не думала, что так быстро сработает в этот раз, вот не думала, - она смотрит на свои руки и крестится. - Матерь Божия, - говорит она, - это тяжко, когда имеешь дар...» [7, с. 330-331]. Фрау Бичек зажигает белые свечи, сжигает листья шалфея на лестнице и вызывает карету «Скорой помощи». Когда приезжают родители, она не отдает им Мальвину, а укладывает ее спать. Проснувшись, девочка видит перед собой подругу-сестру Лиззи и фрау Бичек. Не желая больше молчать, Красная 
Шапочка очищается: «Когда я начала рассказывать, мой голос был холодный, замороженный до синевы, и я слышала себя как будто издалека... Но мне нужно было говорить, сказать правду, мою правду о том, какой была на самом деле моя жизнь» [7, с. 338].

В заключении романа Мальвина отмечает свой день рождения. Вместе с Лиззи и «принцем» она стоит на обломках виллы. Инициация завершена: «Меня зовут Мальвина, мне четырнадцать лет. Я - Мальвина, хранительница закона, храбрая Мальвина, которая не боится прыгать, всегда, даже если не видно земли. Я прыгнула, а внизу стояли Лиззи, Трепло (Муха), фрау Бичек, мама Лиззи и даже Анна. Другие сбежали. Как Пауль и мои родители, которым было стыдно за то, что произошло. Я знаю, что мне нечего стыдиться. Лиззи и Трепло (Муха) помогали мне этому научиться. Каждый день заново. Они ни секунду не оставляли меня одну... Меня зовут Мальвина, и я научилась кричать!» [7, с. 347-348].

В журнале «Итоги» от 23.07.2012 литературный критики Галина Юзефович резюмировала: «Не все в мире будет хорошо, а если и будет, то не всегда это произойдет благодаря нашему опыту, решительности и четким действиям. Кто-то должен сказать эту неприятную правду детям, так почему бы не доверить эту обязанность Беате Терезе Ханике и ее книжке - к слову сказать, совершенно замечательно написанной, мудрой и простой. Думаю, немецкая писательница справилась со своей задачей» [9, с. 46].

Точка зрения Б.Т. Ханики на события реальности однозначна, а с точки зрения литературы - полисемична. Выступая против формального сюжета и временной последовательности, обращаясь к сказочным аллюзиям и двойному кодированию, она создает текст-протест, слова которого интерпретируют действительность, расшатывая всякого рода табу и провоцируя читателя пережить катарсис. «Цель (идеологическая) подобной техники заключается в том, чтобы натурализовать смысл и, стало быть, удостоверить реальность рассказываемой истории» [I, с. 69].

\section{Список литературы}

I $\quad$ Барт P.S/Z. М.: Академический Проект, 2009. 373 с.

2 Вильке Д. Кричи, Красная Шапочка // Переплет. М., 20І2. № 2. С. IO-I5.

3 Гладилин Н.B. Постмодернизм в литературе стран немецкого языка: Генезис и основные тенденции развития: автореф. дис. ... д-ра филол. наук. М.: МПГУ, 2оІ2. 36 с. 
Лотман Ю.М. Возможна ли историческая наука и в чем ее функция в системе культуры? // Ю.М. Лотман. Внутри мыслящих миров. Человек - текст - семиосфера история. М.: Языки русской культуры, 1996. С. 380-385.

Соколова Е. И про нас тоже // Книжная индустрия. М., 20I4. № 6. С. 3 I.

6 Фролов Г.А. Постомодернизм в Германии (к проблеме национальной специфики) // Русская и сопоставительная филология: Лингвокультурологический аспект. Казань: Казан. гос. ун-т, 2004. С. 329-332.

7 Ханика Б.Т. Скажи, Красная Шапочка. М.: КомпасГид, 20II. 352 с.

8 Хёйзинга Й. Homo ludens. Статьи по истории культуры. М.: Прогресс, I997. 4I6 c.

9 Юзефович Г. Спасутся не все // Итоги. М., 20І2. № 30. С. 46.

Io Hanika B.T. Rotkäppchen muss weinen. Frankfurt am Main: Fischer, 2009. 220 S.

\section{References}

I $\quad$ Bart R. S/Z [S/Z]. Moscow, Akademicheskij proekt Publ., 2009. 373 p. (In Russ.)

2 Wilke D. Krichi, Krasnaja Shapochka [Scream, Little Red Riding Hood]. Perepljot, Moscow, 20I2, no 2, pp. IO-I5. (In Russ.)

3 Gladilin N.V. Postmodernizm v literature stran nemetskogo yazyka: Genezis i osnovnyye tendentsii razvitiya [Postmodernism in the German language and literature: Genesis and major trends]: Doct. Habil. Diss. Synopsis. Moscow, MPGU Publ., 20I2. 36 p. (In Russ.)

4 Lotman Yu.M. Vozmozhna li istoricheskaya nauka i v chem ee funkciya v sisteme kultury? [Is historical science possible and what is its function in the cultural system?]. Yu.M. Lotman. Vnutri myslyashchih mirov. Chelovek - tekst - semiosfera - istoriya [Inside the thinking worlds. Man - text - the semiosphere - history]. Moscow, Yazyki russkoj kultury Publ., I996, pp. 380-385. (In Russ.)

5 Sokolova E. I pro nas tozhe [And about us, too]. Knizhnaja industrija, Moscow, 20I4, no 6, p. 3I. (In Russ.)

6 Frolov G.A. Postmodernizm v germanii (k probleme nacionalnoj spezifikij) [Postmodernism in Germany (the issue of national specificity]. Russkaya i sopostavitelnaya filologiya: lingvokulturologicheskij aspekt [Russian and comparative philology: Linguistic and cultural aspects]. Kazan, Kazan. gos. un-t Publ., 2004, pp. 329-332. (In Russ.)

7 Hanika B.T. Skazhi, Krasnaja Shapochka [Say, Little Red Riding Hood]. Moscow, KompasGid Publ., 20II. 352 p. (In Russ.)

8 Huizinga J. Homo ludens. Stati po kulury [Homo ludens. Articles on the history of culture]. Moscow, Progress Publ., I997. 4I6 p. (In Russ.)

9 Juzefovich G. Spasutsja ne vse [Not all will be saved]. Itogi, Moscow, 20I2, no 30, p. 46. (In Russ.)

IO Hanika B.T. Rotkäppchen muss weinen. Frankfurt am Main, Fischer, 2009. 220 S. (In German) 
УдК 821.112 .2 .0

ББК $83.3(4 Г е м) 75$

\section{РЕЛИГИОЗНОЕ ИЗМЕРЕНИЕ НЕМЕЦКОЙ «БЕСКОНЕЧНОЙ КНИГИ» В ДЕТСКОМ ФЭНТЕЗИ К. ФУНКЕ}

(C) 2018 г. Е.В. Астащенко

Литературный институт им. А.М. Горького, Москва, Россия

Дата поступления статьи: 3г июля 2017 г. Дата публикации: 25 марта 2018 г.

DOI: IO.22455/2500-4247-2018-3-I-IO2-II7

Аннотация: В статье исследуется фантастическая проза К. Функе в особом аспекте, связанном с протестантизмом и философией «Als ob». Попутно привлекается немецкая фантастическая романистика последних лет для детей (М. Глейзер, К. Гир, К. Майера, В. Мёрса), в которой культ письменности, литературы, книжности определяет идейно-художественное своеобразие. Таким образом, предпринимается попытка систематизации на ряде примеров черт немецкой идентификации, которые проступают и в феномене детства, и в национальной специфике художества. Символ «бесконечной книги» как обетованного миротворения глубоко укоренен в немецкой культуре, но от Новалиса до М. Энде и К. Функе не утрачивает религиозного измерения. В «Короле воров» («Herr der Diebe») Функе, в том числе благодаря аллюзиям на гофмановскую «Принцессу Брамбиллу», живопись Ф. Пфора и Ф. Овербека, развертывает взаимодействие немецкой устремленности в мир грез и опоэтизированную, увековеченную ими итальянскую жизнерадостность: карусель на острове Тайн позволяет путешествие по предначертанной судьбе, угадывание героями, как и Генрихом фон Офтердингеном, себя «в одежде другой, точно из другого времени». В «чернильной трилогии» («Tintenherz», «Tintenblut», «Tintentod») провозглашена нерукотворность словесной реальности и ее власть над существованием, затронута проблема тождества дара и носителя. Конечно, человек, по мысли Функе, должен соответствовать высокому предназначению и руководствоваться внутренним нравственным законом. Однако именно слова, словно молитвы в позднем кантовском понимании, меняют и создают мир.

ключевые слова: детское фэнтези, Die unendliche Geschichte, герменевтика, назидательность, эскейпизм.

Информация об авторе: Елена Васильевна Астащенко - кандидат филологических наук, Литературный институт им. А.М. Горького, Тверской бульвар, д. 25, I23IO4 г. Москва, Россия.

E-mail: gedda@inbox.ru 


\section{RELIGIOUS DIMENSION OF GERMAN "UNENDING BOOK" IN THE CHILDREN'S FANTASY BY CORNELIA FUNKE}

This is an open access article distributed under the Creative Commons Attribution 4.0 International (CC BY 4.0)
(C) 20I8. E.V. Astashchenko Maxim Gorky Institute of Literature and Creative Writing, Moscow, Russia Received: July oI, 2017

Date of publication: March 25, 2018

Abstract: This article examines a fantasy genre in the work of Cornelia Funke against the background of Protestantism and "Als ob" ("as if") philosophy. Alongside, it also explores fantastic Romantic novels written by modern German authors (M. Gläser, K. Gier, K. Mayer, and V. Moers) that champion the cult of literature and writing. The essay thus attempts to systematize the features of German identity as revealed through representation of childhood and the national specificity of fictional art. The symbol of "an unending book" as a way of reconstructing the world is at the very basis of German culture and is endowed with religious meanings, from Novalis to M. Ende and more recently to C. Funke. In The Thief Lord (Herr der Diebe), a novel full of references to E.T.A. Hoffmann's Princess Brambilla, F. Pforr's and F. Overbek's paintings, Funke seeks to combine German love of dreaming with poeticized Italian joyfulness and love of life. For example, the novel's characters discover a magical carousel on the Isle of Mysteries and set off on an existential journey. In the course of this journey, they try to recognize themselves "in other clothes that seem to belong to the past," in a fashion similar to Heinrich von Ofterdingen. In the Inkheart trilogy (Inkheart, Inkspell, and Inkdeath), the author underscores the vernicle nature of verbal reality and its power over human existence; she also touches upon the problem of the author and her literary gift. According to Funke, a human being should certainly correspond to his or her higher destination and be directed by the inner moral law. However, it is words, like prayers in late Kant, that transform and create the universe.

Keywords: children's fiction, Die unendliche Geschichte, hermeneutics, didacticism, escapism. Information about the author: Elena V. Astashchenko, PhD in Philology, Maxim Gorky Institute of Literature and Creative Writing, Tverskoy bul'var, 25, I23IO4 Moscow, Russia.

E-mail: gedda@inbox.ru 
Неувядающий символ «бесконечной книги» как обетованного миротворения глубоко укоренен в немецкой культуре - от анонимных средневековых манускриптов до романистики модных авторов XXI в. - Мехтильды Глейзер, Кая Майера [26], но вместе с тем не утрачивает и наднационального религиозного значения. Книга в прозе Корнелии Функе, а впоследствии М. Глейзер, К. Майера и на сюжетно-композиционном, и на глубинном уровне всегда не только «die Geschichte», но и« das Buch». Заметно встречное движение материализации духовного мира и пресуществления обыденной жизни. Книга как вещь/rēs, с ее чернильным сердцем («Tintenherz»), словно утверждает органическими метафорами, предельно расширенными в трилогии К. Майера «Время библиомантов» («Die Seiten der Welt»), реальность в ней происходящего, а история и вымысел лишь две стороны («die Geschichte»). Важность в «чернильной трилогии» К. Функе и полиграфического, особо актуального на родине Гутенберга, аспекта книги сразу подчеркивается тем, что главный герой Мортимер - переплетчик, постоянный образ немецкой ирреалистической прозы, как и книжный реставратор типа майринковского Атанасиуса Перната. Показательно, что, например, английские мастера жанра фэнтези и волшебной сказки, Д.Р.Р. Толкин или Ф. Пулман, свои творения, независимо от религиозных предпочтений, именуют «fairy story», «history», «tale»; Толкин черпал вдохновение напрямую в языке, фольклоре, мифе, и скептически относился к литературоведению, которое культивируется

I Как доказательство культа буквы и книги можно привести перекодировку Глейзер знаменитой загадки кэрролловского Болванщика с физико-математической в графическую: на вопрос, что общего между вороном и рыцарем, Эми отвечает, начинаются с одной буквы: Rabe- 
в романах «Книжные странники» («Die Buchspringer»), «Emma, der Faun und das vergessene Buch» М. Глейзер [г8] или в серии, продолженной в «Лабиринте мечтающих книг» В. Мёрса. Ф. Пулман, создающий свои шедевры, по его словам, на завалинке ${ }^{2}$ - «in a filthy tip» [i6, p. I4], а не в библиотеке, провозглашает в «Северном сиянии» высшей непререкаемой ценностью стихийность «божественного ребенка», его архетипическую, а не ученическую память, приоритет природы над культурой: недаром подлинное имя его Лиры - Новая Ева. Конечно, истолкованному таким образом феномену детства найдется противоположность и в английской детской литературе последних лет - не раз упомянутый Функе роман «The Child that books built: A life in Reading» Ф. Спаффорда, недавно опубликованный К.М. Харгрейв роман «The girl of ink and stars» (хотя с его географическим пристрастием скорее приближает к природе, нежели уводит в книжное инобытие), и в испанской, например, «Кладбище забытых книг» К.Р. Сафона. Именно неопытные дети, в силу возраста, внимательнее взрослых к чужому, тем более привлекательному художественному, опыту - мультипликационному, кинематографическому, книжному: Тиму Талеру кажется, что жизнь приобрела «вкус приключенческого романа с злодеями и переодетыми героями» [4, с. 277], «книжная странница» Эмма видит, что «солнце светит ярко, как в любовных романах». К. Функе, которая всю жизнь в разных сферах проработала для детей, в полусотне своих книг ведет непрерывный, тайный и явный в эпиграфах, диалог с мировой, прежде всего немецкой, литературой, выбирая себе единомышленников. В этой связи показательно, что как только Функе обращается к иной культуре, то власть книги распространяется лишь на сквозных героев, хранящих немецкие национальные черты. В третьей части пенталогии «Бесшабашный» - «Золотая пряжа» («Reckless: das golden Garn»), изображена страна, прообразом которой была Россия: время в ней течет свободно, плавно и просто, без извивов и перегородок, в отличие от зазеркального германизированного Шванштайна; пространство расширяется до необъятных лесов, полей, бальных зал дворцов. Хлебосольная, громогласная, роскошная

Reiter, raven-rider [I7, s. I25].

2 Возможно, из-за непрерывной связи с жизнью и бытом по английскому фэнтези охотно устраиваются полевые ролевые игры, тогда как немецкое успешно экранизируется, виртуализируется в интернете, т. е. остается в ирреальном пространстве, хотя в трилогии «Reckless» ролевики усмотрели бы заявку на «пикник на обочине» - игру, дающую право на использование персонажей всех времен и народов. 
русская аристократия, типа ирреализованного в мире фэнтези князя Барятинского, «не стесняет себя четырьмя стенами и даже в городе устраивается с деревенским размахом», что представляет разительный контраст библиотекам и заваленным книгами комнатенкам германизированных героев фантастической прозы Функе и ее современников - М. Глейзер, К. Майера, К. Гир, или кинозалу якобы свободной, а не замкнутой «Альбертины из дома тысячи чудес» Ф. Райфенберга и Я. Штратмана [28]. Вместо скрипториев и ученых в «Золотой пряже» фигурируют сказочные герои, использованы аллюзии на древние предания, городской фольклор начала XX в., анекдоты, в общем «das Garn», как и указано в заглавии, - и прядение, и плетение историй, небылиц о «Железном волке и ковре-самолете <...> ледяном дворце в Якутии, который Николай III, велел выстроить для брата» [8, с. 3II]. В образе Варягии, помимо ориентации на устное народное творчество, нельзя не отметить постоянные экфрасисы икон, на которых «московский бог был теплый, даже горячий, как окружавшее его золотое сияние, несмотря на печальные лица его святых, смотревших со стен темными глазами» [8, с. 471]. Под пером Функе оживают персонажи народных промыслов - Сирин и Алконост, растения и звери с орнаментов рушников, ирреализуется архитектура, например, лестницы во дворце Барятинского «вьются подобно лестницам в небо на варяжских иконах» [8, с. 405]. Русскую удаль герои «Золотой пряжи» застают в лихолетье: революции начала XX в. преломлены в духе дизельпанказ (художественный мир Функе часто несет отпечаток разных поджанров фантастики, типа стоун-, сандал-, миддл-, клок- и стимпанк/паропанк). Русские в медвежьих дохах могут быть опасны, но неповоротливы, в отличие от Джекоба, Лисы и других персонажей, отмеченных немецкими национальными чертами - скрытностью, чрезмерной рассудочностью (свойством, как ни парадоксально, даже Бесшабашных), самоуглубленностью. В любых обстоятельствах сумрачный германский гений, по мысли Функе, проявляется, главным образом, посредством письма, даже любовь вынуждена «просачиваться сквозь витиеватые строчки», каждая записка имеет решающее значение в сюжете и раскрытии идейно-тематического замысла, что издавна подкреплено немецкой детской прозой, например, сюжетослагающей и смыслопорождающей ролью дого-

3 Время первой части пенталогии Функе «Бесшабашный» становится тахогенным: «Es waren Doppeldecker, wie man sie im frühen zwanzigsten Jahrhundert in Europa gebaut hatte. Ein gewaltiger sprung in die Zukunft für die Spiegelwelt <...> Macshinenzauber» [23, s. 224-226]. 
воров, надписей, ребусов и шарад в повести г962 г. «Тим Тайлер, или Проданный смех» («Timm Thaler oder Das verkaufte Lachen») Джеймса Крюса [4, с. 277]. В романе «Повелитель драконов» аналогично с образом России представлен Восток, буддийский и мусульманский, - с поэтизацией пейзажной, архитектурной, скульптурной, живописной, сказочно-мифологической, но не письменной и литературной составляющей культуры.

«Чернильная трилогия» Функе полна немецких аллюзий на символизацию «бесконечной книги», вбирающей читателей, в «импровизациях» P.М. Рильке: «Und manchmal ist in einem alten Buche ein unbegreiflich Dunkles anges trichen. Da warst du einst» [20, s. 420]. Финальная книга «чернильной трилогии» «Tintentod» открывается эпиграфом из «вигилий» Рильке: «Goldig auf dem Bücherstand, / glühn der Bände Rücken: / zu der Fahrt uns Feenland / Pfeiler für die Brücken» [22, s. 8]. Особенно настойчиво писательница полемизирует с поэтессой Ингеборг Бахман, тем творческим периодом, в который «Бахман теряет надежду, что слово участвует в формировании данности мира», по крайней мере, может преобразить жизнь, ибо «реальный язык несет смерть, а идеальный в мире недостижим» [7, с. 33]: «Не давать показаний, молчать, жить, / Предписанной жизнью жить!» [2]. В великом множестве своих книг Функе нацелена изменить «предписание жизни» своим писанием. Одним из прообразов ее хранительницы книжного царства Мегги была Лизель Мемингер из романа «Книжный вор» Маркуса Зусака (немца, пишущего по-английски): так, эпизод стирания книги Каприкорна - специфическая фэнтезийная реминисценция на закрашивание другом Лизель Максом гитлеровского «Mein Kampf» с целью написать и нарисовать (подчеркивается синтез в искусстве создания книги) свою историю [30, с. I5I-I63], реализуя жанр палимпсеста в изначальном значении. Функе солидаризуется с Марией Луизой Кашниц с помощью эпиграфа из ее стихотворения «Ein Gedicht» [25]: «Строка за строкой такой, / Со мной в пустыне сгорая, / За строчкой строка с языка / Откроет врата мне рая» (Перевод Е. Федосюк).

Символ нерукотворного или виртуального, но запечатленного и напечатанного в здешнем мире4 на материальном носителе ${ }^{5}$ каким у немецкой

\footnotetext{
4 Ср.: эпиграф из «Gedicht über die Weise Kunst» М. Конгеля к главе «Unbeschriebenes Papier» книги «Tintenblut» К. Функе: «Wir machen die Sachen, die nimmer vergehen, / Aus Tüchern die Bücher, die immer bestehen, / Wir schicken zu drükken den Drukkern von Hier, / Die geben das Leben dem toten Papier» [20, s. 540].

5 Т.В. Кудрявцева отмечает в немецкой литературе «использование возможностей
} 
писательницы XXI в. в романах для подростков «Зильбер. Дневник сновидений» ${ }^{6}$ является, например, web-страница, Функе выбирает из немецкой литературы от Матиаса Клаудиуса, Михаэля Конгеля до Пауля Целана. Аналогом книги в следующей пенталогии Функе «Бесшабашный» становится музей, а главный герой Джекоб использует свою, казалось бы, революционную храбрость, дабы законсервировать тающее прошлое в виде раритетных вещиц для археологических музеев: сказывается немецкая склонность к упорядочиванию, метафизическая бережливость. В романе «Рыцарь-призрак» беллетризуется учебник истории (по непревзойденному образцу беллетризованной географии С. Лагерлёф), в том числе Солсберийского собора, и продолжается в настоящем - в жизни детей-фантазеров, изучающих эту дисциплину.

Несмотря на благоговейное отношение к старине, библиотекам, архивам К. Функе иногда позволяет себе постмодернистские подмены, симулякры, мистификацию с авторством в эпиграфах, например, в «чернильной трилогии» «Парцифаль» Вольфрама фон Эшенбаха дан в пересказе футболиста ГДР Дитера Кюна, имя уважаемого берлинского репортера второй половины XX в. Альфреда Брауна сливается с именем звезды американских сериалов, фамилия Ахматова в пенталогии «Бесшабашный» намекает на страну и эпоху, но при этом дана носительнице фэнтезийной расы, арабской священной «бесконечной книгой» в «Повелителе драконов» признана «Тысяча и одна ночь», она же названа арабской «бесконечной книгой, которую никто не может дочитать до конца» [II, c. I78].

К. Функе, много лет посвятившая соцзащите детей и юношества, не может не понимать, что эскейпизм «книжности», помимо возвышенности, изысканности, надмирности, оборачивается замкнутостью, поэтому уединенная мечтательность, устремленность ввысь, Sehnsucht немцев в романе «Король воров» разбавлены итальянской жизнерадостностью и общительностью. Идея бракосочетания Германии с Италией не утрачивает актуальности со времен романтизма. Так, например, идея прослеживается у немецких живописцев-назарейцев, возрождающих стиль Средневековья и Раннего

электронного пространства в эстетических целях» с 1979-х гг., а восприятие книги как произведения искусства уже у Й. Гутенберга [5, с. II9].

6 Заглавие «Silber. Das Buch der Träume», в отличие от русского перевода, привлекает внимание к потоку снов и слов, а не дней. 
Ренессанса: и Франц Пфор пишет Италию-Суламифь и Германию-Марию, и Фридрих Овербек запечатлевает этот аллегорический союз. Э.Т.А. Гофман в «Принцессе Брамбилле» противопоставляет немецких девушек итальянским, «милую сморфию» которых нельзя отождествить с тем расположением немок - «молоденьких, едва вышедших из детских лет. Ничто их не радует: всегда им то слишком тесно, то слишком просторно, нигде на нашей планете не находят они удобного местечка для своей крохотной особы». Устами чародея Челионати Гофман также противопоставил задумчивых и рассеянных немецких юношей блистательным римским комедиантам, находчивым и покоряющим толпу. Когда дети из романа Функе «Король воров» после смерти матери сбегают от гамбургского дедушки в Венецию, их чопорная, педантичная и не склонная к грезам (еще один стереотип о немках) тетя жалуется, что ее сестра заморочила детям голову рассказами о «крылатых львах, церквях из чистого золота <...> ангелах и драконах на крышах <...> а вдоль каналов бессчетные лестницы сбегают вверх от самой воды, чтобы водяным по ночам было удобнее выходить прогуляться по суше» [9, с. Іо-ІІ]. Так мальчики и решили, что «прямо в сказку попадут». Праздничная экзотика помогает преодолевать тесноту пространства, а как превозмочь время? Оказывается, на венецианском острове Тайн скрыта Загадочная карусель, очередная версия уэллсовской «машины времени», - только путешествуют на ней не по эпохам, а по этапам своей жизни. Взрослый, у которого отнято детство тяжелой унизительной службой у господ, вернется в пору беззаботных игр, а кто же захочет повзрослеть, минуя детство и юность? Сын миллионера, с которым отец обращается как с вещью, не особенно ему дорогой, готов обрести свободу личности даже такой ценой. Мотив путешествия по собственной предопределенной судьбе - то возвращение к появлению на свет, то предвидение будущего - важен и в библии немецкого романтизма - книге Новалиса «Генрих фон Офтердинген», только Генрих видит себя в бесконечной книге еще и в другом историческом измерении - «в одежде другой, точно из другого времени» [6, с. 272]: юный поэт там живет в веках, включая в свое странствие путь средневекового миннезингера.

Словно перехватывая новалисовскую строку у Михаэля Энде, Функе продолжает и тему, заявленную Энде в книге «Die unendliche Geschichte», также переведенной на русский как «Бесконечная книга», - наследования писательского мастерства. В отличие от идеального ученика Кореандера - Басти- 
ана Букса, из тех «людей, которые уходят в Фантазию, а потом возвращаются и лечат оба Мира» [14, с. 309], Функе в «чернильной трилогии» выбирает в соперники Фенолио конъюнктурщика и злодея Орфея, чье имя по-постмодернистски спорит с мифологемой. Ничтожный носитель имени, в котором свернут миф о тяжбе между любовью и смертью, о трагической обреченности творца и нетленном величии его искусства, о святости и соблазне, герое и толпе, будет наказан пустотой небытия, где ему, вору, присваивавшему чужие живые слова, нечем будет поживиться. Тему нетождественности имени и носителя продолжает Мортимер, становясь разбойником Перепелом. Новое амплуа подсказано главному герою анонимной немецкой книгой о Шиндерханесе, упомянутом в трилогии, - «Leben, Thaten und Ende des berüchtigten Räubers Johannes Bücklergen. Schinderhannes». На примере Мортимера-Перепела писательница ставит перед детьми сложный извечный вопрос о цели и средствах. Может ли разбойник быть благородным, можно ли созидать и вместе с тем разрушать? Сопереживая беднякам волшебного королевства Омбры, книголюб, души не чающий в жене и дочери, становится жестоким мстителем - и это в роковой момент чуть не погубило его: «Сердце у него стало черным от слов Орфея» [г2, с. 56I] и являло ему вместо спасительных образов Мегги и Резы отвратительные кровавые фантомы. Чтобы избавиться от насланных лже-орфеем эриний («Пошли ему ярости, пусть грезит об убийстве, пусть захлебнется гневом, мечтая о кровавой резне»), переплетчику нужно отказаться от роли живодера и вновь вступить на путь созидания, неотделимого от любви и «песен, полных света и надежды, отваги и протеста» [І2, c. 527]. Именно с воскрешения песни подхватывается подлинно орфическая тема Новалиса - о преодолении греха и смерти словом. Но и лже-орфею Функе не выносит окончательного приговора: «Почему под взглядом Мортимера ему становилось так невыносимо стыдно? Почему в его сердце все еще жила любовь?» [І2, с. 587]. Таким образом, нравственные вопросы на фоне грезы о вечной любви обретают статус религиозных: они то фокусируются, то расходятся (как сюжетные линии книги Функе «Золотая пряжа») в «бесконечной книге», первый прообраз которой Бытие, Библия.

К символике Библии, бесконечной истории (именно «history») и книги обращается в трилогии «Властелин колец» и Д.Р.Р. Толкин. Однако именно с медиевистской и католической традицией Толкина будет полемично почти все современное немецкое фэнтези. Так, Сэм Гэмджи думает: «All the big 
important plans are not for my sort. Still, I wonder if we shall ever be into songs or tales <...> great big book» 7 . Подвиги толкиновского братства кольца, никто из которого книг в огне битвы и потоке странствий не пишет (их пишет Бильбо, ушедший на покой), как и подвиги героев средневекового эпоса, станут песней и легендой, но заранее людям ничего неизвестно: «ибо кто познал ум Господень? Или кто был советником Ему?» (г Рим. II: 34). Для Толкина книга - это со-творчество/sub-creation с Богом: прообразом кульминаций толкиновского творчества была евкатастрофа/eukatastrophe - вписывание помыслов и дел полуязыческих персонажей в великий библейский контекст и ожидание в светлом финале возвращения Короля. Пути Господни не открыты даже палантиром героям и автору «Властелина колец», сказавшему биографу, что он творит не по произволу, а по благодати, ссылаясь на апостола Павла, «недосказанности» толкиновского сюжета развертываются в зависимости от нравственного выбора, хотя Сэм и Фродо догадываются, что продолжают историю Берена, в свою очередь, Эарендила в борьбе с тьмой за торжество света, у них возникает вопрос: «Don't the great tales never end?» К. Функе иначе ставит вопрос о свободе и предопределении, мучительный со времен ислама («Мы верим в аль-Лаух/Скрижаль и аль-Калам/Перо и во все, что написано», однако «если бы море превратилось в чернила, то и тогда не переписать всех Слов Аллаха») и уводящий в глубь христианства («Где дух Господен, там свобода», однако «не как Я хочу, но как Ты») и постоянный у самонадеянных богов и героев Гомера, замирающих, когда «будущая судьба колеблется на острие меча»... В отличие от католика Толкина и мусульман Фаиза Ахмеда Фаиза, Халиля Джибрана (фаталистов, несмотря на революционную борьбу за свободу Пакистана, Ливана), к которым апеллирует Функе аллюзиями и эпиграфами, ее герои и миры самодостаточны и сами творят собственный мир, руководствуясь внутренним нравственным законом, и с помощью «правильно подобранных слов» священнодействующих: «ерой сочувствует слабым и идет на смерть не потому, что я так о нем написал, а потому что хочет спасти детей. Может быть, эта история его меняет. Но и он меняет эту историю! Она продолжается, благодаря тому, что он делает, а не тому, что я пишу. Хотя правильно подобранные слова способны ему помочь» [І2, c. 4I6]. Автор приписывает себе большую власть над мирозданием, вдохнов-

7 Не про моего брата всякие важные и великие дела <...> Интересно попадем ли мы в песню или нет? <...> в толстую, большую книгу? (Перевод М. Каменкович, В. Каррика). 
ляясь немецким романтизмом: «Der Herr die unendliche Geschichte» [20, s. 536]. Возможно, самоценное немецкое фэнтези XX-XXI вв., с его магией личного слова, неотъемлемой от индивидуализма и родного идеализма, повлиявшего на весь мир, укоренено еще глубже - в Реформации. Протестантизм, - как пишет С.С. Аверинцев, - ориентирован на «повышенно личностное понимание общения с Богом человека», а не включение его лишь «звеном в цепи сверхличной общности», церковной иерархии, а также на «индивидуализм $<$...> перестройку религиозных представлений, чтобы человек со всем своим личным своеобразием мог включаться в ситуацию религиозного переживания» [I, c. 365]. П.П. Гайденко так же определяет понимание Бога у И. Канта, $\Phi$. Ницше, немецких романтиков, и у протестантов: «Абсолют осознает себя во мне, живет во мне, мое самосознание - это в сущности и есть бытие Бога». От своеобразного личного религиозного переживания не так далеко до немецкой идеи, покорившей мир ${ }^{8}$ в XX в., - философии «идеалистического позитивизма», ирреализма/ «als ob», выстроенной X. Файхингером на основе мнимостей И. Канта и «учения о сознательно желаемом вымысле» Ф. Ницше, «зорким взглядом психолога вскрывающего те механизмы и иллюзии, на которых покоится человеческое существование» [13, с. 87]: «Licht und Finsternis, Schwarz und Weiß, Leben und Tod lauter Kunstprodukte denkendig in dresser ihrer Korrektheit als klarer und sicherer Anhalt, aber in der Anwendung aufs Wirkliche stets mit bedachter Vorsicht zu gebrauchen ${ }^{9}$ [29, s. 339]. Культ художнического произвола, восприятие молитвы больше как способа напрямую творить жизнь, нежели просьбы в диалоге с Богом, отчетливо прослеживается еще в замечании, выделенном, по сообщению К. Форлендера, во втором издании «Критики способности суждения» И. Кантом: философ определяет словесное пожелание и желание как «способность служить посредством своих представлений причиной действительности предметов этих представлений» [3, с. 48]; то же, согласно Канту, справедливо и относительно молитв, с по-

8 Русские филологи (А. Евлахов, П. Сакулин) предлагали обозначать «als ob» иppeалистический тип творчества и метод анализа, англичане Ch.K. Ogden и I.A. Richards в книге «The Meaning of Meaning» предложили гипотезу, что в основе осуществления всего художества потенция «als ob» как вера [27] в то, что мир вымышленный и запечатленный в словах - истина, причем единственная (с чем сразу в книге «Умирание искусства» спорит В. Вейдле, уповая на исконный миф и религию).

9 Свет и Мрак, Черное и Белое, Любовь и Смерть в чистом виде вообразимы в совершенной форме произведения искусства, тогда как постижение и достоверность их реальности в жизни постоянно подвергается сомнению. - Здесь и далее перевод наш. 
мощью которых надеются «достичь целей, недостижимых естественным путем» и которые «доказывают наличие каузальной связи между представлениями и их объектами» [3, с. 48]; «иллюзорность пустых пожеланий есть следствие благотворного устройства нашей природы», по мысли Канта, потому что заставляет стремиться к пока невозможному. Так в немецкой культуре ходовой жанр массовой литературы фэнтези ставит с помощью темы «книжности» вопрос о том, чем становится абсолютно самодостаточное авторство - бегством или торжеством. Одновременно над этим вопросом задумывается элитарная философско-филологическая «теория фикций» В. Изера и О. Маркварда, который отметил в работах «Искусство как антификция: преображение действительности в вымысел» и «Кризис ожидания отсроченного опыта: эстетическая компенсация новейших эмпирических утрат», что в стремительности неуловимой и потому в каждый миг ложно понятой жизни, вечно, незыблемо и самоценно лишь искусство. Основание сравнивать идеи массовой литературы для детей и профессиональной философии можно найти в постоянном обращении Функе в «чернильной трилогии» к «учению о сознательно желаемом вымысле» Ф. Ницше, давно растиражированному на ручках и тетрадках, в главе «Fenoglios Plan» книги «Tintenblut»: «Мне только лист бумаги и перо - и я подниму земной шар». 


\section{Список литературы}

Аверинщев С.С. Протестантизм // Аверинцев С.С. Собр. соч. / под ред.

Н.П. Аверинцевой и К.Б. Сигова. София-Логос-Словарь. К.: ДУХ І ЛІТЕРА, 2006. C. 365-37I.

Бахман И. Воистину: Стихи / составление, вступительная статья и комментарии

Е. Соколовой. М.: Независимая газета, 2000. I76 с.

Кант И. Критика способности суждения. М.: Искусство, І994. 367 с.

Крюс Дж. Тим Талер, или Проданный смех: Фантастическая повесть / пер. с нем.

А. Исаевой. СПб.: Азбука-классика, 2004. 352 с.

Кудрявцева Т.В. Новейшая немецкая поэзия (го0-200о-е гг.): основные тенденции и художественные ориентиры. М.: ИМЛИ РАН, 2008. 344 с.

Новалис. Генрих фон Офтердинген // Избранная проза немецких романтиков:

в 2 т. / сост. предисл. А. Дмитриева; коммент. М. Рудницкого. М.: Худож. лит., I979. T. I. 379 c.

7 Соколова Е.В. Взаимосвязь «пола» и «языка» в творчестве Ингеборг Бахман и Эльфриды Елинек: Аналит. обзор. М.: РАН. ИНИОН. Центр гуманит. науч.-информ. исслед. Отдел литературоведения, 20І2. І30 с.

Функе К. Бесшабашный. Книга 3: Золотая пряжа: История, найденная и записанная Корнелией Функе и Лионелем Виграмом / пер. с нем. О. Боченковой. СПб.: Азбука, 2016. 576 с.

9 Функе К. Король воров / пер. с нем. М. Рудницкого. М.: Росмэн, 2003. 477 с.

го Функе К. Чернильная кровь / пер. М. Сокольской. М.: Росмэн, 2007. 752 с.

II Функе К. Чернильное сердце / пер. М. Сокольской. М.: Махаон, 2009. 496 с. Функе К. Чернильная смерть / пер. М. Сокольской. М.: Махаон, Азбука-Аттикус, $2012.672 \mathrm{c}$.

Эбаноидзе И.А. Фридрих Ницше // Литературный процесс в Германии первой половины XX века (ключевые и знаковые фигуры). М.: ИМЛИ РАН, 2ОI5. С. 64-93. Энде М. Бесконечная История: сказочная повесть / пер. с нем. А. Исаевой, Л. Лунгиной. СПб.: Амфора, 2009. 504 с.

Anhäuser U. Schinderhannes und seine Bande. Einbeck: Rhein-Mosel-Verlag, 2003. I73 s. Dougill J. Oxford. A Literary Guide. Oxford: Oxface Publications, 2006. 39 p. Gläser M. Die Buchspringer. Bindlach: Loewe Verlag, 20I5. $384 \mathrm{~s}$.

I8 Gläser M. Emma, der Faun und das vergessene Buch. Bindlach: Loewe Verlag, 20 I7. $354 \mathrm{~s}$.

Ende M. Die unendliche Geschichte. Stuttgart: Thienemann Verlag GmbH., 2007. 3I5 s. Funke C. Tintenblut. Hamburg: Cecile Dressler Verlag GmbH.\&Co., 2005. 653 s. Funke C. Tintenherz. Hamburg: Cecile Dressler Verlag GmbH.\&Co., 2003. 576 s. Funke C. Reckless: das Goldene Garn. Hamburg: Cecile Dressler Verlag GmbH.\&Co., 20IO. 653 s. 
24 Funke C. Reckless: Steinernes Fleisch. Hamburg: Cecile Dressler Verlag GmbH.\&Co., 20I0. 305 s.

25 Kaschnitz M.L. Ein Gedicht. URL: http://www.gedichte.vu/ein_gedicht.html (дата обращения: І2.05.20I7).

26 Meyer K. Die Seiten der Welt. Nachtland. Frankfurt am Main: Fisher Verlag GmbH., 20I5. $592 \mathrm{~s}$.

27 Ogden Ch.K., Richards I.A. The Meaning of Meaning. A Study of the Influence of Language upon Thought and the Science of Simbolism. NY: Harcourt, Brace\&World, I946. $363 \mathrm{p}$.

28 Reifenberg Fr.M., Strathmann J. Albertine und das Haus der tausend Wunder. Stuttgart: ThienemannVerlag GmbH., 2004. 320 s.

29 Vaihinger H. Die Philosophie des Als Ob. System der theoretischen, praktischen und religiosen Fictionen der Menschheit auf Grund eines idealistischen Positivismus. Mit einem Anhang über Kant und Nietzsche. Leipzig: Verlag von Felix Meiner, I922. 804 s.

30 Zusak M. The book thief. NY: Random House Children’s Books, 2006. 552 p. 


\section{References}

I Averincev S.S. Protestantizm [Protestantism]. Sobranie sochinenij [Works], ed. N.P. Averintsev i K.B. Sigov. Kiev, DUH I LITERA Publ., 2006, pp. 365-37I. (In Russ.) Bahman I. Voistinu: Stihi [It's poetry indeed!] ed., intro. and comment. E. Sokolova. Moscow, Nezavisimaja gazeta Publ., 2000. I76 p. (In German \& Russ.) Kant I. Kritika sposobnosti suzhdenija [The Critique of judgement]. Moscow, Iskusstvo Publ., I994. 367 p. (In Russ.)

4 Krjus Dzh. Tim Taler, ili Prodannyj smeh: Fantasticheskaja povest' [Krüss, James. Tim Taler, or the boy who sold his laughter, trans. from German A. Isaeva. St. Petersburg, Azbuka-klassika Publ., 2004. 352 p. (In Russ.) Kudrjavceva T.V. Novejshaja nemeckaja pojezija (I90o-20oo-e gg.): osnovnye tendencii $i$ hudozhestvennye orientiry [The main trends and the artistic aspects of contemporary German poetry (1900-2000)]. Moscow, IMLI RAN Publ., 2008. 344 p. (In Russ.) Novalis. Genrih fon Ofterdingen. Izbrannaja proza nemeckih romantikov; $v 2 t$. [Heinrich von Ofterdingen. Selected fiction of German Romantics: in 2 vols.], intro. A. Dmitriev; comment. M. Rudnicky. Moscow, Hudozh. Lit. Publ., I979. Vol. I. 379 p. (In Russ.) Sokolova E.V. Vzaimosvjaz' "pola” i "jazyka" v tvorchestve Ingeborg Bahman i Jel'fridy Elinek: Analit. obzor [The correlation of "sex" and "language" in the works by Ingeborg Bahman and Elfrida Elinek]. Moscow, RAN INION Publ., 20I2. I30 p. (In Russ.) Funke K. Bezshabashny [Reckless], trans. from German O. Bochenkova. St. Petersburg, Azbuka Publ., 20I6. 576 p. (In Russ.)

9 Funke K. Korol' vorov [The Prince of the thiefs], trans. from German M. Rudnicky. Moscow, Rosmjen Publ., 2003. 477 p. (In Russ.)

IO Funke K. Chernil'naja krov' [Inkspell], trans. M. Sokol'skoj. Moscow, Rosmjen Publ., 2007. 752 p. (In Russ.)

Funke K. Chernil'noje serdzhe [Inkheart], trans. M. Sokol'skoj. Moscow, Rosmjen Publ., 2007. 752 p. (In Russ.)

Funke K. Chernil'naja smert' [Inkdead], trans. M. Sokol'skaya. Moscow, Mahaon, Azbuka-Attikus Publ., 20I2. 672 p. (In Russ.)

Jebanoidze I.A. Fridrich Nietzsche [Friedrich Nietzsche]. Literaturnij prozhes $v$ Germanii pervoj poloviny XX veka (kluchevije I znakovije fiiguri) [Literary process in Germany in the first half of the $20^{\text {th }}$ century (key and symbolic figures)]. Moscow, IMLI RAN Publ., 2008, pp. 64-93. (In Russ.)

I4 Jende M. Beskonechnaja Istorija: skazochnaja povest' [Unending story: a fairy tale], trans. from German A. Isaeva, L. Lungina. St. Petersburg, Amfora Publ., 2009. 504 p. (In Russ.)

I5 Anhäuser U. Schinderhannes und seine Bande. Einbeck, Rhein-Mosel-Verlag, 2003. I73 s. (In German) 
I6

Dougill J. Oxford. A Literary Guide. Oxford, Oxface Publications, 2006. 39 p. (In English)

Gläser M. Die Buchspringer. Bindlach, Loewe Verlag, 20I5. 384 s. (In German)

Gläser M. Emma, der Faun und das vergessene Buch. Bindlach, Loewe Verlag, 2017. 354 s. (In German)

Ende M. Die unendliche Geschichte. Stuttgart, Thienemann Verlag GmbH., 2007. 3I5 s. (In German)

Funke C. Tintenblut. Hamburg, Cecile Dressler Verlag GmbH.\&Co., 2005. 653 s. (In German)

Funke C. Tintenherz. Hamburg, Cecile Dressler Verlag GmbH.\&Co., 2003. 576 s. (In German)

Funke C. Tintentod. Hamburg, Cecile Dressler Verlag GmbH.\&Co., 2007. 653 s. (In German)

Funke C. Reckless: das goldene Garn. Hamburg, Cecile Dressler Verlag GmbH.\&Co., 20Io. 653 s. (In German)

Funke C. Reckless: Steinernes Fleisch. Hamburg, Cecile Dressler Verlag GmbH.\&Co., 20I0. 305 s. (In German)

25 Kaschnitz M.L. Ein Gedicht. Available at: http://www.gedichte.vu/ein_gedicht.html (Accessed I2 May 20I7). (In German)

Meyer K. Die Seiten der Welt. Nachtland. Frankfurt am Main, Fisher Verlag GmbH., 20I5. 592 s. (In German)

7 Ogden Ch.K., Richards I.A. The Meaning of Meaning. A Study of the Influence of Language upon Thought and the Science of Simbolism. New York, Harcourt, Brace\&World, I946. 363 p. (In English)

28 Reifenberg Fr.M., Strathmann J. Albertine und das Haus der tausend Wunder. Stuttgart, ThienemannVerlag GmbH., 2004. 320 s. (In German)

29 Vaihinger H. Die Philosophie des Als Ob. System der theoretischen, praktischen und religiosen Fictionen der Menschheit auf Grund eines idealistischen Positivismus. Mit einem Anhang über Kant und Nietzsche. Leipzig, Verlag von Felix Meiner, I922. 804 s. (In German)

Zusak M. The book thief. New York, Random House Children's Books, 2006. 552 p. (In English) 
УДК 82І.І6І.І.о

ББК $83.3(2 \mathrm{Poc}=\mathrm{Pyc}) 4$
СВЯТАЯ ЗЕМЛЯ - РИМСКАЯ

ИМПЕРИЯ - ВИЗАНТИЯ - РУСЬ: ИДЕЯ

НАСЛЕДНИЧЕСТВА ПО ПАМЯТНИКАМ ДРЕВНЕРУССКОЙ ЛИТЕРАТУРЫ

(C) 2018 В.М. Кириллин

Институт мировой литературы

им. А.М. Горького Российской академии наук, Москва, Россия

Дата поступления статьи: 2І октября 2017 г. Дата публикации: 25 марта 2018 г.

DOI: IO.22455/2500-4247-20I8-3-I-II8-I39

Аннотация: В статье рассматривается история усвоения древнерусской общественной мыслью идеи преемственной и наследственной связи Руси с древнейшими политическими и духовными центрами христианского мира - Иерусалимом, Римом и Константинополем. Эта идея не получила развернутого доктринального оформления в каких-либо специальных трактатах, но кратко и декларативно, прямо или иносказательно ее выражали авторы ряда литературно исторических, полемических и учительных произведений. Автор статьи значительно расширяет круг источников, в которых посредством приема ретроспективной аналогии события русской истории отождествлялись с событиями истории Святой Земли. В начале весьма косвенное выражение этого тождества («Слово о Законе и Благодати») в агиографическом предании о великом Киевском князе Владимире Святославиче становится неприкрыто конкретным. И затем повторяется с разными акцентами, отражающими реальный ход русской истории, в ряде литературных текстов XV-XVII вв. При этом обозначилось разделение, по которому Рим как символ имперской власти на земле ассоциировался в представлении людей со сферой государственной политики, а Иерусалим как символ царства Божия - со сферой церковно-религиозной жизни.

Ключевые слова: Иерусалим, Рим, Константинополь, Киев, Москва, теория translatio imperii, житие Владимира Святославича, ретроспективная аналогия, «Сказание о русской грамоте», архитектурное оформление Москвы.

Информация об авторе: Владимир Михайлович Кириллин - доктор филологических наук, ведущий научный сотрудник, Институт мировой литературы им. А.М. Горького Российской академии наук, ул. Поварская, д. 25 а, І2Іо69 г. Москва, Россия.

E-mail: kvladimirm@mail.ru 


\section{SACRED LAND - ROMAN EMPIRE - BYZANTIUM - RUS': THE CONCEPT OF HEREDITY IN OLD RUSSIAN LITERATURE}

This is an open access article distributed under the Creative Commons Attribution 4.0 International (CC BY 4.0)
(C) 20I8. V.M. Kirillin

A.M. Gorky Institute of World Literature of the Russian Academy of Sciences, Moscow, Russia

Received: October 2I, 2017

Date of publication: March 25, 2018

Abstract: The article examines the history of the idea of connection, succession, and heredity between Old Rus', on the one hand, and such ancient political and spiritual centers of the Christian world as Jerusalem, Rome, and Constantinople on the other, within the Old Russian political thought. This idea was never documented in particular treatises but was nonetheless present in fictional, polemical and didactic works whether as a marginal or central theme, whether directly or allegorically. The author of the article considerably extends the circle of sources that drew retrospective analogies between Russian history and Sacred Land history. Indirect parallels in the "Word about the Law and the Grace" become explicit and specific in the hagiographic legend about Kiev Prince Vladimir Svyatoslavich and later recur, with different accents, in a number of literary texts in the $15^{\text {th }}-\mathrm{I} 7^{\text {th }}$ centuries, reflecting the course of Russian history. In these texts, we encounter a division between Rome as a symbol of imperial mundane power associated with state politics, and Jerusalem as a symbol of the Kingdom of God associated with church and religion.

Keywords: Jerusalem, Rome, Constantinople, Kiev, Moscow, the theory of translatio imperii, biography of Vladimir Svyatoslavich, retrospective analogy, "Story about Russian Literacy," Moscow architectural design.

Information about the author: Vladimir M. Kirillin, DSc in Philology, Leading Research Fellow, A.M. Gorky Institute of World Literature of the Russian Academy of Sciences, Povarskaya 25 a, I21069 Moscow, Russia.

E-mail: kvladimirm@mail.ru 
Мысль о Москве как третьем Риме зародилась в русском общественном сознании на рубеже XV-XVI вв. Обусловлена она была внутренними и внешними политическими и церковно-историческими обстоятельствами, факторами частного и общего характера, о чем немало написано [22; 57; 46; г]. Мысль эта, будучи отражением библейской [49, с. 49-52 (комментарии к 7 главе Книги пророка Даниила)] и затем средневековой теории translatio imperii, теории наследования одними государствами от других имперского авторитета [27] не получила тогда в России развернутого доктринального оформления в каких-либо специальных трактатах, но декларативно и кратко, прямо или иносказательно она была сформулирована в ряде литературных и публицистических памятников и подразумевала два аспекта: теократический, отражающий аксиологию Церкви (восприятие Россией древних христианских святынь Востока и Запада), и имперский, отражающий аксиологию Государства (восприятие Россией древних регалий царского достоинства). Теократическая подоплека идеологемы о восприятии Русской землей величия Константинополя и Рима отразилась в XVI в. в сказаниях о чудотворных иконах Божией Матери «Тихвинской» (отождествлялась с Влахернским образом Богородицы) [2I, с. 205-206] и «Владимирской» (отождествлялась с нерукотворным образом «Римляныни», а также с Лиддской святыней) [Із, с. 8I-ІІо]. Аналогично интерпретировалась и история белого клобука, головного убора, отличавшего новгородских архипастырей, который некогда будто бы был подарен императором Константином Великим Римскому папе Сильвестру в благодарность за исцеление и приобщение ко Христу и затем чудесным образом оказался в Новгороде 
Великом [І9]. Имперский подтекст убеждения в восприятии Москвой через Константинополь величия древнего Рима образно отразился в «Послании о Мономаховом венце» Киевского митрополита Спиридона-Саввы (византийский император Константин Мономах, как утверждается, передал великому Киевскому князю Владимиру Всеволодовичу свой царский венец и другие атрибуты власти, «И от того часа тем венцем царским 〈...〉 венчяются вси

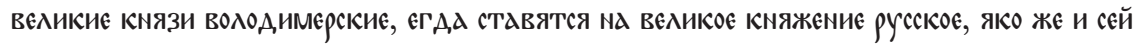
волный самодержьц и царь Великьа Росия Василие Иванович...») [I5, с. I64-I65] ${ }^{\mathrm{T}}$ И в «Сказании о князьях Владимирских» (повторяется рассказ «Послания») [15, c. I76-I77]. Прямо наследственность Москвы по отношению к Константинополю и Риму утверждалась в «Изложении Пасхалии» митрополита Зосимы (см. ниже) [48], в «Послании на зведочетцев» старца Филофея («да

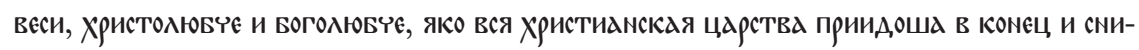
А.шася во едино царство нашего госуадаря, По пророческим книгам то есть Ромейское царство. Ава уво Рима пад,оша, а третий стоит, а четвертому не Быти») [46, с. 345] и в его переделках - «Послании великому князю Василию Ивановичу» [46, с. 360] и «Послании царю Ивану Васильевичу» [46, с. 352]. Оба аспекта данной идеологемы всесторонне рассмотрены в исследовательской литературе. Ее причины и тенденции вполне очевидно связаны с государственным развитием Московской Руси. Однако до сих пор круг источников, содержащих сведения по означенной теме, был достаточно ограничен, тогда как он вполне может быть расширен.

Должно прежде всего заметить, что сама по себе мысль о преемственной причастности Русской земли к мировой истории возникла в русском общественном самосознании задолго до возвышения Москвы и изначально ориентирована была не на Запад, а на Восток, поскольку именно на Востоке началась зафиксированная Священным Писанием история человечества и от Востока нисходит на людей свет Христов.

Поиск в означенном направлении побужден был изучением рефлексивных разделов литературного предания о святом благоверном крестителе Руси Владимире Святославиче. В частности, возникшая на рубеже XIV$\mathrm{XV}$ вв. 4-я редакция так называемого «Обычного жития» князя содержит уникальное гомилетическое размышление о Владимире Святославиче:

I З Зесь и далее древнерусский текст воспроизводится без сохранения его орфографических особенностей. 


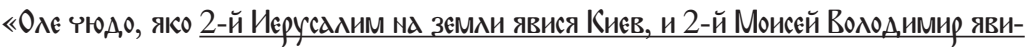

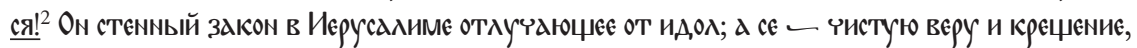

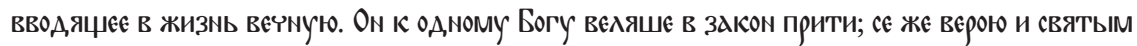

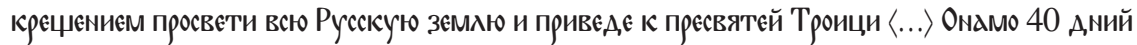
и 3 Моисей, закон дав, преставися и на горе погревен; се Же, 30 дет и 3 БЫв в святом крещеньи, верУ чистую совлюдАЬ...» [55, С. 274].

Как выяснилось, данное чтение заимствовано из «Сказания о русской грамоте» [32, с. 504-505; 55, с. 327-328]. Сравнительно с источником приведенная похвала Владимиру лишь слегка подправлена. Ее содержательная суть при извлечении из другого произведения не изменилась. Будучи идейно и некоторыми фразами связана с отдельными выражениями «Слова о Законе и Благодати» («Изнєсє жє и Моисей от Синдискыд горы

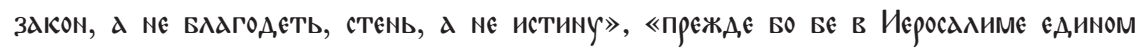
клднятися, пыне же по всей земли», «в Иеросалиме єдином слдвем ве Бог» [4, с. 28 , 32]), эта похвала представляет собой не столько развернутую историческую аналогию на тему духовного тождества деяний пророка Моисея и деяний великого Киевского князя, сколько утверждение превосходства последних над первыми в плане их конечных результатов. Но главное то, что в ней с принципиально новым решением раскрыта тема преемства. Если Иларион в «Слове о Законе и Благодати» лишь фигурально намекал на духовное наследничество Киева по отношению к Иерусалиму через посредство Константинополя, «второго Иерусдлима» («ты жє с Бавою твоено Одьгоюо принесша крест от новадго Иерусалима, Константина града, и

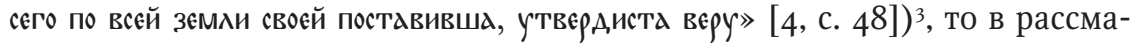
триваемом руссуждении уже прямо и определенно говорится о Киеве как втором Иерусалиме и Владимире как втором Моисее, направившем Русскую землю в Царствие Небесное. Константинополь, таким образом, оказался исключенным из цепочки святых городов, несмотря на то, что в конце цитированного текста великий Киевский князь все-таки отождествлен с главою Римской империи и основателем византийской столицы: «И высть вторый Костямтин в Руской земли Володимиир» [55, с. 274].

2 Здесь уместно отметить повторяющуюся в научной литературе ошибочность утверждения, что эти слова принадлежат Иакову Мниху [43, с 96; I4]. В аутентичном тексте «Памяти и похвалы» Владимиру Святому данного выражения нет.

3 У Илариона так же имеются ретроспективные параллели Владимир - Давид; киевская София - константинопольская София - иерусалимский храм [20, с. 9I]. 
Умолчание о Константинополе как сакральном предместнике или прототипе Киева весьма любопытно. Прежде всего, можно интерпретировать его как идеологически и историософски новую сравнительно с более ранними версиями «Жития» Владимира пропозицию этно-конфессионально-патриотической темы.

Кроме того, считается, что повествование о просветителе славян Константине Философе, славянской азбуке и ее запрете при епископе Пражском Адальберте-Войтехе было объединено в рамках «Сказания о русской грамоте» с повествованием о благоверном великом князе Владимире Святославиче и крещении Руси, которое послужило источником для составителя 4-й Распространенной редакции, около середины XIII столетия [I6, с. II8]. Тогда же, по мнению ряда исследователей, произошло официальное церковное признание святости Владимира и, соответственно, календарное утверждение его памяти на день его кончины I5 июля по ст. ст. [3I; го, с. 77-8I; ІІ, с. 63-64; 53, с. І88-196; 44, с. 439-445] (однако полной ясности по данному вопросу до сих пор нет [2, с. 49; 5I, с. 69-I2I; 38]). Но в этот же день, в І240 г., как свидетельствует летописец, русичи наголову разбили шведов на реке Неве под водительством новгородского князя Александра Ярославича [36, с. 77], который стал затем великим князем Киевским и еще Владимирским († І263) и который являлся, между прочим, прямым потомком крестителя Руси. В середине же 6о-х гг. XIII столетия в обиход русского чтения попала «Повесть о житии Александра»4. Последний факт весьма знаменателен, поскольку в этом новом литературном произведении тоже, подобно «Сказанию о русской грамоте» и 4-й Распространенной редакции «Жития» Владимира, но иначе, оказалась реализованной тема Иерусалима и тоже в контексте ретроспективной аналогии:

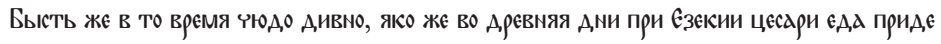
Санахирим, асурийскый цесарь, на Иерусалим, хотя пленити град святый ерусалим, внезАпу

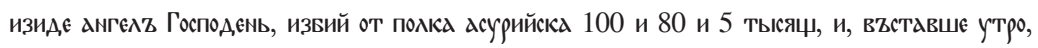
овретошася труПья мертвы вся. Тако же Бысть при поведе Александрове, егАА Поведи короля... $[5, \text { c. } 362]^{5}$.

4 «Того ж лета. Преставися великый князь Олександр сын Ярославль. Скажем же мужство и житье его...» [39, стб. 477-48I; 5, с. 358-369]. О памятнике: [37; 23, с. 209].

5 Здесь уместно отметить, что образ плененного Сеннахиримом Иерусалима будет позднее использован в «Сказании о Довмонте» и «Повести о Темир-Аксаке». 
К разумению читателя, здесь также отмечается прямая, без посредничества Константинополя, связь по схожести. Только с историей Иерусалима сопоставлена уже не история Киева, а история северо-западной Руси, «зємли Алєксдндровой», как она названа в других местах означенного «Жития». Для более позднего источника это естественно, ибо еще 6 декабря I240 г. Киев был взят войском хана Батыя, сожжен и его население почти полностью уничтожено [39, стб. 470; 40, стб. 784-785; 50, с. 195-204], так что после этого он уже вряд ли мог восприниматься в общественном сознании как средоточие духовного величия, особенно когда предстоятель Русской Церкви, митрополит Киевский Кирилл II оставил его, переместив свою резиденцию во Владимир Суздальский (в 50-е гг. XIII в.) [28, с. I6-I7; I2, c. 54-55; 30, с. 237-264]. Вместе с тем само по себе сравнение «матери городов русских» с Иерусалимом (чем не косвенный датирующий признак?) позволяет думать, что содержащая такое сравнение вторая - «владимирская» - часть «Сказания о русской грамоте» появилась все-таки еще до киевского разорения. Объяснимо и умолчание в ней о Константинополе. Ибо как раз во время возникновения данного литературного факта Константинополь находился в составе так называемой Латинской империи (с I2O4 по I26І г.) [52, с. 323-393; I8, с. I5-28; 56] и, соответственно, утратил свое вселенское политическое и конфессиональное значение как цитадель православной государственности. Вероятно, инерция его восприятия таковым не сразу иссякла после возвращения к нему статуса византийской столицы, что и отразилось в «Житии Александра Невского».

Но даже без учета реальных внутренних и внешних жизненных обстоятельств очевидно, что оба интерпретируемых здесь случая решительной констатации тождества Руси Иерусалиму, святому месту, продолжают наметившуюся еще в период киевского культурно-политического процветания идеологическую тенденцию развития представления о Русской земле как воспреемнице духовного наследия Палестины. И бесспорно, это происходило не без влияния со стороны бытовавшей тогда в Европе со времени Константинопольского патриарха Фотия концепции translatio Hierosolymi [43, c. $9 \mathrm{I}-92,95]$.

К сожалению, в древнейших собственно русских литературных текстах нашлось только три примера использования соответствующего исторического уподобления, да и то выраженного весьма околично: 
I) в завершающей «Слово о Законе и Благодати» «Молитве Господу»:

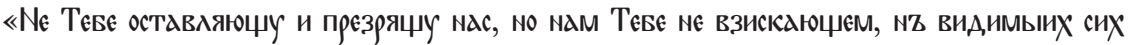

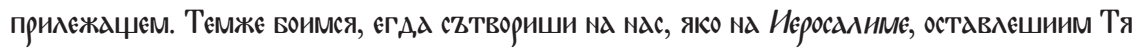
и не ХОАившиим в пути Твод» [4, С. 54];

2) в «Повести временных лет» под IOI5 г.: «Святополк жє оканмый, здый уви Святьслава 〈...〉 Помысли высокоумьем свонм, а не веды, яко “ААєт Бог влАсть, ємужє Хоџєт, поставляєт цесаря и князя Вышний, ємужє Хощєт, Адсть" 〈... Аџє во князи

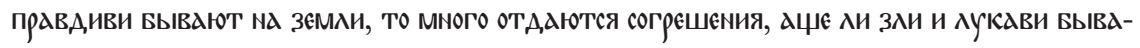

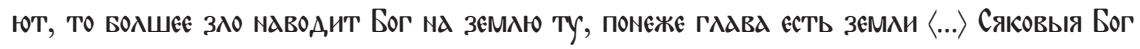

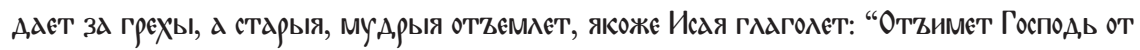
Ерусалима крепость и крепाкаго исполина 〈...〉 И поставьАю уношю князя им и ругателя ИМ, оБАадаюОџА ими". СвятополК жє оканны начА княжити в КЫевє» [4, С. I83-I84];

3) и там же под ІІІ3 г.: «В Аєто 6621. Бысть знаменье ВZ солнци в 1 час А,е

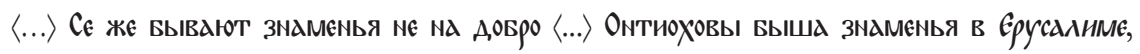

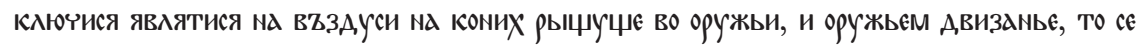

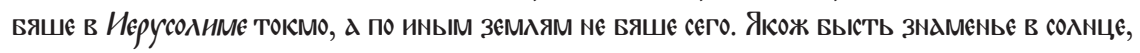
проявляше Святополчю смерть. По сем во приспе празникъ Пасуы, и празноваша, и по празнице разБолися князь. А преставися БАаговерный князь Михаил, зовемый Святополк» $[4$, c. 306].

Бесспорно, показателен еще рассказ Суздальской летописи о разорении

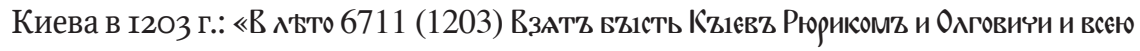

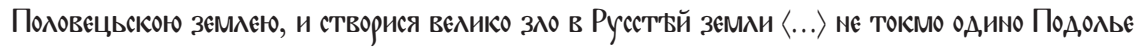

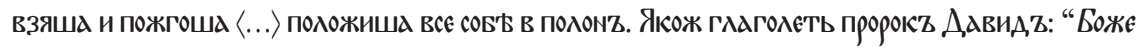

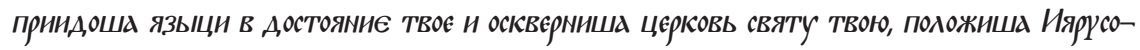

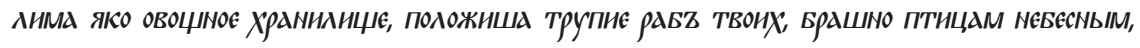

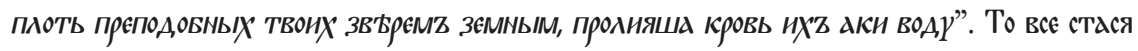
над, Киевом за грєХи нашА» [39, стб. 4I8-4I9] $]^{6}$. Но и это свидетельство основано лишь на соотнесении двух событий. Если оно и подразумевает преемственную связь недавнего с давно минувшим, то все-таки весьма прикровенно.

Таким образом, получается, что прямое словесное отождествление Киева, олицетворяющего Русь, с Иерусалимом было впервые предложено автором владимирской части «Сказания о русской грамоте» (на это, кстати, указывало и устроение Киева в плане и архитектуре до его уничтожения в 
I240 г. [25, c. I78]). Но уже вскоре другой древнерусский грамотник, составитель «Повести о житии Александра Невского», скорректировал данную аналогию, видимо, приняв во внимание конкретную историческую ситуацию и задав вместе с тем вектор для формирования новой идеологемы, - о восприятии духовного значения христианского Востока именно Русским Севером$^{7}$. Так, вслед за ним авторы ряда произведений XIV-XV вв. используют образ Иерусалима в своих размышлениях о событиях псково-новгородской, тверской, московской жизни. Во всяком случае, сходные по общему смыслу построения встречаются:

I) в «Сказании о Довмонте»: «И прославися имя князей наших во всех стрд-

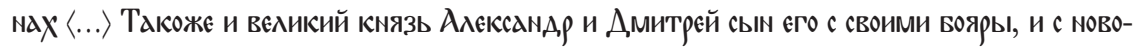

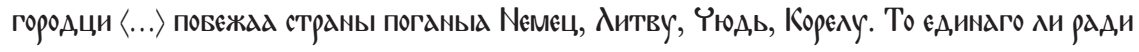
Eзекея съХранен Бысть Иерусалим от Паенениа Синахиримая, царя Асурска? Паки же и

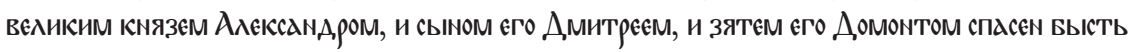
град, Ковгород, и Пеков от напад,ениа поганых немец» [6, с. 62];

2) в службе чудотворной иконе Богородицы «Знамение» стихира на стиховне І гласа: «Якожє древлє во Иерусалимє Зоровавєлєм, державндя Твоя десница

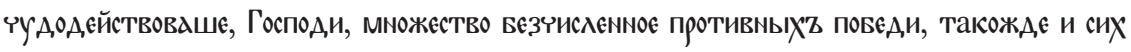
мизложи пришедших разорити град, [Новгород. - В. К.], єгожє искупих єси кровию Tвоен, Слове, да разуменот от Аєл, яко ты извавитель с нами єсн» [34, С. 405];

3) в «Житии Михаила Ярославича Тверского»: «И кмязившу єму [МиХаилу. - В. К.] Аєто в великом княжении, и седе ин царь, именем ОЗБяк. И виде БоГ

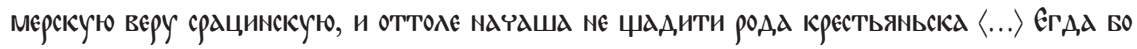
Господь Титу предасть Иерусалим, не Тита Аювя, но Иерусалим казня. И паки, егада Фоце преда ЦарьграА, не Фоцу лювя, но ЦарьграА, Казня за Аюодская прегрешения. ЄЖе и си нас деля Бысть за наша согрєшєния» [6, с. 72];

4) в «Сказании о Мамаевом побоище»: «Ослєплєну жє єму [Мамаю. -

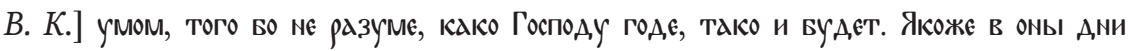
Иерусалим паенен высть Титом римскым и NавХоданасором, Царем вавилонскым за их

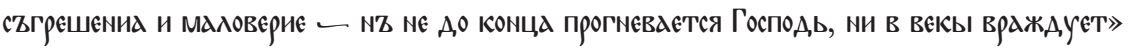
[6, c. I40];

7 Интересно, что в XVII в. идея преемства по отношению к Иерусалиму возрождается в юго-западной Руси. После восстановления киевской иерархии в I620 г. ее прилагали к Киеву в борьбе против унии иеромонах Захария Копыстенский, митрополит Иов Борецкий и другие малороссийские и белорусские мыслители [29, с. 419; 24, с. 207-209; І4]. 
5) в «Повести о Темир-Аксаке»: «Якожє Арєвлє при Єзикєихє цари и при Исаии

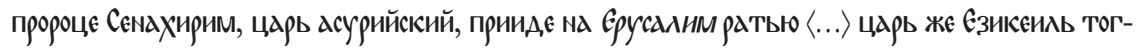

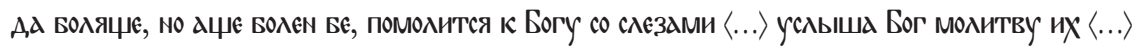

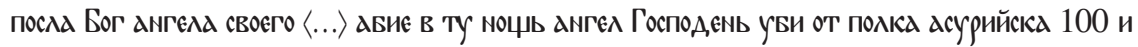
80 и 5 тысяе 〈... ЦАрь Же Асурнйский СенаХирим уБояся зело и устрашися, со остАночными

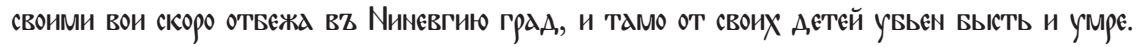
Якоже тогда при Сенахириме Было, тако и ныме при Темир Аксаце, єдин тот Же Бог тогда и

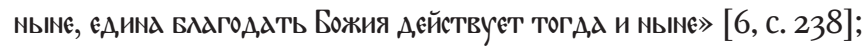

6) в «Слове похвальном» инока Фомы: «№ и ин храм устрои самому царно Христу на вратех Богом спасенаго града, Т фери. И нарекова же имя Храму тому еже "ВХод, въ Иеросалим". No тамо во вход, Господу нашему Иеусу Христу в град, Иерусалим, и от Аєтей еврейскЫХ велику почесть прини, но яко царем израилевЫМ зваХУ'Т ЕГО и "осанна в вышних" вопиахут єму, и понеже єщє мнози не веровахут в Кего, и сим жє и ризи свои

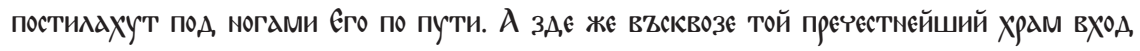
сотворен в вогоспасеный град Тферь» [7, с. 94];

7) в «Московской повести о походе Ивана III Васильевича на Новго-

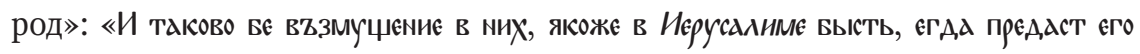
Господ,ь в руце Титовє; якоже Бо ти тоГда,, тако и сии меж севе БрАнь творяху» [7, С. 290].

8) в «Казанской истории»: «А сам (великий князь Ярослав Всеволодович После нашествия хана Батыя) живяшє во Градєє ПерєАслдвлє $\langle\ldots\rangle\rangle$ доколє овновля-

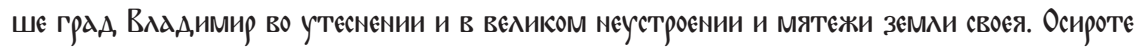

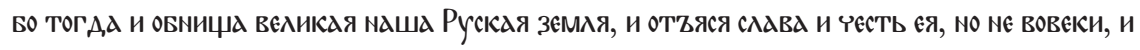

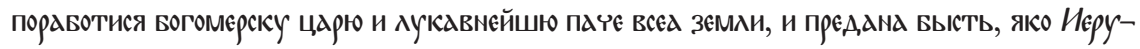
салим в наказание NавХодоносору, царю вавидонскому, яко да тем смирится» [8, с. 256].

Однако особенно показательна «Повесть о нашествии Тохтамыша», автор которой не только соотносит беду, постигшую Русь, с прошлым Иерусалима, но и буквально переделывает библейский текст (Пс. 78: I-3), заменив в нем упоминание Иерусалима указанием на Москву:

Многы монастыри и многы церкви разрушиша [воины Тохтамыша в Москве. B. К.], в святыХ церкваХ уБийство сдеяша, и в свяцанныХ олтареХ кровопролитие створиша

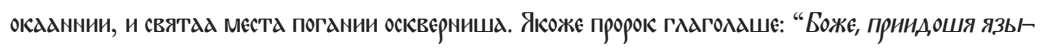

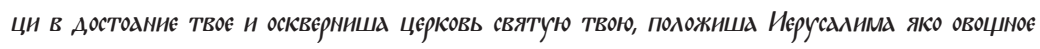

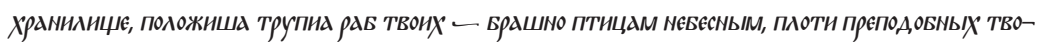

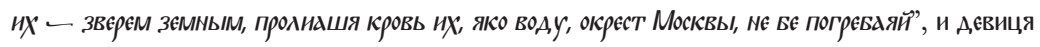




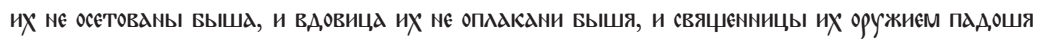
[6, c. 198$]$.

В источниках встречается, наконец, и уподобление Руси Святой земле. Например, один из списков службы князю Владимиру XVI в. содержит тро-

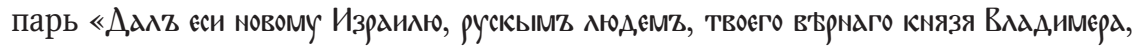
пастыря довляго и заступникА» ${ }^{8}$.

Вероятно, все указанные литературные факты умозрения тогдашних книжников прочно отложились в позднейшей народной памяти, переплавившись в твердую веру.

Так, в XVII в. автор апокрифической повести «Иерусалимская беседа» вкладывает в уста царя Давида толкование сна, который приснился царю Волоту Волотовичу: «...а что с тоє стороны восточныя луч восХОдит солнца красного, освє-

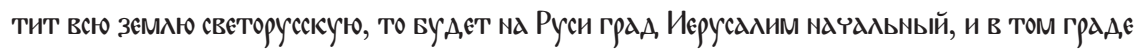
вудет соворная и апостольская церковь Софии премуа,рости Божия о семидеєяти верХаХ, сирєчь святая святых...»; далее Давид толкует другой вопрос Волота Волотовича: «...Я теве про то скажу. Первы град,ОМ мать — ГраА, Иерусалим; его пасхалия азБучная — во всю земхно свєторускую...» [3, с. 307, 308]. Фольклорная природа этого произведения обусловливает неопределенность: понятие Иерусалима распространяется здесь то ли на какой-то город, то ли на всю Россию. Но зато вполне определенен другой автор XVII в. В легендарной повести «О зачале Москвы и о князе Данииле Суздальскомъ» он тенденциозно переделывает текст предсказания святителя Петра относительно будущего Москвы в случае возведения в ней каменного Успенского собора, известный не только по «Житию Петра», но и в изложении Никоновской летописи и Степенной книги. Согласно новой версии, московский митрополит дает еще более ясное пророчество князю Ивану Калите:

\begin{tabular}{|c|c|c|}
\hline Житие Петра & Степенная книга & Повесть о зачале Москвы \\
\hline «...И сам Прославишися Паче & «...И ТеБЕ саМОГО ИМАТ БОГ БАА- & «...яко по Божию Благослове- \\
\hline инеХ князей, и сЫнове, и внУЦЫ & ГОСАОвИТИ И ПрОСААВИТИ ПАЧЕ & нию ВсемогуЧия и Живона- \\
\hline ТВои в РОАЫЫ и РОА,Ы; и ГРАА СеЙ & ИнЕХХZ КНЯЗЕЙ И РАСПрОСТТАНИТТ & чАльмыя Троицы и Пречистыя \\
\hline 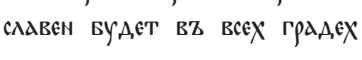 & ГРАА, СеЙ ПАчЕ ИнеХ ГРАА,ОВ; И ИМя & Eго БоГоматерИ И ЦерКвей \\
\hline
\end{tabular}

8 Цит. по статье В.В. Василика [9, с. 7І]. Любопытно, что в позднейшей богослужебной традиции этот тропарь почему-то не остался. 
NЕМ; и вЗЫАУ'Т РУКЫ ЕГО NА ПАЕщу враг єго; и прославится Бог в NeM...» [45, C. IO4].
NЕМ, И NЕ ОСКУАЕНТ АЕРЖАВНИИ ОТ сеМЕнИ ТВОеГО, ОБААААЯ И ЦАРствУя МестОМ сим В РОАЫЫ и рОАЫ и во веки и взыдУт РУки иХ на плєџю враг иХ...» [4I, с. 3I7].
СВяTЫХ БеЗЧИСАЕНПОЕ МнОЖествО И Napeчется сей ГраА вторый ИерУсААим и многим АержАвством oвsaAdét ne tokmo всен Россиен, но и во вся страны прославится...» $[17$, с. 36] .

Замечательный по обратному порядку исправления пример сохранен «Изложением Пасхалии» московского митрополита Зосимы. Естественно, первоначальной в тексте памятника является авторская формулировка: «И Божиєю волєюо сътвори [император Константин Великий. - В. К.] град в имя своє и нарече и град Констянтин, єже єсть ЦарьграА, и наречеся новый Иерусалим» [48, c. 59]. Такое чтение передается тремя самыми ранними списками «Изложения» - Солов. 858 (РНБ), Епарх. 8о (ГИМ), Синод. 7Із (ГИМ). Но в чуть более позднем списке Троицк. 46 (РГБ) - вместо «нарєчєся новый Иерусалим» читается уже корректива: «нарєчєся новым Римом». Но в таком случае последующий текст интерпретировался уже как утверждение преемственности Москвы не по отношению к Иерусалиму, а по отношению к Риму, в согласии с зарождавшейся тогда новой историософской концепцией: «И нымє в послєдмяя сид

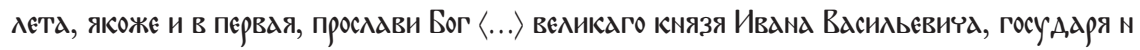
самодръжца всей Руси, новаго царя Константина, новому граду Константину — Москве и всей Русской земхи» [48, с. 6о].

Как видно, формирование в древнерусском обществе идеологического и, вероятно, религиозного убеждения в наследничестве Руси по отношению к Святой земле осуществлялось сообразно историческому ходу развития русской государственности и церковной жизни, при котором Москва, заместив собою Киев, постепенно стала не только политическим центром России, но и духовным. И не исключительно внутренним центром. Лишь однажды, в $\mathrm{XV}$ в., был сделан зигзаг в сторону старой идеологемы. Но он вполне оправдан, ибо сделан при составлении нового канона великому Киевскому князю Владимиру Святому. Вот как оценивает русский гимнограф возведение Владимиром Святославичем Десятинной церкви в Киеве, прикровенно соотнося его со Святой землей: «Аивный проречє Исайя на Иерусалим, вудет явє гора Господня

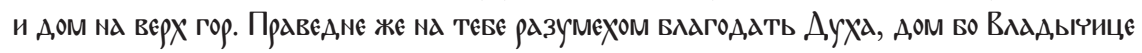


создал єси [Владимир. - В. К.] на вєрХ гор» (2 тропарь 5 песни) [33, л. 222 об.]. Что бы там ни было, но к началу XVI в. в русском обществе, очевидно, созрело ощущение вселенского значения Москвы пусть даже и в границах только православного мира. На ее политический вес фигуративно указывали литературные легенды о наследовании московскими государями царского достоинства. Духовный же ее авторитет имплицировался преданиями о восприятии Русской Церковью святынь палестино-византийско-римского происхождения и чередой ретроспективных аналогий и сопоставлений, способствовавших осмыслению русскими писателями событий русской истории. При этом произошло разделение, по которому Рим как символ имперской власти на земле ассоциировался в представлении людей со сферой государственной политики, а Иерусалим как символ царства Божия - со сферой церковно-религиозной жизни [47, с. 426 (сноска 8); 42]. Кстати, апофеозным рефлексом осознания русским обществом духовной значимости России в мире (прежде всего, христианском) стало, несомненно, архитектурное оформление Москвы в XVI в. не только по подобию Рима [25, с. I73-I75, І90, I95, 228], но и по подобию Иерусалима [25, с. I86, I98-I99, 20I-202, 204, 206, 228; 35, с. I67-I70; 26 , с. I72, I73, 228]. В этом, несомненно, была несокрушимая историко-политическая и историко-конфессиональная логика: Константинополь, будучи наследником Рима, способствовал возвышению Киева, столичное величие которого было воспринято Москвой, а все вместе они, как цитадели земной власти, духовно обращаясь к прошлому или же к будущему, равнялись на альфу и омегу христианства - Иерусалим, град земной и град небесный. 


\section{Список литературы}

I Бауэр Е.А. Идея «Москва - третий Рим» в русской общественной мысли конца $\mathrm{XV}$ - начала XVII вв.: отечественная историография XX столетия: Монография. Нижневартовск: Изд-во Нижневарт. гуманит. ун-та, 20II. I27 с.

2 Бегунов Ю.К. Памятник русской литературы XIII века «Слово о погибели Русской земли». М.; Л.: Наука, І965. 23І с.

3 Беседа Иерусалимская: Повесть града Иерусалима // Памятники старинной русской литературы, издаваемые гр. Григорием Кушелевым-Безбородко под ред. Н. Костомарова: Сказания, легенды, повести, сказки и притчи. СПб., г86о. Вып. второй. С. 307-3Іі.

4 Библиотека литературы Древней Руси / РАН. ИРЛИ; под ред. Д.С. Лихачева, Л.А. Дмитриева, А.А. Алексеева, Н.В. Понырко. СПб.: Наука, І997. Т. г: XI-XII века. 543 с.

5 Библиотека литературы Древней Руси / РАН, ИРЛИ; под ред. Д.С. Лихачева, Л.А. Дмитриева, А.А. Алексеева, Н.В. Понырко. СПб.: Наука, І997. Т. 5: XIII век. $527 \mathrm{c}$.

6 Библиотека литературы Древней Руси / РАН, ИРЛИ; под ред. Д.С. Лихачева, Л.А. Дмитриева, А.А. Алексеева, Н.В. Понырко. СПб.: Наука, г999. Т. 6: XIV - середина XV века. 583 с.

7 Библиотека литературы Древней Руси / РАН, ИРЛИ; под ред. Д.С. Лихачева, Л.А. Дмитриева, А.А. Алексеева, Н.В. Понырко. СПб.: Наука, І999. Т. 7: Вторая половина XV века. 58I с.

8 Библиотека литературы Древней Руси / РАН, ИРЛИ; под ред. Д.С. Лихачева, Л.А. Дмитриева, А.А. Алексеева, Н.В. Понырко. СПб.: Наука, 20оо. Т. го: XVI век. 6I8 c.

9 Василик В.В. Служба св. равноапостольному князю Владимиру и Кирилло-Мефодиевская традиция // Studia Slavica et Balcanica Petropolitana. СПб., 20I3. № 2: июль - декабрь. С. 67-77.

Васильев В. Канонизация русских святых // Чтения в Императорском Обществе Истории и Древностей Российских при Московском Университете. І893 год. Книга третья. М.: Университетская тип., І893. С. I-256. Голубинский Е.Е. История канонизации святых в Русской Церкви. М.: Императорское Общество Истории и Древностей Российских при Московском Университете, I903. $606 \mathrm{c.}$

Голубинский Е.Е. История Русской Церкви. М.: Крутицкое патриаршее подворье, Общество любителей церковной истории, I997. XXIV c. + 968 с. T. II: Период второй, Московский, от нашествия монголов до митрополита Макария включительно. Первая половина тома.

I3 Гребенюк В.П. Икона Владимирской Богоматери и духовное наследие Москвы. М.: Биоинформсервис, I997. 21о с. 
Демчук Р.В. Киев - второй Иерусалим // Россия и христианский Восток: история, наука, культура. [Б. г.] URL: http://ros-vos.net/holy-land/vos-ros/2/I/ (дата обращения: 25.08.2017).

Дмитриева Р.П. Сказание о князьях Владимирских. М.; Л.: Изд-во АН СССР, I955. 465 C.

Живов B.M. Slavia Christiana и историко-культурный контекст Сказания о русской грамоте // Живов В.M. Разыскания в области истории и предыстории русской культуры. М.: Языки славянской культуры, 2002. С. ІІ6-І57.

Забелин И. История города Москвы. Ч. г. М.: Типо-литография Тов-ва И.Н. Кушнерев и Ко, I905. XXVI, 652 c.

Каждан А.П. Латинская империя // История Византии / отв. ред. Г.Г. Литаврин. М.: Наука, 1967. Т. 3. С. $15-28$.

Кириллин В.М. «Повесть о новгородском белом клобуке»: время происхождения и соотношение первых редакций // Герменевтика древнерусской литературы. Вып. ІІ / О-во исследователей Древней Руси; отв. ред. М.Ю. Люстров. М.: Языки славянской культуры; Прогресс-традиция, 2004. С. 393-437.

Кириллин В.М. Оценки Владимира Святославича посредством исторических аналогий в ранних русских гомилиях // Древняя Русь: Вопросы медиевистики. М., 20І6. № 2 (64). Июнь. С. 90-98.

I Кириллин В.М. Сказание о Тихвинской иконе Богоматери «Одигитрия». Литературная история памятника до XVII века. Его содержательная специфика в связи с культурой эпохи. Тексты. М.: Языки славянских культур, 2007.307 с. Кириллов И. Третий Рим: Очерк исторического развития идеи русского мессионизма. М.: Тов-во Типо-Литогр. И.М. Машистова, І9І4. 100 с. Конявская Е.Л. Александр Невский в исторических источниках. 2. Житийная литература // Александр Невский. Государь, дипломат, воин. М.: Р. Валент, 20 оо. C. 209-2I8.

Кралюк П. Становлення та розвиток теорії «Київ - другий Єрусалим» // Християнство і духовність. Зб. матеріалів другої міжнародної наукової конференції циклу наукових конференцій «християнство: історія і сучасність». К.: Знання, I998. C. 207-209.

Кудрявщев М.П. Москва - третий Рим: Историко-градостроительное исследование. М.: Сол Систем, 1994. 257 с.

Ларионов В.Е., Городова М.Н. Священное наследие. М.: Алгоритм, 201о. 576 с. Лурье С.[B]. Imperium (Империя - ценностный и этнопсихологический подход). М.: АИРО-XXI, 2OI2. $272 \mathrm{c}$.

28 Макарий (Булгаков), митр. Московский и Коломенский. История Русской Церкви. М.: Изд-во Спасо-Преображенского Валаамского монастыря, І995. Кн. 3. 704 с. Макарий (Булгаков). История Русской Церкви. М.: Изд-во Спасо-Преображенского Валаамского монастыря, 1996. Кн. 6. 832 с. 
Макарий (Веретенников), архим. Митрополиты Древней Руси (X-XVI века).

М.: Изд-во Сретенского монастыря, 2016. г256 с.

Малышевский Н.И. Когда и где впервые установлено празднование памяти св.

Владимира І5-го июля? // Труды Киевской духовной академии. Киев, І882. № I.

С. $45^{-69 .}$

32 Милютенко Н.И. Святой равноапостольный князь Владимир и крещение Руси: Древнейшие письменные источники. СПб.: Изд-во Олега Абышко, 2008. 578 с.

33 Минея служебная: Июль. М.: Печатный двор, г629. 460 л.

34 Минея: Ноябрь. Ч. 2. М.: Издательский Совет Русской Православной Церкви, 2002. $576 \mathrm{c}$.

35 Мокеев Г.А. О градостроительном символе «Москва - второй Иерусалим» // Богословские труды. М., г999. Вып. 35. С. І67-г70.

36 Новгородская первая летопись старшего извода / под ред. и с предисл. А.Н. Насонова. М.; Л.: Изд-во АН СССР, І950. 642 с.

37 Охотникова В.И. Повесть о житии Александра Невского // Словарь книжников икнижности Древней Руси. Л.: Наука, I987. Вып. I (XI - первая половина XIV в.). С. 354-363.

38 Поппэ А. Владимир Святой: У истоков церковного прославления // Факты и знаки: Исследования по семиотике истории. М.: Языки славянских культур, 2008. Вып. І. С. 60-го7.

39 Полное собрание русских летописей. Л., г927. Т. г: Лаврентьевская летопись. Вып. 2: Суздальская летопись по Лаврентевскому списку. Изд. 2-е. 488 с.

40 Полное собрание русских летописей. СПб.: Тип. М.А. Александрова, I908. T. 2: Ипатьевская летопись. XVI, 938, L, [I4] с.

4I Полное собрание русских летописей. СПб., І908. Т. 2I, ч. г: Книга степенная царского родословия. Первая половина. 342 с.

42 Ранчин A.M. Теория «Москва - Третий Рим» и ее место в русской культуре XVIXVIII вв. // Образовательный портал «Слово». Филология. [Б. г.] URL: http:// www.portal-slovo.ru/philology/44938.php (дата обращения: 27.08.20I7).

43 Ричка В.M. «Київ - Другий Єрусалим» (з історії політичної думки та ідеології середньовічної Русі). К.: Інститут історії України НАН України, 2005. 243 с.

44 Розов Н.Н. Древнейший памятник русской литературы в издании и интерпретации современного немецкого ученого // Известия Отделения литературы и языка АН CCCP. М., I963. № 5. С. 439-445.

45 Седова Р.А. Святитель Петр митрополит Московский в литературе и искусстве Древней Руси. М.: Русский мир, І993. 423 с.

46 Синицына Н.В. Третий Рим: Истоки и эволюция русской средневековой концепции (XV-XVI вв.). М.: Индрик, І998. 4І6 с.

47 Стремоухов Д. Москва - третий Рим: источники доктрины // Из истории русской культуры. М.: Языки славянской культуры, 2002. Т. II, кн. І: Киевская и Московская Русь / сост. А.Ф. Литвина, Ф.Б. Успенский. С. 425-44I. 
48 Тихонюк И.А. «Изложение Пасхалии» Московского митрополита Зосимы // Исследования по источниковедению истории СССР XIII - XVIII вв.

М.: Ин-т истории СССР, І986. С. 46-6I.

49 Толковая Библия, или комментарий на все книги Ветхого и Нового Завета / изд. преемников А.П. Лопухина. СПб., г9го. Т. 7: Даниил и Малые пророки. 445 с.

50 Толочко П.П. Древний Киев. Киев: Наукова думка, І976. 208 с.

5I Успенский Б.А. Когда был канонизирован князь Владимир Святославич? // Усnенский Б.А. Историко-филологические очерки. М.: Языки славянской культуры, 2004. С. 69-І22.

52 Успенский Ф.И. История Византийской империи. М.: Мысль, І997. 829 с.

53 Федотов Г.П. Канонизация святого Владимира // Владимирский сборник. В память 95о-летия Крещения Руси. 988-г938. Белград, г938. С. І88-г96.

54 Шамбинаго С.К. Повести о начале Москвы // Труды Отдела древнерусской литературы / Академия наук СССР. Институт литературы; ред. А.С. Орлов. М.; Л.: Изд-во Академии наук СССР, І936. Т. 3. С. 59-98.

55 Шахматов А.А. Жития князя Владимира. Текстологическое исследование древнерусских источников XI-XVI вв. / подгот. текста, предисл., вступ. статья Н.И. Милютенко; отв. ред. Д.М. Буланин. СПб.: Дмитрий Буланин, 20I4. 380 с.

56 Miller D.A. Imperial Constantinople. NY.: John Wiley, I969. 226 p.

57 Toumanoff Cyril. Moscow the Third Rome: Genesis and Significance of a Politico-Religious // The Catholic Historical Review. Vol. 40. No. 4 (Jan.). Washington, I955. P. 4II-447. 


\section{References}

Bauer E.A. Ideia "Moskva - tretii Rim" v russkoi obshchestvennoi mysli kontsa $X V$ - nachala XVII vv.: otechestvennaia istoriografiia XX stoletiia: Monografiia [The concept "Moscow as the third Rome" in the Russian public thought at the end of the $15^{\text {th }}$ - beginning of $\mathrm{I} 7^{\text {th }}$ centuries: $2 \mathrm{O}^{\text {th }}$ century historiography. A monograph]. Nizhnevartovsk, Izd-vo Nizhnevart. gumanit. un-ta Publ., 20II. I27 p. (In Russ.) Begunov Iu.K. Pamiatnik russkoi literatury XIII veka "Slovo o pogibeli Russkoi zemli" [The manuscript of the $\mathrm{I} 8^{\text {th }}$ century Russian literature "The Word about the death of Russian land”]. Moscow; Leningrad, Nauka Publ., I965. 23I p. (In Russ.) Beseda Ierusalimskaia: Povest' grada Ierusalima [Conversation in Jerusalem: A story of the city of Jerusalem]. Pamiatniki starinnoi russkoi literatury, izdavaemye gr. Grigoriem Kushelevym Bezborodko pod red. N. Kostomarova: Skazaniia, legendy, povesti, skazki i pritchi [Manuscripts of Old Russian literature, published by Grigory KushelevBezborodko under the edition of N. Kostomarov: Stories, legends, stories, fairy-tales and parables]. St. Petersburg, I86o, issue 2, pp. 307-3II. (In Russ.) Biblioteka literatury Drevnei Rusi [The library of the Old Russian literature], IWL RAS; eds. D.S. Likhachev, L.A. Dmitriev, A.A. Alekseev, N.V. Ponyrko. St. Petersburg, Nauka Publ., I997. Vol. I: $\mathrm{II}^{\text {th }}-\mathrm{I}^{\text {th }}$ centuries. 543 p. (In Russ.)

5 Biblioteka literatury Drevnei Rusi [The library of the Old Russian literature], IWL RAS; eds. D.S. Likhachea, L.A. Dmitriev, A.A. Alekseev, N.V. Ponyrko. St. Petersburg, Nauka Publ., I997. Vol. 5: $8^{\text {th }}$ century. 527 p. (In Russ.)

6 Biblioteka literatury Drevnei Rusi [The library of the Old Russian literature], IWL RAS; eds. D.S. Likhachev, L.A. Dmitriev, A.A. Alekseev, N.V. Ponyrko. St. Petersburg, Nauka Publ., I999. Vol. 6: $14^{\text {th }}-$ mid-I $5^{\text {th }}$ centuries. 583 p. (In Russ.) Biblioteka literatury Drevnei Rusi [The library of the Old Russian literature], IWL RAS; eds. D.S. Likhachev, L.A. Dmitriev, A.A. Alekseev, N.V. Ponyrko. St. Petersburg, Nauka Publ., I999. Vol. 7: the second half of the $5^{\text {th }}$ century. 58I p. (In Russ.) Biblioteka literatury Drevnei Rusi [The library of the Old Russian literature], IWL RAS; eds. D.S. Likhachev, L.A. Dmitriev, A.A. Alekseev, N.V. Ponyrko. St. Petersburg, Nauka Publ., 2000. Vol. IO: I6 ${ }^{\text {th }}$ century. 6I8 p. (In Russ.) Vasilik V.V. Sluzhba sv. ravnoapostol'nomu kniaziu Vladimiru i Kirillo Mefodievskaia traditsiia [Church service to St. Vladimir and Cyril-Methodius tradition]. Studia Slavica et Balcanica Petropolitana. St. Petersburg, 20I3, no 2: July-December, pp. 67-77. (In Russ.) $v$ Imperatorskom Obshchestve Istorii i Drevnostei Rossiiskikh pri Moskovskom Universitete. I893 god. Kniga tret'ia [Readings in the Imperial Society of History and Antics at the Moscow University]. Moscow, Universitetskaia tipografiia Publ., I893, pp. I-256. (In Russ.) 
Golubinskii E.E. Istoriia kanonizatsii sviatykh $v$ Russkoi Tserkvi [The history canonization in the Russian church]. Moscow, Imperatorskoe Obshchestvo Istorii i Drevnostei Rossiiskikh pri Moskovskom Universitete Publ., I903. 606 p. (In Russ.) Golubinskii E.E. Istoriia Russkoi Tserkvi [The history of the Russian church]. Moscow, Krutitskoe patriarshee podvor'e, Obshchestvo liubitelei tserkovnoi istorii Publ., I997. Vol. II: Period vtoroi, Moskovskii, ot nashestviia mongolov do mitropolita Makariia vkliuchitel'no. Pervaia polovina toma [The second, Moscow period, from the Mongol invasion to the Metropolitan Makary inclusively. The first half]. XXIV p. +968 p. (In Russ.) Grebeniuk V.P. Ikona Vladimirskoi Bogomateri i dukhovnoe nasledie Moskvy [The icon of Our Lady of Vladimir and Moscow spiritual heritage]. Moscow, Bioinformservis Publ., I997. 2IO p. (In Russ.)

4 Demchuk R.V. Kiev - vtoroi Ierusalim [Kiev as the second Jerusalem]. Rossiia $i$ khristianskii Vostok: istoriia, nauka, kul'tura [Russian and Christian Orient: history, science, and culture]. B. g. Available at: http://ros-vos.net/holy-land/vos-ros/2/I/ (Accessed 25 August 20I7). (In Russ.)

Dmitrieva R.P. Skazanie o kniaz'iakh Vladimirskikh [The story of Prince Vladimir]. Moscow; Leningrad, Izd-vo AN SSSR Publ., I955. 465 p. (In Russ.) Zhivov V.M. Slavia Christiana i istoriko kul'turnyi kontekst Skazaniia o russkoi gramote [The glory of a Christian and the cultural context of the Story of the Russian literacy]. Zhivov V.M. Razyskaniia v oblasti istorii i predystorii russkoi kul'tury [Studies in the historical background of Russian culture]. Moscow, Iazyki slavianskoi kul'tury Publ., 2002, pp. II6-I57. (In Russ.)

7 Zabelin I. Istoriia goroda Moskvy [The history of Moscow city]. Moscow, Tipo litografiia Tov-va I.N. Kushnerev i Ko Publ., I905. Part I. XXVI, 652 p. (In Russ.) Kazhdan A.P. Latinskaia imperiia [Latin empire]. Istoriia Vizantii [History of Bizantium], ed. G.G. Litavrin. Moscow, Nauka Publ., I967, vol. 3, pp. I5-28. (In Russ.)

Kirillin V.M. "Povest' o novgorodskom belom klobuke": vremia proiskhozhdeniia i sootnoshenie pervykh redaktsii ["The story of the Novgorod white hood": the time of writing and juxtaposing of the first editions]. Germenevtika drevnerusskoi literatury. Issue II [Hermeneutics of the Old Russian literature], ed. M.Iu. Liustrov. Moscow, Iazyki slavianskoi kul'tury; Progress traditsiia Publ., 2004, pp. 393-437. (In Russ.) Kirillin V.M. Otsenki Vladimira Sviatoslavicha posredstvom istoricheskikh analogii v rannikh russkikh gomiliiakh [Evaluations of Vladimir Svyatoslavovitch through historical analogies in early Russian gomilias]. Drevniaia Rus': Voprosy medievistiki [Old Rus': Medieval issues]. Moscow, 2016, no 2 (64), pp. 90-98. (In Russ.) Kirillin V.M. Skazanie o Tikhvinskoi ikone Bogomateri “Odigitriia”. Literaturnaia istoriia pamiatnika do XVII veka. Ego soderzhatel'naia spetsifika v sviazi s kul'turoi epokhi. Teksty [Narrative about Tikhvin icon of Our Lady “Odigidriya”. Literary history of the $I 7^{\text {th }}$ century artifact. Its specificity in the contextual framework. Texts]. Moscow, Iazyki slavianskikh kul'tur Publ., 2007.307 p. (In Russ.) 
Kirillov I. Tretii Rim: Ocherk istoricheskogo razvitiia idei russkogo messionizma [The third Rome: a survey of the historical development of the Russian messianism concept]. Moscow, Tov-vo Tipo-Litogr. I.M. Mashistova Publ., I9I4. Ioo p. (In Russ.) Koniavskaia E.L. Aleksandr Nevskii v istoricheskikh istochnikakh. 2. Zhitiinaia literatura [Biography literature]. Aleksandr Nevskii. Gosudar', diplomat, voin [Alexander Nevsky. Sovereign, diplomat, warrior]. Moscow, R. Valent Publ., 20IO, pp. 209-2I8. (In Russ.)

24 Kraliuk P. Stanovlennia ta rozvitok teoriï "Kiïv - drugii Erusalim” [The rise and development of the theory "Kiev as second Jerusalem"]. Khristiianstvo i dukhovnist'. Zb. materialiv drugoï mizhnarodnoï naukovoï konferentsii tsiklu naukovikh konferentsii "khristiianstvo: istoriia i suchasnist”" [Christianity and spirituality. Proceedings of the conference "Christianity: history and modern time" (the title of the series of conferences)]. Kiev, Znannia Publ., I998, pp. 207-209. (In Ukrainian) Kudriavtsev M.P. Moskva - tretii Rim: Istoriko gradostroitel'noe issledovanie [Moscow as the Third Rome: a study in history and architecture]. Moscow, Sol Sistem Publ., I994. 257 p. (In Russ.)

26 Larionov V.E., Gorodova M.N. Sviashchennoe nasledie [Sacred heritage]. Moscow, Algoritm Publ., 20IO. 576 p. (In Russ.)

27 Lur'e S.[V]. Imperium (Imperiia - tsennostnyi i etnopsikhologicheskii podkhod) [Imperium (Empire: values and ethno-psychological approach]. Moscow, AIRO XXI Publ., 20I2. 272 p. (In Russ.)

28 Makarii (Bulgakov), mitr. Moskovskii i Kolomenskii. Istoriia Russkoi Tserkvi [History of the Russian Church]. Moscow, Izd-vo Spaso-Preobrazhenskogo Valaamskogo monastyria Publ., I995. Book 3. 704 p. (In Russ.)

29 Makarii (Bulgakov). Istoriia Russkoi Tserkvi [History of the Russian Church]. Moscow, Izd-vo Spaso-Preobrazhenskogo Valaamskogo monastyria Publ., I996. Book 6. 832 p. (In Russ.)

30 Makarii (Veretennikov), arkhim. Mitropolity Drevnei Rusi (X-XVI veka) [Mitropolitans of the Old Rus' ( $\mathrm{IO}^{\text {th }}-\mathrm{I} 6^{\text {th }}$ centuries)]. Moscow, Izd-vo Sretenskogo monastyria Publ., 20I6. 256 p. (In Russ.)

3I Malyshevskii N.I. Kogda i gde vpervye ustanovleno prazdnovanie pamiati sv. Vladimira I5-go iiulia? [When and where the memory day of St. Vladimir was appointed on the $5^{\text {th }}$ of July?]. Trudy Kievskoi dukhovnoi akademii [The works of Kiev theological academy]. Kiev, I882, no I, pp. 45-69. (In Russ.)

32 Miliutenko N.I. Sviatoi ravnoapostol'nyi kniaz' Vladimir i kreshchenie Rusi: Drevneishie pis'mennye istochniki [St. Vladimir and the baptism of Rus': The oldest written sources]. St. Petersburg, Izd-vo Olega Abyshko Publ., 2008. 578 p. (In Russ.)

33 Mineia sluzhebnaia: Iiul' [Minaion: July]. Moscow, Pechatnyi dvor Publ., I629. 460 p. (In Russ.)

34 Mineia: Noiabr' [Minaion: November]. Moscow, Izdatel'skii Sovet Russkoi Pravoslavnoi Tserkvi Publ., 2002. Part 2. 576 p. (In Russ.) 
Mokeev G.A. O gradostroitel'nom simvole "Moskva - vtoroi Ierusalim"

[On the architectural symbol "Moscow as the second Jerusalem”]. Bogoslovskie Trudy [Theological works]. Moscow, I999, issue 35, pp. I67-I70. (In Russ.) Novgorodskaia pervaia letopis' starshego izvoda [First Novgorod manuscript of the senior canon], ed. and intro. A.N. Nasonov. Moscow; Leningrad, Izd-vo AN SSSR, I950. 642 p. (In Russ.)

Okhotnikova V.I. Povest' o zhitii Aleksandra Nevskogo [The narrative of the life of Alexander Nevsky]. Slovar' knizhnikov i knizhnosti Drevnei Rusi [The dictionary of scribes and book culture]. Leningrad, Nauka Publ., I987, issue I (XI - pervaia polovina XIV v. [Issue $\mathrm{I}$ : $\mathrm{II}^{\text {th }}$-first half of the $\mathrm{I}^{\text {th }}$ centuries]), pp. 354-363. (In Russ.)

38 Poppe A. Vladimir Sviatoi: U istokov tserkovnogo proslavleniia [St. Vladimir: At the origins of church canonization]. Fakty $i$ znaki: Issledovaniia po semiotike istorii [Facts and signs: The study in the history semiotics]. Moscow, Iazyki slavianskikh kul'tur Publ., 2008, issue I, pp. 60-IO7. (In Russ.)

39 Polnoe sobranie russkikh letopisei [Complete collection of Russian manuscripts]. Izd. 2-e. Leningrad, I927. Vol. I: Lavrent'evskaia letopis' [Lavrent'evskaya manuscript]. Issue 2: Suzdal'skaia letopis' po Lavrentevskomu spisku [Suzdal manuscript according to Lavrent'evsky list]. 488 p. (In Russ.) Polnoe sobranie russkikh letopisei [Complete collection of Russian manuscripts]. St. Petersburg, Tip. M.A. Aleksandrova Publ., I908. Vol. 2: Ipat'evskaia letopis' [Ipat'evskaya manuscript]. XVI, 938, L, [I4] p. (In Russ.)

4I Polnoe sobranie russkikh letopisei [Complete collection of Russian manuscripts]. St. Petersburg, I908. Vol. 2I, ch. I: Kniga stepennaia tsarskogo rodosloviia. Pervaia polovina [A book of tzar geneology. First half]. 342 p. (In Russ.) Ranchin A.M. Teoriia "Moskva - Tretii Rim" i ee mesto v russkoi kul'ture XVI-XVIII vv. [The theory "Moscow as the third Rome" and its place in the Russian culture of the $\mathrm{I} 6^{\text {th }}-\mathrm{I} 8^{\text {th }}$ centuries]. Obrazovatel'nyi portal "Slovo". Filologiia [Educational portal "Word." Philology.]. B. g. Available at: http://www.portal-slovo.ru/ philology/44938.php (Accessed 27 August 2017). (In Russ.)

43 Richka V.M. "Kïv - Drugii Erusalim" ( $z$ istoriï politichnoï dumki ta ideologii seredn'ovichnoï Rusi) [Kiev as the second Jerusalem (from the history of political thought and ideology of Medieval Rus')]. Kiev, Institut istoriï Ukraïni NAN Ukraïni Publ., 2005. 243 p. (In Ukrainian)

Rozov N.N. Drevneishii pamiatnik russkoi literatury v izdanii i interpretatsii sovremennogo nemetskogo uchenogo [Old Russian literary text and its edition and interpretation by a contemporary German scholar]. Izvestiia Otdeleniia literatury $i$ iazyka AN SSSR. Moscow, 1963, no 5, pp. 439-445. (In Russ.)

Sedova R.A. Sviatitel' Petr mitropolit Moskovskii v literature i iskusstve Drevnei Rusi [St. Peter, Moscow metropolitan, in Old Russian literature and art]. Moscow, Russkii mir Publ., I993. 423 p. (In Russ.) 
46 Sinitsyna N.V. Tretii Rim: Istoki i evoliutsiia russkoi srednevekovoi kontseptsii $(X V-X V I v v$.) [The third Rome: sources and evolution of Russian medieval concept]. Moscow, Indrik Publ., I998. 4I6 p. (in Russ.)

47 Stremoukhov D. Moskva - tretii Rim: istochniki doktriny [Moscow as the third Rome: sources of the concept]. Iz istorii russkoi kul'tury. T. II. Kn. I. Kievskaia i Moskovskaia Rus' [From the history of Russian culture: vol. 2, book I. Kiev and Moscow Rus'], ed. A.F. Litvina, F.B. Uspenskii. Moscow, Iazyki slavianskoi kul'tury Publ., 2002, pp. 425-44I. (In Russ.)

48 Tikhoniuk I.A. "Izlozhenie Paskhalii” Moskovskogo mitropolita Zosimy [“The narration of Paschalia” by Moscow metropolitan Zosima]. Issledovaniia po istochnikovedeniiu istorii SSSR XIII-XVIII $v$. [Studies in the source history of the USSR:

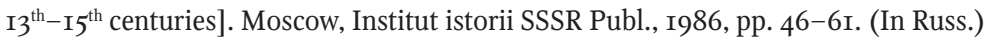

49 Tolkovaia Bibliia, ili kommentarii na vse knigi Vetkhogo $i$ Novogo Zaveta [The commentated Bible, or comments on all of the Old Testament books], ed. by A.P. Lopukhin successors. St. Petersburg, I9Io. Vol. 7: Daniil i Malye proroki [Daniel and minor prophets]. 445 p. (In Russ.)

50 Tolochko P.P. Drevnii Kiev [Old Kiev]. Kiev, Naukova dumka Publ., I976. 208 p. (In Russ.)

5I Uspenskii B.A. Kogda byl kanonizirovan kniaz' Vladimir Sviatoslavich? [When Vladimir Svyatoslavovitch was canonized?]. Uspenskii B.A. Istoriko filologicheskie ocherki [Historical and philological essays]. Moscow, Iazyki slavianskoi kul'tury Publ., 2004, pp. 69-I22. (In Russ.)

52 Uspenskii F.I. Istoriia Vizantiiskoi imperii [History of Byzantium empire]. Moscow, Mysl' Publ., I997. 829 p. (In Russ.)

53 Fedotov G.P. Kanonizatsiia sviatogo Vladimira [Canonization of St. Vladimir]. Vladimirskii sbornik. V pamiat' 950-letiia Kreshcheniia Rusi. 988-I938 [Vladimirsky volume. In memory of the 950 anniversary of baptism in Rus']. Belgrad, I938, pp. I88-I96. (In Russ.)

54 Shambinago S.K. Povesti o nachale Moskvy [Essays on the origins of Moscow]. Trudy Otdela drevnerusskoi literatury [Studies of the Old Russian literature department], Academy of sciences of the USSR. Institute of literature; ed. A.S. Orlov. Moscow; Leningrad, Izd-vo Akademii nauk SSSR Publ., I936, vol. 3, pp. 59-98. (in Russ.) Shakhmatov A.A. Zhitiia kniazia Vladimira. Tekstologicheskoe issledovanie drevnerusskikh istochnikov XI-XVI vv. [Biographies of Prince Vladimir. Textological study of the Old Russian sources, $\mathrm{II}^{\text {th }}-\mathrm{I}_{4}{ }^{\text {th }}$ centuries] $/$ ed. and intro. by N.I. Miliutenko; ed. D.M. Bulanin. St. Petersburg, Dmitrii Bulanin Publ., 20I4. 380 p. (In Russ.)

56 Miller D.A. Imperial Constantinople. NY, John Wiley, I969. 226 p. (In English)

57 Toumanoff Cyril. Moscow the Third Rome: Genesis and Significance of a PoliticoReligious. The Catholic Historical Review, vol. 40, no 4 (Jan.), Washington, 1955, pp. 411-447. (In English) 
УДК 82І.І6І.І.о

ББК $83.3(2 \mathrm{Poc}=\mathrm{Pyc}) 6$
МУЗЫКАЛЬНОЕ МИРООЩУЩЕНИЕ

В РОМАНЕ А.Ф. ЛОСЕВА

«ЖЕНЩИНА-МЫСЛИТЕЛЬ»

(c) 2018 г. Дж. Римонди

Пармский Государственный Университет,

Парма, Италия

Институт мировой литературы

им. А.М. Горького Российской академии наук, Москва, Россия

Дата поступления статьи: 27 июня 2017 г. Дата публикации: 25 марта 2018 г.

DOI: I0.22455/2500-4247-20I8-3-I-I4O-I53

Аннотация: В статье рассматривается роль музыки в контексте художественной прозы А.Ф. Лосева I930-х и І940-х гг. Основные идеи его философии музыки представлены путем анализа отношений между писателем и философом. Особое внимание уделяется выражению философских идей в романе «Женщина-мыслитель», в котором противопоставление рассудочной мысли и антиномическо-жизненного знания проявляется в форме дуализма «музыкального» и «немузыкального», как два способа отношения к сущности. В романе определение специфики музыкального мироощущения получает художественное воплощение в трагической судьбе пианистки Радиной, в образе которой раскрываются глубокие размышления о смысле жизни и о духовном состоянии современности.

Ключевые слова: философская проза А.Ф. Лосева, музыкальный миф, музыкальное мироощущение, «Женщина-мыслитель», автобиографизм, философия музыки.

Информация об авторе: Джорджия Римонди - PhD, Пармский Государственный Университет, Via Università, I2, 43I2I Parma PR, Италия, аспирант, Институт мировой литературы им. А.М. Горького Российской академии наук, ул. Поварская, д. 25 а, г2Іо69 г. Москва, Россия.

E-mail: giorgia.rimondi@gmail.com 


\section{MUSICAL OUTLOOK IN ALEXEY LOSEV'S NOVEL THE WOMAN-THINKER}

(C) 2018. G. Rimondi

This is an open access article distributed under the Creative Commons Attribution 4.0 International (CC BY 4.0)
University of Parma,

Parma, Italy

A.M. Gorky Institute of World Literature

of the Russian Academy of Sciences,

Moscow, Russia

Received: June 27, 2017

Date of publication: March 25, 2018

Abstract: This article discusses the role of music in the context of A.F. Losev's philosophical prose of the I930's and I940's. Describing the key ideas of Losev's philosophy of music, the essay presents Losev as both the writer and the philosopher and analyzes the relationship between these two facets of his work. It pays particular attention to the way philosophical ideas are conveyed in the novel The Woman-Thinker where the opposition of rational thought and antinomical knowledge emerges in the form of a binary of the "musical" and the "non-musical," as two modes of attitude to the being. In the novel, the specificity of the musical worldview is embodied in the tragic fate of the pianist Radina whose character reveals a deep reflection on the meaning of life and the spiritual state of contemporaneity.

Keywords: A.F. Losev's philosophical prose, musical myth, musical worldview, The WomanThinker, autobiographism, philosophy of music.

Information about the author: Giorgia Rimondi, $\mathrm{PhD}$, University of Parma, Via Università, I2, 43I2I Parma PR, Italy, PhD student, A.M. Gorky Institute of World Literature of the Russian Academy of Sciences, Povarskaya 25 a, I21069 Moscow, Russia.

E-mail: giorgia.rimondi@gmail.com 
В ранней статье «Русская философия» (I9I8) А.Ф. Лосев, характеризируя тип русской мысли и ее основные направления, писал о глубокой взаимосвязи философии и литературы, что, по его мнению, является отличительной чертой русской художественной прозы. Мысль о философичности русской литературы не нова - в русской философии проблема рассматривалась С.С. Аверинцевым, В.В. Бибихиным, П.П. Гайденко и другими; также интересные наблюдения можно найти у литературоведов и искусствоведов - А.А. Потебни, С.Л. Выготского, М.М. Бахтина.

Размышляя о специфике русской мысли, Лосев отмечает ее тесную связь с литературной формой:

С этой «жизненностью» русской философской мысли связан тот факт, что изящная литература является колыбелью самобытной русской философии. В прозаических произведениях Жуковского и Гоголя, в творчестве Тютчева, Фета, Льва Толстого, Достоевского, Максима Горького часто обсуждаются основные философские проблемы, разумеется, в их специфически русском, исключительно практическом, ориентированном на жизнь виде. И решаются эти проблемы таким образом, что всякий непредвзятый и компетентный судья назовет эти решения не только «литературными» или «художественными», но философскими и гениальными [6, с. I88-189].

Художественные произведения А.Ф. Лосева продолжают это направление русской литературы, связанной с попыткой решения главных вопросов бытия. 
Лосевское литературное творчество (стихи, рассказы, повести, роман) относится к г930-І940 гг. (период «подполья», поскольку Лосеву было запрещено цензурой заниматься философией), однако долгое время Лосев-писатель был обойден вниманием критиков и литературоведов потому, что его рассказы начали издавать только в начале І990-х гг. К тому же, по мнению Е.А. Тахо-Годи, Лосева долго не признавали как прозаика именно из-за того, что ко времени публикации прозы он уже был признанным философом, так что его литературная работа рассматривалась как «опыт» философа. Помимо этого, как свидетельствовала А.А. Тахо-Годи, Алексей Федорович при жизни никогда о литературных работах не вспоминал и никому их не показывал, рукописи были обнаружены в его домашнем архиве только в г989 г., уже после кончины философа.

Литературное наследие Лосева включает роман «Женщина-мыслитель» (1933-І934) и несколько рассказов и повестей: «Мне было г9 лет» (1932), «Переписка в комнате» (г932), «Театрал» (1932), «Встреча» (I933), «Трио Чайковского» (І933), «Завещание о любви, Метеор, Седьмая симфония» (г933), «Из разговоров на Беломорстрое» (б. д.), «Епишка» (б. д.), «Вранье сильнее смерти» (б. д.), «Жизнь» (194I). Сначала некоторые рассказы были опубликованы в разных журналах и отдельных изданиях, потом они вошли в сборники «Жизнь. Повести, рассказы, письма» (СПб., І993), «Мне было г9 лет. Дневники, письма, проза» (М., І997) и «Я сослан в XX век...» (М., 2002).

Лосевское литературное творчество тесно связано с его ранними теоретическими сочинениями, в нем нашли отражение основные положения его философских трудов г920-х гг. В рассказах и повестях чисто философские идеи переплетаются с художественным сюжетом, следовательно, трудно провести грань между философским и собственно художественным. Многие мотивы и образы (противопоставление романтизма и реализма, идея откровения через искусство, размышления о кризисе современной культуры, онтологическое понимание музыки и пр.), впервые воплощенные в философских работах, получат дальнейшее развитие в прозе, что дает право говорить о «философской прозе» Лосева.

Тот факт, что лосевская проза относится к 1930-1940 гг., когда мыслитель уже был приговорен к «философскому» молчанию, приводит к выводу о том, что отражение философских идей в рассказах совсем не случайно. 
Произведения мыслителя, как философские, так и художественные, образуют собой единое целое по цели и содержанию. Лосевская проза отражает философский мир писателя не только непосредственно, через «философские» монологи и диалоги персонажей, но и опосредованно, через систему образов, благодаря чему достигается глубокая взаимосвязь философских мыслей и формы их выражения в художественном тексте. Как отмечал сам Лосев, говоря о своем романе, «было бы чрезвычайно странно подходить с художественной оценкой к сочинению, состоящему на $1 / 4$ из философских рассуждений, да и остающаяся $1 / 4$, по самому замыслу автора, имеет тут гораздо больше идейное, чем просто художественное значение» [5, с. I42].

Однако присутствие автора в тексте не ограничивается лишь изложением философских взглядов автора, а раскрывается в биографическом следе, который есть в тексте. При этом следует отметить, что лосевская проза писалась «в стол», не для читателя, а для себя, поэтому часто герой является прямым выражением авторской позиции, о чем свидетельствуют мелкие автобиографические детали, разбросанные по тексту. Разные рассказы («Встреча», «Метеор», «Из разговоров на Беломорстрое», «Трио Чайковского») и роман «Женщина-мыслитель» объединяет наличие в них одного и того же лица, Николая Вершинина, охарактеризованного одинаково: он любитель музыки, ученый, вынужденный бросить философскую работу, который влюбляется в женщину-артистку (пианистку или певицу), - и все это характерные черты самого автора.

Говоря об автобиографических чертах автора-философа в лосевской художественной прозе, следует упомянуть о том, что в основе романа «Женщина-мыслитель» лежит встреча с М.В. Юдиной, ставшая значительным событием в жизни Лосева. Со знаменитой пианисткой, которая увлекалась философией, он встречался два раза: в апреле г930, за несколько дней до ареста, и зимой г933 г., после возвращения в Москву [9, с. II6-II7]. Окончив роман, Лосев читал его в двух домах, а также отправил его Юдиной. Однако, к его удивлению, она обвинила его в клевете, поскольку у пианистки из «Женщины-мыслителя» есть ряд недостатков - она истерична, избалованна, непостоянна. Хотя Лосев отрицал, что Юдина послужила прототипом Радиной, А. Кузнецов подчеркивал параллель между радинским окружением и бахтинским невельским кружком, к которому принадлежала и она. 
$<$...> если А.Ф. Лосев и метил в какую-то «цель», написав эту прозу, то ею могла быть прежде всего, по-видимому, не близкая ему «карнавальная» обстановка вокруг тех или иных имен и явлений культуры 20-х годов, в том числе в философских кругах, в частности в Невельском кружке М.М. Бахтина, к которому принадлежала и М.В. Юдина. Пародируя (или продолжая?) в своей прозе «мениппеи» К. Вагинова («Козлиная песнь» и «Труды и дни Свистонова» тогда уже были изданы), он направил ее жало против не соответствующей строгости его платонизма и шеллингианства «эстетической вольности» бахтианцев, с которыми, по всей вероятности, он пересекся. Так и возникли в романе «Женщина-мыслитель» едва скрытые образы М.М. Бахтина (Бахианчик), Л.В. Пумпянского (Пупа), В.Н. Волошинова (Бетховенчик), К.К. Вагинова (Максим Максимович) и так далее [I].

Однако вопрос о полемике Лосева с «невельцами» остается открытым, поскольку нет сведений о том, что Лосев был знаком с ними. Е.А. Тахо-Годи отмечает, что «до написания Женщины-мыслителя Лосев ничего о “невельцах” не знал или их существование его мало занимало - на них нет ни сносок в его философских трудах, ни намека в прозаических вещах, созданных до романа. Кто мог рассказывать о юдинском окружении Лосеву в конце г933 года? “Подельник” Лосева, А.Б. Салтыков - дядюшка юдинского жениха К. Салтыкова? Или лосевский друг по ГАХН М.И. Каган? Но трудно предположить, чтобы Кагана давал иронические отзывы о Бахтине и его кружке» [II, с. 77-78].

Несмотря на то что Лосев был знаком с Юдиной и, вероятно, образ женщины-артистки с ней связан, доказать это сложно. Трудно поверить, что основная цель «Женщины-мыслителя» заключается в карикатуре на артистку, тем более что в письме к Юдиной от I7 февраля I934 г. сам Лосев признавал, что некоторые черты героини списаны не с женщины, а с мужчины, «с одного крупнейшего русского писателя, одного из основателей и столпов символизма» [5, с. I43] ${ }^{\text {I }}$ К тому же Е.А. Тахо-Годи считает, что для понимания лосевской прозы биографические вехи не столь существенны, подчеркивая этим, что жизненный материал не должен помешать читателю увидеть философский смысл лосевской прозы [го, с. 38]. Итак, автобиографизм у Лосева связан не только с фактами, но и с эстетическими структурами, мировоззрением и экзистенциальными ценностями автора-мыслителя.

I E.А. Тахо-Годи полагает, что речь идет о Вяч. Иванове. 
Разочарованный реакцией Юдиной Лосев решил не публиковать роман. Он писал ей I6 февраля I934 г.: «Никому этой рукописи я и не давал и теперь ради Вас, не дам. Я читал в двух домах только І-ю главу, да и то с опущением конца (угрозы разоблачения “секретов”, связанные по сюжету с последующим)» [5, с. I45].

Одной из главных тем, которая занимает особое место как в теоретических работах, так и в прозе в целом является определение сущности музыки и ее роли в жизни человека. Предпочтение Лосевым музыкального искусства объясняется, кроме известных биографических обстоятельств (Лосев был скрипачом и в І920-е гг. занимался музыкальной эстетикой при ГАХН, ГИМН и Московской Консерватории), тем, что оно является безо́бразным выражением смысла. Именно в этом мыслитель усматривает сходство между музыкой и бытием:

Все прочие искусства есть уже внешнее выражение музыки. Всякое не музыкальное искусство создает образ, стоящий между внешним миром и музыкой. <...> Тут есть устойчивая образность, которой совсем лишена музыка. Музыка есть в этом смысле полная безобразность, обнаженная душа искусства, самое сердце бытия, лишенное внешнего тела. В музыке слышится пульсация первозданных основ искусства. <...> Кто пленен музыкой, тот захвачен самыми глубокими корнями своих чувств, тому ведома тайна прорицания самых основ духовно-душевной жизни [2, с. 65].

В музыке человек испытывает не только чисто философское, но и жизненное, духовное откровение. В этой сфере, происходящей из «ощущения бесформенной хаотической качественности бытия», раскрывается трагический характер жизни, напоминающий известное ницшеанское определение «рождении трагедии из духа музыки» [7, с. 320]. Отсюда лосевская критика рассудочного (чисто логического) миросозерцания, противопоставленного мироощущению. Термин мироощущение употребляется не случайно. Лосев проводит четкую границу между мироощущением («мирочувствием») и миросозерцанием [4, с. 782-783]. Первое - это непосредственное и интуитивное видение сущности, второе же - рационалистическое понимание мира.

Подобная концепция лежит в основе романа «Женщина-мыслитель», где в образе пианистки Радиной воплощается конфликт двух мироощущений - музыкального и немузыкального. 
Роман издавался в журнале «Москва» (I993, № 4, 5, 6, 7), а в полном объеме он был опубликован лишь в 2002 г. во втором томе сборника «Я сослан в XX век...». В основе сюжета романа - воспоминание героя Николая Вершинина о встрече на концерте с известной пианисткой Марией Радиной. Наблюдая ее в повседневной жизни, в кругу знакомых, Вершинин понимает, что ее жизнь не соответствует ее гениальности. Она живет в коммуналке, ее окружение пошлое, она истерична, капризна. Вместе с двумя другими поклонниками Радиной он собирается «спасать» пианистку и вырвать ее из пошлого окружения. Однако спасти Радину ему не удается - пианистка погибнет от руки одного из ее поклонников.

События романа разворачиваются на фоне размышлений о связи действительности и искусства. В самом начале романа пианистка изображается как персонификация музыкальной стихии. У нее особое, почти мистическое вдохновение 2 , в ней «нет никакой расчетливости», она мыслит не рассудочно, аналитически, а музыкально [2, с. го]. Герой считает, что в Радиной воплощены черты «музыкального мироощущения», и именно поэтому ее можно назвать «мыслителем». Далее в романе изображение персонажа Радиной доходит до степени магического и чудесного, она «ведьма», «страшная»; ее музыка «магична», «раскрывает само бытие».

В образе Радиной дается обобщенный портрет мыслителя. В «мистериальных ощущениях» пианистки герой усматривает черты философской мысли. Здесь интересно отметить параллель с личным опытом автора. В дневнике от 26 мая І9I4 г. Лосев так описывает философское откровение, которое он испытал после посещения концерта Скрябина: «Приезжавши с концерта, <...> произошло, кажется, откровение через Гуссерля. Кажется, я понял его феноменологию» [2, с. 430]. В «невыразимости» и «бесформенности» заключается специфика музыкального знания, в отличие от рассудочного: «...музыка не изображает вещи <..> Никаким словом, никаким понятием нельзя ознаменовать музыку» [8, c. II5]. В музыке нет никакой законченной оформленности, она прямо

\footnotetext{
2 Попутно отметим, что в письме к Юдиной от г6 февраля 1934 г. Лосев выражает аналогичную мысль применительно к знаменитой пианистке: «В Вашей игре я ощутил свою родную стихию мысли, скрытые - может быть, даже неясные Вам самой - философские постижения, завораживающую глубину и размах прозрения, которые я находил только у крупнейших философов» [2, с. I46].
} 
изображает сущности: «музыка содержит в себе образ стремящегося бытия» [8, c. II5]. Музыка хаотична, рождается из становления противоположных начал (рождение и уничтожение), и человек, который слушает ее, брошен в чистую бытийственность. В лосевской прозе музыка всегда связана с переживанием героя, она то вызывает воспоминания, то сопровождает чувства, то меняет его душевное настроение. В рассказе «Мне было I9 лет» молодой человек, влюбленный в певицу, теряет ощущение реальности на концерте. Таким же образом герой «Трио Чайковского» после слушания арии из оперы «Франческа да Римини» Рахманинова ощущает действие «тайной силы» над собой [8, с. I63].

Музыкальный опыт служит откровением высшей, подлинной реальности. Переживая музыку, герой соприкасается с тайной жизни:

Только в музыке оживляется, одухотворяется и одушевляется внешний мир. Пропадает безличие мира, исчезает его косность и механизм, и мы начинаем слышать как бы самый пульс мировой и всемирно-божественной жизни. Только музыка открывает человеку тождество его душевных движений с процессами объективной действительности [2, с. 84].

В «Женщине-мыслителе» размышление о музыкальном искусстве передается в разговоре персонажей, рассуждающих о роли музыки в жизни. Как писал сам Лосев, говоря о структуре своего романа, «речь Телегина об отношении музыки и жизни (а это ведь целая большая статья!), где поставлен кардинальный вопрос всего мировоззрения <...> речь Вершинина о молитве и умном делании (а это ведь тоже целая большая статья!), где решается вопрос о двояком пути восхождения и, вместе с тем, вопрос о философской значимости двух великих культур» [5, с. I49].

Проблема эстетического бытия человека обсуждается в речи персонажей. С одной стороны, музыка - фикция, платоновская «копия копии», не только не имеющая ничего общего с действительностью, но и даже отрешенная от последней. Эта позиция выражается в речи студента Телегиным:

Искусство не есть творчество самой жизни. Искусство есть только творчество жизненных форм. Подлинное искусство не заинтересовано в жизни. $<. .>$ Эстетическое бытие не есть бытие реальности, физической или психиче- 
ской. Эстетическое бытие - нейтрально в отношении всякого бытия. <... > уже по одному тому, что искусство есть искусство, оно есть некий уход от жизни, некое оставление ее на произвол судьбы. Искусство создает то, чего нет, не-сушее. Самое реалистическое и насквозь натуралистическое искусство все-таки не есть жизнь, а только изображение жизни. <...> Если человек только и живет искусством, это значит, что он находится всецело во власти несуществующего. Он творит и мыслит несуществующее [2, с. 62-63].

Телегину возражает Воробьев, который предупреждает о мире, лишенном музыки:

- Жизнь была бы тюрьмой, - читал он, - если бы не было искусства. <...> Искусство - воплощает идеи, материализует чувства, осуществляет мечту, делает телесным то, чего едва только могут касаться люди своим воображением. <...> Искусство живет совпадением всего идеального и реального, синтезом бесконечного и конечного, тождеством возвышенного и житейски-обыкновенного. В искусстве нет ничего теоретического, отвлеченного, условного, выдуманного, фиктивного. <...> оно - человеческая жизнь в своем конкретном явлении [2, с. 82].

Лосевская антитеза искусства и действительности находит свое яркое воплощение в образе Радиной. В героине персонифицирована несовместимость музыки и действительности, ее жизнь явно не соответствует ее музыкальной личности. После встречи героя с Радиной на концерте автор дает портрет ее бытовой жизни, в котором она изображается как обыкновенная женщина, мещанка, окруженная пошлыми поклонниками. Тем не менее сам автор уточняет, что «Радина изображена запутавшейся, - но совсем не мелкой (это я много раз подчеркиваю), а только запутавшейся и опустившейся» [5, с. I47].

Изображения Радиной-мыслителя и Радиной-женщины совершенно не соответствуют друг другу. Речь не идет просто о теме падшей женщины-артистки, жизнь на сцене которой отличается от ее повседневной жизни. Через личную драму автор изображает более глубокий раскол. Как подчеркивает сам Лосев, сцены первого посещения пианистки Вершининым «задуманы как контраст к I-й главе» [5, с. I43]. Пианистка как бы разделена надвое, она потеряла смысл существования, не признает своего гения и не 
раз выражает намерение бросить музыку, которая ее «сгубила» и «проглотила». В разговорах Радиной с Вершининым (alter ego Лосева) о смысле музыки автор старается показать, как отказ от признания главенствующей роли искусства для жизни приводит к опустошению внутреннего мира человека: «...музыкант есть выродившийся, падший, внутренне потерянный человек. $<. .>$ Радина закрыта от мира. Только в минуты ее вдохновения за фортепиано - можно одним глазом заглянуть в это ослепительное царство чудес и тайн, которые ведомы Радиной» [2, с. 67-69].

Отметим, что человек-артист в лосевской прозе страдает оттого, что он не мог объединить искусство и жизнь. Это также поднимает вопрос о природе гения и о его нравственной свободе, который обсуждается Воробьевым, одним из поклонников пианистки: «Гений и любовь не нуждаются в дисциплине. <...> Артист сам себе закон. На нем мы учимся свободе» [2, с. 83]. Этому Телегин возражает, что «трудно музыканту быть личностью <..> великие откровения музыки <...> невозможно реально воплотить и - остаться живым» [2, с. 7I]. Мистическое переживание артиста иллюстрирует противопоставление музыкального и немузыкального миропонимания, художественного и рассудочного.

В романе «Женщина-мыслитель» этот вопрос также рассматривается с точки зрения оппозиции музыки и современности. Контраст между двумя планами жизни Радиной (образ великого музыканта и падшей женщины, романтическое и реалистическое изображение) символизирует контраст между двумя планами бытия в «немузыкальном» обществе. Иными словами, образ Радиной воплощает в себе пропасть, возникшую в современном обществе между личностью и миром. Мир, в котором живут лосевские персонажи, движется к нигилизму, «надвигается новая культура, где этот абсолютизированный человеческий субъект будет повергнут в прах и где весь его романтизм, вся его значимость будет перенесена на внеличную стихию <...> И музыка перестанет удовлетворять человека так же, как перестало удовлетворять умное делание...» [2, с. 79].

Отсюда возникает лосевская оценка современности как процесса и результата мифологического «хаоса» в сознании человека, которая уже высказывалась в «Диалектике мифа» (І930). Абсолютизация субъекта современной эпохи привела к уничтожению личности, абсолютный миф был разрушен и разделен на ряд отдельных (относительных) мифов, которые, однако, никак не могут заменить первый. Итак, роман также можно прочи- 
тать на философском уровне как осознание невозможности совмещения этих фрагментов мифа. Не случайно герой представляется как тот, кто пытается спасти пианистку, но ему это не удается.

Все эти вопросы выявляют связь между писателем и мыслителем. Философия и художественная сфера составляют теоретический аппарат и общий контекст творчества Лосева. Они связаны единством замысла, тем и идей. И в прозе, и в теоретических трудах проявляется целостный замысел, призванный осветить отдельные философские аспекты. Художественный мир не только продолжает и возобновляет темы теоретических трудов, но и перерабатывает их и передает по-другому. Это обусловлено тем, что, по Лосеву, сферы познания не существуют отдельно друг от друга, а каждая передает фрагмент мировоззрения. Философия, музыка и литература отличаются только по способу передачи смысла. Уже в «Музыке как предмете логики» (1927) Лосев посвятил одну из глав «музыкальному мифу», где он писал: «..эти страницы <...> должны явиться мифологическим закреплением нашего отвлеченного анализа и опытным описанием того, как из океана алогической музыкальной стихии рождается логос и миф» [3, с. 470]. Подлинное познание мира дается не теоретически, а эстетически, знание через искусство не менее значительно, чем дискурсивное (логическое).

В романе следует выделить еще один аспект. Как уже отмечалось, лосевское осмысление музыки в теоретическом плане в І920-х гг. (в «Музыке как предмете логики», «Диалектике художественной формы», «Очерке о музыке») находит продолжение в литературных произведениях I930-х гг. Однако в конце І920-х гг. Лосев, по собственному признанию, перестал заниматься музыкой [5]. Причину этого мыслитель открыто не назвал, но, судя по содержанию текстов, происходит своего рода переоценка роли музыки и искусства в целом. В этом смысле следует понимать один из главных лейтмотивов лосевской прозы - сближение музыки и молитвы: оба опыта обеспечивают доступ к ноуменальному миру, при этом не менее реальному, чем мир явлений: «Есть тайная связь между откровениями мысли и внутренним отвержением себя, аскетизмом» [2, c. I6]. Однако в письме к Юдиной Лосев писал: «Я не скрываю от Вас, что музыка, да и Вы сами - для меня сейчас только результат моей слабости, как слабеет монах на тяжелом подвиге и вместо молитв иной раз требует утешения в леденцах» [5, с. I53]. 
Можно предположить, что пересмотр роли музыки привел Лосева к осознанию того, что над музыкой есть высшая область, где звучит «музыка самого бытия человека» [2, с. 77]. Истинное счастье и спасение можно найти только в религиозной сфере, в жизни души. Если применять эту точку зрения к образу Радиной, которой не удается примирить музыкальный и духовной восторг и даже понять значение музыкально-душевной сферы, становится понятным, что ее попытка найти смысл жизни обречена на провал. Возможно, через «музыкальный миф» своего романа автор стремился показать, как мир, лишенный музыки и потерявший связь с подлинным бытием, движется к расколу человеческой души.

\section{Список литературы}

Кузнецов А. Узрение существа музыки при посредстве естества женского и безумия артистического. URL: http://magazines.russ.ru/novyi_mi/1994/6/knobozoz.html (дата обращения: 28.03.2016).

Лосев А.Ф. Женщина-Мыслитель // Лосев А.Ф. «Я сослан в XX век...»: в 2 т. / под ред. А.А. Тахо-Годи; сост. и коммент. А.А. Тахо-Годи, Е.А. Тахо-Годи, В.П. Троицкого. М.: Время, 2002. Т. 2. С. 7-I4I.

3 Лосев А.Ф. Музыка как предмет логики // Лосев А.Ф. Форма. Стиль. Выражение / сост. А.А. Тахо-Годи; общ. ред. А.А. Тахо-Годи и И.И. Маханькова. М.: Мысль, г995. C. $405-583$. Лосев А.Ф. О мировоззрении Эсхила // Лосев А.Ф. Форма. Стиль. Выражение. М.: Мысль, 1995. С. 78I-876.

5 Лосев А.Ф. Приложение к роману Женщина-мыслитель // Лосев А.Ф. «Я сослан в $\mathrm{XX}$ век...»: в 2 т. / под ред. А.А. Тахо-Годи; сост. и коммент. А.А. Тахо-Годи, Е.А. Тахо-Годи, В.П. Троицкого. М.: Время, 2002. Т. 2. С. І42-162.

6 Лосев А.Ф. Русская философия // Лосев А.Ф. На рубеже эпох: Работы гіг-х начала г920-х годов / общ. ред. и коммент. А.А. Тахо-Годи, Е.А. Тахо-Годи,

В.П. Троицкого; сост. Е.А. Тахо-Годи, В.П. Троицкий. М.: Прогресс-Традиция, 2015. C. $188-189$.

7 Лосев А.Ф. Строение художественного мироощущения // Лосев А.Ф. Форма. Стиль. Выражение / сост. А.А. Тахо-Годи; общ. ред. А.А. Тахо-Годи и И.И. Маханькова. М.: Мысль, 1995. С. 297-320.

8 Лосев А.Ф. Трио Чайковского // Лосев А.Ф. «Я сослан в ХХ век...»: в 2 т. / под ред. А.А. Тахо-Годи; сост. и коммент. А.А. Тахо-Годи, Е.А. Тахо-Годи, В.П. Троицкого. М.: Время, 2002. Т. г. С. 106-230.

9 Тахо-Годи А.А., Тахо-Годи Е.А., Троиикий В.П. А.Ф. Лосев. Философ и писатель. М.: Наука, 2003. 395 с.

Iо Тахо-Годи Е.А. На пути к невесомости или в плену Содома // Лосев А.Ф. «Я сослан в XX век...»: в 2 т. / под ред. А.А. Тахо-Годи; сост. и коммент. А.А. Тахо-Годи, Е.А. Тахо-Годи, В.П. Троицкого. М.: Время, 2002. Т. г. С. 7-48. 
Тахо-Годи Е.А. Художественный мир прозы А.Ф. Лосева. М.: Большая Российская энциклопедия, 2007. 399 с.

\section{References}

I Kuznecov A. Uzrenie sushhestva muzyki pri posredstve estestva zhenskogo i bezumija artisticheskogo [Grasping the essense of music through femininity and artistic madness]. Available at: http://magazines.russ.ru/novyi_mi/r994/6/knobozo3.html (Accessed 28 March 20I6). (In Russ.)

2 Losev A.F. Zhenshhina-Myslitel' [The Woman-Thinker]. Losev A.F. “Ja soslan v XX vek...”: in $2 t$. [I am exiled in the $20^{\text {th }}$ century: in 2 vols.], ed. A.A. Taho-Godi; eds. And comment. A.A. Taho-Godi, E.A. Taho-Godi, V.P. Troitsky. Moscow, Vremja Publ., 2002, vol. 2, pp. 7-I4I. (In Russ.)

3 Losev A.F. Muzyka kak predmet logiki [Music as the subject of logic]. Losev A.F. Forma. Stil'. Vyrazhenie [Form. Style. Expression], ed. A.A. Taho-Godi; general ed. A.A. TahoGodi i I.I. Mahan'kov. Moscow, Mysl' Publ., I995, pp. 405-583. (In Russ.)

4 Losev A.F. O mirovozzrenii Eshila [On the worldview of Aeschylus]. Losev A.F. Forma. Stil'. Vyrazhenie [Form. Style. Expression], ed. A.A. Taho-Godi; general ed. A.A. TahoGodi i I.I. Mahan'kov. Moscow, Mysl' Publ., I995, pp. 78I-876. (In Russ.)

5 Losev A.F. Prilozhenie k romanu "Zhenshhina-myslitel'” [Appendix to the novel The Woman-Thinker]. Losev A.F. "Ja soslan $v$ XX vek...": in $2 t$. [I am exiled in the $2 \mathrm{O}^{\text {th }}$ century: in 2 vols.], ed. A.A. Taho-Godi; eds. and comment. A.A. Taho-Godi, E.A. Taho-Godi, V.P. Troitsky. Moscow, Vremja Publ., 2002, vol. 2, pp. I42-I62. (In Russ.)

6 Losev A.F. Russkaja filosofija [Russian philosophy]. Losev A.F. Na rubezhe jepoh: Raboty I9Io- $h$ - nachala I920- $h$ godov [On the turn of centuries: Works of the I9IOs-beginning of the I920s], general ed. and comment. A.A. Taho-Godi, E.A. Taho-Godi, V.P. Troitsky; eds. E.A. Taho-Godi, V.P. Troitsky. Moscow, Progress-Tradicija Publ., 2015, pp. I88-I89. (In Russ.)

7 Losev A.F. Stroenie hudozhestvennogo mirooshhushhenija [The structure of artistic worldview]. Losev A.F. Forma. Stil'. Vyrazhenie [Form. Style. Expression], ed. A.A. TahoGodi; general ed. A.A. Taho-Godi i I.I. Mahan'kov. Moscow, Mysl' Publ., I995, pp. 297-320. (In Russ.)

8 Losev A.F. Trio Chajkovskogo [Tchaikovsky trio]. Losev A.F. “Ja soslan v XX vek...”: in $2 t$. [I am exiled in the $20^{\text {th }}$ century], ed. A.A. Taho-Godi; eds. and comment. A.A. Taho-Godi, E.A. Taho-Godi, V.P. Troitsky. Moscow, Vremja Publ., 2002, pp. I06-230. (In Russ.)

9 Taho-Godi A.A., Taho-Godi E.A., Troickij V.P. A.F. Losev. Filosof i pisatel' [A.F. Losev. Philosopher and writer]. Moscow, Nauka Publ., 2003. 395 p. (In Russ.)

IO Taho-Godi E.A. Na puti k nevesomosti ili v plenu Sodoma [Towards zero grafity or indented by Sodom]. Losev A.F. “Ja soslan $v$ XX vek...”: in $2 t$. [I am exiled in the $20^{\text {th }}$ century: in 2 vols.], ed. A.A. Taho-Godi; eds. and comment. A.A. Taho-Godi, E.A. Taho-Godi, V.P. Troitsky. Moscow, Vremja Publ., 2002, vol. I, pp. 7-48. (In Russ.) Taho-Godi E.A. Hudozhestvennyj mir prozy A.F. Loseva [Losev's fictional world]. Moscow, Bol'shaja Rossijskaja jenciklopedija Publ., 2007. 399 p. (In Russ.) 


\section{COMMENT LES FRANÇAIS ONT DÉCOUVERT NA DNE}

(C) 20I8. S. Rolet

This is an open access article distributed under the Creative Commons Attribution 4.0 Université de Lille, Lille, France Envoyé le I7 janvier 2018

International (CC BY 4.0)

DOI: I0.22455/2500-4247-20I8-3-I-I54-I77

Résumé: Malgré l'extraordinaire célébrité de M. Gorki en France depuis les premières années du XXe siècle, le public français n’a découvert «Les Bas-fonds» qu'en octobre I905, plus tard qu'ailleurs en Europe. La concurrence entre deux traducteurs, Eugène Séménoff et Élie Halpérine-Kaminski, a donné lieu à un procès, qui a gelé le travail de mise en scène pendant deux ans. Après le procès, la pièce a été rapidement montée à Paris par Lugné-Poë au théâtre de «L'Euvre». La presse de l'époque a annoncé que le spectacle constituerait le sommet de la saison théâtrale. Le moment le plus marquant a été la soirée du 23 octobre I905: la tragédienne italienne Eleonora Duse a joué le rôle de Vassilissa en italien, les autres acteurs jouant en français.

Mots clés: Maxime Gorki, «Les Bas-fonds», Antoine, Lugné-Poë, Eleonora Duse, procès, J. Marchlewski, Eugène Séménoff, Élie Halpérine-Kaminski, Serge Persky.

Informations sur l'auteur: Serge Rolet, professeur, Université de Lille, 42, rue Paul Duez, 59000 Lille, France.

E-mail: serge.rolet@univ-lillez.fr 


\section{HOW THE FRENCH DISCOVERED THE LOWER DEPTHS}

(C) 20I8. S. Rolet

This is an open access article distributed under the Creative Commons Attribution 4.0 International (CC BY 4.0)
University of Lille, Lille, France. Received: January I7, 2018

Date of publication: March 25, 2018

Abstract: Despite the exceptional fame of Maxim Gorky in France since the very beginning of the $2 \mathrm{O}^{\text {th }}$ century, the French public did not discover The Lower Depths until October 1905, later than other European countries. The competition between two translators, Eugène Séménoff and Élie Halpérine-Kaminski, lead to a lawsuit, which delayed the staging of the play for two years. Following the end of the trial, the play was immediately produced by Lugné-Poë at L'Euvre Theatre; the press had advertised the play as the pinnacle of the theatrical season. The most noteworthy event was the performance on October 23, I905 when Italian tragic actress Eleonora Duse played the part of Vassilissa in Italian, while other actors played their parts in French.

Keywords: Maxim Gorky, The Lower Depths, Antoine, Lugné-Poë, Eleonora Duse, trial, J. Marchlewski, Eugène Séménoff, Élie Halpérine-Kaminski, Serge Persky.

Information about the author: Serge Rolet, Professor, University of Lille, 42, rue Paul Duez, 59000 Lille, France.

E-mail: serge.rolet@univ-lille3.fr 
УДК 82I.I6І.І.о

ББК $83.3(2 \mathrm{Poc}=\mathrm{Pyc}) 6$

\section{КАК ФРАНЦУЗЫ ОТКРЫЛИ «НА ДНЕ»}

(C) 2018 г. С. Роле

Университет Лилль,

Лилль, Франция

Дата поступления статьи: І7 января 2018 г. Дата публикации: 25 марта 2018 г.

DOI: I0.22455/2500-4247-2018-3-I-I54-I77

Аннотация: Несмотря на чрезвычайную знаменитость М. Горького во Франции в самом начале XX в., французская публика открыла «На Дне» только в октябре г905 г., значительно позднее, чем в других странах Европы. Конкуренция между двумя переводчиками, Е. Семеновым и И. Гальпериным-Каменским привела к процессу, который задержал работу театральных деятелей до октября І905 г. После процесса пьеса была немедленно поставлена Люнье-По в театре «Л’евр». В современной печати было заранее объявлено, что спектакль непременно будет вершиной театрального сезона. Самым интересным моментом был вечер 23 октября г905 г., когда итальянская трагическая актриса Елеонора Дузе играла роль Василисы поитальянски, а остальные актеры - по-французски.

Ключевые слова: М. Горький, «На дне», Антуан, Люнье-По, Елеонора Дузе, судебный процесс, Ю. Мархлевский, Е. Семенов, И. Гальперин-Каминский, С. Перский.

Информация об авторе: Серж Роле - доктор наук, профессор, заведующий кафедрой русской литературы, Университет Лилль, факультет иностранных языков, 42, rue Paul Duez, 59000 Лилль, Франция.

E-mail: serge.rolet@univ-lillez.fr 
L'histoire des Bas-fonds en France présente certaines particularités exceptionnelles dans la réception de Gorki à l'étranger. Le succès phénoménal de Gorki partout en Europe et jusqu'aux États-Unis provoquait souvent une concurrence entre les éditeurs, entre les traducteurs, mais dans la cas des Bas-fonds, cette rivalité a eu pour effet, en France, de geler le travail des théâtres pendant deux ans et demi. La présente étude se propose de suivre le parcours ralenti de la pièce, tel que le retracent les périodiques autour de 1903-1905.

\section{Gorki aux yeux des Français avant les Bas-fonds: déjà une vraie légende}

Pour comprendre comment la plus célèbre pièce de Gorki a été perçue en France, il faut avoir à l'esprit la réputation vraiment extraordinaire que l'écrivain avait déjà acquise depuis son entrée fracassante sur le marché des biens symboliques, à peine quelques années plus tôt.

Dans les premières années du $\mathrm{XX}^{\mathrm{e}}$ siècle, après la publication de plusieurs recueils de ses récits aux éditions du Mercure de France et, en même temps, dans des revues littéraires comme la Revue bleue et la Revue de Paris, Gorki est la coqueluche des journaux. D'un côté, son nom revient régulièrement, souvent sur des sujets avec lesquels il n'a pas grand-chose à voir, et quelquefois même rien du tout. D'un autre côté, le contenu de ce qui s'écrit sur Gorki laisse penser que sa très flatteuse renommée en tant qu'écrivain est en réalité superficielle. 
Aussitôt qu'il a été publié en français, Gorki est devenu une référence majeure dans la presse française, un repère. C'est avec lui que sont comparés la plupart des auteurs et artistes russes de l'époque, comme Chaliapine ou Tchékhov, c'est par rapport à lui que la presse les situe, et non l'inverse, comme il semblerait plus juste de le faire, puisqu'ils sont ses aînés dans la vie culturelle russe, telle que les Français la connaissent. Si Gorki est lui-même comparé à quelqu'un, c'est à Tolstoï, à Dostoïevski: à tout seigneur, tout honneur. Ces rapprochements sont rapides, peu rigoureux, ils doivent plus à un enthousiasme collectif, contagieux, aussi vague qu'excessif, qui se nourrit certes des œuvres de l'écrivain, mais tout aussi bien, et probablement plus encore, de sa personne. Bien entendu, son côté «va-nu-pieds», forcément un peu mauvais garçon, marque les esprits; c'est lui qui lui vaut d'être présenté comme un Villon des temps modernes: «Bientôt il quitta tout, laissa Konovalov et les vingt-six et recommença sa course errante, à la Villon, lisant beaucoup, écrivant peu, mais contemplant le humbles et les travailleurs, mêlé au peuple, ami des gueux $<\ldots>\gg^{\text {I }}$. Sa santé, sa vie privée, ses affaires et, surtout, ses positions politiques font l'événement sans coup férir, à un rythme qui fait presque de lui un personnage de feuilleton: il est des périodes où son nom apparaît quotidiennement dans la presse française.

Vues de France, les positions politiques de Gorki, auxquelles des traductions de ses lettres ouvertes, adresses, déclarations à la presse, donnent un large écho, apparaissent comme démocratiques et pleines de panache. La France républicaine apprécie en Gorki le rebelle à l'autocratie. L'Aurore publie en 1903, en première page, une longue déclaration de Gorki, sous un titre en gros caractères: «Opinion de Maxime Gorki sur le "pogrom” de Kischineff». En voici le début:

Depuis quelques années, notre pays est de plus en plus fréquemment le théâtre d'événements qui le déshonorent. Mais l'événement le plus déshonorant, événement qui excite l'horreur, la honte et l'indignation, c'est l'épouvantable massacre des juifs de Kischinef $(\text { sic })^{2}$.

Pour les Français, l'écrivain devient presque immédiatement la figure de proue de l'opposition au gouvernement russe et en même temps sa première victime. On lit à la première page de l'Aurore, au moment des troubles de I90I:

I Pilon Edmond. Maxime Gorki, La Revue bleue, janvier-juin I905, p. I57.

2 Opinion de Maxime Gorki sur le "pogrom” de Kischineff, L’Aurore, 23 mai I903, p. I. 


\section{Gorki}

Le tsar va-t-il avoir un nouvel assassinat sur la conscience?

Maxime Gorki, le jeune écrivain que la police et les Cosaques s’ingénient à maltraiter, parce qu'il a pris parti pour les révoltés, est dans un état presque désespéré.

On vient de le transporter de la prison à l'hôpital de Nijni-Novgorod.

Gorki n’a pas trente ans. Sa popularité est telle que tous les jours des centaines de lettres, dont beaucoup de paysans, arrivent à son adresse, demandant anxieusement des nouvelles 3 .

De grands noms du monde de la politique et de la culture, des autorités morales prennent la défense de Gorki dans la presse. Citons, parmi beaucoup d'autres, l'éditorial très véhément de Francis de Pressensé dans l'Aurore, en mars 1902. Diplomate puis député et journaliste, directeur de l'Aurore au temps de l'affaire Dreyfus, Pressensé (I853-I9I4) est membre fondateur de la Ligue des droits de l'homme. Il en devient le président en I903. C'est une des grandes voix de la gauche dreyfusarde.

Je ne sais si personne a rendu plus fortement, avec une réalisme plus splendidement symbolique et une poésie plus âprement exacte ce déséquilibre, ce vertige, cet état d'âme d'un peuple du haut moyen âge aux prises avec les problèmes du XXe siècle, que Maxime Gorki dans ses nouvelles et dans ses deux puissants romans: Thomas Gordeief et Les Trois. Cet écrivain a le don, que seuls les plus grands possèdent: il confère à ses personnages une vie si intense, il fait couler dans leurs veines un sang si rouge, il met dans leur yeux un rayon si étincelant que les faits et gestes de cette humanité artificielle nous intéressent, nous remuent, nous hantent plus que ceux de tant de créatures falotes, effacées du Grand Démiurge.

Et c'est cet homme, ce romancier, ce littérateur que le Tsar Nicolas a jeté en prison et qu'il a interné et qu'il laisse gardé à vue comme un malfaiteur, au risque de hâter la marche d'une cruelle maladie. Tant le pouvoir criant l'esprit, et tant l'autorité, qui est une usurpation, redoute cette libre royauté, cette royauté émancipatrice, du génie!

Toujours les Bastilles ont été pour les hommes de lettres plus encore que pour les grands seigneurs ou les princes du sang. Et le peuple, en les détruisant , 
sait bien ce qu'il fait, malgré les sarcasmes des plaisantins de la réaction: il affranchit l'esprit et délivre son libérateur'.

Gorki fait l'actualité littéraire, mais surtout l'actualité politique internationale. Son nom revient fréquemment comme une référence vague, allusive et un peu automatique, à propos de l'agitation en Russie, en I90I et, encore plus largement, en 1905 .

Quant aux œuvres proprement dites de Gorki, publiées en entier ou par extraits, et disputées entre plusieurs éditeurs qui souvent leur donnent des titres différents en fonction de l'accent qu'ils désirent y porter et des morceaux qu'ils y choisissent, leur compréhension reste immédiate et assez naive: c'est la relation du texte avec la réalité, avec la biographie de l'auteur qui intéresse, qui impressionne, qui fascine: la misère, la route, l'existence «romantique» des vagabonds. On n'est pas très loin de ce que Merejkovski désigne comme «morceau de vie avec la chair et le sang» («кусок жизни с мясом и кровью»). À l'exception notable d'un grand article d'Eugène Melchior de Vogüé, paru dans la Revue des deux mondes en août I90I, la plupart des commentaires des journalistes, critiques et hommes de lettres français se contentent de reprendre, pour l'essentiel, le fond de deux ou trois ouvrages et articles, dus à des émigrés russes de Paris, Mme Starkoff, Ivan Strannik, G. Savitch, Eugène Séménoff.

Gorki est le célèbre inconnu de la presse française. Il occupe le devant de la scène, mais pendant des années, on continue à le présenter comme si les lecteurs ne savaient à peu près rien de lui . Les informations les plus élémentaires sont indéfiniment reprises, dans toutes sortes de publications, qui vont des grandes revues littéraires aux quotidiens comme la Presse, l'Aurore, le Figaro, le Temps, Gil Blas. Plusieurs années après les premiers succès de Gorki en France, ceux qui écrivent sur lui dans les journaux sont encore si peu familiers de ses œuvres qu'il suffit qu'un récit déjà publié paraisse sous un titre inédit pour qu'ils s'extasient sur l'originalité d'«un Gorki inconnu, [d']un Gorki nouveau» ${ }^{6}$. La rubrique «Bibliographie» de l'Aurore présente comme une nouveauté une énième traduction de Makar Čudra, intitulée

4 Pressensé, Francis de. Toutes les Russies (éditorial), L'Aurore, ier mars 1902, p. I.

5 Strozzi. Dans les Bas-fonds de Maxime Gorki (éditorial), Gil Blas, 6 octobre 1905, p. I.

6 L'Aurore, 30 juin I905, p. 3. 
L'Amour mortel. On trouve encore ce genre de notice, parue dans le quotidien $L a$ Presse, en I905, à l'occasion de la sortie d'un recueil de récits courts aux éditions du Mercure de France, sous le titre «L'Annonciateur de la tempête»:

Dans toute l'Europe, où il n'était guère connu que d'une élite, on traduit actuellement et on vend très bien les œuvres du romancier révolutionnaire. Ses œuvres d'ailleurs méritaient d'être mieux connues, même pour ceux qui les louent de confiance, pour embêter le tsar, si j'ose m'exprimer ainsi. Dans le recueil de nouvelles, publié par M. Séménoff, il n’y a rien qui ne soit vraiment très supérieur à la plupart des livres que nous servent les fabricants d'aujourd'hui. <...> La traduction de M. Séménoff m’a paru très littéraire, et son étude critique et biographique sur Maxime Gorki est digne de servir de préface à cette réunion de minuscules chefs-d'œuvre .

Lauteur de l'article semble ignorer que plusieurs des traductions qui composent le recueil avaient déjà été publiées dans des revues, et qu'Eugène Séménoff avait déjà fait paraître plusieurs notes biographiques et critiques sur Gorki, auxquelles la préface dont il est question n'apporte pratiquement rien de nouveau' ${ }^{8}$ Le passage cité est intéressant surtout par l'aveu qu'il contient: «louer de confiance» Gorki signifie qu'on l'encense sans l'avoir vraiment lu, et on comprend que tel est souvent le cas. On peut pour cette raison avoir des doutes sur la consistance de sa célébrité comme écrivain. Le discours des Français sur Gorki est très enthousiaste, et très approximatif. De grands noms de la presse publient sur lui dans les journaux des articles éloquents, le plus souvent assez creux. Ceux de Maurice Le Blond, gendre de Zola, dans l'Aurore, sont un modèle du genre. Le Blond reprend la légende de Gorki, dont la presse française ne se lasse pas, il cite l'article d'Ivan Strannik, où elle est apparue pour la première fois.

Ce fut dans une sombre échoppe de cordonnier, où il travaillait comme apprenti, que s'éveilla la sensibilité du jeune orphelin. Il a subi les coups de patrons alcooliques, et parmi l'odeur forte des cuirs, l'impressionnable et taciturne petit garçon percevait déjà dans un vague instinct le sentiment de l'iniquité sociale. <...> Oui, ce fut une opiniâtre existence que la sienne, une lutte indiscontinue pour la conquête du

7 La Presse, 27 mai 1905, rubrique «La semaine littéraire», p. 3.

8 Séménoff E. Gorki agitateur, La Revue blanche, rubrique «La quinzaine. Notes politiques et sociales», Janvier I902, pp. 617-619. 
pain, un calvaire obscur et prolongé, une ascension entêtée de la brute asservie vers un état d'intelligence. Ce chemineau, ce trimardeur, ce vagabond au ventre creux, a connu les drames de la faim et les tragédies de l'alcool. Il a dormi avec des assassins, dans des bouges infects, auprès de poêles nauséabonds. Il a assisté à des agonies lamentables, il a vu de ses yeux de femmes mourir de froid. Il fut le spectateur de toutes les lâchetés, de toutes les ignominies et déchéances fatales.

Son œuvre se ressent de tout cela. Les Vagabonds, Dans les Bas-Fonds, Wania, sont le récit sans ornement, le martyrologe amer, coloré, vigoureux, et âpre des multiples misères de l'immense prolétariat slave. <...>

Aussi n'est-il pas surprenant que la représentation des Bas-Fonds, au théâtre artistique de Moscou, ait pris tout à coup l'importance d'un événement considérable. La venue de Gorki aura-t-elle sur les destinées de l'empire moscovite une influence analogue à celle de Jean-Jacques sur la monarchie française ? Rousseau révéla la nature à des gens qui ne l'avaient jamais regardée. Il est possible que Gorki soit le prophète de la misère, que cet être primitif et neuf conquière l'aristocratie russe à la notion de justice, qu'il la touche dans son égoïsme <...>.

Quoi qu'il en soit, il existe de nombreuses similitudes entre l'existence de Rousseau et celle de Maxime Gorki. Tous deux connurent les conditions les plus infimes, menèrent la vie la plus accidentée et s'ils sont devenus de grands écrivains, ce fut comme malgré eux et par des voies inattendues.

Tout cela ne prouve-t-il pas que la meilleure école littéraire c'est encore celle de la vie ${ }^{9}$

Quelques mois plus tard, à l'occasion du lancement par les frères Margueritte du «Prix de Rome des écrivains», Le Blond livre ses réflexions à propos des conditions qui doivent favoriser l'apparition d'un grand écrivain:

$\mathrm{Au}$ lieu de faciliter les débuts des nouveaux écrivains, il serait bon de leur opposer tous les obstacles. Les grands mouvements d'idées naissent de la persécution et les génies véritables se trouvent exaltés par l'hostilité du milieu où ils vivent.

Ne perdons pas de vue l'exemple de la littérature russe, si véhémente et si forte, qui a communiquéà notre vieille Europe un frisson nouveau de justice et de pitié! est-ce qu'il a connu les faveurs du gouvernement russe, l'auteur des Bas-Fonds, Maxime Gor- 
ki, lequel a exercé les tâches les plus pénibles et les plus sordides? Il s'est fait tout seul, celui-là! et Dostoïewski, l'immortel romancier de l'Idiot et de la Maison des Morts? ${ }^{\text {Io }}$

La légende qui s'est créée, en France comme ailleurs, autour de Gorki est telle que la moindre apparition de son nom dans la presse étrangère trouve un écho à Paris, dans les rubriques consacrées à la «revue des revues». Dans le quotidien $L a$ Presse du 8 septembre I902, à la rubrique «Le théâtre», on lit, sous le sous-titre «Le théâtre à l'étranger: (Anvers, Odessa, Moscou, Dresde)»: «Maxime Gorki, le grand écrivain russe, vient d'écrire, pour être représenté cet hiver à Moscou, un nouveau drame intitulé "Dans le Bas-Fond” (sic), œuvre terriblement réaliste et qui fera, diton, sensation ${ }^{\text {II }}$. Gorki attire l'attention au point de faire l'objet d'une brève alors que le spectacle dont il est question n’a pas encore été monté, et que personne, en tout cas dans le monde de la presse française, n'en a même encore lu le texte. Le seul fait que la pièce existe et la rumeur lointaine, au delà des frontières, suffisent à susciter l'effervescence en France.

Les périodiques français font état des œuvres que Gorki a, parait-il, simplement l'intention d'écrire, alors que, quelquefois, ces projets ne se réalisent pas. En février 1903, dans une rubrique fourre-tout figurant en première page de la Presse, après un article sur l'assurance contre l'appendicite en Grande-Bretagne, on trouve en caractères gras: «gorki. Annonce de la mise en répétition de "Au fond” ". La brève se termine ainsi: «Ajoutons que Gorki achève en ce moment d'écrire une nouvelle pièce Le Juif (sic) appelée à un grand retentissement $\gg^{12}$.

On pourrait croire que dans un tel climat de gorkolâtrie, Na dne aurait rapidement fait un tabac en France. Tel n’a pas été le cas.

\section{Le parcours tortueux de Na dne en France}

La pièce a suscité beaucoup d'intérêt en France dès l'automne I902, comme partout en Europe, mais elle a été montée avec beaucoup de retard. Les Français ne l'ont vue qu'à l'automne 1905, alors que, écrit le critique de théâtre André Nède, elle a déjà été jouée 600 ou 700 fois en Allemagne et Ioo fois en Italie ${ }^{\mathrm{I} 3}$. On se demande à quoi un tel décalage est dû.

Io Le Blond, Maurice. Le prix de Rome des écrivains, L’Aurore, 7 février I904, p. 2.

II Senner Gaston. La Presse, rubrique «Le théâtre», 8 septembre I902, p. 3.

I2 La Presse, 8 février I903, p. I.

I3 Nède André. Dans les bas-fonds, rubrique «Avant-premières», Le Figaro, II octobre 1905, p. 4. 


\section{Une concurrence paralysante}

Le I2 janvier 1903, le correspondant du Figaro à Pétersbourg indique que Dans les bas-fonds est joué en Russie ${ }^{\mathrm{I}}$. Le 24 février, les lecteurs du journal apprennent que la pièce est interdite, ce qui probablement aiguise leur curiositér ${ }^{15}$. Dans l'Aurore, la décision du gouvernement russe est explicitement liée à la situation politique: les autorités ont voulu

ôter aux agitateurs politiques l'occasion que, d'après les rapports de police, la représentation de cette pièce devait leur fournir de provoquer des démonstrations perturbatrices parmi le public qui y assisterait.

D’assez nombreuses arrestations d'agitateurs ont été opérées pendant les dernières semaines à Saint-Pétersbourg et dans quelques autres villes de l'empire russe $^{\mathrm{I} 6}$.

Dans ce contexte, les journaux s'empressent de faire écho aux premières initiatives des traducteurs et des hommes de théâtre français. En mars I903, la Revue bleue commence à faire paraitre le texte de la pièce, dans une traduction d'Élie (ou Ilia) Halpérine-Kaminski. Dans plusieurs titres de la presse parisienne, on lit, repris mot pour mot d'un journal à l'autre, dans une série de brèves portant sur le théâtre:

M. Antoine a pris l'habitude de consacrer chaque année l'un de ses spectacles à l'ouvrage étranger qui lui paraît le plus significatif ou le plus intéressant dans le flot de la production européenne de l'année à l'étranger. Cette année, il a fait choix du nouveau drame de Gorky les Bas-Fonds, dont M. Halpérine-Kaminsky lui a remis le manuscrit. On va s'occuper immédiatement de la distribution et de la mise en scène ${ }^{\mathrm{I} 7}$.

Le projet de mise en scène des Bas-fonds par André Antoine répond au désir longtemps inassouvi du public de simplement découvrir une pièce de Gorki jouée en français. Ce spectacle devait être une première dans la réception du théâtre de Gorki en France. Les Petits-bourgeois (Meščane) avaient bien été joués en 1902 à Pa-

I4 Oleg. Lettre de Saint-Pétersbourg, Le Figaro, I2 janvier 1903.

I5 Argus. Nouvelles diverses, Le Figaro, 24 février 1903.

I6 Un drame de Gorki interdit, L’Aurore, 24 février I903, rubrique «En Russie».

I7 La Presse, 20 mars 1903, p. 3. 
ris au Nouveau-Théâtre, avec l'actrice Lydia Iavorskaïa en tête de distribution, mais en russe. On trouve une critique du spectacle par Emmanuel Arène dans le Figaro du 2I juin 1902. Le public disposait de la traduction de Séménoff et Smirnoff, qui venait tout juste de sortir, ce qui pouvait l'aider à comprendre le spectacle, mais tout de même, l'obstacle de la langue restreignait forcément la portée de l'événement ${ }^{18}$. On peut penser que si le public de cette époque, à Paris comme ailleurs n’a pas vu les Petits-bourgeois en français, malgré l'existence d'une traduction, c'est que la pièce a été bientôt évincée par l'arrivée des Bas-fonds. André Nède écrit en 1905 que les Petits-bourgeois ne sont 《guère connus en Europe ${ }^{19}$.

Antoine n’a pas monté les Bas-fonds. L'annonce du spectacle dans la presse a été immédiatement suivie par la diffusion d'un avertissement d'Eugène Séménoff, auteur lui-même d'une traduction de la pièce, alors sur le point de paraître, et présentée comme destinée au théâtre ${ }^{20}$. La fin de l'ouvrage indique «achevé d'imprimer le 30 mars I903». Le Figaro du I6 mars I903 annonce: «Les Bas-fonds < ..> viennent d'être traduits par notre confrère M. E. Séménoff en vue d'une adaptation française. M. Séménoff est en pourparlers avec un théâtre des boulevards pour les représentations des Bas-Fonds à Paris». Séménoff menaçait de traîner en justice quiconque se servirait à la scène d'une autre traduction que la sienne, selon lui la seule licite, c'est-à-dire respectueuse des droits que la maison d'édition allemande Marchlewsky détenait sur les œuvres de Gorki à l'étranger.

Le Figaro publie la lettre suivante d'Eugène Séménoff:

«Vous annoncez aujourd'hui la réception par M. Antoine de la pièce de Gorki les Bas-Fonds. Voulez-vous avoir l'obligeance extrême de prévenir les directeurs de thêâtre français et autres intéressés dans la question que les éditeurs de Gorky ont cédé tous les droits sur les Bas-Fonds en Europe, à la maison d'éditions (sic) étrangères Marchlewsky et Co de Munich. Cette dernière a publié le texte russe à Munich le 5 janvier dernier, deux mois avant son apparition en Russie.

I8 Gorki M. Les Petits-bourgeois, trad. d'Eugène Séménoff et E. Smirnoff, Paris, éditions du Mercure de France, I902. L'initiale «E.» Smirnoff n’a, semble-t-il, pas de développement, car il s'agit d'un pseudonyme (celui d'Èmmanuil Gurevič), comme, d'ailleurs, dans le cas d'Eugène Séménoff (Solomon Kogan). La mention «achevé d’imprimer» porte la date du I5 juin I902.

I9 Nède A. Dans les bas-fonds, rubrique «Avant-premières», Le Figaro, i octobre i905, p. 4.

20 Gorki M. Dans les bas-fonds, traduction d'Eugène Séménoff, Paris, Société du Mercure de France, I903. La fin de l'ouvrage indique «achevé d'imprimer le 30 mars I903». 
D’après la convention de Berne et le Code français, cette édition russe donne le droit surtoutes les traductions des Bas-Fonds, à la seule maison Marchlewsky. Je suis le seul en France qui ait ce droit. Tous les autres traducteurs des Bas-Fonds et leurs éditeurs, ainsi que les directeurs de théâtre, se verront en conséquence intenter des procès par ladite maison d'édition.

En confrère et Parisien, je les préviens. D’ailleurs, le Mercure de France a déjà annoncé ma traduction il y a plus de six semaines ${ }^{2 \mathrm{~T}}$.

Or précisément, la traduction de Halpérine-Kaminsky, sur laquelle devait travailler André Antoine, contournait délibérément Marchlewsky²2. Le metteur en scène a renoncé à poursuivre le projet de monter les Bas-fonds, mais Halpérine-Kaminsky, lui, dont la traduction avait déjà paru en revue, a préféré aller en justice. Il se prévalait de l'accord tacite de Gorki lui-même, et contestait la réalité des droits de Marchlewski sur sa traduction.

Les positions des deux parties sont largement exposées dans la presse en mars $1903^{23}$. Elles sont récapitulées à la rubrique «Échos» des numéros du Mercure de France parus après le procès. Halpérine-Kaminsky déclare qu'il s'estimait couvert par le silence de Gor'kij, qu'il avait, écrit-il, «avisé» de son intention de donner la pièce à jouer à Antoine ${ }^{24}$. Selon lui, Marchlewsky et Cie n’auraient pu arguer de leurs droits sur la traduction de la pièce que si le texte en était paru initialement dans l'un des pays couverts par la Convention de Berne. En effet, en Russie, le droit de traduction tombe, à l'époque, dans le domaine public dès le jour de la première publication. Or, affirme Halpérine-Kaminsky, $\mathrm{Na}$ dne avait été publié d'abord à Saint-Pétersbourg. Cette démonstration reposait sur le fait que le visa de censure de la cinquième édition russe de la pièce (d'après laquelle avait été faite la traduction) portait une date antérieure à la sortie du texte en Allemagne. Bien qu'il soit courant que la publication d'un texte soit plus tardive que la date figurant sur son visa de censure, Halpérine-Kaminsky pouvait espérer établir que la première édition russe était bien antérieure à l'édition allemande. La correspondance de Gorki montre que l'écrivain n'avait donné à Halpérine-Kaminsky aucun accord, même informel, pour que ce dernier publie hors droits une traduction de $\mathrm{Na}$ dne. Dans un télégramme à

2I Le Figaro, 20 mars 1903, p. 5.

22 Gorki M. Dans les bas-fonds, traduction du russe par E. Halpérine-Kaminsky, La Revue bleue,

$\mathrm{n}^{0}$ II à I4 (quatre numéros hebdomadaires consécutifs de à partir du I4 mars I903).

23 Halpérine-Kaminsky E. Lettre à la rédaction du Figaro, Le Figaro, 25 mars 1903, p. 4.

24 Le Mercure de France, 15 novembre 1905, p. 315. 
Konstantin Piatnitski, Gorki indique que Halpérine-Kaminsky lui a adressé sa traduction de $\mathrm{Na}$ dne et «demande l'autorisation» de la faire jouer par Antoine. La date indique que Gorki a reçu la traduction de Halpérine-Kaminsky alors qu'elle était en cours de publication dans la Revue bleue, et après la mise en garde de Séménoff. Dans une lettre du même jour à Piatnitski, Gorki dit avoir «appris» à le lecture de la presse que Marchlewski avait l'intention de faire un procès à Halpérine-Kaminsky, et précise que la lettre reçue de ce dernier, dans laquelle il sollicite l'autorisation de traduire Na dne «pourra servir» à Marchlewsky [I, T. 3, c. I67]. Le 29 mars I903, Pâtnickij envoie à Marchlewsky plusieurs pièces de nature à étayer sa position contre Halpérine-Kaminsky [I, T. 3, c. 392-393].

L'affaire a été longuement instruite, et, en fin de compte, quand le procès s'est ouvert, en juillet I905, le tribunal nel'a pas jugée au fond. Constatant que Marchlewky n’avait pas satisfait aux obligations de la procédure, il a refusé de trancher. Les plaignants, MM. Helphand et Marchlewsky, ont été déboutés de leur action pour n'avoir pas versé dans les délais impartis le cautionnement de 2000 francs que, à la demande faite par Halpérine-Kaminsky, en sa qualité de naturalisé Français, le tribunal avait exigé d'eux, en leur qualité d'étrangers. Fort de cette non-décision, dans laquelle il voyait une reconnaissance de la légalité de sa traduction, Halpérine-Kaminsky a fait jouer la pièce, au théâtre de «l'EEuvre», cette fois, dans une mise en scène de Lugné-Poë, avec des décors d’Alexandre Bailly (I866-I947), peintre-décorateur, élève, puis associé de Marcel Jambon (I848-I908), et très connu dans le monde du théâtre [2]. Séménoff a eu beau chercher à prouver la mauvaise foi de Halpérine-Kaminsky dans les colonnes du Mercure de France, le spectacle s'est tenu à l'automne I905, avec un décalage de deux ans et demi par rapport au projet initial.

On peut se demander si ce retard n'était pas de nature à diminuer l'intérêt des Français pour la pièce. Compte tenu du rythme auquel Gorki écrivait pour le théâtre à cette époque, les Bas-fonds ne risquaient-ils pas d'apparaître comme «du réchauffé»? En octobre 1905, le Mercure de France évoque à la même page la tenue du procès intenté à Halpérine-Kaminski et l'achèvement des Barbares (Varvary), alors que, précise la revue, les Enfants du soleil (Deti solnca) ne sont pas encore traduits. Ces œuvres nouvelles n'allaient-elles pas éclipser les Bas-fonds comme les Bas-fonds avaient éclipsé les Petits-bourgeois? La question se pose d'autant plus que le public parisien avait déjà vu une pièce vaguement semblable aux Bas-fonds, susceptible de remplacer les Bas-fonds, et cette pièce ne s'était pas montrée à la hauteur de ses attentes. 


\section{Wania, faible ersatz des Bas-fonds}

Loccasion fait le larron. Voyant que la mise en scène de la pièce dans la traduction de Halpérine-Kaminsky était gelée pour une durée qui, pouvait-on prévoir, serait longue, étant donnés le «maquis de la procédure» (l'expression est de Séménoff) et la lenteur avec laquelle les affaires judiciaires étaient traitées par les tribunaux français, Serge Persky a eu l'idée de remplir le vide ainsi créé. Traducteur d'un récit de Gorki, paru en 1902 chez Perrin sous le titre Wania (il s'agit en fait de Prestupniki), dans un recueil qui reprenait le même nom, Persky a tiré une pièce de ce texte et l'a fait jouer au théâtre de l'Odéon ${ }^{25}$. La confusion entre les deux Wania (le récit de Gorki traduit par Persky et la pièce de Persky tirée du récit) a permis à ce dernier de faire passer sa pièce pour une pièce de Gorki, ce qui lui promettait d'attirer l'attention du public, en profitant de son immense célébrité. Les informations publiées par la presse sont assez embrouillées. Le titre de la pièce est orthographié dans le même journal de manière variable, avec ou sans «W». On lit d'abord au début du mois de juin 1903 que «[d]ans quelques jours, l'Odéon donnera la première représentation de Vania, pièce tirée d'un roman de Gorki par le comte Prozor $\langle\ldots\rangle \gg^{26}$. Trois jours plus tard, on apprend que «[1]'Odéon ne donnera que trois représentations de Wania, la première œuvre du grand écrivain russe Maxime Gorki, adaptée à la scène française par S.M. Persky, le traducteur habituel de Gorki ${ }^{27}$. Les précisions apportées par le Figaro, visiblement mieux informé, ne semblent pas avoir éclairé grand monde sur l'identité de l'auteur de Wania. Robert de Flers commençait ainsi sa longue critique:

Odéon: Wania (histoire d'un crime), pièce en deux actes et quatre tableaux d'après Maxime Gorki, par M. Perski;

Il importe de déclarer, tout d'abord, que Maxime Gorki, le grand écrivain russe $<\ldots>$ n'a presque rien à voir en cette affaire.

M. Perski, son admirateur trop dévoué et son fidèle traducteur, a eu l'idée plutôt inutile de découper dans une nouvelle du maître un petit drame en quatre $\operatorname{actes}^{28}$.

25 Gorky M. Wania (histoire d'un crime), dans: Wania. Récits de la vie russe, traduits par S.M. Persky, Perrin, 1902.

26 L'Aurore, 5 juin I903, p. 4.

27 L'Aurore, 8 juin 1903, p. 4.

28 Flers, Robert de «Les théâtres», Le Figaro, I2 juin I903. Deux semaines plus tôt, le Figaro écrivait que Vania était «le titre provisoire» d'«un drame de Gorki» (Le Figaro, 23 mai 1903). 
Deux semaines plus tôt, le Figaro écrivait que Vania était «le titre provisoire» d'«un drame de Gorki» ${ }^{29}$. Ailleurs dans la presse, Wania (la pièce) continue couramment à être considérée comme une œuvre de Gorki. C'est le cas dans l'article de Le Blond cité précédemment. La première critique parue dans la Presse portant sur le spectacle ne mentionne même pas le nom de Persky.

Lauteur, qui a mis en scène des vagabonds, s'y connaît en la matière. Gorki n'a que trente-six ans et il fut apprenti cordonnier, peintre d'icones, marmiton, aide-jardinier, cuisinier $<\ldots>>^{30}$.

En tête de la chronique publiée par le quotidien deux jours plus tard, on lit: «Odéon. Wania. Drame en quatre tableaux de Gorki. Traduction de M. Persky». L'insipide adaptation de Persky se confond avec les Bas-fonds. Le glissement d'une pièce à l'autre est facilité par l'asile de nuit, lieu emblématique de «la célèbre pièce», où se réfugient aussi les personnages de Wania.

Le grand succès du jour, dans les théâtres, est la nouvelle pièce de l'auteur à la mode, Gorki: les Bas-Fonds. C'est une suite de tableaux réalistes. La scène se passe dans un asile de nuit où les filles, les déclassés et les misérables se rencontrent ${ }^{31}$.

L'expression elle-même, «asile de nuit» renvoie au titre de la version allemande de la pièce, Nachtasyl (Asile de nuit), que les Français férus de théâtre connaissaient par les échos à l'actualité des scènes européennes parus dans les périodiques $^{32}$.

Wania a été éreinté par la critique des journaux. Citons, parmi d'autres, la chronique de Louis Artus, dans la Presse. Après avoir résumé l'action de la pièce, le critique livre son avis:

Supposez que vous ou moi nous ayons eu l'idée d'écrire là dessus une pièce en quatre actes et de la porter à l'Odéon, vous pensez que l'on eût ri au nez! Seulement voilà, c'est traduit du russe. Ce médiocre fait-divers que rien n'excuse, qui n'est relevé

29 Le Figaro, 23 mai 1903, p. 4.

30 La Presse, «La vie au théâtre»: «À l'Odéon», I3 juin I903, p. 3.

3I Oleg. Lettre de Saint-Pétersbourg, Le Figaro, I2 janvier 1903.

32 Le Figaro, rubrique «Courrier des théâtres», I9 mai I903, p. 4. 
par aucune idée générale, aucun aperçu nouveau, n’est même pas défendu comme il l'est peut-être dans son pays d'origine par quelque beauté littéraire; la traduction ou adaptation de M. Persky est plate et ne décèle aucune originalité.

Alors?

Alors, je vous l'ai dit, Wania est signé d'un nom étranger, et, quelque invraisemblable que cela paraisse, il semble qu'il n'y ait pas de titres meilleurs auprès du directeur subventionné de notre second théâtre national33.

La critique parue dans le Figaro est pleine d'ironie. Le chroniqueur explique que l'action se passe parmi de très pauvres gens, ce qui est pain béni pour le metteur en scène, car les décors coûtent moins cher à fabriquer que ceux d'une pièce ordinaire: le bénéfice tiré de ce genre de spectacle a toute chance d'être intéressant. Il précise qu'il y avait un vrai cheval sur la scène, et que le bruit de ses sabots sur le plancher ne laissait plus aucun doute à ceux qui se demandaient qu'il y ait un soussol sous la scène.

On comprend que la diversion opérée par ce terne Wania n’a pas rassasié les Français de leur faim des Bas-fonds. Les circonstances politiques ont encore aiguisé leur appétit de voir la pièce, la vraie, enfin jouée.

\section{Les Bas-fonds de Lugné-Poë}

Après deux ans d'attente, l'actualité éditoriale très embouteillée de Gorki et le coup d'épée dans l'eau de Wania n'ont pas amoindri l'attrait des Bas-fonds. Tout au contraire, la période qui sépare la tenue du procès Halpérine-Kaminsky et la première du spectacle est courte (deux mois et demi), ce qui est plutôt le signe de l'impatience des milieux du théâtre parisien à rattraper le temps perdu.

\section{Les Bas-fonds en I905: une pièce «actuelle»}

L'intérêt pour les Bas-fonds était stimulé par les informations d'ordre biographique que la presse avait diffusées tout au long de l'année I905 au sujet de Gorki. Les lecteurs de la presse avaient été tenus en haleine par une succession de nouvelles alarmantes et contradictoires. Dès le début des événements de janvier 1905, l'Aurore avait présenté Gorki comme «le grand écrivain qui s’[était] courageusement 
mis à la tête d'une organisation de combat» ${ }^{34}$. Sous le titre général «L'agitation en Russie. - La guerre. - L'après-midi sportif», sur six colonnes, la Presse du 20 janvier 1905 avait annoncé en première page, en gros caractères gras: «Dernière heure. Gorki malade», et avait précisé: «On mande de Saint-Pétersbourg: On annonce que Maxime Gorki est atteint du typhus qui règne en ce moment parmi les détenus de la forteresse Pierre-et-Paul». Tel jour on apprenait que l'écrivain avait été arrêté, tel autre jour les journaux se faisaient l'écho de la rumeur de son exécution prochaine, puis de sa libération. En février, plusieurs quotidiens (par ex. le Temps, Gil Blas), indiquaient que le sort de Gorki avait été évoqué dans une interview que le Grandprince Vladimir Alexandrovitch avait accordée à un journal britannique. Le haut personnage avait assuré que la nouvelle selon laquelle Gorki allait être pendu était «absurde», mais l'inquiétude persistait ${ }^{35}$. En avril, dans l'Aurore, alors que le procès à huis-clos de l'écrivain était annoncé comme imminent, Bernard Taft écrivait:

Le huis-clos pour Gorki c'est la condamnation fatale. Gorki, pour le gouvernement du tsar, n'est pas qu'un révolté, il n'est pas que l'homme qui a osé se dresser contre l'autocratie toute-puissante et meurtrière. Il est un symbole, il est l'incarnation même de la révolte. C'est pour cela qu'il faut l'abattre. <...> Donc Gorki jugé à huisclos, c'est Gorki condamné, et condamné à mort ${ }^{36}$.

Les informations qui paraissent d'un jour à l'autre sur la préparation du spectacle mêlent constamment le théâtre et le sort de Gorki, qui est en train de se jouer.

Tandis qu'en Russie se prépare le procès de Maxime Gorki, le fameux écrivain révolutionnaire, la direction de «l'Euvre» presse les répétitions de Dans les bas-fonds traduction de M. Halpérine-Kaminsky37.

Quelques jours avant la première des Bas-fonds, le Figaro rapportait les propos du Premier ministre Sergueï Witte en personne, selon lequel la sortie de prison de Gorki était liée à son rayonnement en tant qu'artiste ${ }^{38}$. Monter la pièce, assister au spectacle, c'était renforcer le capital symbolique de Gorki, et œuvrer concrète-

34 Gayrault-Richard, Alfred-Léon, La petite République, cité dans l'Aurore, 25 janvier 1905, p. 3.

35 La situation politique en Russie, Le Temps, 3 février I905, p. I-2.

36 Taft Bernard. Pour Gorki, L’Aurore, 25 avril I905, p. 2.

37 Le Figaro, rubrique «Courrier des théâtres», 2 octobre 1905.

38 Strozzi. Dans les Bas-fonds de Maxime Gorki (éditorial), Gil Blas, 6 octobre I905, p. I. 
ment à le sauver. Les Bas-fonds sont l'œuvre qui symbolise le mieux l'art et la personne de Gorki: Gorki, c'est les Bas-fonds.

Ce nom, «les bas-fonds», extrêmement évocateur, revient fréquemment dans les journaux bien avant l'automne 1905. Le fait qu'à peu près personne ne sache exactement ce qu'est la pièce ainsi nommée ne retire rien à la fascination particulière qu'elle exerce sur les Français presque aussitôt que son existence est annoncée. Gorki, devenu le héraut de la révolution, est appelé «le grand écrivain», le grand romancier russe», ou «l'auteur des Bas-fonds». Si, dans la presse, on cite un texte de Gorki, c'est en général les Bas-fonds. S'agit-il de savoir comment devenir écrivain? L'Aurore répond: «Voici la recette, telle que la préconisent du moins l'œuvre et le talent de Maxime Gorki, l'auteur des Bas-fonds» ${ }^{39}$. Plus que tout autre texte de Gorki, la pièce est l'emblème de toute son œuvre et, plus largement, de ses positions révolutionnaires, parce que son titre renvoie à la réalité sociale explosive de la Russie.

La bourgeoisie a enveloppé le peuple de ses tendances grises et visqueuses, mais elle sent sous cette couche mince et froide bouillonner les instincts hostiles, elle devine la pensée hardie et implacable qui allume et grandit pour consumer le mensonge séculaire.

Cette poussée d'énergie qui monte des bas-fonds fit naître dans la bourgeoisie une terreur angoissante de la vie $4^{40}$.

Le mot «bourgeoisie», qui ici traduit «meřčnstvo», établit entre la situation russe et la situation française une certaine proximité. Par delà toutes les différences, les lecteurs français, en tout cas ceux de l'Aurore, peuvent se reconnaître dans ce qui leur est dépeint de la Russie en 1905.

\section{Un événement culturel}

L'aura exceptionnelle de Gorki, la notoriété de Lugné-Poë, l'enthousiasme de la presse, l'impatience du public garantissaient à l'avance le succès des BasFonds. L'Aurore écrit:

M. Lugné-Poë a tenu à entourer de tout l'éclat possible ces représentations. Elles provoqueront certainement un mouvement de sympathie en France, auprès de

39 «Pour devenir écrivain!», L’Aurore, 6 octobre I903.

40 Persky S. La crise russe. Maxime Gorki et la révolution russe, L’Aurore, 23 novembre i905. 
tous ceux que le sort du célèbre écrivain, dont le procès va commencer en Russie, peut intéresser ${ }^{4}$.

La veille de la première, la probabilité («certainement») s'est changée en certitude:

Nous pouvons d'ores et déjà dire que cette série de représentations du chefd'œuvre de l'écrivain russe comprendra une soirée exceptionnelle qui constituera un véritable événement littéraire et artistique ${ }^{42}$.

Les journaux ont assuré une couverture serrée du travail de Lugné-Poë sur le Bas-fonds et de tout ce qui l'entourait. Les péripéties qui marquent la préparation du spectacle y sont évoquées presque quotidiennement. La distribution est annoncée le 30 septembre. Quelques jours plus tard, la presse lève le voile sur les décors, «qui seront des plus pittoresques et qui, brossés d'après des documents authentiques, reconstitueront exactement ceux qui furent exécutés pour les représentations de la pièce au théâtre artistique de Moscou Stanislawski en I902»43.

Des conditions particulières ont encore accentué l'importance de l'événement. Il y a d'abord eu, aux derniers jours qui ont précédé le spectacle, une incertitude au sujet des dates de la générale et de la première. Le 26 septembre, les journaux annoncent qu'elles sont fixées au 9 et au Io octobre, mais au bout de trois ou quatre jours, ces dates sont à nouveau indiquées, cette fois, comme «irrévocables», ce qui paradoxalement semble faire écho à une incertitude, peut-être à une rumeur de report de la générale et de la première ${ }^{44}$. Et de fait, deux jours avant la tenue annoncée de la générale, la presse informe le public de ce que,

étant donnée l'abondance de premières et par déférence pour la critique, M. Lugné-Poë a décidé de reculer de quelques jours les représentations de Dans les bas-fonds, le fameux drame de Maxime Gorki ${ }^{45}$.

4I L'Aurore, 26 septembre I905, p. 4.

42 L'Aurore, rubrique «Courrier des théâtres», Io octobre 1905, p. 4.

43 Gil Blas, rubrique «Courrier des théâtres», 2 octobre 1905, p. 3.

44 Le Figaro, rubrique «Les théâtres», 29 septembre i905, p. 5.

45 Le Figaro, 7 octobre I905, p. 4. 
La générale et la première ont bien eu lieu le II et le I2 octobre I905, mais les surprises n'ont pas pour autant cessé.

Les représentations des iI et I2 octobre n'ont pas complètement rempli leur fonction de générale et de première des Bas-fonds. En effet, si l'on ose dire, une deuxième première s'est tenue une dizaine de jours plus tard. Cet étrange bégaiement de «l'événement théâtral de la saison» est dû à l'entrée tardive, non prévue officiellement mais en réalité très attendue, de la grande tragédienne italienne Eleonora Duse dans la distribution. Dès le 8 octobre, Gil Blas avait écrit:

La Duse, en ce moment à Paris, assiste tous les soirs aux répétitions de «'CEuvre», au Nouveau-Théâtre.

On sait que le nouveau spectacle est composé des Bas-Fonds, de Gorki, et il est à peu près certain que la grande comédienne italienne jouera un rôle à l'une des représentations de la pièce ${ }^{46}$.

Eleonora Duse était assez célèbre en France pour que la presse signale sa présence avec toute sa troupe à Vichy au mois d'août $1905^{47}$. Il se trouve que son imprésario en France n'était autre que Lugné-Poë.

Le I2 octobre, dès le lendemain de la première «première», le public pouvait découvrir en première page du Figaro que la Duse avait d'abord refusé d'interpréter l'un des rôles de la pièce, mais qu'elle s'était laissé convaincre de le faire par les acteurs de «l'EEuvre». Le I4, on apprenait qu'après avoir assisté à la pièce, la tragédienne avait demandé à Lugné-Poë de féliciter les acteurs. Le I6, son nom figure dans la distribution pour une représentation unique, la semaine suivante. L'Aurore explique que «depuis longtemps l'idée de jouer la tragique Vassilissa des Bas-fonds hantait Mme Eleonora Duse», et annonce: «Cette véritable première se trouve fixée au 23 courant» ${ }^{8}$. Le Figaro justifie l'usage apparemment impropre du mot «première» en précisant que la Duse se préparait à interpréter le rôle de Vassilissa en Italie, mais que le rôle serait bel et bien créé à Paris le 23 octobre ${ }^{49}$.

Les journaux ont annoncé cette représentation exceptionnelle avec plus d'insistance qu'à l'accoutumée. On lit à la première page du Figaro:

46 Gil Blas, rubrique «Courrier des théâtres», 8 octobre 1905, p. 3.

47 Le Figaro, rubrique «Courrier des théâtres», I9 août I905, p. 5.

48 L'Aurore, I6 octobre I905, p. 4. C'est moi, SR, qui souligne.

49 Eleonora Duse \& Suzanne Després dans les Bas-fonds, Le Figaro, I6 octobre I905, p. 5. 
L'intérêt de voir l'illustre tragédienne jouer pour la première fois avec une troupe française s'augmente de ce que la soirée sera unique. Aussi les places sontelles prises d'assaut au Nouveau-Théâtre ${ }^{\circ}$.

La presse, qui avait longtemps évoqué les résonances politiques des Basfonds, prévoyait maintenant que le spectacle serait suivi par le Tout-Paris. L'écrivain va-nu-pieds, le révolutionnaire que, paraît-il, le tsar voulait pendre, plaisait aux marquises et aux barons. Au cours de l'été 1905, la rubrique mondaine du Figaro se faisait l'écho du «vif succès [d'] Asile de nuit» à Baden-Baden ${ }^{51}$. Le 22 octobre, le journal écrit que «le Tout-Paris artistique et mondain se fera un devoir d'assister» à la représentation du lendemain ${ }^{52}$. On comprend néanmoins que le gratin parisien, certes conquis d'avance, se demandait tout de même si le spectacle où allait jouer la Duse ne serait pas le mariage de la carpe et du lapin.

Depuis deux jours ont commencé au Nouveau-Théâtre les répétitions de la mise au point des Bas-Fonds avec Mmes Eleonora Duse et Suzanne Després. C'est un spectacle des plus curieux que celui de ces répétitions dans la clarté blême de la scène vide où, enveloppée d'un grand manteau, l'illustre tragédienne «enchaine» ses répliques avec celles de ses camarades de «'Euvre». On sait que Mme Eleonora Duse jouera le rôle de Vassilissa en italien, et ce n'est point sans un étonnement mélangé d'un peu d'inquiétude que les artistes français attendaient l'effet de ces répétitions. L'expérience a été concluante et n'a pas manqué d'émerveiller les uns et les autres. La langue si admirablement nuancée que parle Mme Eleonora Duse s'harmoniste de la façon la plus inattendue avec celle des autres interprètes et contribue à former avec elle une surprenante homogénéité. Cette répétition a pleinement rassuré M. Lugné-Poe sur la parfaite interprétation des Bas-Fonds, qui obtiendront demain sur la scène du Nouveau-Théâtre un succès sans précédent53.

Le public a-t-il été, lui aussi, «rassuré» à la vue du spectacle? L'étude de la critique des Bas-fonds de Lugné-Poë n'entre pas dans le cadre de cet article, mais nous pouvons toutefois citer un dernier extrait du Figaro. Le lendemain de la soi-

50 Le Figaro, rubrique «Échos» («À travers Paris»), 2I octobre I905, p. I.

5I Villes d'eau, rubrique «Le Monde \& la Ville», Le Figaro, I8 juillet I905, p. 2.

52 Le Figaro, rubrique «Courrier des théâtres», 22 octobre I905, p. 4.

53 Le Figaro, rubrique «Courrier des théâtres», 22 octobre 1905, p. 4. 
rée où a joué la Duse, on découvre dans la chronique humoristique du quotidien, signée «Un monsieur de l'orchestre», la liste des figures du Tout-Paris aperçues dans la salle. Le monsieur s'étonne qu'il y ait peu d'Italiens, mais beaucoup d'Anglais et «d'Américains authentiques», décidés à «ne pas manque cette rare attraction: la Duse!».

Et voilà pourquoi, hier soir, au Nouveau-Théâtre, où une illustre comédienne italienne jouait une pièce russe traduite en français, on parla surtout anglais dans les couloirs!

Une des curiosités de cette représentation consistait en ce fait que Mme Eleonora Duse devait seule dans cette pièce parler italien. L'effet de cette «polyglottie» fut, on s'en doute, assez étrange. On se rendit compte de ce que devait être jadis une représentation théâtrale dans la tour de Babel, l'ancêtre de tous les instituts polyglottes. Mais c'est le propre des grands génies dramatiques de se faire comprendre presque sans le secours de la parole, par la seule magie du geste et de la physionomie ${ }^{54}$.

Le nom de la Duse est resté attaché à la première mise en scène française des Bas-fonds. La traduction de Halpérine-Kaminski, parue fort à propos le I4 octobre 1905 chez Fasquelle, est dédiée à la Duse et à Lugné-Poë. Les rééditions sont agrémentées de photos tirées du spectacle, qui montrent les décors imitant ceux du Théâtre d'Art de Moscou.

54 Un monsieur de l'orchestre, rubrique «Nouvelles diverses» («La soirée»: «Au théâtre de l'(Euvre»), Le Figaro, 24 octobre I905, p. 4. «Villes d'eau», rubrique «Le Monde \& la Ville», Le Figaro, I8 juillet I905, p. 2. 


\section{References}

I Gor'kii M. Poln. sobr. soch.: Pis'ma: v 24 t. [Complete works. Letters: in 24 vols.] Moscow, Nauka, IMLI RAN Publ., I997. (In Russ.)

2 Wild N. Décors et costumes du XIXe siècle, tome 2. Paris, Éditions de la Bibliothèque nationale de France, I993, édition numérique corrigée, 20I4. Available at: http://books. openedition.org/editionsbnf/858?lang=fr (Accessed 03.03.20I7) (In French) 


\section{GORKI ET LE THEATRE D'ART DE MOSCOU: DES AFFINITES SELECTIVES}

(C) 20I8. M.-Ch. Autant-Mathieu

This is an open access article distributed under the Creative Commons Attribution 4.0 International (CC BY 4.0)

CNRS, EUr'ORBEM, Paris, France Envoyé le 1o janvier 2018 Publiéle 25 mars 2018

DOI: I0.22455/2500-4247-20I8-3-I-I78-I95

Annotation: Gorki a débuté comme dramaturge au Théâtre d'Art pour lequel il écrivit ses premières pièces, se trouvant en concurrence avec Tchekhov qui y était joué durant la même période. Ainsi, les deux directeurs Stanislavski et Nemirovitch-Dantchenko furent-ils confrontés à deux auteurs qui s'appréciaient mais dont les modes d'écriture divergeaient. La communication, qui n'est qu'une partie d'un travail plus global concernant les mises en scène de Gorki au Théâtre d'Art, se concentrera sur la façon dont les deux directeurs du Théâtre d'Art, dans leur biographies écrites en période soviétique, I926 pour Ma vie dans l'art et I936 pour Iz prošlogo (Extraits du passe), ont réécrit et embelli leur relation avec un écrivain qui leur a donné du fil à retordre, à la fois de par son engagement politique et de par la difficulté que les comédiens éprouvaient à jouer ses personnages. A partir du milieu des années I920, Gorki est apparu comme un protecteur du Théâtre d'Art qui va porter son nom dès les années I930. Dès lors, les deux directeurs ont gommé leurs divergences politico-esthétiques et cherché à se concilier Gorki qui, en, effet contribua à faire du MKHAT le phare de tous les théâtres de l’URSS, appuya Stanislavski pour la fondation de son dernier studio lyrico-dramatique et le soutint dans l'écriture et la publication de son Système de formation de l'acteur.

Mots clés: Théâtre d'Art de Moscou, A. Tchekhov, K. Stanislavski, V. Nemirovitch-Dantchenko, Ma vie dans l'art. Iz prošlogo, politique culturelle soviétique, écriture tendancieuse, Les Bas-Fonds, Les Petits Bourgeois, Les Estivants, Les Enfants du soleil.

Information sur l'auteur: Marie-Christine Autant-Mathieu, directrice de recherches au CNRS, directrice adjointe de l'unité CNRS-Paris Sorbonne EUR'ORBEM, 9 rue Michelet, 75006 Paris.

E-mail: autant.mathieu@wanadoo.fr 


\section{GORKY AND MOSCOW ART THEATRE: SELECTIVE AFFINITIES}

(C) 20I8. M.-Ch. Autant-Mathieu

CNRS, EUr'ORBEM,

Paris, France

This is an open access article

Received: January IO, 2018

Commons Attribution 4.0

International (CC BY 4.0)

Date of publication: March 25, 2018

Abstract: Gorky started his literary career as a playwright at the Moscow Art Theatre. He wrote his first plays for its troupe in competition with Chekhov whose plays were performed there during the same period. Thus, two Moscow Art Theatre directors, Stanislavsky and Nemirovich-Danchenko dealts with two authors whom they valued but whose approaches differed. My paper that forms part of a study concerning Gorky's collaboration with the Moscow Art Theatre, focuses on the way in which Stanislavsky and Nemirovich-Danchenko revised and embellished the history of their relationship with Gorky in their autobiographies both written in the Soviet period, My Life in Art (I926) and My Life in the Russian theatre (1936) respectively. In real fact, the relationship was problematic due to Gorky's political opinions and the difficulties that the actors encountered playing his characters. Since the middle of the I920s, Gorky became a defender of the Moscow Art Theatre and consequently, the two directors put their political and aesthetic contradictions aside and sought to reconcile themselves with Gorky who contributed to make the Art Moscow Theatre a model Soviet theatre. Besides, the writer supported Stanislavsky in founding an opera-dramatic studio in I935 and writing and publishing “The Stanislavsky System.”

Keywords: Moscow Art Theatre, Chekhov, Stanislavsky, Nemirovich-Danchenko, My life in Art, My Life in the Russian Theatre, Soviet cultural politics, biased writing, The Lower Depths, Small people, Summerfolk, The Children of the Sun.

Information about the author: Marie-Christine Autant-Mathieu, Director of Research at the CNRS, Associate Director of the Institute Eur'ORBEM (CNRS-Paris Sorbonne), 9 rue Michelet, 75006 Paris.

E-mail: autant.mathieu@wanadoo.fr 
УДК 821.І6І.І.о

ББК $83.3(2 \mathrm{Poc}=\mathrm{Pyc}) 6+$ $85.334(2)$

\section{ГОРЬКИЙ И МОСКОВСКИЙ ХУДОЖЕСТВЕННЫЙ ТЕАТР: ИЗБИРАТЕЛЬНОЕ СРОДСТВО}

(C) 2018 г. М.-К. Отан-Матье Национальный Центр научных исследований Францзии, Париж, Франиия Дата поступления статьи: Іо января 2018 г. Дата публикации: 25 марта 2018 г.

DOI: IO.22455/2500-4247-20I8-3-I-I78-I95

Аннотация: М. Горький дебютировал как драматург в Художественном театре, для которого он написал первые пьесы, находясь «де факто» в соревновании с А.П. Чеховым, произведения которого там ставились в то же время. Два директора театра - К.С. Станиславский и В.И. Немирович-Данченко - сотрудничали, таким образом, с двумя авторами, творческие подходы которых разнились. Настоящая статья представляет собой фрагмент глобального исследования, касающегося сотрудничества Горького с Художественным театром; она повествует о том, как Станиславский и Немирович-Данченко в своих биографиях, созданных уже в советский период («Моя жизнь в искусстве», І926; «Из прошлого», І936), значительно изменили свое отношение к писателю, которые изначально были весьма сложны - как из-за политической ангажированности Горького, так и из-за трудностей (преимущественно в актерской среде), возникавших в процессе постановок пьес. С середины І920-х гг. Горький оказывается защитником Художественного театра, а оба директора забывают о политических и эстетических разногласиях и стремятся помириться с ним. Горький же способствовал превращению МХАТа в образцовый театр СССР, впоследствии названный его именем, а также поддержал Станиславского в его стремлении основать опернодраматическую студию (I935) и обнародовать его «систему».

Ключевые слова: Московский Художественный театр, А.П. Чехов, К.С. Станиславский, В.И. Немирович-Данченко, «Моя жизнь в искусстве», «Из прошлого», советская культурная политика, тенденциозность, «На дне», «Мещане», «Дачники», «Дети солнца».

Информация об авторе: Мари-Кристин Отан-Матье - главный научный сотрудник Национального Центра научных исследований Франции, заместитель директора института EUR'ORBEM при НЦНИ и Пари Сорбонн, 9 рю Мишле, 75006 Париж.

E-mail: autant.mathieu@wanadoo.fr 
Dans le cadre plus vaste d'une relecture des relations entre Gorki et le Théâtre d'Art de Moscou (MKhAT) - une relecture que la célébration du $\mathrm{I}_{5} \mathrm{O}^{\mathrm{e}}$ anniversaire de la naissance de l'écrivain en 2018 vient encourager, je me limiterai ici à comparer l'image de Gorki dans les biographies des deux directeurs du Théâtre, parues en I926 et I936. Puis je rappellerai le rôle crucial que joua Gorki après I9I7 pour faire de la compagnie un phare de l'art théâtral russe.

Il faudrait, pour que cette relecture soit complète, évoquer aussi en détail la correspondance fortement censurée et falsifiée entre l'écrivain et les deux directeurs du MKhAT: Stanislavski et Nemirovitch-Dantchenkor ${ }^{\mathrm{I}}$ étudier les répétitions et représentations des pièces de Gorki au Théâtre d'Art. Il faudrait également rappeler un aspect peu étudié mais fondamental: le rôle de Gorki pour créer des compagnies provinciales «accessibles à tous», reliées à la maison mère moscovite, et son soutien au premier studio du MKhAT, notamment pour le travail de création à partir de textes-canevas retravaillés collectivement et par improvisations.

L'histoire des relations entre l'écrivain et le Théâtre d'Art est liée d'une part à la quête d'un répertoire nouveau, actuel, par une compagnie qui depuis la toute fin du XIX ${ }^{\mathrm{e}}$ siècle cherche à réformer l'art de la scène, et d'autre part à la politique de soviétisation théâtrale dont Gorki fut le fer de lance. En septembre 1932, trente ans après que la mouette de Tchekhov avait été placée sur le rideau du Théâtre d'Art² ${ }^{2}$ la compagnie était rebaptisée du nom de Gorki comme nombre

I Dans la suite de l'article, nous utiliserons les abréviations: KS pour Konstantin Stanislavski et ND pour Vladimir Nemirovitch-Danchenko.

2 En I902, le théâtre quitta le bâtiment de l'Ermitage pour s'installer rue Kamerguerski. Les 
de lieux et d'établissements à ce moment-là : il fallait honorer l'écrivain qui rentra définitivement en URSS en mai I933 et allait devenir un an plus tard le père du réalisme socialiste.

Gorki figure au répertoire du Théâtre d'Art en parallèle à Tchekhov entre I902 et 1905: La Mouette, Oncle Vania, Les Trois sœurs, La Cerisaie côtoient Les Petits Bourgeois, Les Bas-Fonds et Les Enfants du soleil 3. Puis c'est un grand vide jusqu'en $1933^{4}$. Entre I933 et la mort de KS en I938, se succèdent ${ }^{4}$ quatre spectacles: l'adaptation de V ljudjah, Egor Boulitchev, Les Ennemis, Dostigaev et les autres, ainsi que la lecture de Vassa Jeleznova (la seconde variante). ND monte deux de ces représentations, données en compétition avec d'autres théâtres.

Les relations entre Gorki et les directeurs du Théâtre d'Art seront complexes et par moments exécrables (en 1904, ulcéré par la réaction très négative de ND à la lecture des Estivants, Gorki rompt avec le Théâtre ce qui amène sa compagne Maria Andreeva, une des premières actrices du Théâtre, à quitter la troupe).

Tout change, non pas après I9I7 (on sait que Gorki, en désaccord avec la politique des Bolcheviks, sera expulsé en I92I) mais lorsque le MkhAT devient le théâtre officiel de l’URSS. Le rapprochement à la toute fin des années I920, très officiel et médiatisé, manqua de cordialité. KS qui avait renoncé à jouer les rôles principaux dans Les Petits Bourgeois et Les Enfants du soleil, abandonna aussi la mise en scène de Dostigaev au début des années trente. Gorki ne vint pas assister aux répétitions de ses spectacles et préféra souvent les mises en scène d'autres théâtres. Les contacts restèrent protocolaires et souvent épistolaires. Mais le rôle de protecteur de Gorki fut crucial, non seulement pour sauver le Théâtre des attaques prolétariennes mais aussi pour en faire un modèle national. Gorki contribua également à la promotion du système de formation

\footnotetext{
travaux d'aménagement (plateau tournant, dispositif électrique moderne, salle équipée en sièges rabattables, magasins en sous-sol, loges spacieuses, rideau orné d'une mouette) furent financés par le riche industriel Morozov.

3 Liste des premières: Les Petits-Bourgeois, 26/03/1902, mise en scène de Stanislavski et Loujski, décors de Simov (création à Saint-Pétersbourg). Les Bas-Fonds, I8/12/1902, mise en scène de Stanislavski et Nemirovitch-Dantchenko, décors de Simov. Les Enfants du soleil, 24/10/1905, mise en scène de Stanislavski et Nemirovitch-Dantchenko, décors de Simov. V ljudjah, adaptation de Soukhotine, 25/09/1933, mise en scène de Kedrov, décors d'Ivanov. Egor Boulitchev et les autres, 06/02/1934, mise en scène de Nemirovitch-Dantchenko et Sakhnovski, décors de Iouon. Les Ennemis, Io/10/1935, mise en scène de Nemirovitch-Dantchenko et Kedrov, décors de Dmitriev. Dostigaev et les autres, 3I/10/1938, mise en scène de Leonidov et Raevski, décors de Ryndine.

4 Seuls Les Bas-Fonds continueront de figurer au répertoire après Octobre I9I7.
} 
de l'acteur, mis au point par KS, et qui allait devenir à la mort de son créateur en I938, un catéchisme obligatoire. En période de terreur, cet embaumement permit la conservation du vieux théâtre célèbre pour son professionnalisme et son réalisme mais il accéléra sa sclérose au fil des années et le figea dans un académisme pompeux.

\section{L'Image retouchée de Gorki dans les biographies des directeurs du Théâtre d'Art}

La troupe du Théâtre d'Art a fait la connaissance de Gorki et Tchekhov à Yalta en I900, à l'occasion de sa tournée en Crimée5. En 1900, Gorki est déjà un écrivain très connu, il a été remarqué par Tolstoï, Tchekhov l'apprécie et c'est lors de ces rencontres en Crimée qu'il se laisse convaincre d'écrire des pièces pour la compagnie moscovite à laquelle il propose un milieu, des personnages totalement nouveaux. Ses petits bourgeois, ses va nu pieds des bas-fonds contrastent avec les personnages historiques (Tsar Fiodor, Jules César) ou les intellectuels désenchantés présentés jusqu'alors par KS et $\mathrm{ND}^{6}$.

Il est intéressant de comparer l'image que les deux directeurs du Théâtre ont donné de Gorki dans leurs mémoires, parues à dix ans d'intervalle.

Dans $M a$ vie dans l'art (1926), KS intitule le chapitre consacré à Gorki: «Общественно-политическая линия». Il y inscrit Ibsen: Un ennemi du peuple mais fait de Gorki son «главным начинателем и создателем» [І2, т. I, с. 324].

Que met-il en avant dans ce chapitre?

Il insiste sur la période politiquement et socialement instable que sont les années 1902-1905, cequi modifie les attentes du public, le détourne des questions esthétiques et le pousse à des applaudissements tendancieux. Or, écrit KS cinq ans après la révolution d'Octobre, «Лишь только к искусству подходят с тенденциозными, утилитарными и другими нехудожественными помыслами оно вянет, как цветок в руке Зибеля» [І2, т. I, с. 324].7 KS exprime donc très nettement son aversion pour les spectacles politiquement engagés.

Lorsqu'il évoque Les Petits Bourgeois, la première pièce proposée par Gorki dès l'automne I900 pour la toute première version [5, c. 6I, 67, 248; II,

5 Tournée à Sébastopol (IO-I5 avril) et Yalta (I6-2I avril) I900. Le Théâtre présenta $L a$ Mouette, Oncle Vania, et aussi Les Âmes solitaires de Hauptmann et Edda Gabler de Ibsen.

6 La même année que Les Bas-Fonds, les acteurs du Théâtre sont amenés à interpréter aussi des rôles nouveaux pour eux: les paysans de la pièce de L. Tolstoï La Puissance des ténèbres.

7 Zibel' un personnage de Faust. 
c. 8-9] ${ }^{8}$ (elle sera représentée au printemps 1902), il ne parle pas de l'élaboration du spectacle dont il a écrit pourtant le «режиссерский экземпляр», mais du contexte de sa réception: la censure est sur les dents, le théâtre, temple de l'art, devient brusquement une arène politique. Il ne mentionne pas ses essais dans le rôle de Nil, sur le conseil de Gorki et de Tchekhov, et met l'accent sur le succès fou remporté par un vrai choriste pour jouer le chantre Teteriev: par son naturel très primitif, cet amateur a charmé le public, en particulier les dames du monde... car la première eut lieu à Saint-Pétersbourg où la réputation sulfureuse de Gorki, alors sous étroite surveillance policière, suscita la curiosité des aristocrates, des ministres et du Grand duc Constantin.

KS ne dit pas un mot des Estivants, refusés par le Théâtre et s'attarde sur les Bas-Fonds. Il développe là le pittoresque de leur excursion dans un asile de nuit afin de saisir sur le vif le cadre et les personnages que les acteurs devront incarner. Il évoque l'autre difficulté de ce spectacle : trouver «новый тон и манера игры, новый быт, новый своеобразный романтизм, пафос, с одной стороны, граничащий с театральностью, а с другой - с проповедью» [І2, т. I, с. 328]9. Distribué dans le rôle de Satine, KS a travaillé la manière de dire les monologues édifiants de manière simple, «c естественным внутренним подъемом» [І2, T. I, C. 329].

A l'en croire, il aurait réussi à faire coïncider la dramaturgie de Gorki avec ses principes de jeu, le «переживание». Or, les historiens du théâtre relèveront un évident anachronisme. En I9O2, le Système de KS n'existait pas (les premières traces d'écriture datent de 1906 et le terme apparait en 1909). Le jeu ressenti n'était ni théorisé ni pratiqué et les comédiens furent justement confrontés, après Tchekhov qu'il fallait ressentir (переживать), à Gorki qu'il fallait «dire» (докладывать).

Lorsqu'en 1924-I926, date de l'écriture de Ma vie dans l'art, KS affirme que l'on peut jouer ce théâtre sans pathos, sans théâtralité romantique, et que, si l'on trouve la «потайной ключ к душе автора», тогда «эффектные слова босяцких афоризмов и витиеватых фраз проповеди наполнятся духовной сущностью самого поэта, и артист заволнуется вместе с ним» [г2, т. І, с. 329], cette assertion se trouve en contradiction avec ses lettres écrites entre 1902-1905,

8 Ce premier jet fut détruit. Après une lecture de sa pièce à ND qui lui fit plusieurs remarques, Gorki réécrivit son texte et le trouva très amélioré.

$9 \quad$ KS ne dit pas que ce nouveau ton lui a été soufflé par ND. 
au moment où il travaille sur les premières pièces de Gorki. KS «oublie» les difficultés éprouvées sur le moment pour trouver le bon «ton» et gomme l'autre handicap: l'engagement de l'auteur.

KS consacre une simple demi-page aux Enfants du soleil à la fin du chapitre sur le studio de la rue Povarskaïa. Là encore, il se focalise sur l'atmosphère qui entoure le spectacle en octobre I905 (le public, survolté par les tensions politiques, prend un groupe de figurants pour un vrai escadron de Cent-Noirs) [12, T. I, c. 363]. Il évoque les énormes coupures imposées par la censure, mais ne dit rien de sa conception de la mise en scène à l'acte II, qu'il a dû remanier en raison des réserves de Gorki qui écrit le 25 septembre à sa femme E. Pеchkova: «Поставлено отвратительно. Играют пакостно. Пьеса вся искажена и, вероятно, со скандалом провалится» $\left[4\right.$, т. 28, с. 389; I5, c. 518 ${ }^{\text {10 }}$. La mise en scène provoqua bien un scandale, mais il ne fut pas d'ordre artistique. L'auteur, comme les artistes du Théâtre, oublièrent ce spectacle balayé par l'actualité politique et qui ne donna pas lieu à d'abondantes analyses détaillées [I3, c. I57-I6I $]^{\mathrm{II}}$.

Dans Ma vie dans l'art, KS dissocie l'homme Gorki de la figure politique et militante. En I924-I926, il a oublié l'aversion que lui ont procurée Les Estivants, puis Les Enfants du soleil et ne dit mot des attaques de Gorki en I9I3 contre les mises en scène de Dostoïevski. KS ne garde en mémoire que l'être séduisant, chaleureux, au cœur pur dont il a fait connaissance à Yalta. «Горьковское обаяние было сильно. В нем была своя красота и пластика, свобода и непринужденность. В моей зрительной памяти запечатлевалась его красивая поза, когда он, стоя на молу Ялты, провожал меня и ожидал отхода парохода <...> Он задумчиво смотрел вдаль, и казалось, еще немного - и вот отделится от мола и полетит куда-то далеко, за своей мечтой» [I2, T. I, c. 333].

Pour sa part ND, dans sa biographie parue en I936, dix ans après celle de KS: Extraits du passé (Iz prochlogo) [8, т. 4 $]^{\mathrm{12}}$ articule l'histoire du Théâtre d'Art autour des écrivains qui ont fait sa célébrité: Tchekhov, Tolstoï et Gorki, présenté

Io Les coupures imposées furent respectées à la première, puis progressivement rétablies au fil des représentations.

II Pour analyser l'œuvre, Marianna Stroeva s'appuie sur le cahier de mise en scène des Enfants $d u$ soleil et s'attarde peu sur le spectacle lui-même.

I2 La première édition parut chez «Academia» en I936. L'ouvrage parut en anglais sous le titre My Life in The Russian Theatre, Boston, Little Brown and co, 1936. Une seconde édition corrigée sortit en 1938: c'est cette version qui est reprise dans la réédition de 2003. 
comme le marqueur du courant «gorkovien» (горьковское). L'art tendancieux, rejeté sous l'ancien régime, a été promu par les œuvres de Gorki qui ont rendu évidente la formule selon laquelle «Искусство не может быть аполитично, даже по своей природе» [8, т. 4, с. 405].

ND décrit lui aussi l'atmosphère surchauffée qui entoure la première des Petits Bourgeois à Petersbourg, insiste sur son rôle pour faire autoriser la pièce dans un cercle limité, pour convaincre les étudiants installés au poulailler de ne pas créer de provocation [8, т. 4, c. 38I-382]. Il évoque également le succès du chantre amateur Baranov qui fascina les élégantes parfumées par son primitivisme d'enfant de la nature.

Dans son portrait de Gorki, au centre de l'attention en I902, ND souligne le caractère entier du personnage («если вы “свой”, сейчас же полюбит вас») et la grande confiance en lui du dramaturge débutant: «на репетициях был прост, искренен, доверчив, но, где надо, и безобидно настойчив». Gorki, assure ND, ne doute jamais, ni dans ses actes, ni ses paroles [8, т. 4, c. 384, 40I].

Le co-directeur du Théâtre d'Art insiste sur l'énorme succès des Bas-Fonds encore à l'affiche lorsqu'il écrit son livre [8, т. 3, c. 4II; I, c. 2OI-204 $]^{\mathrm{I3}}$ et conclut que l'année г902-1903 fut placée «под знаком Горького» [8, т. 4, с. 386], ce qui est une drôle de manière de réécrire l'histoire, en oubliant Les Trois Sœurs et en assurant que le public préféra la pièce de Gorki à La Cerisaie ${ }^{I 4}$.

ND ne dit rien de sa rupture avec Gorki durant l'été 1904, s'attarde lui aussi sur les événements politiques d’octobre-décembre I905 qui eurent de fâcheuses incidences sur la première des Enfants du soleil. Il décrit le final de l'acte IV imaginé par Gorki: le professeur Protassov agite son mouchoir face à un groupe de gens en colère qui l'accusent d'avoir propagé le choléra. Ses agresseurs le cernent, le font tomber. Il s'évanouit. Alors, la femme de Protassov, armée d'un révolver, sort sur le perron et tire sur les assaillants que le gardien de la maison frappe à coup de planche. La scène est tragicomique. ND mentionne les rires qui fusent à la générale et assure que Gorki ne s'en soucia pas, ce qui contredit le

I3 En I934, il y avait eu 800 représentations des Bas-Fonds. La gloire phénoménale de Gorki est venue d'un coup, avec ce spectacle, même si, auparavant, il bénéficiait déjà d'une grande popularité: Bounine dira que les intellectuels russes étaient fous de lui et que chacune de ses nouvelles œuvres faisait événement.

I4 ND se vante aussi du succès de sa mise en scène de Jules César, qui fut en réalité un cuisant échec. Trop coûteuse et difficile à jouer (elle impliquait 200 figurants), il la vendit au bout de deux ans à un théâtre de Kiev. 
récit que KS fait de cette scène à son amie l'actrice Vera Kotliarevskaïa (sa lettre du 3 novembre I905 parut pour la première fois en 1995, elle manquait dans la première édition des lettres en I960).

«Какой ужас играть и репетировать в такое время эту галиматью и бездарность: “Дети солнца”. Но еще ужаснее видеть то, что было на первом представлении. Надо сказать, что я с Горьким разругался и видеть его больше не могу. Это образец самонадеянности и безвкусия. Он изломал всю постановку, задуманную нами, и теперь пьеса идет так, как режиссируют в Царевококшайске. Это ужас! ... по банальности. Увы, именно оно-то и имеет успех у публики. Дошли до 4-ого акта. На репетиции мы катались по полу от хохота, когда врывались на сцену черносотенцы и дворник колотил толпу по головам картонной доской. Конечно, поехали без меня просить Горького убрать эту петрушечью деталь - они рассердились и не допустили» [І2, т. 7, c. 6Io].

ND assure aussi qu'il a signé seul le spectacle, alors qu'en réalité il a suivi le cahier de mise en scène composé par KS (qu'il a, il est vrai, dû modifier au fil des répétitions).

On notera que dans l'édition américaine de ses mémoires (My Life in The Russian Theatre, 1936), ND évoque le départ en émigration de Gorki accompagné de Maria Andreeva juste après l'échec de la révolution de 1905 et indique à tort: «Связь между ним и театром была прервана. Горький написал после этого несколько пьес; но ни мы их не ставили, ни он не предлагал нам» [8, т. 4, с. 499].

En I913, une nouvelle divergence de fond opposera l'écrivain exilé et le Théâtre: elle concerne les adaptations de Dostoievski. ND est le seul à en parler dans ses mémoires, car il est le responsable du choix des Karamazov et des Démons, ainsi que l'auteur des adaptations et le co-metteur en scène (avec Loujski) des deux spectacles donnés en octobre I9IO et I9I3. Dans Extraits du passé, ND reprend les arguments qu'il avait donnés à son biographe en I9I8 [ı, c. 78-79]. Seule la littérature nationale fournit un vrai terrain de création pour l'acteur russe: or Dostoievski offre un matériau très riche dans le domaine de la psychologie et du jeu car il est «бесконечно театрален, <...> пластичен и выразителен» [8, т. 4, c. 402]. Ainsi ND justifie-t-il qu'après Gorki et son militantisme, il ait choisi en I9Iо Les Karamazov transformés en un «спектакль-мистерия» [8, т. 4, с. 403] et trois ans plus tard, la satire féroce contre les révolutionnaires que sont Les Démons (l'adaptation fut jouée sous le titre Nikolaï Stavroguine). 
ND referme la parenthèse dostoievskienne et achève son chapitre en évoquant les rencontres avec Gorki des années trente mais sans donner de détail sur les cinq pièces ou adaptations de l'écrivain qui ont été montées en l'espace de six années (1933-1938) et dont il a assumé à deux reprises la direction artistique. Seule sa correspondance, et la presse des années trente, gardent la trace de son travail.

Quelles conclusions tirer de ces deux récits biographiques, le premier écrit par KS à 63 ans, à la veille du «Grand tournant», le second par ND à 78 ans durant la campagne contre le cosmopolitisme.

Ils s'accordent sur trois points:

*Gorki n'est pas un auteur comme Tchekhov et ses contemporains: Naïdionov, Tchirikov, Iouchkevitch, Sourgoutchov, Andreev. Il a manifesté lors du dimanche sanglant dans une colonne d'ouvriers avec un groupe de Bolcheviks appelant à renverser le tsar, il a travaillé dans la presse illégale, il a achevé Les Enfants du soleil dans la prison de Petropavlovsk en février I905. Pour lui, la littérature et le théâtre sont des chaires légitimes pour s'adresser au peuple.

*Dans ses premières pièces, Gorki met en accusation l'intelligentsia, il la rend responsable de l'aveuglement, de l'arriération du peuple. Et dans Les Enfants du soleil, c'est l'actrice Maria Andreeva, sa compagne révolutionnaire qui, dans le rôle de Liza, condamne l'idéalisme de Protassov, à l'origine interprété par KS ${ }^{15}$. «Вы, опьяненные красивыми словами и мыслями, не видите это, а я видела, как вырвалась на улицу ненависть <...>. Однажды их злоба обратиться на вас...» [3]. Gorki amène donc le Théâtre d'Art à polémiquer avec Tchekhov et à se trouver en contradiction avec son credo: cultiver «la vie de l'esprit humain», croire à la «солнечную силу красоты» ${ }^{16}$.

*Enfin, il semble que ni KS ni ND n'aient été vraiment enthousiasmés par l'écriture de Gorki entre I902 et I905, une écriture de dramaturge débutant qui utilise une langue très littéraire sur le plateau. Gorki montre avec les mots, par la description [I5, c. 382]. La critique de l'époque n’a pas manqué de le relever. A propos des Petits Bourgeois, S. Iablonski écrit: «Горький - огромный бел-

I5 Melania fut interprétée par Olga Knipper; Elena, par Maria Guermanova, Liza, par Maria Andreeva, Protassov par Vassili Katchalov, Antonina par Elena Mouratova, Fima par Nina Litovtseva.

I6 Cette aspiration au Beau à l'acte II des Enfants du Soleil est exprimée par Elena, la femme de Protassov. 
летристический талант - как драматург (по крайнем мере, судя по первому дебюту) стоит не особенно высоко, и «Мещане» гораздо более яркое и цельное впечатление производят в чтении, чем на сцене». Ju. Ajkhenvald confirme: «Сцены в доме Бессеменовых, как характерно и умно они ни написаны, для театрального воплощения не годятся. <...> Это скорее ряд афоризмов и сентенций, иногда остроумных и метких <...> . Même les Bas-Fonds passent aux yeux de certains critiques pour une pièce artificielle. Pour Kougel, Gorki y est «больше демонстратор, стоящий позади экрана и объясняющий картины волшебного фонаря, чем художник» [6, т. I, с. 282, 290, 333].

\section{Gorki devient un protecteur}

Après I9I7, ND qui a d'abord pris parti pour le gouvernement provisoire, soutenu Kerenski et été pressenti pour diriger les ex-théâtres impériaux de Moscou, se rapproche de Lounatcharski et voit très vite en Gorki un protecteur du Théâtre d’Art.

Il s'accommode désormais de la «gorkiade» $[8 \text {, т. I, c. 432-433 }]^{17}$, dont KS donnait cette définition en I908: «реализм стал временами мешать, а художественная сторона - страдать», ustupaja «ходячим теориям» $\mathrm{i}$ «проповедям» [9, с. 4I4]. ND s'adresse à l'écrivain lorsque la situation matérielle de la compagnie et de ses studios devient alarmante [8, т. 2, c. 63I-632 $]^{18}$. KS lui aussi sollicite l'intervention de Gorki pour faire libérer la sœur d'un ami aristocrate, rédactrice des œuvres de Tolstoï, en juin 1920 [15, c. II8].

Dans les années 1920, lorsque les premiers récits officiels se constituent sur la dramaturgie du Théâtre d'Art et qu'un ouvrage est consacré aux Bas-Fonds de Gorki $[2]^{\text {I9 }}$, tandis que les pièces de Tchekhov sont conspuées par la gauche révolutionnaire, ND commence à forger la légende de ses liens privilégiés avec Gorki. Il insiste sur son rôle pour sortir le Théâtre d'Art du naturalisme et trouver un nouveau ton. «Подтвердят и Вишневский с Качаловым, каких усилий стоило мне вести Конст. Серг. на «горьковский» или «босяцкий» романтизм, как я тогда окрестил» $[8, \text { т. 2, с. } 650]^{20}$.

\footnotetext{
I7 Lettre de ND à KS du 28 juillet 1902.

I8 Lettre du 28 septembre I92I,

I9 Louvrage est préfacé par ND qui dressera aussi un bilan de la dramaturgie du Théâtre d'Art dans la revue Teatr, le 3I octobre I922, pour le trentième anniversaire de l'activité littéraire de Gorki.

20 Lettre de ND à N. Efros, été 1922.
} 
Heureux de pouvoir tirer la couverture à lui, à un moment où KS brille à l'étranger (à l'occasion de la tournée internationale du Théâtre d'Art qu'il dirige entre I922 et I924), ND assure que sans lui, KS aurait été incapable de comprendre le nouveau théâtre proposé par Gorki [8, T. 2, c. 650].

Les relations directes avec Gorki reprennent en 1928, lors du trentième anniversaire du Théâtre d'Art, célébré en grande pompe. Puis, en 1932, lorsque la compagnie prend le nom de Gorki, c'est sous son patronage que la vie artistique s'organise. C'est aussi sous son autorité, et sans doute sur son instigation, qu'est lancé un projet d'Académie théâtrale dont le MKhAT serait le cœur (concrétisé en septembre 1933, le projet avortera quelques mois plus tard pour des raisons qui resteront obscures à KS lui-même [ı2, т. 9, c. 548] ${ }^{21}$ ).

Dès le début des années trente, le rôle d'intercesseur et de protecteur de Gorki se confirme. Pour maintenir Boulgakov au répertoire, pour essayer de faire autoriser Le Suicidé de Erdman. Ou pour des difficultés d'ordre personnel. Par exemple, ND qui s'est endetté dans les casinos italiens en I933 eta besoin de devises pour pouvoir rentrer à Moscou, demandera et obtiendra l'appui de Gorki ${ }^{22}$.

L'heure n'est plus aux critiques ou aux réserves. «Ровно зо лет прошло с постановки «Мещан» и «На дне». Тогда я испытывал к Вам чувство самого искреннего восхищения», - assure ND [8, т. 3, с. 36I $]^{23}$. A la réception de la pièce Egor Boulitchev, le 22 décembre I932, il admire cette pièce «пленительная». En août 1933, il trouve Dostigaev magnifique: «Именно вот как поколения должны ощущать человеко-звериную растерянность в самый приход Октября» $[8$, т. 3, с. 393].

La saison I933-I934 est célébrée officiellement comme «gorkovienne», avec cinq autres mises en scène de l'écrivain dans la capitale. O. Litovski, le président du Glavrepertkom, déclare que la dramaturgie de Gorki, quels que soient ses défauts scéniques, correspond parfaitement aux exigences du théâtre soviétique [6, т. 3, ч. 2, c. II2]. Bien plus, il invite les théâtres à reprendre les anciennes mises en scène de Gorki: dans les Bas-Fonds, les acteurs doivent désormais dénoncer le personnage du grand consolateur et conciliateur Luka, et dans Les Enfants du Soleil, le savant idéaliste Protassov doit être «démasqué» [I6,

2I Lettre de KS du 8 décembre I933 à Z. Sokolova et V. Alexeev.

22 Gorki appuiera la demande de I50o dollars.

23 Lettre à Gorki, 23 oct. 1932. 
c. I49-I5O ${ }^{24}$. Le MKhAT est placé sous haute surveillance car il doit donner des objectifs de classe à sa «vieille méthode»: le réalisme psychologique [6, т. 3, ч. 2, c. I33].

La censure du répertoire durant cette saison-là ${ }^{25}$ oblige le Théâtre à se tourner vers un dramaturge sûr: malgré les difficultés des acteurs à composer les personnages gorkoviens selon les nouveaux critères idéologiques ${ }^{26}$; malgré aussi le temps limité des répétitions imposé par la planification qui régit aussi la vie culturelle. A la première de Egor Boulitchev, le ıo février 1934, tous les officiels, Staline en tête, sont là $[8, \text { т. 3, c. 403 }]^{27}$. Monter Gorki relève d'un acte politique.

En mars 1934, à l'occasion de la 800 représentation des Bas-Fonds, ND écrit à Gorki que l'œuvre, favorite du prolétariat, est un modèle de vraie pièce populaire. «MХАТ глубоко счастлив, что связь его с Вами с каждым днем растет и укрепляется, и с нетерпением ждет встречи с Вами в своих стенах» $[8, \text { т. 3, с. 4II, } 402-403]^{28}$.

La lecture de la presse révèle le carcan qui se resserre de plus en plus sur le MKhAT transformé, entre I933 et I938 en vitrine de l'art théâtral soviétique. Il n'est plus question désormais de représenter les personnages de Gorki en leur donnant des allures de marchands ostrovskiens ou d'intellectuels tchekhoviens, ce que les comédiens de la première génération savaient faire. Il faut insister non pas sur l'appartenance à un milieu, mais sur les contradictions entre les classes sociales et dénoncer ce qui appartient à l'ancien monde.

C'est seulement avec Les Ennemis en 1935 que le MKhAT réussira pleinement sa conversion idéologique ${ }^{29}$. La mise en scène est imposée au Théâtre d'Art par Staline qui a vu la pièce trois fois au Maly ${ }^{30}$. Il est difficile dans ces conditions

\footnotetext{
24 V. Katchalov -l'interprète de Protassov, eut beaucoup de mal à reprendre son personnage.

25 Le Mensonge d'Afinoguénov, les pièces de Erdman et Boulgakov, et même la reprise de L'Oiseau bleu sont interdits.

26 Leonidov, mal à l'aise dans le rôle de Boulitchev, sera doublé par Katchakov.

27 Lettre de ND à KS entre le II et 22 février 1934. Gorki ne s'empressa pas d'aller voir la mise en scène du Théâtre d'Art et préféra celle du Théâtre Vakhtangov.

28 ND regrettait le relatif échec de Leonidov dans le rôle principal de Boulitchev. Il se vantait d'avoir trouvé le moyen d'introduire des détails du quotidien sans que cela ne détourne l'attention du public.

29 Le premier pas dans cette direction avait été accompli en 1927 avec la mise en scène de Train blindé I4-69 de V. Ivanov.

30 Staline l'ayant beaucoup appréciée, les responsables politiques pressent la direction artistique de monter la pièce. Staline imposera au MKhAT aussi Lioubov Iarovaja de Trenev qu'il aurait vue 28 fois...
} 
d'apprécier à sa juste valeur le réel impact de la pièce à l'intérieur du Théâtre et sur le public ${ }^{31}$. ND qualifia le spectacle de meilleur de la saison [8, т. 3, c. 450] et il semble, selon Olga Knipper, que les interprètes aient essayé de lutter contre les clichés de leur jeu (le sentimentalisme, la lenteur, la fausse simplicité) et qu'il en ait résulté un spectacle simple, plein de fraicheur [8, т. 3, c. 660]. La critique loua «органическое свойство нового советского актера, чье профессиональное мастерство обогатилось передовыми идеями социалистической эпохи» [6, т. 3, ч. 2, c. 205]. Katchalov (Bardine) ou Knipper (Polina) auraient enraciné leur personnage dans un terreau familier avant de s'en détacher: la critique apprécie leur «début tchekhovien» qui «закономерно и последовательно привело к горьковскому концу: внутреннему доказательству гнилости и пустопорожности в этой женской вариации либеральствовавшей интеллигенции» $[6$, т. 3 , ч. 2, с. 215$]$.

Le Théâtre reçut un satisfecit sans réserve:

«"Враги” во MXАТе - политический спектакль в лучшем, полнейшем значении этого слова, и именно потому он подлинно горьковский спектакль, что театр Горького всегда был, есть и будет политическим театром. Для МХАТа спектакль “Враги” явился поворотным спектаклем, определившим значительный шаг вперед этого великолепного театра по дороге социалистического реализма» [6, т. 3, ч. 2, с. 337].

Ce qu'il reprochait aux Estivants, ND l'apprécie désormais. Montrer, à travers l'affrontement des personnages, un parti pris politique très marqué est cette fois une qualité artistique et une marque d'objectivité [8, т. 3, c. 478 $]^{32}$. ND voit en Gorki le père d'un nouveau réalisme simple, vrai, servi par une langue magnifique, et porté par des idées pathétiques. Et il conclut «Такой материал сейчас наиболее отвечает моим сценическим задачам <...> формулой которого является синтез трех восприятий: жизненного (не житейского), театрального и социального» [8, т. 3, с. 478].

Le vieux directeur du MKhAT tente de se mettre sur un pied d'égalité artistique avec l'écrivain devenu un intouchable. Peut-être espère-t-il sa protection une fois encore, lors de la nouvelle vague de répression du début 1936. Le Théâtre d'Art joue gros: il présente, après sept ans de répétitions et d’interdictions, la

3I Les Ennemis furent joués le I5 juin 1935 au Théâtre MOSPS, et le Io octobre au Maly. La pièce figura au répertoire de tous les théâtres de l'URSS.

32 Lettre du 4 février I936, à propos de Vassa Jeleznova, seconde version. 
pièce de Boulgakov La Cabale des dévots/Molière. Mais Gorki ne sauvera pas le spectacle, créé le 6 février et retiré au bout de sept représentations. L'écrivain disparaîtra cet été-là, peut-être assassiné par les hommes de main de Staline [I4, p. 388-4I2].

Face à un ND qui se plie aux impératifs et abandonne en privé et en public tout sens critique à l'égard de la dramaturgie de Gorki, KS lui, s'en détourne résolument. Mais dès que Gorki devient l'artiste clé de la politique culturelle en I933, chargé d'homogénéiser les arts par un style unique et de trouver des modèles à imiter, KS n'a de cesse de le convaincre de l'importance du MKhAT pour maintenir la vie théâtrale à un niveau d'excellence. KS voit en Gorki un artiste de sa génération qui rejette la productivité, la rentabilité en art, et qui est capable d'apprécier le travail en profondeur, le sérieux du travail collectif.

Gorki devint l'ange gardien du MKhAT. De I900 à I938, avec des hauts et des bas, les liens qui l'ont uni au Théâtre ont été cruciaux. Mais en s'efforçant de gommer les différends qui ont marqué ce long et houleux compagnonnage, les historiens du théâtre soviétique ont simplifié un tableau d'une riche complexité qu'il faudrait aujourd'hui essayer de reconstituer avec toute la documentation disponible et en toute objectivité. 


\section{References}

I Basinskii P. Gor'kii [Gorky]. Moscow, Molodaia gvardiia Publ., 2005. 45I p. (In Russ.)

2 Efros N. "Na dne”. P'esa M. Gor'kogo v postanovke MKhAT [The Lower Depths. Gorky's play staged in the Moscow Art Theatre]. Moscow, GIZ Publ., I923. II4 p. (In Russ.)

3 Gor'kii M. Deti solntsa [The children of the sun]. Available at: web.archive.org/ web/20040II5201908/http://www.maximgorkiy.narod.ru/pesy/deti.htm (Accessed at 13 December 20I7) (In Russ.)

4 Gor'kii M. Sobranie sochinenii: $v$ so t. [Complete works: in 30 vols.]. Moscow, Khudozh. lit. Publ., I949-I956. (In Russ.)

$5 \quad$ M. Gor'kii i A. Chekhov: perepiska, stat'i i vyskazyvaniia [Gorky and Chekhov: Correspondence, essays and statements]. Moscow, Izdatel'stvo Akademii nauk SSSR Publ., I937. 286 p. (In Russ.)

6 Moskovskii Khudozhestvennyi teatrv russkoi teatral'noi kritike: $v 3 t$. [Moscow Art Theatre in Russian theatrical criticism: in 3 vols.]. Moscow, Artist. Rezhisser. Teatr Publ., 2005-20I0. 976 p. +878 p. +440 p. +656 p. (In Russ.)

$7 \quad$ Nemirovich-Danchenko V.I. My Life in the Russian Theatre. Boston, Little, Brown \& Co., I936. 358 p. (In English)

8 Nemirovich-Danchenko V.I. Tvorcheskoe nasledie: $v 4 t$. [Heritage: in 4 vols.]. Moscow, Moskovskii khudozhestvennyi teatr Publ., 2003. 450 p. + 8I4 p. +699 p. + 734 p. (In Russ.)

9 Radishcheva O.A. Stanislavskii i Nemirovich-Danchenko. Istoriia teatral'nykh otnoshenii: $v 3 k n$. [Stanislavsky and Nemirovitch-Danchenko]. Moscow, Artist. Rezhisser. Teatr Publ., I994. Book I. I897-I908. 46I p. (In Russ.) Sobolev Iu. Vl.I. Nemirovich-Danchenko [Vl. I. Nemirovitch-Danchenko]. Petersburg, Khudozh. izd-vo "Svetozar” Publ., I9I8. I64 p. (In Russ.) Solov'eva I.N. Pervye vstrechi s Gor'kim [First encounters with Gorky]. Rezhisserskie ekzempliary K.S. Stanislavskogo: $v 6 t$. [Stanislavsky's director's samples: in 6 vols.]. Moscow, Iskusstvo Publ., I986, vol. 4, p. Io. (In Russ.) Stanislavskii K.S. Sobranie sochinenii: $v 9 t$. [Complete works: in 9 vols.]. Moscow, Iskusstvo Publ., I988-1999. (In Russ.) Stroeva M.N. Rezhisserskie iskaniia Stanislavskogo: I898-I9I7 [Director's quests of Stanislavsky: I898-I9I7]. Moscow, Nauka Publ., I973. 373 p. (In Russ.) Vaksberg A. Le Mystère Gorki, trad. Dimitri Sesemann. Paris, Albin Michel, I997. 452 p. (In French)

I5 Vinogradskaia I.N. Zhizn' i tvorchestvo K.S. Stanislavskogo. Letopis' [Life and work of Stanislavsky. Chronicle.]. Moscow, Moskovskii khudozhestvennyi teatr Publ., 2003. I850 p. (In Russ.) 
I6. Volkov N.D. Obrazy Chekhova i Gor'kogo v tvorchestve V.I. Kachalova [Images of Chekhov and Gorky in the work of V.I. Kachalov]. Vasilii Ivanovich Kachalov. Sbornik statei, vospominanii, pisem [Vasily Ivanovitch Kachalov. A collection of essays, memoir, and letters]. Moscow, Iskusstvo Publ., I954, pp. I38-I57. (In Russ.) 


\section{UNIVERSELLE RUSSITE: LES BAS-FONDS, OU GORKI REVU PAR ZAMIATINE REVU PAR RENOIR}

This is an open access article distributed under the Creative Commons Attribution 4.0 International (CC BY 4.0)
(C) 20I8. L. Heller

Université de Lausanne,

Suisse

Envoyé le I4 janvier 2018

Publié le 25 mars 2018

DOI: I0.22455/2500-4247-20I8-3-I-I96-2II

Résumé: L'article traite de l'histoire des «Bas-Fonds», un film que Jean Renoir tourne en 1936 en se basant sur la fameuse pièce de Maxime Gorki adaptée pour l'écran d'abord par Evguéni Zamiatine et Jacques Companeez et ensuite par Renoir et son scénariste Charles Spaak. D'abord, un certain nombre d'inexactitudes est corrigé concernant notamment la réception du film, plus problématique qu'il n'y paraît à cause de son caractère national «brouillé» et de son infidélité par rapport à l'œuvre de Gorki. Ensuite, nous abordons la complexité de la situation culturelle en 1936 et le rôle dans la réalisation du film de la société de production Albatros fondé par les Russes et dont le personnel se compose en majorité des Russes émigrés. C'est avec le travail de tels techniciens, l'œuvre d'un grand écrivain russe et le scénario d'origine rédigé par deux auteurs émigrés que le film prend la tournure de cette «universelle russité» qui pouvait autant impressionner qu'agacer. Dans la conclusion, de nouvelles questions sont formulées quant aux rôles respectifs de différents auteurs dans la rédaction du scénario.

Mots clés: Jean Renoir, Evgueni Zamiatine, Maxime Gorki, «Les Bas-Fonds», cinéma français, culture de l'émigration russe, transferts culturels, écriture scénaristique, adaptation filmique, scénariste comme auteur.

Informations sur l'auteur: Leonid Heller, professeur honoraire, Université de Lausanne, CH-IoI5 Lausanne, Suisse.

E-mail: leonidh@infonie.fr 


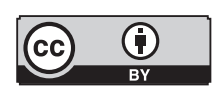

This is an open access article distributed under the Creative Commons Attribution 4.0 International (CC BY 4.0)

\section{UNIVERSAL RUSSIANNESS, OR GORKY'S THE LOWER DEPTHS INTERPRETED BY ZAMYATIN INTERPRETED BY RENOIR}

(C) 20I8. L. Heller

Lausanne University, Switzerland.

Received: January 14, 2018

Date of publication: March 25, 2018

Abstract: This paper discusses a I936 French film The Lower Depths based on the famous Maxim Gorky's play and directed by Jean Renoir. The script was initially written by Evgeny Zamyatin and Jacques Companeez and then rewritten by Charles Spaak and Renoir. The first part of the paper is dedicated to the problematic reception of this film that was due to its blurred Russian-French outlook and to its seeming infidelity to Gorky's work. Further, the essay sheds light on the intricacy of the 1936 circumstances surrounding the film production. It also discusses the role that the Albatros production society whose technical crew was composed mostly of the Russian émigré specialists played in the making of the film. Such a crew, together with the fact that the original play and its screen adaptation were written by two émigré writers, endowed the film with "universal Russianness" of a sort. The last part of the paper attempts to clarify the complicated issue of the scenario by comparing its several script versions with the final version. The paper raises new questions concerning respective roles played by different authors of the adaptation in the production of The Lower Depths.

Keywords: Jean Renoir, Evgeni Zamyatin, Maxim Gorky, The Lower Depths, French cinema, Russian émigré culture, cultural transfer, screenplay writing, screen adaptation, scenario authorship.

Information about the author: Leonid Heller, honorary professor, Lausanne University, CH-IOI5 Lausanne, Switzerland.

E-mail: leonidh@infonie.fr 
УДК 82І.І6І.І.о

ББК $83.3(2 \mathrm{Poc}=\mathrm{Pyc}) 6$

\section{УНИВЕРСАЛЬНАЯ РУССКОСТЬ, ИЛИ ГОРЬКИЙ ГЛАЗАМИ ЗАМЯТИНА И РЕНУАРА}

(C) 2018 г. М.Л. Геллер

Лозаннский университет,

Швейцария.

Дата поступления статьи: І4 января 2018 г. Дата публикации: 25 марта 2018 г.

DOI: I0.22455/2500-4247-20I8-3-I-I96-2II

Аннотация: Тема статьи «Универсальная русскость, или Горький глазами Замятина и Ренуара» - французский фильм «На дне», снятый Жаном Ренуаром в 1936 г. на основе пьесы Максима Горького по сценарию Евгения Замятина и Жака Компанейца, переработанному режиссером и Шарлем Спааком. Первая часть статьи посвящена сложностям рецепции фильма, связанным с зыбкостью его русско-французского «профиля» и с отходом от буквального переноса пьесы на экран. Затем обсуждается обстановка I936 г. и роль в создании фильма компании «Альбатрос», большую часть персонала которой составляли русские эмигранты. Их вклад придает фильму, поставленному по пьесе русского автора и по сценарию двух эмигрантских писателей, особый характер «универсальной русскости», который то смущал, то восхищал его первых зрителей. В последней части статьи делается попытка хотя бы частично прояснить проблему создания сценария. После сравнения ряда его сценариев между собой и с их реализацией в фильме можно ставить вопрос о роли разных его авторов.

ключевые слова: Жан Ренуар, Евгений Замятин, Максим Горький, «На дне», французское кино, культура русской эмиграции, культурный трансфер, кинодраматургия, экранизация, сценарист как автор фильма.

Информация об авторе: Леонид Михайлович Геллер - почетный профессор, Лозаннский университет, Іог5 г. Лозанна, Швейцария.

E-mail: leonidh@infonie.fr 
Le sujet de cet exposé est le film de Jean Renoir tourné en I936, la première adaptation cinématographique des Bas-Fonds, pièce de Maxime Gorki, basée sur un scénario écrit par Evguéni Zamiatine.

En dehors des cinéphiles et historiens du cinéma, ce film est important pour les chercheurs de plusieurs domaines: pour ceux qui étudient Gorki et Zamiatine, bien entendu, mais aussi ceux qui s'intéressent aux échanges entre les cultures russe et française dans la première moitié du XX $\mathrm{XX}^{\mathrm{e}}$ siècle, enfin, pour ceux qui se penchent sur les rapports entre la littérature et le film. Chaque domaine a ses propres enjeux et construit ses propres perspectives de recherche. Le point de vue adopté ici est celui de l'intermédialité et des études zamiatiniennes.

N'étant pas spécialiste de Gorki, je ne sais pas vraiment si et comment les spécialistes de son œuvre ont abordé le film de Renoir. Je sais en revanche que depuis trente ans, ce film est évoqué par les «zamiatinistes», le plus souvent en passant, mais plusieurs travaux plus pointus ont déjà été consacrés aux scénarios de Zamiatine, dont celui des Bas-Fonds. Pour ma recherche je me suis abondamment servi dans les publications de Natalia Primotchkina, Brian D. Harvey, Marina Loubimova, Natalia Jeltova [9; 13; 15; 22; 21]; je leur dois toute ma reconnaissance, ainsi qu'aux regrettés Alexandre Galouchkine ${ }^{\mathrm{I}}$ et Rashit Ïanguirov [7; II], sans qui aucune recherche dans les domaines évoqués n'aurait été possible.

Ainsi, le sujet des Bas-Fonds a été abordé, mais il apparaît quelque peu voilé par un grand nombre d'affirmations contradictoires, provenant souvent des héros mêmes de notre recherche. Il reste beaucoup à creuser.

I Galushkin A. Parizhskii arkhiv Evgeniia Zamiatina. Annotirovannyi katalog [Annotated catalogue of the Parisian archives of Evgenii Zamiatin], ms (20I2) (In Russ., unpublished). 
Résumons en simplifiant les points qui reviennent dans les travaux dont j'ai connaissance et qui semblent être passés dans le savoir acquis. (a) Zamiatine écrit une adaptation cinématographique de la pièce en réalisant une idée qu'il aurait conçue depuis longtemps, peut-être même avant son départ de la Russie; (b) cette adaptation respecte la pièce tout en y opérant des transformations nécessaires compte tenu les exigences filmiques; (c) l'écrivain trouve un metteur en scène qui s'intéresse au scénario; (d) grâce à ce dernier, le film réalisé sur sa base obtient un grand succès autant public que critique, on lui attribue le premier prix Louis Delluc du meilleur film français de l'année; (e) la critique de l'époque, qui encense Renoir, néglige l'importance du scénariste et il s'agit aujourd'hui de la rétablir ainsi que, plus généralement, de valoriser la maîtrise scénaristique de Zamiatine.

Jusqu'à un certain point, on peut être d'accord avec ces affirmations. Mais jusqu'à un certain point seulement. Le but de ce qui va suivre n'a rien de polémique; je tenterai d'ajouter quelques détails, d'en préciser quelques autres et d'interroger la place du scénario zamiatinien dans le processus de l'écranisation ainsi que son rapport à la pièce et au film réalisé. Tout cela sera fait trop rapidement: le vrai traitement du sujet demanderait l'espace d'une vaste monographie (un travail plus élaboré qui doit inclure nombre d'informations qui n'ont pas pu être intégrées ici, est en préparation en russe).

Commençons par la fin: on a pris l'habitude de parler du grand succès des Bas-Fonds. Or, c'est à l'évidence «un film sous-estimé» [6], au moment de sa sortie comme plus tard. Encore aujourd'hui, bien qu'un certain regain d'intérêt se laisse observer, il est de loin le moins étudié parmi les œuvres reconnues de Renoir. Tantôt accueilli avec bienveillance, tantôt rejeté, il sera malgré l'obtention du prix Delluc fortement critiqué par la suite; certains s'en prendront à son «réalisme de compromis» [5, p. I78], certains autres à l'éclectisme dans le choix des acteurs, mais surtout à la supposée trahison de Gorki. Le critique et historien Pierre Leprohon donnait plus tard cette formule: «On attendait Gorki; on ne l'y trouvait guère. Aujourd'hui, on attend Renoir: on l'y trouve.» Et d'ajouter: «Le drame social de Gorki, comme la Nana de Zola, se trouvé transposé, au-delà du réalisme naturaliste, dans une sorte de fantaisie désinvolte» [I2, p. 73].

Le gros de reproches porte cependant sur le ton supposé «faussement russe». On ironisait: «Quant aux interprètes des Bas-Fonds, à qui fera-t-on croire qu'ils sortent du livre de Gorki? <...> Les fausses barbes et les perruques des moujiks parisiens se décollent manifestement» [4, p. 69-70]. Et en même temps on descendait Vladimir 
Sokolov pour avoir joué Kostylev "à la russe” dans la pire convention du genre [ı2, p. 72]. A lire les commentaires, la «russité» apparait, pour les créateurs mêmes du film, comme une des grandes axes problématiques de sa réalisation et il semblerait que leurs intentions aient été mal comprises par certains critiques de l'époque.

Le peintre, décorateur et costumier, ami proche de Zamiatine, Georges Annenkov se rappelle, dans ses célèbres mémoires, que celui-ci, après avoir choisi Les Bas-Fonds pour en faire un scénario, s'attache à rendre la pièce plus compréhensible pour le spectateur: «L'amour pour la création gorkienne et l'amitié qui le liait à Gorki incitèrent Zamiatine à transposer une de ses pièces sur l'écran français. Après moult hésitations, il arrêta son choix sur Les Bas-Fonds. La tâche n'a pas été facile car l'ambiance des «bas-fonds» russes fut étrangère en France au large public cinématographique. Zamiatine a décidé de franciser la pièce, la transposer sur le sol français» [2, c. 276].

Comme le dit l'historien, Renoir aurait donné son accord pour la réalisation du film à condition qu'on n'essaie pas de faire de la Russie authentique. Or, curieusement, Zamiatine joue dans ce récit un rôle très secondaire même par rapport à son co-auteur avéré Jacques Companeez: «Il a accepté un sujet proposé par Kamenka, l'adaptation du roman [sic] de Gorki, Les Bas-Fonds, qui, pour plusieurs raisons, peut sembler aux goûts du jour: l'idéalisme révolutionnaire et le climat social de I936, la vogue du film slave et celle des héros déclassés - ces derniers devant être interprétés par des vedettes ayant la faveur du public. Jacques Campaneez écrivit le scénario avec le concours d'un Russe, Eugène Zamiatine, qui prit soin d'envoyer son script à l'auteur: «Gorki était très content de voir bientôt son œuvre à l'écran. Hélas! il est mort avant qu'on ait pu lui montrer le film terminé...» Dans l'intervalle, Renoir avait donné son accord pour la réalisation à condition qu'on n'essaie pas de faire de la Russie authentique. Il reprit l'adaptation avec Charles Spaak et s'empressa de bouleverser la production qui répondait trop bien aux normes de la fabrication [I2, p. 7I].

Renoir lui-même revient sur cette question plus d'une fois, notamment dans une interview écrite bien connue qui date de I937; il y dit en substance qu'il n'a jamais voulu réaliser «un film russe», mais un drame humain: «je crois qu'en laissant de côté le tape-à-l'œil russe, les samovars, les balalaïkas et les tsiganes <...> pour cabarets montmartrois, j'ai mieux respecté l'idée principale de Gorki» [I7, p. I22].

Si l'on en croit au metteur en scène, l'envie d'écranisation des Bas-Fonds a germé en lui en réponse au défi lancé par l'écrivain lui-même: lors d'une projection 
de La Mère de Poudovkine, en I928, Gorki aurait jugé Les Bas-Fonds impossibles à filmer (peut-être, mais Renoir ne pouvait pas le savoir, après avoir tenté lui-même une expérience scénaristique avec Sur la route vers les bas-fonds [8], une ébauche restée dans ses archives dans laquelle la préhistoire des héros de la pièce était esquissée).

C'est dans ce même interview que Renoir parle avec enthousiasme du scénario de Zamiatine (sans évoquer Companeez) comme «d'un grand poème, libre de toute convention, un poème lyrique et déchirant». On a cité ce passage en oubliant la suite: «A partir de ce scénario, Charles Spaak, mon collaborateur, et moi-même, retravaillâmes d'arrache pied» [I7, p. I22]. Autrement dit, le poème de Zamiatine avait une grande force poétique, mais sans une refonte ne pouvait servir de cadre pour le tournage.

Dans un écrit plus élaboré que l'interview cité, Renoir explique, en reprenant certaines de ses expressions, pourquoi il n'avait pas cherché à injecter de la «russité» dans son film. Pour cette adaptation, dit-il, deux solutions existaient: reconstituer l'atmosphère originale ou transposer. Lui-même, dit-il, aurait préféré la première. Mais pour une reconstitution fidèle la production manquait de moyens, et «les extérieurs eussent été faux». Or, «la moindre fausse note eût risqué de nuire sérieusement à l'impression générale. C'est pourquoi un tel travail appartenait bien plutôt au cinéma soviétique. <...> Quant à nous, <...> nous voulions avant tout reproduire l'esprit de l'œuvre qui, après tout, ne reposait que bien peu sur la couleur locale». Le réalisateur choisit donc une «troisième solution... qui consistait à ne pas la situer de la façon précise, à la laisser dans une atmosphère neutre» [I6, p. 238-239].

On notera que cette réflexion contredit le témoignage d'Annenkov, en ce qui concerne à la fois la «francisation» des changements apportés à la pièce et leur cause: non pas la crainte de l'incompréhension du public (au contraire, on l'a vu, ce dernier se préparait à voir une mise à l'écran proche de l'original), mais des raisons inhérentes au travail du cinéaste.

Une autre remarque entre parenthèses: le vœu de Renoir de voir le cinéma soviétique reprendre le travail sur Les Bas-Fonds ne sera exaucé qu'en I952, seize ans après la sortie de son film; depuis, des adaptations se suivent en Russie à un rythme lent, mais régulier (MKHaT, mise en scène fleuve de Stanislavski et NemirovitchDanechenko, V. Orlov, I. Raevski; 1952: Andreï Frolov; 1972: un film tv de Galina Voltchek et Leonid Ptchelkine). Récemment, en 20I5, Vladimir Kott, dans un film 
pour la télévision, a tenté non seulement d'ancrer la pièce de Gorki dans notre époque mais aussi de rapprocher son esthétique des usages du cinéma actuel. La comparaison entre les versions écranisées des Bas-Fonds constituerait un passionnant sujet en soi. Paradoxalement, si le tout premier livre sur Renoir est écrit en I938 par un historien soviétique, Georgiï Avenarius [3], ses films sont rarement montrés en URSS et Les Bas-Fonds ne le sera jamais. Sa version DVD n'a été présentée au public russe que lors des journées zamiatiniennes de Tambov en 2004 [2I, c. 78].

Fermons la parenthèse. Renoir précise sa méthode dans $M a$ vie et mes films, un bilan écrit en 1974, quelques années avant sa mort.

Une Partie de Campagne et Les Bas-Fonds illustrent bien ce que je pense des rapports entre le scénario et la prise de vue. Ces rapports sont caractérisés par un manque de fidélité apparent. Il y a un monde entre le plan et le résultat final. Néanmoins, mon infidélité n'est que superficielle, car je crois être toujours resté fidèle à l'esprit général de l'œuvre. Un scénario, pour moi, ça n'est que qu'un outil que l'on change au fur et à mesure que l'on progresse vers un but qui, lui, ne doit pas changer. $<\ldots>$

Le cinéaste proclame son droit de modifier le scénario car c'est lui, le cinéaste, qui après avoir saisi l'esprit général de l'œuvre, cherchera comment la transposer à l'écran. Et de préciser que sa recherche ne pourra se faire en solitaire: «Ce but, l'auteur le porte en lui souvent à son insu <...> Sa conviction intérieure n'apparaît qu'avec le temps et, en général, par la collaboration avec les artisans du film, acteurs, techniciens, éléments naturels ou travaux du décorateur. <...> Le metteur en scène n'est pas un créateur, il est une sage-femme [I8, p. II5].

«Le metteur en scène n'est pas un créateur, il est une sage-femme»: Renoir souligne que le tournage est un processus maïeutique qui se fait collectivement. Renoir, homme d'équipe: tous les témoignages confirment sa déclaration.

C'est une raison d'ouvrir notre problématique sur celle du travail au cinéma, nécessairement collectif, et pour le cas que nous étudions, de nous intéresser à l'équipe qui travaillait avec Renoir - et avec Zamiatine - pour Les Bas-Fonds: les historiens du cinéma aiment évoquer, et parfois décrire par le menu les équipes de tournage; les spécialistes de la littérature lorsqu'ils parlent des films le font rarement, du moins à ma connaissance. 
Aussi, en parlant du scénario des Bas-Fonds, oublie-t-on systématiquement de mentionner que dans beaucoup de documents afférant au film, ainsi que dans le générique, celui-ci est donné comme écrit conjointement par Zamiatine et Jacques Companeez, en russe: Jakov Kompaneec, ou Kompanejcev. Zamiatine lui-même parle de son scénario; je ne me souviens pas d'un endroit dans ses écrits ou ses interviews où il aurait évoqué son co-auteur. Le rôle de ce dernier, son œuvre, son parcours ne sont pas pris en compte. Dommage: il s'agit d'un personnage plus qu'intéressant. Jacques Companeez (1906-1956), père de la cinéaste Nina Companeez et grand scénariste, commence sa carrière en Allemagne et en 1936, année de la création des Bas-Fonds, arrive en France où il finira par avoir 80 films à son actif dont certains pour les metteurs en scène aussi importants que L'Herbier ou Duvivier. Avec Jacques Becker (l'assistant de Renoir sur Les Bas Fonds), il signera en 1952 le célèbre Casque d'or. Dans les années I930, il a également collaboré avec des cinéastes russes qui tournaient leur films en Europe, avec Tourjanski, Moguy, Ozep. Or, ce dernier et Zamiatine travaillent ensemble sur le projet avorté d'Anna Karénine. On voit combien serré était le milieu du cinéma à cette époque. Un dossier Companeez est conservé aux archives de l'IMEC; il comprend plusieurs listes de ses travaux accomplis, destinées à être inclues dans ses curricula vitae et composées par lui-même; lorsqu'il y note Les Bas-Fonds, il apparaît dans la liste comme seul auteur; il ne précise pas, comme il le fait pour d'autres œuvres, qu'il avait un co-auteur et ne mentionne pas Zamiatine. Voilà un mystère qu'il serait passionnant d'élucider.

Pas moins intéressant que Companeez est le personnage d'Eugène Lourié (I9II-200I), un des tous grands décorateurs du cinéma, dont l'activité s'étend depuis Abel Gance jusqu'à Clint Eastwood. Lourié travaillait sur Les Bas-Fonds et il semblerait que c'était lui qui avait suggérer à Renoir hésitant d'abandonner le style pseudo-russe. Il se souvient: «J'ai proposé à Renoir qu'on élimine tout détail ethnologiquement russe. Renoir souriait, ravi, en me répondant que nos vues cinïncidaient et que c'était justement son intention de réécrire le scénario en collaboration avec Charles Spaak, avec cette même idée de l'universalité comme but» [5, p. I76].

Davantage. Lourié que c'était lui qui avait conseillé au producteur artistique du film de prendre à la mise en scène Renoir avec qui il avait travaillé sur Madame Bovary [5, p. I76].

Pourquoi parler de ces collaborateurs de Renoir et de Zamiatine? Trois raisons à cela. D'abord, nous apprenons à les connaître ce qui nous offre une chance de 
savoir du nouveau sur la vie de Zamiatine et sur ses travaux: pour cela, il faudra les pister avec assez de persévérance jusque dans leurs archives. La deuxième raison: en approchant différents créateurs qui élaborent une œuvre commune, on peut voir de plus près leur contribution et ce faisant, trouver une nouvelle perspective sur l'œuvre entière et sur le travail particulier des membres de l'équipe.

Revenons à Lourié pour expliciter ce point: son décor dans Les Bas-Fonds est riche, diversifié, très cohérent, ni russe ni français, et très actif. On a dit souvent que le film de Renoir effaçait le conflit central de la pièce de Gorki, la rupture entre l'idéal et la réalité, la vérité et le mensonge. A mon sens pourtant, le film donne à voir ce conflit par des moyens subtils, tels notamment que l'interaction entre les personnages et le décor. Seul exemple: dans les scènes qui se déroulent dans l'appartement rempli de bric-à-brac de Kostylev, vieux revendeur, on aperçoit placée à côté de la porte, sur un meuble, une sculpture très années folles d'un menestrel noir avec un bandjo. Cette figure fait écho, comme une sorte de contraste ironique, à une statue pseudo-antique dans l'appartement du Baron; chez Kostylev, elle accompagne toutes les échanges entre les personnages, comme pour relativiser en raillant toutes leurs querelles et leurs mensonges.

La troisième raison de prêter attention à l'équipe du film est que cela nous permet d'élargir le sujet déjà entamé de la «russité». Comme l'a montré une publication récente [2I, c. 79-80], Alexandre Prokofiev, connaissance pétersbourgoise de Zamiatine, avait été sollicité pour la musique des Bas-Fonds. Il a refusé et c'est Jean Wiéner qui reprend le flambeau, dont la musique, si ostentatoirement épurée de motifs russes que cela en devient suspect, est digne d'une analyse elle aussi. L'intérêt de la publication en question est d'ajouter de l'information sur les relations au sein du milieu artistique russo-français; ainsi le fait que Prokofiev avait été abordé par Vladimir Zederbaum, producteur administratif des Bas-Fonds et collaborateur d'Alexandre Kamenka, le producteur artistique du film et directeur de la société de production Albatros. Ce nom d'Albatros n'est pas correctement commenté dans la publication; les études zamiatiniennes oublient fréquemment de le mentionner. Or, il s'agit d'une société de production française. Il existe des travaux, dont celui, pionnier, de François Albéra [r], ainsi que la magnifique chronique de Rashit Ïanguirov [II], sur la société qui avait joué un rôle primordial dans l'évolution du cinéma français et du cinéma tout court.

Son personnel technique et administraif, composé en grande majorité des spécialistes russes émigrés, représentait dans les années vingt le plus haut niveau 
mondial. C'est de cette équipe que vient la plupart de ceux qui assurent la réalisation des Bas-Fonds: outre le décorateur, le chef opérateur (Fédote Bourgassoff), le maquilleur (Igor Keldisch), le régisseur (Basile Kourotchkine, «Koura» dans le générique), les spécialistes d'effets spéciaux (Paul Minine et Nicolas Wilcke), quelques acteurs (surtout Vladimir Sokolov dans le rôle du vieux Kostylev).

On a pu dire que Renoir s'était consacré au cinéma, impressionné par les films d'Ivan Mosjoukine produits par Albatros. Dans ses mémoires, il confirme qu'il était «un admirateur enthousiaste des films muets tournés par cette société» [I8, p. II7-II8]. Notons que Charles Spaak s'est formé à Albatros.

Notons également qu'à côté de Jacques Becker, assistant attitré de Renoir, un deuxième poste d'assistant à la mise en scène a été confié à Joseph Soiffer, un émigré russe qui ne venait pas d'Albatros. On peut supposer que cet homme de cinéma et de théâtre, installé en France depuis I929 et connu pour ses films d'avant la révolution, avait pour fonction d'assurer la bonne communication entre Renoir et ses collaborateurs.

Voilà «une belle équipe» qui assura la qualité du film par son savoir faire, son travail d'ensemble et par cette «universelle russité» qui attirait le public tout en rendant moins aisée la perception du film. Dans ce processus, Zamiatine eut une part importante, mais non exclusive.

On ne peut qu'imaginer comment Zamiatine s'est-il mit à travailler pour Albatros. Son contact aurait pu être le metteur en scène Fédor Ozep, pendant un temps lié à Albatros et déjà évoqué plus haut; grâce à ce contact Zamiatine aurait pu proposer à la société d'adapter la pièce de Gorki; cette éventualité rendrait plus probable l'affirmation d'Annenkov selon laquelle le scénario des Bas-Fonds était un projet que Zamiatine caressait depuis longtemps.

Dans le même passage déjà cité des mémoires, Renoir complète sa version de la génèse «scénaristique» des Bas-Fonds. «Incapable de suivre un plan tracé par quelqu'un d'autre», il transforme avec Spaak le scénario de Zamiatine et Companeez. Il souligne que seul le travail en commun l'intéresse: pourrait-on en déduire que Zamiatine et Companeez, ensemble ou séparément, participaient à ce travail de transformation? Je manque d'éléments tangibles pour l'affirmer, mais la chose semble possible. «Le scénario que nous établîmes Spaak et moi était bien différent de la pièce originale de Gorki. Nous le soumîmes à son approbation. Il répondit par une lettre à Kamenka dans laquelle il disait sa croyance en une adaptation libre et nous approuvait entièrement» [I8, p. II7]. 
Ici, un nouveau mystère apparaît. La lettre dont Renoir parle n'a jamais été retrouvée, ni dans ses archives, ni dans celles de Kamenka. Se trouve-t-elle dans celles de Gorki?

Dans un interview au tournage, Zamiatine donne sa version de l'histoire (il la confirmera dans l'article à la mémoire de Gorki): «J'ai changé un peu la pièce, raconte M. Zamiatine, le scénariste. Je montre la vie de chacun avant qu'il ne soit tombé dans les "bas-fonds". Un mois avant la mort de Gorki, je lui ai envoyé le scénario en demandant son avis. Il était satisfait. Dans une longue lettre, il m'expliqua l'orthographe de "Louka" qu'on ne devait pas écrire anec un $u$, mais avec ou, parce que qutrement on ne le prononcerait pas juste... Gorki était très content de voir bientôt son œuvre à l'écran. Hélas! il est mort avant qu'on ait pu lui montrer le film terminé...» [I9].

Le texte que Renoir et Spaak mirent à l'approbation de Gorki, qu'a-t-elle en commun avec l'envoi dont parle Zamiatine et qui contiendrait son scénario à lui? Il y a-t-il eu deux lettres? Gorki a-t-il répondu à deux? Acquiesça-t-il à deux propositions?

Selon Zamiatine, Gorki aurait insisté dans sa réponse sur quelques détails et, entre autres, sur l'écriture du nom de Louka. Or, dans une des versions du scénario, le tapuscrit français de la BiFi de Paris intitulé «Les Bas-Fonds. Exposé de Zamiatine-Companeez», la première mention du personnage est écrite «Lucas» et les suivantes «Louka». Pour simplifier, imaginons donc une séquence suivante: Kamenka envoie à Gorki une lettre avec le texte de Zamiatine-Companeez. Il reçoit une réponse, peut-être non pas directement de Gorki, mais par un intermédiaire quelconque, par exemple, par sa compagne Moura Boudberg qui connaissait aussi bien Zamiatine que les responsables d'Albatros à qui elle avait vendu les droits d'adaptation; l'absence de la lettre pourrait s'expliquer par la supposition que la réponse n'était pas écrite mais transmise oralement à Kamenka et à Zamiatine en même temps. Ils font corriger le nom dans la deuxième copie, sa première occurence restant là par omission. Dans cette version, Renoir aurait tout simplement confondu les envois, sa moûture du scénario ayant été écrite après la reception du feu vert de Gorki, tandis que Zamiatine imaginait une longue lettre de Gorki là où il n'y avait peut-être que quelques mots rapportés par sa secrétaire.

A cette étape de l'enquête, il est impossible d'être plus précis.

Pour cette raison, passons à un autre problème et, toujours afin de simplifier, concentrons-nous sur cette version du scénario qui existe en plusieurs va- 
riantes quasi-identiques qui ne diffèrent que par quelques corrections cosmétiques et de mise en page et qui portent toutes l'intitulé réunissant les deux co-auteurs: «exposé de Zamiatine-Companeez».

Ainsi, j'aborde enfin la question: le scénario des Bas-Fonds a-t-il évolué et comment? Que garde-t-il du texte russe des archives Bakhmétiev (appelons-le «texte A») tel qu'il a été publié dans l'édition 2oro des œuvres de Zamiatine [20]?

Sur le fond du texte de la pièce (texte o), j'ai comparé ce texte A à l'exposé français Zamiatine-Companeez (texte B) et au script de tournage en français gardé aux archives BiFi, qui intègre au texte du départ les dialogues de Spaak et les changements apportées par Renoir (texte C).

Il serait trop long d'exposer les différences. Je me contente de dire que le texte $B$ suit l'histoire et la séquence de scènes du texte $A$, en modifiant légèrement le découpage (selon l'habitude théâtrale, le texte russe marque chaque entrée de personnages), et en arrondissant des angles: le style est plus littéraire, certains détails brutaux effacés, notamment dans les descriptions de Natacha martyrisée. On pourrait deviner que Companeez supervisait la «francisation» du texte initial; connaissant le fonctionnement des studios, il était à même de proposer de légers changements.

En revanche, le texte A comporte un bon nombre de changements par rapport au texte o. Zamiatine a effectivement changé la pièce; il élimine les scènes «philosophiques» chères à Gorki au profit de l'intrigue sentimentale, modifie les rapports et les fonctions des personnages, met l'accent sur le Baron et raconte aussi bien son histoire d'avant la chute (seulement suggérée dans la pièce) que son amitié avec Pepel, déplace le suicide de l'Acteur de la fin vers le milieu de l'histoire, fait Vassilisa tuer son mari en accusant Pepel. Il ajoute également plusieurs scènes autour du chantier: le Baron commence à y travailler en simple ouvrier, et Pepel y est engagé, prêt à commencer une nouvelle vie par l'amour pour Natacha. Le meurtre du vieux le mène en prison, mais il va bientôt en sortir, innocenté par une improbable délégation des gueux au commissariat de police. Dans une interview, Zamiatine dit que «le Baron comprend que sa destinée est de devenir ouvrier» [2I, c. 78]. Une curieuse conception que Renoir ne retiendra pas. Il fera le contraire, en faisant la promotion de la paresse libertaire.

Des textes A-B, le film (texte C) reprend le rôle essentiel du Baron, l'histoire de celui-ci, son amitié avec Pepel devenu le personnage principal ainsi que l'effacement relatif d'autres personnages de l'asile et la démultiplication de décors s'ouvrant encore plus sur l'extérieur, vers la cour, vers la nature. 
Renoir bouleverse du tout au tout la séquence posée par les textes A-B, tout en en gardant beaucoup de scènes et de plans. Paradoxalement, dans son script (et dans le film), il revient vers Gorki: il rétablit le motif de la mort d'Anna la tuberculeuse, remet à leur place finale deux autres morts de l'histoire, redonne à l'épisode du meurtre son caractère accidentel, retrouve les monologues de Louka, de l'Acteur, du Baron; et il fait tout cela en s'inscrivant dans la lignée des films du Front Populaire, son film sombre s'éclaircit parfois, exhale un air léger, fantaisiste et, surtout à la fin, très chaplinesque.

Arrêtons-nous ici. L'enquête continue. Pour le moment cependant, l'essentiel a été dit. On l'a vu, l'«universelle russité» - la mise en place d'une esthétique compréhensible pour tous mais enracinée dans la culture russe, la réalisation d'un film français avec une équipe des créateurs et techniciens russes - a été, pour le film de Renoir, en même temps, un problème à résoudre et un avantage. Il est vain de vouloir déterminer qui gagne le plus haut grade du mérite artistique, la pièce, le scénario, le film. Comme on le sait, dans le genre d'entreprise artistique qu'est le cinéma, la seule garantie du succès est la collaboration de toute l'équipe. D'autre part, chaque texte mérite un traitement particulier et une mise en contexte qui permet de découvrir des pistes de recherche et d'analyse insoupçonnées. En ce qui concerne la relation de l'adaptation scénaristique et l'œuvre initiale, tous deux, Zamiatine et Renoir sont restés, me semble-t-il, fidèles à Gorki, mais chacun à sa manière, chacun mettant en lumière différentes facettes de la pièce. 


\section{References}

Albéra F. Albatros - Des Russes à Paris I919-I929. Mazzotta-Cinémathèque française, I995. 250 p. (In French)

Annenkov Iu. Dnevnik moikh vstrech. Tsikl tragedii [Journal of my encounters. A cycle of tragedies]. New York, Mezhd. literatur. sodruzhestvo Publ., I966. Vol. I. 35 o p. (In Russ.)

Avenarius G. Zhan Renuar. Ocherk iz istorii kino vo Frantsii [Jean Renoir. Pages from the history of the cinema in France]. Moscow, Kinoizdat Publ., I938. 72 p. (In Russ.) Bazin A. Jean Renoir. Paris, G. Lebovici, I989. 285 p. (In French)

Borger L. Grand illusionniste. Jean Renoir. Le passé vivant. Cahiers du cinéma, I989, p. I78. (In French)

Cavagnac G. Mise en scène du destin. Symposium international du cinéma. Colloque Jean Renoir. Tokyo, Musée national d'art moderne, I997. (In French)

Galushkin A. "Vozvrashchenie” E. Zamiatina. Materialy k zarubezhnoi bibliografii E.I. Zamiatina (I925-I995) [The "Coming Back" of Evgenii Zamiatin. Materials for the abroad bibliography of E.I. Zamiatin (1925-I995)]. Tvorcheskoe nasledie Evgeniia Zamiatina: Vzgliad iz segodnia [Literary heritage of Evgenii Zamiatin. A view from today]. Tambov, Tambovskii gos. un-t Publ., I997, book III, pp. 159-20I. (In Russ.) Gor'kii M. Po puti na dno (I928-I930) [On the road to the lower depths (I928-I930)]. Gor'kii M. Polnoe sobr. sochinenii [The Complete Works]. Moscow, Nauka Publ., I973. Vol. I9: P'esy, stsenarii, dramaticheskie nabroski. I9I7-I935 [Plays, screenplays, dramatic sketches.I9I7-I935]. (In Russ.)

Harvey Brian D. Evgenii Zamiatin-stsenarist [Evgenii Zamiatin as a screenplay writer]. Kinovedcheskie zapiski, 200I, no 53. (In Russ.) Available at: http://www.kinozapiski. $\mathrm{ru} / \mathrm{ru} /$ article/sendvalues/739/ (Accessed I2 May 20I7).

Hobzová D. Catalogue des archives parisiennes d'Evgeni Zamyatin. Cahiers du monde russe et soviétique, 1972, vol. 13, no 2, pp. 232-258. (In French)

Iangirov R. Khronika kinematograficheskoi zhizni russkogo zarubezh'ia: $v 2 t$. [Chronicle of the cinematographic life of the Russian diaspora]. Vol. I: I9I8-I929; Vol. 2: I930I980. Moscow, Knizhnica; Russkii put Publ., 20I0. 544 p. + 637 p. (In Russ.)

Leprohon P. (éd.) Jean Renoir. Paris, Eds Seghers, 1967. I9I p. (In French)

I3 Liubimova M. O zakone khudozhestvennoi èkonomii, fabule i novykh kontsakh. E. Zamiatin - stsenarist frantsuzskogo filma "Na dne" [About the law of artictic parsimony, the plot and new endings. E. Zamiatin as a screenplay writer of a French film]. Russian Studies, 1996, vol. 2, no 2, pp. 375-386. (In Russ.)

Nusinova N. Kogda my v Rossiiu vernemsia... Russkoe kinematograficheskoe zarubezh'e. I9I8-I939 [When we'll be back in Russia... Russian cinematographic diaspora]. Moscow, NIIK-Eisenstein-Tsentr Publ., 2003. 464 p. (In Russ.) 
I5 Primochkina N. M. Gorkii i E. Zamiatin (k istorii literaturnykh otnoshenii) [M. Gor'kii i E. Zamiatin (a supplement for the history of literary relations)]. Russkaia literatura, I987, no 4, pp. I48-I6o. (In Russ.)

I6 Renoir J. Ecrits I926-I97I. Paris, Belfond, I974. 309 p. (In French)

I7 Renoir J. Gorki in celluloid. Interview. The New York Times, 5 septembre I937. (In English)

I8 Renoir J. Ma vie et mes films. Paris, Flammarion, I974. 279 p. (In French)

I9 T.L. (Tamara Lundina). Dans les Bas-Fonds, avec Jean Renoir. Pour Vous, I936, no II. (In French)

20 Zamiatin E. Na dne [The Lower Depths]. Zamiatin E. Sobranie sochinenij: $v$ t. [Works in 5 vol.]. Moscow, Dmitrii Sechin;Respublika Publ., 20Io, vol. 4: Besedy eretika [Conversations of a heretic], pp. I6I-I77. (In Russ.)

2 Z Zheltova N. et al. (publ.) Neizvestnyi Zamiatin. Po stranitsam frantsuzskoi gazety Comœdia [An unknown Zamiatin on the pages of a French journal Comœdia]. Filologicheskaia regionalistika, 2013, no 2 (IO), pp. 75-8I. (In Russ.)

22 Zheltova N. Nauka o E.I. Zamiatine v monografiiakh nachala XXI veka [The Zamiatin studies at the beginning of the XXI century]. Vestnik Tambovskogo Gos. Un-ta, 20I2, issue 2 (I06), pp. 52-58. (In Russ.) 
УДК 821.І6І.І.о

ББК $83.3(2 \mathrm{Poc}=$ Рус $) 6$

\section{ТВОРЧЕСТВО ГОРЬКОГО \\ И ВОЗНИКНОВЕНИЕ \\ СОЦИАЛИСТИЧЕСКОГО РЕАЛИЗМА}

(C) 2018 г. Л.А. Спиридонова

Институт мировой литературы

им. А.М. Горького Российской академии наук,

Москва, Россия

Дата поступления статьи: 20 декабря 2017 г. Дата публикации: 25 марта 2018 г.

DOI: IO.22455/2500-4247-20I8-3-I-2I2-233

Аннотация: В 1932 г. партийные идеологи по воле Сталина объявили М. Горького «основоположником социалистического реализма». Это определение, превратившись в идеологический штамп, сопровождает его до сих пор, мешая разглядеть в писателе не только классика советской литературы, но и талантливого художника-новатора, который всю жизнь стремился к созданию нового метода в русской литературе. Считая классический реализм отжившим, Горький уже в самом начале XX в. писал о необходимости искусства, которое рассматривало бы жизнь с высоты идеалов будущего. Начиная с повести «Мать» (I906), он шел по пути синтеза художественного сознания с социалистическим идеалом, который мыслился ему как способ гармонического устроения нового мира. В «Сказках об Италии» и автобиографической трилогии («Детство», «В людях». «Мои университеты») мечта Горького о грядущей справедливой и разумной жизни при социализме выражается с помощью синтеза реализма и романтизма. В последние годы жизни, выступая в публицистических статьях с пропагандой метода социалистического реализма, сам Горький не создал ни одного художественного произведения в соответствии с догматическими принципами, разработанными после смерти писателя.

Ключевые слова: Горький, Сталин, социалистический реализм, синтез, реализм, модернизм.

Информация об авторе: Лидия Алексеевна Спиридонова - доктор филологических наук, профессор, заведующий отделом изучения и издания творчества М. Горького, Институт мировой литературы им. А.М. Горького Российской академии наук, ул. Поварская, д. 25 а, І2Іо69 г. Москва, Россия.

E-mail: spirlid@mail.ru 


\section{GORKY'S WORK AND THE RISE OF SOCIALIST REALISM}

This is an open access article distributed under the Creative Commons Attribution 4.0 International (CC BY 4.0)
(C) 20I8. L.A. Spiridonova

A.M. Gorky Institute of World Literature of the Russian Academy of Sciences, Moscow, Russia Received: December 20, 2017

Date of publication: March 25, 2018

Abstract: In I932, the Communist party ideologists called Maxim Gorky the founder of socialist realism at the behest of Stalin. This tag has turned into an ideological cliché that accompanies the writer's image even in the present day and does not allow us to see him as a talented artist who sought to create a new method in Russian literature. Believing classical realism to be outdated already at the beginning of the $20^{\text {th }}$ century, Gorky called for such artistic format that would describe human life from the height of futuristic ideals. Starting with the novella Mother (I906), he sought to implement the synthesis of artistic consciousness with socialist ideals that he considered the means of harmonious rearrangement of the new world. In The Tales about Italy and in the autobiographical trilogy (Childhood, My Apprenticeship, and My Universities), Gorky's dream of the happier future life under socialism manifests itself through the synthesis of realism and romanticism. In his late years, while advocating the method of "social realism" in his essays, Gorky did not write a single fictional work that would incarnate dogmatic principles that were developed already after his death.

Keywords: Gorky, Stalin, socialist realism, synthesis of realism and modernism.

Information about the author: Lydia A. Spiridonova, DSc in Philology, Professor, Head of the Department, A.M. Gorky Institute of World Literature of the Russian Academy of Sciences. Povarskaya 25 a, I21069 Moscow, Russia.

E-mail: spirlid@mail.ru 
Теория социалистического реализма как нового творческого метода советской литературы разрабатывалась партийными идеологами в мае 1932 г. по инициативе Сталина, которому сразу же стали приписывать его идею и название. В «Литературной газете» 23 мая 1932 г. впервые появилась формулировка нового метода, закрепленная в І934 г. в уставе Союза советских писателей․ И.М. Гронский впоследствии утверждал, что «определение социалистического реализма как основного метода советской литературы было дано еще 20 мая 1932 г.» в кабинете Сталина во время беседы с ним [5, c. I44-I46]. Тогда же Горький, вернувшийся из Сорренто 25 апреля I932 г., узнал, что он теперь не только «первый пролетарский писатель», но и «основоположник социалистического реализма», зародившегося в недрах старого строя в его повести «Мать», написанной в 1906 г. в Америке.

Казалось бы, как мог «основной метод» советской литературы, возникшей лишь после Октября I9I7 г., зародиться в самом начале XX в.? Впрочем, мысли о том, что в обществе будущего, которое многим уже тогда представлялось социалистическим, будет какой-то иной метод отражения жизни в искусстве, высказывались давно. Фактически в конце XIX в. наметилось обновление не только реализма, но и романтизма, который связывали с мечтой о социализме. В «Истории всемирной литературы» говорится, что «на рубеже нашего столетия романтические тенденции в искусстве возродились с особой силой. Они проявлялись в разной форме - на уровне стиля, тематики или даже метода. Эта новая романтическая волна в литературе была одной из

I Обеспечим все условия творческой работы литературных кружков. На собрании актива литературных кружков Москвы // Литературная газета. I932. № 23, 23 мая. С. I. 
форм реакции на натурализм, и термин “неоромантизм” обычно рассматривают в ряду других постнатуралистических течений» [6, с. 2І3].

Для литературного процесса в России конца XIX - начала XX вв. характерна идея обновления творческих методов и поиск художественного синтеза. Критический реализм, так ярко расцветший в XIX в., уже не удовлетворял запросам времени, в котором ощутимо чувствовалось неминуемое приближение войн и революций. В начале января 1902 г. Горький писал А.П. Чехову: «Знаете, что Вы делаете? Убиваете реализм и убьете Вы его скоро-насмерть, надолго. Эта форма отжила свое время, это факт!» Добавив, что сам он этому «убийству» очень рад, Горький пояснил, что «настало время нужды в героическом: все хотят возбуждающего, яркого, такого, знаете, что бы не было похоже на жизнь, а было бы выше ее, лучше, красивее» [2, т. 2, c. 9]. Иначе говоря, само время диктовало писателям необходимость создания искусства будущего, в котором были бы элементы романтизма и призыв к подвигу.

Об этом писали Горькому его адресаты. Сибирский писатель В.И. Анучин поделился с ним своими мыслями: «Как в науке одинаково пользуются и анализом, и синтезом, так и в литературе должны применяться на равных правах реализм и романтизм. Они не противостоят, не замещают друг друга, они соседствуют. И вполне возможно (может быть, необходимо!) применение обоих в одном произведении. <...> Какова будет литература при социалистическом строе? Ответ: не знаю, конечно. Но социализм (движение, подъем, творчество) настолько романтичен сам по себе, что реализм, несомненно, отходит на второй план. Поскольку социализм впереди жизни, а не в уровне с нею, ему недостаточно простой правды, его не удовлетворит реалистический диагноз, ему нужен романтический прогноз. Вероятно, в социалистическом искусстве будет какой-то свой новый метод» [2, т. Іо, с. 532]. Горький согласился с Анучиным, ответив ему 22 октября (4 ноября) І9І2 г.: «Мысль о том, что это будет и не реализм, и не романтизм, а синтез их обоих, - мне кажется приемлемой. Да, возможно, что так и будет» [2, т. Іо, с. I73].

Реализм и модернизм существовали в русской литературе начала XX в. не только во взаимной борьбе и отрицании, но и во взаимопроникновении, что выражалось в возникновении неореализма и неоромантизма. Критик Э.М. де Вогюэ заметил, что процесс возрождения романтизма происходит не только в России, но и в европейских странах Он писал, что, изменившись 
в соответствии со временем, романтический лев сменил аристократический плащ Чайльд-Гарольда на демократическую рубашку мужика, но «остался таким же, как был, несмотря на всякие литературные украшения, «молодым животным, гордым и разнузданным». Это возрождение романтизма происходит по всей Европе: Горький, Д. Аннунцио, Р. Киплинг, Г. Гауптман, Г. Сенкевич - это «все родные братья одного духовного отца - Ницше»².

Горький был одним из тех писателей, которые искали пути обновления реализма. Как известно, его ранние рассказы озадачили В. Короленко, который не знал, кем выступает в них автор: реалистом или романтиком. Они и вправду написаны как будто разными писателями. Достаточно сравнить рассказы «Старуха Изергиль» и «На соли», созданные почти одновременно. Действие в них происходит на берегу Черного моря, который по-разному видится автору. Романтическому описанию пейзажа в «Старухе Изергиль» соответствуют характеристика героев, их чувств, настроений и размышлений, их действий, исключительных и необычных. В рассказе «На соли» тоже изображены море, небо, солнце, берег лимана, но колорит повествования совсем другой: нестерпимо палящий зной, сухая растрескавшаяся земля, красно-бурая, как кровь, трава, жирная черная грязь ила, в которой копошатся, словно черви, серые фигуры мужчин и женщин. Вместо романтической сказки перед нами реалистическая картина тяжелого труда на соляных промыслах. Можно сделать вывод, что в раннем творчестве Горького реализм и романтизм существовали рядом, так как он пробовал себя и в том, и в другом виде творчества.

Осваивая традиции русской и мировой литературы, Горький с самого начала творческого пути искал свою дорогу, отвергая существующую жизнь, несправедливую и безобразную, и утверждая величие подвига во имя счастья людей. Его босякам присуща безудержная жажда свободы, анархическое бунтарство, дерзкое неприятие существующего порядка. Проблема личности в ее отношении к обществу и миру, столь характерная для европейского «нового искусства», превратилась у Горького в прославление Человека с большой буквы. Воспевая сильного и независимого героя, непохожего на окружающих, писатель перекликался не только с Ницше, но и с К. Гамсуном, изображавшим индивидуалистический бунт личности против обывательской среды.

2 Яковлев С. Литературное обозрение. Иностранцы о Горьком // Волгарь. І902. І8 июля. 
Но его Данко, Сокол и Буревестник символизируют не «сверхчеловека», а нового героя времени, готового отдать жизнь за счастье людей и призывающего революционную бурю.

Романтическая идея определила художественное своеобразие произведений раннего Горького: исключительность героев, обстановки действия, языка. Но вместе с тем в них наличествуют черты, которые присущи только Горькому: контрастное сопоставление героя и мещанина, Человека и раба, альтруиста и эгоиста. В центре действия - диалог идей, возникающий вокруг противоположных духовных полюсов или разных героев. Все это создает фон, на котором звучит голос самого автора, размышляющего о счастье и справедливости, о правде и лжи, о лучшем жизненном устройстве. Поэтому уже в конце г890-х гг. критики В. Поссе, А. Скабичевский, М. Гельрот и др. признавали новаторство поэтики Горького [ІІ, с. 239, 263, 403].

Но был ли Горький «первым по времени и по рангу пролетарским писателем», как назвал его А.В. Луначарский [9, с. 23]? Ведь его босяки, грузчики на Волге, рыбаки, пекари, плотники и даже наборщики и машинисты паровоза не пролетарии в обычном, классовом, смысле слова. Люмпен-пролетариев он тоже изображал не первый. Среди писателей XIX в. назовем хотя бы Жоржа Экоуда, в очерках которого «Из мира бывших людей» заметна романтизация «отверженных», или Жана Ришпена и Жана Риктю, с которыми сравнивал Горького в 1898 г. критик И. Игнатов [ІІ, с. 324]. В том же году А. Скабичевский заметил, что от горьковских героев «и не пахнет тем, что на Западе известно под именем пролетариата. Перед нами явление самобытно-русское, исконно-историческое, подобное которому в настоящее время вряд ли можно найти где бы то ни было...» [ІІ, с. 240].

Социалистические идеи широко распространялись во второй половине XIX в. во всем мире. Не только в прозе (Э. Золя «Жерминаль», «Ругон-Маккары», Т. Манна «Будденброки», Д. Лондона «Мартин Иден», М. Твена «Железная пята», К. Лемонье «Клещи», М.А. Нексе «Пеле-победитель» и мн. др.), но и в поэзии (Э. Потье, А. Рембо, Э. Верхарн), говорилось о безжалостной эксплуатации человека при капитализме. Что касается Горького, он в раннем творчестве никогда не выступал как ортодоксальный марксист. В феврале г897 г. он писал А.М. Скабичевскому: «Я - не марксист и оным не буду вовеки, ибо считаю стыдом исповедовать “марксизм по-рус- 
ски и по-немецки”, ибо я знаю, что жизнь творят люди, а экономика только влияет на нее» [2, т. І, с. 218].

Истинной верой писателя всю жизнь было «человекопоклонничество». В г9оо г. он признался Л.Н. Толстому: «Глубоко верю, что лучше человека ничего нет на земле, и даже, переворачивая Демокритову фразу на свой лад, говорю: существует только человек, все же прочее есть мнение, Всегда был, есть и буду человекопоклонником...» [2, т. 2, с. 2I]. И о том же в письме А.П. Чапыгину г3 августа г925 г. «Верю же я только в человека. Только в него. Это вся моя религия, весьма мучительная, но в той же мере и радостная» [2, T. I5, C. I35].

Протестуя против стремления нарядить Горького в костюм «первого пролетарского писателя», критик еженедельника «Nation» писал, что «мерка, по которой сшит этот костюм, подошла бы с таким же успехом и Джеку Лондону, и О’Генри»³. Объясняя причины «притягивания» Горького к пролетарскому революционному движению, А. Удодов пишет: «Для леворадикальной интеллигенции (прежде всего марксистского толка) оказалось весьма удобным связать пафос свободы, стремление к “правде-справедливости”, подъем “чувства личности”, характерные как приметы времени и для горьковского творчества, - с классовой сущностью пролетариата, ориентированного на революцию» [I7, с. 22г]. В.А. Келдыш видит более глубокие причины горьковского феномена. Он пишет: «Пролетарская литература на Западе, возникшая задолго до рождения Горького-художника, на первых порах - и это было закономерно - развивалась как литература преимущественно рабочей темы, обращенная к мотивам пролетарской борьбы и труда <...> Однако Горького таким определением объяснить уже невозможно, при всей важности, которую имела для него революционно-пролетарская тема <...> Именно у Горького социалистическое художественное мышление впервые становится явлением синтетическим, ключом к целостному познанию бытия» [6, с. 63].

Романтического героя и «философствующих босяков» в творчестве Горького вскоре сменил реальный человек труда, протестующий против угнетения и насилия. Первым из них был Нил в пьесе «Мещане», громко заявивший: «Хозяин - тот, кто трудится» [3, т. 7, с. 48]. Главное художественное открытие писателя во второй период творчества - попытка найти нового 
героя времени, способного изменить застойное течение жизни. В повестях «Мать», «Исповедь» и пьесе «Враги» социалистическая идея, лежащая в их основе, придает произведениям мифотворческий характер, а реалистическое изображение рабочей слободки в Сормове, борьбы непримиримых классовых врагов, описание Исетского завода и народного крестного хода полны реальных жизненных деталей. Можно сказать, что в этих произведениях Горький впервые попытался совместить реализм и романтизм в рамках одного повествования.

В центре внимания автора - преображение человека в процессе борьбы за свои права, рост самосознания народа, проблема коллективной психологии масс, превращающихся из слепой толпы в организованную силу под влиянием социалистических идей. Понимая, что православную Русь можно поднять на борьбу только с помощью новой веры, столь же сильной, как христианство на заре возникновения, «буревестник революции» Горький считает социализм именно такой верой. Это заставляет его прибегать к новаторским приемам изображения: черно-белая гамма красок, использование религиозной образности (Ниловна сравнивается с Богоматерью, Павел с Христом, его друзья-социалисты - с апостолами), символика и аллегоризм. И хотя в повести «Мать» изображено много действительных событий, а некоторые герои имеют даже жизненные прототипы, ее вряд ли можно назвать реалистической в традиционном понимании. Горький выступает как новатор, создавая одновременно новое «евангелие» для пролетариата и летопись реальных событий из истории революционной борьбы. Идеи социализма он считает новой религией трудящегося человека, поэтому его герои напоминают не только пролетарских революционеров, но и двенадцать апостолов, несущих народу новую веру.

Богостроительство Горького, возникшее под влиянием философии прагматизма (У. Джемс, Д. Дьюи) и идей А. Богданова, В. Базарова, А. Луначарского, базировалось на идеалистической основе. Анализируя «Исповедь», М. Никё определил своеобразие повести как «оригинальный синтез ницшеанства и марксизма» [19, с. 423]. Как известно, такой синтез, а главное, попытка подменить религию верой в социализм вызвали резкую критику «Матери» в либеральной и даже в социал-демократической прессе. Одно это уже свидетельствует о том, что Горький, по его неоднократному признанию, был «плохим марксистом». Ему важнее было показать в повести «Мать» не 
эпизод классовой борьбы, а процесс духовного воскрешения человека под влиянием новых идей.

В повести «Исповедь» писатель прослеживает развитие идеи коллективизма, которая у него не ограничивается классовым лозунгом «Пролетарии всех стран, соединяйтесь!» Называя себя «преколлективистом по Базарову», Горький формулирует собственную богостроительскую идею о возникновении коллективного мирового «бога-народушки», объединенного общей верой и потому способного творить чудеса. Познакомившись с новейшими теориями о превращении материи в энергию, писатель поверил, что эманация слитой воедино воли одинаково мыслящих людей способна стать чудотворной. Реальная мечта социал-демократов о единении пролетариата разных стран в процессе классовой борьбы за свои права превратилась у Горького в утопическую идею «бога-народушки», который может изменить ход истории и даже исцелить безнадежно больного. В финале повести эманация энергии людей, идущих крестным ходом к храму, поднимает на ноги парализованную девушку.

Чутко уловив мифопоэтический подтекст повести «Мать», Л. Андреев писал Горькому: «...то, что здесь считается твоим падением (“социал-демократ увлекается политикой, и оттого талант падает”) один только я верно оцениваю как новый подъем на огромную небывалую высоту» [8, с. 289]. Он имел в виду попытку Горького создать новаторское произведение, соединяя в одно целое романтическую мечту о социалистическом будущем, поиск героя времени и реалистические приемы его изображения. В повестях «Мать», «Исповедь» и пьесе «Враги» отразился новый этап творческой эволюции Горького - мифологизация человека и коллектива, объединенного общей верой, иначе говоря, идея «собирания» разрозненных членов общества в одного Человека с большой буквы.

Свою концепцию личности Горький сформулировал в письме И. Репину от 24 (3) ноября І899 г.: «Я не знаю ничего лучше, сложнее, интереснее человека. Он - все. Он создал даже Бога <...> . Верю в бесконечность жизни, а жизнь понимаю как движение к совершенствованию духа» [2, т. 2, c. 377]. Обратим внимание на последние слова: «совершенствование духа», а не призыв к пролетарской революции. Горьковский мятежный человек, который шествует «всё вперед и выше», скорее сопоставим с библейскими героями, восходящими на гору, чтобы услышать слово Божие и нести его 
людям. Он, несомненно, близок к мифологическим архетипам, бытующим в христианстве и древнерусской литературе, ибо включен в круг не только земной, но и небесной жизни. Традиционный цикл (рождение - земное житие - смерть - воскресение) изображается Горьким как путь к воскрешению духа. В отличие от Ницше, он верит в прогресс, поэтому его Человек стремится «вперед и выше» и утверждает, что распутает загадки бытия, создаст гармонию между собой и миром, усовершенствует самого себя.

Сблизившись с большевиками, познакомившись с европейскими и американскими социал-демократами, Горький опустил своего героя на землю, сделав его пролетарским революционером Павлом Власовым, но не лишив при этом идеальных черт. Еще более идеализирована «душа воскресшая» Ниловна, образ которой большевистский критик В. Воровский счел нетипичным для рабочей среды. Рассматривая образную систему повести «Мать» в контексте христианской и фольклорной традиции, Е.И. Маркова пишет: «...мать-старуха, воспринявшая революционное учение как слово правды новых христиан, раздает листовки (слово Сына) сначала на фабрике вместе с обедом (Хлебом насущным), затем идет по деревням (в Народ) и наконец на вокзале (в Пути) она последний раз служит Правде Сына» [І2, с. 48].

В «Исповеди» сделан следующий шаг по созданию мифопоэтической образности. Искатель правды Матвей находит истину не в общении с протопопами, схимонахами, духовными проповедниками, отшельниками, а в духовном единении с народом. Происходит то, что Горький назвал в статье «Разрушение личности» (1909) синтезом мифа и эпоса. Он писал, что героический эпос был «вместилищем знаний народа о себе и требований к себе самому. Затем миф и эпос сливались воедино, ибо народ, создавая эпическую личность, наделял ее всей мощью коллективной психики и ставил против богов или рядом с ними» [4, т. 24, с. 26]. Героиня «Матери» Ниловна, как любой человек, посвятивший себя революции, может погибнуть за веру, ибо личность смертна. Народ (коллектив) бессмертен, именно поэтому Горький сравнивает его с Богом. В статье «Разрушение личности» он обосновывает эту мысль, утверждая: «Коллектив не ищет бессмертия, он его имеет, личность же, утверждая свою позицию владыки людей, необходимо должна была воспитать в себе жажду вечного бытия» [4, т. 24, с. 26].

Разоблачая буржуазный индивидуализм, Горький пишет: «Народ - не только сила, создающая все материальные ценности, он - единственный и 
неиссякаемый источник ценностей духовных, первый по времени, красоте и гениальности творчества философ и поэт, создавший все великие поэмы, все трагедии земли и величайшую из них - историю всемирной культуры» [4, т. 24, с. 30-3I]. Эти слова прямо перекликаются с утверждением отца Ионы в повести «Исповедь»: «Все, что есть на земле и в памяти твоей, все народом создано» [3, т. I, с. 344]. Торжествует мысль о народе как единственной созидающей силе, способной преобразить землю и людей. Таким образом, народ уравнивается с Создателем мира, а мифотворчество Горького приобретает облик богостроительства.

Во многом разделяя взгляды философов-коллективистов А.А. Богданова (Малиновского) и В.А. Базарова (Руднева), Горький пытался воплотить их идеи в конкретные художественные образы. Интересны рассуждения В. Базарова, сделанные вскоре после выхода повестей «Мать» и «Исповедь». Считая, что писатель должен осуществлять синтез классицизма и романтизма, он связывал это требование с ростом социалистического сознания и чувства коллективизма в русском народе. II февраля г908 г. он писал Горькому: «Необходимо показать с полной отчетливостью, что в искусстве, в характерном для его развития чередовании эпох классицизма и романтизма, прогресс реализовывался в таком же искалеченном, однобоко изуродованном виде, как и в остальных сферах деятельности скованного социальным рабством человечества» [I, с. I3I].

Отвечая на горьковский вопрос, как может художник отразить новую тенденцию в творчестве, Базаров заметил: «...социализм несет с собой синтез. Но как конкретно осуществить этот синтез, - на этот вопрос литератор-беллетрист не найдет ответа у теоретика социализма. Тут требуется не анализировать, а демонстрировать. “В начале было дело”, - и это дело должны совершить не аналитики, а художники нового духа, от них же первый есть Вы» [I, c. I3I]. Как видим, один из теоретиков марксизма назвал Горького первым из творцов нового искусства еще в 1908 г. Несмотря на отрицательные отзывы критики и утверждения либералов о «конце Горького», писатель продолжал искать пути синтеза в искусстве.

Социальный романтизм, определивший своеобразие Горького-художника и сущность его новаторства, отчетливо проявился в «Сказках об Италии». Колоритные описания итальянских городов и островов, мастерски сделанные портреты простых людей позволяют назвать писателя реалистом, 
верно рисующим итальянскую жизнь. Но циклу присуща и другая особенность - широкое использование символистской образности для создания мифа о счастливом будущем человека труда при социализме. «Сказки об Италии» печатались в российских газетах и журналах I9II-I9I3 гг. как очерки об итальянской жизни. По жанру они действительно являются художественными очерками, в которых повествуется о прекрасной стране и ее удивительном народе. Во всех очерках перед читателем предстает сама Италия: ее города, острова, горы, море. Срисованные с натуры фигуры рабочих, крестьян, рыбаков, солдат, торговцев составляют коллективный портрет итальянцев, «веселых и шумных, подвижных, как ртуть» [3, т. І2, с. 9]. На фоне блистательной итальянской природы они выглядят не очень красиво: чумазый смазчик, кривой старик, торговка, «старый мешок, туго набитый мясом и костями и кое-где сильно сморщенный» [3, т. І2, с. 69], древний старец Этторе Чекко «с длинными руками обезьяны, с голым черепом мудреца, с лицом, так измятым временем, что в его дряблых морщинах почти не видно глаз» [3, т. I2, c. І2г]. Тяжелая трудовая жизнь измяла и изуродовала их, не лишив при этом чувства собственного достоинства.

Казалось бы, Горький выступает в «Сказках об Италии» как реалист. Однако этому выводу противоречит другая особенность цикла - широкое использование символистской образности и создание мифа о счастливом будущем народа. Реальные события, описанные Горьким: забастовка трамвайщиков, встреча детей из голодающей Пармы, строительство Симплонского туннеля, волнение крестьян в Болонье - подчинены определенной художественной задаче - показать, что «все мы идем к свободе» [3, т. І2, с. 4I]. Таким рисовалось писателю будущее в свете социалистического идеала. Поэтому реальные картины жизни и быта итальянцев даются на фоне романтического изображения самой Италии, ее народа и природы. Солидарность людей, идущих к новой жизни, преображает не только их, но все окружающее: город гудит, поет море, ярко сверкает солнце, творя чудесную сказку о будущем.

Горький постоянно использует в «Сказках об Италии» прием одушевления неживого: остров Капри «кажется лобастым зверем: выгнув мохнатую грудь, он прильнул к морю огромной пастью и молча пьет воду, застывшую, как масло» [3, т. I2, с. I42], он спит, окутанный тишиной. Среди темной равнины вод он кажется писателю подобным «жертвеннику пред лицом бога-солнца» [3, т. І2, с. І2г]. Море и солнце в «Сказках об Италии» - символы, 
играющие сюжетообразующую роль. «Любит солнце эту землю», - говорит писатель об Италии [3, т. І2, с. 27]. Горький уравнивает понятия Солнце и Жизнь. Он видит в нем живое существо, сообщая читателям: «солнце смеется», «тает солнце», «истекает кровью», «небо ласково смотрит на землю голубым ясным оком, солнце - огненный зрачок его» [3, т. І2, с. 9].

Столь же значим для поэтики «Сказок по Италии» символический образ моря, которое тоже одушевлено: «поет море», «заснувшая вода», «не совсем проснулось море», «тихий говор волн», «шелковый шорох моря», «звенят волны, веселые и зеленые», «мягко звучит море». Горький широко пользуется приемами, характерными для поэтики символизма. Но, в отличие от символистов, его мысль нацелена не на воспевание миров иных и поиск индивидуального счастья, а на романтизацию подвига, совершаемого во благо всего народа.

В «Сказках об Италии» на новом материале продолжается тема социализма как нового миросозерцания трудящихся. Утопизм писателя сказывается в идеализации распространяемых в народе революционных идей, которыми он был увлечен. Общаясь с итальянскими социалистами Артуро Лабриола, Джиовани Бергамаско, Энрико Ферри, членами редакции газеты «Аванти!»,читая двухтомное исследование Альфредо Анджиолини «История социализма в Италии» (1907), Горький постоянно размышлял о том, что новую жизнь могут создать только новые люди. Именно такими он хотел видеть простых итальянцев, знающих цену тяжкому труду и сердечной доброте. Размышляя о социализме как обществе будущего, Горький связывает его возникновение с демократией, властью народа, мечтающего о свободной и справедливой жизни. Поэтому в Италии он подмечает все проявления солидарности людей труда, их бескорыстие, товарищескую взаимопомощь, энтузиазм и доброту. Живые картинки жизни итальянского народа даются сквозь призму социалистического идеала.

Сам Горький считал социализм высшей формой духовной жизни общества, строй, при котором жизнь станет «праздником для всех», богатых и бедных, как писал он графине Ф.Э. Уоррик [2, т. 5, с. І68]. Понимание социализма как новой «религии» связывало Горького не с ортодоксальными марксистами, а с его собственным убеждением, что общественным прогрессом движет разум, проводником которого должен быть Человек с большой буквы. Романтическая мечта о новом человеке, внутренне свободном, гар- 
монически цельном, окрашивает не только «Сказки об Италии», но и цикл «По Руси», где Горький приветствует рождение нового жителя страны, которому суждено изменить «окуровскую» глубинку.

«Сказки об Италии» и цикл «По Руси» стали следующими шагами в создании гармоничного синтеза в творчестве Горького. Л. Андреев, единственный, кто заметил качественное изменение его творческого метода, писал: «И если теперешние писания твои не удаются тебе и еще долго не будут удаваться, то причина - в новизне и гениальности твоего нового теперешнего мироощущения, мирочувстввования» [8, с. 380]. Удача пришла уже в цикле «По Руси», а еще больше в автобиографической трилогии Горького «Детство», «В людях». «Мои университеты».

Концепция Человека-творца, активно перестраивающего мир и себя, постоянно углублялась и трансформировалась в творчестве Горького. Следующим этапом его эволюции стала автобиографическая повесть «Детство», в центре которой сложный процесс формирования духовной личности ребенка, который, несмотря на кошмарные условия жизни, вырастает новым человеком, мечтающим перестроить мир на основе разума и справедливости. Образ Алеши Пешкова автобиографичен. Писатель рисует реальную обстановку, в которой проходило его детство и юность, мастерски воссоздает портреты близких: бабушка, дедушка, мать, отчим, родня. Эффект подлинности изображаемого усиливается с помощью повествования от первого лица.

Но фактическая сторона повести является лишь канвой, по которой Горький искусно вышивает художественное произведение. Его главная мысль - человека создает активное сопротивление среде и постоянное самосовершенствование. Показывая рождение нового героя в недрах старого строя, писатель уверяет, что, несмотря на «свинцовые мерзости жизни», в России «победно прорастает яркое, здоровое, творческое, растет доброе, человечное» [3, т. I5, с. І34]. Чтобы передать сложную морально-философскую проблематику повести, Горький использует мифологию и символику, древнерусское житие, героическую притчу и аллегорию. Алеша Пешков - не просто мальчик, а «Алексей, Божий человек», бабушка и дедушка выражают мировоззрение двух контрастно противоположных типов: пассивного и активного, альтруиста и эгоиста. «Символ бессознательного» по Юнгу - книга как сила, защищающая человека от злых духов, становится главным стимулом духовного развития героя. 
Американский исследователь Б. Шерр, рассматривая повесть «Детство» с точки зрения развития религиозного сознания, писал о Горьком: «Автобиография сама по себе является менее важной, чем идеи, которые он пытается выдвинуть, и метод, с помощью которого он так делает» [20, с. 221]. Обратим внимание на слово «метод». Можно сказать, что именно в автобиографической трилогии Горький достиг успеха в создании новаторского метода изображения действительности с точки зрения будущего. Биографический, литературный и исторический контексты образовали синтез, в котором сплетаются «лирика мифа и сила факта». Творя миф о себе самом, писатель подчинил все реальные факты определенной художественной задаче: создать в трилогии сложное единство, в котором тесно сплетаются христианская символика, славянская мифология и народная мечта о лучшем будущем. Признавая, что изображение мира порой бывает у него чересчур темным, писатель замечает: «Но правда выше жалости, а ведь не про себя я рассказываю, а про тот тесный, душный круг жутких впечатлений, в котором жил - да и по сей день живет, - простой русский человек» [3, т. 15, с. 30].

Сложный процесс формирования детской души под влиянием окружающей обстановки, описанный в трилогии, сочетается с кардинальными мировоззренческими вопросами о вере и безверии, назначении человека и смысле жизни, свободе и необходимости, гуманизме и жестокости. Алеше ближе добрый Бог бабушки, чем жестокий и злой Бог дедушки, наказывающий человека за любую провинность. Но христианское всепрощение тоже чуждо Алеше: он не может подставить другую щеку, когда его бьют, и не прощает обид. Со временем у него рождается своя «еретическая» вера, которая заменяет ему религию - вера в Человека с большой буквы. В трилогии Горького, особенно в ее последней части, ощутимо присутствует национальноисторическая тема России и ее судьбы. Повествование о жизни Алеши Пешкова и окружающих его людей вписано в широкую картину народной жизни. Выразительные портреты «хозяев» и работников, противопоставленные друг другу, позволяют Горькому показать и положительные, и отрицательные черты национального характера. В «пестрых душах» россиян уживаются дерзкая непокорность и рабская психология, звериное и человеческое, но это не мешает писателю верить, что народ все-таки добьется лучшего будущего.

Автобиографическая трилогия является несомненным художественным достижением Горького. «Это лучшее изо всего, что им создано», - пи- 
сал К. Чуковский, отмечая изумительный образ бабушки как «средоточие света»4. Д. Мережковский увидел в ней саму Россию, «не святую, а грешную». Он писал: «Да, не в “святую”, смиренную, рабскую, а в грешную, возмущающуюся, освобождающуюся Россию верит Горький, знает, что “Святой Руси” нет, верит, что “Святая Россия будет” [ІІ, с. 856]. Эти оценки подтверждают значение автобиографической трилогии в процессе развития творческого метода писателя. Пройдя путь от ницшеанства к социализму и пытаясь совместить в одном произведении реализм и романтизм, он создал новаторский метод изображения действительности в ее революционном развитии.

В г9зо-е гг. этой особенностью творчества Горького воспользовались советские идеологи, которые по совету Сталина объявили его «основоположником социалистического реализма», а созданную в 1906-I907 гг. повесть «Мать» первым образцом нового метода. Эти штампы надолго закрепились в советском литературоведении и дожили до наших дней, постоянно мелькая в СМИ, в пособиях по литературе Серебряного века и даже в историях русской и зарубежной литературы для студентов гуманитарных вузов. И хотя в конце $\mathrm{XX}$ в. резко изменилось представление о литературном процессе и были разрушены методологические догмы марксизма-ленинизма, эволюцию Горького-художника по-прежнему представляют как путь от революционного романтизма к реализму, а потом к социалистическому реализму. Этот стереотип советских лет мешает читателям разглядеть в «пролетарском писателе» и «основоположнике социалистического реализма» оригинального мыслителя и талантливого художника-новатора.

В мае г932 г. Горького не было в кабинете Сталина, когда в беседе вождя с И. Гронским рождалось название нового метода советской литературы [5, с. I45]. Его не было и на заседании комиссии Политбюро, где присутствовали писатели из РАППа, ВОАППа и МОРПа (А. Афиногенов, В. Киршон, Б. Ясенский, Б. Иллеш и др.), когда социалистический реализм был утвержден как творческий метод советской литературы. Однако председательствующий П. Постышев заявил, что метод возник в его творчестве задолго до Октября. Сам писатель до конца жизни так и смог четко определить сущность нового метода, именуя его чаще всего социалистическим романтизмом. В 1934 г. в статье «О бойкости» Горький писал: «Революционный романтизм - это, 
в сущности, псевдоним социалистического реализма, назначение коего не только критически изобразить прошлое и настоящее, но главным образом способствовать утверждению революционно достигнутого в настоящем и освещению высоких целей социалистического будущего» [2, т. 2, с. I59].

Фактическое участие Горького в определении нового метода ограничилось популярной статьей «О социалистическом реализме» для начинающих писателей в № I «Литературной учебы», вышедшей I7 июля I933 г. Но самое главное, в годы советской власти, рекламируя соцреализм в публицистике, Горький в художественных произведениях оставался верен собственному творческому методу. Драматургия этого периода («Егор Булычов и другие». «Достигаев и другие», второй вариант «Вассы Железновой») носит все признаки новой европейской драмы. Изображение исторических событий сочетается в них с углубленным вниманием к внутреннему миру человека, острая социальная и нравственная проблематика разрушает привычные стереотипы семейно-бытовой драмы. Голос автора звучит в произведениях одновременно с голосом истории, создавая тщательно скрытый второй план.

Догмы социалистического реализма, разработанные партийными чиновниками уже после смерти Горького, не имеют ничего общего с художественным миром писателя. В его пьесах ощутимо чувствуются особенности «новой драмы», характерной для европейских писателей. «Метод картин», создающий видимость реальности, превратился в горьковские «сцены» со всеми признаками нового жанра. Многоаспектность интерпретации событий, сочетание трагизма и комизма, вставные игровые эпизоды, диалог идей позволяют говорить о новаторстве Горького-драматурга. Изображение жизни как потока истории, разрушение традиционного сюжета, архитектоника вместо композиции - все это роднит «сцены» Горького с пьесами Г. Ибсена, К. Гамсуна, Б. Шоу, Г. Гауптмана, М. Метерлинка, Л. Пиранделло и других известных писателей.

Монументальный роман-эпопею Горького «Жизнь Клима Самгина» советские литературоведы упорно называли произведением социалистического реализма, основываясь на том, что российская действительность показана писателем в ее революционном развитии [13, с. 403]. Историзм, действительно, присущ произведению. Но сложное полифоническое единство, в котором судьба отдельной личности рассматривается на фоне сорока лет жизни России и развития общественного сознания интеллигенции, никак не 
назовешь типичным образцом соцреализма. Показывая трагедию личности в период смены эпох и всеобщей переоценки ценностей, Горький следует за мастерами европейского интеллектуального романа (Р. Роллан, Г. и Т. Манн, Г. Уэллс, Д. Джойс и др.). Даже психологическая проза М. Пруста, которого неоднократно критиковал Горький, явно повлияла на изображение «потока сознания» главного героя «Жизни Клима Самгина».

Повествование о герое плавно переходит в рассказ о судьбах русской интеллигенции на переломе XIX-XX вв. и - шире - о трагической истории страны и ее народа. Самгин выступает в роли медиума, сознание которого вызывает к жизни «все наши ходынки», «все гекатомбы, принесенные нами в жертву истории» [II, с. 644]. Постижение России происходит параллельно с раскрытием характера главного героя. Художественное мастерство писателя столь велико, что каждая идея облекается в образы реальных персонажей, а иногда и в образы исторических деятелей эпохи. По словам М. Голубкова, Горький использует в произведении «принципы типизации, присущие новому реализму» [I4, с. I3I].

Как же называть творческий метод Горького и можно ли его тесно связывать с социалистическим реализмом? Если обратиться к периодике I930-х гг., мы обнаружим полный разнобой в названиях метода советской литературы: «новый реализм» у А. Воронского, «тенденциозный реализм» В. Маяковского, «монументальный реализм» А. Толстого, «фантастический реализм» С. Есенина. Возникающая советская литература создавалась не на пустом месте, а на базе творчески переосмысленных традиций прошлого, поэтому слово реализм сохранялось, свидетельствуя о приверженности писателей правдивому изображению жизни. И хотя резко изменились ценностные ориентиры, а марксизм-ленинизм стал «наукой наук», заменяющей философию, структура литературного процесса в советские годы во многом основывалась на архетипах русской культуры.

Тем не менее революционная эпоха диктовала свои требования. И они реализовались в теории нового литературного метода. Предвосхищая его создание, Горький писал в статье «О литературе и прочем» (I93I): «Не следует ли поискать возможности объединения реализма и романтизма в нечто третье, способное изображать героическую современность более яркими красками, говорить о ней более высоким и достойным ее тоном» [2, т. 26, с. 53]. Именно этого он добивался в собственном творчестве. 
Споры о сущности социалистического реализма, начавшиеся в I930-х гг., не утихают до сих пор. А.Д. Синявский и его единомышленники объявили основной метод советской литературы «грубой демагогией Жданова или старческой причудой Горького» [I5, с. I39]. По их мнению, его главная особенность заключается в телеологии, т. е. стремлении выдать желаемое за действительное. Синявский находит в советском искусстве родство с классицизмом, хотя считает, что романтизм «охватил, главным образом, предысторию и начало социалистического реализма» [I5, с. I65].

В г988 г. на страницах «Литературной газеты» развернулась дискуссия «Отказываться ли нам от соцреализма?», в итоге которой он был признан определенной художественной системой, возникшей в результате закономерного развития литературного процесса в мире. Пытаясь исследовать его структуру. В. Страда пишет: «Именно сейчас, когда соцреализм перестал быть гнетущей реальностью и ушел в область исторических воспоминаний, необходимо подвергнуть феномен соцреализма тщательному изучению, чтобы выявить его истоки и подвергнуть анализу его структуру» [І6, с. 64].

Теория соцреализма представляется В. Страде синтезом трех начал: ницшеанства, марксизма и богостроительства. Идя по пути к синтезу, Горький, как мыслитель, прошел все эти стадии и со временем разочаровался в них. Его взгляды были шире каждой из составляющих этого единства, ибо писатель создавал собственный художественный синтез, ставший основой его творческого метода. Он выступил в русской литературе начала XX в. зачинателем нового литературного направления, которое сегодня все чаще называют «новым реализмом» или неореализмом, а в живописи даже «романтическим реализмом». Внимательно присматриваясь к новаторским, в том числе и модернистским художественным открытиям, и стремясь с максимальной полнотой отразить своеобразие революционного времени, Горький шел по пути синтеза романтизма, реализма и социалистического мифотворчества. Социальный идеализм, историзм, народность и вера в Человека с большой буквы определили своеобразие его взгляда на действительность и создали предпосылки новаторства писателя. 


\section{Список литературы}

Горький и его корреспонденты. М.: ИМЛИ РАН, 2005. 680 с. (М. Горький. Материалы и исследования. Вып. 7).

2 Горький М. Полн. собр. соч.: Письма: в 24 т. М.: Наука, ИМЛИ РАН, 997.

3 Горький М. Полн. собр. соч.: Художественные произведения: в 25 т. М.: Наука, г969.

4 Горький М. Собр. соч.: в 30 т. М.: Гос. изд-во худож. лит., І 953.

5 Гронский И., Овчаренко А. К истории партийной политики в области литературы (Переписка И. Гронского и А. Овчаренко) // Вопросы литературы. I989. № 2. C. I43-I66.

6 История всемирной литературы: в 9 т. М.: Наука, І994. Т. 8. 850 с.

7 Литературное наследство. М.: Наука, I963. Т. 70: Горький и советские писатели. Неизданная переписка. 734 с.

8 Литературное наследство. М.: Наука, I963. Т. 72: Горький и Леонид Андреев. Неизданная переписка. 630 c.

9 Луначарский А.В. Статьи о литературе: в 2 т. М.: Худож. лит., г988. Т. 2: Советская литература. Теория и литературная критика / сост. Л. Истомина. 493 с.

Iо Луначарский А.В. Статьи о советской литературе. М.: Просвещение, 1971. 567 с.

II Максим Горький: pro et contra. Антология. СПб.: Изд-во Русского христианского гуманитарного ин-та, I997. 90 с с. Маркова Е.И. Творчество Николая Клюева в контексте северно-русского словесного искусства. Петрозаводск: Карел. НЦ РАН, І997. 316 с.

I3 Михайловский Б.В. Творчество Горького и мировая литература. М.: Наука, I965. 648 c.

I Наука о литературе в XX в. (история, методология, литературный процесс». М.: ИНИОН, РАН, 200I. 376 с.

I5 Синявский А. (Абрам Тери) Литературный процесс в России. М.: РГГУ, 2003. 4 I8 c.

I6 Страда В. Советская литература и русский литературный процесс XX в. // Вестник МГУ. Сер. 9. I995. № 3. С. 45-64.

I7 Удодов А.Б. Феномен М. Горького как эстетическая реальность: генезис и функционирование. (I890 - начало І90о-х годов). Воронеж: Воронежский гос. пед. ун-т, I999. 442 c.

I8 Barrat A. Maxim Gorky. Boston: Twayne, I988. I40 p.

I9 Niqueux M. Qu'en est-il de l'influence de Nietzsche sur Gor'kij? // Slavica occitana. 2006. № 22.

Sherr Barry P. Godbuilding redux: the religion impuls in Gorky's «Childhood» // Modern greek studies yearbook. 20I2. Vol. 24/25. P. I5O-I6I. 


\section{References}

I Gor'kii i ego korrespondenty [Gorky and his correspondents]. Moscow, IMLI RAN Publ., 2005. 680 p. (M. Gor'kii. Materialy i issledovaniia. Vyp. 7 [M. Gorky: materials, issue 7]). (In Russ.)

Gor'kii M. Poln. sobr. soch.: Pis'ma: $v 24$ t. [Complete works: Letters in 24 vols.]. Moscow, Nauka, IMLI RAN Publ., I997. (In Russ.)

3 Gor'kii M. Poln. sobr. soch.: Khudozhestvennye proizvedeniia: v 25t. [Gorky M. Complete works in 25 vols.]. Moscow, Nauka Publ., I969. (In Russ.)

4 Gor'kii M. Sobr. soch.: v 30 t. [Gorky M. Works: in 30 vols.]. Moscow, Gos. izd-vo khudozh. lit. Publ., I953. (In Russ.)

$5 \quad$ Gronskii I., Ovcharenko A. K istorii partiinoi politiki v oblasti literatury (Perepiska I. Gronskogo i A. Ovcharenko) [To the history of the Communist party politics in literature (Correspondence of I. Gronsky and A. Ovcharenko]. Voprosy literatury, I989, no 2, pp. I43-I66. (In Russ.)

6 Istoriia vsemirnoi literatury: $v 9 t$. [History of world literature in 9 vols.]. Moscow, Nauka Publ., I994. Vol. 8. 850 p. (In Russ.)

7 Literaturnoe nasledstvo [Literary heritage]. Moscow, Nauka Publ., I963. Vol. 70: Gor'kii i sovetskie pisateli. Neizdannaia perepiska [Vol. 70: Gorky and Soviet writers. Unpublished correspondence]. 734 p. (In Russ.) Literaturnoe nasledstvo [Literary heritage]. Moscow, Nauka Publ, I963. Vol. 72: Gor'kii i Leonid Andreev. Neizdannaia perepiska [Gorky and Leonid Andreev: Unpublished correspondence]. 630 p. (In Russ.)

9 Lunacharskii A.V. Stat'i o literature: $v 2 t$. [Essays on literature in 2 vols]. Moscow, Khudozh. lit. Publ., I988. Vol. 2: Sovetskaia literatura. Teoriia i literaturnaia kritika [Soviet literature. Theory and literary criticism], ed. L. Istomina. 493 p. (In Russ.) Lunacharskii A.V. Stat'i o sovetskoi literature [Articles on Soviet literature]. Moscow, Prosveshchenie Publ., I97I. 567 p. (In Russ.) Maksim Gor'kii: pro et contra. Antologiia [Maxim Gorky: pro et contra. Anthology]. St. Petersburg, Izd-vo Russkogo khristianskogo gumanitarnogo in-ta Publ., I997. 90I p. (In Russ.)

Markova E.I. Tvorchestvo Nikolaia Kliueva v kontekste severno-russkogo slovesnogo iskusstva [The work of Nikolay Kluev against the background of Northern Russian verbal art]. Petrozavodsk, Karel. NTs RAN Publ., I997.3I6 p. (In Russ.)

I3 Mikhailovskii B.V. Tvorchestvo Gor'kogo i mirovaia literatura [Gorky's work and world literature]. Moscow, Nauka Publ., I965. 648 p. (In Russ.)

I4 Nauka o literature $v X X v$. (istoriia, metodologiia, literaturnyi protsess) [Literary studies in the $2 \mathrm{O}^{\text {th }}$ century (history, methodology, literary process)]. Moscow, INION, RAN Publ., $200 \mathrm{I}$. 376 p. (In Russ.)

Siniavskii A. (Abram Terts) Literaturnyi protsess $v$ Rossii [Literary process in Russia]. Moscow, RGGU Publ., 2003. 4I8 p. (In Russ.) 
I6 Strada V. Sovetskaia literatura i russkii literaturnyi protsess XX v. [Soviet literature and Russian literary process in the $20^{\text {th }}$ century]. Vestnik MGU, Issue 9, I995, no 3, pp. 45-64. (In Russ.)

I7 Udodov A.B. Fenomen M. Gor'kogo kak esteticheskaia real'nost': genezis ifunktsionirovanie. (I89o - nachalo I90o-kh godov) [Gorky phenomenon as aesthetic reality: genesis and functioning (I890 - the beginning of the I900s)]. Voronezh, Voronezhskii gos. ped. un-t Publ., I999. 442 p. (In Russ.)

I8 Barrat A. Maxim Gorky. Boston, Twayne, I988. I40 p. (In English)

I9 Niqueux M. Qu'en est-il de l'influence de Nietzsche sur Gor'kij? Slavica occitana, 2006, no 22. (In French)

20 Sherr Barry P. Godbuilding redux: the religion impuls in Gorky"s "Childhood". Modern greek studies yearbook, 2012, vol. 24/25, pp. I5O-I6I. (In English) 
УДК 82І.І6І.І.о

ББК $83.3(2 \mathrm{Poc}=\mathrm{Pyc}) 6$

\section{М. ГОРЬКИЙ КАК ТЕОРЕТИК ЛИТЕРАТУРЫ}

(C) 2018 г. О.А. Овчаренко

Институт мировой литературы

им. А.М. Горького Российской академии наук,

Москва, Россия

Дата поступления статьи: І5 декабря 2017 г. Дата публикации: 25 марта 2018 г.

DOI: I0.22455/2500-4247-20I8-3-I-234-25I

Аннотация: В центре внимания статьи - взгляды М. Горького как теоретика литературы на проблемы собственного художественного метода и творческого метода других писателей (Гоголя, Тургенева, Достоевского и др.). Кризис критического реализма был осознан Горьким еще в самом начале пути. Анализ теоретических воззрений Горького приводит к выводу о глубокой неудовлетворенности писателя эстетическими достижениями современности. Очевидно, именно это и заставляло его на протяжении всей жизни искать пути обновления реализма. Основываясь на концепции Б.В. Михайловского о кризисе реализма на рубеже XIX-XX вв., автор статьи характеризует различные попытки, предпринятые писателем на этом пути, и их интерпретации в современном литературоведении. Вместе с тем в статье рассматриваются различные определения романтизма, предложенные Горьким, и его внимательное отношение к модернизму, нашедшее реализацию в рассказах І922-І924 гг. В разделе «Характерология» поднимается вопрос о неудовлетворенности писателя образами положительных героев, созданных представителями критического реализма, и его стремлении возместить эти недостатки, создав новую типологию образов, незнакомых современникам образы правдоискателей, босяков, женщин-борцов.

Ключевые слова: критический реализм, кризис, романтизм, модернизм, творческий метод.

Информация об авторе: Ольга Александровна Овчаренко - доктор филологических наук, ведущий научный сотрудник, Институт мировой литературы им. А.М. Горького Российской академии наук, ул. Поварская, д. 25 а, І21069 г. Москва, Россия.

E-mail: olgaimli@yandex.ru 


\section{GORKY AS A THEORETICIAN OF LITERATURE}

This is an open access article distributed under the Creative Commons Attribution 4.0 International (CC BY 4.0)
(C) 20I8. O.A. Ovcharenko

A.M. Gorky Institute of World Literature of the Russian Academy of Sciences, Moscow, Russia Received: December 15, 2017

Date of publication: March 25, 2018

Abstract: The essay focuses on the theoretical problem of M. Gorky's artistic method claiming that Gorky's work combines elements of realism, Romanticism, and modernism. Already at the beginning of his career, he realized that critical realism was in crisis as his opinions about the work of such realist writers as Gogol, Turgenev, Dostoevsky and others testify. Gorky was deeply unsatisfied by either his predecessors or contemporaries as we can tell based on the analysis of his critical views, and this feeling of dissatisfaction forced him to look for the ways of modernizing realism during his whole lifetime. Bearing on the concept of B.V. Mikhailovsky about the crisis of realism at the turn of the $\mathrm{I}^{\text {th }}$ and $2 \mathrm{O}^{\text {th }}$ centuries, author of this article discusses Gorky's attempts to do something about this and of these attempts interpretation in contemporary literary studies. At the same time, the essay examines different definitions of Romanticism as suggested by Gorky as well as his interest in modernism that found manifestation in his tales written from 1922 through I924. The section entitled "Characterology" raises the question of Gorky being unsatisfied with positive characters of critical realism and his attempts to make up for the deficiency of the latter in the images of truth-searchers, tramps, and women.

Keywords: critical realism, crisis, Romanticism, modernism, artistic method.

Information about the author: Olga A. Ovcharenko, DSc in Philology, Leading Researcher, A.M. Gorky Institute of World Literature of the Russian Academy of Sciences, Povarskaya 25 a, I21069 Moscow, Russia.

E-mail: olgaimli@yandex.ru 
Тема, вынесенная в заглавие этой статьи, является, в сущности, необъятной и позволяет во многом дополнить известный нам образ М. Горького. Сейчас, когда публикуется Полное собрание сочинений писателя и становятся общедоступными многие ранее малоизвестные материалы, эта работа может быть лишь первым приближением к осмыслению вклада Горького в теорию литературы, тем не менее попытаемся наметить основные теоретические проблемы, попавшие в поле зрения писателя.

\section{Проблема кризиса критического реализма и необходимости его обновления}

Кризис критического реализма был осознан Горьким еще в самом начале его творческого пути, что и явилось причиной недоумения В. Короленко, считавшего его реалистом и романтиком одновременно. Впрочем, Короленко говорил: «Это - романтизм, а он давно скончался. Очень сомневаюсь, что сей Лазарь достоин воскресения... Реалист вы, а не романтик, реалист...» ${ }^{\mathrm{I}}$ («В.Г. Короленко»)

А в 1900 г. Горький писал А. Чехову по поводу «Дамы с собачкой»: «Знаете, что вы делаете? Убиваете реализм. И убьете вы его скоро - насмерть, надолго. Эта форма отжила свое время - факт. <...> реализм Вы укокошите» [8, т. 2, с. 8].

I Горький М. В.Г. Короленко. URL: http://gorkiy-lit.ru/gorkiy/vospominaniya/v-gkorolenko.htm (дата обращения: І2.09.2017). 
В свое время за концепцию кризиса реализма был подвергнут критике замечательный горьковед Б.В. Михайловский. В наши дни эту концепцию возрождает, например, М.М. Голубков [3, с. 32-35], но без ссылки на предшественников.

Думается, что Горький всю жизнь искал пути обновления реализма.

В «Истории русской литературы» писатель так определяет реализм: «Объективное изображение действительности, изображение, которое выхватывает из хаоса житейских событий, человеческих взаимоотношений и характеров наиболее общезначимое, наичаще повторяющееся, слагает наиболее часто встречающиеся в событиях и характерах черточки и факты и создает из них картины жизни, типы людей» [5, с. І20].

Критикуя концепцию, согласно которой основоположником русского реализма был Н. Гоголь, Горький считает, что в «Ревизоре» он представил искаженное изображение русского чиновничества:

...во времена Гоголя провинциальными чиновниками были Герцен, Огарев, Бакунин, Сатин, Сазонов, Пасек, Витберг, Салтыков-Щедрин и еще десятки таких же крупных людей; сам Гоголь - тоже чиновник.

B «Мертвых душах» - тот же недостаток объективизма, свойственный вообще всем романтикам: время Чичикова и Гоголя имело уже таких дворян, каковы были Аксаковы, Хомяковы, Киреевские, Виельгорские, Бакунины, Жадовские, Сазоновы, Растопчины и опять-таки целый ряд исторических семейств, общекультурное влияние которых на жизнь в ту пору уже начало сказываться [5, с. І25-І26].

Горький упрекает И. Тургенева в слишком критическом изображении «лишних людей» [5, с. I76], а также, наряду с Н. Гоголем и Л. Толстым, в упрощенном изображении народа: «Все они в описании психических свойств мужика сходятся, одинаково ярко подчеркивая его кротость и способность к терпению, все замолчали его склонность к бунтам» [5, с. I87].

Любимым писателем Горького был Н. Лесков, и это объясняется тем, что он сумел разглядеть положительного героя в русской жизни и изобразить его в литературе: 
Лесков изображает своих героев праведниками, людьми крепкими, ищущими упрямо некой всесветной правды, но он относится к ним не с истерическими слезами Достоевского, а с иронией добродушного и вдумчивого человека <...> особенность Лескова: он писал не о мужике, не о нигилисте, не о помещике, а всегда о русском человеке, о человеке данной страны.

Каждый его герой - звено в цепи людей, в цепи поколений, и в каждом рассказе Лескова вы чувствуете, что его основная дума - дума не о судьбе лица, а о судьбе России [5, с. 276-277].

В статье «Н.С. Лесков» (г923) Горький писал: «Он прекрасно чувствовал то неуловимое, что называется “душою народа”... После злого романа "На ножах" <...> он начинает создавать для России иконостас ее святых и праведников. Он как бы поставил целью себе ободрить, воодушевить Русь, измученную рабством, опоздавшую жить, вшивую и грязную, вороватую и пьяную, глупую и жестокую страну, где люди всех классов и сословий умеют быть одинаково несчастными, - проклятую страну, которую надо любить и почему-то необходимо любить так, чтобы сердце каждый день и час кровью плакало от мучений этой любви, столь похожей на пытку невинного сладострастным мучителем» [7, с. 228].

Горький постоянно размышлял о богатых возможностях романтизма, необходимости обновления реализма и возможности приукрашивания жизни с целью создания у масс боевого, революционного настроения.

В г919-г920 гг. в предисловии к «Сказкам об Италии» Горький доказывал:

...вообще - немножко прикрасить человека - не велик грех; людям слишком часто и настойчиво говорят, что они плохи... Если всегда говорить людям только горькую правду о их недостатках - этим покажешь их такими мрачными красавцами, что они станут бояться друг друга, как звери, и совершенно потеряют чувство доверия, уважения и интереса к ближнему... Кроме огромных недостатков, в людях живут маленькие достоинства, и вот именно эти достоинства, выработанные человеком в себе самом очень медленно, с великими страданиями, - эти достоинства необходимо - иногда приукрасить, преувеличить, чтобы тем поднять их значение, расцветить красоту ростков добра, которые - будем верить! - со временем разрастутся пышно и ярко [г, т. 3, с. 222-223]. 
Писатель с молодых лет задумывался о том, как обновить реализм. Романтизм всегда привлекал его, и в «Сказках об Италии» он отразил не столько итальянскую действительность, сколько свое, «духоподъемное» представление о ней, так что это произведение, конечно, романтическое.

Известно, что Горький «прославился» своим делением романтизма на «активный» и «пассивный», в свое время входившим даже в школьные учебники литературы. Отказавшись определить романтизм теоретически, Горький квалифицировал его как «настроение, сложное и всегда более или менее неясное отражение всех оттенков чувствований и настроений, охватывающих общество в переходные эпохи, но его основная нота - ожидание чего-то нового, тревога перед новым, торопливое, нервозное стремление познать это новое... Можно очень удобно разделить романтизм на два течения: первое исполнено болезненно повышенной чувствительностью, непомерно развитой фантазией, это направление - пассивно, оно не имеет иных задач, кроме желания выразить смутную тревогу, а иногда - ужас перед чем-то непонятным, что обнимает человека со всех сторон и душит его... Второе направление более широко, оно имеет характер активный, воинствующий, оно складывается уже после I789 года» [5, с. 42-44].

В 1928 г. в статье «Еще о механических гражданах» Горький утверждал: «Пассивный романтизм - это романтизм усталых мещан, он всегда является на сцену жизни после бурных общественных трагедий и на смену активному романтизму, который обычно предшествует революциям» [7, с. 450-45I].

Тем не менее, из приводимых Горьким цитат понятно, что он осознает, что романтик отражает мир не столько в тех формах, в которых его создал Бог, сколько в тех, в которых его воспринимает сознание художника. Приведя соответствующие слова из Тика, Горький замечает: «Все наши русские модернисты во главе с Ф. Сологубом радостно подпишутся под этими словами; признает их истиною и Л. Андреев - современный нам представитель романтизма воинствующего, активного» [5, с. 45].

В этой цитате заключено немало интересных мыслей. Во-первых, из нее следует, что Горький признает вечность романтизма, перманентность его существования в мировом литературном процессе; во-вторых, писатель понимает, что по крайней мере некоторые модернистские течения являются разновидностью романтизма, что, по нашему мнению, совершенно верно. 
Конечно, противопоставление «активности» и «пассивности» внутри романтизма носит скорее политический, чем эстетический характер.

Проблема творческого метода волновала Горького всю жизнь, и у него можно найти подчас самые противоречивые высказывания о романтизме и модернизме.

В г896 г. в статье «Еще поэт» он отрицательно отзывается о творчестве Сологуба, но в том же году выходит в свет знаменитая статья «Поль Верлен и декаденты», где Горький заявляет, что «декадентство - явление вредное, антиобщественное, - явление, с которым необходимо бороться» [7, с. I25]. И в то же время Горький пишет, что декаденты «искали выхода из буржуазной клоаки, из этого общества торжествующих свиней» и сочувственно упоминает Бодлера, Метерлинка, Малларме, Рембо и, конечно, самого Верлена. Вообще статья свидетельствует о том, что Горький, насколько это возможно в переводах, серьезно изучал поэзию французских символистов.

В том же I896 г. писатель на Всероссийской промышленной и художественной выставке познакомился с творчеством Врубеля, в частности, с панно «Принцесса Греза» и «Микула», но на первых порах нашел в них «нищету духа и бедность воображения» [7, с. I66].

«Или искусство понятно и поучительно, или оно не нужно для жизни и людей, - писал Горький. - Доказано, что искусство Врубеля понятно только специалистам. Каково же его жизненное значение?» [7, с. I68].

И еще: «В жизни достаточно непонятного и туманного, болезненного и тяжелого и без фабрикантов фирмы Врубель, Бальмонт, Гиппиус и Ко. Жизнь требует света, ясности и нимало не нуждается в туманных и некрасивых картинах и в нервозно-болезненных стихах, лишенных всякого социологического значения и неизмеримо далеких от истинного искусства» [7, с. I82]. Впрочем, как утверждает Б.А. Бялик, к I9I8 г. отношение Горького к Врубелю изменилось [2, с. І8].

Он стал относиться с большим вниманием и к творчеству других модернистов. Как показывают новейшие исследования, он сумел воздать должное 3. Гиппиус: «В русской литературе немало женщин-поэтесс, некоторые из них сильно и своеобразно талантливы, а среди них творчество Зинаиды Гиппиус, совершенно исключительное по виртуозности формы стиха и по характеру своему, поставило ее на почетное место, рядом с од- 
ним из крупнейших и оригинальнейших поэтов русских, Федором Тютчевым» [13, с. 5I].

Многолетние дружеские отношения связывали Горького с В. Ходасевичем. И об Андрее Белом, предварительно раскритиковав его, Горький замечает, что «он - поэт, несмотря на свои фокусы и вопреки им, он настоящий поэт» [13, c. I62]. Со временем, как показывают изыскания Н.Н. Примочкиной, Горький сумел оценить талант Вяч. Иванова и помочь музе Брюсова и Белого Нине Петровской.

Это объясняется не только добротой писателя и его осознанием внутреннего единства русской литературы XX в.

Дело в том, что в книге Горького «Рассказы 1922-І924 годов» и в произведениях «Проводник», «Мамаша Кемских», «Убийцы», «О тараканах» писатель разрабатывает приемы и ситуации, традиционно связываемые с модернизмом. Из смеси яви и галлюцинаций состоит рассказ «Голубая жизнь», который хвалили Пришвин и Вяч. Иванов [ІІ, с. 65]. А.И. Овчаренко считал, что в «Голубой жизни» действительность показана «с четырех точек зрения» [І, с. 66]. В «Рассказе об одном романе» не имеющий тени инженер Волков объясняет героине, что он плод вымысла писателя Фомина, но роман остался незаконченным и герои сами пытаются его закончить. Пусть это, как говорил сам Горький, «урок чистописания», но он предваряет опыты столь важных для XX в. произведений, как «Вор» Л. Леонова, «Фальшивомонетчики» А. Жида и «Контрапункт» О. Хаксли.

В рассказе «Карамора» Горький исследует психологию бывшего революционера Каразина, сотрудничавшего с охранкой, но «устраивавшего товарищам маленькие удовольствия» типа побегов из тюрьмы или из ссылки. Карамора все время ощущает раздвоенность, а то и более многоплановое расщепление своей личности. Одна из последних фраз рассказа («Поток мысли. Непрерывное течение мысли») выводит нас уже на литературу «потока сознания».

«В этот период, - пишет Н.Н. Примочкина, - Горький внимательно присматривался к тому кругу русских писателей-современников, в творчестве которых сочетались реализм и модернизм, натурализм и символизм, реальность и фантастика. Стремясь к расширению возможностей творческого метода, он включал в художественную ткань произведений элементы искусства нереалистических течений» [4, с. 30I-302]. Сам Горький писал 
Зазубрину, что его «странная проза» - это «ряд поисков иной формы, иного тона для «Клима Самгина» [II, с. 70].

Вообще поиски Горького в области творческого метода ждут своих новых, современно мыслящих исследователей. Так, Л.А. Спиридонова считает, что в основе художественного мира Горького «чаще всего лежит мифопоэтическая система, близкая христианской и древнерусской поэтике» [15, с. г8о]. Этот мифологизм видится исследовательнице в сотворении Горьким мифа о новом человеке и коммунистическом обществе. Она выделяет в творчестве Горького ряд мифологем (Огня, Воздуха, Воды, Бога, Космоса, Матери, жизненного цикла).

Л.А. Спиридонова полагает, что мифопоэтическая система в творчестве Горького дожила до второй половины І920-х гг., уступив место вначале модернизму (в уже упоминавшихся произведениях), а потом - «социальному романтизму».

Краеугольным камнем в обосновании наличия в творчестве Горького «мифопоэтической системы» является признание повести «Мать» «евангелием новой веры» [15, с. 64]. Безусловно, обращение к теории богостроительства не только углубляет наши представления о писателе, но и позволяет утверждать, что именно он и его единомышленники имели представление о «социализме с человеческим лицом». Но исследовательница проводит мысль о том, что «Горький попытался создать не просто хронику деятельности социал-демократов в Нижнем Новгороде и Сормове, а новое Евангелие пролетариата. Поэтому, в соответствии с замыслом, образ матери ориентирован не столько на реальных женщин, которых встречал писатель, сколько на образ Богоматери, а Павел и его друзья напоминают Христа и святых апостолов» [I5, с. 72]. Можно согласиться с тем, что образ матери является одним из главных во всем творчестве Горького (вспомним матерей из «Сказок об Италии» - мать, пришедшую к Тамерлану в поисках сына; мать, убившую сына-предателя, и т. д.; а также, конечно, образ бабушки из «Детства», в котором действительно можно усмотреть мифопоэтическое начало). Не уверена насчет апостолов - в конце концов, и среди них были разные люди, как и среди горьковских героев, - но думаю, что Павла Власова соотнести с Христом трудно. Христос умел разглядеть божественное начало в каждом человеке, а Павел Власов даже к матери начинает относиться более или менее по-человечески, когда она становится 
его идейной единомышленницей. Да и его невеста Саша заранее согласна с тем, что не должна мешать его революционной деятельности. Кажется, в пылу революционных восторгов исследователи не разглядели, что в лице Павла Власова Горький изобразил классического «революционера на время» из «Несвоевременных мыслей»: «Он прежде всего обижен за себя. За то, что не талантлив, не силен, за то, что его оскорбляли, за то, что некогда он сидел в тюрьме, был в ссылке, влачил тягостное существование эмигранта. Он весь насыщен, как губка, чувством мести и хочет заплатить сторицей обидевшим его» [6, с. 258].

Более того, сам приход матери к революционным идеям, для того чтобы стать ближе к сыну и заставить его обратить на себя внимание, представляется психологически более обоснованным, чем непосредственный приход людей, подобных Ниловне, к марксизму. Возвращаясь к вопросу о повести «Мать» как горьковском Евангелии, думаю, что с евангельской традицией больше всего связан образ Ниловны, все остальное проблематично.

Л.А. Спиридонова, ставя вопрос об эволюции творческого метода Горького, говорит, что ее невозможно понять, «если руководствоваться определениями романтизма, критического реализма, модернизма, социалистического реализма. Кстати, сам писатель чаще говорил о социалистическом романтизме как творческом методе, который позволяет увидеть настоящее с высоты будущего» [15, c. I82]. «Социальный романтизм - вот что определяло своеобразие Горького-художника и сущность его новаторства» [15, с. 206], - считает исследовательница.

Представляется, что это все-таки не так просто. В докладе на І съезде советских писателей Горький сказал следующее: «Отнюдь не отрицая широкой огромной работы критического реализма, высоко оценивая его формальные достижения в искусстве живописи словом, мы должны понять, что этот реализм необходим нам только для освещения пережитков прошлого, для борьбы с ними, вытравливания их. Но эта форма реализма не послужила и не может служить воспитанию социалистической индивидуальности, ибо - все критикуя, она ничего не утверждала, или же - в худших случаях - возвращалась к утверждению того, что ею же отрицалось»².

2 Первый Всесоюзный съезд советских писателей. I934. Стенографический отчет. М.: Худож. лит., I934. С. I7. 
В этом же докладе Горький замечает, что фольклору, на который следует ориентироваться советской литературе, чужд пессимизм, и обращается к проблеме мифа.

Миф - это вымысел. Вымыслить - значит извлечь из суммы реально данного основной его смысл и воплотить в образ - так мы получили реализм. Но если к смыслу извлечений из реально данного добавить-домыслить, по логике гипотезы - желаемое, возможное, и этим еще дополнить образ, - получим тот романтизм, который лежит в основе мифа и высоко полезен тем, что способствует возбуждению революционного отношения к действительности, отношения, практически изменяющего мир³.

Однако все-таки Горький не лишал реализма будущего. Что касается «добавления-домысливания», то думается, что в том или ином виде оно присутствует не только у романтиков, но и у каждого писателя -реалиста. Не случайно так отличаются друг от друга художественные миры Толстого и Достоевского, а герой Достоевского, в свою очередь, обижается на Гоголя за образ Акакия Акакиевича. «Добавить-домыслить», конечно, можно по-разному. Можно даже и бессознательно. В случае с Горьким, если брать его творчество, а не его декларации, нельзя даже определенно сказать, что речь всегда идет об идеализации и оптимизме. К оптимизму он, конечно, стремился, но, например, в романе «Дело Артамоновых», может быть, невольно для себя самого, показал, что человек из народа Тихон Вялов остается в стороне от революции. Случайно ли это? Или исконная народность творчества Горького переиграла его соцреализм? Или же задумал Горький написать «историю пустой души», желая показать, как интеллигенция постепенно отходит от революции, а на самом деле показал, как революция предает интеллигенцию. Да и может ли Клим Самгин быть «пустой душой», если среди его прототипов были такие незаурядные люди, как С.П. Мельгунов, В.С. Миролюбов, К.П. Пятницкий, А.А. Ярошевский, В.С. Лукин и даже, если верить Е.П. Пешковой, И.А. Бунин [І2, с. 2I-22]?

Да и кого Горький идеализировал? Большевики (Павел Власов, Кутузов) предстают в его произведениях довольно бледными фигурами. Ма- 
терей? Так он их такими видел. Босяков? Но здесь все тоже не так просто. Разве мы не знаем бомжей из интеллигенции, так называемых «бичей» и т. п.? Революционеров-интеллигентов в повести «Мать»? Но действительно до І905 г. большая часть интеллигенции находилась в оппозиции к режиму. Русскую буржуазию? Она у него показана разной, и знал он ее хорошо.

Всю жизнь он мечтал о создании образа положительного героя, он и в докладе на I съезде писателей призвал изображать «человека, организуемого процессами труда», создавать «яркие образы советских женщин» и «утверждать бытие как деяние, как творчество», но сам при этом предпочитал творить образы героев старой России.

Думается, что единственный случай, когда Горький мог несколько покривить душой и его не на шутку подвела теория возможности отступления от правды факта во имя «правды века», - это написание очерка «В.И. Ленин».

«Разгадывать» Ленина Горький начал еще в период пребывания «вождя» на Капри; позднее, в I9I7 г., в знаменитой статье «Вниманию рабочих» из цикла «Несвоевременные мысли» он говорит о Ленине: «Он работает как химик в лаборатории, с тою разницей, что химик пользуется мертвой материей, но его работа дает ценный для жизни результат, а Ленин работает над живым материалом и ведет к гибели революцию... с русским рабочим классом проделывается безжалостный опыт, который уничтожит лучшие силы рабочих и надолго остановит нормальное развитие русской революции» [6, с. ІІз].

Но в какой-то момент, испугавшись размаха этой самой революции, Горький решил, что только большевики во главе с Лениным могут «призвать к порядку» разбушевавшуюся стихию.

В письме к Роллану от I5 января I924 г. Горький говорил: «В начале I8-ого года я понял, что никакая иная власть в России невозможна и что Ленин - единственный человек, способный остановить процесс развития стихийной анархии в массах крестьян и солдат». Кроме того, как это ни странно, но Горький Ленина любил. В том же письме он писал: «И, несмотря на то, что я люблю этого человека, а он меня, кажется, тоже любил, моментами наши столкновения будили взаимную ненависть» [Іо, с. I8]. И чуть позже, 3 марта I924 г., Горький скажет в письме к тому же адресату: 
«Я его любил и люблю. Любил с гневом. Говорил с ним резко, не щадя его. С ним можно было говорить так, как ни с кем иным, - он понимал то, что лежит за нашими словами, каковы бы они ни были. Я особенно нежно и глубоко любил его за ненависть к страданию, за его неукротимую вражду ко всему, что искажает человека. Он был очень большой русский человек. Вы правильно оценили его. Толстой и он - двое чудовищно больших людей. Я горжусь, что видел их» [8, т. І4, с. 308].

Отзыв противоречивый, но, видимо, Горький ценил масштабность деятельности Ленина, не предполагая ее конечных результатов.

Вследствие этого он со временем и начал создавать миф об идеальном вожде. Однако, как человек творческий, Горький вряд ли может нести ответственность за нормативность эстетики социалистического реализма и постепенное превращение его в окостеневшую догму. Еще в г9г7 г. (письмо от I7/30 марта), разъясняя Роллану свое видение детской и юношеской литературы, он пишет: «Наша цель - возбудить в сердцах юношества социальный романтизм, настроение любви и доверия к жизни, к людям; мы хотели бы воспитывать героическое, мужественное отношение к действительности, хотели бы внушить человеку, что это он - творец и хозяин мира, и на нем лежит ответственность за все грехи земли. Точно так же, как ему слава за все прекрасное в жизни» [Іо, с. I8].

Еще раз уточним, что оптимизм и стремление найти в жизни героическое начало совсем необязательно должны быть связаны с романтизмом; думается, что лучшие горьковские произведения являются реалистическими и, может быть, реализм, о котором он мечтал, можно назвать героическим или духовным, хотя эта квалификация все больше применяется к произведениям И. Шмелева и Б. Зайцева, созданным в основном в эмиграции. Но ведь у этих писателей также присутствует изрядная доля идеализации, правда, в отличие от горьковской, устремленной в будущее, она обращена в прошлое.

Что касается краеугольного камня эстетики социалистического реализма - партийности, то, в отличие, например, от Шолохова, периодически упоминавшего о ней в своих речах, Горький и сам вышел из партии, и никогда полностью не стоял на ее позициях. Обсуждая в письме к Роллану от I5 января І924 г. возможность своего возвращения в Россию, он писал: «Нет, в Россию я не уеду, и все более чувствую себя человеком без роди- 
ны, без отечества. Я даже склонен думать, что в России мне пришлось бы играть роль крайне странную, - роль врага всем и всему, и при некоторой необузданности мыслей, слов, действий я встал бы там в смешную позицию человека, который бьет лбом в стену» [ı, с. 87].

Горький неповинен в том, в чем обвиняли социалистический реализм. Как мы видели, он с пониманием и интересом относился к творческим поискам писателей-своих современников и все время думал об обновлении реализма. На Родине, как он и предчувствовал, он оказался «еретиком». Его именем и словами «великий пролетарский писатель» пытались прикрыть догматический официоз. Он же был просто великим писателем, в значительной степени олицетворяющим собой ХХ в.

\section{Характерология}

Полная характеристика новаторства Горького в этой области является совместной задачей теоретиков и историков литературы и, конечно, не может быть исчерпывающе исследована в рамках настоящей статьи. Тем не менее, пройти мимо проблемы характерологии Горького нельзя, ибо именно его взгляд на русский характер обусловил его колоссальную популярность во всем мире.

В докладе на I съезде писателей Горький, в присутствии высоких партийных чинов, осмелился, в частности, сказать: «...русская литература, так же, как и западная, прошла мимо помещиков., организаторов промышленности и финансистов в дореволюционной эпохе, а у нас эти люди были гораздо более своеобразны и колоритны, чем на Западе <...> Черты отличия нашей крупной буржуазии от западной весьма резки, обильны и объясняются тем, что наш исторически-молодой буржуа, по преимуществу выходец из крестьянства, богател быстрее и легче, чем исторически весьма пожилой буржуа Запада. Наш промышленник, не тренированный жестокой конкуренцией Запада, сохранял в себе почти до XX века черты чудачества, озорства, должно быть вызывавшегося его изумлением пред дурацкой легкостью, с которой он наживал миллионы» ${ }^{4}$.

Русский буржуа - правдоискатель, не довольствующийся своими миллионами, а пытающийся найти в жизни высокую идею, ради которой 
стоит жить. Если же такой идеи не находится или же этот человек осознает ложность выбранных идеалов, он погибает.

Этот характер проходит через все творчество Горького, начиная с Фомы Гордеева («Ему тесно, Жизнь давит его, он видит, что героям в ней нет места, их сваливают с ног мелочи, как Геркулеса, побеждавшего гидр, свалила бы с ног туча комаров» [І4, с. 543]), через Вассу Железнову, которую сам писатель сравнивал с Екатериной П, и кончая Егором Булычовым и Лютовым, мучительно размышляющим о судьбах русского народа.

Но думается, что главным героем Горького, обеспечившим ему поддержку и симпатию мирового общественного мнения, был, как ни странно, русский босяк, причем особенностью горьковского гения является то, что верно уловленные им характеры с течением времени выглядят едва ли не более актуально, чем в то время, когда он создавал свои произведения. Теперь их называют бомжами, бичами, шабашниками... имя им легион. Они постоянно меняют работу и жилье, перебиваются случайными заработками, не имеют семьи или живут с ней в разлуке, но тем не менее даже на дне жизни остаются людьми, живут духовными запросами, обсуждают вопросы «не субъективные, а общефилософские» и пытаются морально поддержать других людей. И у Горького пекарь-пьяница Коновалов пытается «перевоспитать» проститутку Капу, сочувствует героям Решетникова, любит свою работу, интересуется русской историей. Но приступы тоски, переходящие в запои, всегда приводят к тому, что он теряет очередную работу и пристанище.

Обаяние образа Коновалова оказалось настолько велико, что в I930 г. к Горькому с письмом обратились два подростка из Сормова, заявляя: «Хотим быть такими же, как Ваш Коновалов, т. е. людями, вечно ищущими счастья и не находящими себе постоянного места на земле». Пытаясь отговорить советских подростков от подражания Коновалову, Горький писал: «Был он человек по характеру своему пассивный, был одним из множества людей того времени, которые, не находя себе места в своей среде, становились бродягами, странниками по “святым местам” или по кабакам. Если б он дожил до 905 года, он одинаково легко мог бы стать и “черносотенцем” и революционером, но в обоих случаях - ненадолго» [I, т. 6, с. 228]. Между прочим, не самая плохая характеристика.

Аналогичные чувства выражает и сапожник Григорий Орлов (а имято какое - словно символ вырождения русского человека), который чув- 
ствовал себя на месте, только ухаживая за больными в холерном бараке; к спокойному, честному труду он не способен, либо пьет, либо зверски избивает ни в чем не виноватую перед ним жену и кончает в ночлежке.

«За кадром» произведений Горького остаются обстоятельства, приводящие людей в ночлежки и делающие их босяками, но, поскольку таковых обстоятельств в то время, как и сейчас, было немало, то конкретные их подробности не важны для читателя. Вольно или невольно Горький, говоря об отчаянии и самоотрицании босяка, показывает отход человека от веры и, вследствие этого, его духовную неприкаянность. 


\section{Список литературы}

I Архив A.M. Горького: в II т. / под общ. ред. акад. И.К. Луппола; Акад. наук СССР. Ин-т мировой лит. им. А.М. Горького. М.: Худож. лит., І939-І965. Бялик Б.А. М. Горький - литературный критик. М.: Гос. изд-во худож. лит.,І960. $378 \mathrm{c.}$

3 Голубков М.М. Максим Горький. М.: Изд-во МГУ, 200о. 96 с.

4 Горький и его эпоха. Вып. 3: Неизвестный Горький: материалы и исследования. М.: Наследие, ИМЛИ РАН, І994. 328 с.

5 Горький М. История русской литературы. М.: Гос. изд-во худож. лит., І939. 340 с.

6 Горький М. Несвоевременные мысли. Париж: Editions de la Seine, I97I. 237 с.

7 Горький М. Собр. соч.: в 30 т. М.: Гос. изд-во худож. лит., І953. Т. 24. 402 с.

8 Горький М. Полн. собр. соч.: Письма: в 24 т. М.: Наука, ИМЛИ РАН, 1997.

9 Евстигнеева Л.А. Примечания // Горький М. Полн. собр. соч.: Художественные произведения: в 25 т. М.: Наука, I969. Т. 3: Рассказы, очерки, І896-I897. 599 с.

Iо М. Горький и Р. Роллан: Переписка (І9І6-I936). М.: Наследие, І995. 543 с.

II Овчаренко А.И. М. Горький и литературные искания XX столетия. М.: Худож. лит., І982.512 с.

I2 Овчаренко А.И. Роман-эпопея М. Горького «Жизнь Клима Самгина». М.: Худож. лит., І965. I66 с.

I3 Примочкина Н.Н. Горький и писатели русского зарубежья. М.: ИМЛИ РАН, 2003. 36I c.

I4 Соколов А.Г. История русской литературы конца XIX - начала XX века. М.: Худож. лит., І979. 287 с.

I5 Спиридонова Л.А. М. Горький: новый взгляд. М.: ИМЛИ РАН, 2004. 262 с. 


\section{References}

I Arkhiv A.M. Gor'kogo: v II $t$. [A.M. Gorky's archive], under general ed. of acad. I.K. Luppol; Academy of sciences of the USSR. A.M. Gorky Institute of World Literature. Moscow, Khudozh. lit. Publ., I939-1965. (In Russ.)

2 Bialik B.A. M. Gor'kii - literaturnyi kritik [Gorky as a literary critic]. Moscow, Gos. izd-vo khudozh. lit. Publ., I960. 378 p. (In Russ.)

3 Golubkov M.M. Maksim Gor'kii [Maxim Gorky]. Moscow, Izd-vo MGU Publ., 2000. 96 p. (In Russ.)

$4 \quad$ Gor'kii i ego epokha. Vyp. 3: Neizvestnyi Gor'kii: materialy i issledovaniia [Gorky and his time. Issue 3: Unknown Gorky: materials]. Moscow, Nasledie, IMLI RAN Publ., I994. 328 p. (In Russ.)

5 Gor'kii M. Istoriia russkoi literatury [History of Russian literature]. Moscow, Gos. izd-vo khudozh. lit. Publ., I939. 340 p. (In Russ.)

6 Gor'kii M. Nesvoevremennye mysli [Untimely thoughts]. Paris, Editions de la Seine, I97I. 237 p. (In Russ.)

7 Gor'kii M. Sobr. soch.: v 30 t. [Works: in 30 vols.]. Moscow, Gos. izd-vo khudozh. lit. Publ., I953. Vol. 24. 402 p. (In Russ.)

8 Gor'kii M. Poln. sobr. soch.: Pis'ma: $v 24$ t. [Complete works: Letters: in 24 vols.]. Moscow, Nauka, IMLI RAN Publ., I997. (In Russ.)

9 Evstigneeva L.A. Primechaniia [Notes]. Gor'kii M. Poln. sobr. soch.: Khudozhestvennye proizvedeniia: v 25 t. [Complete works in 25 vols: Fiction]. Moscow, Nauka Publ., I969. Vol. 3: Rasskazy, ocherki, I896-I897 [Tales, sketches]. 599 p. (In Russ.)

IO M. Gor'kii i R. Rollan: Perepiska (I9I6-I936) [M. Gorky and R. Rolan: correspondence]. Moscow, Nasledie Publ., I995. 543 p. (In Russ.)

II Ovcharenko A.I. M. Gor'kii i literaturnye iskaniia XX stoletiia [M. Gorky and literary quests of the $2 \mathrm{O}^{\text {th }}$ century]. Moscow, Khudozh. lit. Publ., I982.512 p. (In Russ.) Ovcharenko A.I. Roman-epopeia M. Gor'kogo “Zhizn' Klima Samgina” [Gorky’s Epic novel The Life of Klim Samgin]. Moscow, Khudozh. lit. Publ., I965. I66 p. (In Russ.)

I3 Primochkina N.N. Gor'kii i pisateli russkogo zarubezh'ia [Gorky and Russian emigrant writers]. Moscow, IMLI RAN Publ., 2003. 36I p. (In Russ.)

I4 Sokolov A.G. Istoriia russkoi literatury kontsa XIX - nachala XX veka [History of Russian literature at the turn of the $19^{\text {th }}$ and $20^{\text {th }}$ centuries]. Moscow, Khudozh. lit. Publ., I979. 287 p. (In Russ.)

I5 Spiridonova L.A. M. Gor'kii: novyi vzgliad [M. Gorky: New perspective]. Moscow, IMLI RAN Publ., 2004. 262 p. (In Russ.) 
УДК 821.І6І.І.о

ББК $83.3(2 \mathrm{Poc}=\mathrm{Pyc}) 6$

\section{ПЬЕСА М. ГОРЬКОГО «НА ДНЕ» \\ НА НЕМЕЦКОЙ СЦЕНЕ (ПО МАТЕРИАЛАМ \\ МУЗЕЯ А.М. ГОРЬКОГО ИМЛИ РАН)}

(C) 2018 г. С.М. Демкина

Институт мировой литературы

им. А.М. Горького Российской академии наук, Москва, Россия

Дата поступления статьи: Іо января 2018 г. Дата публикации: 25 марта 2018 г.

DOI: IO.22455/2500-4247-20I8-3-I-252-265

Аннотация: В статье, посвященной сценической истории пьесы М. Горького «На дне» в Германии, автор рассматривает опыт обращения немецких театров к творчеству Горького на фоне социально-художественной проблематики XX столетия. Устойчивый интерес к горьковской драматургии в Германии объясняется острой общественной значимостью и универсальностью поднятых писателем вопросов. На документальном материале фондов Музея А.М. Горького РАН исследуются интерпретации европейскими режиссерами-реформаторами актуальной своей общечеловеческой составляющей и авторской гуманистической философией культовой драмы Горького. Значительный массив раздела «Горький и немецкий театр» хранения Музея М. Горького ИМЛИ РАН связан с драмой «На дне». С первой немецкой постановкой «Ночлежки» знакомят две серии фотографий. Спектакль Макса Рейнгардта и Рихарда Валлентина, представивших в берлинском Малом театре (Kleines Theater) Iо-23 января I903 г. «Nachtasyl», имел оглушительный успех и хорошие сборы. После этой премьеры внимание к личности Горького продолжало усиливаться, в Европе он стал самым популярным русским писателем. В фашистский период имя Горького оказалось под запретом. После окончания Второй мировой войны, поделившей Германию на две части, Горький снова появился на немецкой сцене. В конце 6о-х, в связи со столетием Горького (I968), волна постановок его пьес отмечалась по всему миру. Своеобразный ренессанс Горького-драматурга наблюдался в 7о-е. Пьеса «На дне» ставилась в Европе, США, Англии. И режиссерами, и критиками драматургия Горького воспринималась в контексте произведений его современников - Шоу, Ибсена, Гауптмана, Толстого, Чехова.

Ключевые слова: театр, Горький, писатель, литература, пьеса, режиссеры, сцена.

Информация об авторе: Светлана Михайловна Демкина - кандидат филологических наук, заведующий Музеем А.М. Горького, Институт мировой литературы им. А.М. Горького Российской академии наук, ул. Поварская, д. 25 а, І2І069 г. Москва, Россия.

E-mail: DemkinaSvetlana@yandex.ru 


\section{THE LOWER DEPTHS ON THE GERMAN STAGE}

This is an open access article distributed under the Creative Commons Attribution 4.0 International (CC BY 4.0)
(C) 20I8. S.M. Demkina

\author{
A.M. Gorky Institute of World Literature \\ of the Russian Academy of Sciences, \\ Moscow, Russia \\ Received: January IO, 2018 \\ Date of publication: March 25, 2018
}

Abstract: This article examines the stage history of M. Gorky's play The Lower Depths in Germany. The author discusses German stage history of Gorky's work against the social background and in the context of major artistic tendencies of the $20^{\text {th }}$ century. Steady interest in Gorky as a playwright in Germany is due to the acute social importance and universality of the problems reflected in his dramas. Bearing on the archive materials of the Gorky Museum, the essay explores interpretations of Gorky's cult drama The Lower Depths in the work of European stage directors, acclaimed reformers of theatrical art. A significant part of the "Gorky and German Theater" section of the Gorky Museum (IWL RAS) is devoted to The Lower Depths. Two series of photographs represent the first German staging of Nachtasyl (German translation of The Lower Depths). The performance of Max Reinhardt and Richard Vallentin in Berlin Kleines Theater on January 10-23, 1903, had great success and good takings. After the premiere, attention to the personality of Gorky in Europe increased; he became the most popular Soviet author. When Nazi came to power, they banned Gorky's work in Germany: he reappeared on the German stage only after the World War II. In the late I96os, on the wave of Gorky's centenary (I968), world theatres ran a series of performances based on his plays. The I970s were marked by a renewal of interest to Gorky the playwright. The Lower Depths was staged in Europe, the USA, and the UK. Both directors and critics perceived Gorky's dramaturgy in the context of works of his contemporaries - Shaw, Ibsen, Hauptmann, Tolstoy, Chekhov.

Keywords: theatre, Gorky, writer, literature, play, stage directors, stage.

Information about the author: Svetlana $\mathrm{M}$. Demkina, $\mathrm{PhD}$ in Philology, Director of the Gorky Museum, A.M. Gorky Institute of World Literature of the Russian Academy of Sciences, Povarskaya 25 a, I2Io69 Moscow, Russia.

E-mail: DemkinaSvetlana@yandex.ru 
Немецкий театр одним из первых обратился к горьковской драматургии. Горьковское ощущение наступившего двадцатого столетия («новый век воистину будет веком духовного обновления» [3, т. 2, с. 97]) оказалось созвучным настроениям передовой Европы. Атмосфера Германии тех лет была так же насыщена революционными ожиданиями, как и в России. Европейскую культуру сближали поиски новых форм сценического процесса - начиная с драматургического материала через современное прочтение к экспериментальной подаче текста публике.

Интерес к творчеству М. Горького в Германии на рубеже XIX-XX вв. был столь велик, что премьеры его пьес там проходили практически одновременно с Россией. «Мещан» в первый раз показал МХТ 26 марта I902 г. на гастролях в С. Петербурге, в том же году успел и берлинский «Лессинг-театр», в январе г903 г. драму увидели в Мюнхене.

Премьера на сцене МХТ второй горьковской пьесы, впоследствии получившей Грибоедовскую премию и ставшей визитной карточкой драматурга, обернулась настоящим триумфом. Успех «На дне» Вл.И. Немирович-Данченко назвал мировым; а сезон І902-I903 гг. - прошедшим «под знаком Горького». Автор видел во всем этом исключительно заслугу Московского Художественного: «Успех пьесы исключительный, я ничего подобного не ожидал. И - знаете - кроме этого удивительного театра - нигде эта пьеса не будет иметь успеха» [3, т. 3, с. І26]. Но тут Горький ошибся. Пьеса прижилась не только в России, но и в зарубежных театрах, и прежде всего в Германии.

На родине с самой известной горьковской пьесой возникали трудности: ее ставили с цензурными купюрами и специальными согласованиями. 
Из-за такой мелочи, как роль пристава, Немировичу-Данченко пришлось за два дня до премьеры срочной телеграммой запрашивать в управлении по делам печати разрешение выпустить того без слов в третьем акте. Немецких режиссеров эти обстоятельства, репутация пьесы и ее автора скорее привлекали.

Горький был уверен в общности с немецкими коллегами: «Ничто не объединяет людей так глубоко, как искусство, так да здравствует же искусство и те, что служат ему, не страшась изображать суровую правду жизни такой, какова она есть!» [3, т. 3, с. I84]. Интерес к «На дне» Макса Рейнгардта и Рихарда Валлентина, представивших зрителю в берлинском Малом театре (Kleines Theater) Iо-23 января I903 г. «Nachtasyl» («Ночлежку»), вполне понятен. Вызывающий натурализм и яркая театральность Валлентина удачно совпали с новаторскими идеями Рейнгардта. Успех «Ночлежки» в Берлине не уступал московскому. Если в постановке МХТ только один из режиссеров Станиславский - был на сцене (Немирович-Данченко вышел в костюме босяка для шутливого снимка), то в Малом берлинском театре роли исполнили оба постановщика. Публика с восторгом приняла Сатина - Р. Валлентина и Луку - М. Рейнгардта.

Современные зрители могут оценить немецких босяков по материалам Музея М. Горького ИМЛИ РАН, хранящего многочисленные свидетельства участия драматурга в становлении театрального искусства двадцатого века. Самый значительный массив раздела «Горький и немецкий театр» связан с историей пьесы «На дне». Мизансцены, придуманные много лет назад творцами спектаклей - автором, режиссером, художником, исполнителями ролей превращают читателя в зрителя. Этот зритель погружается в «предлагаемые обстоятельства», начинает сопереживать, обнаружив, что острота драматургического конфликта не исчезла.

С первой немецкой постановкой «Ночлежки» знакомит серия фотографий Отто Беккера и Мааса на фирменных паспарту. І903, янв., кон. февр. Берлин. Спектакль Kleines Theater «Ночлежка» («Nahtasyl»), по пьесе М. Горького «На дне». Режиссеры М. Рейнгардт, Р. Валлентин. Перевод А.К. Шольца. На оборотах чернилами надписи рукой К.П. Пятницкого. На снимках, поступивших в І937 г. из ГЛМ: Ганс Вассерман - Барон; Эмануэль Рейхер - Актер; Альфред Кюне - Татарин; Адольф Эдгар Лихо - Клещ; Иозеф Дилл - Медведев. К этой же постановке относится вторая серия фотографий Цандера и 
Лабиша на фирменных паспарту. І903, янв., кон. февр. Берлин. Спектакль Kleines Theater «Ночлежка» («Nahtasyl»), по пьесе М. Горького «На дне». Режиссеры М. Рейнгардт, Р. Валлентин. Перевод А.К. Шольца. На обороте всех фотографий, попавших в Музей в 1937 г. из архива семьи Р. Валлентина, карандашом, возможно, рукой дарителя: «Gorkij “Nahtasyl”» Uraufführung Berlin 23, I.03. Kleines Theater Regie: Richard Vallentin. Rollen siehe. Regiebuch. Здесь можно увидеть декорации всех пяти актов пьесы.

Эти снимки интересно сравнить с коллекцией мхатовской постановки: в музее находится около трехсот фотографий актерских групп, обитателей ночлежки, массовых сцен и декораций. Здесь Сатин - Станиславский («Сатин в четвертом акте - великолепен, как дьявол»); Лука - И.М. Москвин («Москвин играет публикой, как мячом»); Барон - В.И. Качалов («Качалов - изумительно хорош» [3, т. 3, с. І26-І27]). В немецком варианте Сатин - Р. Валлентин, Лука - М. Рейнгардт, Барон - Ганс Вассерман.

Труппа берлинского театра вслед за МХТ стремилась к достоверности. 8 декабря I902 г. на бланке Kleines Theater Горький получил письмо с приглашением на премьеру и просьбой прислать в Берлин побольше материалов для создания нужной атмосферы, авторские советы и указания. В Москве, например, автор лично учил О. Книппер-Чехову (Настю) скручивать «собачью ножку». Сначала в Берлине получили снимки постановки Художественного театра (те самые, варианты которых хранятся в Музее), но попросили иных - настоящих, а «не театральных» босяков. Горький отправил в Берлин свою фотографию г9оо г. (ее тоже просили) и галерею снимков «Типы босяков с берегов Волги», «Типы странников», «Татарин-торговец» и др. Эти фотографии в основном были выполнены хорошим знакомым писателя - знаменитым мастером М.П. Дмитриевым. Максим Петрович - один из основоположников русской фотографической школы и публицистического репортажа; с І886 г. и до конца жизни работал в Н. Новгороде. Участник Всероссийской торгово-промышленной и художественной выставки I896 г., за свою деятельность был удостоен ряда медалей на российских и международных фотовыставках. Дмитриев фотографировал жителей Нижегородского края, выставки, ярмарки, исторические события в Нижнем и Москве, последствия неурожая I89I-I892 гг., Волгу и ее города от истоков до устья, промышленность, транспорт и жизнь Поволжья, а также современников Горького - писателей, художников, артистов, ученых, местную интелли- 
генцию. Писатель и фотограф были дружны семьями, Максима Петровича приглашали для съемок на квартиру Пешковых, жена фотографа вместе с Е.П. Пешковой участвовала в общественных начинаниях.

Большая часть наследия Дмитриева (фотографии, лейки, стеклянные негативы) хранится в фондах Музея А.М. Горького. При подготовке к постановке «На дне», помимо экскурсий художественников на Хитровку, Горький заказал фотографу серию разнообразных социальных типажей - «пособие» по гриму и костюмам для героев пьесы. Немецким коллегам все присланное помогло, получился и оказавшийся самым трудным образ Луки.

Горький в письме М. Рейнгардту благодарил труппу «за исполнение вами моей пьесы» и отмечал, как «близко Вы и группа Ваша подошли в изображении типов и сцен моей пьесы к русской действительности» [3, т. 3, c. I84]. Особую благодарность заслужил «немецкий» Сатин. Автор подарил ему свою фотографию с дарственной надписью: «Талантливому исполнителю роли “Сатина” въ пьесе “На дне” Господину Рихардъ Валентинъ М. Горькій».

В музейной коллекции есть фотографии постановщиков «На дне» в берлинском театре. Это снимок І903 г. Макса Рейнгардта, благодарившего в письме автора «На дне» «за предоставление нашему театру Вашего потрясающего жизненной правдой творения. Чтение его произвело на нас трогательное, но при том и возвышающее впечатление» (АГ. КГ-инГ-3-59-3). Драматургия Горького оказалась близка режиссеру-новатору, и позднее в основанном им Берлинском театре Рейнгардт ставил «Последние» (I9Iо), инсценировал рассказы «Макар Чудра», «Хан и его сын». Их переписка продолжалась с 1902 по I928 гг. (известно 2 письма Горького Рейнгардта и 6 писем Рейнгардта Горькому). Как и Горький (I918, I923, I928, І93І и І933), Рейнгардт впоследствии номинировался на Нобелевскую премию (I932).

Хранится в коллекции и фотография Рихарда Валлентина (1903-I904. Берлин), подаренная Музею Максимом Валлентином - сыном режиссера. Актер по образованию, он выступал в театрах Берлина и Цюриха. В 1933 г. Максим уехал в Советский Союз, где изучал систему Станиславского. Вернувшись после войны на родину, он создал первый театральный институт в Веймаре, в котором преподавали по Станиславскому. Из первого выпуска института в І950 г. Максим Валлентин организовал студию «Молодой ансамбль», позднее преобразованную в Театр им. Максима Горького (Берлин). Здесь он с успехом поставил горьковскую пьесу «Достигаев и другие» (I954). Фонды 
Музея Горького располагают интересным документом. Это письмо профессора Максима Валлентина, адресованное редколлегии «Летописи жизни и творчества А.М. Горького». Через шестьдесят лет после премьеры «Ночлежки» на сцене Kleines Theater он просил исправить неточность, допущенную, по его мнению, авторами труда. Максим Валлентин обнаружил ошибку, «которая неоднократно повторялась в буржуазной истории театра и привела к возникновению легенды. Факты, однако, опровергают эту легенду. Режиссером первой постановки «На дне» Максима Горького (премьера 3.2.1903) был не Макс Рейнгардт, а Рихард Валлентин». Далее профессор приводит доказательства своей позиции, ссылаясь на различные факты и документы. К примеру, он цитирует книгу Макса Эпштейна (19I8); где говорится, что «Валлентин создал постановку полную глубокого настроения» (Машинопись на немецком языке на официальном бланке проф. М. Валлентина. Музей А.М. Горького ИМЛИ РАН).

Думается, что заслуги обоих создателей «Ночлежки» очевидны и не подлежат сомнению. Как и коллеги из Московского Художественного, они выпустили живописную серию открыток со сценами своего спектакля. Открытки прекрасного качества позволяют составить впечатление о режиссерских решениях, художественных находках и актерской игре. Вот Васька Пепел - руки в карманах, с вызывающим пренебрежением слушает Василису; справа лежит умирающая Анна; с печки за происходящим внимательно наблюдает Лука. На другой открытке Лука утешает бедную женщину, а рядом с азартом «режутся» в карты «соседи» по подвалу. Эмоциональный центр следующего снимка - тело умершего Костылева на ступенях лестницы; над ним торжествующая Василиса, потрясенный Пепел и остальные обитатели ночлежки. Декорации спектакля в чем-то напоминают московскую постановку: в середине стол с круговой скамьей, широкая печь, лежанка у входа. Довольно высокая лестница и окно над ней создают ощущение глубокого подвала, сырого и темного. Персонажи костюмами и гримом (в том числе выражениями лиц, шапками, бородами, лаптями, гармонью) очень похожи на русских босяков.

Спектакль, имевший оглушительный успех, принес театру отличную выручку, а режиссерам и актерам - известность. О «На дне» писали, говорили; в Берлине даже открылся ресторан под названием «Ночлежка» с официантами в стилизованных лохмотьях. На многих провинциальных 
сценах Германии прошли «версии» прославившейся «Ночлежки» Рейнгардта. Знаменитый режиссер Эрвин Пискатор видел ребенком подобный спектакль в Ганновере. В г927 г. он создал свою постановку «На дне» в Театре «Фольксбюне», пожалуй, самое интересное прочтение горьковской пьесы после Версальского мира. Обратившись к хорошо известной к тому времени в Европе драме, Пискатор просил автора внести в текст изменения, добавив революционные моменты. Горький остался верен себе, пояснив, что давно законченную пьесу, отразившую определенную историческую эпоху, считает раз и навсегда завершенной. Тогда Пискатору, по его собственному признанию, пришлось самому раздвигать рамки пьесы.

В Музее А.М. Горького есть изображение одного из фрагментов спектакля. На сцене скошенный помост, вся ночлежка (нары, печь, стена) словно накренилась вправо и в любой момент вместе с обитателями будет сметена. Все персонажи, кроме одного в центре (Сатин), лежат. На первый взгляд, их лица и позы безвольны, апатичны; но скрытая угроза ощущается в этих людях, и в этом подвале, и в этой гнетущей безнадежности. Название «Ночлежка», крупными буквами помещенное на заднике, воспринимается как вызов, даже некий приговор тем, кто внутри сценического пространства, и тем, кто вне его.

Пискатор, сторонник политического театра, стремясь создать яркий революционный спектакль, героев пьесы сделал волевыми, сильными личностями, практически революционерами. Зрители услышали выстрелы, увидели и демонстрации, и ночлежников, отбивающих Ваську Пепла у полицейских, и арест Луки, и др. За ночлежниками-революционерами Пискатора (Лука - А. Гранах, Сатин - Лео Штеклер, Барон - Э. Кассер) тем не менее угадывались ставшие классическими актерские решения спектакля Рейнгардта. В музее хранится программа-брошюра спектакля «Nachtasyl» в театре «Volksbühne».

Программы, сопровождающие эту постановку и многие другие, очень важны для зрителя. Человеку, даже достаточно образованному, трудно погрузиться в атмосферу иной страны, чужой жизни. Россия, порой представлявшаяся экзотической и загадочной, открывалась иностранцу своей культурой - живописью, литературой, театром. Специфика горьковской драматургии нуждалась в дополнительном информационном сопровождении. К спектаклям немецких театров, как правило, прилагались програм- 
мы-буклеты - добротные, яркие - с подробными сведениями об авторе, историческом контексте, социальных аспектах происходящего и т. д.

В начале столетия личность Горького стала предметом изучения и споров известных немецких литературоведов и критиков. Брандес Г., Поритцкий Е., Март Е., Феликс О., Ганс Г., Штекер К. видели в нем «смесь животного и человечного, философа и ребенка, ангела и бестии, короля и нищего, сатирика и меланхолика, обвинителя и защитника», называли «великим босяком», мировоззрение которого «в двадцать пять лет сводится к тому же, к чему Толстой пришел в пятьдесят»; «самым отчаянным пессимистом в Европе после Шопенгауера»; обсуждали его «ницшеанство» и даже «аристократизм» [2, c. 250]. По данным журнала «Das literarische Echo» («Литературное эхо»), в немецкой прессе только в период с октября I90I г. по май I902 г. о Горьком было напечатано 24 статьи, тогда как о Толстом - I7, о Гоголе -8 , о Чехове всего 2.

После европейской премьеры «На дне» внимание к личности Горького продолжало усиливаться. В период 1905-I907 гг. деятельность писателя максимально соответствовала образу «буревестника революции», мимо которого не прошли такие ключевые события, как Кровавое воскресенье, демонстрация в Севастополе, забастовки, восстания на броненосце «Потемкин» и в Свеаборге, декабрьские дни в Москве, введение конституции, открытие I Государственной думы. Месяц Горький провел в камере Трубецкого бастиона Петропавловской крепости. В его поддержку выступила мировая общественность. Среди музейных экспонатов этого периода - листовки в защиту писателя (1905), многочисленные подписи деятелей культуры Германии под протестом против ареста Горького, статьи из газет «Берлинер Тагеблат» («Berliner Tageblat», январь-февраль г905 г.) с требованиями об освобождении, запрещенная в России брошюра Горького «9 января», вышедшая в самом начале 1907 г. в берлинском издательстве И.П. Ладыжникова.

На призыв «Berliner Tageblat» откликнулись все немецкие союзы, учрежденные в память Гете в Берлине, Бореславле, Дармштадте, Дрездене, Кенигсберге и т. д., под петицией подписались ученые, литераторы, юристы, в том числе Г. Гауптман, Г. Зудерман, пастор Фридрих Науман, Э. Геккель и др. После освобождения Горький написал в редакцию газеты «Berliner Tageblat»: «<... я прошу Вас принять мою искреннюю благодарность и передать ее людям всех стран, почтивших меня лестными выражениями симпатии ко мне, 
рядовому солдату непобедимой армии тех людей, которые отдают свой ум и свое сердце на борьбу за свободу, истину, красоту и за уважение к человеку» [3, т. 5, c. 27].

С I6 февраля (I марта) по 7 (20) марта I906 г. проездом из Копенгагена в Глион (Швейцария) Горький впервые побывал в Берлине. За три недели писатель успел встретиться деятелями германской социал-демократической партии А. Бебелем, К. Каутским, К. Либкнехтом; с артистами МХT, находившимися там на гастролях. У Горького тоже получились небольшие гастроли. 2 марта I906 г. на встрече, устроенной «Verein für Kunst» в зале «Secession», он читал поэму «Человек». В Deutsches Theater 25 февраля (го марта) 1906 г. программа русского вечера состояла из произведений писателя. Горький читал «Легенду о Данко» («Старуха Изергиль»); В.И. Качалов «Песню о буревестнике»; Макс Рейнгардт - монолог Луки; известный немецкий актер Deutsches Theater Шильдкраут - рассказ «О Чорте» и «Весенние мелодии». В концертном исполнении сцен из 3-акта «На дне» Горький сыграл Луку (одного из самых нелюбимых своих персонажей), М.Ф. Андреева - Наташу и Настю, Качалов - Барона и Пепла, И.М. Москвин - Клеща и Бубнова.

В Берлине за Горьким по пятам ходили и журналисты, и агенты тайной полиции; за его исполнением роли Луки из литерной ложи наблюдали сыновья кайзера Вильгельма и кронпринц. Качалов вспоминал, как публика встала при появлении Горького, восторженно аплодируя. Большинство зрителей не понимали по-русски; они пришли посмотреть на живого кумира, чье имя гремело по всей Германии. Участие Горького в революционных событиях способствовало росту популярности драматурга не только в Германии, но и во всей Европе. В музее хранится коллекция шаржей и карикатур, тематически связанных с событиями 1905-1907 гг. Некоторые из них свидетельствуют о значимости личности Горького в политической иерархии и восприятии писателя современниками.

Специфика отношения старой Европы к русской революции прочитывается за сатирической аллегорией неизвестного художника - автора «Карикатуры на М. Горького по поводу его сотрудничества в легальной большевистской газете «Новая жизнь». І905». На рисунке, опубликованном в журнале «Шут» (І905, № 45, ноябрь), Горький сидит, скрестив босые ноги, на круглом стуле с винтовой ножкой, укрепленном на стопе книг с названиями произведений писателя. На ножке стула надпись: «Новая жизнь». 
У постамента - босяки. Один из них держит зажженный факел с надписью «Социальная революция». Пламя освещает красноватым тоном Горького и сидящую на втором плане старуху «Европу» в очках и чепце, которая с ужасом смотрит на «программу» с изображением смерти в руках Горького. Под рисунком текст: «Европа: А я-то его, голубчика, по головке гладила, сочинения его читаючи».

В Германии карикатур и шаржей на русского писателя публиковалось очень много. В коллекции музея, например, хранится, работа Гейне Томаса Теодора (Германия) «Der Zar bei Gorki» ${ }^{1}$ (1904-1905), - карикатура на Николая II и его отношение к Горькому. На ней Николай II в горностаевой мантии и короне стоит рядом с сидящим Горьким, положив руку ему на плечо. Под изображением текст на немецком языке: «Пожалуйста, сидите, любезный Горький. Куда это должно привести, каждый захочет выступить против своего правительства, поскольку у него причина для недовольства?! Господь бог обходился со мной последнее время далеко не лучшим образом. Но разве я пытался свергнуть его по этой причине?»² Те же персонажи фигурируют на рисунке неизвестного художника (Горький и Николай II. I904-I905.) Крупным планом изображен человек, похожий на Горького, с длинными волосами, руками, закованными в кандалы и соединенными цепью за спиной. Он полулежит на земле. Слева стоит маленький человек, на шляпе которого надпись: «Nikolaus», смотрит издали на скованного великана. Перерисовка из журнала «Simplicissimuss» (Б. цв., тушь, перо). Горький - главный герой двух шаржей немецкого художника Олафа Гульбрансона из серии «Galerie berühmter Zeitgenossen»3. Один из рисунков - «Максим Горький»4 (1904I905) - интересен и тем, что был воспроизведен в журнале «Гвоздь» (I906, № 2, с. 7) рядом с шаржем на Л.Н. Толстого с подтекстовками: «С.-д. Максим Горький. Мещанин Лев Толстой».

Во втором зале литературной экспозиции на Поварской теме «Горький на немецкой сцене» посвящен целый раздел. Здесь представлены несколько лучших фотографий из внушительной фондовой коллекции немецких актеров (Сатин - Р. Валлентин, Актер - Эмануэль Рейхер, Пепел - Э. Винтер-

\footnotetext{
I Царь у Горького (нем.).

2 Перерисовка художника В.Г. Орлова из журнала «Simplicissimuss», 9. Jahrgang (I9041905), № 48, S. 472. (Б., тушь).

3 Галерея знаменитых современников (нем.).

4 Перерисовка художника В.Г. Орлова из журнала ««Simplicissimuss», 9. (Б., тушь).
} 
штейн, Василиса - Роза Бартенс); известный снимок Горького с дарственной надписью Рихарду Валлентину; большая афиша международной гастрольной поездки немецкой труппы под руководством М. Дорни с постановкой пьесы «Ночлежка» по Германии, Австрии, Англии, Голландии, Турции, России и др. Вверху плаката несколько стилизованных символических образов - героев горьковской драматургии. Это лица философов, отрешенно погруженных в свои размышления. Человек в центре напоминает самого Горького, каким мы увидим его в старости.

Драматическая история Германии середины XX столетия оставила трагический след в культуре страны. Фашистский период отразился полным крахом художественных произведений, постулирующих гуманистические ценности. Репутация Горького-антифашиста, которого преследовал в Италии пришедший к власти Муссолини, русского и советского «буревестника революции», ярого противника антисемитизма со времен черносотенных погромов (активный защитник прав евреев, автор публицистических статей и сборников), способствовала полному запрету творчества писателя. После окончания Второй мировой войны, поделившей Германию на две части, Горький снова появился на немецкой сцене. Его имя можно было увидеть на афишах и в ГДР, и в ФРГ.

В конце 6о-х, в связи со столетием Горького (І968), волна постановок его пьес отмечалась не только в Советском Союзе и социалистических «братских» странах, но и по всему миру. Своеобразный ренессанс Горького, особенно как драматурга, наблюдался в 7о-е. Горького ставили в Европе, США, Англии. Кто-то объяснял это актуальностью пьес (причем не только «На дне») в период всеобщей депрессии, другие обращали внимание на универсальность его драм в сочетании с глубинно русским духом, что обеспечивало им прочное место в международном классическом репертуаре. И режиссерами, и критиками творчество Горького воспринималось в контексте произведений его современников - Шоу, Ибсена, Гауптмана, Толстого, Чехова.

О постановках «На дне» в течение прошлого столетия много писали режиссеры, актеры, критики, газетчики, литературоведы. В І975 г. немало откликов вызвал гастрольный тур «Ночлежки» городского театра Хильдесхейма (режиссер Ян Бичицкий (JanBiczycki), художник Борис Кубик). Музей хранит газетные вырезки статей с говорящими названиями: «Пе- 
са Горького "На дне" - мучительное смешение стилей», «Пьеса Горького “На дне” - портрет отбросов человечества», «Горький - урок человечности», «Даже в самой большой нужде зарождается надежда». Театральные критики хвалили постановку, работу художника; отмечали сильное впечатление, произведенное на зрителей, которые, в финале, опомнившись, оглушительно аплодировали. Главное, авторы статей писали об актуальности поставленных Горьким в начале века проблемах человеческого бытия, не отпускающих не только несчастную Россию, но и благополучную Европу.

Газеты отмечали стремление осовременить знаменитое натуралистическое произведение Горького, в котором он в далеком г902 году показал людей, брошенных на дно жизни с их разрушенными надеждами и оставшимися без ответа вопросами о смысле существования. Критикам представлялось важным то, ради чего зрителям показывали «дно жизни». Они искали и находили параллели мрачной картины старой дореволюционной России в современном европейском обществе. Немецкий спектакль середины 7о-х гг. показал, что среда люмпенпролетариата царского времени I902 г. - вовсе не ушедшее в историю явление царской России, а печальная действительность существующего общества потребления.

Личность Горького и его творчество оказали заметное влияние на художественные процессы в Германии. Эрвин Пискатор в поздравительном письме к шестидесятилетию писателя утверждал: «Борьба - вот наш лозунг, товарищ Горький, борьба на стороне живого, сознательного рабочего класса, и все мы благодарим Вас, нашего духовного вождя, и друга и советчика великих русских революционеров» [I, с. I95].

В собранной коллекции Музея А.М. Горького, среди фотографий, афиш, программ, эскизов декораций, рисунков и газетных вырезок, немецкая страница - одна из самых ярких. Художественное наследие немецкого театра в горьковском контексте важно для формирования целостного пространства, вобравшего в себя противоречивую и сложную историю целого столетия. Творчество Горького-драматурга вышло за рамки национального, выдержав испытание временем и оставшись интересным для режиссеров всего мира. Двадцать первый век вслед за двадцатым сохранил для себя личность Горького, записавшего в I90о г. в альбом МХТ: «Мало на свете хорошего. Самое хорошее - искусство» $[4$, с. 270]. 


\section{Список литературы}

I Архив А.М. Горького. Переписка А.М. Горького с зарубежными литераторами. М.: Худож. лит., І96о. Т. 8.446 с.

2 Березарк И. Сценическая история // «На дне» М. Горького. Материалы и исследования. М.; Л.: ВТО, І940. С .227-276.

3 Горький М. Полн. собр. соч. Письма: в 24 т. М.: Наука, І997-20I7.

4 Летопись жизни и творчества А.М. Горького. І958-г960. Вып. I-4. М.: Изд-во АН СССР, г958. Вып. І. 702 с.

\section{References}

I Arkhiv A.M. Gor'kogo. Perepiska A.M. Gor'kogo s zarubezhnymi literatorami [A.M. Gorky archive. Gorky's correspondence with foreign literati]. Moscow, Khudozh. lit. Publ., I960. Vol. 8. 446 p. (In Russ.)

2 Berezark I. Stsenicheskaia istoriia [Stage history]. "Na dne” M. Gor'kogo. Materialy $i$ issledovaniia [Gorky's The Lower Depths. Materials and studies]. Moscow; Leningrad, VTO Publ., I940, pp. 227-276. (In Russ.)

3 Gor'kii M. Poln. cobr. soch. Pis'ma: $v 24$ t. [Complete works. Letters: in 24 vols.]. Moscow, Nauka Publ., I997-20I7. (In Russ.)

4 Letopis' zhizni i tvorchestva A.M. Gor'kogo. I958-I96o. Issue I-4 [The annals of A.M. Gorky's life and work]. Moscow, Izd-vo AN SSSR Publ., I958. Issue I. 702 p. (In Russ.) 
УДК 82I.I6I.I.0 + 792

ББК $83.3(2 \mathrm{Poc}=\mathrm{Pyc}) 6+$

85.334(4Ита) 6
ПЬЕСА М. ГОРЬКОГО «НА ДНЕ» В ИТАЛИИ: ПОСТАНОВКА ТРУППЫ ТАТЬЯНЫ ПАВЛОВОЙ 1926 Г. (ПО МАТЕРИАЛАМ АРХИВА А.М. ГОРЬКОГО)

\author{
(c) 2018 г. М.А. Ариас-Вихиль \\ Институт мировой литературы \\ им. А.М. Горького Российской академии наук, \\ Москва, Россия \\ Дата поступления статьи: І3 января 2018 г. \\ Дата публикации: 25 марта 2018 г.
}

DOI: I0.22455/2500-4247-20I8-3-I-266-28I

При поддержке гранта РФФИ/РГНФ «М. Горький в Италии. К г5о-летнему юбилею со дня рождения писателя» № 16-04-00394.

Аннотация: Русская актриса и режиссер Татьяна Павлова в I926-I928 гг. осуществила две успешные постановки пьес Максима Горького на итальянской сцене. Речь идет о самой известной пьесе Горького «На дне» и пьесе «Фальшивая монета», которая писалась Горьким в Сорренто и была поставлена впервые труппой Татьяны Павловой как европейская премьера. Интерес этих постановок - в попытке Татьяны Павловой поставить эти пьесы в традиции Московского художественного театра, осуществившего первую постановку пьесы «На дне» в I9O2 г. Максим Горький, находившийся в то время в Италии, участвовал в подготовке спектакля «На дне», приглашал актеров Татьяны Павловой к себе на виллу Галотти в Позиллипо, читал им текст пьесы, как когда-то делал это в МХТ. Однако спектакль Павловой не повторил постановки МХТ, отличавшейся, по мнению современников, излишней натуралистичностью. Спектакль Павловой поразил зрителей своей мистической атмосферой. При этом особенности «новой драмы», создаваемой Горьким в русле художественных исканий драматургов начала XX в., таких как А.П. Чехов, Г. Ибсен, А. Стриндберг, М. Метерлинк, были восприняты публикой и критикой как существенные недостатки драматургии Горького: на итальянской сцене в то время царил «театральный театр» А. Брагальи. Отсутствие драматического действия, обилие диалогов, отсутствие разделения персонажей на главные и второстепенные, перегруженность мелкими эпизодами мешали, по мнению критики, восприятию трагического содержания пьесы Горького. Премьера спектакля Павловой состоялась в декабре г926 г., а в декабре г927 г. в том же римском театре Валле состоялись гастроли МХАТа и итальянские зрители смогли увидеть и сопоставить два выдающихся спектакля. Это сравнение открыло зрителю своеобразие «жизни русской души», с ее пессимизмом и фатализмом, в то время как героев Павловой отличали ясное сознание и понимание своего положения.

Ключевые слова: Горький, Татьяна Павлова, пьеса «На дне» в Италии в I926-г927 гг., театр Валле, «новая драма», итальянская театральная критика о пьесе «На дне».

Информация об авторе: Марина Альбиновна Ариас-Вихиль - кандидат филологических наук, старший научный сотрудник, Институт мировой литературы им. А.М. Горького Российской академии наук, ул. Поварская, д. 25 а, І2Іо69 г. Москва, Россия.

E-mail: arias-vikhil@mail.ru 


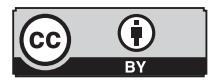

This is an open access article distributed under the Creative Commons Attribution 4.0 International (CC BY 4.0)
THE LOWER DEPTHS IN ITALY: THE 1926 PERFORMANCE BY TATYANA PAVLOVA (BASED ON THE ARCHIVES

\author{
OF A.M. GORKY)
}

(C) 20I8. M.A. Arias-Vikhil

A.M. Gorky Institute of World Literature

of the Russian Academy of Sciences, Moscow, Russia

Received: January I3, 2018

Date of publication: March 25, 2018

Acknowledgement: This work was supported by the Russian Foundation for Humanities (RFH) / Russian Foundation for Basic Research (RFBR). Project title " $M$. Gorky in Italy. To the sesquicentennial." № I6-04-00394.

Abstract: Russian actress and stage director Tatyana Pavlova successfully staged two of Maxim Gorky's plays in Italy from 1926 through I928. Those were The Lower Depths, the most famous play by Gorky, and Counterfeit Coin, a play he wrote in Sorrento; Tatyana Pavlova's troupe played it for the first time. These productions are interesting mainly as attempts to follow the tradition of the Moscow Art Theater where The Lower Depths was staged for the first time in I902. Maxim Gorky who was in Italy at a time participated in the staging of his play: he invited Tatyana Pavlova and her actors to his villa Galotti in Posillipo and read them the text of the play aloud, as had done it at the Moscow Art Theater. However, Pavlova's performance did not simply reproduce the production of the Moscow Art Theater that contemporaries found too naturalistic. Pavlova's performance impressed the audience with its mystical atmosphere instead. At the same time, the elements of the "new drama" that Gorky introduced in his play in the fashion of such early $20^{\text {th }}$ century playwrights, as Chekhov, Ibsen, Strindberg, and Maeterlinck, did not meet Italian public's approval due to the popularity of Anton Giulio Bragaglia's "theatrical theatre" that reigned on the Italian stage at that time. Absence of dramatic action, abundance of dialogues, no division of characters into main and secondary, and overload with secondary, minor episodes hindered, in the opinion of critics, the perception of the tragic content of The Lower Depths. The premiere of Pavlova's performance took place in December 1926, and in December 1927, the same Valle theater in Rome hosted the tour of the Moscow Art Theater. This way Italian public was able to see and compare two outstanding performances. This comparison revealed the specificity of the "Russian soul," its pessimism and fatalism, while the characters in Pavlova's play were distinguished by a sharp understanding of their existential situation.

Keywords : Gorky, Tatyana Pavlova, The Lower Depths, Italy, I926, I927, Vallee Theater, "new drama," Italian theater criticism.

Information about the author: Marina A. Arias-Vikhil, PhD in Philology, A.M. Gorky Institute of World Literature of Russian Academy of Sciences, Povarskaya 25 a, I2IO69 Moscow, Russia.

E-mail: arias-vikhil@mail.ru 
Татьяна Павлова (Татьяна Павловна Зейтман, 1893-1975) - легендарная русская актриса и режиссер, построившая свою карьеру в Италии, - уникальный случай в театральной истории XX в. Начинала она в московской труппе П.Н. Орленева, где дебютировала в роли Агнесс в пьесе Г. Ибсена «Бранд». После І9Іо г. она играла у многих режиссеров, в труппе Московского драматического театра, в том числе сезон I9I5-I9I6 гг. - в театре «Эрмитаж», и получила большой профессиональный опыт (среди ее ролей - фрекен Джулия А. Стриндберга, Грушенька в «Братьях Карамазовых», Маргарита Готье в «Даме с камелиями» и др.). В г920 г. она начала работать в компании «Амброзио Фильм» в Турине, на первой кинофабрике в Италии, где снималась в немых кинофильмах у режиссера Уральского («Роковая орхидея», «Цепь», «Муки совести, «Смертельное очарование»). В І92г г. Павлова эмигрировала из Советской России в Италию, где организовала свою труппу и работала в ней как актриса, режиссер и директор, пропагандируя русскую драматургию и русскую драматическую школу. 3 октября г923 г. Павлова дебютировала со своей труппой в Театре Валле в Риме в «Сне любви» А.И. Косоротова. Ее труппа играла на сцене Театра Филодраматичи в Милане и Театра Гольдони в Венеции, в неаполитанском Театре Политеама она представляет драму «Ревность» М.П. Арцыбашева (1926). Она ставила пьесы А.Н. Островского («Бесприданница», І926), Горького («На дне», І926; «Фальшивая монета», І928), Л.Н. Толстого («Воскресенье», І929; «Живой труп», І94I), «Дорога цветов» (I947) В.П. Катаева, пьесы Л.Н. Андреева, Ю.Д. Беляева и др. В конце І920-х у нее уже был свой театр во Флоренции, куда она пригласила главным режиссером В.И. Немировича-Данченко (1930-1933), поставившего «Вишневый сад» и 
свою собственную пьесу «Цена жизни». В письме своему секретарю О.С. Бокшанской Немирович писал в то время, что Компания Павловой считается лучшей в Италии. Художником спектакля «Вишневый сад» был Н.А. Бенуа, художник-декоратор Мариинского театра, ставший в I936 г. главным художником и заведующим художественно-постановочной частью театра Ла Скала. В последующие годы Павлова поставила еще несколько пьес, в том числе «Анну Каренину», где главную роль играла известная итальянская актриса Марта Абба. C 1934 г. она преподавала систему Станиславского в созданной ею совместно с театральным деятелем Сильвио д’Амико Академии драматического искусства, в І938 г. вышла замуж за писателя и сценариста Нино Д'Арома, фашиста по политическим убеждениям, близкого к Муссолини. Заведовала кафедрой режиссуры в Королевской академии драматургического искусства в Риме. В г95о-е гг. Т. Павлова работала как режиссер оперных спектаклей, поставила «Бориса Годунова» в Ла Скала, «Пиковую даму» (1953) и «Войну и мир» С. Прокофьева (I953) в Театре Комунале во Флоренции, «Сказание о невидимом граде Китеже» Римского-Корсакова в Риме (1960) и др.

В Архиве А.М. Горького ИМЛИ РАН хранятся газетные вырезки из итальянской прессы за 1926-I928 гг. (коллекция П. Цветеремича), относящиеся к постановке пьесы «На дне» труппой Татьяны Павловой на итальянской сцене. Постановка драматической труппы Татьяны Павловой осуществлена в 1926 г., а в декабре г927 г., год спустя, в Италии гастролировал Московский Художественный театр, показавший свой спектакль «На дне» итальянскому зрителю в том же Театре Валле в Риме. В это же время шел спектакль по пьесе «Мещане», поставленный Эммой Граматикой в Театре «И Фьорентини». В 1927 г. Татьяна Павлова обращается к еще одной пьесе Горького «Фальшивая монета» - театральной новинке, написанной писателем уже в Сорренто (хотя начата пьеса была еще в І9г3 г., но не закончена автором и положена в стол). Такой интерес к театру Горького не случаен и показывает востребованность его драматургического творчества в его бытность в Италии: присутствие писателя придает премьерам спектаклей особую актуальность, да и сам Горький по мере сил помогает режиссеру и актерам, благо в данном случае режиссер - русская актриса, понимающая писателя с полуслова. Обращает внимание тот факт, что в Театральной энциклопедии в статье о режиссерской работе Татьяны Павловой год постановки пьесы «На дне» указан неверно (1927 вместо I926 [8]). Исследование итальянской прессы тех 
лет позволяет узнать точную дату премьеры пьесы «На дне»: 30 марта I926 г. («Il Mezzogiorno», I926, 28-29 марта).

Замысел постановки пьесы Горького «На дне», возможно, возник у Татьяны Павловой в связи с возможностью работать над спектаклем совместно с автором. 20 ноября г925 г. Горький переехал из Сорренто в Неаполь, так как нуждался в лечении. На его вилле «Иль Сорито» в Сорренто шел ремонт, и писатель поселился в Позиллипо, на вилле Галлоти, где провел зиму г925I926 гг. В Сорренто он вернулся 7 мая г926 г. [4, с. 745].

Нарушив свое привычное уединение в Сорренто, Горький в Неаполе пользуется возможностью участвовать в театральной жизни Италии: «Вчера Горький посетил театр Политеама, чтобы присутствовать на постановке Татьяны Павловой (была премьера «Ревности» М. Арцыбашева), и после второго акта прошёл за кулисы, где имел продолжительную беседу со знаменитой русской актрисой» («Il Mezzogiorno», I926, 24 февраля). Горький пригласил к себе в гости режиссера и труппу. Проект совместной работы, восходящий, вероятно, к беседе за кулисами, обрел вполне конкретные очертания: «Вчера синьора Павлова посетила в Позиллипо дом Максима Горького, которому знаменитая актриса представила основных актеров своей труппы» («Il Mezzogiorno», г926, 24 февраля).

«Состоялось значительное событие в артистической жизни, что подтверждается самой рубрикой, освещающей эту новость: великий писатель прочел своим гостям пьесу «Ночлежка» (под таким названием в Италии знали пьесу «На дне». - М.А.), замечательное произведение для театра, которое в постановке Татьяны Павловой будет представлено нашей публике. Максим Горький также проиллюстрировал выдающимся актерам различные типы, выведенные в его пьесе, раскрыв им в тончайших деталях психологический рисунок драмы» («В доме Горького», «Il Mezzogiorno», I926, 3-4 марта, средачетверг). Горький оказался в числе зрителей и почитателей Татьяны Павловой: «М. Горький, замечательный русский писатель, живший в течение двух лет на вилле в Сорренто, несколько дней назад переехал в Позиллипо <...> Он ходит в театр, с интересом смотрит постановки, аплодирует, поздравляет актеров. Постановки Татьяны Павловой < ...> нарушили покой его “виллы Галлотти” в Позилиппо» (Горький работал над романом «Сорок лет», который мы знаем как «Жизнь Клима Самгина»; в итальянской прессе встречается и другое название романа: «Исследователь». - M.A.) («Il Mezzogiorno», I926, 23-24 марта). 
Итальянская пресса пристально следит за творческой и личной жизнью писателя. Журналист Джино Казерта пишет: «Максим Горький в Неаполе. Он будет нашим гостем еще долгое время - так сложились обстоятельства, что в его обычной резиденции в Сорренто начат ремонт, и Горький в ожидании возвращения в свой любимый дом решил приехать к нам. Сейчас он живет на вилле на холме Позиллипо в исключительно русском окружении - с сыном, невесткой и графиней Будберг, милой дамой, его личным секретарем, чудом избежавшей советской бойни, - и принимает только русских - художника Бориса Григорьева, Татьяну Павлову, адвоката Якова Львова, интеллигентного и смелого русско-итальянского журналиста, синьору Шаляпину, жену знаменитого баса (имеется в виду вторая жена Ф.И. Шаляпина М.В. Петцольд, брак с которой Шаляпин заключил в 1927 г. - M.А.) с дочерью синьориной Татьяной и некоторых других» («Il Mezzogiorno», I926, 23-24 марта).

В интервью итальянскому журналисту Горький объяснил, отвечая на вопрос о новом спектакле по его пьесе:

- Через несколько дней мы увидим большую премьеру новой постановки вашей «Ночлежки».

- «На дне», - поправляет Горький, - буквально это переводится так (итал. Sul fondo или Nei bassifondi). Это название переводили как «Приют для бедных» - Albergo dei poveri, а затем «Ножлежка» - Asilo notturno, - может быть, потому что действие разворачивается в типичном русском ночлежном доме - в подвале, где сдаются за плату грязные тюфяки. Я с большим удовольствием дал разрешение на постановку, поскольку Татьяна Павлова - прекрасная актриса, хорошо понимающая свою художественную задачу. Я даже приду на несколько последних репетиций, чтобы указать замечательным актерам ее труппы на отдельные колоритные детали, которые, естественно, могут от них ускользнуть» («Il Mezzogiorno», I926, 23-24 марта).

I Татьяна Федоровна Шаляпина-Либерати (г905-1993) - дочь Ф.И. Шаляпина от первого брака, актриса, в Италии играла в труппе Татьяны Павловой, жила в Европе и в США. В Италии вышла замуж за театрального импресарио Эрмете Либерати, который помогал в организации концертов Шаляпина и переводил его русские арии на итальянский язык. После разрыва с мужем жила в Берлине, во время войны нашла убежище в Нью-Йорке, где жили ее брат и сестры. В третий раз вышла там замуж. Последние десять лет своей жизни провела в Риме. Скончалась во время пребывания в Москве на торжествах по случаю г2олетия со дня рождения отца, и была похоронена, как и он, на Новодевичьем кладбище. 
Горький активно включился в работу, как это было некогда с постановками «На дне» МХТ и труппой М. Рейнхардта в Берлине, взяв за образец сотрудничества с труппой Павловой модель своих отношений с В.И. Немировичем-Данченко и труппой МХТ, когда он встречался с актёрами, заказывал фотографии типажей, рисунки декораций. Л.Н.Андреев писал по этому поводу в I902 г.: «М.П. Дмитриев (нижегородский фотограф, с которым был дружен Горький. - М.А.) с риском для себя собирает их на нижегородской Миллионке, в ночлежных домах и всюду, где ютятся забытые богом и людьми герои Горького. Я видел у Горького эти художественные снимки и понял, какое важное и необходимое подспорье составляют они для театра, имеющего дело с совершенно новой и неисследованной областью жизни» [2]. Эту же атмосферу Горький стремился передать, работая над спектаклем с труппой Татьяны Павловой, включая читку и разбор ролей, что было традицией MXT. 30 марта 1926 г. состоялась премьера спектакля в неаполитанском Театре Политеама. Газета анонсировала присутствие автора на премьере: «Во вторник состоится большое представление, интересное в высшей степени также и в литературном смысле, по самой сильной и гуманистической драме Горького “Ночлежка”. На спектакле будет присутствовать автор пьесы» («Il Mezzogiorno», I926, 28-29 марта, воскресенье-понедельник). Затем Павлова гастролировала с этим спектаклем по Италии и в декабре I926 г. показала его на сцене старейшего и престижнейшего римского Театра Валле. В анонсе премьеры в Валле говорилось: «Труппа Татьяны Павловой представит сегодня в Театре Валле «Ночлежку» Максима Горького. Эта талантливая драма не ставилась в Италии много лет. Синьора Павлова подготовила ее постановку в сотрудничестве с самим Горьким. Постановка соответствует первой постановке этой пьесы на сцене Московского художественного театра» («Il Giornale d'Italia», I926, 3г декабря, пятница). Насколько реальным было это соответствие? Удалось ли Татьяне Павловой найти ключ к этой пьесе?

Известно, что пьеса Горького представляла определенные трудности для сценического воплощения, связанные с новаторским характером драмы Горького и её новыми для сцены героями [г]. А.П. Чехов, например, воспринял пьесу как пессимистическую и мрачную. А финал и вовсе показался ему неудачным: «Этот акт может показаться скучным и ненужным, особенно если с уходом более сильных и интересных актеров останутся одни только сред- 
ние. Смерть актера ужасна; Вы точно в ухо даете зрителю, ни с того ни с сего, не подготовив его» (письмо от 29 июля г9о2 г.) [9, с. 236-238].

Несмотря на трудности постановки, спектакль МХТ имел огромный успех, равный успеху «Чайки» (по отзыву О.Л. Книппер). Немирович-Данченко не сразу, но «нашел настоящую манеру играть пьесы Горького» (письмо А.П. Чехову от І3 декабря I902 г.) [6, с. 3Іо]. К.С. Станиславский писал: «Для всей пьесы выработали мы тон новый для нашего театра - бодрый, быстрый, крепкий, не загромождающий пьесу паузами и малоинтересными подробностями» [7, с. 252].

Судя по рецензиям итальянской театральной критики, ключ, найденный Татьяной Павловой, был другим: постановка была выдержана в тоне лирико-мистической экзальтации, сквозь которую «светилась и мерцала славянская душа» («Il Giornale d'Italia», ı927, г января, суббота).

По словам самой Павловой, она стремилась к тому, чтобы постановка была сделана в духе русского мироощущения, с тем особым «безысходным и яростным русским сценическим натурализмом» («Il Giornale d'Italia», I927, г января, суббота), в котором критика увидела отражение драмы целого народа. «Этническая живописность», отличавшая спектакль Павловой, не вызвала со стороны критики упрёков в излишней натуралистичности и «ненужной правде», как в своё время это произошло со спектаклем МХT. В статье «Ненужная правда. По поводу Художественного театра», напечатанной в программном журнале русского символизма «Мир искусства», В.Я. Брюсов критиковал натуралистические тенденции МХT, преувеличенное внимание к воссозданию жизнеподобия на сцене [3, с. 67].

Труппа Татьяны Павловой инсценировала драму «с образцовым вкусом и знанием дела». Кровавые отблески света, нагромождение грязных нар, ужасные переплетения лестницы, завывания ветра, всполохи солнца - всё служило созданию особой атмосферы, заставляя зрителей смотреть широко раскрытыми глазами на «убожество этого логова» и содрогаться от ужаса при виде «мужчин и женщин, опустошённых, отупевших от страдания и лишённых всякой чувствительности» («Il Mezzogiorno», I926, 3I марта - I апреля, среда-четверг).

Действительно, итальянскую публику поразила необычность героев горьковской драмы: «В два часа ночи закончилось представление драмы в четырех актах Максима Горького “Приют для бедных”. Двадцать лет назад 
эта драма ставилась Труппой Де Санктиса² под более элегантным названием “Ночлежка”. Однако ни одно из этих названий не соответствует мысли знаменитого русского романиста. Оригинальное название означает социальное подполье, в котором обитает слой нищих морально и физически, циничные, преступные алкоголики и воры, бродяги-паразиты, человеческие отбросы» («Il Mezzogiorno», I926, 3І марта - I апреля, среда-четверг).

Барон Саверио Прочида (Saverio Procida, I867-I933), знаменитый неаполитанский театральный и музыкальный критик, востребованный журналист, сотрудничавший в самых авторитетных итальянских газетах «Il Pungolo», «Corriere della Sera», «Il Popolo», «Gazzetta del Mezzogiorno», «Resto del Carlino», увидел характерную черту новой драмы в отсутствии катарсиса в традиционном понимании. По его мнению, эта особенность «новой драмы», представленной Горьким, связана с особой типологией горьковских персонажей: «Сострадание не может победить ужаса и отвращения <...>. Отвращение сильнее рыдания, сдавившего горло. Жалость и сострадание не воздействуют должным образом» («Il Mezzogiorno», I926, 3І марта - г апреля, среда-четверг).

Интересно, что, воспитанная на традициях «театрального театра» Антона Брагальи, итальянская критика сопоставила драматургию Горького с чеховской, и художественные особенности «новой драмы», восходящие к идеологическим установкам писателей, сочла недостатками «построения» пьесы. Так, один из критиков говорит о «благородном порыве актрисы (Т. Павловой. - M.А.), которая из уважения к художнику принесла себя в жертву постановке, где само построение пьесы предполагает отсутствие главных и второстепенных персонажей и каждый герой становится всего лишь штрихом в общей картине». Отсутствие разделения персонажей на главные и второстепенные было воспринято как «ограниченность» («Il Giornale d'Italia», I927, г января, суббота).

Несмотря на то что пьеса относилась к «незапамятным временам», ее новаторский характер с трудом воспринимался итальянской публикой. Еще ярче это глубинное непонимание проступило во время гастролей МXT в декабре г927 г., год спустя после премьеры труппы Павловой. Парадокс

2 Альфредо де Санктис (Alfredo De Sanctis, I865-1954) - итальянский актер театра и кино, певец. В г898 руководил Драматической компанией Театра Арте в Турине. В г90о, став капокомико, создал свою собственную компанию с исключительным репертуаром эпохи (Ибсен, Горький, Брие, Бутти). В г92І триумфально гастролировал в Париже в Театре Евр. Прославился также своими актерскими работами в кино (1930-1940-е). 
восприятия этих постановок состоит в том, что при неприятии характерных особенностей «новой драмы», обе постановки имели успех и собирали многочисленную публику.

Отсутствие действия в традиционном смысле слова стало самой большой трудностью для восприятия пьесы публикой: «За исключением двух-трех сцен, в “Приюте для бедных” ничего не происходит. Защитники нового искусства отвечали: ничего и не может происходить, т. к. в пьесе выведено сборище неудачников, априори обреченных на поражение и не способных действовать по определению. "Ну и что же? - ответят недовольные, - Гамлет тоже не мог действовать, однако посмотрите, что сделал Шекспир в то же самое время, чтобы показать неспособность своего героя к действию: когда Гамлет решается, наконец, на удар шпаги, уже накапливается такой ряд катастроф и смертей, что для перечисления их не хватит пальцев руки” («La Tribuna», г927, 4 декабря, воскресенье).

Другая пьеса, показанная МХT (комедия «Бедность не порок»), так же новая для итальянского зрителя, была сразу понятна: «это был театральный театр, как сказал бы Брагалья» («La Tribuna», I927, 4 декабря, воскресенье). Происшествия, события, небольшие сценические эффекты - публика развлекалась. На представлении пьесы Горького, напротив, на сцене господствовало, за исключением двух-трех кульминационных моментов, «Его Величество Слово» (Гастон Бати $\left.{ }^{4}\right)$ : “Приют для бедных" - это сплошные слова, то есть диалоги и исповеди; разглядеть в этом драматический сюжет для публики, не знающей языка, - нелегкая задача» («La Tribuna», I927, 4 декабря, воскресенье). Сложность состояла в том, что публика за словами должна была увидеть драму; подобно тому,

3 Антон Джулио Брагалья (Anton Giulio Bragaglia, I890-I960) - итальянский художник, фотограф и кинорежиссёр-футурист, театральный деятель. Родился в семье режиссера кино Ф. Брагалья. В І9І6 г. создает свою киностудию, на которой ставит, совместно с художником-футуристом Э. Прамполини, 3 фильма. В г9І8 г. основал в Риме Дом Искусств Брагальи, а в 1922 г. - театр. Выступал как эссеист и театральный критик.

4 Гастон Бати (Gaston Baty, I885-I952) - французский драматург и режиссёр, теоретик театра, один из основателей в г927 г. знаменитого театра «Картель» (фр. Cartel des quatre). Совершенствовался в театральной режиссуре в Германии и России, проявил большой интерес к взглядам Макса Рейнхардта и Станиславского на реформирование театра. С конца г920-х по середину г940-х гг. работал во многих театрах Франции, в том числе в Театре Елисейских полей и Théâtre de l'Avenue, в г930 г. занял место директора театра Монпарнас. 
как в чеховских драмах публика должна была увидеть драму не за словами, а в паузах, не в том, что герои говорили, а в том, о чем они молчали. И в этом колоссальное отличие новой драмы от «театрального театра». В этой связи «трагическая фреска» драмы Горького показалась «слишком многословной, слишком пространной, слишком подробной, перегруженной мелкими эпизодами, иной раз избыточными для целей искусства и театральной экономии» («La Tribuna», I927, 4 декабря, воскресенье). Hеприятие формальных приемов новой драмы не помешало критике оценить по достоинству содержание горьковской пьесы, которое и есть выражение души художника, если воспользоваться определением В.Я. Брюсова. В Горьком увидели продолжателя высоких традиций русской литературы, наследника Достоевского и Толстого. Анализируя впечатление, производимое пьесой на строй чувств современников, «с ее вспышками поэзии и политическими и социальными коннотациями», критика заявила о своем несогласии «с мнением Льва Толстого, смотревшего, как вспоминает сам Горький в своих знаменитых “Заметках”, несколько свысока на его творчество» («Il Giornale d'Italia», I927, г января, суббота).

Наибольший интерес вызвал образ Луки, который Д.С. Мережковский считал «величайшим созданием Горького», «главным и, в сущности, единственным героем “На дне”» [5, с. 663].

Мережковский увидел в «старце лукавом» проповедника религии лжи и богоборца («Религия “старца лукавого” и есть религия лжи. Дьявол - “отец лжи”; он истину ненавидит, потому что не устоял в истине; когда говорит ложь, свое говорит, потому что он - отец лжи и вечная ложь его оружие в борьбе с Вечною Истиною - с Богом» [5, с. 664]. Трактовка Д.С. Мережковского по сути близка к позиции Горького: «Они (Лука и Великий Инквизитор. - М.А.), подобно отцу своему, отцу лжи, который “человекоубийца был искони”, хотят не спасти, а погубить мир. Оба они знают, что человек никогда ни для какого блаженства не откажет окончательно от свободы, никогда, ни для какой утешительной лжи не отвергнет истину окончательно, никогда, ни для каких золотых снов земли не забудет снов небесных окончательно. Оба они знают, что рано или поздно человек проснется от сна, затоскует и в рабстве, проклянет ложь и увидит за ложью бездонную пустоту, в которую влечет его “отец лжи” $[5$, с. 666]. Горький писал по этому поводу: «Успех “Дна” приподнял всех на высоту полной потери 
разума... Тем не менее - ни публика, ни рецензята - пьесу не раскусили. Хвалить - хвалят, а понимать не хотят. Я теперь соображаю - кто виноват? Талант Москвина-Луки или же неуменье автора?» [4, т. 3, с. І27]. «Лука жулик. Он, собственно, ни во что не верит. Но он видит, как страдают и мечутся люди. Ему жаль этих людей. Вот он и говорит им разные слова - для утешения» $[4$, т. 3, с. 356].

В отличие от Горького и Мережковского, рецензент спектакля Саверио Прочида с образом Луки связывает «свет христианской кротости», «религиозной надежды»: «Но свет христианской кротости, сладкая иллюзия, сияние веры проникает и в эту пугающую тьму. Странник Лука приносит с собой слова надежды, обещания будущей награды, напоминает о Боге тем, кому нечего ждать от людей. И это утешение от символического персонажа, которого то осмеивают, то принимают как единственный проблеск радости и надежды на высшую справедливость, - пожалуй, единственная вера, которая может родиться среди этого мрачного ужаса» («Il Mezzogiorno», I926, 3I марта - г апреля, среда-четверг). Более глубокая трактовка, чем в рецензии Прочида, и более близкая к трактовке Мережковского содержится в рецензии Сильвио д’Амико: «Появляется, как бы в функции “хора”, посреди трясины отчаяния добродушный старец Лука, с белой бородой и сердцем благочестивого анархиста; но свет его пламени слишком слаб, чтобы осветить эту тьму, его сократовское лицо скорее подходит наивному философу, чем христианину, его усилия и доброта сводятся к призыву на помощь иллюзии. Разражается катастрофа, а он исчезает. На всеобщей трагедии лишь остаётся написать слово приговора: бесполезно» («La Tribuna», I927, 4 декабря, воскресенье). Очень интересно сравнение роли Луки с функцией «хора» в греческих трагедиях. Хор - безличный коллективный разум, высшая мудрость рода, оценивающий действия героя-протагониста. Хор хвалит его, предостерегает от ошибок и заблуждений и порицает, если герой ошибается. Хор может утешать героя, сострадать ему. То же самое делает Лука, персонифицируя функцию хора: хор не участвует в действии, как отстранен от действия Лука.

Проецируя образ Луки на античную трагедию, Сильвио д’Амико дает более глубокую перспективу восприятия драмы Горького, ее мистерийности, закладывает возможности новых глубоких интерпретаций путешествия души, её нисхождений и восхождений. 
В январе 1927 г. в Театре Валле шла постановка Т. Павловой, а в декабре того же года со спектаклем «На дне» в Рим приехал на гастроли MXАТ: «Создалось впечатление, что публика увидела новое произведение; даже не понимая слов актеров, зрители прекрасно поняли состояние души каждого персонажа, так как трагическая атмосфера создавалась каждой деталью мизансцены, каждым словом и даже интонацией каждого слова! Ни малейшая деталь не отвлекла внимание публики, которая сидела не шелохнувшись, и, можно даже сказать, она жила жизнью героев, такая абсолютная тишина стояла в зале» («Il Giornale d'Italia», I927, I января, суббота). Создание атмосферы критика сочла главным достоинством мхатовского спектакля. Удивительный результат дало сопоставление двух спектаклей: «Год назад мы слушали эту пьесу в прекрасной интерпретации итальянской труппы: сейчас мы ждали с большим интересом русскую интерпретацию, но мы никогда бы не поверили, что сопоставление двух этих спектаклей может быть таким занимательным. Оно позволило нам понять, в каком-то смысле, особенности и секреты жизни русской души. Итальянские актеры поддерживают в горьковских персонажах ясное сознание относительно их положения, и именно эта бдительность и понимание внушают настоящий ужас. В исполнении русских актеров Московского художественного театра горьковские герои, напротив, явились бессознательными и безотчётными. Их речь представляет собой не умозаключения, рассуждения, лирические или трагические пассажи, а бесполезные слова, сказанные в состоянии полуавтоматизма. Но когда приходит осознание собственного положения, разверзшейся бездны, на краю которой они очутились, эти люди сопротивляются боли и убивают себя, как Актёр, или готовятся к самоубийству, как Настенька» («Il Messaggero», I927, 3 декабря, суббота).

Проявление на сцене бессознательного - «полуавтоматизма» - открывает дорогу фрейдистской трактовке. Такое исполнение явилось настоящим открытием для итальянского зрителя. Успех спектакля МХАТ был велик: «Многочисленная публика долго аплодировала, начиная с того момента, когда был опущен занавес и до самого конца, включая выходы на поклон актёров семь или восемь раз, вызываемых возгласами энтузиазма» («Il Messaggero», 1927, 3 декабря, суббота).

Действительно, с пьесой «На дне» связано немало открытий. Ее постановки открыли итальянскому зрителю целый мир с его особыми героями. 
К г5о-летию М. Горького / М.А. Ариас-Вихиль

Ведь именно эта пьеса признана вершиной творчества писателя: «Горький заслужил свою славу: он открыл новые, неведомые страны, новый материк духовного мира; он первый и единственный, по всей вероятности, неповторимый в своей области» [5, с. 645]. 


\section{Список литературы}

I Aриас-Вихиль М.А. Идеи и драмы Максима Горького в Италии в 1905 году (по материалам Архива A.M. Горького) // Новые российские гуманитарные исследования. Вып. 8. 20I3. URL: http://nrgumis.ru/articles/270/ (дата обращения: о8.oI.20I7).

2 Андреев Л.Н. // Курьер. I902. 25 августа.

3 Брюсов В.Я. Ненужная правда (По поводу Московского Художественного театра) // Мир искусства. І902. № 4. С. 67-69.

4 Горький М. Полное собрание сочинений. Письма: в 24 т. М.: Наука, I997. 478 с. Т. 3; М.: Наука, 2012. Т. І5. 966 с.

5 Мережковский Д.С. Чехов и Горький // Максим Горький: pro et contra. СПб.: Изд-во РХГА, І997. 880 с.

6 Немирович-Данченко В.И. Избранные письма: в 2 т. М.: Искусство, І979. Т. г: І879-г909 / сост., вступ. ст. В.Я. Виленкин. 608 с.

7 Станиславский К.С. Собр. соч.: в 8 т. М.: Искусство, г96о. Т. 7: Письма г886-г917. 8 I2 c.

8 Театральная энциклопедия. М.: Сов. энциклопедия, I965. T. IV. URL: www. вокабула.рф/энциклопедии/театральная-энциклопедия/павлова35 (дата обращения о8.oi.20I8).

9 Чехов А.П. Полное собрание сочинений и писем: в 30 т. Письма: в г2 т. / АН СССР. Ин-т мировой лит. им. А.М. Горького. М.: Наука, I974-I983. Т. Іг: Письма, июль декабрь г903. М.: Наука, І982. 719 с. 


\section{References}

I Arias-Vikhil' M.A. Idei i dramy Maksima Gor'kogo v Italii v I905 godu (po materialam Arkhiva A.M. Gor'kogo) [Ideas and dramas by Maxim Gorky in Italy in I905: On the material of A.M. Gorky archive]. Novye rossiiskie gumanitarnye issledovaniia, issue 8, 2013. Available at: http://nrgumis.ru/articles/270/ (Accessed o8 January 20I7) (In Russ.)

2 Andreev L.N. Kur'er, I902, 25 avgusta.

3 Briusov V.Ia. Nenuzhnaia pravda (Po povodu Moskovskogo Khudozhestvennogo teatra) [Unnecesary truth: on the Moscow Art Theatre]. Mir iskusstva, I902, no 4, pp. 67-69. (In Russ.)

4 Gor'kii M. Polnoe sobranie sochinenii. Pis'ma: $v 24$ t. [Complete works. Letters: in 24 vols.] Moscow, Nauka Publ., I997. Vol. 3. 478 p.; Moscow, Nauka Publ., 20I2. Vol. I5. 966 p. (In Russ.)

5 Merezhkovskii D.S. Chekhov i Gor'kii [Chekhov and Gorky]. Maksim Gor'kii: pro et contra [Maxim Gorky: pro et contra]. St. Petersburg, Izdatel'stvo RKhGA Publ., I997. 880 p. (In Russ.)

6 Nemirovich-Danchenko V.I. Izbrannye pis'ma: $v 2 t$. [Selected letters: in 2 vols.] Moscow, Iskusstvo Publ., I979. Vol. I: I879-I909 / ed., intro. V.Ia. Vilenkin. 608 p. (In Russ.) Stanislavskii K.S. Sobranie sochinenii: $v 8 t$. [Works: in 8 vols.] Moscow, Iskusstvo Publ., I960. Vol. 7: Pis'ma I886-I9I7 [Letters I886-I9I7]. 8I2 p. (In Russ.)

8 Teatral'naia entsiklopediia [Theatrical encyclopedia]. Moscow, Sovetskaia entsiklopediia Publ., I965. Vol. IV. Available at: www. vokabula.rf/entsiklopedii/teatral'naiaentsiklopediia/pavlova35 (Accessed January 08, 20I7). (In Russ.)

9 Chekhov A.P. Polnoe sobranie sochinenii i pisem: $v$ zot. Pis'ma: $v$ I2 $t$. [Complete works and letters: in 30 vols.], AN SSSR. In-t mirovoi lit. im. A.M. Gor'kogo. Moscow, Nauka Publ., I974-I983. Vol. II: Pis'ma, iiul' - dekabr' I903 [Letters, July - December I903]. Moscow, Nauka Publ., I982. 7I9 p. (In Russ.) 
УДК 398 (477)

ББК 82.3(4Укр)

\section{ЭПИЧЕСКОЕ СВОЕОБРАЗИЕ УКРАИНСКИХ НАРОДНЫХ ДУМ}

(C) 2018 г. С.К. Росовецкий

Киевский национальный университет

им. Тараса Шевченко,

Киев, Украина

Дата поступления статьи: 20 ноября 2017 г. Дата публикации: 25 марта 2018 г.

DOI: I0.22455/2500-4247-20I8-3-I-282-30I

Аннотация: В статье рассматривается вопрос об эпическом своеобразии украинских дум. Проблема решается как демонстрацией оригинальности словесной формы думы, музыкальной составляющей ее текстов и самобытности исполнителей, слепых музыкантов, так и обсуждением места дум среди других явлений мирового эпоса. В то время как С.Н. Азбелев видит в думе явление перед-эпоса, соответствие гипотетической «лиро-эпической кантилене» (А.Н. Веселовский), Б.Н. Путилов относит думы к поздней, «постклассической» стадии в развитии эпоса, собственно, к пост-эпосу. Показано, что только думы о Хмельниччине создавались «по горячим следам исторических событий», но и они содержат в себе приметы определенного художественного обобщения. В произведениях героического «ядра» думного эпоса обнаруживаются некоторые признаки эпоса именно «классического» типа: герои думы, в быту обыкновенные люди, как воины проявляют эпический гиперболизм. Таковы атаман Матяш Старый и Иван Коновченко, Вдовиченко. В думах встречается характерная для классического эпоса «двупланная» композиция, присутствуют образы изменников, есть признаки начала циклизации дум вокруг определенных героев. В то же время в думах нет «эпического центра», нет своего варианта «эпического правителя», нет сюжета о несправедливом заточении им эпического героя, нет героического сватовства, нет сюжета о бое отца с сыном. Объясняются эти особенности тем, что жанр дум создавался, а их сюжетный состав формировался в отношении дополнительности с древним эпосом, былинами, продолжавшими бытование до XVII в. У творцов нового жанра вообще не было необходимости сочинять думы на названные сюжеты, ведь такие песни ещё можно было услышать в жанровой форме былины. Переход в украинской эпической традиции от былины к думе был связан с изменениями исторических условий, «социального заказа» и культурных типов исполнителей.

Ключевые слова: дума, эпос, кантилена, былина, гиперболизм.

Информация об авторе: Станислав Казимирович Росовецкий - доктор филологических наук, профессор, Киевский национальный университет им. Тараса Шевченко, бул. Шевченко, д. І4, оІо33 г. Киев, Украина.

E-mail: js_rosovezki@hotmail.com 


\section{EPIC SPECIFICITY OF UKRAINIAN FOLK DUMAS}

This is an open access article distributed under the Creative Commons Attribution 4.0 International (CC BY 4.0)
(C) 20I8. S.K. Rosovetsky

Taras Shevchenko

National University of Kiev,

Kiev, Ukraine

Received: November 20, 2017

Date of publication: March 25, 2018

Abstract: The article examines the epic specificity of Ukrainian dumas. It does it by demonstrating the originality of the verbal form of dumas, the musical elements of its texts and their performers, blind musicians, and by discussing the place of the genre among similar epic phenomena in the world literature. While S.N. Azbelev considers dumas to be a pre-epic form correspondent to the hypothetical "lyrico-epic cantilena" (A.N. Veselovskiy), B.N. Putilov relates them to the later, "post-classic" stage in the epos development, or, namely, to "post-epos." The essay claims that only the dumas about Khmel'nichchina were composed "on hot tracks of historical events," but even these works brought their plotline to a more general level. One can trace the features of the "classic" type of epos in the heroic "core" of dumas: their heroes, while shown as ordinary people in the everyday life, nevertheless demonstrate epic hyperbolism as warriors. Such are ataman Matyash the Old and Ivan Konovchenko, Vdovichenko. The captivity dumas reveal certain hyperbolism as well. These dumas often use a "two-level" structure that is usual for the "classic" epos; they feature traitors and contain signs indicating the beginning of cyclization around certain characters. At the same time, they have no "epic center" nor they have an "epic ruler" variant; they do not have such typical plots as unfair incarceration of the epic hero by the epic ruler, or heroic courtship, or the fight between father and son. The essay explains these gaps by the fact that the genre of dumas emerged and their plot structure developed as complimentary to an older epic form, bylynas that continued to circulate in the $16^{\text {th }}$ century. The creators of the new genre did not have to compose their dumas because songs on the same themes already circulated at that time and belonged to the generic form of bylina. The author explains transition from bylina to duma within Ukrainian epic tradition by historical changes, "social demand," and cultural types of the performers.

Keywords: duma, epos, cantilena, bylina, hyperbolism.

Information about the author: Stanislav K. Rosovetsky, DSc in Philology, Professor, Taras Shevchenko National University of Kyiv, Shevchenko, I4, оIO33 Kiev, Ukraine.

E-mail: js_rosovezki@hotmail.com 
Изучение жанра дум на Украине оживилось с середины 90-х гг. XX в., когда вышли из местных «спецхранов» классическая, хоть и не завершенная антология К.М. Грушевской $[27 ; 26]$ и фундаментальная рецензия на ее первый том В.Н. Перетца [І4].

Со временем появились попытки теоретических обзоров истории самого термина «дума» и определений жанра [6], актуальных проблем изучения дум и состава их корпуса с учетом опыта русского советского эпосоведения и «теории Перри-Лорда» [20, с. 360-395], эти и другие материалы были обобщены во вступительных статьях М.К. Дмитренко и С.И. Грицы к первому тому новой пятитомной антологии, подготовленном в Отделе фольклористики Института искусствознания, этнологии и фольклора имени М.Т. Рыльского, Национальной академии наук Украины (г. Киев) и изданном в 2009 г. $[7 ; 4]$. Второй том задерживается в издательстве института (устное сообщение М.К. Дмитренко).

Исходя из понимания в фольклористике жанра как типа художественной формы, мы позволим себе «без излишнего предварительного теоретизирования считать думами все фольклорные неравносложные песни (от 4 до 30 слогов в стихе), исполнявшиеся речитативом в сопровождении аккомпанемента на кобзе, бандуре (теперь это названия одного и того же инструмента) или на лире; рифма почти обязательна и, как правило, глагольная; текст разделяется на “уступы” (группы стихов, от 2 до І2), в каждом из которых изложена одна мысль; иногда такие “уступы” объединяются сквозной рифмой; конечное славословие персонажам, одна из думных “эпических формул”, тоже обязательно» [20, с. 360-36г]. 
Принципиально важным для понимания жанровой специфики думы а заодно и позволяющим почувствовать ее эстетичное своеобразие, - есть разделение ее при исполнении на упомянутые «уступы». Ф.М. Колесса видел в них «словно бы разновидности строфы» и отмечал, что словесной законченности такого «уступа» отвечает «комплекс тесно соединенных с собой музыкальных фраз, который называем периодом»; при этом «каденция каждого периода приводит в тексте и в мелодии к малому перерыву, наполненному игрой на кобзе» [II, c. 54, 59].

Специалисты не пришли к согласию по вопросу, совпадают ли по жанру известные нам народные украинские думы с «dumamy», о которых упоминают польские писатели конца XVI-XVII вв. В XIX в. кобзари и лирники называли думы «козацькими піснями», «піснями про старовину» и даже - так называемые невольнические думы - «псальмами».

Эти народные певцы и музыканты, коих и называли по инструментам, которыми они владели, а именно кобзарями, бандуристами, лирниками (далее бандуристов и лирников условно называем кобзарями), в то время, когда привлекли внимание фольклористов, были слепыми нищими, их увечье не позволяло им прожить земледелием или каким-либо иным ремеслом. В XIX в. исследователи еще застали профессиональные лирницкие и кобзарские «цеха», своеобразные нищенские братства, имевшие «панмайстра», «майстрів» и «підмайстрів» (учеников), свой устав, ритуалы и даже профессиональный язык - «лебійську мову». Обучение происходило индивидуально, было трехлетним и завершалось экзаменом. Выдержав его, слепец специальным ритуалом («обкліщини» или «визвілка») посвящался в «майстра», т. е. получал право носить инструмент, играть на нем и петь за вознаграждение в определенной местности. Мрачная легенда, согласно которой лирник иногда «осліпляв свою дитину, призначивши іiї лірникувати» [Іо, с. 7I], не имеет документальных подтверждений.

Главным в обучении было овладеть игрой на музыкальном инструменте (кобзе, бандуре или лире) и заучить на память от учителя словесные тексты. Кобзой (от тюркского «кобыз») и бандурой (от итальянского «pandura») в XIX в. называли уже фактически один и тот же музыкальный инструмент, как правило, с г2 струнами (у некоторых виртуозов было и до 45), «из которых 6 (изредка 3-5) больших (так называемые бунты) натянуты на гриф, иногда пустотелый, а другие, малые струны (так называемые приструнки) в 
количестве от 6 до 3о, закрепляются на кольях, которые идут по краю верхней деки (брямка) <...> Малые струны бандуры расположены в соответствии с древнегреческим гипполидийским ладом» [9, с. 373, 375]. В конце XIX в. народу больше нравились звуки лиры, клавишного инструмента (в средневековой Западной Европе он назывался «organistrum»); лира имела 3 струны, 9-I2 клавишей, а ее валик крутил правой рукой сам музыкант, лирник.

Достаточно распространенное представление о кобзарях и лирниках как об исполнителях лишь думного эпоса, является ошибочным: репертуар их включал также «псальмы», духовные стихи, свадебные и танцевальные, юмористические и сатирические песни. Напротив, в XIX в. именно думы стали из репертуара исчезать. Простой народ уже не интересовался, как раньше, казацкими подвигами и «козацьким життям», поэтому кобзари переставали петь думы и понемногу стали уже их забывать. Так думы и погрузились бы в пучину забвения, если бы не фольклористы: именно их заинтересованность заставила кобзарей, вообще чувствительных к запросам аудитории, вернуться к думному эпосу, и уже в конце XIX в. они стали заучивать думы из книжек (см. о последнем казусе: [І2]). И это лишь два из аспектов того многостороннего «сотрудничества» эпических певцов и фольклористов, благодаря которому наука получила для изучения многочисленный корпус текстов украинских народных дум.

А вот как украинская фольклористика распорядилась великолепным подарком судьбы, это уже другой разговор. Одним из неизученных направлений в исследовании дум остается определение их места в жанровом многообразии мирового эпоса. Связано это отставание с тем прискорбным фактом, что словесная фольклористика на Украине до середины 9о-х гг. XX в. оставалась регрессивной, сталинской, и ведущие ее представители боялись компаративистики, как огня, а какие-либо сравнения ограничивались восточнославянским и славянским ареалами (см. подробнее: [2I, с. 20-25]).

Между тем специфику даже таких ярких явлений, как украинские думы, нельзя выявить, рассматривая их исключительно как «вещь в себе», не привлекая международного контекста. Вот в самом простом понимании эпоса, предложенном Б.Н. Путиловым, - «собственно “эпос" - это героические и героико-романные поэмы и сказания, песни» [16, с. 3] - встречаем определение «героико-романные», которое к думному эпосу как раз и не относится: «романной» темы он именно и не знает, а в единственном исключении, в думе 
«Іван Богословець», сюжет обнаруживает лишь определенные потенции для рассказа о любви пленника-«гетьмана» и молодой турчанки, однако вовсе не реализует их. Двучленная классификация мирового эпоса, выдвинутая Б.Н. Путиловым, разграничивает два генетически связанных между собой эпоса - «архаичный» и «классический». Названия их не являются оценочными, хотя, по мнению теоретика, во втором типе «жанровые универсалии находят завершенную структурно-художественную реализацию, и жанры героического эпоса предстают в наиболее ясных, самых совершенных и самых “чистых" формах».

Поскольку в думах мы не встретим ни великанов, ни Сциллы и Харибды, то выходит, что они более близки к эпосу «классическому». Однако не все так просто. В послесловии монографии Б.Н. Путилов добавляет к двум типам эпоса еще и третий - «поздний». Он «может быть определен как реально исторический или конкретно исторический. Содержанием песен становятся реальные исторические события, которые поддаются датировке и могут быть связаны с конкретными местностями, а героями - настоящие исторические лица. <...> У них резко ослаблена или совсем отсутствует фантастика, связь с мифологией. В отличие от классического эпоса с его идеей конечной победы героя, здесь история изображена как исполненная драматизма и трагических развязок. Также усиливается реальность фона, деталей» [I6, с. 207]. В думах, как легко убедиться, можно найти много похожего.

В одной из предыдущих классификаций Б.Н. Путилов разделяет «эпосы народов СССР» на три стадиальных ряда. К первому принадлежат «якутские олонхо, бурятские улигеры» и т. п., ко второму - «Давид Сасунский», русские былины, «Манас», «Алпамыс», «Джангар», тогда как в «третьем стадиальном ряду» автор видит явления «от украинских дум до историко-героических песен народов Кавказа, от ранних русских исторических песен до песен разинского, пугачевского циклов и т. д.» [24, с. 4]. Торопиться принимать этот приговор не стоит, но запомним, что Б.Н. Путилов относит думы к поздней, «постклассической» стадии в развитии эпоса.

В свое время А.Н. Веселовский различал четыре последовательных формы эпоса. Первая - это «лирико-эпические песни», составленные «по горячим следам исторического события». Речь идет о «лиро-эпической кантилене», важнейшем пункте в теории эпоса ученого. Вторая форма возникает, когда народная память о реальных событиях, отразившихся в кантиленах, 
переживает поколения, когда появляются эпические повторения, «общие места», исторический материал получает «выражение в эпических формах» [2, c. 492]. Третью и четвертую формы эпоса (циклизация песен вокруг «одного лица и возникновения эпопей») А.Н. Веселовский с думами не связывает, потому что о них пишет: «Лирико-эпическая песнь стоит в хронологической и генетической связи с эпосом: различие между нею и последним мы можем заметить наглядно, на примере, сравнивая наши былины с малороссийскими думами, в которых несравненно более лиризма, чем в наших былинах» [2, c. 464-465]. Этот взгляд на думы принимает и развивает С.Н. Азбелев: «Украинские думы в большинстве своем демонстрируют собой как раз первобытную стадию» развития эпоса: они, собственно, и являются «лиро-эпическими песнями», составленными «по горячим следам исторического события» [I, c. 3I].

Что ж получается? По одной классификации думы - это еще передэпос, а по другой - уже после-эпос! Однако вернемся к истории вопроса. Мысль о лиро-эпическом характере думы как первобытной «лиро-эпической кантилены» возникла у А.Н. Веселовского при сравнении думы с былиной, в контексте размышлений о генезисе эпоса вообще. Другой, основанный уже на конкретных наблюдениях, путь к этой мысли проложил И.Н. Жданов, обративший внимание на одинаковое окончание «Слова о полку Игореве», былин и дум - «славами». Следовательно, в древние времена такая песня «должна была оканчиваться провозглашением славы, должна соединяться с народным величаньем» [8, с. 352]. В другой работе И.Н. Жданов делает такой вывод: «С самых давних времен были песни исторического содержания. Эти песни имели характер величаний, потому их можно назвать лиро-эпическими, а не просто эпическими» [13, с. 53-54].

Для нас сейчас важно, что речь идет - точно так же, как и в гипотезе А.Н. Веселовского о «плачах» как о другом обрядовом источнике «лиро-эпических кантилен», развитой Ф.М. Колессой в теорию происхождения дум из причитаний, - не о реальных песнях, а о гипотетических, о происхождении, генезисе дум, а не об их феноменологии.

Что же касается лиризма современных дум, то сам А.Н. Веселовский остерегал: «Лирико-эпическая песня, однако, далеко не то же, что лирика в нашем смысле» [2, с. 465]. Об этом отличии забывают современные фольклористы, которые определяют думу как «лиро-эпический жанр». Ведь и 
М.Т. Рыльский резонно замечал, что, «может быть, не следует считать лиризм исключительной особенностью дум, хоть в них он и выступает несравненно сильнее, чем в эпических произведениях других народов» [I7, с. 4I]. Стоит лишь добавить, что никто не относит к лиро-эпическим текстам «Илиаду», хотя лирический момент весьма заметен и в сцене оплакивания Патрокла, и в сцене прощания Гектора с Андромахой.

Однако главным признаком «лиро-эпических кантилен» в интерпретации А.Н. Веселовского и его последователей оказывается даже не лиризм, а то, что они складывались «по горячим следам исторических событий». Относительно дум С.Н. Азбелев в этом аспекте ссылается на Б.П. Кирдана, который писал: «Историко-героические думы, как правило, создавались или во время событий, в них отраженных, или же вскоре после этого» [25, с. 32]. Из трех циклов «историко-героических дум» лишь думы о Хмельниччине отвечают сказанному Б.П. Кирданом. Но те их тексты, которые дошли до нас, содержат в себе приметы определенного художественного обобщения событий: географические реалии наиболее похожей на «лиро-эпическую кантилену» думы «Корсуньська перемога», как на это указывает и сам исследователь, относятся не только к битве под Корсунем, но и к поражениям польских войск «после нее» [25, с. 459], а в думе «Смерть Хмельницького» характеристика Выговского («Луговского») отражает его политическую линию времен гетманства и т. п. Наконец, разве можно отнести к первичному отображению событий финальную формулу этих дум, где сказано, что «тоді вони [персонажи. - C.P.] умерли»? А главное, думы о Хмельниччине специалистами никогда и не рассматривались как образующие поэтический канон думы. Напротив, не может быть никакого сомнения, что их творцы использовали формальные особенности уже существовавшего жанра, - примерно так же, как поступал кобзарь М.С. Кравченко, создавая свои две думы (или два варианта одной думы) о восстании г905 г. в селе Сорочинцах.

Если же приложить основные признаки гипотетической «лиро-эпической кантилены» (лиризм и отражение событий недавнего прошлого) к думам о вооруженной борьбе с турками и татарами, получим картину хотя и достаточно сложную, но выразительную. Начать с того, что текст думы «про козака-нетягу» (тот, кто не платит налог; в поздних вариантах «козак-голота») прямо свидетельствует против отождествления ее с «лиро-эпической кантиленой». Допустим, что колоритную запорожскую иронию можно счи- 
тать проявлением лиризма, однако о каком историческом событии вообще идет речь? Возможно ли назвать отражением такого события рассказ о том, как безымянный татарин попробовал около города Килии поймать и продать в рабство пешего казака, а тот исхитрился подстрелить его и, согласно праву войны, ограбить? Нет сомнения, что и этот татарин, и тоже, кстати, безымянный казак (именем Голота он обязан фольклористам) являются поэтическими обобщениями, типологически близкими образам «козаков» в лирических песнях.

С огромными трудностями, используя детали из разных, часто поздних, вариантов (это вообще уязвимое место в методике «исторической школы» второй половины XX в.) М.M. Плисецкий реконструирует историческую основу думы «Іван Коновченко, Вдовиченко». По его гипотезе, это поход в I628 г. «"охочего войска” под предводительством Филоненко на турецкую крепость Тягину (Бендери) в Молдавии; во время похода, очевидно, погиб какой-то молодой герой, герцовник, о котором в письменных источниках нет никаких упоминаний» [I5, c. 347]. Правдоподобнее выглядит догадка М.Г. Халанского, что заключенный в думе «поэтический образ был создан раньше времен казачества. Он, очевидно, принадлежал Руси дотатарской. Во времена казачества он только получил новое применение, был иначе истолкован, сообразно историческим обстоятельствам времени» [30, с. 5I]. Добавлю, что наблюдения этномузыковедов (В.И. Харькова, К.В. Квитки, С.И. Грицы) выводят на мысль, что и мелос более архаичных вариантов этой думы ближе к былинному. Наконец, думу «Отаман Матяш Старий», как и произведения еще одного цикла из героического «ядра» думного эпоса, «невольничьего», не удалось связать с определенной битвой или историческим лицом. Единственное исключение составляет, на первый взгляд, дума «Самійло Кішка», но ее сюжет не поддается отождествлению с каким-то конкретным случаем удачного восстания пленных галерников (не говоря уже о том, что во всех известных историкам случаях повстанцы-гребцы уводили захваченную галеру на Запад).

В то же время самые характерные для думного эпоса произведения, относящиеся к его героическому «ядру», обнаруживают некоторые признаки эпоса именно «классического» типа. Это касается прежде всего образа главного героя. В науке не раз подчеркивалось, что в думах это обычный человек, никоим образом не полумифический богатырь, как Добрыня Никитич или Марко Королевич. Знаменательно, что Фесько Ганжа Андибер даже захмелел 
от «коновки» (кружки) кислого пива. Такое посчитал бы для себя позором Марко Королевич, а былинные богатыри выпивают «чару в полтора ведра» без признаков опьянения. Однако таковы герои дум только в быту, зато в боевых подвигах «украинские богатыри казацкой поры», как называл героев дум И.М. Каманин, проявляют «гомерические» свойства. В этой связи вспомним атамана Матяша Старого, который «6 тисяч турок-яничар побіждаєть», а Иван Коновченко, Вдовиченко, в вариантах, самостоятельно побеждает от I2 до 9000 врагов. Собственный гиперболизм у невольнических дум: Маруся Богуславка освобождает 700 пленников, а «гетманы», которые выводят из неволи своих казаков, возвеличиваются с помощью еще одной гиперболы, связанной с литотой, как, например, Самийло Кишка: «Сорокъ годив ты въ неволь пробувалъ, | Ни одного козака из войска своего не утерялъ» [28, c. 5I4]. В условиях действительно каторжного труда на турецких галерах вторая часть этой формулы выглядит даже более фантастически, чем количество пленников, освобожденных Марусей Богуславкой. Эпический гиперболизм в думах распространен и на чёрные, грешные деяния. Если уже грешник Алексей Попович проливает христианскую кровь, то злодейство его гиперболизировано и по объекту («діток маленьких добрим конем розбивав»), и по количеству жертв («триста душ маленьких дітей»).

В идейно-художественной структуре отдельных дум обнаруживаем и другие приметы эпоса «классического» типа. Это, например, «двупланная» композиция, когда действие происходит попеременно то в лагере «своих», то в лагере врагов. Так построена «Илиада»; эпосоведы находят подобную структуру в «Песни о Роланде», киргизском «Манасе» и т. п. Но и в художественном пространстве думы «Самійло Кішка» возникают зоны «своих» и «чужих». После восстания, например, такой «чужой» зоной становится «Трапезон», а «своей» - галера. Интересно, что в записях XIX в. эта «двупланновость» художественного пространства возникает и в думе «про козака-нетягу»: появляется турецкая зона действия, город Килия, из которого татарин посматривает на поле (здесь - зона казака) и ведет диалог с татаркой. Четкая «двупланная» структура в думах о Хмельниччине связана, по-видимому, не столько с эпической традицией, как с необходимостью учитывать при организации художественного пространства реальную географию отраженных в них исторических событий. Исключение составляет дума «Хмельницкий и Барабаш», где подобное влияние эпической традиции, наверное, имело ме- 
сто. Обращает на себя внимание и присутствие образов изменников, таких, как Лях Бутурлак, Барабаш, Голуб Волошин, «джура» (оруженосец) несчастливого сына Ивана Сирка - Романа Сирченко в поздней думе «Вдова Івана Сірка і Сірченки», в некоторых случаях они даже психологически разработаны. Однако образы изменников существуют только в эпосе «классическом»: Ганелон в «Песни о Роланде», Вук Бранкович в Косовском цикле сербского эпоса и др.

Безусловной приметой эпической зрелости дум является хорошо развитая и сквозная система эпических формул и «тем», вообще постоянство стилистического (в частности, версификационного) канона и мелодичного узора, традиционность кобзарской манеры исполнения. Хотя сюжетной циклизации вокруг определенных героев в думах нет (не учитываем здесь естественную, так сказать, циклизацию дум о Хмельниччине вокруг образа славного гетмана), но, по-видимому, процесс циклизации в них начинался: иначе трудно объяснить, почему персонаж Иван Богословець (Богуславець) появляется в таких разных произведениях, как аллегорическая дума «Сокіл $\mathrm{i}$ соколя» и явно вторичная - «Іван Богословець».

Все перечисленное и позволяет выбросить из дефиниций думного эпоса определение «лиро-эпический», а также не отводить думы слишком далеко от стадиальной группы эпосов «классического» типа. А как тогда объяснить явный недостаток общеизвестных признаков этого «классического» типа? И в самом деле, в думах нет эпического центра, как Киев в былинах (некоторые его функции выполняет Сечь), нет своего варианта «эпического правителя» (типа Карла Великого, Владимира «Красное Солнышко», князя Лазаря), нет сюжета о несправедливом заточении им эпического героя, нет героического сватовства, нет сюжета о бое отца с сыном и вообще большинства типичных сюжетов мирового эпоса. Однако ведь и современный этномузыковед резюмирует свои наблюдения таким парадоксом: «В думах, типологически связанных с самыми древними образцами древнеиндийской, древнегреческой монодии, преобладают черты новейшего стиля - “эмоциональное” свободное стихотворение, богато орнаментированный импровизационный мелос с признаками развитого в позднем средневековье народно профессионального вокально инструментального исполнительства, который на украинской почве нашел своё самобытное проявление» [5, с. І88]. 
Загадка разгадывается, если привлечь наблюдения над одной из мутаций, произошедшей в период формирования украинского этнического фольклора, а именно мутации в сфере эпического творчества и исполнительства, которая привела к смене в жанровой структуре былин думами. Речь идет не об одномоментном замещении былин думами, оба жанра на Украине некоторое время бытовали параллельно. При этом жанр дум создавался, их сюжетный состав формировался в отношении дополнительности с древним эпосом, былинами. У творцов нового жанра вообще не было необходимости сочинять думы о «героическом сватовстве», например, или же на другие «романные» эпические сюжеты - и только потому, что такие песни еще можно было услышать в жанровой форме былины.

Сама же дума разрабатывает сюжеты, былине как раз не присущие, например, «невольнические»: если былинный богатырь и попадает в плен к врагу-иноземцу («Илья и Калин-цар», «Соломан и Василий Окулович»), то лишь для того, чтобы вскоре его уничтожить. «Невольнические» сюжеты в определенной степени датируют происхождение соответствующих дум. Если «Слово о полку Игореве» удостоверяет существование уже в конце XII в. баллады о побеге воина из степного плена [19], и в связи с этим фактом сюжетные истоки думы «Втеча трьох братів з Азову» можно искать в балладном репертуаре ещё киевских времен, то захват турками в плен больших масс казаков стал возможен, только начиная с конца XVI в., когда запорожцы возобновили древнерусскую традицию морских походов на страны черноморского «Помория».

Не известны былинам и отдельные сюжеты об одинокой смерти воина в поле, детально разработанные думой: даже если былина и специально посвящалась мистической «гибели богатырей», смерть её героя всегда происходит на людях. Однако существование таких песен удостоверяет опять-таки «Слово о полку Игореве» (фрагмент о гибели князя Изяслава Васильковича), и снова прототип нужно искать в дружинной балладе той поры [I8].

Как возникновение жанра дум нельзя объяснить лишь необходимостью приспособления эпической формы к определенной тематике, так и исчезновение былин из украинского репертуара - только их неспособностью отражать определенные явления исторической действительности XVXVII вв. Действовал целый комплекс факторов, не все из них возможно теперь воспроизвести, но бесспорно, что «экстрафольклорные» были среди них 
определяющими. Когда в XIII-XIV вв. величественный Киев навсегда, как казалось, потерял свое политическое и экономическое значение, а «своего» великого князя в своей столице заступили иноземные, а чаще и иноверные правители, сидящие в Сарае, Тракае, Вильно, Кракове или Варшаве, народ постепенно приспособился к новым реалиям - и киевский пафос былинного эпоса стал восприниматься как культурный анахронизм. Как определенную параллель к этому явлению можно напомнить, что и в конце XVI - начале XVII вв. «Первое возрождение» (М.С. Грушевский) происходило на основах не древнерусских, а польской версии общеевропейской культуры и что когда позже, в XVII в., украинские писатели заинтересовались культурным наследием Киевской Руси, то обращаться к истокам им пришлось при посредничестве московской рукописной книжности и польских печатных хроник.

Можно утверждать также, что в Украине XVI-XVII вв. былины и думы исполнялись певцами-профессионалами, принадлежавшими к разным корпорациям. Сопоставим такие факты. В «Слове о полку Игореве» уважительно вспоминается Боян, дружинный певец XI в., воспевавший князей-современников. Некоторые былины изображают исключительно события киевского придворного быта, и одну из таких «боярских новелл», «Соловей Будимирович», об ухаживании заезжего богатыря за киевской княжной, Б.А. Рыбаков пытался атрибутировать Бояну [22, с. 78-85]. Папский посол А. Контарини был в I474 г. в Киеве на приеме у литовского воеводы «Паммартина» (Мартына Гаштольта), и там «пели певцы» [23, с. 4I]. Через столетие, «I574 года, августа 5 дня» шляхтич Филон Кмита Чернобыльский пишет из Орши, с московской границы, письмо к Остафию Воловичу, кастеляну троцкому, где жалуется, что «от голода сдох на сторожы. Помсти, Боже, хосударю хрехопаденийе, хто розумейет! Бо прийдет час, коли будет надобе Илии Муравленина и Соловя Будимировича, - бо прийдет час, коли будет служб наших потреба!» (транслитерировано с польской латиницы [3, с. 64]). А.Н. Веселовский, первым обратив внимание на значение этой ламентации для истории нашего эпоса, отметил, что «Воловичу должны же были быть понятны аллюзии на богатырей, да и Кмита поминает их как нечто общеизвестное» [3, с. 6I]. Понятно, почему себя, предводителя пограничной «сторожи» Речи Посполитой, Филон Кмита сравнивает с вожаком былинной «заставы богатырской», а об упоминании Соловья Будимировича А.Н. Веселовский писал: «Соловей Будимирович в сообществе с Ильей мог бы возбудить вопрос о причинах та- 
кого сопоставления, если бы не представлялась вполне естественной догадка, что имя первого явилось случайно, на место любого другого богатыря и вне внутренней связи со значением Ильи» [3, с. 65]. Как представляется, имя Соловья Будимировича названо в письме тоже не случайно. Остафий Волович был, с одной стороны, доверенным лицом короля Сигизмунда II Августа; подканцлер литовский, он выполнял важнейшие дипломатические поручения. С другой стороны, православный, затем протестант, меценат и покровитель протестантов, патриот Литвы, он не мог полностью адаптироваться при католическом польском королевском дворе. Возможно, это двойственное положение сановного адресата и побудило Филона Кмиту сопоставить его с иноземным богатырём Соловьём Будимировичем, взявшим в жены киевскую княжну. Прототипом персонажа былины был, по нашему мнению, аристократ из прибалтийских славян. Но возникает вопрос, где мог слушать былины сам Остафий Волович? Не исключаем возможности, что и в собственном дворце на пиру от скомороха. Почему бы нет, если уже в середине XVIII в. скоморох Кирша Данилов развлекал былинами на пирах сибирских богачей Строгановых.

Осмысленные совместно, эти одиночные свидетельства позволяют утверждать, что древнекиевская традиция княжеских певцов не сразу исчезла на Украине. В литовские времена их последователи продолжали петь уже при дворах таких литовских магнатов, как «господин Мартин», которому, по-видимому, льстило приравнивание его к прежним обладателям Киева. И даже после унии Польши и Литвы, когда украинские и литовские аристократы начали быстро переходить в католичество и полонизироваться, эта придворная версия древнерусского былинного эпоса некоторое время продолжала сохраняться.

Думы же создавались в ответ на принципиально иной «социальный заказ» и, что следует отметить, ярко воплощают ментальность своих слушателей. Безбрачное рыцарство, национальное неприятие богатства, доводившее до абсурда, полумонахи, которые, будто придерживаясь евангельского призыва Христа (Мт. Іо: Іо и др.), не имели на себе двух одеяний, постники во времена военные и беззаботные пьяницы - в мирные дни, эти слушатели дум и в богатом украинском шляхтиче Богдане Хмельницком желали видеть гетмана голи, а поскольку было это трудновато, мечтали о гетмане-«нетяге», и мечта их объективизирована была в образе гетьмана Феська Ганжы Анди- 
бера, воспетого в посвященной ему думе. Иными словами, составители дум ориентировались в первую очередь на запорожское казачество.

Но ответ на вопрос, кто же были эти творцы дум, остается открытым. Даже из XVIII в. имеем сведения лишь о бандуристах-музыкантах, но из текстов нельзя понять, пели ли они вообще под свою игру, а когда пели, то что именно. Единственное драгоценное исключение - фрагмент из воспоминаний В. Кребс, дочери уманского губернатора, о временах перед Колиивщиной: «Как-то мой отец услышал, что в одном месте казаки пели думы о Хмельницком. Он тотчас же позвал Обуха и попросил его раз и навсегда запретить пение подобных дум...» [29, с. I7]. Если мемуаристка ничего не перепутала, выходит, что дворовые казаки поют думы сами - а не слушают кобзаря. Это в таком случае свидетельствует, что думы цикла о Хмельниччине могли исполняться и непрофессионально, и даже, кажется, хором. Однако это случайное, собственно говоря, наблюдение было бы слишком смелым проектировать на более отдаленные времена и видеть в казаках XV-XVII вв. не только возможных исполнителей, но и создателей думного эпоса. Для такого умозаключения не имеем достаточных оснований - и в первую очередь из-за того, что думы о Хмельниччине, которые, если поверить В. Кребс, самостоятельно исполнялись дворовыми умансками казаками, это думы явно вторичные. В них нет загадочных «гомеровских» эпитетов и церковнославянизмов, этих важных свидетельств участия украинских книжников в создании думного стиля (П.Г. Житецкий, В.Н. Перетц). Следовательно, проблема возникновения дум, одной из мутаций, революционных переворотов в истории украинского фольклора, не может быть решена без обращения к изучению взаимодействия фольклора и литературы. Однако для такого решения фатально не достаёт надёжных фактических данных.

Таким образом, в плане формальном эпическое своеобразие украинских дум достаточно четко обеспечивается их своеобычным стилем с оригинальной системой рифмовки «уступами», с собственной системой эпических формул и «тем», рецитацией и своеобразными ее мелодиями. Достаточно самобытны и традиционные исполнители дум, слепые кобзари и лирники. В плане сюжетном думы обнаруживают, с одной стороны, тяготение к собственно балладной сюжетике, с другой - отсутствие в корпусе воплощений большинства сюжетов так называемого «классического эпоса». Последнее явление связано с соотнесением дум их творцами в период, когда думы созда- 
вались, с былинным эпосом, уже разработавшим эти сюжеты. Тем не менее некоторым персонажам дум присущ эпический гиперболизм. Думы нецелесообразно полностью выводить из сферы «классического эпоса», относя их к перед-эпосу, соответствию первичным «кантиленам», равно как нельзя их всех сплошь рассматривать как пост-эпос, ведь в них выработанная внутренней жанровой традицией эпическая форма используется отнюдь не только для отражения конкретных исторических событий, как в думах о Хмельниччине.

\section{Список литературы}

I $\quad$ Азбелев С.Н. Историзм былин и специфика фольклора. Л.: Наука, I982. 327 с.

2 Веселовский А.Н. Историческая поэтика. Л.: Худож. лит., І940. 648 с.

3 Веселовский А.Н. Южнорусские былины. Приложение к XXXIX тому Записок Имп. Академии наук № 5. СПб.: Тип. Имп. АН, І88I. 4II с.

4 Грица С. Думи в синтезі слова, музики та виконавства // Українські народні думи у п’яти томах. Київ: Видавництво ІМФЕ ім. М.Т.Рильського НАН України, 20о9. Т. І. C. 33-II8.

5 Грица С.Й. Мелос української народної епіки. Київ: Наук. думка, І979. 248 с.

6 Дмитренко М. Українські народні думи: термін і дефініція // Міфологія і фольклор. Львів. 2008. № I. С. 20-27.

7 Дмитренко М. Українські народні думи як феномен традиційної культури // Українські народні думи у п’яти томах. Київ: Видавництво ІМФЕ ім. М.Т.Рильського НАН України, 2009. Т. г. Думи раннього козацького періоду. С. 6-32.

8 Жданов И.Н. Русская поэзия в домонгольскую эпоху // Сочинения И.Н. Жданова. СПб.: Тип. Имп. Академии наук, І904. Т. г. С. 333-359.

9 Зеленин Д.К. Восточнославянская этнография / пер. с нем. К.Д. Цивиной. М.: Наука, Гл. ред. вост. лит-ры, г99г. 5 І2 с.

г К Квітка К. Професіональні народні співці й музиканти на Україні. Програма для досліду їх діяльности й побуту. Київ: 3 друкарні У.А.Н., І924. 226 с.

II К Колесса Ф.М. Мелодії українських народних дум / підгот. С.Й. Грица. Київ: Наукова думка, І969. 59 г с.

I2 Кононенко Н. Диктований текст / співаний текст: техніка навчання українських співців // Усна епіка: етнічні традиції та виконавство. [Київ]: ВАТ «Книжкова друкарня наукової книги», І997. Ч. І. С. I43-152.

I3 История русской словесности: Лекции проф. И.Н. Жданова / изд. І курс Ист.-филол. ин-та. [СПб.]: Литография Фомина, г893. [2], 221 с.

I4 Перети В. Українські думи в новому виданні К.М. Грушевської // Етнографічний вісник. І928. Кн. 7. С. 73-І32. 
I5 Плисеикий М.M. Взаимосвязи русского и украинского героического эпоса. М.: Изд-во АН СССР, І963. 448 с.

I6 Путилов Б.Н. Героический эпос и действительность. Л.: Наука, I988. 223 с.

I7 Рильський M. Героїчний епос українського народу // Рильський М. Література і народна творчість. Київ: Радянськийписьменник, І958. С. 29-54.

I8 Росовецкий С.К. «Слово о полку Игореве» и дружинная поэзия Киевской Руси. Статья третья // Русистика. Сб. научн. тр. Киев: Издат-полиграф. центр «Київськийуніверситет», 2003. Вып. 3. С. 64-69.

I9 Росовецкий С.К. «Слово о полку Игореве» и дружинная поэзия Киевской Руси. Статья четвертая. Устные источники рассказа о бегстве князя Игоря из плена: песни // Русистика. Сб. научн. тр. Киев: Издат-полиграф. центр «Київський університет», 2004. Вып. 4. С. 46-53.

20 Росовецький С. Український фольклор у теоретичному висвітленні. Підручник. Київ: Издат.-полиграф. центр «Київський університет», 2008. 623 с.

2I Росовецький С. Якого оновлення потребує українська компаративістика: нотатки традиціоналіста // Слово і час. 2003. № 5. С. 19-30.

22 Рыбаков Б.А. Древняя Русь: Сказания. Былины. Летописи. М.: Изд-во АН СССР, I96I. 36I c.

23 Січинський, В. Чужинці про Україну. К.: Довіра, І992. 254 с.

24 Типология народного эпоса. М.: Наука, г975. 326 с.

25 Украинские народные думы / изд. подгот. Б.П. Кирдан. М.: Наука, Гл. ред. вост. лит-ры, І972. 560 с.

26 Українські народні думи / тексти і вступ К. Грушевської. Київ: Державне вид-во «Пролетар». І93І. Т. 2. XXX, 307 с.

27 Українські народні думи / тексти і вступ К. Грушевської. Харків: Державне вид-во України, І927. Т. І корпусу. СССХХ, І76 с.

28 Українські народні думи у п’яти томах. Київ: Видавництво ІМФЕ ім. М.Т. Рильського НАН України, 2009. Т. г: Думи раннього козацького періоду. 865 с.

29 Уманская резня (Записки Вероники Кребс) / пер. с предисл. И.М. Рева. Киев: Тип. С.В. Кульженко, г879. 36 с.

30 Халанский М. Великорусские былины киевского цикла. Варшава: тип. М. Зенкевича, г885. 235 с. (Отд. оттиск из «Русского филологического вестника»). 


\section{References}

I Azbelev S.N. Istorizm bylin i specifika fol'klora [Historical aspect of bylinas and the specificity of folklore]. Leningrad, Nauka Publ., I982. 327 p. (In Russ.)

2 Veselovskij A.N. Istoricheskaja pojetika [Historical poetics]. Leningrad, Hudozh. lit. Publ., I940. 648 p. (In Russ.)

3 Veselovskij A.N. Juzhnorusskie byliny. Prilozhenie k XXXIX tomu Zapisok imp. Akademii nauk No 5 [South-Russian bylinas. Appendix to the 39th volume of Proceedings of imp. Academies of sciences \# 5]. St. Petersburg, Tipografija Imp. AN Publ., I88I. 4II p. (In Russ.)

4 Grica S. Dumi v sintezi slova, muziki ta vikonavstva [Dumas in the synthesis of word, music and performance]. Ukraïns'ki narodni dumi u p’jati tomah [Ukrainian folk dumas in five volumes]. Kiev, Vidavnictvo IMFE im. M.T. Ril's'kogo NAN Ukraïni Publ., 2009, vol. I, pp. 33-II8. (In Ukrainian)

5 Grica S.J. Melos ukraïns'koï narodnoï epiki [Melos of Ukrainian folk epic]. Kiev, Naukova dumka Publ., I979. 248 p. (In Ukrainian)

6 Dmitrenko M. Ukraïns'ki narodni dumi: termin i definicija [Ukrainian folk dumas: term and definition]. Mifologija ifol'klor [Mythology and folklore]. Lviv, 2008, no I, pp. 20-27. (In Ukrain.)

7 Dmitrenko M. Ukraïns'ki narodni dumi jak fenomen tradicijnoï kul'turi [Ukrainian folk dumas as a phenomenon of traditional culture]. Ukraïn'ki narodni dumi u p’jati tomah [Ukrainian folk dumas in five volumes]. Kiev, Vidavnictvo IMFE im. M.T. Ril's'kogo NAN Ukraïni Publ., 2009, vol. r: Dumi rann'ogo kozac'kogo periodu, pp. 6-32. (In Ukrainian)

8 Zhdanov I.N. Russkaja pojezija v domongol'skuju jepohu [Russian poetry in a preMongol epoch]. Sochinenija I.N. Zhdanova [Works by I.N. Zhdanov]. St. Petersburg, Tipografija Imp. Akademii nauk Publ., I904, vol. I, pp. 333-359. (In Russ.) Zelenin D.K. Vostochnoslavjanskaja etnografija [East-Slavic ethnography], thans. from German K.D. Civinoj. Moscow, Nauka Publ., I991. 5I2 p. (In Russ.) Kvitka K. Profesional'ni narodni spivci j muzikanti na Ukraïni. Programa dlja doslidu ïh dijal'nosti j pobutu [Professional folk singers and musicians in Ukraine. Program for experience of their activity and way of life]. Kiev, Z drukarni U.A.N. Publ., I924, I20 p. (In Ukrainian) Kolessa F.M. Melodii ukraïn'kih narodnih dum [Melodies of Ukrainian folk dumas], Pidgot. S.J. Grica. Kiev, Naukova dumka Publ., I969. 59I p. (In Ukrainian) Kononenko N. Diktovanij tekst / spivanij tekst: tehnika navchannja ukraïns'kih spivciv [Dictated Text / Sung Text: The Learning Techniques of Ukrainian Minstrels]. Usna epika: etnichni tradicii ta vikonavstvo [Oral Epic: Ethnic Traditions and Performance]. [Kiev], VAT “Knizhkova drukarnja naukovoï knigi” Publ., I997, Ch. I, pp. I43-I52. (In Ukrainian) 
Istorija russkoj slovesnosti: Lekcii prof. I.N. Zhdanova [History of Russian literature: Lectures by prof. I.N. Zhdanov], Edition of the Institute of Philosophy [St. Petersburg], Litografija Fomina Publ., I893. [2], 22I p. (In Russ.)

I4 Peretc V. Ukraïns'ki dumi v novomu vidanni K.M. Grushevs'koï [Ukrainian dumas in the new edition by K.M. Grushevska]. Etnografichnij visnik, I928, book 7, pp. 73-I32. (In Ukrainian)

I5 Pliseckij M.M. Vzaimosvjazi rucskogo i ukrainskogo geroicheskogo eposa [Intercommunications of the Russian and Ukrainian heroic epos]. Moscow, Izd-vo AN SSSR Publ., I963. 448 p. (In Russ.) Putilov B.N. Geroicheskijj epos i dejstvitel'nost' [Heroic epos and reality]. Leningrad, Nauka Publ., I988. 223 p. (In Russ.)

Ril's'kij M. Geroïchnij epos ukraïns'kogo narodu [Heroic epos of Ukrainian people]. Ril's'kij M. Literatura i narodna tvorchist' [Literature and folk art]. Kiev, Radjans'kij pis'mennik Publ., I958, pp. 29-54. (In Ukrainian)

Rosoveckij S.K. "Slovo o polkuIgoreve” i druzhinnaja pojezija Kievskoj Rusi. Stat'ja tret'ja [The «Lay of Igor's Warfare» and military poetry of Kievan Rus. Article third]. Rusistika. Sb. nauchn. tr. [Russian studies. Collection of academic works]. Kiev, Izdat-poligraf. centr "Kiïvs'kij universitet" Publ., 2003, issue 3, pp. 64-69. (In Russ.)

I9 Rosoveckij S.K. "Slovo o polku Igoreve” i druzhinnaja pojezija Kievskoj Rusi. Stat'ja chetvertaja. Ustnye istochniki rasskaza o begstve knjazja Igorja iz plena: pesni [The "Lay of Igor's Warfare" and military poetry of Kievan Rus. Article fourth. Oral sources of the recital about the escape of Prince Igor from captivity: songs]. Rusistika. Sb. nauchn. tr. [Rusistika. Collection of scientific works]. Kiev, Izdat-poligraf. centr "Kiïvs'kij universitet" Publ., 2004, issue 4, pp. 46-53. (In Russ.) Rosovec'kij S. Ukraïns'kij fol'klor u teoretichnomu visvitlenni. Pidruchnik [Ukrainian folklore in theoretical perspective. Textbook]. Kiev, Izdat-poligraf. centr "Kiïvs'kij universitet" Publ., 2008. 623 p. (In Ukrainian) Rosovec'kij S. Jakogo onovlennja potrebu€ ukraïns'ka komparativistika: notatki tradicionalista [Ukrainian Comparative studies in the need of update: notes of as traditionalist]. Slovo i chas [Word and Time], 2003, no 5, pp. 19-30. (In Ukrainian) Rybakov B.A. Drevnjaja Rus': Skazanija. Byliny. Letopisi [Ancient Rus: Stories. Bylinas. Chronicles]. Moscow, Izd-vo AN SSSR Publ., I96I. 36I p. (In Russ.)

23 Sichins'kij, V. Chuzhinci pro Ukraïnu [Foreigners about Ukraine]. Kiev, Dovira Publ, I992. 254 p. (In Ukrainian)

24 Tipologija narodnogo eposa [Typology of folk epos]. Moscow, Nauka Publ., I975. 326 p. (In Russ.) Ukraïns'kije narodnije dumi [Ukrainian folk dumas], ed. B.P. Kirdan. Moscow, Nauka Publ., I972. 560 p. (In Russ.) Ukraïns'ki narodni dumi [Ukrainian folk dumas], texts and intro. by K. Grushevs'kaya. Kiev, Derzhavne vid-vo "Proletar” Publ., I93I. Vol. 2. XXX, 307 p. (In Ukrainian) 
27 Ukraïns'ki narodni dumi [Ukrainian folk dumas], texts and intro. K. Grushevs'koï. Harkiv, Derzhavne vid-vo Ukraïni Publ., I927. Vol. I. CCCXX, I76 p. (In Ukrainian)

28 Ukraïns'ki narodni dumi u p'jati tomah [Ukrainian folk dumas in five volumes]. Kiev, Vidavnictvo IMFE im. M.T. Ril's'kogo NAN Ukraïni Publ., 2009. Vol. I: Dumi rann'ogo kozac'kogo periodu [Dumas of early cossack period]. 865 p. (In Ukrainian)

29 Umanskaja reznja (Zapiski Veroniki Krebs) [Uman's carnage (Messages by Veronika Krebs)], trans. with intro. I.M. Reva. Kiev, tip. S.V. Kul'zhenko Publ., I879. 36 p. (In Russ.)

30 Halanskij M. Velikorusskie byliny kievskogo cikla [Russian bylinas of the Kievan series]. Varshava, v tip. M. Zenkevicha Publ., I885. 235 p. (Otd. ottisk iz "Russkogo filologicheskogo vestnika” [Separate print from the Russian Philological Messenger]). (In Russ.) 


\title{
БЕГСТВО СВЯТОГО СЕМЕЙСТВА В ЕГИПЕТ В СЛАВЯНСКИХ ЭТИОЛОГИЧЕСКИХ ЛЕГЕНДАХ О ДЕРЕВЬЯХ
}

\author{
(C) 2018 г. Т.А. Агапкина \\ Институт славяноведения \\ Российской академии наук, \\ Москва, Россия \\ Дата поступления статьи: І5 сентября 2017 г. \\ Дата публикащии: 25 марта 2018 г.
}

DOI: IO.22455/2500-4247-20I8-3-I-3O2-3I7

Работа выполнения при поддержке Российского научного фонда по проекту

«Славянские архачческие зоны в пространстве Европы: этнолингвистические исследования" (№ I7-I8-OI373).

Аннотация: В статье рассматриваются славянские этиологические легенды о бегстве Св. Семейства в Египет после рождения Иисуса Христа. Это легенды о том, как деревья, которые Св. Семейство встретило на пути в Египет, помогали Ему и в награду вместе с благословением Богородицы получали какие-нибудь полезные свойства и способности, или, напротив, когда вместо помощи они выдавали Св. Семейство войску Ирода, за что были прокляты Богородицей и наделены Ею определенными негативными качествами. Автор анализирует фольклорные легенды, известные восточным, западным и южным славянам; выявляет круг растительных символов, которые встречаются в этих легендах, описывает их сюжетику, а также соотносит народные легенды с апокрифическими сказаниями, источником которых послужило апокрифическое Евангелие Псевдо-Матфея, влияние которого было ощутимо преимущественно на западе Славии, там же, где фиксировался основной корпус соответствующих этиологических легенд.

ключевые слова: апокрифы, этиологические легенды, символика, славяне, этноботаника, деревья.

Информация об авторе: Татьяна Алексеевна Агапкина - доктор филологических наук, ведущий научный сотрудник, Институт славяноведения Российской академии наук, Ленинский пр., д. 32 а, ІІ999г г. Москва, Россия.

E-mail: agapi-t@yandex.ru 


\section{THE FLIGHT TO EGYPT IN SLAVIC ETIOLOGICAL LEGENDS ABOUT THE TREES}

This is an open access article distributed under the Creative Commons Attribution 4.0 International (CC BY 4.0)
(C) 20I8. T.A. Agapkina Institute of Slavic Studies of the Russian Academy of Sciences, Moscow, Russia Received: September 15, 2017

Date of publication: March 25, 2018

Acknowledgements: This work was supported by the Russian Science Foundation, project "Slavic archaic zones in the space of Europe: ethnolinguistic research" (grant number I7-I8-OI373)

Abstract: The paper examines Slavic etiological legends on the Flight to Egypt plot. These legends feature trees and bushes growing on the way of Maria's and Joseph's flight to Egypt. Some of these plants helped Christ and his parents escape while others betrayed them to the Herod's army. Virgin Mary endowed the plants with "positive" or "negative" qualities respectively, as either a reward or a sign of damnation. The author analyzes folk legends that were familiar to Eastern, Western, and Southern Slavs; points out which plants were mentioned in the legends and describes the circle of plant symbols; enlists themes, types and motifs of these legends and compares them to other apocryphal legends that had the same source, namely the Gospel of Pseudo-Matthew. The Gospel of Pseudo-Matthew seemed to be influential mainly in Western Slavia where the main core of etiological legends was recorded.

Keywords: trees, apocrypha, etiological legends, symbolism, ethnobotany, Slavs.

Information about the author: Tatyana A. Agapkina, DSc in Philology, Leading Research Fellow, Institute of Slavic Studies of the Russian Academy of Sciences, Leninsky Ave., 32 a, II999I Moscow, Russia.

E-mail: agapi-t@yandex.ru 
Славянские легенды о происхождении деревьев или отдельных их особенностей, рассказы о благословении деревьев, объясняющие их полезные свойства, и, наоборот, рассказы об их проклятии и появлении у деревьев негативных черт - все они являются частью широкого этиологического корпуса текстов, посвященных происхождению мира. Значительная часть этих рассказов восходит, что вполне понятно, к событиям Священной истории, главным образом в ее апокрифической версии.

Самым репрезентативным событием фольклорной версии Священной истории, которое касается непосредственно деревьев, является бегство Святого Семейства в Египет: в славянском фольклорном «дендрарии» почти половина деревьев принимает участие в этом событии, вне зависимости от того, как в этом контексте оцениваются их «поступки».

Ниже мы предполагаем рассмотреть славянские этиологические легенды, посвященные бегству Св. Семейства в Египет, в частности, установить географическое распространение легенд на этот сюжет на территории современной Славии, выявить круг деревьев и кустарников, упоминаемых в этих нарративах, а также описать особенности сюжетики этих легенд. Кроме того, на материале легенд о бегстве Св. Семейства в Египет мы обратимся к проблеме взаимодействия фольклора и апокрифического сказания.

Напомним, что эпизод, посвященный бегству в Египет, встречается только в Евангелии от Матфея: «Когда же они <волхвы> отошли, - се, Ангел Господень является во сне Иосифу и говорит: встань, возьми Младенца и Матерь Его и беги в Египет, и будь там, доколе не скажу тебе, ибо Ирод хочет искать Младенца, чтобы погубить Его. Он встал, взял Младенца и Матерь Его 
ночью и пошел в Египет, и там был до смерти Ирода <...> (Мф 2: I3-I4). $\mathrm{B}$ апокрифах же упоминания о бегстве Св. Семейства в Египет, напротив, довольно часты: это Слово на Рождество Христово о пришествии волхвов, Житие Пресвятой Богородицы и др. - прежде всего из числа апокрифов, принадлежащих к так называемым евангелиям детства и «дополняющих» историю рождения и детства Марии и Иисуса. Вместе с тем, хотя в апокрифических сказаниях бегство в Египет и присутствует (в виде краткого сообщения или подробного рассказа о чудесах, случившихся во время этого путешествия), тем не менее упоминаний о деревьях, поклонявшихся Св. Семейству или помогавших в пути, в них практически нет. И лишь в Евангелии Псевдо-Матфея (лат. «Evangelium pseudo-Matthaei»; другие его названия «Книга детства Марии и Христа Спасителя», «История рождения Марии и детства Спасителя» и т. д.), которое было создано отчасти под влиянием Первоевангелия Иакова и Евангелия от Фомы, причем довольно поздно (возможно, не ранее IX в.), и сохранилось или было составлено на латыни, появляется эпизод, в котором деревья проявляют почтение к беглецам и оказывают им помощь (об истории апокрифических евангелий, в том числе Евангелия Псевдо-Матфея, см. специально: [г2]).

Имеются в виду XX и XXI главки этого апокрифического текста, в которых говорится следующее: уставшая по дороге Мария решила отдохнуть под пальмой, на которой было много плодов, однако Иосиф не мог дотянуться до них; Иисус приказал пальме наклониться, и Мария смогла насытиться ее плодами; у путников кончались запасы воды, и тогда по воле Иисуса из-под корней пальмы забил источник; на следующий день, когда путешественники собирались продолжить свой путь, Иисус, в благодарность за помощь, сделал так, что одну из ветвей этой пальмы ангел унес в рай, где ее и посадили [7, с. 52-53]. Очевидно, что и сам эпизод (отдых/укрывание под деревом), и особенно отдельные его мотивы (ниспадание/склонение ветвей, последующее благословение/награждение дерева со стороны Иисуса или Богородицы) отразились в фольклорной традиции, хотя и в сильно преображенном виде. В свою очередь пересказы этих апокрифических евангелий и соответствующих фольклорных легенд, включая интересующий нас эпизод, вошли в народную литературу, распространявшуюся массовыми тиражами, что также способствовало их популяризации в фольклорной среде [25, s. 265]; пример апокрифической песни на этот сюжет, изданной для народа, приводит 
И. Франко [15, с. 404-408]. Эпизод с деревом отдохновения был известен также по Четьям-минеям Дмитрия Ростовского распространению сюжета оказала и иконография, в которой присутствуют изображения древа отдохновения, под которым остановилось Св. Семейство (см. подробнее: [8, с. 23I-236]).

Обратимся теперь к собственно фольклорным текстам, восходящим к сюжету о бегстве Святого Семейства в Египет. Сюжет представлен в основном в этиологических легендах (объясняющих происхождение отдельных свойств тех или иных деревьев), а также в колядках (в балканославянской традиции), которые, что вполне объяснимо, активно развивают рождественскую тематику. Вопреки рассказу Евангелий (канонического и апокрифических), в которых Св. Семейство благополучно скрывается от Ирода, сюжет фольклорной легенды развивается по-разному, и во многих случаях ее финал оказывается принципиально иным: Святому Семейству не всегда удается скрыться от преследователей, поскольку дерево своим поведением выдает беглецов или из страха отказывает им в убежище. Что касается самого дерева, то в зависимости от того, оказало оно помощь Святому Семейству или нет, его благословляют (обычно это делает Богородица) или проклинают, «награждая» негативными качествами: осину и тополь обрекают на то, что они будут вечно трястись и дрожать, останутся бесплодными, не будут давать тени и т. д.; бузину - тем, что она будет плохо пахнуть, ель и пихту - тем, что они останутся бесплодными, терновник - тем, что будет колючим, и т. д., хотя конкретное содержание проклятия может и не уточняться. Напротив, деревья-помощники получают благословение и одариваются множеством полез-

I С. под датой 26 декабря: «Когда они вошли в Египетскую страну и находились в пределах Фиваиды, приблизились они к городу Ермополю. Близ входа в сей город росло очень красивое дерево, называвшееся персея, которое тамошние жители, по своему идолопоклонническому обычаю, почитали как бога - из-за его высоты и величественной красоты, поклоняясь ему и принося ему жертвы, ибо в том дереве жил и бес, почитаемый ими. Когда Пречистая Богоматерь с Божественным Младенцем приблизилась к тому дереву, тотчас оно сильно потряслось, ибо бес, убоявшись пришествия Иисусова, бежал. А дерево приклонило свою верхушку до самой земли, воздавая подобающее поклонение своему Создателю и Его Родительнице, Пречистой Деве, кроме того, оно оградило их тенью своих многолиственных ветвей от солнечного зноя и тем дало возможность утомленным святейшим путникам отдохнуть. И в таком наклоненном виде осталось то дерево в очевидное знамение пришествия Господа в Египет. После того, как под сим деревом Господь с Своею Материю и Иосифом отдыхали, это дерево получило целебную силу, ибо от его ветвей исцелялись всякие болезни» [го]. 
ных свойств: они дают вкусные плоды, предоставляют тень в жару, оберегают человека от грозы, остаются зелеными весь год и т. д. ${ }^{2}$

Указатель международных сказочных сюжетов [24, N 75oE] называет в качестве помощников Святого Семейства самые разные деревья, другие растения, а также людей и животных, но о статусе его противников не сообщает почти ничего. Вместе с тем именно тема предательства и страха, проявленных некоторыми деревьями в отношении Святого Семейства во время его бегства в Египет, оказывается, по нашим наблюдениям, едва ли не основной в рассматриваемых легендах, в том числе славянских.

Выбирая дерево на роль противника и предателя Святого Семейства, фольклорная традиция следует своей логике, отдавая предпочтение тем деревьям и кустарникам, которые и без того имеют негативный ореол. На территории Восточной и Западной Славии, реже у южных славян основным противником Св. Семейства выступает осина. Количество легенд, в которых в этом сюжете фигурирует именно она, в несколько раз превышает тексты с участием всех других деревьев вместе взятых.

Фольклорная традиция по-разному толкует предательство осины. Чаще всего причиной предательства осины становится ее страх: при появлении Св. Семейства осина пугается и шевелением ветвей невольно выдает место их укрытия: «Раньшы говорылы, такэ што... Як Буг народыса и его шукалы яўрэи, хотели ўбиць, этого Бога, а ўон буў маленькый шчэ. И Маци яго заховала пуд осиною, дак они стали шукаць, эта осина задрыжала, лысточкы. И ўот оны нашлы под тую ўосиною. А Божа маць, говораць, сказал, штоб ты усё сваё уремья дрыжала»3.

В других легендах причины такого поступка осины остаются неизвестны: осина просто не пускает под свои ветви Св. Семейство или отказывает им в укрытии. Согласно польской легенде, когда Св. Семейство убегало в Египет, по дороге они то ли попали под дождь шел, то ли там было слишком жарко, вот они и захотели спрятаться под осиной, а осина не пустила их; в наказание за это она и дрожит всегда [20, s. 84, N B]. В сербском легендарном нарративе

\footnotetext{
2 О мотиве проклятия деревьев, в том числе бесплодием, за то, что они не поклонились Богородице и Христу, в болгарских колядках и религиозных песнях см.: [3, с. г35 и след.], хотя связь этих мотивов колядок с апокрифами гораздо слабее, чем у легенд. О теме проклятия и благословения деревьев в целом на славянском материале см. специально: [14].

3 Полесский архив Института славяноведения РАН (далее - ПА), Стодоличи Лельчицкого р-на Гомельской обл.
} 
говорится о том, как Богородица с новорожденным Христом бежала и спряталась в лесной чаще (от Ирода или от дождя), но осина подняла листья, и они не смогли укрыться. За это Богородица прокляла дерево, сказав: «Трептала до века, ни од ветра, ни од кише, већ од страха божјега и на томе остане» [Чтобы ты трепетала вечно, не от ветра, не от дождя, а от страха Божьего, и пусть будет так] ([ІІ, с. І29] зап. Сербия).

В фольклорной традиции западных регионов Южной Славии сюжет о бегстве Св. Семейства в Египет иногда переносится с осины (Populus tremula) на другое дерево того же ботанического рода, а именно на тополь (Populus alba), который в диалектах называется часто так же, как и осина, трепетљика. В хорватской колядке из Отока поется о том, как Мария бежала от своих преследователей с младенцем Иисусом и просила тополь спустить ветви и скрыть ее, но тополь не сделал этого: «Ој topolo, topolo, / Savi grane do zemlje, / Sakri sinka i mene, / Nek židovi ne vidu, / Pa neka nas obidu, / Da mi sinka ne otmu... / A topola ni 'tila, / Proklela je Marija: / Oj topolo, topolo, / Lelala se, lelala / U pol lita bez vitra, / U pol zime bez sniga» [Ой тополя, тополя, спусти ветви до земли, скрой сыночка и меня, пусть евреи не видят и нас пусть обойдут, у меня сыночка не отнимут... а тополя не хотела, прокляла ее Мария: «Ой тополя, тополя, колыхалась, колыхалась, пол лета без ветра, пол зимы без снега»] [I9, s. 194].

Таким образом, предательство осины оказывается как намеренным, так и случайным; последнее, однако, не отменяет последовавшего за этим проклятия осины, обычно от лица Богородицы. Проклятие является кульминацией сюжета, которая выражена в его итоговой формуле, вложенной в уста Богородицы, ср. польскую формулу из легенды: «Skoro mnie nie chcesz ukryć, będziesz się trzęsła całe życie» [Раз ты не хочешь спрятать меня, будешь трястись всю жизнь $]^{4}$ с русинской формулой из колядки: «Осико, осико, бодай єс ся трясла / Од віка вічного до Суда Страшного» [4, с. 944].

Помимо осины, в качестве противника Святого Семейства выступают колючие кустарники, участвовавшие в Крестных муках Спасителя (ср. терновый венец и т. п.). Так, в устной традиции славян-мусульман Сербии сюжет о бегстве Св. Семейства в Египет трансформировался в рассказы о бегстве Мухаммеда; эти рассказы этиологически «обосновывают», в частности, про-

4 Archiwum Katedry Etnologii i Antropologii Kulturowej Uniwersytetu Warszawskiego: O/3I, Мазовше. (Польша, Варшава). 
клятие колючей ежевики. В легенде из сербского Ниша говорится, что, когда Мухаммед бежал от преследования врагов, он запутался в поле в кустах ежевики и упал, да так что враги едва не настигли и не схватили его, после чего он и проклял ежевику [6, с. 2І2].

Впрочем, иногда в рамках тех же легенд и сюжетных ходов колючее растение становится чудесным помощником Св. Семейства и, как результат, получает от них не проклятие, а благословение. Такова, в частности, хорватская легенда, гласящая, что когда Мария и Иосиф с новорожденным Иисусом шли по лесу, ежевика зацепилась за плащ Марии; Мария испугалась, решив, что это враги настигли ее, но когда оглянулась и увидела ежевику, сказала: «...ежевика, будь ты всегда зеленой» ([I8, s. 44] община на севере Хорватии).

«Благородной» парой к осине и помощником Св. Семейства в фольклоре чаще других выступает лещина, которую Богородица или Христос благословляют и вознаграждают, наделяя какими-нибудь полезными качествами. Лемки на юго-востоке Польши называли лещину «святым деревом», так как она дала укрытие спасавшейся от преследования Богородице, и с тех пор град и молния будто «не видят» тех мест, где растет лещина [22, s. 57], поэтому для защиты от молнии ветки лещины держат в доме. Другим защитником и помощником Св. Семейства оказывается липа, которая на западе Славии традиционно считается деревом Богородицы. Примечательна чешская легенда, которая связывает липу, пчелу и легендарный сюжет о бегстве в Египет. Согласно ей, во время этого путешествия Св. Семейство сопровождали рои пчел, чтобы защитить их от солдат Ирода. Пчелы бы, безусловно, погибли, так как в пустыне не было никакой цветущей зелени. Однако Христос позаботился об их пропитании, и в пустыне неожиданно выросла липа и появился колодец. Люди освежились водой, а пчелы подкрепились липовым нектаром. Пчелы сопровождали Св. Семейство до конца, а на обратном пути встретили солдат Ирода и сильно покусали их [І7, s. 289].

Если рассматривать корпус этиологических легенд о бегстве Св. Семейства в Египет в целом, то становится понятно, что значительное место в нем занимают тексты, в которых в рамках одного сюжета противопоставляются «хорошие» и «плохие» деревья, выступающие в роли помощников и противников Св. Семейства. Такое противопоставление, с одной стороны, создает интригу легенды, обеспечивает ее «занимательность» и интерес со стороны слушателей. С другой - оно объясняет различия в природных свой- 
ствах деревьев, формирует двуполюсный этиологический миф. Одни деревья оказываются «хорошими» и «полезными»: обычно это береза (Белоруссия, Польша), лещина (Польша, зап. Украина и Карпаты, зап. Белоруссия, Словакия), липа (Польша, Чехия), изредка ель (зап. Белоруссия, Зап. Украина), калина (Польша) и верба (Хорватия). Другие - признаются «вредными» или «бесполезными»: это, как мы уже отмечали, прежде всего осина (Белоруссия, Зап. Украина, Карпаты, Польша, Босния, Зап. Сербия), а также тополь (Хорватия), бузина (Зап. Украина и Карпаты), иногда ель и пихта (Чехия), ежевика (Сербия) и терновник (Чехия, Зап. Украина).

Согласно польскому нарративу, Богородица с младенцем, убегая от царя Ирода, спрятались под осиной, но та не смогла укрыть беглецов, так как дрожала от страха, что царь Ирод ее срубит. Тогда Мария перебежала под лещину, которая, как могла, укутала ее своими ветвями, и Ироду пришлось вернуться ни с чем. Поэтому Христос сделал так, что осина дрожит даже при хорошей погоде, а под лещиной можно укрыться даже в грозу, поскольку гром туда не бьет ([23, s. II7] центр. Польша). Словаки в обл. Высоких Татр рассказывали о том, что Св. Семейство при бегстве в Египет застала гроза: осина, под которой они хотели спрятаться, подняла свои ветки, и беглецы намокли, а лещина раскинула ветки и укрыла их; за это Богородица наделила лещину плодовитостью, и с тех пор ее считают счастливым деревом [2I, s. 265].

В рамках этиологической легенды евангельское событие может почти полностью отходить на второй план, становясь лишь поводом к объяснению отдельных свойств деревьев, таких как трепетание ветвей осины или сладость плодов лесного ореха, а также особенностей поведения живущих на них птиц. Приведем в качестве примера брестскую легенду, «соединяющую» в одном нарративе оба варианта развития событий - трагический, с участием осины, и благополучный, с участием лещины: «Як Христос родиўся и утекаў Йосиф из Божой Матерью, и рэбёнка неслы, и воны ховалися. Як воны ховалися, так воны сели под осиною, а осина то траслася, лякалася, так воны осину прокляли: “Шоб ты век траслася”. А на осине и кукушка закоўала, то воны казали: “Шоб ты <кукушка>, кажэ, ковала до Петра только, а после Петра уже тоби голос прэкратиўся, з(а) тобою шоб гонялыся ўсякие птицы”, бо воны ховалися, а вона их выдала А потом, як стали под орэш-

5 О мотиве сезонного прекращения кукования кукушки и потери кукушкой голоса в середине лета см.: ([5, с. 687] и след.). 
ником, а орэшник низко ж [растет], и прикрыў их. Як ехали тые, етые за ними ў погони, да нэ побачили, минули. То они сказали: “Шоб на тобе такие плоды були, шо ўсе люди ели” » ${ }^{6}$ Впрочем, иногда легенды, избегая прямых оценок и сравнений, просто объясняют особенности облика дерева, например белую кору березы и ее плакучие, ниспадающие ветви: «Matka Boska lubi naj-bardziej brzozy prawdopodobnie. Uchowała sie od deszczu pod brzozo, bo dlatego ma uwieszone taki gałęzie, wiszo, mówio, Matka Boska sie schowała» [Богородица, вероятно, любит больше всего березы. Она спряталась от дождя под березой, поэтому у нее такие свисающие ветки, говорят, Богородица спряталась] ([20, s. II4, № г8о] Замойское воев.).

Наконец, среди славянских легенд на тему бегства Св. Семейства в Египет есть небольшой круг текстов неэтиологических, которые не определяют и не мотивируют появление у деревьев какие-либо свойств, но при этом деревья в них остаются активными «участниками» легендарных событий. Таковы, в частности, некоторые легенды о колючих кустарниках. Согласно чешской легенде, когда Мария с Иосифом и Младенцем Христом бежали в Египет, их преследователи солдаты Ирода, чтобы найти и убить Христа. Путники, видя, что у них нет шанса спастись, опустились на колени и помолились Богу, чтобы тот помог им. Пока они молились, за их спинами вырос неприступный густой терновник (чеш. trnka), через который солдаты не смогли пройти и вынуждены были вернуться ни с чем [I7, s. 282]. В сербской легенде из окр. Ниша рассказывается о том, что, когда Св. Семейство остановилось на отдых во время своего бегства, Богородица взмолилась о помощи и защите, и кусты ежевики буйно поднялись, сплелись ветвями и запутали их преследователей, так что Богородица с Христом смогли спрятаться в них (цит. по: [9, с. 202, № 6]). Как видим, в этих легендах отсутствуют мотивы благословения или проклятия, в них не объясняется появление у того или иного кустарника такого объективно неприятного свойства, как колючесть их ветвей, однако само это свойство, использованное во имя спасения Св. Семейства, как бы освящается христианской историей.

Суммируя сказанное, можно утверждать, что сюжет о бегстве в Египет выступает в славянском фольклоре в качестве своего рода классификатора, разделяющего деревья на «хорошие» и «плохие», а сама Священная история и ее события оказываются универсальным мотивационным инструментом, 
владение которым позволяет традиции найти ключ для объяснения самых разных особенностей славянского фольклорного дендрария.

$* * *$

Возвращаясь к апокрифической традиции, которая, как нам представляется, сыграла немалую роль в становлении и распространении народных легенд о бегстве Св. Семейства в Египет, напомним, что Евангелие Псевдо-Матфея было известно в Европе на латыни и оказало заметное влияние на развитие старочешской и польской книжности и литературы - апокрифов, сказаний, стихотворных поэм, в том числе разного рода текстов, издававшихся для народа (см. об этом специально: [І2, с. 82 и след.], там же см. литературу вопроса; [I5, с. XXII, XVI-XVII, LXVII, LXII]). Его влияние было заметно также в карпатоукраинской книжности, о чем писал И. Франко [І6]. В частности, украинские апокрифы, включающие соответствующие эпизоды (дерево отдохновения на пути в Египет; дерево перед входом в Гермополис, которое склонилось перед Христом и Марией, «отдавая им честь» и даруя свои плоды), имеются в трех украинских рукописях из собрания И. Франко (см.: [I5, c. I52-I57, рукописи Б, В и Г]). При этом одна из этих рукописей происходит из Угорской Руси (Рукопись Степана Теслевцьового, конец XVII - начало XVIII в.), а вторая, так называемая Сокольская рукопись XVIII в., является, как отметил Франко, переводом с польского.

Если в контексте сказанного внимательно присмотреться к географии славянских легенд о деревьях, которые «принимали участие» в эпизоде бегства Св. Семейства в Египет, то станет очевидно, что эти легенды явно тяготеют к западу Славии: они зафиксированы преимущественно в Польше, Чехии, Словакии, на Западной Украине и в Белоруссии, особенно западной, а также в Хорватии, Боснии и Западной Сербии. В то же время в балканославянской традиции и в России такие легенды встречаются крайне редко (что, в частности, подтверждается отсутствием соответствующих текстов в репрезентативном собрании русских этиологических легенд, см.: [Із] ). Иными словами, этиологические легенды, рассказывающие о бегстве Св. Семейства в Египет и помощи, которую оказывали им разные деревья, известны на территорияx Slavia Latina и сопредельных им, там же, где были известны апокрифы, восходящие к Евангелию Псевдо-Матфея. Это позволяет нам с осторожностью предположить, что Евангелие Псевдо-Матфея, в котором присутствует 
упомянутый выше эпизод с деревьями, было одним из далеких источников сюжета соответствующих легенд о бегстве Св. Семейства в Египет, во время которого Св. Семейству помогали в том числе и деревья, хотя влияние Евангелие Псевдо-Матфея на фольклорную традицию западной части Славии было непрямым и осуществлялось опосредованно - через апокрифические сказания, народную литературу, литургические чтения, иконографию и т. д.

И, наконец, последнее. В корпусе славянских легенд, посвященных событиям христианской истории, имеется небольшая группа текстов, также о бегстве, но не о бегстве Св. Семейства в Египет после рождения Христа, а о бегстве самого Христа перед Распятием и его попытках спрятаться и найти убежище - от преследователей, а также от грозы, дождя, чумы и иных подстерегавших его опасностей. Мы полагаем, что это легенды-«дериваты», которые сюжетно опираются на легенды о бегстве в Египет, но при этом развивают темы Страстей Христовых.

Как и легенды, о которых говорилось выше, нарративы о попытках Иисуса Христа укрыться перед Распятием сильно расходятся с событиями христианской истории, моделируя возможность его спасения. Основным действующим лицом этих легенд становится не Богородица, а именно Христос, который благословляет укрывшее его дерево или проклинает то, которое его выдало: это может быть дуб (Болгария), сосна (Болгария, Россия), верба (Россия), осина (Россия, Сербия) и др. На Русском Севере в легендах на этот сюжет чаще других фигурирует можжевельник: «А как уж к Пасхе ближе - вот это Страшна [Страстная. - T.A.] недиля пойдёт. Всё говорили, что за Христом беси бегают, а он прятается (ведь на Страшной недиле его хватали и распияли). И всю недилю беси-ти за Христом бегает; он прячется от них. В Великой четверг по межжевёл ходили - говорят, Иисус Христос спрятается под можжевёл...» [2, с. 59]. Болгарская легенда рассказывает о том, что под сосной (смрика) Христос смог укрыться от чумы, за что она и получила Божье благословение: «Тизе, смрико, се зелена, да си зиме и лете!» [Пусть ты, сосна, будешь зеленой зимой и летом!] [I, с. I38].

Подобные фольклорные нарративы о Христа, который пытался укрыться перед Распятием, получили распространение преимущественно в русской и балканославянской среде (Россия, особенно Русский Север, Болгария, восточная Сербия), т. е. там, где легенды о бегстве в Египет известны мало. Иными словами, можно с осторожностью предположить, что две 
эти группы легенд - о бегстве Св. Семейства в Египет и о попытках Христа спрятаться перед Распятием - находятся между собой в отношениях дополнительной дистрибуции.

\section{Список литературы}

I Ангелова Р. Село Радуил. Народопис и говор // Известия на семинара по славянска филология при Университета в София. София, І948. Т. 8-9. С. 48-І5о.

2 Ветлужская сторона / общая ред. А.В. Кулагиной. Кострома, І996. Вып. 2. 336 с.

3 Вранска Цв. Апокрифите за Богородица и българската народна песень // Сборник на Българската академия на науките. София: Българската академия на науките, I940. Кн. 34. С. I-208.

4 Горбаль M. Сюжети лемківських різдвяних легенд та переказів // Народознавчі зошити. Львів: Інститут народознавства НАН України, 20II. № 6. С. 94I-946.

5 Гура А.В. Символика животных в славянской народной традиции. М.: Индрик, I997. 9I2 c.

6 Ђорђевић T.P. Природа у веровању и предању нашега народа. Београд: Српска краљевска академија, І958. Књ. 2. 556 с. (Српски етнографски зборник. Књ. 72).

7 Новозаветные апокрифы / сост. и коммент. С.А. Ершова. СПб.: Амфора, 200I. 423 с.

8 Покровский Н.В. Евангелие в памятниках иконографии, преимущественно византийских и русских. М.: Прогресс Традиция, 200I. 564 с.

9 Самариија С.Д. Приче о постанку и особинама биља и растиња (Антологија) // Гора Љиљанова (Биљни свет у традиционалној култури Срба. III). Нови Сад: Универзитетска библиотека «Светозар Марковић», 20I6. С. І99-230. Святитель Димитрий Ростовский. Жития святых. Житие II37. URL: https:// azbyka.ru/otechnik/Dmitrij_Rostovskij/zhitija-svjatykh/ıI37 (дата обращения: I5.08.20I7).

II Coфpић П. Главније биље у народном веровању и предању код нас Срба. Београд: Српска краљевска академија, І9г2. 432 с.

I2 Сперанский М.Н. Славянские апокрифические евангелия. М.: Тов-во Тип. А.И. Мамонтова, І895. 138 с.

I3 У истоков мира. Русские этиологические сказки и легенды / сост. и коммент. О.В. Беловой, Г.И. Кабаковой. М.: Форум Неолит, 20I4. 528 с.

I4 Усачева В.В. Судьба благословенных и про́клятых деревьев в традиционной культуре славян // Этноботаника: растения в языке и культуре / отв. ред. В.Б. Колосова. СПб.: Наука, 201о. С. І30-163.

I5 Франко I. Апокріфи і лєгенди з українських рукописів. Львів: Науково Товариство імени Шевченка, I899. Т. 2. 444 с. 
I6 Франко İ. Апокріфічне євангелиє псевдо Матвія і його сліди в українсько руськім письменстві // Записки Наукового товариства ім. Шевченка. Львів, г9оо. Т. 35-36. C. $\mathrm{I}-32$.

I7 Košt’ál J. Rostlinstvo v podání prostonárodním. Velké Meziř̌ičí, I902. 308 s.

I8 Kotarski J. Lobor // Zbornik za narodni život i običaje Južnih Slavena. Zagreb: Jugoslav. akademija znanosti i umjetnosti, I9I8. Knj. 23. Sv. I. S. II-63.

I9 LovretićJ. Otok. Narodni život i običaji // Zbornik za narodni život i običaje Južnih Slavena. Zagreb: Jugoslav. akademija znanosti i umjetnosti, I897. Knj. 2. S. 9I-459.

$20 \quad$ Niebrzegowska S. Przestrach od przestrachu: Rośliny v ludowych przekazach ustnych. Lublin: Wydawnictwo Uniwersytetu Curie Skłodowskiej, 2000. 266 s.

2I OlejnikJ. Poverove predstavy o ženských demonických bytostiach vo Vysokých Tatrách // Nové obzory. Spoločenskovedný sborník Východného Slovenska. Košice, I963. № 5 . S. 215-227.

22 Reinfuss R. Śladami Łemków. Warszawa: Wydawnictwo “Kraj”, I990. I52 s.

23 Siarkowski W. Podania i legendy o zwierzętach, drzewach i roślinach // Zbiór wiadomości do antropologii krajowej. Lwów: Komisyja Antropologiczna Akademii Umiejętności, I883. T. 7. S. II2-I23.

24 Uther H.J. The Types of International Folktales. A Classification and Bibliography. Helsinki: Academia Scientiarum Fennica, 2004. Vol. I-III. (FF Communications No. 284-86). Vol. I. 620 p.; Vol. 2. 536 p.; Vol. 3.286 p.

25 Zowczak $M$. Biblia ludowa. Interpretacje wątków biblijnych w kulturze ludowej. Wrocław: Fundacja na rzecz nauki polskiej, 2000. $258 \mathrm{~s}$. 


\section{References}

I Angelova R. Selo Raduil. Narodopis i govor [Village of Raduil. Folk culture and dialect]. Izvestiia na seminara po slavianska filologiia pri Universiteta $v$ Sofiia [Proceedings of the seminar of Slavic Philology at the Sofia university]. Sofia, I948, vol. 8-9, pp. 48-150. (In Bulgarian) Vetluzhskaia storona [The region on the banks of the Vetluga], ed. A.V. Kulagina. Kostroma, I996. Vol. 2. 336 p. (In Russ.) Vranska Tsv. Apokrifite za Bogoroditsa i bylgarskata narodna pesen' [Apocryphal stories about the Virgin and Bulgarian folk song]. Sbornik na Bylgarskata akademiia na naukite [Edited collection of Bulgarian Academy of Sciences]. Sofia, Bylgarskata akademija na naukite Publ., I940, vol. 34, pp. I-208. (In Bulgarian) Gorbal' M. Siuzheti lemkivs'kikh rizdvianikh legend ta perekaziv [On some subjects of Lemko Christmas legends and tales]. Narodoznavchi zoshiti. L'viv, Institut narodoznavstva NAN Ukrajini Publ., 20II, no 6, pp. 94I-946. (In Ukrainian) Gura A.V. Simvolika zhivotnykh v slavianskoi narodnoi traditsii [Symbolism of animals in Slavic folk tradition]. Moscow, Indrik Publ., I997. 9I2 p. (In Russ.)

Dzhordzhievich T.R. Priroda u verovaniu i predaniu nashega naroda [The nature in beliefs and legends of our people]. Belgrade, Srpska kralevska akademiia Publ., I958. Vol. 2. 556 p. (Srpski etnografski zbornik. Vol. 72). (In Serbian) Novozavetnye apokrify [Apocryphal stories of the New Testament], compilation and commentary by S.A. Ershova. St. Petersburg, Amfora Publ., 200I. 423 p. (In Russ.) Pokrovskii N.V. Evangelie v pamiatnikakh ikonografii, preimushchestvenno vizantiiskikh i russkikh [The Gospel in iconographic monuments, mainly Byzantine and Russian]. Moscow, Progress Traditsiia Publ., 200I. 564 p. (In Russ.) Samardzija S.D. Priche o postanku i osobinama bilia i rastinia (Antologija) [Stories about the genesis and specificity of plants (Anthology)]. Gora Lilianova (Bilni svet $u$ traditsionalnoi kulturi Srba. III) [Liliana's Mountain. World of the plants in traditional Serbian culture]. Novi Sad, Univerzitetska biblioteka “Svetozar Markovich” Publ., 20I6, pp. I99-230. (In Serbian)

IO Svjatitel' Dimitrij Rostovskij. Zhitija svjatyh [Lives of the Saints]. Zhitie II37. Available at: https://azbyka.ru/otechnik/Dmitrij_Rostovskij/zhitija-svjatykh/II37 (Accessed I5 August 20I7). (In Russ.)

Sofrich P. Glavnije bile u narodnom verovaniu i predaniu kod nas Srba [The main plants in our Serbian beliefs and legends]. Belgrade, Srpska kralevska akademiia Publ., I9I2. 423 p. (In Serbian) Speranskii M.N. Slavianskie apokrificheskie evangeliia [Slavic apocryphal gospels]. Moscow, Tovarishhestvo Tipografii A.I. Mamontova Publ., I895. I38 p. (In Russ.) U istokov mira. Russkie etiologicheskie skazki i legendy [At the world origins. Russian etiological fairy-tales and legends], compilation and commentary by O.V. Belova, G.I. Kabakova. Moscow, Forum Neolit Publ., 20I4. 528 p. (In Russ.) 
Usacheva V.V. Sud'ba blagoslovennykh i prókliatykh derev'ev v traditsionnoi kul'ture slavian [The destiny of the blessed and damned plants in Slavic folk culture]. Etnobotanika: rasteniia v iazyke i kul'ture [Ethnobotanics: plants in language and culture], ed. V.B. Kolosova. St. Petersburg, Nauka Publ., 20I0, pp. I30-I63. (In Russ.) Franko I. Apokrifichne jevangelije psevdo Matviia i iogo slidi v ukraïns'ko rus'kim pis'menstvi [The apocryphal gospel of Pseudo-Matthew and its traces in Ukrainian and Russian medieval writing]. Zapiski Naukovogo tovaristva im. Shevchenka. L'viv, I900, vol. 35-36, pp. I-32. (In Ukrainian) Franko I. Apokrify i ljegendy z ukrajins'kyh rukopysiv [Apocrypha and legends in Ukrainian manuscripts]. L'viv, Naukovo Tovaristvo im. Shevchenka Publ., I899. Vol. 2. 444 p. (In Ukrainian)

Košt’ál J. Rostlinstvo v podání prostonárodním [Plants in folk beliefs]. Velké Meziříčí, I9O2. 308 p. (In Czech)

I8 Kotarski J. Lobor. Zbornik za narodni život i običaje Južnih Slavena [A collection of folk life and customs of Southern Slavs]. Zagreb, Jugoslav. akademija znanosti i umjetnosti Publ., I9I8, book 23, issue I, pp. II-63. (In Croatian)

I9 Lovretić J. Otok. Narodni život i običaji [Island. Folk life and customs]. Zbornik za narodni život i običaje Južnih Slavena [A collection of folk life and culture of Southern Slavs]. Zagreb, Jugoslav. akademija znanosti i umjetnosti Publ., I897, book 2, pp. 9I-459. (In Croatian)

20 Niebrzegowska S. Przestrach od przestrachu: Rosliny v ludowych przekazach ustnych [Fear coming from fear: plants in oral folk tales]. Lublin, Wydawnictwo Uniwersytetu Curie Skłodowskiej Publ., 2000. 266 p. (In Polish) Olejník J. Poverove predstavy o ženských demonických bytostiach vo Vysokých Tatrách [Superstitions about feminine demonic beings in high Tatras]. Nové obzory. Spoločenskovedný sbornik Východného Slovenska [New Horizons. Oriental studies collection on Eastern Slovakia]. Košice, I963, no 5, pp. 215-227. (In Slovak) Reinfuss R. Śladami Łemków [Following Lemkis]. Warszawa, Wydawnictwo “Kraj” Publ., I990. I52 p. (In Polish)

23 Siarkowski W. Podania i legendy o zwierzętach, drzewach i roślinach [Stories and legends about animals, trees and plants]. Zbiór wiadomości do antropologii krajowej [A collection on national anthropology]. Lwów, Komisyja Antropologiczna Akademii Umiejętności Publ., I883, vol. 7, pp. II2-I23. (In Polish)

24 Uther H. J. The Types of International Folktales. A Classification and Bibliography. Helsinki, Academia Scientiarum Fennica, 2004. Vol. I-III. 620 p. + 536 p. + 286 p. (In English)

25 Zowczak M. Biblia ludowa. Interpretacje wątków biblijnych w kulturze ludowej [The Folk Bible. Interpretation of byblical themes in folk culture]. Wrocław, Fundacja na rzecz nauki polskiej Publ., 2000. 258 p. (In Polish) 
УДК $398+82$ I.I6I.I.O

ББК

$82.3+83.3(2 \mathrm{Poc}=\mathrm{Pyc}) 6$
О ФОЛЬКЛОРНОЙ КОЛЛЕКЦИИ В АРХИВЕ ЕВГЕНИЯ ПЛАТОНОВИЧА ИВАНОВА, ХРАНЯЩЕЙСЯ В ОТДЕЛЕ РУКОПИСЕЙ ИМЛИ РАН

(C) 2018 г. А.Л. Налепин Институт мировой литературы им. А.М. Горького Российской академии наук, Москва, Россия Дата поступления статьи: І7 октября 2017 г. Дата публикации: 25 марта 2018 г.

DOI: I0.22455/2500-4247-20I8-3-I-3I8-33I

Аннотация: Статья открывает исследовательскую тему «Значение материалов фольклорного наследия и народной культуры, хранящихся в Отделе рукописей ИМЛИ РАН, а также в других архивохранилищах как в России, так и за рубежом» и предлагает филологическое осмысление неизвестных широкой научной общественности образцов русской фольклорной культуры как живой традиции, во многом определяющей пути развития русской цивилизации и смыслы национальной ментальности. Важную роль в этом играют народная культура и фольклор и, конечно же, отечественная и мировая филологическая фольклористика, изучающая обретенные фольклорные памятники, их мировоззренческие доминанты и эстетические концепты. Исследование, основанное на конкретном анализе обретенного фольклорного наследия, попыталось найти и определить значимость вводимых в научный оборот материалов, их гармоничное вхождение в уже существующую фольклорную систему, что, несомненно, обогатит как русскую фольклористическую мысль, так и отечественное литературоведение.

Ключевые слова: Евгений Платонович Иванов, русский фольклор, этнология, фольклористика, народная культура, скоморохи, этнографический театр, архивы.

Информация об авторе: Алексей Леонидович Налепин - доктор филологических наук, ведущий научный сотрудник, Институт мировой литературы им. А.М. Горького Российской академии наук, ул. Поварская, д. 25 а, І2I069 г. Москва, Россия.

E-mail: a_nalepin@ mail.ru 


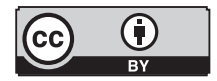

This is an open access article distributed under the Creative Commons Attribution 4.0 International (CC BY 4.0)
FOLKLORE COLLECTION IN THE ARCHIVE OF EVGENY PLATONOVITCH IVANOV HELD BY THE IWL RAS MANUSCRIPT DEPARTMENT

(C) 20I8. A.L. Nalepin

A.M. Gorky Institute of World Literature of the Russian Academy of Sciences, Moscow, Russia

Received: October I7, 2017

Date of publication: March 25, 2018

Abstract: The article opens up a new research series entitled "Significance of the Folklore Materials, stored in the Department of Manuscripts at IWL RAS and in other archives, both in Russia and abroad" and offers philological interpretation of the samples of Russian folklore culture, hitherto unknown to the broad academic community. These samples belong to the tradition fundamental for the development of Russian civilization and the meanings of national mentality. Folk culture / folklore play important role in this development, as do folklore studies that examine folklore sources, their ideological constants and aesthetics concepts. The study, focusing on the analysis of the newly acquired folklore heritage, attempts to evaluate the significance of these materials and ensure their harmonious entry into the already existing folklore system. The presented research will undoubtedly enrich both Russian folklore studies and literary criticism.

Keywords: Evgeny P. Ivanov, Russian folklore, ethnology, folklore studies, folk culture, buffoons, ethnographic theater, archives.

Information about the author: Alexey L. Nalepin, DSc in Philology, Leading Research Fellow, A.M. Gorky Institute of World Literature of the Russian Academy of Sciences. Povarskaya 25 a, I21069 Moscow, Russia.

E-mail: a_nalepin@mail.ru 
22 марта 2016 г. в Отделе фольклора ИМЛИ РАН состоялся научный семинар, посвященный жизни и деятельности русского писателя, журналиста, фольклориста, этнографа, автора опубликованной в г985 г. в издательстве «Московский рабочий» книги «Меткое московское слово» Евгения Платоновича Иванова (г884, Нижний Новгород - I967, Москва) и судьбе его уникального фольклорного архива, поступившего на хранение в Отдел рукописей ИМЛИ РАН.

Переданные на хранение в Отдел рукописей ИМЛИ РАН архивные материалы Е.П. Иванова сформировали личный фонд фольклориста - Фонд № 630, содержащий I7I единицу хранения. Так завершился долгий путь возвращения научного наследия талантливого собирателя и исследователя традиционной народной культуры в большую науку.

Характерной особенностью исследовательского метода Е.П. Иванова было самое внимательное отношение к любому архивному источнику, который проходил через его руки, начиная от обширных полевых записей и кончая случайными, вроде бы незначительными текстами, которую архивисты называют «архивной пылью». Если переосмыслить знаменитые строки Анны Ахматовой «Когда б вы знали, из какого сора растут стихи, не ведая стыда», то можно смело утверждать, что в фольклоре и в фольклористике «архивная пыль», «архивная смесь» и другой всякого рода «архивный сор» обладали тем самым креативным потенциалом, который ориентировал исследовательскую мысль на поиск новых, нестандартных выводов и решений. Эта фольклорная часть его коллекции, казалось бы, безвозвратно утраченная после смерти Е.П. Иванова в 1967 г., в 8о-е гг. прошлого столетия была счастливо 
спасена и обретена научным сообществом благодаря бескорыстным усилиям писателя Александра Григорьевича Морозова (1944-2015).

Тот факт, что бесхозный архив скончавшегося 83-летнего старца Е.П. Иванова был спасен именно А.Г. Морозовым, был не случаен. Он, как никто другой, понимал ценность и творческую потенцию архивного документа, сделав частные письма, случайно им обнаруженные среди, казалось бы, никому не нужных вещей где-то на антресолях заброшенного дома, мощным креативным творческим материалом. А.Г. Морозов родился в интеллигентной «читающей» семье врача и учительницы. В 1968 г. Морозов окончил филологический факультет МГУ имени М.В. Ломоносова. В студенческие годы, начиная с г965 г., участвовал в деятельности неформального творческого объединения «СМОГ». Аббревиатура «СМОГ» расшифровывалась как «Смелость, Мысль, Образ, Глубина». А в качестве творческого лозунга Объединения аббревиатура «СМОГ» читалась ее создателями как «Самое Молодое Общество Гениев».

После окончания МГУ Морозов работал в газетах «Московский комсомолец» и «Литературная газета», в издательстве «Молодая гвардия», редактором богословского отдела в «Журнале Московской Патриархии», а затем Ответственным секретарем Правления в Международном фонде славянской письменности и культуры.

В г968 г. А.Г. Морозов написал свой первый роман «Чужие письма», который был рекомендован его университетским учителем В.Н. Турбиным и В.Я. Лакшиным для публикации в журнале «Новый мир». Однако редколлегия журнала «Новый мир» по идеологическим соображениям отвергла роман, и лишь в 1997 г. А.Г. Морозов смог напечатать в журнале «Знамя» роман «Чужие письма» [2], а его автор получил престижную литературную премию «Русский Букер» [3]. В г975 г. им было написано своеобразное продолжение романа «Чужие письма» - роман «Общая тетрадь. Солилоквиум», опубликованный лишь в г999 г. [4].

Тот факт, что именно А.Г. Морозов бережно сохранял и сохранил творческое наследие Е.П. Иванова, оригинального русского исследователя, был по достоинству оценен научной общественностью. Доктор филологических наук Александр Павлович Чудаков, заставивший «вспомнить» отечественную фольклористику в 8о-е гг. прошлого столетия имя «забытого» на долгие годы Е.П. Иванова, с благодарностью отмечал: «Пользуюсь случаем побла- 
годарить А.Г. Морозова, у которого хранятся данные материалы, за любезно предоставленную мне возможность ознакомиться с ними» [8, с. 7].

Основная часть творческого архива Е.П. Иванова хранится в Российском государственном архиве литературы и искусства (РГАЛИ), в состав литературных фондов которого «входят фонды не только писателей, поэтов, драматургов, но и историков литературы, языковедов, филологов, фольклористов и этнографов» $[6$, с. 3$]$.

В РГАЛИ существует небольшой Фонд № 224, в котором собраны архивные материалы журналиста и этнографа Евгения Платоновича Иванова (1884-1967). Электронная Аннотация Фонда № 224 сообщает следующее: «Оп. І. І908-І92І гг. Рукописи Е.П. Иванова, Д.Д. Бурлюка, Е.И. Вашкова, А.С. Грина, А.М. Пазухина, Н.П. Смирнова-Сокольского и др. "Вечное” коллективный шуточный роман с наклеенными рисунками, открытками, афишами, билетами и пр. (I9I5). Альбом “Балаганчика искусства”, сост. Е.П. Ивановым. Записи Н.А. Адуева, А. Арго, М.П. Арцыбашева, М.Н. Гаркави, А.М. Данкмана, Б.А. Лавренева, В.Е. Лазаренко, В.Э. Мейерхольда, Н.А. Павлович, П.М. Садовского-младшего, Ю.Л. Слезкина, Н.П. Смирнова-Сокольского, А.И. Южина и др.; рисунки, фото, программы, афиши, билеты “Балаганчика искусства”; письмо А.М. Горького - М.Г. Григорьеву [1918] и др. (1918-г920). Письма провинциальных актеров и их фото, присланные в редакцию журн. “Театр в карикатурах” (I9II-I9I2). Дело Томского окружного суда по обвинению корнета Н.Э. Савина (графа Тулуз-Лотрека) (1908-I9I4). Количество единиц хранения 35. Крайние даты документов I908-І92I гг.» .

Кроме этого, в РГАЛИ в Фонде Н.С. Ашукина хранятся воспоминания Е.П. Иванова под названием «Дочери крестьянина Прокопия Суслова», посвященные двум двоюродным сестрам матери Е.П. Иванова - знаменитым женщинам России конца XIX столетия - первой в России женщине-врачу Надежде Прокопьевне Сусловой (I843-I9I8) и ее не менее известной сестре, той самой загадочной и инфернальной Аполлинарии Прокопьевне Сусловой (I840-1919), чье имя в истории русской литературы было связано с именами Ф.М. Достоевского и В.В. Розанова (РГАЛИ. Ашукин Н.С. Фонд № І890. Оп. І. Ед. хр. 84). Позже, составляя автобиографию, Иванов с признательностью и 
гордостью говорил об Аполлинарии Сусловой: «Она давала направление моему робкому перу, бранила за неудачи, и я очень считался с ее мнением» [1, с. 7].

Во многом благодаря трогательному вниманию и заботам Аполлинарии Прокопьевны Сусловой, переписка с которой, по признанию Е.П. Иванова, существенно повлияла на его литературное самоопределение и его становления как писателя, драматурга, этнографа и фольклориста.

Переданная на архивное хранение в Отдел рукописей ИМЛИ РАН коллекция Е.П. Иванова во многих жанровых отношениях значительно превосходит и вместе с тем качественно дополняет известное собрание Василия Ивановича Симакова (г879-I955), ныне хранящееся в Рукописном отделе Института русского языка имени В.В. Виноградова РАН [5, с. I07-I57].

Научное и культурное значение такого рода материалов трудно переоценить, поскольку она представляет «отражение пестрой стихии и многоголосия русского торжка на устной поэзии которого сказались разнообразные влияния сменявшихся поколений, укладов жизни. Здесь слышатся голоса разных “персонажей” - от крестьян, ремесленников и купчиков XIX века (эпохи Островского и Лескова) до кустарей времен нэпа» [5, с. Iо7].

Творческая биография Е.П. Иванова имеет как бы три равнозначные версии. Первая лапидарно и сухо отражает основные этапы его интенсивной научной деятельности и сводится к следующей схеме. Родившийся в I884 г. в Нижнем Новгороде Е.П. Иванов начал свою трудовую деятельность с должности нотариуса, одновременно занимаясь мелкой «литературной поденщиной». Он пишет и публикует в местных изданиях рассказы и пьесы (две из них были поставлены в сезоне г909-І9Іо гг.). С г9го г. Е.П. Иванов жил в Москве, постепенно становясь модным драматургом. В І9І3-I9I4 гг. издавал журнал «Театр в карикатурах», в котором, помимо хроники и рецензий (не только на спектакли, но и на концерты, выставки, новые книги), публиковались художественные произведения; в частности, первая публикация стихотворения В.В. Маяковского «Скрипка и немножко нервно». Уже взрослым человеком Е.П. Иванов в I9I5 г. поступил в Московский археологический институт и окончил его. Большую часть своей дальнейшей жизни Е.П. Иванов занимался этнографией, изучением русского народного театра, обрядов и т. п. В І924 г. он был одним из организаторов Первого научно-этнографического театра, в котором реконструировались старинные русские обряды и ритуалы. В 1937 г. подготовил и выпустил книгу-альбом «Русский лубок», в 
дальнейшем работал над сборником «Орнаменты народов СССР», изданию которого помешала начавшаяся Великая Отечественная война. Предмет особого научного интереса Иванова составляло скоморошество, понимаемое весьма широко. Наиболее известным трудом Е.П. Иванова является составленный им сборник народных речений под названием «Меткое московское слово» [I], опубликованный в 1985 г. в издательстве «Московский рабочий» при участии доктора филологических наук Александра Павловича Чудакова. В книге были представлены слова, выражения и целые речевые фрагменты, записанные у представителей самых разных слоев (в том числе и маргинальных) городского населения и воспроизводящие сословные и профессиональные особенности речи.

Вторая версия творческой биографии Е.П. Иванова, насыщенная яркими эпизодами его нестандартного быта, прекрасно выписана А.П. Чудаковым в его очерке «Бытописатель и собиратель живого слова», который сопровождает книгу «Меткое московское слово». Методы работы Е.П. Иванова с информантами были самые разнообразные. «Так, изучая скоморохов, - писал А.П. Чудаков - кроме вполне “академически” собранного (впоследствии) огромного материала он отыскивал последних живых носителей этой вымершей профессии. Всех людей из фольклорного прошлого: гусляров, скоморохов, вожаков медведей, сказителей, ложечников - можно было встретить в квартире на Тверской, в доме 28 , где сам ее эксцентричный хозяин прожил более полувека, и которая многие годы была “открытым домом”. Как вспоминает дочь Иванова Л.Е. Семенова (р. І909), иногда ее отец принимал своих гостей лежа в гробу, который ставил посреди своего кабинета» [8, с. 22]. Или еще один красочно-трагичный эпизод его научной биографии, когда вся собранная им за долгие годы огромная коллекция «вяземских, тульских, московских, медовых, “одномедных”, сахарных, сусляных, заварных, сырцовых , клюквенных, мятных, ржаных, печатных, вырубных, лепных, расписных пряников <...>. была съедена в годы войны» [8, с. 2г].

Хранящиеся в Отделе рукописей ИМЛИ РАН архивные материалы Е.П. Иванова позволяют представить именно научную биографию ученого, дают полное представление о характере и объемах конкретных изысканий ученого, а также о динамике исследовательских интересов и тем. При формировании любого архивного фонда в зависимости от специфики фонда «в аннотации на личный фонд можно наметить семь основных групп материа- 
лов, последовательность которых уже более или менее установилась. Первая группа - это творческие материалы: рукописи писателя, ноты композитора, рисунки художника. <..> Вторая группа материалов - это переписка. <..> Третья группа - это перечисление официальных документов, относящихся к биографии фондообразователя. <...> Четвертая группа - статьи и заметки о фондообразователе, воспоминания о нем, библиография и т. п. Пятая группа - это краткое описание материалов родственников. <..> Шестая группа, в которой указываются отдельные, наиболее значимые документы “инородного” происхождения, без каких-либо оговорок. <...> В последней, седьмой, группе фотографии фондообразователя, фотографии разных лиц, рисунки и другие изобразительные материалы» [7, с. 6-7].

Конечно, представленная схема относится к «идеальному», полноценному архивному фонду. Что касается фонда Е.П. Иванова, то это собрание включает в свой состав лишь то, что удалось спасти А.Г. Морозову. Поэтому все семь указанных выше групп материалов в этом фонде отсутствуют. Но зато наиболее ценны и представляют несомненный интерес для исследователей материалы, относящиеся к первой группе, объединившей многолетние творческие изыскания Е.П. Иванова.

Все фольклорные и этнографические материалы из фонда Е.П. Иванова так или иначе посвящены одной исследовательской теме - скоморошеству.

Он верил, и собранные им материалы подтверждали это, что этот социально-культурный общественный институт, официально запрещенный в XVII в., не мог исчезнуть бесследно и потому искал следы его современного, латентного, существования в самых различных памятниках русской народной культуры. Отсюда его пристальный интерес к красноречию русского торжка, к Корабельному радению хлыстов (Ед. хр. 7), к «скоморошьим посрамительным скороговоркам» (Ед. хр. 67), к «скоморошьему свадебному шутовству (Ед. хр. 70, 7I), к речи дедов-грибоедов и дедов-лаптеедов и т. д. В Фонде № 630 хранятся и более развернутые исследования Е.П. Иванова, как-то: «Словарь языка и азбука звуков зрелищных скоморохов (Скоморошья пляска)» (Ед. хр. 75), «Описание народных инструментов, бытующих у скоморохов» (Ед. хр. 77), «Профессор шансонетного искусства Андрей Захарович Серполетти» (Ед. хр. Iо6) и, наконец, главный труд Е.П. Иванова с предисловием профессора А.И. Успенского (Ед. хр. 42) «Скоморохи» 
(Ед. хр. 48), посвященный «Светлой памяти моих незабвенных родителей Платона Памфиловича и Анны Иосифовны Ивановых» (Ед. хр. 42). Кстати говоря, лишь из этого хранящегося в архиве 630 посвящения удалось выяснить имена его родителей

И еще одно «открытие» Фонда № 630, хранящегося в Отделе рукописей ИМЛИ РАН. Долгое время считалось, что многое из творческого наследия Е. Иванова было безвозвратно утрачено. Так, в 1985 г. А.П. Чудаков сетовал, что «в издательстве "Искусство" во время войны были утрачены рукописи книг "Русский народный орнамент” и “Орнаменты народов СССР” $[8$, с. I9]. В Фонде Е.П. Иванова хранится машинописная копия объемом II4 листов с рукописными вставками и правкой автора считавшейся утраченной книга Е.П. Иванова «Орнаменты народов нашей страны» (Ед. хр. І7о), правда, без иллюстративного материала.

Ниже публикуется документ из фонда № 630 (Оп. г. Ед. хр. 56), который в полной мере отражает характер и круг интересов фондообразователя, а также особенности его исследовательского инструментария: особенности паспортизации и фонетической фиксации фольклорного материала.

Данная фольклорная запись представлена авторизованной рукописью (машинопись с правкой автора и переписчика). При публикации сохранены все особенности стилистики, орфографии и пунктуации оригинала:

\section{«ВАСЯ, РОДНОЙ ПЛЕМЯННИК АТАМАНА-КАЗАКА СТЕПАНА РАЗИНА.}

(Записано в 1907 году, в Нижнем Новгороде, от собиравших подаяние: уроженца Макарьевского уезда - мещанина Василия Порфирьевича Климова и неизвестного слепца, отказавшегося дать сведения о своем происхождении, назвавшего себя Петром Матвеевым).

Климов: «А, дозвольте сказать, собиранием милости добрых людей еще с папашей - Порфирием Ивановичем, от бедности, был занят. Папаши были у меня безрукие. Дитёй по этому занятию ходил. Мамаши у меня не было. Не совсем не было, а они умерли от моих родов, - при деторождении. Шестьдесят четыре года имею, перекваска - как сказать... К иному занятию, што блажить, не способен - по трясению правой руки от удара бревном. Имею еще один глаз, второй угомонился, заслеп и вытек по установлению докторского сведетельства. Товарищ мой тоже сослеп с тридцати пяти лет от 
черной воды в глазах. До того случая был писмоводителем при конторе имения у господ. Стихи хороших людей составления, если кто не хочет так подать вспомоществование бедному, поет по силе возможности голоса. Еще встанет, наберется народ, с кого милость собрать после можно, он и споет. Про Васю, дозвольте сказать, роднова племяннича Стеньки Разина затайка был, проживал плывучкой в нашем Макарьевском уезде и объявился лет с полста назад. Колотырный мальчёнка.... Потом их с есаулами, за «бог вам в помочь», на купеческом капитале, согнали в Сибирь. Присмертили они не мало люду... Казацкий наговор ведали - от стрелы и лезвия... Делать нечи... Очень интерес большой, все слушают, люди торгового звания - те особенно. Вольготный стих... Ну, вот-с!... Мальчик, поотойди взад, мне малось места надо. Не прогневайтесь, коли что не в память... Пой, Петя, добрые люди подошли...

Матвеев:

Много Волга-река привольная,

Много судов, реченька, перенесла.

И казны купецкой, золота

Людам вольным поотдала.

Вася, Разина племянничек,

Молодой был атаман,

С есаулами тремя командовал,

В плен расшивы забирал.

Как поедет он на лодочке

И казачье слово сказанет,

Так бурлацкая ватага

Лягит воя, как ни жива.

Вася на борт смело всходит

И приказчика зовет,

Говорит ему: «купецкую

Пусть казну ко мне несет!

А вы, вольные ватажники,

Сдайте мне купца в полон,

Наряжу я Вас, сермяжники,

Собирайтесь в мой затон.

Кто отдаст казну по воле,

Тех купцов я пощажу, 
А кто будет со мной биться -

В реке-Волге утоплю!

Я сам Разина племянничек,

Я природный атаман,

Со мной три есть есаула,

Мы сговорены от ран.»

Выйдет сам к нему приказчичек,

Несет в руках сундучок,

Говорит «возьми, разбойничек,

Вот хозяйское добро!

Ты ли Разина-племянничек,

Где себя ты хоронил,

Где сберег себя от каторги

И от лютых палачей?»

«По сестре Степана родственник,

Кровь казацкая во мне,

С Волгой я, по дальней памяти,

Тоже в близком родстве.

Собираю голь бурлацкую

Вкруг себя я воевать -

У богатого для беднова

Казну буду отбирать.

Ты иди, иди приказчичек,

Не продажная душа,

Мы тебя за то не тронем,

Что отдал все до гроша!»

Свистнет Вася есаулам,

Примут те сундучок,

Лодка чайкою несется

От расшивы к берегам.

Бурлачки подымут головы

И посмотрят ему в след,

Он помашет им ручкою

И исчезнет без примет.

Кандалы гремят в Сибири, 
Там всех примут рудники

И прикован цепью к тачке

Вася с Волги реки.

Пропала буйная головка,

Занесен песками след,

Атаманова сноровка

И не мил ему божий свет».

Запись этого несложного, лишенного основной обработки, но несомненно обладающего некоторой поэтической формой произведения, которое не пелось, а скорее декламировалось «в напев» навела меня на мысль исследовать его интересную тему. Последняя, насколько мне известно, нигде в литературе не встречалась. Из опроса исполнителя и его спутника, а позднее и ряда других лиц, я узнал, что в Макарьевском уезде, Нижегородской губернии, в середине прошлого столетия, объявился восемнадцатилетний юноша, именовавший себя «Васей, родным племянником атамана-казака Стеньки Разина». Вместе с несколькими, (кажется троими) бродягами, или, по местному, «есаулами» юноша совершал отчаянные налеты на самостоятельно спускавшиеся вниз по течению реки купеческие «расшивы». Подъехав на лодки, крикнув волжское «сарынь на кичку», призвав многочисленным бурлакам-работникам судна не двигаться с места, он смело поднимался на палубу вызывал доверенного-приказчика, отбирал у него всю денежную наличность и, не торопясь, благополучно скрывался в береговых зарослях. Местом для нападения, обычно, выбирался речной поворот, возле которого наметывались, препятствовавшие быстрому движению, песчаные косы. При этом, действуя запугиванием, Вася никогда не появлялся неожиданно. За несколько часов до налета, есаулы его подъезжали к расшиве и на традиционный бурлацкий «бог в помощь», отвечали: «ждите в ночь гостя - Васю, роднова племянника казацкого атамана Стеньки Разина. Вас - бедных, коль драться не будете, не обидит, а казну хозяйскую возьмет на хорошее дело!» Несколько десятков людей приходило в испуг от угроз двоих-троих смельчаков. Причина несомненно крылась в суеверном страхе. Считали, что храбрый, отчаянный человек, владеет секретом «казачьего слова», при котором «пуля не берет, сабля не ранит» и что сопротивление поэтому не только лишне, но и опасно. На этом основывали свой успех многие, как их называли, 
«волжские баловники». Стоило еще лет пятьдесят, семьдесят тому назад, приблизиться к борту грузового судна и крикнуть призвание «атаману с есаулами не перечить, из фузей не стрелять и слову казачьему чиниться», как все исполнялось в точности. Покорных не трогали, ослушников же наказывали самыми жестокими мерами, вплоть до розог, битья «под вздохи» и поджигания тела тлеющим канатом.

В Макарьевском уезде в 1907-08 годах «Васю» помнили хорошо, и старики могли рассказывать, хотя и расплывчато, но целые эпизоды из его похождений. Кончил атаман свои дни печально, по одним сведениям в Сибири, на каторге, по другим - от «не побоявшихся казачьего слова» пуль, отправленных властями на его поимку, солдат. «Племянник Разина» - личность во всяком легендарно-популярная и, хотя и скудно, но всё же отмеченная в бытовой словесности местных жителей. Говорили мне, что будто бы народные, «раусные» хоры песенников, выступавшие на гуляньях старой «Макарьевской ярмарки» имели в своем репертуаре сложенные про него, песни. Вероятно, к числу их относится и приведенный мною вариант. Можно предположить, что составлена она, как отражение местных, стародавних преданий, к.п. примитивистом автором, и играла роль балаганно-вокального репертуара. После исчезновения «Васи», вероятно в связи с его первыми успехами, появлялся еще второй «племянник казака Разина», но оперировал он непродолжительное время и словесной «памяти» о нем я не встречал».

Отдельные слова и выражения:

«Колотырный» - образованный, получивший шлифовку, нахватавшийся, - отсюда - бывалый;

«Затайка» - в данном случае тайно воспитанный, тайно выращенный;

«Присмертить» - убить;

«Плывучка» - перепрятываемый, скрываемый через многие руки;

«Перекваска» - перестоявшее тесто» (Л. I-6). 


\section{Список литературы}

I Иванов Е.П. Меткое московское слово. М.: Московский рабочий, г985. 320 c.

2 Морозов А.Г. Чужие письма. Эпопея // Знамя. I997. № II. С. 5-65.

3 Морозов А.Г. Чужие письма. Эпопея. М.: Грантъ, І999. І28 с.

4 Морозов А.Г. Общая тетрадь. Солилоквиум. М.: Грантъ, І999. г26 с.

5 Симаков В.И. Красноречие русского торжка. Материалы из архива В.И. Симакова. Публикация Т.Г. Булак. // Из истории русской фольклористики. Л.: Наука, Ленинградское отделение, І978. С. Іо7-І57.

6 ЦГАЛИ СССР. Путеводитель. Литература. М.: Главное Архивное Управление при Совете Министров СССР, г963. 8Іо с.

7 ЦГАЛИ СССР. Путеводитель. Выпуск 5. Фонды, поступившие в ЦГАЛИ СССР в I972-I977 гг. М.: Главное Архивное Управление при Совете Министров СССР, I982. $497 \mathrm{C}$.

8 Чудаков А.П. Бытописатель и собиратель живого слова // Иванов Е.П. Меткое московское слово. М.: Московский рабочий, г985. С. 6-40.

\section{References}

I Ivanov E.P. Metkoe moskovskoe slovo [Accurate Moscow word]. Moscow, Moskovskii rabochii Publ., I985. 320 p. (In Russ.)

2 Morozov A.G. Chuzhie pis'ma. Epopeia [Other People’s Letters. Epic]. Znamia, I997, no II, pp. 5-65. (In Russ.)

3 Morozov A.G. Chuzhie pis'ma. Epopeia [Other People's Letters. Epic]. Moscow, Grant" Publ., I999. I28 p. (In Russ.)

4 Morozov A.G. Obshchaia tetrad'. Solilokvium [A notebook. Solilloquium]. Moscow, Grant" Publ., I999. I26 p. (In Russ.)

5 Simakov V.I. Krasnorechie russkogo torzhka. Materialy iz arkhiva V.I. Simakova. Publikatsiia T.G. Bulak [Eloquence of Russian marketplace. Materials from V.I. Simakov archive]. Iz istorii russkoi fol'kloristiki [From the history of Russian folklore studies]. Leningrad, Nauka Publ., I978, pp. I07-I57. (In Russ.)

6 TsGALI SSSR. Putevoditel'. Literatura [TsGALI USSR. A guide. Literature]. Moscow, Glavnoe Arkhivnoe Upravlenie pri Sovete Ministrov SSSR Publ., I963. 8Io p. (In Russ.)

7 TsGALI SSSR. Putevoditel'. Vypusk 5. Fondy, postupivshie v TsGALI SSSR v 1972-1977 gg. [TsGALI USSR. Funds acquired by TsGALI in I972-I977]. Moscow, Glavnoe Arkhivnoe Upravlenie pri Sovete Ministrov SSSR Publ., I982. 497 p. (In Russ.)

8 Chudakov A.P. Bytopisatel' i sobiratel' zhivogo slova [The narrator of everyday life and collector of the living word]. Ivanov E.P. Metkoe moskovskoe slovo [Accurate Moscow Word]. Moscow, Moskovskii rabochii Publ., I985, pp. 6-40. (In Russ.) 
УДК $398+82$ I.I6I.I.O

ББК $82.3+83.3(2 \mathrm{Poc}=\mathrm{Pyc}) 6$
НОВЫЕ ПОСТУПЛЕНИЯ В ФОНДЫ МОСКОВСКОГО ЛИТЕРАТУРНОГО МУЗЕЯ-ЦЕНТРА К.Г. ПАУСТОВСКОГО

(C) 2018 г. А.И. Дормидонтова Московский литературный музей-центтр К.Г. Паустовского, Москва, Россия Дата поступления статьи: І2 января 2018 г. Дата публикащии: 25 марта 2018 г.

DOI: I0.22455/2500-4247-20I8-3-I-332-343

Аннотация: Представлен обзор новых материалов, поступивших в Московский литературный музей-центр К.Г. Паустовского в 2017 г., в год І25-летия со дня рождения писателя. Коллекция состоит из 366 единиц хранения. Это рукописи творческого характера, биографические документы, письма, книги с автографами, а также фотографии, афиши, буклеты, рисунки. Они представляют значительный интерес для изучения творческой лаборатории писателя, его биографии, для уяснения круга его общения и контактов с современниками. В обзоре воспроизводится ряд документов.

Ключевые слова: К.Г. Паустовский, рукописи, биография, творческая история произведений, переписка, дарственные надписи, Московский литературный музей-центр К.Г. Паустовского.

Информация об авторе: Анжелика Игоревна Дормидонтова - кандидат культурологии, директор Московского литературного музея-центра К.Г. Паустовского, ул. Кузьминская, д. 8, Іо9472 г. Москва, Россия.

E-mail: angelica_d@mail.ru 


\section{NEW ADMISSIONS TO THE K.G. PAUSTOVSKY MOSCOW LITERARY MUSEUM-CENTER}

This is an open access article distributed under the Creative Commons Attribution 4.0 International (CC BY 4.0)
(C) 20I8. A.I. Dormidontova

K.G. Paustovsky Moscow Literary Museum-Center, Moscow, Russia

Received: January $\mathrm{I} 2,2018$

Date of publication: March 25, 2018

Abstract: This is an overview of a new collection received by the K.G. Paustovsky Moscow Literary Museum-Center in 20I7, the year of the I25th anniversary of his birth. The collection consists of 366 items. Among them are manuscripts, biographical documents, letters, books with autographs, photographs, posters, booklets, and drawings. These items are of considerable interest for the study of the writer's methods, his biography as well as for understanding the circle of his contacts. The overview incorporates a number of authentic documents.

Keywords: Konstantin Paustovsky, manuscripts, biography, history of literary works, correspondence, inscriptions, K.G. Paustovsky Moscow Literary Museum-Center.

Information about the author: Angelica I. Dormidontova, $\mathrm{PhD}$ in Cultural Studies, Director of the K.G. Paustovsky Moscow Literary Museum-Center, Kuzminskaya 8, I09472 Moscow, Russia.

E-mail: angelica_d@mail.ru 
В 2017 г. в России широко отмечалось І25-летие со дня рождения К.Г. Паустовского. Прошли международные научно-практические конференции, были организованы выставки, круглые столы, конкурсы, реализованы различные образовательные проекты, вышли книги писателя, наблюдался значительный рост числа научных публикаций о нем, а также материалов в печатных и электронных СМИ. Среди наиболее важных событий прошедшего года - значительное пополнение фондов Московского литературного музея-центра К.Г. Паустовского. Правительством Москвы была закуплена коллекция рукописей, писем, книг с автографами, а также других уникальных документов. Коллекция включает в себя 366 мемориальных предметов.

Среди приобретенных документов особую ценность имеет открытка, отправленная К.Г. Паустовскому И.А. Буниным I5 сентября 1947 г.

В открытке содержится отзыв на рассказ К.Г. Паустовского «Корчма на Брагинке», являющийся главой автобиографической книги писателя «Повесть о жизни»:

Дорогой Собрат! Я прочел Ваш рассказ «Корчма на Брагинке» и хочу Вам сказать о той редкой радости, которую испытал я: если исключить последнюю фразу этого рассказа («Под занавес»), он принадлежит к наилучшим рассказам русской литературы.

Привет, всего доброго!

I5.IX.47

Ив. Бунин 

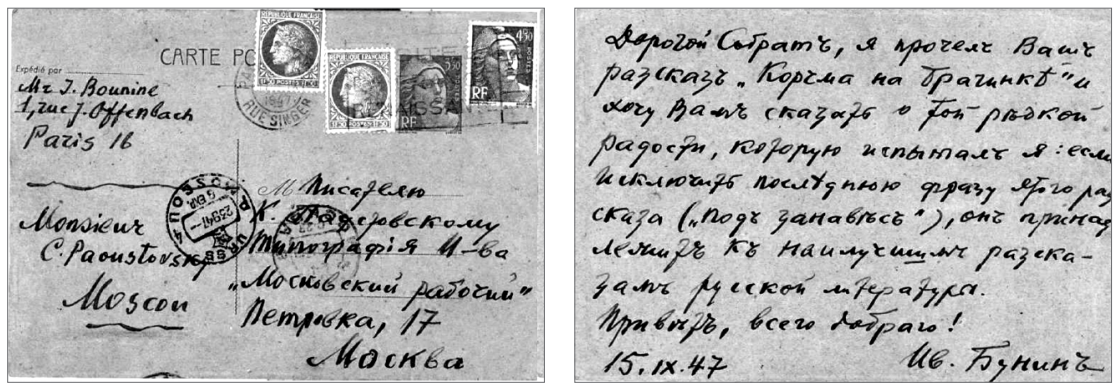

Отзыв И. А. Бунина на рассказ К.Г. Паустовского «Корчма на Брагинке» Ivan Bunin's review of Paustovsky's story "A Tavern at Braginka”

Известно, что К.Г. Паустовский очень дорожил данной открыткой, считал ее своей самой большой литературной наградой. Поступление этого документа в фонды музея, в котором хранится значительная часть писательского архива, - символический подарок писателю в юбилейный год.

В коллекцию также входят книги с автографами К.Г. Паустовского, фотографии, письма, записки, афиши, буклеты, рисунки, различные документы. Они относятся к периоду 1930-І940-х гг. и имеют высокую ценность для коллекции музея, так как данный период жизни и творчества К.Г. Паустовского ранее был представлен в музейном собрании малым числом материалов.

Особо ценными среди документов, пополнивших музейные фонды, являются рукописи (рабочие записи) пьес К.Г. Паустовского «Созвездие гончих псов», «Пока не остановится сердце», «Наш современник»; письма и телеграммы периода Великой Отечественной войны (I94I-I945); личные документы, фотографии и удостоверения писателя I9I7-I94I гг.

Книги с автографами К.Г. Паустовского хранились наследниками второй жены писателя Валерии Владимировны Валишевской на протяжении 60 лет. Автографы писателя представлены на прижизненных изданиях его произведений: «Мещёрская сторона», «Дождливый рассвет», «Кара-Бугаз», «Степная гроза», «Монисто». В коллекции также имеются автографы на изданиях произведений писателя на иностранных языках и книгах других авторов (Шарль де Костер «Легенда об Уленспигеле и Ламме Гудзаке», И. Гончаров «Обрыв», Р. Джованьолли «Спартак»). На авантитулах и форзацах некоторых книг приклеена марка «А.С. Пушкин» (юбилейная). Известно, что К.Г. Паустовский в І930-I940-е гг. помечал данной маркой книги из лич- 
ной библиотеки, так как не имел собственного экслибриса. Книжные здания с такой же маркой хранятся в Мемориальном доме писателя в Тарусе. Автографы на книгах поступившей в музей-центр коллекции обращены к В.В. Валишевской и приемному сыну писателя Сергею Михайловичу Навашину. Записи носят личный характер, указывают на теплые семейные отношения, свидетельствуют об увлечениях писателя, о географии его поездок и путешествий, о творческих планах, об истории создания некоторых произведений.

Частью данной коллекции является семейный фотоархив 1930I940-х гг. В нем представлены фотографии периода проживания писателя в поселке Солотча Рязанской области; фотографии, сделанные во время поездок писателя в Крым; групповые семейные фотографии. Большой блок фотоархива представлен авторскими фотографиями, сделанными писателем в 1930-I940-е гг. во время путешествий по России. Фотография - одно из любимых увлечений К.Г. Паустовского, однако большая часть сделанных им снимков не сохранилась. Писатель любил фотографировать пейзажи, людей и жанровые сцены из провинциальной жизни. Представленные работы отражают особое «живописное» видение мира писателем, произведения которого часто называют «картинами в прозе».

В данный архив входят также личные документы и записки писателя, относящиеся к периоду I917-1950-х гг. Среди них: удостоверение военного корреспондента TACC (I94I); удостоверение члена Совета работников Сухума (I922); членский билет Всероссийского союза работников просвещения (Московский губотдел; І9I7); членский билет К.Г. Паустовского № 2046I25 (АВИАХИМ РСФСР; 2 июня І926) и другие документы.

Несомненную мемориальную ценность имеет блок писем, телеграмм и записок писателя домочадцам, друзьям, знакомым; а также писем, обращенных к писателю, творческих рукописей К.Г. Паустовского (95 единиц хранения, все документы подлинные). Среди данных документов имеются особо ценные. Это фрагменты рукописей таких произведений, как «Созвездие гончих псов», «Пока не остановится сердце», «Наш современник». Значительный интерес представляют письма и телеграммы военного периода (I94I-I945): телеграмма о возвращении с фронта (I94I), письмо бойца К.Г. Паустовскому с благодарностью за творчество (I942), несколько писем из Алма-Аты, где писатель с семьей находились в период эвакуации. В эту часть коллекции входят письма от редакций разных периодических изданий 
с приглашением к сотрудничеству, приглашение от имени А.А. Фадеева принять участие в работе Шевченковского пленума правления Союза писателей СССР, письмо о защите усадьбы И. Пожалостина в Солотче. Все они имеют несомненную мемориальную, культурную и историческую ценность.

В коллекцию входят также афиши театральных постановок по произведениям К.Г. Паустовского. Работа для театра по созданию сценариев, либретто - малоизученная сторона творчества К.Г. Паустовского. Начиная с І930-х гг. по совету Ю.К. Олеши К.Г. Паустовский начинает писать для театра. Наиболее известны такие его пьесы, как «Простые сердца», «Созвездие гончих псов», «Пока не остановится сердце», «Кружевница Настя», «Преодоление времени», «Поручик Лермонтов», «Наш современник».

Несомненную мемориальную ценность имеют также коллекции писем и книг с автографами К.Г. Паустовского первой жене Екатерине Степановне Загорской и старшему сыну Вадиму Константиновичу Паустовскому.

В фондах музея-центра хранится значительная часть архива первой семьи писателя, переданная на государственное хранение старшим сыном писателя В.К. Паустовским. Из-за сложных жизненных обстоятельств и частых переездов В.К. Паустовского часть семейного архива была им утеряна, в том числе закупленные в настоящее время письма. Приобретение их в коллекцию музея-центра имеет большое значение для изучения творчества и биографии писателя.

В письмах речь идет о частной жизни К.Г. Паустовского, в некоторых из них имеются указания на важные моменты, связанные с его творческой работы над текстами. Например, в письме от 3 января г930 г. содержатся сведения о написании рассказа «Сумрак». Это первое известное нам упоминание об этом произведении.

Книги с автографами К.Г. Паустовского, адресованными сыну В.К. Паустовскому и жене Е.С. Паустовской (Загорской), позволяют восстановить некоторые события жизни писателя и его семьи, доказывают сохранение его теплых отношений со старшим сыном на протяжении всей жизни.

Закупленные предметы имеют исключительную мемориальную и культурно-историческую ценность, требуют всестороннего изучения. Документы были впервые представлены на юбилейных выставочных проектах: мобильной выставке «Россия глазами Паустовского» (Москва, Старый Арбат, I-2I ноября 20I7), на выставках «Паустовский и кино» (Москва, галерея 
«Беляево», І ноября - I5 декабря 20I7) и «Константин Паустовский. Без купюр» (Москва, Государственный музей А.С. Пушкина, выставочные залы на Арбате; г4 декабря 20I7 - 4 февраля 2оІ7 года).

Ниже впервые публикуется несколько документов из поступившей в фонды Московского литературного музея-центра К.Г. Паустовского коллекции.

\section{І. Письмо. К.Г. Паустовского В.К. Паустовскому. 09.08.1937. I л.}

В конверте, с указанием отправителя:

Солотча, Мос<кковской > области, Рязанского района, дом 8о, К.Г. Паустовский

Получатель:

Одоев, Московской области

с. Николо-Жупань

Дом отдыха Литфонда

Вадиму Константиновичу Паустовскому

Москва 9 августа

Димушка-мальчик, получил ли ты мою открытку с реки Десны. Союз писателей послал меня на Десну с двенадцатью московскими комсомольцами, чтобы пройти на лодках от Брянска до Новгород-Северска (около 400 километров). Мы прошли 200 километров до города Трубачевска за 8 дней и там я прекратил эту экспедицию и отправил всех в Москву, т. к. большинство комсомольцев - горожане, совершенно неприспособленные к экспедиционной жизни и не умеющие работать, даже гресть. Был даже один, который впервые в жизни видел, как кипит ключом в котелке вода (на костре) и страшно испугался, - поднял крик на весь лагерь.

Река очень быстрая, в некоторых местах течение идет со скоростью І2 километров в час, есть громадные водовороты и плыть по такой реке с неопытными людьми - очень трудно. Я очень устал, но окреп и страшно загорел. На днях поеду в Солотчу и засяду там за работу на всю осень, - летом я много ездил и работать не успевал. Напиши мне в Солотчу (Солотча, Московской области, Рязанского района, дом 80) как твое здоровье, как ты живешь и когда вернешься в Москву, - я к этому времени пришлю в Москву деньги.

Целую тебя крепко 
Письмо. К.Г. Паустовского В.К. Паустовскому. 09.08.1937

A letter from K.G. Paustovsky to V.K. Paustovsky. 09.08.1937

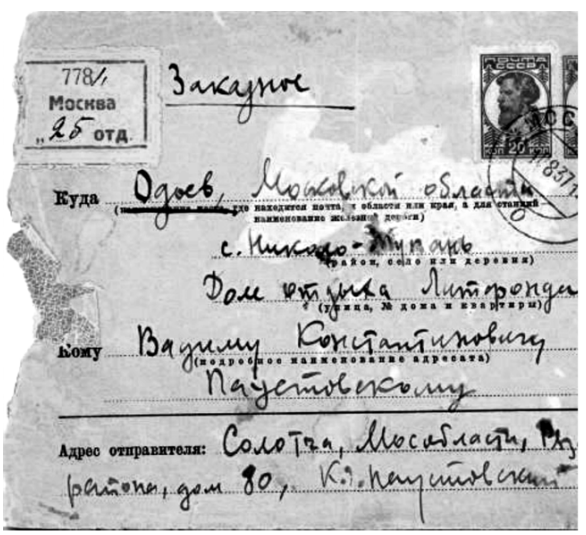

\section{leockba 9 abrucia}

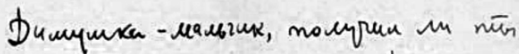
soro otkpbiniky c peren becren. Cores rucaiterent rocuar sums wa becry $c$ gbesragyañitro uoculobckerem komcouseryam, ztío de upointu na logkak ot Splnurea yo thesopoq-Cebepma (Oxoces too kunsvermfoe). Me mpousm 200 keres;

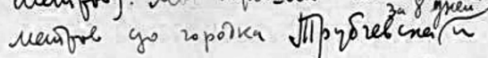

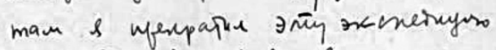
$n$ appabur bes b luscly, $m . K$.

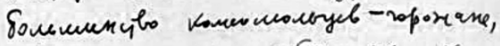

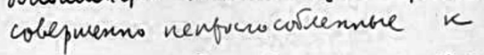

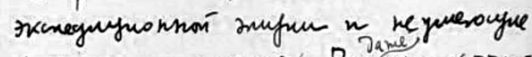

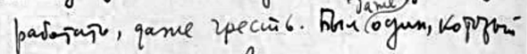

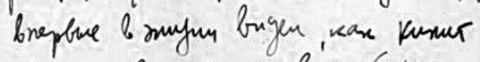
kisorem l koience boga ( her vacrol $x$ croamsno uariparas, -

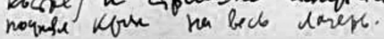

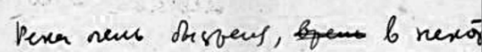
resat trenice nget do cregrsor 12 kicousofe Plac, ent youcasic

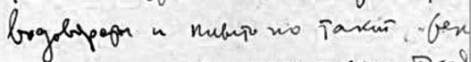

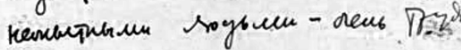
S reces yciar, two oxfen "s croen zenfen. Ha quex noety \& Covoing grution tam ja pasory ha bse ocent, - repour \& uscors gore. parotame ve Ycrelan. Hanumus une b Couoring (Covo

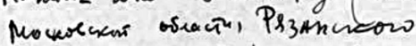
pañonea, gom 80) kan fove Yopobe, cox in mubeuss n visou bepreasus b lessely,

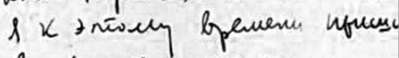
l nocrey genom.

Mana. 


\section{2. Пропуск К.Г. Паустовскому на Красную площадь в день похо- рон А.М. Горького. 20 июня 1936}

Пролетарии всех стран, соединяйтесь! Пропуск № 918

Тов. Паустовский для входа на Красную площадь в день похорон

Алексея Максимовича Горького

20 Июня 1936 года.

\section{Нач. Оперода ГУГБ НКВД}

Комиссар Гос <ударственной $>$ Безопасн< <ости $>2$ ранга Паукер.

Левая трибуна

Вход со стороны площ. Революции через Кремлевский проезд.

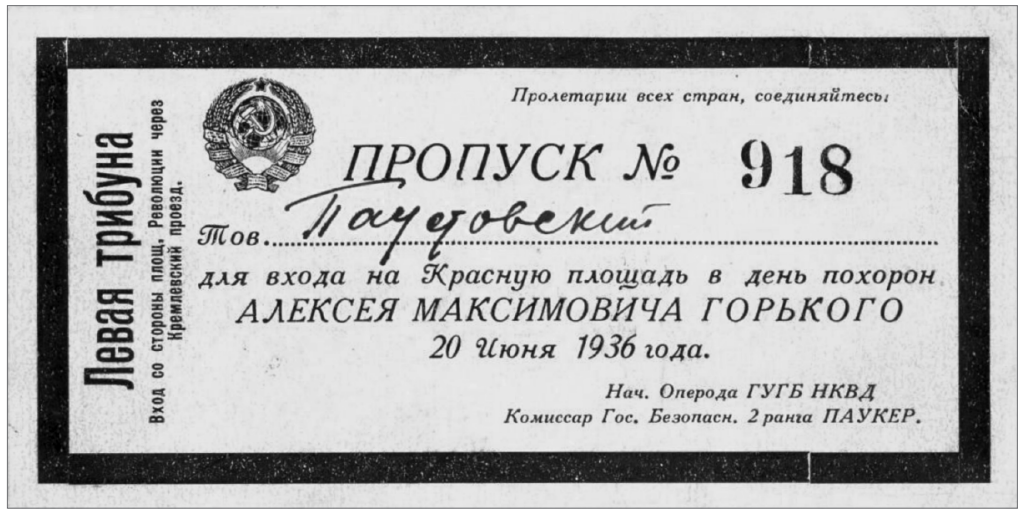

Пропуск К.Г. Паустовскому на Красную площадь в день похорон А.М. Горького. 20 июня 1936

Paustovsky's pass on Red Square on the day of Maxim Gorky's funeral, June 20, I936 


\section{3. Членский билет Всероссийского союза работников просве- щения на имя К.Г. Паустовского}

Пролетарии всех стран, соединяйтесь! ВСЕРОССИЙСКИЙ СОЮЗ РАБОТНИКОВ ПРОСВЕЩЕНИЯ

Московский Губотдел

Членский билет № 5 IIO8

Москва

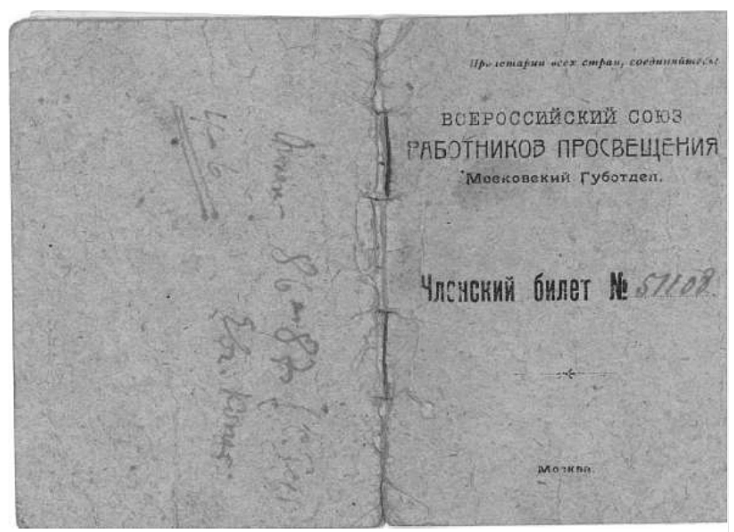

Пролетарии всех стран, соединяйтесь!

Всероссийский Союз Работников Просвещения

Московский Губотдел

Уотделение

Секция Раб<отников > печати

ЧЛЕНСКИЙ БИЛЕТ № 51108

Фамилия Паустовский

Имя, Отчество Конст <антин> Геор <гиевич>

Год рождения 1892

Специальность журнал<ист>-литер <атор >

Семейное положение женат

Число лиц, находящ<ихся> на иждивении $I$

Время вступления в Союз 1917

Секретарь Губотдела < подпись> 
Зав. орготделом $<$ подпuсb $>$

Дата выдачи билета <не заполнено>

Печать

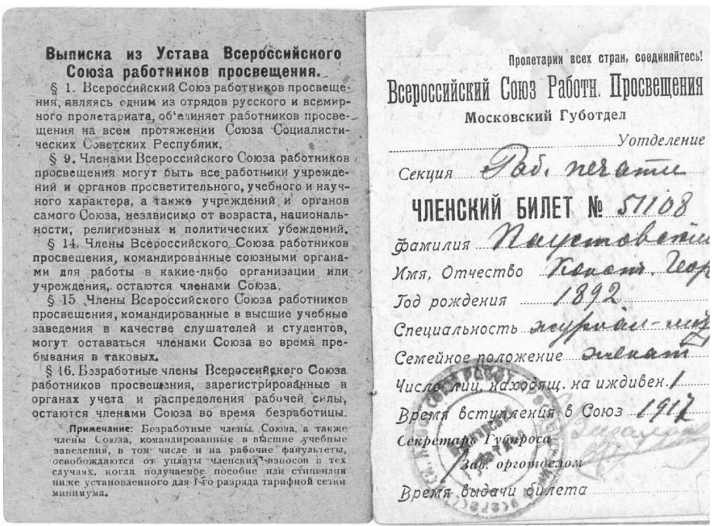

Членский билет Всероссийского союза работников просвещения на имя К.Г. Паустовского

Paustovsky's Membership ID of the All-Russian Union of Education Workers

\section{4. Удостоверение К.Г. Паустовского - специального военного корреспондента TACC. I94I}

Телеграфное агентство Советского Союза при Совнаркоме СССР

TACC

\section{УДОСТОВЕРЕНИЕ}

Предъявитель сего тов. Паустовский Константин Георгиевич является специальным военным корреспондентом ТАСС в Действующей Красной Армии.

Действительно до зІ декабря I94I 2.

Ответственный руководитель ТАСС $<$ подпись $>$ (Я. Хавинсон)

Москва, «27» июня I94I г. № 207

Печать

Личная подпись $<$ К.Паустовский>

Зав. отделом кадров $<$ подпись $>$

«27》 июня I94I г.

Печать 


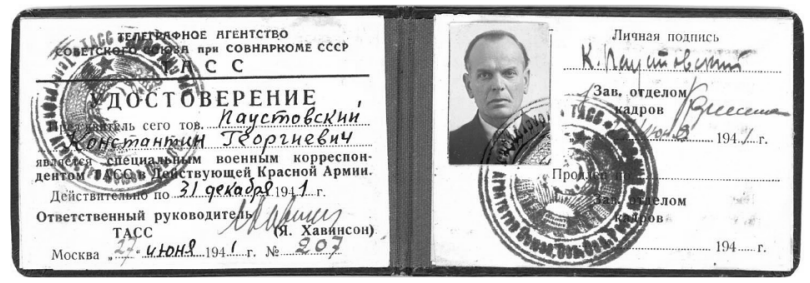

Удостоверение К.Г. Паустовского - специального военного корреспондента ТАСС. I94I

Paustovsky's ID as a special military TASS correspondent, I94I

\section{5. Дарственная надпись К.Г. Паустовского В.В. Навашиной.}

\section{Январь 1947.}

Валюшке - первый экземпляр книги, которую она уговорила меня написать.

Костя.

Январь, 47 г.

На книге:

Паустовский К. Далекие годы. Повесть о детстве и юности. Рис. Б. Дехтерева. М. - Л.: Детгиз, І946. 332 с., илл.

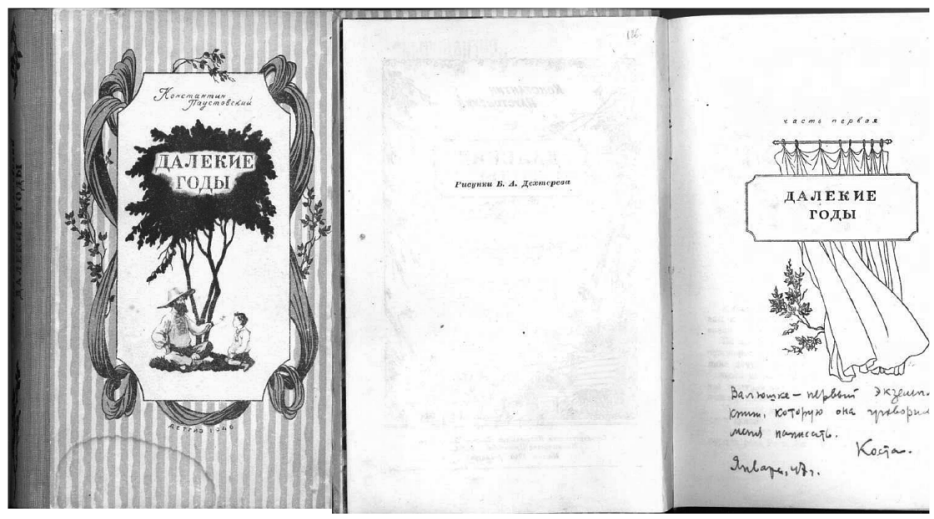

Дарственная надпись К.Г. Паустовского В.В. Навашиной. Январь 1947 Inscription dedicated to V.V. Navashina. January 1947 
(c) 2018 г. Л.П. Якимова

Институт филологии Сибирского отделения Российской академии наук,

Новосибирск, Россия

Дата поступления статьи: 24 августа 2017 г. Дата публикации: 25 марта 2018 г.

DOI: IO.22455/2500-4247-20I8-3-I-344-358

Ключевые слова: всесоюзная конференция, инонациональная русская литература, поэтика остранения, национальные литературы Сибири, Ташкент, Самарканд.

Информация об авторе: Людмила Павловна Якимова - доктор филологических

наук, главный научный сотрудник, Институт филологии Сибирского отделения Российской академии наук, ул. Николаева, д. 8, 630090 г. Новосибирск, Россия. E-mail: MalininaLG@ipgg.sbras.ru 


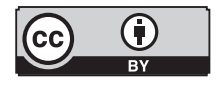

This is an open access article distributed under the Creative Commons Attribution 4.0 International (CC BY 4.0)
FROM THE MEMOIR OF AN ACADEMIC LADY. ABOUT THE ALL-UNION ACADEMIC CONFERENCE IN TASHKENT, 1975 (INTRODUCTION BY ELENA A. PAPKOVA)

(C) 20I8. L.P. Yakimova Institute of Philosophy, Siberian Department of the Russian Academy of Sciences, Novosibirsk, Russia

Received: August 24, 2017

Date of publication: March 25, 2018

Keywords: All-Union conference, Russian literature in languages other than Russian, the poetics of "estrangement," Siberian national literatures, Tashkent, Samarkand.

Information about the author: Liudmila P. Yakimova, DSc in Philology, Director of Research, Institute of Philosophy, Siberian Department of the Russian Academy of Sciences, Nikolaeva 8, 630090, Novosibirsk, Russia.

E-mail: MalininaLG@ipgg.sbras.ru 


\section{Предисловие}

Ученым-филологам, наверное, не нужно представлять Людмилу Павловну Якимову, автора и героиню этих воспоминаний, - главного научного сотрудника Института филологии СО РАН, доктора филологических наук, автора семи монографий по истории русской литературы и более 300 научно-теоретических и литературно-критических статей, посвященных творчеству А.С. Пушкина, Ф.М. Достоевского, И.А. Гончарова, Д.Н. Мамина-Сибиряка, А.П. Чехова, Л.М. Леонова, Вс.В. Иванова и других писателей. Над своими мемуарами Л.П. Якимова работает последние годы, большая часть их опубликована в № 4-6 журнала «Сибирские огни» за 20І7 г., отдельный фрагмент, с подзаголовком «Из воспоминаний об Академгородке», напечатан в небольшом сборнике «III-IV Литературно-краеведческие Ивановские чтения. 20I5-20I6. Статьи, материалы, сообщения» (Новосибирск, 20I7). Людмила Павловна, урожденная нижегородка, беспредельно благодарная городу, «откуда есть пошла» ее жизненная дорога, предстает в этих мемуарах как человек, очарованный Сибирью, не устающий восхищаться «нестандартностью архитектурного облика сибирских городов, неповторимыми особенностями их культурно-исторической атмосферы, своеобразием их человеческого климата». Представляемая читателю глава этих мемуаров посвящена, однако, не Сибири, а Востоку - поездке в Ташкент на научную конференцию, где произошли значимые для автора встречи, в том числе и с сотрудниками ИМЛИ, научные и личные открытия.

Елена Алексеевна Папкова, кандидат филологических наук, старший научный сотрудник, Институт мировой литературы им. А.М. Горького

Российской академии наук 
В плавно текущем десятилетии 7о-х из самой середины их память выхватывает несколько главных событий. Одно из них - это летом 1975 г. поездка в Ташкент на Всесоюзную научную конференцию, которая, с одной стороны, в живых красках и звуках, природных картинах и человеческих образах оставила яркий след в общем опыте моих путешествий, ответив моему неутолимому любопытству к жизни других стран и народов, а с другой стороны, сверх моих ожиданий поездка оказалась чрезвычайно важной в плане как стабилизации моих научных интересов, так и определения перспектив научной работы.

Я поехала на эту конференцию на свой страх и риск, не возлагая каких-то особых надежд на участие в ней, а приехав, удивилась ее научно-организационному размаху. Это был настоящий филологический форум, прямо-таки съезд известных литературоведов всего СССР, собравшихся на обсуждение важнейших проблем развития многонациональной литературы страны в свете тех сдвигов, которые происходили в методе социалистического реализма. Для участия в конференции прибыли ученые Азербайджана, Армении, Таджикистана, Казахстана, Киргизии, Татарстана, Литвы, Калмыкии, Бурятии... Приехала и большая группа москвичей - сотрудников Института мировой литературы АН СССР, членов редколлегии журнала «Вопросы литературы», среди которых хорошо запомнилась строгая и неприступно державшаяся Анна Николаевна Дмитриева, многие годы бывшая бессменным ответственным секретарем «Воплей». И хотя Программа конференции ориентировала на внимание к особенностям социалистического реализма в литературах Востока, уже первые доклады повернули ее в русло обсуждения общетеоретических проблем, и тон задали москвичи. Доклад Г.И. Ломидзе, открывшего конференцию, назывался «Спорные проблемы 
теории социалистического реализма», доклад одного из известных в те годы литературоведческих теоретиков Л. Якименко - «Проблемы социалистического реализма», 3.С. Кедрина выступила с докладом «Новая историческая общность людей - советский народ и литература социалистического реализма». Ее приезд на Ташкентскую конференцию приобретал знаковый смысл. Ей было тогда 70 лет, выглядела она, как мне показалось, старше, воспринималась как патриарх советской многонациональной культуры. Она стояла у истоков критической мысли о творчестве писателей, ставших классиками советской многонациональной литературы и своих национальных литератур - М. Ауэзова, М. Ибрагимова, Ч. Айтматова и др., много сделала для практического и теоретического обоснования советской школы переводчиков с национальных языков. Мы жили в одном гостиничном номере, но сил на общение не оставалось: у одной - из-за обилия почестей и внимания к глубокоуважаемому литературоведу, у другой из-за переполненности впечатлениями от самого Узбекистана. Встретимся уже близко к ночи в номере, поулыбаемся друг другу и заснем, как убитые, до утра.

Из сибиряков на конференции, кроме меня, был еще Василий Цыренович Найдаков, но тогда мы и с ним были еще не знакомы, и я с любопытством вглядывалась в лица ее участников, когда однажды во время перерыва с удивлением услышала обращенный ко мне вопрос:

- Так это Вы - Якимова? Я знаю Ваши работы. Моя статья со ссылкой на них только что вышла в «Вопросах литературы». Номер у меня с собой, я Вам его подарю...

Это был Роберт Гатович Бикмухаметов, он много тогда писал о младописьменных и новописьменных литературах России и вел речь о статье «Десять лет спустя», которой я еще в «Вопросах литературы», собираясь на конференцию, увидеть не успела.

- А я по Вашим статьям представлял Вас другой.

- Какой же?

- Ну, солидней, старше что ли. Вроде Зои Сергеевны... А Вы такая... Вы куда вечером идете?

- Куда пригласят...

- А примыкайте к нам.

«Ими» оказались как раз сотрудники ИМлИ и «Воплей», и это послужило началом многолетнего сотрудничества, в разной степени интенсивности проявлявшегося в многообразии научных контактов. Вспоминаются выездные 
сессии ИМлИ в Якутск и Улан-Удэ, общая работа на заседаниях Ученых советов, связанных с обсуждением и защитой диссертаций... Теперь, приезжая в Москву, чаще всего по делам продвижения двухтомных «Очерков русской литературы Сибири» в печать, я уже не могла не нанести дружеского и профессионального визита в Отдел литературы народов СССР, а иногда и в редакцию «Вопросов литературы».

Мой доклад на Ташкентской конференции назывался «Об одном малоизученном аспекте интернационализма советской литературы», и интерес к нему был закономерен во многих отношениях. Русскоязычное литературоведение Сибири я представляла одна, при этом, что значило немало, я была из Академгородка, Сибирь же тех лет с ее мощным рывком индустриального развития в глазах всей страны предстала как форпост социализма, что естественным образом сопровождалось и ее культурными успехами, весьма заметными как в русской, так и национальных литературах.

Еще работая в авторском коллективе «Истории Сибири» под руководством А.П. Окладникова, я обратила внимание на широкий круг русских писателей, сосредоточивших свой творческих интерес на изображении текущей жизни и исторических судеб других народов Сибири, т. е. на инонациональной теме русской литературы, ее глубинном интернационализме.

С течением времени у этой темы отчетливо выявился особый ракурс, связанный с пристальным вниманием к тем народам, которые до Октября сохраняли общинно-родовой строй и своей письменности не создали. И если такие сибирские народы, как якуты, буряты, хакасы, тувинцы и алтайцы, письменностью располагавшие, вошли в новую жизнь с привившимися уже в разной степени ростками национальной литературы, то миссию определить в мире культурно-историческую роль таких народов, как чукчи, ненцы, нивхи, удэге, нанайцы, эвены, эвенки, юкагиры и др. взял на себя русский писатель, равно как на другом континенте эту миссию рассказать читателю о жизни эскимосов взяли на себя американец Рокуэлл Кент и канадец Фарли Моуэтт.

И так продолжалось до тех пор, пока в культурном пространстве этих народов не родился свой национальный писатель - Владимир Санги у нивхов, Григорий Ходжер у нанайцев, Юрий Рытхэу у чукчей... Именно тогда возникла необходимость в появлении новой терминологии, обеспечившей различение младописьменных, как якутская, и новописьменных, как нивхская, литератур. Пока шел процесс оформления младописьменных и новописьменных литератур, 
в русской литературе возник мощный отряд писателей, сосредоточивших исключительное внимание на изображении жизни многочисленных народов страны, населяющих бескрайние побережья Северного Ледовитого океана до Дальнего Востока, Приамурья, Якутии, Хакасии, Тувы, Горного Алтая... Взгляд русского писателя проник в лопарскую хоту, юкагирскую урасу, ненецкий чум, чукотскую ярангу, алтайский аил: русская литература за короткое время невиданно обогатилась живописанием исторических судеб многочисленных, ранее неизвестных миру народов России, их истории, образа жизни, обычаев, психологии. Это был в истории российской литературы период, когда одновременно щедрую дань инонациональной теме отдали В. Арсеньев, М. Задорнов, Т. Семушкин, А. Коптелов, К. Урманов, А. Сорокин, М. Ошаров, Р. Фраерман, Г. Гор, И. Кратт. Незаконченным романом «Последний из удэге» откликнулся на актуальную тему А. Фадеев.

Тема жизни и исторических судеб народов, сразу чуть ли не из первобытного бытия - общинно-родового строя - шагнувших в не виданную ранее реальность, оказавшихся в мире осуществления нового социального проекта строительства социализма с прицелом на коммунизм, таила огромный смысловой и эстетический потенциал, оказалась необычно продуктивной для писателей и притягательной для читателей. За горячим материалом в Сибирь буквально хлынула лавина литераторов разного творческого профиля - журналистов, прозаиков, очеркистов. Особенно притягательна была высказанная Ф. Энгельсом в работе «Происхождение семьи, частной собственности и государства» мысль о перекликающейся через столетия близости многих социально-этических норм первобытно-общинного строя и социалистического общества.

Обращаясь к инонациональной проблематике, русский писатель стремился испытать ее в разнообразии жизненных ракурсов, расширяя диапазон эмоционально-смысловых и эстетических ощущений читателя. Так в целом ряде своих повестей - «Ланжеро» (І937), «Неси меня, река» (I938), «Синее озеро» (1939), «Юноша с далекой реки» (І953) и многих рассказов - Г. Гор как бы переворачивает типичную для произведений на инонациональную тему ситуацию, изображая не представителя цивилизованного мира в окружении детей природы, а именно представителя нетронутой цивилизацией среды погружая в мир современной культуры, и она предстает в виденье человека, абсолютно не искушенного в ее ценностях, наделенного особой остротой, свежестью и непосредственностью восприятия жизни, того наивного изумления и первозданного взгляда на нее, какой характерен, например, для юного Нота Чевыркайна, из 
повести «Юноша с далекой реки», приехавшего в Ленинградский Институт народов Севера из таежного нивхского стойбища, предоставляя и читателю видеть окружающий мир как бы заново, в фокусе широко развернутой поэтической фигуры остранения.

В этого рода произведениях русский писатель обращается к нетронутым залежам фольклора народов Сибири, богатствам этнографического колорита их жизни - изображению характера социальных и семейных отношений, особенностей труда и быта, жилищного устройства, национальной педагогики, разнообразия верований, особенностей бытовых, трудовых, религиозных ритуалов, привлекая читателя новизной впечатлений от многообразия форм человеческой жизни.

Примечательно, что инонациональный слой русской литературы отмечен ярко выраженным авторским стремлением расширить пространство символического звучания образной системы, что находит отчетливое отражение в названиях произведений: «Великое кочевье» - роман А. Коптелова о крутой перемене исторического курса алтайского народа в зо-е годы; роман М. Ошарова «Большой аргиш» (1936) о тяжких испытаниях эвенков в годину исторического перелома, связанного с проникновением буржуазных отношений в сибирскую таежную глушь; «Последний из удэге» (I929-I94I) А. Фадеева, «Последний костер» (I968 и 198I) Г. Федосеева, «Дерсу Узала» В. Арсеньева - все они так или иначе в разной степени полнятся той атмосферой интертекстуальности, которая восходит к обширному массиву произведений зарубежной литературы типа «Последний из могикан» Фенимора Купера, озабоченных судьбой народов (индейцы, эскимосы и др.), попавших под пресс цивилизации.

Несомненное своеобразие и неповторимость поэтики произведений на инонациональную тему, создавая отдельное идейно-тематическое, образно-мотивное и жанровое пространство советской литературы, обретает благодаря широкому использованию их авторами принципов теории остранения, исходившей из требований художественного живописания предметов, явлений, обстоятельств как впервые увиденных, или, как говорил В. Шкловский, «вывода вещи из автоматизма восприятия».

Во многом благодаря притягательной силе поэтического мира произведений на инонациональную тему, обнажающих нетленные залежи фольклорного и этнографического материала, а равно сохраняющих эффект искреннего изумления человека перед таинством бытия разных народов, читательский интерес к ним 
не иссякает и по сию пору. По-прежнему с интересом читается и «Дерсу Узала» В. Арсеньева, и «Чукотка» Т. Семушкина, и «Последний костер» Г. Федосеева. Не исчерпана ни идейно-тематическая, ни эстетическая продуктивность инонационального жанра, свидетельством чего служит, например, появление на страницах «Сибирских огней» новой повести Г. Прашкевича «Хромой пастух» (20I7, № 6), воспроизводящей жизнь юкагиров на заре колонизации Сибири русскими, убеждая в эффективности характерной для такого рода произведений поэтики остранения.

И если, обращаясь к 30-40-50-м годам, учесть, что наряду с русскими писателями, изображающими жизнь сибирских народов, и среди национальных писателей появились пишущие на русском языке, то разобраться в этом сложном культурно-литературном субстрате оказалось не просто, что и вызвало появление новых литературоведческих дефиниций. Я просекала этот богатый литературный пласт в разных направлениях: и в академических изданиях «Известия СО АН СССР», «Наука в СССР», и в журналах «Сибирские огни», «Дальний Восток», «Енисей» появлялись мои статьи и на инонациональную тему, т. е. о творчестве А. Коптелова, М. Ошарова, А. Сорокина, К. Урманова и т. д., обращенном к изображению жизни алтайцев, казахов, эвенков и др., и о первом национальном романе в алтайской («Арина» Л. Кокышева), тувинской («Слово арата» С. Тока), нанайской («Амур широкий» Г. Ходжера) литературах, и в аспекте сопоставления творчества советских и зарубежных писателей, писавших о народах, шагнувших в цивилизацию прямо из родового строя. Именно об этом была моя статья «“Чукотка” Тихона Семушкина и “Саламина” Рокуэлла Кента».

Итогом перманентного, начиная со времени работы в Горном Алтае, моего интереса к этой действительно мало изученной проблеме русской литературы явилась монография «Многонациональная Сибирь в русской советской литературе» (1982), вышедшая в один год с коллективным трудом сибирских филологов «Очерки русской литературы Сибири» в двух томах. Важно отметить, что даже из числа близких коллег, непосредственно работавших над осуществлением проекта «Очерков русской литературы Сибири», не все понимали смысл моих «отвлечений» в сторону инонациональной проблематики и проблем становления национальных литератур Сибири. Как непосредственный руководитель проекта, Ю.С. Постнов склонен был даже, не без оттенка ревности, усматривать в этих моих статьях такого рода работу, на которую затрачивается время в ущерб интересов двухтомника. С похожей позицией столкнулась и при подготовке к печати 
сборника статей, сопутствующих двухтомнику, когда с подачи редактора, желающего подстраховаться от ошибок, директор издательства «Наука» Омбыш-Кузнецов усомнился в необходимости моей статьи о первых романах в национальных литературах Сибири. По плану подготовки двухтомника к печати я готовила разделы о сибирском очерке, производственном романе, творческом пути отдельных сибирских писателей, но отчетливо видела глубинную связь путей русской литературы Сибири и культуры ее народов. Связь эта, не всегда отчетливо видимая, была органичной, системной, не исключая того, что опыт русских писателей в освещении сибирских реалий послужил своего рода почвой для развития национальных литератур Сибири.

На Ташкентской конференции я обрела всесоюзную трибуну для научной презентации своей концепции, и еще то было важно, что многое восуществилось в личные контакты с людьми, занимающимися одной проблемой. С членами Отдела, возглавляемого Г.И. Ломидзе, сложились отношения научно-производственного взаимопонимания, а в случае с Н.Н. Воробьевой - переросшие в сердечно-теплую дружбу. Междугородний характер дружбы придавал ей особый эмоциональный колорит, и, кстати сказать, все жизненное поведение Нины Николаевны очень выразительно характеризовало межнациональные отношения в стране: среди ее аспирантов были выпускники Грозненского университета и иногда девушки-черкешенки находили гостеприимный кров в ее квартире на Комсомольском проспекте, куда любила приходить и я провести иногда вечер в кругу ее семьи - мамы и мужа.

Не менее важной стороной этой поездки на Ближний Восток была возможность познакомиться с Узбекистаном как одной из пятнадцати республик, входивших в состав СССР, и широта национального гостеприимства такой возможности соответствовала. C I876 г. Узбекистан входил в состав Российской империи, Ташкент - город хлебный - воспринимался как город российский. В I966 г. мощное землетрясение превратило его в руины, и в восстановлении разрушенного города приняла участие вся страна. К тому времени, когда там проходила Всесоюзная научная конференция, он производил уже впечатление современного европейского города, и облик Востока придавала ему не архитектура, а природа и люди. Шел конец октября, но здесь царила райская благодать лета: небо сияло нежной глазурью, вдоль улиц, создавая прохладу, журчали арыки, все цвело и благоухало, фруктовый аромат проникал в конференц-зал, в холле которого стоял стол, уставленный вазами с виноградом, чашами с фруктами, сте- 
клянными кувшинами с соками. На улицах лица прохожих были приветливы и улыбчивы, я глаз не могла оторвать от прелести молодых узбечек в их длинных, до пят, из струящегося шелка платьях, с их длинными косами, гладко причесанными головками, легкостью и изяществом походки.

В желании побродить по улицам города, вглядываясь в его повседневность, вслушиваясь в музыкальное струение фонтанов, проникая любопытным взором в магазины и мастерские ремесленников, я была не одинока: у меня появился спутник. Это был азербайджанский литературовед А.А. Гаджиев, человек, по-видимому, чиновный, судя по тому, что за нами неотставаемо следовала черная «Волга». Он обратился ко мне с просьбой помочь ему выбрать шелк на платье для жены и какое-нибудь украшение в национальном стиле. О более приятной просьбе в помощи можно было только мечтать, и тут немножко открылся мне мир народных промыслов Узбекистана: малый бизнес здесь не преследовался, с частной собственностью так строго, как у нас в России, не боролись, и мастерские чеканщиков, ювелиров, ковровщиков, шитья золотом, гончаров, ткачей и т. д. работали бойко, и торговля сувенирами шла споро. Я заметила, что филологи национальных республик материально более, чем мы, обеспечены, в распоряжении денежными средствами более свободны. На свои средства я могла купить здесь лишь хорошенький керамический кувшинчик, а набор кобальтового цвета пиалок, расписанных в национальный орнамент, нам с 3.С. Кедриной принесли в номер гостиницы. Такой подарок сделали всем участникам конференции.

О благосостоянии национальной интеллигенции можно было судить по пышности тех дастарханов, которые накрывались для нас в домах хозяев. Главным вниманием окружены были, разумеется, москвичи, и на меня, как нечаянно к ним примкнувшую, распространялась общая волна национального гостеприимства. В огромных казанах готовили плов из целого барана, пригоняемого из личной отары, пасущейся в горах. И хозяйские жены, не таясь, блистали дорогими украшениями. По всему было видно, что на принципы равенства, братства и свободы взгляд в республике был более широкий, чем требовал Устав КПСС.

Чтобы показать Восток, сохранившийся в исторической нетленности, гостям по указанию Ш. Рашидова был предоставлен самолет, доставивший нас в Самарканд. В гиды нам был назначен ученый из историко-археологического центра Афрасиаб, и нам открылось представление о немыслимых глубинах узбекской истории, о чем говорила многометровая толща археологических напластований, лежавшая прямо под нашими ногами. 
В ходе завоевательных войн Афрасиаб неоднократно разрушался до основания, но, как феникс из пепла, возрождался вновь, и реальным воплощением исторического своеобразия национальной культуры Востока предстали перед нами памятники древней архитектуры религиозно-ритуального предназначения. Прежде всего Регистан - главная площадь Самарканда в окружении трех величественных медресе, одно из которых построено по замыслу Улугбека в начале XV в. И, конечно же, Гур Эмир - усыпальница Тимура и его потомков, голубой купол которой высотой в сорок метров, кажется, упирается в небо и сливается с его лазурью. Но главное - это вытянувшаяся в целую улицу череда мавзолеев Шахи-Зинда, архитектурный декор которых изумляет такой мерой богатства и разнообразия, что рискует, кажется, перейти границы чрезмерности и избыточности. Хотя Шахи-Зинда возникала вне единого замысла, она воспринимается как стройный ансамбль, когда к одной усыпальнице, как бы соревнуясь в красоте и оригинальности оформления, присоединялась другая, в течение веков выстраиваясь в не виданную миром улицу архитектурных шедевров, приводящих на память волшебный мир восточной сказки. Здесь архитектура впитала все многообразие видов национальных искусств и ремесел, демонстрируя мастерство кирпичной кладки, изощренность орнамента и инкрустации, резьбы по дереву, мрамору, полудрагоценному камню и т. д.

Излишне говорить о моем отношении к неповторимой красоте архитектурных форм русского храма, потрясает величественность готического собора, изумляют ампир и барокко, но тогда во время пребывания в Узбекистане колдовская сила древней архитектуры восточного города, сливаясь с сиянием летнего дня, бездонностью лазурного неба, журчанием арыков, захватила без остатка. Способствовала общему эмоционально-психологическому настрою и компания московских коллег, с которыми можно было разделить свои чувства. Иногда, утомленные столько же ходьбой, сколько и впечатлениями, мы заходили в чайхану, и когда чайханщик в полосатом халате и ярко расшитой феске выносил поднос с пиалами и ставил на стол под чинарой чайник со свежезаваренным чаем, то этот дымящийся терпким ароматом горячий напиток в жаркий день казался божественным нектаром.

Узбекистан во многом предопределил мою тягу на Восток, мои планы и желание увидеть и Таджикистан, и Азербайджан, и Армению, и Грузию, но даже соседнего Казахстана увидеть не удалось: с историческими путями страны мои личные планы не совпали. 
Следующая моя встреча с Узбекистаном состоялась уже в годы Перестройки. Профсоюз Института организовал групповую поездку по маршруту Ташкент-Навои, и я удачной возможности еще раз встретиться с солнечным краем обрадовалась. Но стояла глубокая осень, непогода добралась и до Узбекистана, да и люди, вошедшие в группу, хотя и были институтскими коллегами, при ближайшем рассмотрении ехали не столько за экзотическими ощущениями туманов и запахов, сколько из меркантильных целей прицениться к каракулю, прикупить сухофруктов и риса. Ташкент встретил уныло моросящим дождиком, походил на большую барахолку, фонтаны не били, арыки не журчали, лица людей были озабочены. Но в Ташкенте мы не задержались, а Навои без туристических впечатлений не оставил, во многом даже компенсировав первоначальное разочарование поездкой. Город, названный именем основоположника узбекской литературы, возник на месторождении редкоземельных металлов. Чем-то он неуловимо напоминал Академгородок. Если одни родился в глубине тайги, то другой вырос среди зыбучих песков, оба воздвигались по единому архитектурному плану. Навои тоже был отмечен чертами города социалистической мечты, что находило зримое отражение в его облике. У него не было окраин, в нем не было старых зданий, он весь состоял из прямых, как стрела, улиц, по сторонам которых располагались дома простой и удобной планировки, национальное своеобразие которым придавали просторные балконы с решетками, имитирующими резьбу по камню.

И хотя на улицах узбекской столицы уже беззастенчиво торжествовал лихой дух рыночной экономики, и здесь практичные хозяева в целях расширения жилплощади, безжалостно разрушая целостность городского облика, деловито остекляли разнокалиберными рамами свои балконы, казалось, что окончательно атмосфера одухотворенности большой идеей в Навои еще не выветрилась. Еще сохранялся принцип централизованного снабжения промышленно-продуктовыми товарами, шли советские фильмы, звучала «наша» музыка. Я сделала здесь, как и все другие туристы, несколько полезных покупок - ткань на шторы, настольные часы, которые исправно тикают до сих пор. Но главное, что поразило, - это книжный магазин: здесь свободно можно было купить Набокова, Булгакова, Тэффи...

«Заболела» ли я Востоком во время поездки в Японию или сама эта поездка определилась уже каким-то внутренним интересом к Востоку, но Узбекистан эту тягу к восточной культуре закрепил, и она уже из моего мироощущения 
не уходила никогда. Я много путешествовала, если, конечно, туризм можно отнести к роду путешествий. Я видела Стамбул, Афины, Каир, Дели, Куала-Лумпур, Сингапур, Ханой, Сайгон и т. д., но не была в Париже! Я не видела ни Лондона, ни Берлина, ни Вены, меня никогда не тянуло в Америку.

Я не стала востоковедом. Востоковедом стала моя дочь. Лично она какой-либо внутренней связи моих духовных интересов со своей профессией не ощущает и не осознает, но независимо от субъективных факторов эта связь существует. Недавно она вернулась из поездки в Китай, в заповедные центры даосской культуры - ритуальные комплексы Уданшаня: привезла богатый фотоматериал, написала статью для востоковедческого журнала.

Возраст не дает мне поводов мечтать о поездке даже за пределы Академгородка, но приобщение к этим материалам дает что-то вроде подпитки моей неукротимой тяге к Востоку; сегодня мне и этого достаточно, чтобы как когда-то вернулась память к стихам, кочующим по моему Дневнику из десятилетия в десятилетие. Не поленюсь их переписать и на сей раз - в тексте и контексте совсем другого характера. Автор этих стихов тоже болел Востоком:

Зачем опять мне вспомнился Восток!

Зачем пустынный вспомнился песок!

Зачем опять я вспомнил караваны!

Зачем зовут неведомые страны!

Зачем я вспомнил смутный аромат

И росной розы розовый наряд!

Как слитно многокрасочен Восток!

Как грустен нескончаемый песок!

Как движутся размерно караваны!

Как манят неизведанные страны!

Как опьяняет юный аромат!

И росной розы розовый наряд!

Моей мечты подобие - Восток!

Моей тоски подобие - песок!

Моих стихов подобье - караваны!

Моих надежд - неведомые страны 
Моей любви подобье - аромат

И росный розы розовый наряд.

Вот почему мне вспомнился Восток,

Вот почему мне видится песок,

Вот почему я слышу караваны,

Вот почему зовут и снятся страны. 
ПРАВИЛА

ОФОРМЛЕНИЯ СТАТЕЙ 
I K рассмотрению и опубликованию принимаются статьи, оформленные в соответствии с правилами, принятыми в журнале. Объем статьи вместе с примечаниями не более г п.л. - 40 ооо знаков вместе с пробелами (для аспирантов - не более о,5 п.л. - 20 ооо знаков вместе с пробелами), включая примечания.

2 Автор представляет все материалы (текст статьи, дополнительные шрифты, если таковые использовались в тексте, договор ${ }^{\mathrm{I}}$ ) по электронной почте: stud-lit@mail.ru или отправляет статью через услугу на сайте журнала www.studlit.ru

3 Текст должен быть напечатан в текстовом редакторе Microsoft Word, формат A4, поля - 2 см со всех сторон, шрифт - Times New Roman, кегль I4, межстрочный интервал - I,5, абзацный отступ (красная строка) - I,25, ориентация - книжная, без переносов.

4 Первая страница должна содержать следующую информацию:

- название рубрики, кегль - г4;

- УДК (см., например, teacode.com/online/udc или udk-codes.net), кегль - І4;

- ББК (см., например, http://roslavl.library67.ru/files/382/bbk.pdf), кегль - I4.

I B соответствии с частью четвертой Гражданского кодекса Российской Федерации (раздел VII «Права на результаты интеллектуальной деятельности и средства индивидуализации») представляемые в журнал статьи должны сопровождаться лицензионным договором о передаче Учредителю журнала неисключительных авторских прав. 
- Название статьи - по центру, без отступа, полужирным шрифтом, прописными буквами, кегль - I4.

- Под названием статьи по центру указывается знак авторского права, год, инициалы и фамилия автора/ов, кегль - I2.

- Далее по центру указывается полное название организации, город, страна, кегль - г2.

- По правому краю размещается информация о дате отправки статьи.

- Далее приводятся сведения о финансовой поддержке работы (грант и др.), кегль - г2, выравнивание по ширине.

- Размещаются аннотация (200-250 слов; она должна представлять собой реферат-резюме статьи с соблюдением последовательности изложения) и ключевые слова на русском языке, кегль - I2, выравнивание по ширине.

- Информация об авторе: имя, отчество, фамилия, ученая степень (если есть), звание (если есть), должность, полное название организации, адрес организации вместе с индексом, город, страна, E-mail, кегль - I2.

- После этого размещается та же самая информация на английском языке:

- Название статьи на английском языке - по центру, без отступа, полужирным шрифтом, прописными буквами, кегль - I4.

- Под названием статьи по центру указываются фамилия, имя, отчество автора/ов, кегль - г2.

- Далее по центру указывается полное название организации, город, страна, кегль - І2.

- По правому краю размещается информация о дате отправки статьи.

- Далее приводятся сведения о финансовой поддержке работы (грант и др.) (Acknowledgements), аннотация и ключевые слова (Abstract, Keywords), информация об авторе (Information about the author), кегль - г2, выравнивание по ширине.

- Далее - текст статьи - выравнивание по ширине, без переносов.

5 В конце статьи приводится СПИСОК ЛИТЕРАТУРЫ в алфавитном порядке (сначала русские источники, затем иностранные) в соответствии с ГОСТом 7.0.5.-2008 в виде нумерованного списка. Фамилия и инициалы авторов пишутся раздельно. В тексте статьи ссылки оформляются следующим образом: [І], [2, с. 5], [3, с. 34; 5, с. 2], [7, стб. 23], [Іо, л. 6]. 
6 Примечания оформляются в виде постраничных автоматических сносок. Цифра сноски в конце предложения ставится перед точкой. Шрифт сносок: Times New Roman, кегль I2.

7 Ссылки на архивные материалы даются в виде постраничных автоматических сносок.

8 После Списка литературы приводится REFERENCES:

- Транслитерируются только источники, написанные кириллицей; французские, немецкие, итальянские, польские и пр. источники не транслитерируются и не переводятся.

- Для выполнения транслитерации необходимо использовать специальную программу.

- Войти в программy http://translit.net/ и выбрать вариант системы Библиотеки Конгресса (LC).

- Вставить в специальное поле весь текст библиографии на русском языке и нажать кнопку «в транслит».

- Затем копировать транслитерированный текст в готовящийся список References.

- Далее необходимо отредактировать полученное и добавить переводы на английский язык:

- перевести на английский язык название книги, источника и др. и вставить его в квадратных скобках [] после соответствующих названий;

- заменить // на точку;

- заменить / на запятую;

- перевести на английский язык место издания (например, было М. - после редактирования: Moscow);

- заменить двоеточие после названия места издания на запятую;

- после транслитерации издательства добавить Publ.;

- исправить обозначение страниц: вместо 235 s. - 235 р., вместо S. $45-47-$ pp. 45-47;

- курсивом выделить название источника;

- в конце библиографической ссылки необходимо добавить указание на оригинальный язык статьи (In Russ.).

9 Сокращения. При первом упоминании лица обязательно указываются И.О., И.О. отделяются пробелом от фамилии. Годы при указании опре- 
деленного периода указываются только в цифрах: 30-е гг., а не тридцатые годы. Конкретная дата дается с сокращением г. или гг.: I920 г., I920-I922 гг. Не век или века, а в. или вв. (римскими цифрами): IX в. Писать только полностью: так как, так называемые. Из сокращений допускаются: т. д., т. п., др., т. е., см.

Iо Кавычки - только «», если закавыченное слово начинает цитату или примыкает к концу цитаты, употребляются кавычки в кавычках: «раз”, два, три, “четыре”».

II Архивные материалы должны сопровождаться вступительной статьей, оформленной в соответствии с вышеизложенными правилами. 


\section{ПОРЯДОК РЕЦЕНЗИРОВАНИЯ}

Рукописи, поступившие в редколлегию журнала «Studia

Litterarum», проходят обязательное рецензирование с целью их экспертной оценки.

На первом этапе редакцией проводится экспертиза рукописей на предмет их соответствия формальным требованиям.

3 Рукописи, не соответствующие требованиям к оформлению и не отвечающие содержательно-тематическому профилю журнала, не рассматриваются и не рецензируются. Решение об отклонении статьи от рассмотрения и публикации в этом случае принимается редколлегией. 4 Рукописи, соответствующие содержательно-тематическому профилю журнала и удовлетворяющие формальным требованиям, передаются на рецензирование двум независимым экспертам, имеющим наиболее близкую к теме статьи специализацию.

5 Экспертная оценка рукописи проводится по принципу внешнего двойного «слепого» рецензирования, когда ни рецензент не знает имени автора, ни автор не знает имени рецензента.

6 Для проведения экспертной оценки рукописи могут привлекаться как члены редколлегии, так и высококвалифицированные специалисты из ИМЛИ РАН и других организаций. Рецензенты обязаны следовать принятой в журнале Публикационной этике.

7 Рецензии пишутся в свободной форме или по разработанной редколлегией схеме.

8 Текст рецензии предоставляется автору по его запросу без указания Ф.И.О., должности и места работы рецензента. В случае наличия в рецензии рекомендации доработать и/или переработать текст статьи автору направляется сокращенный текст рецензии с конструктивными замечаниями без указания Ф.И.О., должности и места работы рецензента. В случае отклонения статьи от публикации автору направляется мотивированный отказ.

9 Статья, направленная автору на доработку, должна быть возращена в сроки, указанные в письме.

Iо Статья, не рекомендованная рецензентами к публикации, к повторному рассмотрению не принимается и не рассматривается на заседании редколлегии. 
Сроки рецензирования в каждом отдельном случае определяются с учетом возможности максимально оперативной публикации статьи. Максимальный срок рецензирования статьи - 3 месяца.

I2 Статьи, успешно прошедшие процедуру рецензирования, рассматриваются на заседании редколлегии. После принятия редколлегией решения о допуске статьи автор получает письмо с краткой информацией о результатах рецензирования и примерных сроках публикации рукописи. I3 Оригиналы рецензий хранятся в архиве журнала «Studia Litterarum» в течение 5 лет.

I С Сать членов редакции, редколлегии и международного редакционного совета, имеющих право на приоритетную публикацию в журнале I (одной) статьи в год, подвергаются рецензированию и обсуждаются на заседании редколлегии в общем порядке. 


\section{PEER-REVIEW PROCESS}

It is mandatory that all manuscripts submitted to the journal Studia Litterarum are peer reviewed by experts in the field.

$2 \quad$ At the first stage of the reviewing process, the Editorial Department reviews manuscripts on the subject of their compliance with the journal's formal requirements.

3 Manuscripts that do not meet the formal requirements or the subject scope of the journal will not be considered or peer reviewed. The Editorial Board decides whether the essay shall not be considered or accepted for publication.

4 Manuscripts that meet the formal requirements or the subject scope of the journal are sent to two independent reviewers in the specific field of the submitted manuscript.

5 The essay undergoes a double "blind" review process, e.g. when any of the reviewers knows the author's name nor the author knows the names of the reviewers.

The invited reviewers may be members of the Editorial Board or any other highly qualified experts from IWL RAS and other institutions. Reviewers must follow the principles of Publishing Ethics accepted by the journal.

Reviews are written in a free form or according to the scheme developed by the Editorial Board.

8 The review is sent to the author on his or her request without indicating the reviewer's name, job title, and place of work. If the reviewer recommends that the author revises/makes minor revisions and resubmits the manuscript, he or she will be sent a partial text of the review with suggestions without indicating the reviewer's name, job title, and place of work. In case of rejection, the author will receive a motivated refusal.

9 The essay sent to the author for revision shall be returned by the time specified in the letter.

Io The essay rejected by reviewers shall not be resubmitted or considered at the Editorial Board meeting.

II The time period of the review is determined in each particular case considering the most rapid possible publication of the essay. It takes the maximum of three months to have the manuscript reviewed.

I 2

The manuscripts that have successfully undergone the peer review process will be considered at the Editorial Board meeting. After making a decision 
about the essay's acceptance, the author will receive a letter briefly informing him or her about the results of the review and the possible date of publication.

I3 The original copies of reviews are kept in the archive of the journal Studia Litterarum for 5 years.

I4 Members of the Editorial Board, international Editorial Board, and the Editorial Department have the right for the priority publication of one (I) article per year; these articles are reviewed and accepted for publication on a common basis.

\section{ПОДПИСКА}

\section{Уважаемые коллеги!}

Оформить подписку на журнал «Studia Litterarum» можно во всех отделениях Почты России по каталогу ОАО Агентства «Роспечать» «Газеты. Журналы».

Подписной индекс -80538 .

Рассылка экземпляров журналов производится только по подписке.

По поводу приобретения отдельных номеров журнала необходимо обращаться в редколлегию: І2Іо69 г. Москва, ул. Поварская, д. 25 а. 


\section{STUDIA LITTERARUM}

Литературные исследования

Literary Studies

Научный журнал

Academic journal

Том 3, № I

Vol. 3, no I

Дизайн обложки и макет журнала В.А. Музыченко

Верстка А.З. Бернштейн

Корректор Е.Н. Сченснович

I6+

Подписано в печать \#\#.\#\#.2018

Формат 60×901/16

Усл.-печ. л. 23,0

Тираж \#\#\# экз. Заказ №

Отпечатано в ППП «Типография “Наука”

І2Іо99, Москва, Шубинский пер., д. 6

Институт мировой литературы им. А. М. Горького

Российской академии наук

І21069, Москва, ул. Поварская, д. 25 а

тел. (495) 69I-23-0I, 690-05-6I 